\title{
Plant communities of the upper Murrumbidgee catchment in New South Wales and the Australian Capital Territory
}

\author{
R.C. Armstrong ${ }^{1,4}$, K.D. Turner ${ }^{2}$, K.L. McDougall ${ }^{1}$, R. Rehwinkel ${ }^{1}$ \& J.I. Crooks Re $^{3,5}$ \\ ${ }^{1}$ Regional Operations Group, Office of Environment and Heritage, Queanbeyan NSW 2620, AUSTRALIA. \\ ${ }^{2}$ Scientific Services Division, Office of Environment and Heritage, Wollongong NSW 2500, AUSTRALIA. \\ ${ }^{3}$ Scientific Services Division, Office of Environment and Heritage, Queanbeyan NSW 2620, AUSTRALIA. \\ ${ }^{4}$ Current address: Umwelt (Australia) Pty. Limited, P.O. Box 6135, O’Connor ACT 2602, AUSTRALIA. \\ ${ }^{5}$ Current address: Department of Primary Industries, Coffs Harbour NSW 2450, AUSTRALIA. \\ Corresponding author: rarmstrong@umwelt.com.au
}

\begin{abstract}
Native vegetation of the upper Murrumbidgee catchment in southeast NSW and the Australian Capital Territory (ACT) was classified into 75 plant communities across 18 NSW Vegetation Classes within nine Structural Formations. Plant communities were derived through numerical analysis of 4,106 field survey plots including 3,787 plots from 58 existing survey datasets and 319 new plots, which were sampled in under surveyed ecosystems. All plant communities are described at a level appropriate for discrimination of threatened ecological communities and distinct vegetation mapping units.
\end{abstract}

The classification describes plant communities in the context of the upper Murrumbidgee catchment and surrounding landscapes of similar ecological character. It incorporates and, in some instances, refines identification of plant communities described in previous classifications of alpine vegetation, forest ecosystems, woodlands and grasslands across the Australian Alps and South Eastern Highlands within the upper Murrumbidgee catchment. Altitude, precipitation, soil saturation, lithology, slope, aspect and landscape position were all important factors in guiding plant community associations.

Nine Threatened Ecological Communities under Commonwealth, NSW and ACT legislation occur in the upper Murrumbidgee catchment. This study has also identified five additional plant communities which are highly restricted in distribution and may require active management or protection to ensure their survival.

Cunninghamia (2012) 13(1): 125-266

doi: 10.7751/cunninghamia.2013.13.003

\section{Introduction}

The classification of vegetation into distinct recurring species assemblages is an essential precursor to the mapping of vegetation distribution patterns. Together, vegetation classification and mapping are commonly used to inform biodiversity impact assessment and local and regional land use planning. Systematic vegetation classification and mapping also provide valuable information to identify threats and risks to various components of biodiversity, and to prioritise specific ecological values for targeted protection.

Systematic vegetation classification based on numerical analysis of field survey data is widely used in Australia and other parts of the world where sufficient field data are available. Numerical analysis of field 'relevé' data has been progressively developed in Europe through the European Vegetation Survey project (e.g. see Bruelheide \& Chytrý 2000; Tichý 2002; Schaminée et al. 2007; De Cáceres et 
al. 2009). In the development of the United States National Vegetation Classification System, Grossman et al. (1998) noted that vegetation classification ideally should be based on the analysis of high quality field data spanning the full geographic and environmental range of related vegetation, and the subsequent US National Vegetation Classification Standard Version 2.0 (FGDC 2008) proposed that natural vegetation types be derived from analysis of field plot data, with these data providing the fundamental information for the numerical description of types.

Within NSW, many natural resource management decisions are made by Catchment Management Authorities (CMAs) based on information and assessment at the scale of broad catchments. Within the Murrumbidgee CMA area and the ACT, the upper Murrumbidgee River catchment contains a diverse range of landscapes and vegetation types which are subject to ongoing land-use pressures including clearing of native vegetation for farming and urban development, urban expansion and ongoing pastoral management. The upper Murrumbidgee catchment has a relatively high density of existing vegetation survey plot data collected by previous vegetation studies, ranging from specific conservation reserve surveys to a large regional inventory of forest ecosystems on public lands, but to date it has not had a systematic classification of all plant communities across all Structural Formations across all tenures.
This study aimed to classify and describe the native plant communities of the upper Murrumbidgee catchment at a consistent classification scale or level of detail, based on numerical analysis of the best available set of full-floristic field survey plot data. Plant communities were delineated and described at an 'association' level compatible with adjacent regional vegetation classifications and with NSW Scientific Committee determinations, and a level that could be recognised in the field by people with botanical training. The study will contribute to the NSW Vegetation Classification and Assessment project (Benson 2006) and the State-wide Vegetation Information System Classification Database (OEH unpublished a).

\section{Study Area}

The study area (referred to here as the 'upper Murrumbidgee catchment'), an area of 1.741 million ha, within the Murrumbidgee catchment in NSW and the Australian Capital Territory (ACT) (Figure 1). The upper Murrumbidgee catchment is characterised by two distinctive bioregions (or IBRAs): the Australian Alps and the South Eastern Highlands (Thackway \& Cresswell 1995, IBRA version 6.1). Approximately $86 \%$ of the upper Murrumbidgee catchment falls within the South Eastern Highlands bioregion, with the Australian Alps bioregion comprising the remaining 14\%. Most bioregions contain multiple subregions, based on finer differences in biophysical attributes such as vegetation,

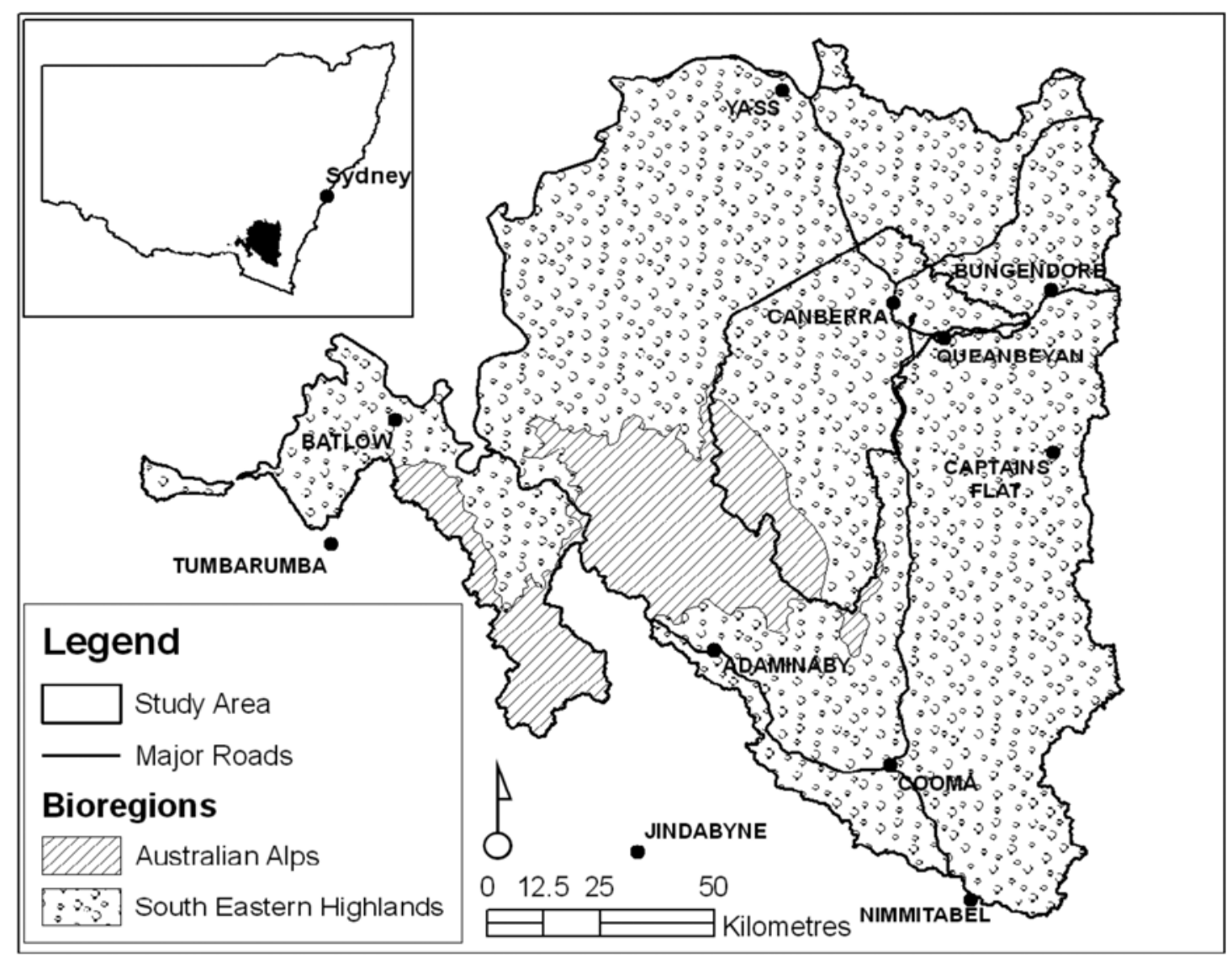

Fig. 1. The upper Murrumbidgee catchment study area including major population centres, roads and bioregions. 
geology and soil type (NPWS 2003a). The Australian Alps bioregion contains only one subregion (Australian Alps), which occurs across the Alps in NSW, Victoria and the ACT. The South Eastern Highlands bioregion contains ten subregions, five of which (Bondo, Crookwell, Kybean Gourock, Monaro and Murrumbateman) occur within the upper Murrumbidgee catchment (Figure 2). The biophysical characters of these subregions are outlined in Table 2.

The upper Murrumbidgee catchment encompasses parts of 11 local government areas: Cooma-Monaro, GoulburnMulwaree, Greater Hume, Gundagai, Palerang, Queanbeyan City, Snowy River, Tumbarumba, Tumut, Upper Lachlan and Yass Valley, as well as the entire jurisdiction of the ACT. Cities within the study area include Canberra and Queanbeyan, with regional centres including Adaminaby, Batlow, Bungendore, Captains Flat, Cooma and Yass. The upper Murrumbidgee catchment is primarily within the Southern Tablelands botanical subdivision, with parts of the north-west within the South Western Slopes botanical subdivision (Anderson 1961).

In developing a plant community classification for the upper Murrumbidgee catchment it was recognised that many plant communities would be distributed beyond the edges of the catchment, particularly in similar tableland environments to

Table 1: Climate data for the study area.

\begin{tabular}{|c|c|c|c|c|c|c|c|}
\hline Location & $\begin{array}{l}\text { Altitude } \\
\text { (m) }\end{array}$ & $\begin{array}{l}\text { Highest mean } \\
\text { max. mean } \\
\text { daily temp } \\
\left({ }^{\circ} \mathrm{C}\right)\end{array}$ & $\begin{array}{l}\text { Lowest mean } \\
\text { max. mean } \\
\text { daily temp } \\
\left({ }^{\circ} \mathrm{C}\right)\end{array}$ & $\begin{array}{l}\text { Frost days } \\
\text { (ave. no. days/ } \\
\text { year of daily } \\
\text { min. } \leq 0^{\circ} \mathrm{C} \text { ) }\end{array}$ & $\begin{array}{l}\text { Ave. annual } \\
\text { precipitation } \\
(\mathbf{m m})\end{array}$ & $\begin{array}{l}\text { Lowest mean } \\
\text { monthly } \\
\text { rainfall }(\mathrm{mm})\end{array}$ & $\begin{array}{l}\text { Highest mean } \\
\text { monthly rainfall } \\
(\mathrm{mm})\end{array}$ \\
\hline Cabramurra & 1482 & $21.4(\mathrm{Jan})$ & - $0.9(\mathrm{Jul})$ & 81 & 1155 & 43 (Jan) & 135 (Aug) \\
\hline Canberra Airport & 578 & 28.0 (Jan) & $-0.1(\mathrm{Jul})$ & 60 & 616 & 40 (Jun) & 64 (Nov) \\
\hline Cooma (Visitors centre) & 778 & $27.2(\mathrm{Jan})$ & $-2.8(\mathrm{Jul})$ & 104 & 533 & 27 (Aug) & 66 (Nov) \\
\hline Thredbo AWS * & 1957 & $16.3(\mathrm{Feb})$ & $-5.3(\mathrm{Jul})$ & 167 & 1355 & 85 (June) & 151 (Sep) \\
\hline Tumbarumba PO & 655 & $28.7(\mathrm{Jan})$ & $-0.2(\mathrm{Jul})$ & 60 & 976.4 & $54(\mathrm{Feb})$ & 107 (Aug) \\
\hline Yass & 520 & 29.5 (Jan) & 1.1 (Jul) & 46 & 651 & 46 (Feb) & $65(\mathrm{Oct})$ \\
\hline
\end{tabular}

Source: BoM (2011)

* Thredbo is located outside the upper Murrumbidgee catchment, but is included as an indication of the climate of alpine areas within the study area.

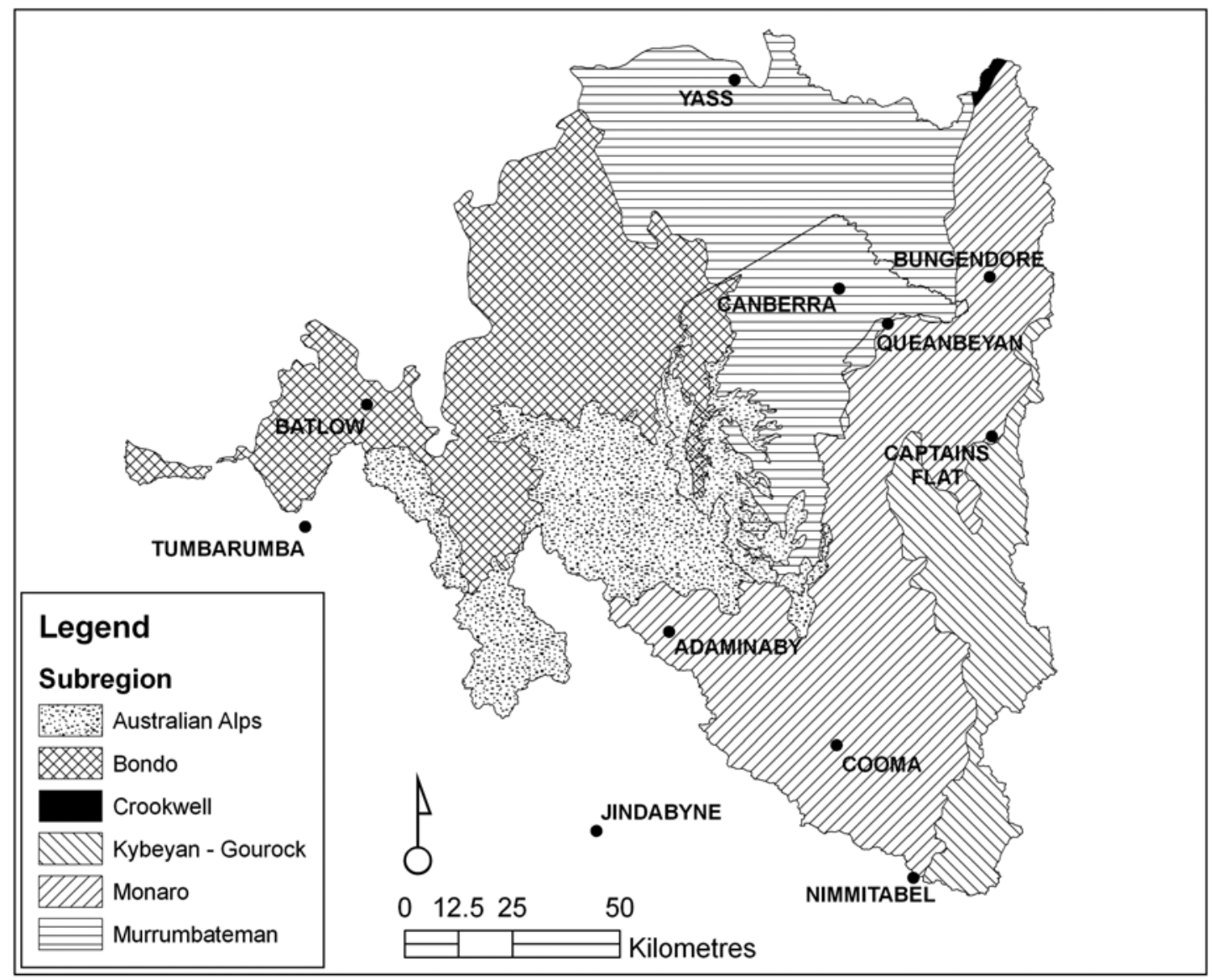

Fig. 2. IBRA subregions of the upper Murrumbidgee catchment study area. 
the north and south. In order to address this issue, floristic plot data from a broader area (referred to as the 'broader analysis area') were included. This encompassed the Australian Alps and South Eastern Highlands bioregions from the Victorian border north to Oberon Shire. The broader analysis area included a $10 \mathrm{~km}$ buffer on the western edge of the study area, and all of Boorowa Shire.

\section{Climate}

Climate varies greatly across the upper Murrumbidgee catchment, in response to topographic variation and its effect on atmospheric pressure, wind, precipitation, light and cloud cover. The Australian Alps bioregion contains areas of alpine, sub-alpine and montane landforms, with the South East Highlands being primarily tablelands with occasional montane features (Costin 1954).

Mean annual precipitation from weather station records ranges from $533 \mathrm{~mm}$ at Cooma within the Monaro rain shadow to $1,115 \mathrm{~mm}$ at Cabramurra on the main Kosciuszko range (Table 1; BoM 2011). Annual precipitation is highest in the southwest, where alpine peaks are modelled as receiving up to $2,150 \mathrm{~mm}$, much of this as snow in cooler months. Within the Monaro rain shadow, annual precipitation is modelled to be as low as $450 \mathrm{~mm}$ southwest of Cooma, where a lack of rainfall combined with severe winter frosts restricts tree growth (Figure 3) (Anon 2009). Cooma has the highest recorded temperature variation, with a highest mean daily temperature of $27.2^{\circ} \mathrm{C}$ in January and a minimum mean daily temperature of $-2.8^{\circ} \mathrm{C}$ in July (BoM 2011).

\section{Settlement and landuse}

The upper Murrumbidgee catchment was occupied by Aboriginal people for at least 21,000 years before European settlement (Lennon 2003, Hancock 1972). The Walgulu and Djilamatang people generally utilised the alpine areas, with Ngunnawal and Ngarigo people on the slopes and tablelands. At times, Wiradjuri people may have extended eastward into western sections of the study area (Tindale 1974). European settlers started arriving in the mid-1820s, with squatters establishing pastoral camps over much of the Monaro by the 1830s (Hancock 1972). Pastoralism commenced in the Australian Alps in the 1820s (HO \& DUAP 1996) and by the 1850s most of the Alps were used for stock grazing during the warmer months (Lennon 1999).

Climate, remoteness and the rugged terrain influenced both Aboriginal and European settlement and land use patterns (Lennon 2003). Easily accessible parts of the upper Murrumbidgee catchment have been developed primarily for wool and beef production; other land uses include urban development, forestry, cereal cropping (Hancock 1972), and conservation in national parks such as Kosciuszko NP. Other land uses include gold mining, the Snowy Mountains Hydro-

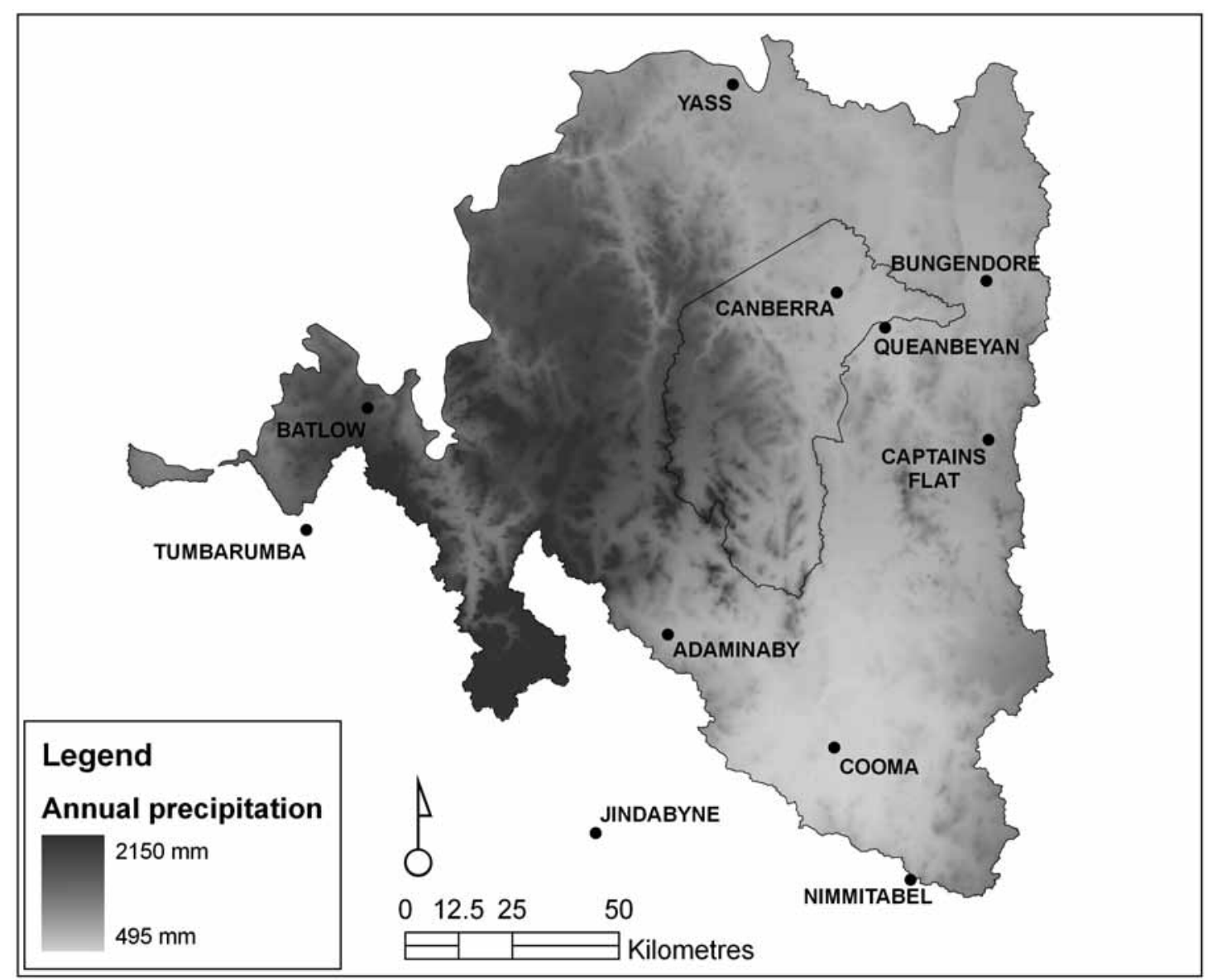

Fig. 3. Annual precipitation of the study area, showing higher rainfall in alpine and montane areas, and the dry Monaro rainshadow around Cooma. 


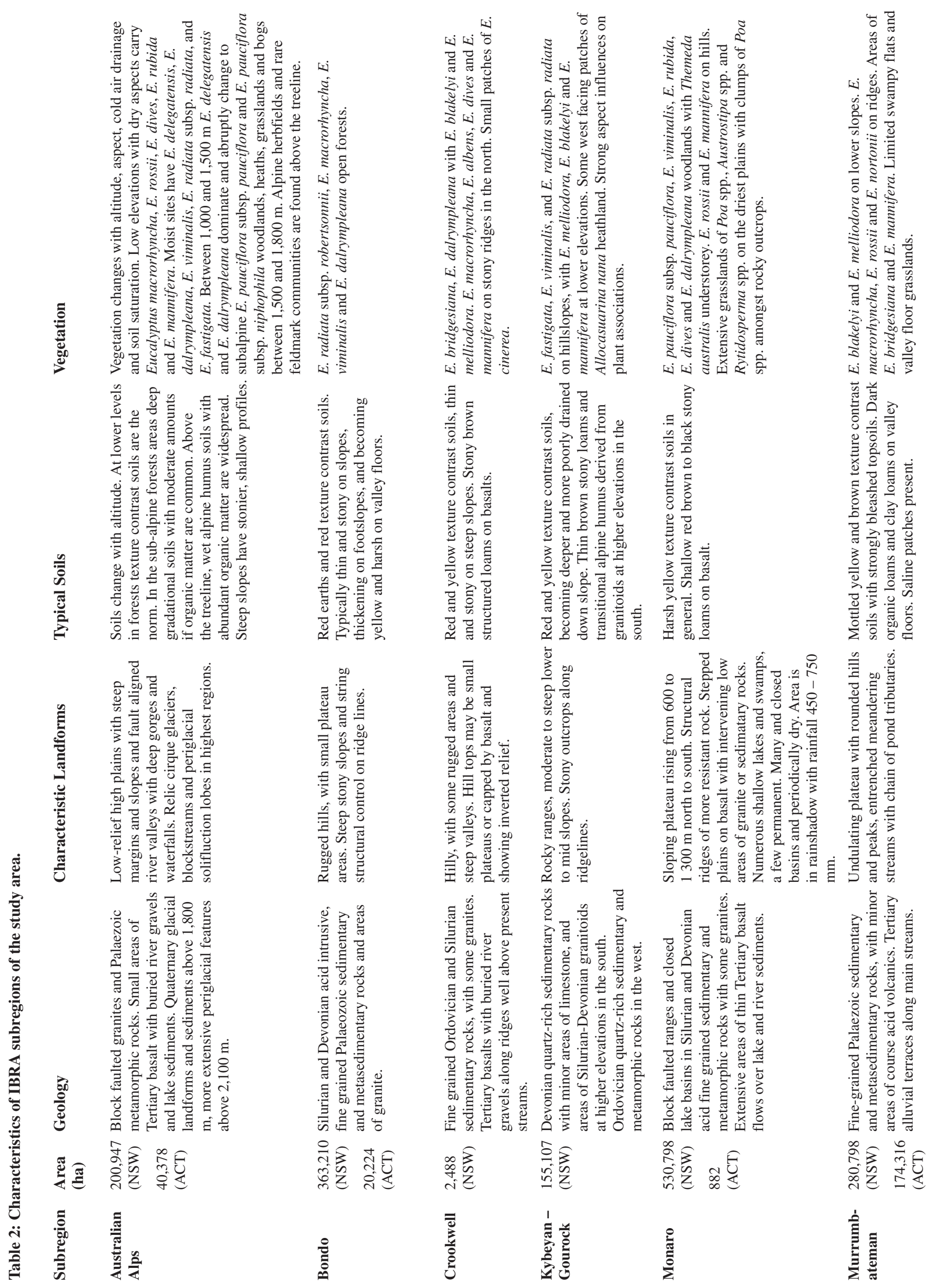


Electric scheme and recreational ski-field development in the Alps, and orcharding in the central and western parts of the South Eastern Highlands.

Natural vegetation in the upper Murrumbidgee catchment has been affected by domestic grazing, tree clearing (including ringbarking and logging), cultivation, altered hydrology and altered fire regimes. Introduced herbivores and omnivores, including rabbit (Oryctolagus cuniculus), hare (Lepus spp.), horse (Equus caballus), deer (numerous genera of the Cervidae family), pig (Sus scrofa) and goat (Capra hircus) continue to have negative impacts on the structure and floristic composition of native plant communities. The severity of impacts varies depending on ecosystem resilience and the timing and intensity of the threats (Costin 1954).

\section{Previous botanical studies}

Past qualitative and quantitative botanical studies in the upper Murrumbidgee catchment include:

- A study of the vegetation and soils of the Monaro region and much of the Australian Alps bioregion (Costin 1954).

- Classifications of wetlands and grasslands of the Monaro (Benson \& Jacobs 1994, Benson 1994).

- The Southern CRA Forest Ecosystem classification and mapping project, focussing on forest ecosystems on public lands (Thomas et al. 2000).

- Refinement of Thomas et al. (2000) undertaken by Gellie (2005).

- A classification of vegetation of the treeless alps in NSW and Victoria (McDougall \& Walsh 2007).

- A classification of native vegetation of southeast NSW (Tozer et al. 2010), which refined and integrated previous work by Tindall et al. (2004), Keith \& Bedward (1999) and others.

- A number of regional vegetation studies in the ACT (e.g. Ingwersen et al. 1974, Ingwersen 2001, Johnston et al. 2008, Sharp et al. 2007).

For a list of botanical survey data used as part of this study refer to Table 3 .

\section{Methods}

\section{Existing floristic survey data}

Existing floristic survey data from the broader analysis area were compiled from datasets held by the NSW Office of Environment and Heritage in the 'YETI' database (Bedward et al. 2011). Datasets were assessed for inclusion in the analysis based on the following criteria (adapted from Keith \& Bedward 1999):

i complete list of vascular plant species within each survey plot (i.e. full-floristic plot survey), as well as the moss Sphagnum spp., which was important for alpine classification; ii plot location recorded with a precision of $100 \mathrm{~m}$ or better;

iii species importance values recorded on a scale that could be transformed to a common cover-abundance scale;

iv area of each plot within the range 0.04 to 0.1 ha.

Exceptions made to criterion (iv) were the dataset of McDougall \& Walsh (2007), which included samples of between 0.002 and 0.05 ha, and the data of Benson \& Jacobs (1994), which involved whole-lake samples of up to 215 ha in area. These datasets represented the only survey data available for these habitats within the area. The smaller area plots collected by McDougall \& Walsh (2007) were considered to capture floristic variation for alpine plant communities.

The data compilation process included correction or masking of obvious taxonomic data entry errors, exclusion of plots that were clearly not full-floristic (e.g. canopy only or APIchecking plots) and correction of obvious plot location errors (where georeference data did not match text location description).

A total of 3,787 survey plots from 58 survey datasets (Table 3) across the broader analysis area were accepted for inclusion in the analysis, including data from 193 plots in three surveys which were located and entered into the YETI database as part of this study. Spatial and floristic variation within these datasets formed the basis for planning additional survey using stratified and preferential sampling techniques (Bell 2013).

All plots stored in the YETI database are identified by unique alpha-numeric labels and many of the plots extracted from the current broader analysis area had been classified during one or more previous studies. The group definitions (or plot memberships of groups) of previous studies by Benson \& Jacobs (1994), Gellie (2005), McDougall \& Walsh (2007) and Tozer et al. (2010) were obtained to allow exploration of relationships between groups defined by these previous classifications and the current study.

\section{Additional survey}

Using a Geographic Information System (GIS), the distribution of existing survey plots was stratified by the NSW Landscapes ("meso-scale ecosystems") as delineated by Mitchell (2003), and revised by EcoLogical (2008). These Landscapes represent areas of similar geology, topography and climate. Based on existing survey plot data, undersampled Landscapes were identified for further sampling. Calculations included a $10 \mathrm{~km}$ buffer beyond the upper Murrumbidgee catchment boundary, as existing survey plots outside this area, but within areas of similar biogeographic character would be included in the classification across the broader analysis area.

A total of 270 new field survey plots were proposed for sampling in remnant vegetation within 29 NSW Landscapes. Targeted plot locations were allocated across under-sampled Landscapes in the upper Murrumbidgee catchment using 
Table 3: Datasets used as part of the floristic analysis.

\begin{tabular}{|c|c|c|}
\hline $\begin{array}{l}\text { YETI Survey } \\
\text { identifier }\end{array}$ & $\begin{array}{l}\text { No. of } \\
\text { plots used }\end{array}$ & Reference \\
\hline ACT_GUD & 188 & Ingwersen (2001) \\
\hline ACT_MT.WD & 106 & Gilmour et al. (1987) \\
\hline ACT_UC & 107 & Helman et al. (1988) \\
\hline ALP_ASH & 61 & DECCW (2010a) \\
\hline AUSALPS & 359 & McDougall \& Walsh (2007) \\
\hline BALLNDCARE & 29 & Crawford (1999) \\
\hline CS_CLYDE & 22 & Helman (1983) \\
\hline EA_TSR & 83 & Hibberd \& Taws (1993) \\
\hline EDENVI & 9 & Keith \& Bedward (1999) \\
\hline FLOYDRF & 3 & Floyd (1990) \\
\hline kosc_xtra & 19 & Miles \& Robertson (2008) \\
\hline KOWMUNG & 110 & Steenbeeke (1990) \\
\hline KOWMUNGHAK & 5 & Steenbeeke (1996) \\
\hline KTWETQUD & 4 & Turner (2007) \\
\hline MER_SR & 6 & DECCW (2010b) \\
\hline MILES_06 & 16 & Miles (2006) \\
\hline MONWET & 65 & Benson \& Jacobs (1994) \\
\hline NADGIG_NR & 12 & Miles (2010a) \\
\hline NALBAUGH & 62 & Binns \& Kavanagh (1990) \\
\hline NP_BONDI & 24 & Fanning \& Rice (1989) \\
\hline NP_BRIN & 130 & Doherty (1997a) \\
\hline NP_BUR & 33 & Doherty $(1998 ; 2004)$ \\
\hline NP_DEUA & 20 & Gilmour (1985) \\
\hline NP_ECRA & 66 & Keith \& Bedward (1999) \\
\hline NP_GOULB & 36 & Miles (2010b) \\
\hline NP_KOSI & 39 & AALC (no date) \\
\hline NP_MONGA & 11 & Miles (2007) \\
\hline NP_MUND & 17 & Doherty (1996) \\
\hline NP_SCQBYN & 10 & NPWS (undated a) \\
\hline NP_SCRA & 788 & Thomas et al. (2000) \\
\hline NP_TIND & $1^{*}$ & Doherty (1997b) \\
\hline NP_WADAN & 5 & Mackenzie et al. (1998) \\
\hline NP_WOGWO & 12 & Fanning \& Fatchen (1990) \\
\hline NPA_ABER & 32 & Togher (1996) \\
\hline P_MONARFB4 & 33 & Crawford (2002a) \\
\hline P5MA & 506 & Tindall et al. (2004) \\
\hline P5MA_XTRAS & 2 & Tindall et al. (2004) \\
\hline RH & 43 & NPWS (undated b) \\
\hline SCRA_NTH & 39 & Thomas et al. (2000) \\
\hline SEFCOMB & 100 & Keith \& Bedward (1999) \\
\hline SF_BAGO & 26 & Binns (1997) \\
\hline SF_BM & 4 & Binns (1997) \\
\hline SF_BMFLS & 64 & Binns (1997) \\
\hline SF_MAR & 5 & Binns (1997) \\
\hline SF_QFS & 100 & Jurskis et al. (1995) \\
\hline SFTUMB04 & 24 & Binns (2004) \\
\hline SWS_Gellie & 133 & EcoGIS (2004) \\
\hline TARAL & 15 & Fisher \& Ryan (1994a) \\
\hline TOL_BUN_BN & 35 & Miles (2005a) \\
\hline UMC_ACT & 31 & ACT CP\&R (2010) \\
\hline UMC_GA & 54 & this study \\
\hline
\end{tabular}

$\begin{array}{lll}\text { YETI Survey } & \begin{array}{l}\text { No. of } \\ \text { plots used }\end{array} & \text { Reference } \\ \text { identifier } & \end{array}$

$\begin{array}{lll}\text { UMC1 } & 40 & \text { this study } \\ \text { UMC2 } & 26 & \text { this study } \\ \text { UMC3 } & 46 & \text { this study } \\ \text { UMC4 } & 29 & \text { this study } \\ \text { UMC5 } & 25 & \text { this study } \\ \text { UMC6 } & 32 & \text { this study } \\ \text { UMC7 } & 36 & \text { this study } \\ \text { V_BOMBFB4 } & 19 & \text { Miles (2005b) } \\ \text { V_BONDIFB4 } & 10 & \text { Crawford (2002b) } \\ \text { V_COOLAFB4 } & 9 & \text { Miles (2002) } \\ \text { V_COOLUFB4 } & 9 & \text { Crawford (2002c) } \\ \text { V_COOMAFB4 } & 27 & \text { Miles \& McPherson (2004) } \\ \text { V_MONGAFB4 } & 6 & \text { Gellie (2002) } \\ \text { V_TANTYFB3 } & 13 & \text { Miles (2001) } \\ \text { V_TBLD_FB4 } & 5 & \text { Miles (2004) } \\ \text { WARRAGAMBA } & 70 & \text { NPWS (2003b) } \\ \text { TOTAL: } & 4106 & \end{array}$

* Note: 49 of the 50 survey plots collected by Doherty (1997b) were stored within the NP_SCRA survey.

a random point generator in the GIS, constrained to areas of public tenure [including national parks, State forests, travelling stock reserves (TSRs) and Crown reserves] and 22 private properties whose owners had granted access for surveys. A small number of random target locations were modified by moving to areas of greater accessibility, such as to within a few hundred metres of an access track. All moved target plots remained within the same Landscape and in a similar landscape position to that of the original randomly selected location (e.g. drainage line, mid-slope or hill top). A further 49 new field survey plots were sampled in vegetation or habitat types believed to be under-sampled based on consultation with local botanists and review of previous descriptions of plant communities across the study area.

Data collected for this study largely conform with the NSW Native Vegetation Type Standard (Sivertsen 2009), including recording of precise plot location, basic floristic structure, condition, tree health, physiography, land use, disturbance and full-floristic plot data with percent foliage cover. All surveyors estimated percent foliage cover for all taxa in each full-floristic quadrat; one team also recorded separate abundance scores. These new plots brought the total number of field survey plots available for analysis to 4,106. Table 3 summarises the sources of the plot data. 


\section{Data analysis}

Floristic data from 4,106 field survey plots were collated in a relational database (Bedward et al. 2011) and exported in a format suitable for analysis. Through the export process all exotic taxa were excluded, a standardisation of taxonomic names was applied, and species-importance scoring systems were transformed to their closest equivalent on a coverabundance scale of 1 to 6 (1: uncommon and less than 5\% cover; 2 : common and up to $5 \%$ cover; 3 : up to $20 \%$ cover; 4: up to $50 \%$ cover; 5 : up to $75 \%$ cover; and 6 : over $75 \%$ cover) modified from Braun-Blanquet (1932). Exported data consisted of transformed cover-abundance values in a matrix of 4,106 plots (objects) by 2,067 taxa (attributes).

Exported data were examined using the homogeneity analysis algorithm developed by Bedward et al. (1992), to assess the number of floristic groups (i.e. the classification level) likely to be most efficient at describing the floristic diversity of the broader analysis area. This assessment, combined with review of previous plant community classifications covering parts of the study area, suggested an initial classification level of 200 groups.

Survey plot data were then analysed to search for groups of consistently co-occurring plant taxa at the chosen classification level, using the PATN software developed by Belbin (1995a, 1995b). Cluster analysis began with the PATN non-hierarchical clustering strategy 'ALOC', as recommended by Belbin (1995a) for datasets containing large numbers of objects (plots). ALOC was run with objectcentroid distances calculated using the Bray and Curtis association measure, using the first plot as an initial seed, specifying an output of 200 initial groups and accepting the PATN default maximum number of iterations of allocation -> centroid re-definition -> re-allocation .

As outlined above, the classification dataset came from a variety of sources, and the data were known to contain survey-related variance factors with the potential to interfere with the clustering algorithm's recognition of 'real' floristic groups. These included varied plot sizes; some surveys with many records of coarse identification to genus level only (e.g. Rytidosperma spp.); different original species cover and abundance scoring systems used by some surveys; and irreconcilable taxonomic changes between old and recent surveys. For these and other reasons, the initial clustering output was considered likely to reflect both real (i.e. species' response to environmental gradients) and apparent (i.e. artefacts of survey method, disturbance etc.) patterns in species composition, and so the output of the automated free-ALOC clustering process was examined in detail.

The compositional attributes of each of the initial free-ALOC groups were examined by tabulating species frequencies and median cover scores using the FIDEL software developed by Bedward (1999). The homogeneity of each group was examined by computing a matrix of plot/centroid associations, and plotting in a GIS the spatial distribution of group members against mapped substrate, physiography and climate attributes. Graphical representations of group structure (dendrograms and ordinations of subset data) were also examined in PRIMER v5 (Clarke \& Gorley 2001). Relationships between free-ALOC groups and the groups identified by previous numerical classifications overlapping the study area (Benson \& Jacobs 1994; Gellie 2005; McDougall \& Walsh 2007; and Tozer et al. 2010) were also examined.

Individual plots with a weak association with the nearest centroid or anomalous spatial distribution were either reallocated to a 'near-neighbour' group supported by the above information, or excluded from further analysis if they could not be reliably assigned to any other floristic group and were not considered to represent a distinct new group. At a broader level, each of the initial groups were either retained (in some cases with minor reallocation into or out of the group), split into two or more separate groups, or merged with other groups. Groups were retained where a clear compositional dichotomy was associated with an environmental gradient. Merging was considered for groups that were:

- dominated by plots from single surveys or observers, with some consistent characteristic of that survey likely to blur true composition differences (e.g. distinctive cover-score systems, high frequency of genus-only records);

- seeded by disturbed plots, such as recently burnt or logged plots dominated by dense tree regrowth, or grazed TSR plots dominated by exotic pasture with very low native species richness and cover;

- seeded by or dominated by aberrant plots, which had been missed in the first series of data cleaning. This was commonly caused by either unusually large survey plots (most plots were 20 x $20 \mathrm{~m}$; larger $20 \mathrm{x}$ $50 \mathrm{~m}$ plots have a higher likelihood of containing more than one plant community or higher species richness), plots that contained suspiciously large species lists and may have been random meanders rather than plotbounded surveys, and plots clearly representing sampling across an ecotone (such as boundaries between wetland perimeters and forest).

The eastern edge of the broader analysis area included a small number of plots representing the margins of moist coastal/escarpment plant community types, which had been classified as such by Tozer et al. (2010) in their coast/ escarpment/eastern tablelands context. In the absence of their related plots outside the broader analysis area, the ALOC process tended to group these plots with moist tableland plots and blur the recognition of tableland groups. This was treated by accepting the Tozer et al. (2010) allocations of these moist coastal/escarpment plots, and excluding these groups when considering alternative allocations of tableland plots. This is further discussed below in Relationship with previous classifications.

A systematic examination of all initial free-ALOC groups and group assignments produced a revised allocation of all plots to groups (or identified plots for exclusion). This revised group definition was used to seed a subsequent round of ALOC clustering, involving both a zero-iteration run (to 
examine the affinity of objects/plots to the revised groups) and a 10-iteration/0.8-radius run to test the stability of those groups and search for additional groups recognisable in the absence of outlier plots. The outputs of each iteration were again examined through ALOC tabulations of plot/centroid associations, group species frequency, cover and fidelity data (for non-grassland plots), comparison with previous study plot allocations, spatial distribution of plots, dendrograms etc., in order to further refine the definition of groups and the allocation of plots to those groups. This iterative process of refinement, re-run and checking continued until group membership was considered stable and a final allocation of plots to groups was accepted.

Plant ecologists familiar with the vegetation of the area were consulted during the analysis to gauge whether numerical data interpretations matched their perceptions of consistent floristic associations.

\section{Grasslands of the South Eastern Highlands bioregion}

Analysis of grassland floristic survey data within the South Eastern Highlands bioregion was carried out through a separate classification process described by Rehwinkel (unpublished). After various data cleaning operations, transformation of cover-abundance scores into a common system, and dealing with taxonomic consistency issues, field data from 437 grassland samples were analysed using the PATN software (Belbin 1995a, 1995b). Grassland classification followed the agglomerative hierarchical fusion strategy, using the Kulczynski measure of association and applying the flexible UPGMA formula with the default Beta value of -0.1. After multiple iterations run to explore the data and potential groups, a final analysis defined eight grassland plant communities (see Rehwinkel unpublished).

\section{Relationship with previous classifications}

Relationships between the communities identified by this study and communities identified by overlapping previous broad classifications (i.e. Benson \& Jacobs 1994, Gellie 2005, McDougall \& Walsh 2007 and Tozer et al. 2010) were explored by comparing the assignments of floristic plots to groups between current and previous group definitions. General relationships between the sampling density and classification scale of the current study and the previous broad regional classifications of Gellie (2005) and Tozer et al. (2010) were examined in each area of spatial overlap by comparing the numbers of plots classified and the number of separate groups (communities/assemblages) identified from those plots by each study.

\section{Community descriptions}

Plant communities identified in this study were labelled with an alpha-numeric code reflecting the dominant origin of that group's definition. Where a plant community corresponded closely with a group defined by a previous study, it was assigned a code reflecting this relationship:
- groups related to alpine communities identified by McDougall \& Walsh (2007) are denoted by an 'a' for alps (note that some finer-scale closely related alpine groups were combined here; the code used for the resulting group was based on the original community considered to dominate the composite group);

- communities corresponding with map units described by Tozer et al. (2010) retained the alpha-numeric code assigned in that study (prefixes 'e', 'm' and 'p');

- groups closely matching the vegetation groups identified by Gellie (2005) are identified by ' $\mathrm{g}$ ';

- tableland lake groups identified by Benson \& Jacobs (1994) are denoted by 'L'; and

- grassland communities analysed and classified separately by Rehwinkel (unpublished) and described here are identified by an 'r' prefix.

Where an identified community had no clear relationship with any of the groups of previous regional classifications, its alpha-numeric code was prefaced by ' $u$ '.

Plant communities were related to the hierarchy of NSW Structural Formations and Vegetation Classes of Keith (2004) based on their floristic and structural characteristics and the distribution of assigned plots.

Final groups of classified plots were used to characterise the properties of each community. Mean native species richness and cover were calculated from plots allocated to each community, and the vegetation structure of each community was described based on summaries of the structural variable estimates (height and cover for each stratum) recorded for plots within the dataset. The frequency of commonlyoccurring weeds within each group was also identified from classified plots. The frequencies of weeds occurring in grasslands classified by Rehwinkel (unpublished) are not known as this separate analysis was undertaken in a dataset only containing native taxa.

Field data were used to generate lists of diagnostic plant taxa for each community and assist with identification in the field. The 'FIDEL' software developed by Bedward (1999) was used to calculate the frequency of each plant taxon within each group and in all other samples in the dataset. These frequency data were used to identify 'positive' and 'constant' diagnostic taxa for each community following the process developed by Tozer (2003) and described by Tozer $e t$ al. (2010). Positive diagnostic taxa were identified as those which occurred more frequently within a community than in other plant communities (i.e. a hypergeometric probability $<0.001$ ). Those taxa occurring with frequency $<0.2$ within the community and coefficient of variation $>0.05$ were excluded to minimise the inclusion of unreliable diagnostic taxa. Constant diagnostic taxa were identified as those which occur frequently in the community $(>0.4)$ but also occur frequently in other groups.

Fidelity measures were not calculated for grassland plant communities of the South Eastern Highlands bioregion identified by Rehwinkel (unpublished) as these were 
described through separate analysis. For these plant communities, cover/abundance and frequency information is presented.

The habitat or broad environmental domain of each community was described based on GIS intersects of plot locations against spatial environmental data including surface geology (DMR undated), soil landscapes (OEH unpublished b), modelled climate layers (Hutchinson 1989, Anon 2009), and topographic variables (altitude, slope, aspect) derived as part of this study from a $25 \mathrm{~m}$ grid digital elevation model (LPI 2006). This information was derived from across the broader analysis area, and in some cases augmented by the local knowledge of the authors. Additionally, each plant community contains tabulated summary information on the number of samples, mean species richness, slope, altitude, average annual rainfall and annual temperature range.

\section{Nomenclature}

Plant taxonomic nomenclature in this report follows the Australian Plant Census (ANBG 2011). Where the authors were aware of recent accepted taxonomic changes yet to be updated on the Australian Plant Census website, the latest nomenclature was used.

Naming of plant communities follows the format suggested by Benson (2006). For common names this includes one or more of the dominant / diagnostic plant species, the most prevalent structure and height class of upper stratum (based on Walker \& Hopkins 1990), a reference to characteristic soil, substrate or climate, and reference to the main geographic occurrence of the plant community such as a location or bioregion. For community scientific names, up to 12 binomial scientific names of characteristic taxa are given, separated into up to three height strata. Alpine communities (i.e. plant communities with a prefix of 'a') are treated similarly, although ubiquitous taxa not aiding in plant community diagnosis are not included. Plant communities identified here are considered to fit within the 'association' level identified as Level V in Australia's NVIS hierarchy (ESCAVI 2003).

\section{Results}

\section{Field survey and sample distribution}

This study collected 319 new full-floristic survey plots. Of these, 270 survey plots targeted remnant woody vegetation within 29 Landscapes considered to have proportionally low existing sampling. A further 49 survey plots sampled vegetation or habitat types perceived to be under-sampled based on reviews of previous plant community classifications and expert knowledge of floristic datasets across the upper Murrumbidgee catchment and surrounds. This additional floristic information enabled greater refinement of floristic definitions for 44 of the 75 plant communities described within the upper Murrumbidgee catchment. Many of the plant communities such as lowland remnant woodland and riparian shrubland communities are of limited extant distribution; the additional survey data increased the sampled distribution range of many plant communities. The surveys also increased sampling in 38 of the 49 Landscapes in the upper Murrumbidgee catchment.

The distribution of survey plots used in the analysis is shown in Figure 4, with Table 4 showing the sampling intensity of Landscapes prior to and after the additional survey. However, strong biases towards areas of public tenure remain and obvious coarse spatial sampling gaps remain on the Monaro plains, the lowlands of the ACT and areas north and west of Yass. Additionally, there are particular habitat types which remain undersampled, including riparian areas and smallscale wetlands.

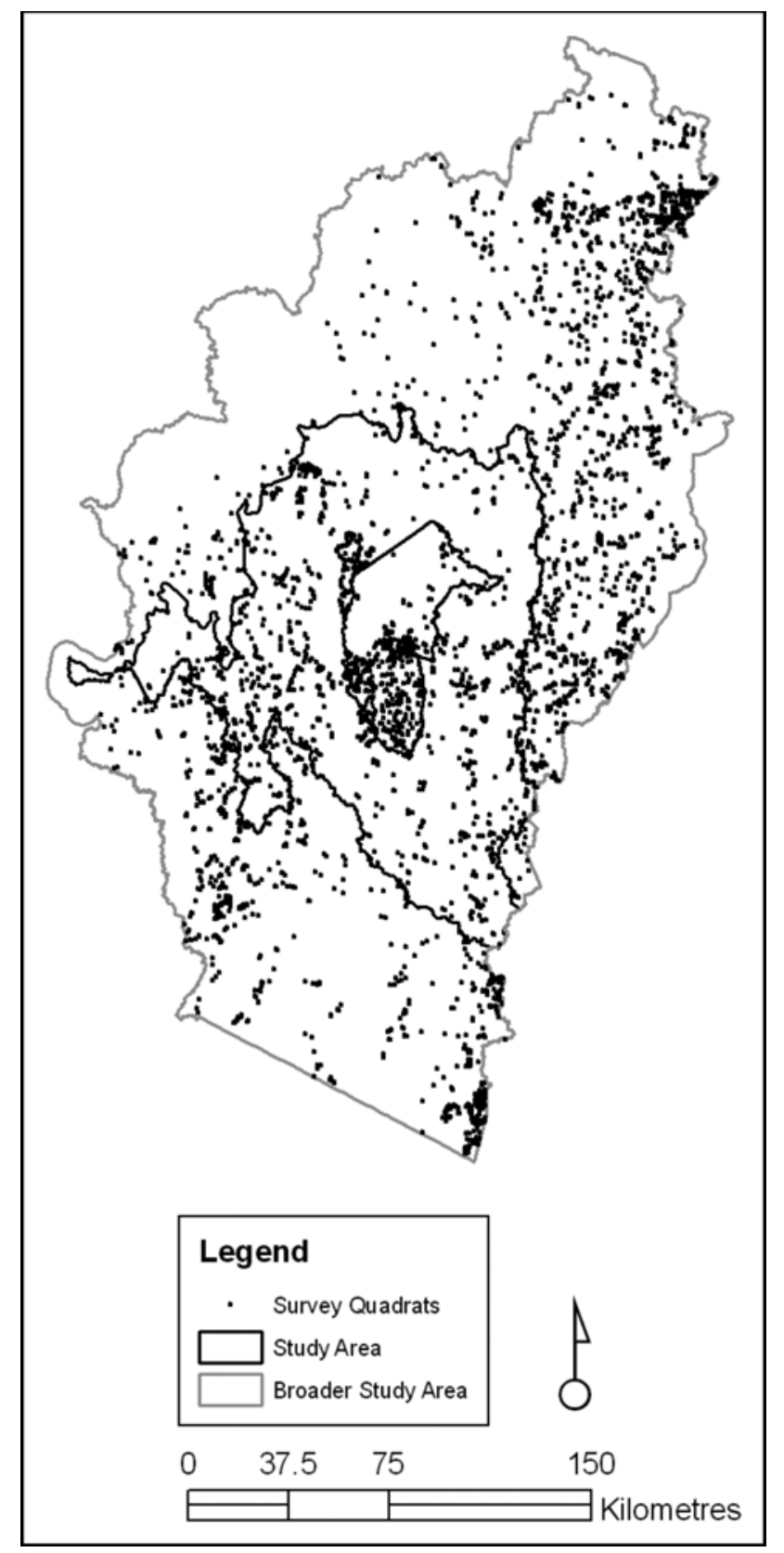

Fig. 4. Distribution of survey plots across the broader analysis area. 
Table 4: Plot sampling intensities for each vegetated NSW Landscape within woody vegetation types in the upper Murrumbidgee catchment prior to (pre-study sampling) and collected as part of this study (revised sampling).

Pre-study sampling

NSW Landscape

Adelong Granite Ranges

Adrah Hills \& Ranges

Alpine Zone

Bogong Montane

Boorowa Volcanics

Breadalbane Swamps \& Lagoons

Burrinjuck Ridges

Cabramurra - Kiandra Basalt

Caps \& Sands

Canberra Plains

Carabost Hills \& Ranges

Coolangubra - Good Good Plateau

Cootamundra - Tumut Serpentinite \&

Ultramafics

Cullarin Range Fault Block

Dalton Hills

Doura Volcanics

Gourock - Tindery Ranges

Gourock - Tindery Slopes

Gundary Plains

Gunning Hills

Jagungal Tops

Jindabyne Plains

Jingera Valley

Kings Cross Montane

Kings Cross Sub-alpine

Lake George Complex

Main Range Sub-alpine

Marilba Range

Minjary Hills \& Ranges

Molonglo Channels \& Floodplains

Molonglo Ranges

Monaro Alluvium

Monaro Lakes

Monaro Plains Basalts \& Sands

Monaro Plains Granites

Monaro Plains Meta-sediments

Mt Bundarbo Basalt Caps

Murrumbidgee - Tarcutta Channels \&

Floodplains

Namadgi Range Alpine

Namadgi Range Montane

Namadgi Range Sub-alpine

Oberon - Kialla Granites

Pinbeyan - Ravine Ranges

Tantangara High Plains \& Peaks

Tooma Granite Ranges

Upper Murrumbidgee Channels \&

Floodplains

Upper Murrumbidgee Gorge

Upper Murrumbidgee Valley

Yarrangobilly - Cooleman Karst

Young Hills \& Slopes

\section{Area \% Previous \\ (ha) ${ }^{1} \quad$ vegetated $^{2}$ \\ no. of plots}

Sampling
intensity
(ha/plot)

$\begin{array}{ll}\text { New plots } & \begin{array}{l}\text { Revised } \\ \text { (this study) } \\ \text { total no. } \\ \text { of plots }\end{array}\end{array}$

$21,067 \quad 18$

$90,121 \quad 23$

$408 \quad 99$

$1,864 \quad 100$

$74,271 \quad 10$

$11,898 \quad 9$

$38,982 \quad 11$

$29,049 \quad 82$

$50,986 \quad 15$

$16,182 \quad 29$

$164,400 \quad 77$

$6,899 \quad 9$

$18,474 \quad 31$

$132,333 \quad 15$

$232,494 \quad 55$

$23,753 \quad 96$

$131,114 \quad 73$

$98,550 \quad 28$

20,299 6

$27,319 \quad 99$

$76,936 \quad 40$

$14,534 \quad 32$

$119,993 \quad 99$

74590

$46,789 \quad 9$

$22,951 \quad 92$

$27,284 \quad 16$

$70,801 \quad 39$

$2,934 \quad 35$

$134,740 \quad 55$

$2,931 \quad 26$

$428 \quad 32$

$96,295 \quad 34$

$2,353 \quad 46$

$27,928 \quad 48$

$4,760 \quad 28$

$1,461 \quad 9$

$14,739 \quad 100$

$121,850 \quad 66$

$74,816 \quad 98$

$5,446 \quad 11$

$28,500 \quad 94$

$33,508 \quad 95$

$140,144 \quad 52$

$9,598 \quad 5$

$18,365 \quad 21$

$40,681 \quad 35$

$3,292 \quad 91$

100,7109
632

864
37

932

743

535

1,072

449

588

4,693

1,073

155

nil

473

551

633

886

613

406

615

2,565

4,651

950

nil

602

3,519

141

531

nil

772

nil

17

1,056

nil

4,469

333

nil

278

406

431

150

1,914

1,592

714

nil

nil

1,187

214

267
Revised sampling

Revised

sampling

intensity

(ha/plot)

542

864

37

266

323

268

286

441

382

4,693

1,021

89

954

315

526

556

778

511

406

601

1,184

1,550

808

nil

301

1,320

132

502

171

628

nil

17

1,023

271

1,117

333

132

278

389

429

150

864

860

701

80

482

407

214

189

$\mathbf{1}$ within upper Murrumbidgee catchment plus $10 \mathrm{~km}$ buffer

2 Remnant vegetation (\% remaining) for entire NSW Landscape. Source: OEH (unpub. a) 


\section{Data analysis}

Floristic data collected from 4,106 field survey samples met the criteria for inclusion in the analysis. Of these, 738 samples (18\%) were not assigned to a final group for various reasons: these were generally identified by high allocation radii (association value) from nearest group centroids, and on detailed inspection were found to include highly disturbed sites; 'mixed' plots including both riparian or wetland taxa and elements of adjacent drier habitats; samples which claimed to be plots but appeared to be random meander lists from a range of habitats with very high species richness; and plots from surveys using species-importance schema that did not transform well to the modified Braun-Blanquet coverabundance scale used in this study. Grassland sites were not included in the final analysis as these had previously been analysed and classified by Rehwinkel (unpublished).

The remaining 3,368 field samples were assigned to 145 vegetation groups or plant communities across the broader analysis area. Of these, 67 plant communities were recorded within the upper Murrumbidgee catchment or considered likely to occur there. An additional eight grassland communities were identified through the process described by Rehwinkel (unpublished). These 75 plant communities are listed in Table 6 and described in Appendix 1. Coarse floristic relationships between the plant communities identified in this study are indicated by the dendrogram (Figure 5).

Specific relationships between the plant communities identified by this study and those identified by previous numerical classifications (Benson \& Jacobs 1994, Gellie 2005, McDougall \& Walsh 2007 and Tozer et al. 2010) were explored by comparing the assignments of sites to groups between the current study and these previous classifications. The table in Appendix 2 indicates the strongest relationships identified between current and previous classification groups.

The upper Murrumbidgee catchment area overlaps to different extents the classification studies of Gellie (2005) and Tozer et al. (2010) and general relationships between the plot clusters identified by this study and the earlier regional classifications were examined. In areas of overlap, the current study utilised all of the field survey plots classified by these previous studies as well as additional recent survey data. The number of groups identified from field survey plots shared by the current and earlier works indicates that Gellie
(2005) identified groups at a finer classification scale than the current project [ 895 shared sites allocated to 75 groups by Gellie (2005) and 67 groups by the current study], while classification by Tozer et al. (2010) was at a similar scale to that of the current study (44 shared sites into 13 groups versus 14 groups in the current study). The current study classified an additional 683 field survey plots in the area of overlap with Gellie (2005) and an additional 29 plots in the area of overlap with Tozer et al. (2010) (Table 5).

\section{Vegetation distribution}

The 75 plant communities identified by numerical analysis from the upper Murrumbidgee catchment [including grasslands identified by Rehwinkel (unpublished)] occur across 18 of the NSW Vegetation Classes within nine of the Structural Formations described by Keith (2004) (Table 6). The sampled distribution of plant communities within each Structural Formation is shown in Figure 6 (refer to Appendix 1 for sampled distribution of each plant community).

Plant communities within the Alpine Complex Formation are distributed primarily in higher parts of the Australian Alps bioregion, although there are examples of these communities within montane environments in adjacent areas of the South Eastern Highlands. Rainforests, while defined from plots outside of the upper Murrumbidgee catchment, are known to occur in the Bogong Peaks Wilderness Area (Greening Australia 2011). Wet sclerophyll forests are generally found in the Brindabella, Namadgi and western fall of the main Kosciuszko range areas in the west, the Tallaganda ranges in the east, and in between at Tinderry NR where a variety of taxa characteristic of both eastern and western wet sclerophyll environments occur. Dry sclerophyll forests occur on relatively infertile exposed hills and slopes across most of the study area exclusive of the Kosciuszko main range. Heathlands are found on exposed ridges in Dangelong NR in the southeast of the upper Murrumbidgee catchment, and may occur in similar locations. Forested wetlands occur primarily on major water courses as narrow remnants on alluvial plains, or surrounded by dry sclerophyll forests in riverine gorges. Freshwater wetlands occur in depressions of variable size across the Monaro and in montane areas as bogs and fens. Grassy woodlands generally occur as degraded remnants across much of the upper Murrumbidgee catchment (exclusive of the Monaro rain shadow grassland and treeless alpine areas), as small remnants across the highly cleared

Table 5: Comparison of site availability and classification scale in areas of overlap between the upper Murrumbidgee catchment and those of Gellie (2005) and Tozer et al. (2010).

\begin{tabular}{|c|c|c|c|c|c|c|}
\hline Previous Study & $\begin{array}{l}\text { Area shared } \\
\text { with current } \\
\text { study area (ha) }\end{array}$ & $\begin{array}{l}\text { Number of sites } \\
\text { classified in this } \\
\text { study shared with } \\
\text { previous study }\end{array}$ & $\begin{array}{l}\text { Number of } \\
\text { groups to which } \\
\text { those sites were } \\
\text { allocated by each } \\
\text { previous study }\end{array}$ & $\begin{array}{l}\text { Number of } \\
\text { groups to which } \\
\text { those sites were } \\
\text { allocated by the } \\
\text { current study }\end{array}$ & $\begin{array}{l}\text { Number of sites } \\
\text { classified in this } \\
\text { shared area by } \\
\text { the current study }\end{array}$ & $\begin{array}{l}\text { Number of groups } \\
\text { to which those sites } \\
\text { were allocated by } \\
\text { the current study }\end{array}$ \\
\hline
\end{tabular}

$\begin{array}{lllllll}\text { Gellie (2005) } & 1.817,000 & 932 \text { sites } & 77 \text { groups } & 43 \text { groups } & 1627 \text { sites } & 68 \text { groups } \\ \text { Tozer } \text { et al.( (2010) } & 258,000 & 75 \text { sites } & 14 \text { groups } & 16 \text { groups } & 155 \text { sites } & 23 \text { groups }\end{array}$




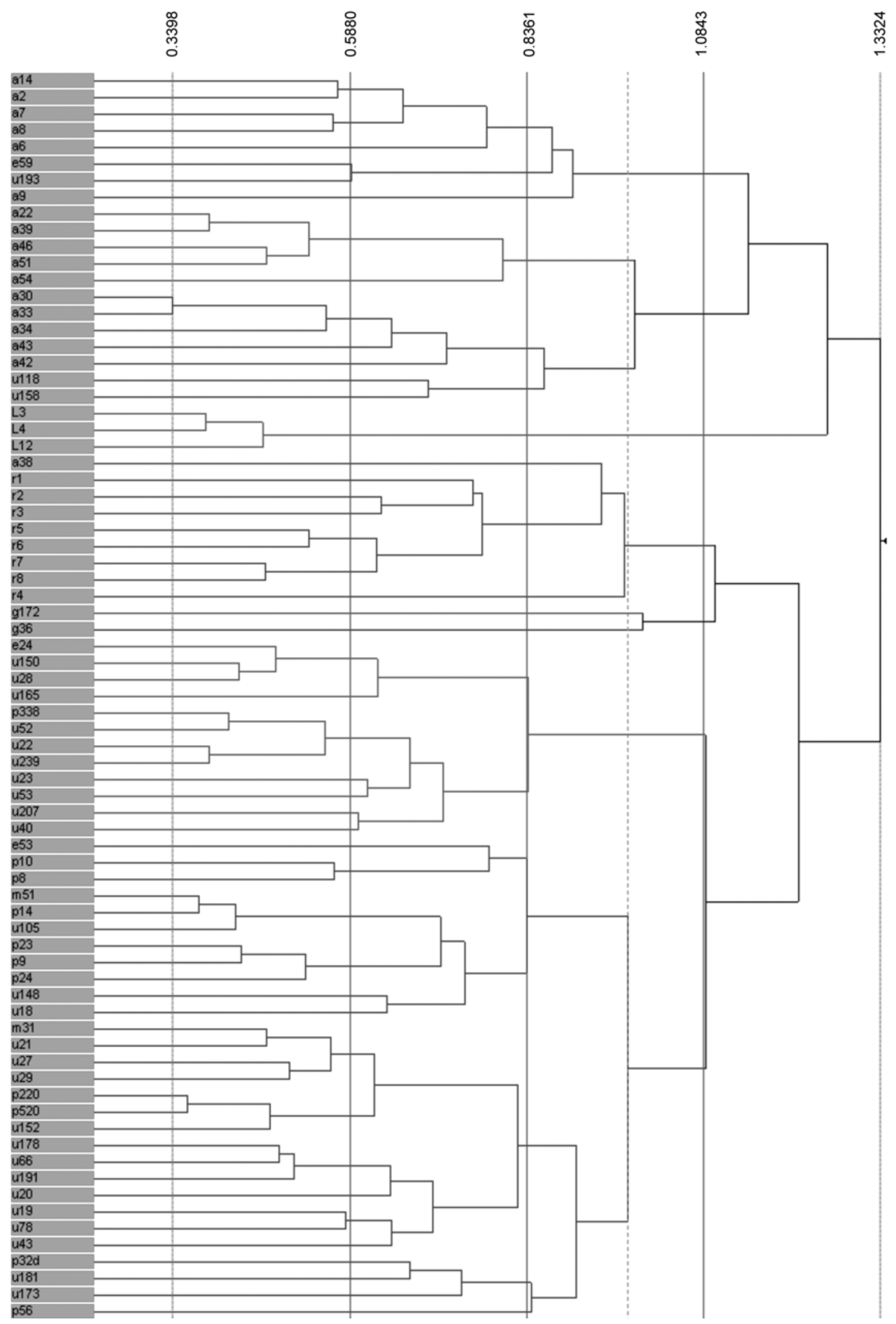

Fig. 5. Dendrogram showing hierarchical relationships between 75 vegetation communities of the upper Murrumbidgee catchment identified from analysis of quantitative survey plot data. 


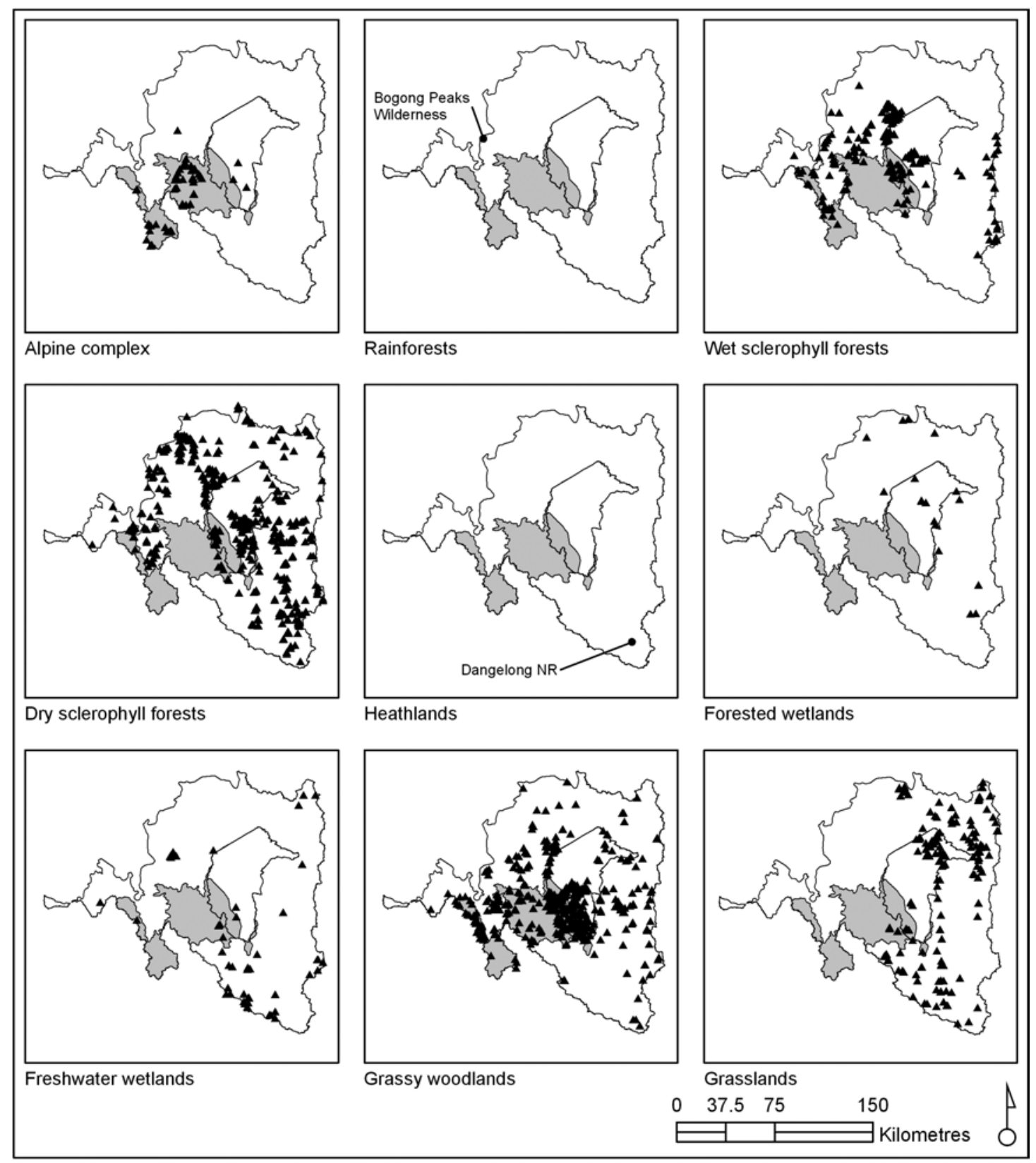

Fig. 6. Distribution of plots occurring within the upper Murrumbidgee catchment area assigned to plant communities in each Structural Formation [Known (rather than sampled) distribution of Rainforest and Heathland also shown; Australian Alps bioregion shaded].

Monaro and Murrumbateman subregions and as patches amongst wet or dry sclerophyll forests. Grasslands are known primarily from valleys and depressions influenced by cold air drainage prohibiting tree growth, and on open basalt plains of the Monaro.

\section{Threatened Ecological Communities}

Of the 75 plant communities listed in Table 6, four have affinities with Threatened Ecological Communities (TECs) currently listed under the EPBC Act 1999, three with communities listed on schedules of the TSC Act 1995, and two declared under the NC Act 1980 (Table 7).

\section{Discussion}

\section{Factors guiding the distribution of plant communities}

While producing a vegetation map was beyond the scope of this study, the distribution of plot data provides an indicative distribution of plant communities in the upper Murrumbidgee catchment and surrounds (Figure 6; refer to maps in Appendix 1 for sampled distribution of individual plant communities). The distribution of Structural Formations is generally guided by strong variation in climate (precipitation, temperature and wind), topographic relief (altitude, slope and aspect) and broad lithology. Within each Formation, plant communities are distributed based on finer scale variations of these, along with changes in soil fertility, acidity, frost persistence, water 
retention and humification. Where relevant, the descriptions of individual plant communities in Appendix 1 include discussion of environmental factors considered likely to be influencing distribution.

\section{Non-floristic factors which may influence vegetation classification}

The ability of analytical processes (such as clustering algorithms) to identify recurring plant associations at a consistent classification level can be influenced by variable density or bias in sampling intensity (see Bell 2013), survey timing (e.g. season and precedent wet/dry conditions), sampling effort, species misidentifications and estimation of cover-abundance (see discussion by Tozer et al. 2010). The influence of these factors is potentially greatest when particular areas or habitat types are only sampled by one survey or surveyor and there is no alternative source of field data. As outlined in the Results section, data lineage and potential bias was considered throughout the analysis to ensure plant communities were not defined based on sampling artefacts. Nevertheless, we have identified some plant communities that are defined primarily on the basis of a single survey. Generally, these plant communities occupy ecological niches subject to specific studies such as treeless alpine areas or wetlands of the Monaro. Three woodland/ forest plant communities were also identified on the basis of one survey: u20: Kurrajong - Bursaria spinosa - Themeda australis shrub-grass mid-high open woodland on limestone karsts in the Wee Jasper area; u66: Mealy Bundy - Red Stringybark grass-herb mid-high open forest of the South Eastern Highlands and Upper Slopes Subregion of the South Western Slopes bioregion; and u191: Black Cypress Pine - Brittle Gum tall dry open forest on hills primarily in the Cooma region. Each of these plant communities was identified through data collected in poorly sampled landscapes and dominated by a distinct suite of taxa not characteristic of other plant communities within the broader analysis area. We believe these plant communities are sound but more widespread sampling in similar vegetation will be useful to confirm this and better define relationships with other plant communities.

Numerical classification of plant communities relies on survey plots distributed across the environmental domains considered to govern plant distributions. Plant communities which occur in domains primarily distributed outside a study area may be poorly described, or remain unrecognised, as their full range of variation has not been sampled. For this reason, it is appropriate for vegetation classification studies to include a buffer beyond the study area boundary and include plot samples that assist in adequately identifying and describing such plant communities by incorporating data from across their full environmental domain. In the current study of the upper Murrumbidgee catchment area classification being based on samples from a much larger area of interest, the "broader analysis area" (covering the NSW sections of the Australian Alps and South East Highlands bioregions, from the Victorian border north to the Oberon shire, and the Boorowa Shire). This broader analysis area allowed exploration of relationships between plant communities in the upper Murrumbidgee catchment and the bioregions that it sits within, ensuring that plant communities defined in the upper Murrumbidgee catchment fit within a broader bioregional context.

Differentiation between natural plant communities may also be blurred by widespread disturbance in sampled vegetation, an effect which may be stronger in some plant communities than others. In native vegetation remnants on the tablelands of NSW, for example, disturbance associated with grazing (including selective removal of more durabletimbered tree species, long exclusion of fire, increased soil nitrogen, loss of palatable understorey taxa, invasion by exotic plants and selective grazing of more palatable herbs) (e.g. see Leigh \& Holgate 1979; Prober \& Thiele 2005) may lead to simplification of structure and composition and consequent blurring of floristic differences between related plant communities. In the current study, plant communities associated with landscapes of high to moderate agricultural suitability are likely to be most prone to classification blurring, such as vegetation of moist alluvium, grassy woodlands and grasslands of undulating tableland and slopes landscapes.

The ability of numerical classification to identify plant associations at a consistent classification level can also be influenced by plot size. Otýpková \& Chytrý (2006) found that variation in plot size affected the ability of ordination techniques to identify stable groups and potentially distorted plant community group clustering in ordination. Two plots sampling the same plant community with widely different plot sizes may have reduced association or similarity values simply because a larger plot may include taxa absent from the smaller plot. The effect of plot size on ordination was not tested as part of this study, rather floristic information was reviewed to exclude plots that were considered unusual (e.g. likely to be sampling across an ecotone or collected through random-meander). Plot size could be dictated at a Structural Formation classification level (or a similar broad classification) to guide appropriate plot size relative to functions of scale and floristic variation. For example, McDougall (1978) found that a plot size of $8 \mathrm{~m}^{2}$ was sufficient to capture $95 \%$ of species in a diverse open heathland on the Bogong High Plains in the Australian Alps bioregion in Victoria. Neldner \& Butler (2009) suggest that, in Queensland, the rate of new species being encountered in rainforests did not decline until about 2,000 $\mathrm{m}^{2}$ had been sampled.

In the present study, variable plot size was potentially a strong influence in the identification of tableland lake plant communities. The majority of samples from this habitat available to the present study (65 out of 76) were whole-lake samples by Benson \& Jacobs (1994), recording all plant taxa from both the strandline margin and standing water of each lake surveyed. Lakes ranged in size from less than 1 ha up to 215 ha, with a median size of over 5 ha. In contrast, the 11 more recent lake samples involved 0.04 ha plots, generally located in standing water parts of wetlands. In the cluster analysis, the Monaro lake samples showed a clear tendency 
Table 6: Plant communities occurring in the upper Murrumbidgee catchment area, and their relationship with the Vegetation Classes and Structural Formations of Keith (2004).

\section{ALPINE COMPLEX}

\section{Class: Alpine Herbfields}

a6: Ranunculus millanii - Pratia surrepens - Carex gaudichaudiana herbfield of shallow depressions in the Australian Alps bioregion

a14: Poa costiniana - Carex gaudichaudiana subalpine valley grassland of the Australian Alps bioregion

a22: Poa fawcettiae - Celmisia costiniana - Craspedia maxgrayi grassland of the Australian Alps bioregion

a30: Poa hookeri - Poa clivicola - Oreomyrrhis argentea - Ranunculus graniticola grassland of the Australian Alps bioregion

a38: Themeda australis - Galium roddii - Leucochrysum alpinum grassland of steep limestone slopes in the Australian Alps bioregion

Class: Alpine Heaths

a33: Bossiaea foliosa - Cassinia monticola - Kunzea muelleri - Hovea montana heathland of the Australian Alps bioregion

a39: Epacris sp. - Pentachondra pumila - Poa fawcettiae heathland of the Australian Alps bioregion

a42: Epacris celata - Poa clivicola - Dillwynia palustris grassy heathland of the Australian Alps bioregion

a43: Bossiaea riparia - Themeda australis low open heathland of the Australian Alps bioregion

a46: Prostanthera cuneata - Orites lancifolius - Nematolepis ovatifolia heathland of the Australian Alps bioregion

a51: Podocarpus lawrence - Rytidosperma alpicola - Brachyscome nivalis low open heathland of rock outcrops of the Australian Alps bioregion

a54: Podocarpus lawrencei - Pimelea ligustrina subsp. ciliata heathland of screes and boulder-fields of the Australian Alps bioregion

g36: Leptospermum micromyrtus - Kunzea muelleri - Kunzea ericoides dry heathland on skeletal ridges primarily of the Namadgi region

Class: Alpine Bogs and Fens

a2: Baeckea gunniana - Epacris paludosa - Richea continentis - Sphagnum cristatum wet heathland of the Australian Alps bioregion (Bog) a7: Ranunculus pimpinellifolius - Gonocarpus micranthus herbfield of wetland margins in the Australian Alps bioregion

a8: Carex gaudichaudiana - Myriophyllum pedunculatum - Deschampsia cespitosa sedgeland of the Australian Alps bioregion (Fen)

\section{RAINFORESTS}

\section{Class: Cool Temperate Rainforests}

g172: Black Sassafras temperate rainforest of wet sheltered slopes in the Australian Alps and Bondo subregion of the South Eastern Highlands bioregions

\section{WET SCLEROPHYLL FORESTS}

\section{Class: Montane Wet Sclerophyll Forests}

u40: Alpine Ash very tall wet sclerophyll open forest primarily of the Australian Alps bioregion

u53: Mountain Gum - Blackwood tall wet sclerophyll open forest primarily on granitoids of the Australian Alps and western South Eastern Highlands bioregions

u239: Alpine Ash - Mountain Gum \pm Snow Gum wet sclerophyll open forest of the Australian Alps and South Eastern Highlands bioregions

\section{Class: Southern Tableland Wet Sclerophyll Forests}

u52: Ribbon Gum - Robertson's Peppermint very tall wet sclerophyll open forest primarily of the Bondo subregion of the South Eastern Highlands and the northern Australian Alps bioregions

\section{Class: Southern Escarpment Wet Sclerophyll Forests}

p338: Brown Barrel wet sclerophyll very tall grass-herb open forest primarily of the Gourock and Tallaganda Ranges in the South Eastern Highlands bioregion 


\section{DRY SCLEROPHYLL FORESTS}

\section{Class: Southern Tableland Dry Sclerophyll Forests}

e24: Mountain Gum - Snow Gum very tall dry shrubby open forest primarily in the Kybeyan - Gourock subregion of the South Eastern Highlands bioregion

m31: Ribbon Gum - Snow Gum - Cassinia longifolia tall shrub-grass open forest of gullies in quartz-rich ranges in the Monaro and KybeyanGourock subregions of the South Eastern Highlands bioregion

m51: Brittle Gum - Scribbly Gum shrub-grass tall dry sclerophyll open forest on exposed quartz-rich slopes and ridges at primarily in the Monaro and Kybeyan - Gourock subregions of the South Eastern Highlands bioregion

p8: Silvertop Ash - Narrow-leaved Peppermint shrubby tall dry open forest primarily on sedimentary ridges of the eastern South Eastern Highlands bioregion

p10: Black She-oak - Silvertop Ash tall shrubby dry sclerophyll open forest primarily in the Bungonia subregion of the South Eastern Highlands bioregion

p9: Brittle Gum - Scribbly Gum shrubby tall dry open forest on infertile low ridges and hills primarily of the Bungonia subregion of the South Eastern Highlands bioregion

p14: Red Stringybark - Scribbly Gum - Rytidosperma pallidum tall grass-shrub dry sclerophyll open forest on loamy ridges of the central South Eastern Highlands bioregion

p23: Red Stringybark - Broad-leaved Peppermint tall dry sclerophyll grassy open forest on loamy rises primarily in the Bungonia subregion of the South Eastern Highlands bioregion

u18: Mealy Bundy - Broad-leaved Peppermint shrubby mid-high open forest on granite substrates primarily in the South Eastern Highlands u21: Broad-leaved Peppermint - Candlebark tall dry sclerophyll open forest of quartz-rich ranges of the upper South East Highlands and lower Australian Alps bioregions

u29: Apple Box - Broad-leaved Peppermint tall shrub-grass open forest primarily on granitoids of the South Eastern Highlands bioregion u105: Broad-leaved Peppermint - Brittle Gum - Red Stringybark tall shrub-grass dry sclerophyll open forest of lower ranges of the western South Eastern Highlands and upper South Western Slopes bioregions

u148: Red Stringybark - Red Box grass-forb tall open forest of the upper South Western Slopes and western South Eastern Highlands bioregions u150: Broad-leaved Peppermint - Mountain Gum shrubby tall open forest of the South Eastern Highlands and Australian Alps bioregions u152: Robertson's Peppermint - Red Stringybark very tall grass-forb sheltered open forest of the southwest South Eastern Highlands and upper South Western Slopes bioregions

u165: Robertson's Peppermint very tall shrubby open forest primarily of the Bondo subregion of the South Eastern Highlands bioregion u191: Black Cypress Pine - Brittle Gum tall dry open forest on hills primarily in the Cooma region

\section{Class: Upper Riverina Dry Sclerophyll Forests}

u43: Mealy Bundy - Acacia implexa - Allocasuarina verticillata - Ricinocarpos bowmanii tall grassy open woodland on serpentinite in the Coolac-Goobarragandra area primarily of the upper South Western Slopes bioregion

u66: Mealy Bundy - Red Stringybark grass-forb mid-high open forest of the South Eastern Highlands and Upper Slopes Subregion of the South Western Slopes bioregion

\section{HEATHLANDS}

\section{Class: Southern Montane Heaths}

e53: Allocasuarina nana shrubland on exposed skeletal ridges of primarily in the eastern South Eastern Highlands bioregion

\section{FORESTED WETLANDS}

\section{Class: Eastern Riverine Forests}

p32d: River She-oak riparian forest on sand/gravel alluvial soils along major watercourses of the South Eastern Highlands and upper South Western Slopes bioregions

p56: Leptospermum grandifolium - Hakea microcarpa - Lomatia myricoides riparian very tall shrubland of the eastern South Eastern Highlands bioregion

u181: Callistemon sieberi - Kunzea ericoides rocky riparian tall shrubland in the South Eastern Highlands and upper South Western Slopes bioregions 


\section{FRESHWATER WETLANDS}

\section{Class: Inland Riverine Forests}

u173: River Red Gum \pm Apple Box very tall grass-forb riparian woodland on alluvial flats in the South Eastern Highlands and upper South Western Slopes bioregions

\section{Class: Montane Bogs and Fens}

a9: Carex gaudichaudiana - Ranunculus amphitrichus - Phragmites australis aquatic herbfield of waterways in the Australian Alps and South Eastern Highlands bioregions

e59: Hakea microcarpa - Baeckea utilis - Leptospermum myrtifolium subalpine wet heathland on escarpment and eastern tableland ranges of the South Eastern Highlands bioregion

u193: Hakea microcarpa - Epacris breviflora - Epacris paludosa subalpine wet heathland of the Australian Alps and western South Eastern Highlands bioregions

\section{Class: Montane Lakes}

L12: Freshwater sedge-herb marsh of shallow, commonly inundated wetlands of the eastern South Eastern Highlands bioregion

L3: Freshwater sedge-herb marsh of shallow ephemeral lakes of the eastern South Eastern Highlands bioregion

L4: Freshwater sedge-herb marsh of deep semi-permanent and/or slightly saline wetlands of the eastern South Eastern Highlands bioregion

\section{GRASSY WOODLANDS}

\section{Class: Subalpine Woodlands}

a34: Weeping Snow Gum shrub-grass open woodland of the Australian Alps bioregion

u22: Mountain Gum - Snow Gum \pm Robertson's Peppermint grass-forb very tall woodland to open forest of the Australian Alps and South Eastern Highlands bioregions

u23: Snow Gum - Drumstick Heath - Leptospermum myrtifolium tall woodland to open forest of drainage depressions primarily of the South Eastern Highlands bioregion

u27: Snow Gum - Candlebark tall grassy woodland in frost hollows and gullies of the South Eastern Highlands bioregion

u28: Snow Gum - Mountain Gum - Daviesia mimosoides tall dry grass-shrub subalpine open forest of the Australian Alps and South Eastern Highlands bioregions

u118: Black Sallee grass-herb woodland in drainage depressions and moist valley flats in the South Eastern Highlands and Australian Alps bioregions

u158: Alpine Sallee shrub-grass subalpine mid-high woodland of the Australian Alps bioregion

u207: Jounama Snow Gum - Snow Gum shrubby mid-high woodland on granitoids primarily of the Namadgi region

\section{Class: Southern Tableland Grassy Woodlands}

p24: Yellow Box - Blakely's Red Gum tall grassy woodland on undulating sedimentary and acid-volcanic substrates in the Goulburn area of the South Eastern Highlands bioregion

u19: Blakely's Red Gum - Yellow Box \pm White Box tall grassy woodland of the Upper South Western Slopes and western South Eastern Highlands bioregions

u20: Kurrajong - Bursaria spinosa - Themeda australis shrub-grass mid-high open woodland on limestone karsts in the Wee Jasper area u178: Yellow Box \pm Apple Box tall grassy woodland of the South Eastern Highlands bioregion

\section{Class: Tableland Clay Grassy Woodlands}

p220: Ribbon Gum - Snow Gum tableland flats tall grassy woodland primarily on granitoids in the Kybean - Gourock and Monaro subregions of the South Eastern Highlands bioregion

p520: Ribbon Gum very tall woodland on alluvial soils along drainage lines of the eastern South Eastern Highlands bioregion

u78: Snow Gum grassy mid-high woodland of the South Eastern Highlands bioregion

\section{Class: Temperate Montane Grasslands}

r1: Sub-montane moist tussock grassland of the South Eastern Highlands bioregion

r2: Poa labillardierei - Themeda australis - Juncus sp. wet tussock grassland of footslopes, drainage lines and flats of the South Eastern

Highlands bioregion

r3: Rytidosperma sp. - Themeda australis - Juncus sp. tussock grassland of occasionally wet sites of the South Eastern Highlands bioregion

r4: Lacustrine Grass-forbland of the South Eastern Highlands bioregion

r5: Rytidosperma sp. - Austrostipa bigeniculata - Chrysocephalum apiculatum tussock grassland of the South Eastern Highlands bioregion

r6: Dry tussock grassland of the Monaro in the South Eastern Highlands bioregion

r7: Themeda australis - Rytidosperma sp. - Poa sieberiana moist tussock grassland of the South Eastern Highlands bioregion

r8: Themeda australis - Lomandra filiformis - Aristida ramosa dry tussock grassland in the South Eastern Highlands bioregion 
to form three main groups identified by Benson \& Jacobs (1994), with minor shifts in group membership. The newer 0.04 ha plot samples showed a moderate tendency to join the larger Monaro groups; as there were no strong differences in elevation, substrate or other factors to justify a separation between the wetland vegetation sampled by newer plots and the Monaro whole-lake wetland samples, the plot samples were assigned to the Monaro groups. Further sampling and clarification of tableland lake communities using a consistent set of methods is desirable, particularly as larger lake systems with variable water depth may contain more than one plant community.

\section{Relationships with overlapping previous regional classifications}

Based on comparisons of group memberships, the plant communities identified by the current study show varying relationships with groups identified by previous studies (Appendix 2). The treeless alpine plant communities identified by McDougall \& Walsh (2007) are largely retained in the current study, with some merging of related types reflecting a somewhat broader classification scale applied by the current study, and the absence of Victorian plots in the analysis. The tableland lake communities identified by Benson \& Jacobs (1994) are also essentially retained, with two highly similar types merged. Many of the plant communities identified in the east of the current study area have clear relationships with the associations identified by Tozer et al. (2010), however some are described in the context of the broader analysis area based on inclusion of a larger pool of tableland samples than was available to that study, and to some extent, a different study area context. In the central and western parts of the upper Murrumbidgee catchment, relationships between plant communities of the current study and the vegetation groups of Gellie (2005) are far more complex, with few close equivalents. This different relationship may be attributable to the different classification scales adopted, and to the significant additional field survey data available to the current study both within areas of overlap and extending beyond previous study boundaries (see Table 5).

The reader should be aware that two communities with the same identifier in different classifications may have a different diagnostic species list in each. This may be caused by the additional plots available to the current study or differences in study area boundaries. For instance, plant community p14 in the current classification contains 101 of 154 plots used by Tozer et al. (2010) to define map unit p14 in that study, and an additional 64 plots that were not used in the original classification. Map unit p14 as defined by Tozer et al. (2010) and p14 as described in this study are likely to be equivalent, given the dominance of plots used in the initial classification and the similarity in diagnostic species. Similarly, Community p520 as described in Tozer et al. (2010), while considered equivalent to p520 in this study, contains a higher frequency of Eucalyptus pauciflora ssp. pauciflora, with less Eucalyptus stellulata.

The effect of spatial context is especially strong when considering plant communities occurring on the edge of the broader analysis area. For example, the broader analysis area of the current study overlaps the study area of Tozer et al. (2010) to the east and north, and a number of eastern escarpment and central tablelands vegetation types identified by that study are peripheral to the broader analysis area, with just a small portion of their distribution overlapping. Of the 30 field samples allocated to map unit e11 [Tantawangalo Wet Shrub Forest] by Tozer et al. (2010), only one was in the broader analysis area; of 131 samples of p40 [Temperate Dry Rainforest], three were in the broader analysis area; and of 125 samples allocated by Tozer et al. (2010) to p144 [Wingecarribee-Burragorang Sandstone Forest], only two were in the broader analysis area. Where the majority of an original group's membership was outside the broader analysis area, samples were automatically allocated to the

Table 7: Relationships between plant communities described in this study and Threatened Ecological Communities under Commonwealth, NSW and ACT legislation.

\section{Threatened Ecological Community}

Alpine Sphagnum Bogs and Associated Fens

Montane Peatlands and Swamps of the New England Tableland, NSW

North Coast, Sydney Basin, South East Corner, South Eastern Highlands and Australian Alps bioregions

Natural Temperate Grassland

Natural Temperate Grassland of the Southern Tablelands of NSW and the Australian Capital Territory

Tablelands Snow Gum, Black Sallee, Candlebark and Ribbon Gum Grassy TSC Act 1995

Woodland in the South Eastern Highlands, Sydney Basin, South East

Corner and NSW South Western Slopes bioregions

Upland Wetlands of the New England Tablelands and the Monaro Plateau

White Box Yellow Box Blakely's Red Gum Woodland

White Box Yellow Box Blakely's Red Gum Grassy Woodland and Derived EPBC Act 1999 Native Grassland

Yellow Box/Red Gum Grassy Woodland
EPBC Act 1999

TSC Act 1995

\author{
Legislation \\ Plant community \\ EPBC Act 1999 a2, a8 \\ TSC Act 1995 a2, a7, a8, e59, u193
}

NC Act $1980 \quad r 1, r 2, r 3, r 5, r 7, r 8$

$\mathrm{r} 1, \mathrm{r} 2, \mathrm{r} 3, \mathrm{r} 4, \mathrm{r} 5, \mathrm{r} 6, \mathrm{r} 6, \mathrm{r} 8$

u27, u118, p220, p520, u78 (all); e24, m31, u21, u22, u23, u28 (may contain)

L12, L3, L4

p24, u19, u178 (all); p23, u20 (may contain)

p24, u19, u178 (all); p23, u20 (may contain)

r178, u19 
group identified by Tozer et al. (2010). However, none of these plant communities occur in the upper Murrumbidgee catchment.

The large number of endemic species in plant communities in the Australian Alps means that diagnostic taxa may be identified for these communities simply because they do not occur in non-Alps communities. The diagnostic taxa are therefore useful for distinguishing Alps communities from non-Alps communities but not necessarily for distinguishing Alps communities from each other. We suggest that users attempting to identify Alps communities place less value on species that are diagnostic in many Alps communities (e.g. Carex gaudichaudiana, Poa costiniana, Grevillea australis) and make decisions based on the presence of many taxa from the diagnostic species list.

The diagnostic species lists in this paper will aid plant community identification within the upper Murrumbidgee catchment but should not be used to identify the same communities beyond. When a seamless plant community classification is produced for NSW, the floristic character of the resulting communities, which will be based on all available data and their entire extent, may be subtly different from the current and previous classifications.

The method for identifying diagnostic taxa in this study has been used in several plant community classifications in NSW. Experience from this study suggests that development of a less context-sensitive measure of fidelity (the basis for the identification of diagnostic taxa), is desirable for large regional classifications. Alternative metrics are presented by De Cáceres et al. (2008).

\section{Threats to plant communities}

Whilst legislation [e.g. Native Vegetation Act 2003 (NSW) and the Planning and Development Act 2007(ACT)] has reduced the threat of broad scale clearing in NSW and the ACT, many of the plant communities described in this study are subject to ongoing threats. Land-clearing, stock and feral herbivore grazing, weed invasion, altered hydrology, climate change and alteration of fire regimes continue to significantly reduced the distribution, floristic integrity and genetic variability of vegetation across the landscape (Keith \& Auld 2009). This is evident in the majority of plant communities within the upper Murrumbidgee catchment, and perhaps more so in Grassy Woodlands, Grasslands, Forested Wetlands and Freshwater Wetlands Formations occurring in highly altered landscapes at lower elevations. Many Dry Sclerophyll Forests, Wet Sclerophyll Forests and Heathlands are relatively well protected in the formal reserve system or managed on Forests NSW estate. Plant communities in the Alpine Complex are, for the most part, well protected in the formal reserve system. However, even in the Alps, changes in vegetation distribution and functionality are likely to occur due to increased temperatures, decreased precipitation and decreased duration of snow cover related to anthropogenic climate change (Pickering \& Armstrong 2003). Rainforests, while formally reserved and small in extent, need to be protected from extreme fire events. The scale of threat to all plant communities identified in this study and the adequacy of protection can only be assessed once mapping and detailed threat analysis has been completed.

Nine Threatened Ecological Communities (TEC) under Commonwealth, NSW and ACT legislation occur in the upper Murrumbidgee catchment (Table 7). This study has also identified five additional plant communities which are highly restricted in distribution and may require active management or protection to ensure their survival. Community g172 [Black Sassafras temperate rainforest of wet sheltered slopes in the Australian Alps and Bondo subregion of the South Eastern Highlands bioregions] is found in isolated patches along creeks in the Bogong Peaks wilderness area, Geehi Valley, and Jacobs and Pinch River Gorges. It occurs in small and potentially genetically isolated patches which, to date, have escaped severe wildfires (Doherty et al. 2011, Greening Australia 2011). Community u20 [Kurrajong - Bursaria spinosa - Themeda australis shrub-grass midhigh open woodland on limestone karsts in the Wee Jasper area] is highly restricted, believed to have approximately 10 ha remaining and contains a number of threatened and unusual plant taxa. Community u43 [Mealy Bundy Acacia implexa - Allocasuarina verticillata - Ricinocarpos bowmanii tall grassy open woodland on serpentinite in the Coolac-Goobarragandra area primarily of the upper South Western Slopes bioregion] is restricted in distribution, and is highly fragmented with little recruitment of woody species observed within sampled areas. Community u173 [River Red Gum \pm Apple Box very tall grass-forb riparian woodland on alluvial flats in the South Eastern Highlands and upper South Western Slopes bioregions] occurs on fertile alluvial flats adjacent to major rivers and has been extensively cleared, with isolated remnants commonly degraded by grazing and weed invasion. Community a54 [Podocarpus lawrencei - Pimelea ligustrina subsp. ciliata heathland of screes and boulder-fields of the Australian Alps bioregion] is highly restricted and the primary habitat of the endangered Mountain Pygmy Possum. Most examples of community a54 in NSW were burnt in 2003, with the dominant species of this species-poor community (Podocarpus lawrencei) sensitive to fire (McDougall et al. 2012), potentially taking a decade or more to be reproductive. These communities should be assessed for eligibility for protection under State and/or Commonwealth legislation.

\section{Acknowledgements}

This study was funded by Catchment Action NSW.

The authors would like to thank Geoff Robertson and John Briggs from the NSW Office of Environment and Heritage; Greg Baines, Margaret Kitchin, Emma Cook and Luke Johnston from ACT Environment and Sustainable Development Directorate; Michael Doherty from CSIRO Sustainable Ecosystems; John Benson from NSW Royal Botanic Gardens and Domain Trust and Jackie Miles for their ongoing support and advice on specific communities within the upper Murrumbidgee catchment. In particular, Geoff Robertson and John Briggs contributed text to specific 
plant community descriptions. Nicki Taws, Bindi Vanzella (Greening Australia ACT); Tom O'Sullivan (Bluegum Ecological Consulting); Ryan Smithers, Bruce Mullins, Phil Gilmour (EcoLogical Australia Pty. Ltd.); David Eddy (private consultant), John Briggs, Geoff Robertson and the authors undertook additional plot survey in spatial and thematic gaps. Staff from the Murrumbidgee CMA provided initial liaison with private landholders to facilitate survey access. Plant community type photographs were supplied by the authors and other staff of the Office of Environment \& Heritage, ACT Environment and Sustainable Development Directorate, David Eddy, Phil Gilmour and Jackie Miles. The authors would also like to thank the anonymous referees for reviewing and improving the manuscript.

\section{References}

AALC (undated) Fire monitoring project: established 1996. Australian Alps Liaison Committee - NSW National Parks and Wildlife Service, ACT Parks and Conservation Service, Vic. Department of Natural Resources.

ACT CP\&R (2010) Unpublished flora survey data from ACT targeted vegetation types by B.J. Mullins and M. Sullivan. Collected for ACT Conservation Planning and Research, Canberra.

ANBG (2011) Australian National Botanic Gardens Australian Plant Census [URL: http://www.anbg.gov.au/chah/apc/]. Website accessed July 92012.

Anderson, R.H. (1961) Introduction. Flora series nos. 1-18: 1-16. Contributions from the New South Wales National Herbarium. Royal Botanic Gardens: Sydney.

Anonymous (2009) Bioclim annual mean precipitation $250 \mathrm{~m}$ climate grid, 2009. OEH corporate data holdings.

Bedward, M. (1999). Fidel: A utility to profile classification groups in terms of attribute fidelity (Version 2.1 for Windows 9x/NT). Unpublished report for NSW National Parks and Wildlife Service Southern CRA Unit, Queanbeyan.

Bedward, M., Ellis, M. \& Gleeson, P. (2011) YETI version 3.2.27. Yet another vegetation survey database. NSW National Parks and Wildlife Service, compiled $11^{\text {th }}$ March 2011.

Bedward, M., Keith, D.A. \& Pressey, R.L. (1992) Homogeneity analysis: assessing the utility of classifications and maps of natural resources. Australian Journal of Ecology 17: 133-139.

Belbin, L. (1995a) Users guide - PATN pattern analysis package. CSIRO Division of Wildlife and Ecology, Canberra.

Belbin, L. (1995b) Technical reference - PATN pattern analysis package. CSIRO Division of Wildlife and Ecology, Canberra.

Bell, S. A. J. (2013) Defining and mapping vegetation communities: improving techniques to assist land-use planning and conservation. PhD thesis University of Newcastle.

Benson, J.S. (1994) The native grasslands of the Monaro region: southern tablelands of New South Wales. Cunninghamia 3: 609-650.

Benson, J. S. (2006) New South Wales vegetation classification and assessment: introduction - the classification, database, assessment of protected areas and threat status of plant communities. Cunninghamia 9: 331-382.

Benson, J.S. (in prep.) New South Wales vegetation classification and assessment: Part 4. Plant communities of the west South Eastern Highlands and Australian Alps bioregions. Botanic Gardens Trust, Sydney.

Benson, J.S. \& Jacobs, S.W.L. (1994) Plant communities of the Monaro lakes. Cunninghamia 3: 651-676.
Benson, J.S., Richards, P.G., Waller, S. \& Allen, C.B. (2010) New South Wales vegetation classification and assessment: Part 3. Plant communities of the NSW Brigalow Belt South, Nandewar and west New England bioregions and update of NSW Western Plains and South Western Slopes plant communities. Version 3 of the NSW VCA database. Cunninghamia 11: 457-579. Botanic Gardens Trust, Sydney.

Binns, D.L. (1997) Unpublished flora survey data from the Bago and Marangle State Forests. Forests New South Wales.

Binns, D.L. (2004) Unpublished flora survey data from state forests of the Tumbarumba district. Forests New South Wales.

Binns, D.L. \& Kavanagh, R.P. (1990) Flora and fauna survey of Nalbaugh State Forest (part), Bombala district, Eden region, South-eastern New South Wales. Forest resources series no. 9, Forestry Commission of New South Wales.

BoM (2011) Bureau of Meteorology: monthly climate statistics. [URL: http://www.bom.gov.au/]. Website accessed August 4 2011.

Braun-Blanquet, J. (1932) Plant Sociology. McGraw Hill, New York.

BRS \& SFNSW (1999) A report on forest wood resources for Southern NSW CRA Region. Bureau of Rural Sciences and State Forests of NSW New South Wales Government, Sydney.

Bruelheide, H. \& Chytrý, M. (2000) Towards unification of national vegetation classifications: a comparison of two methods for analysis of large data sets. Journal of Vegetation Science 11: 295-306.

Carey, A., Evans, M., Hann, P., Lintermans, M., MacDonald, T., Ormay, P., Sharp, S., Shorthouse, D. \& Webb, N. (2003) Wildfires in the ACT 2003: Report on initial impacts on natural ecosystems . Technical Report 17, Wildlife Research and Monitoring, Environment ACT, Canberra.

Charman, P.E.V. (1978) Soils of New South Wales - their characterisation, classification and conservation. NSW Soil Conservation Service, Sydney.

Clarke K.R. \& Gorley R.N. (2001) PRIMER v5. PRIMER-E, Plymouth Marine Laboratory, UK.

Clements, D.R., Cole, D.E., Darbyshire, S., King, J. \& McClay, A. (2004) The biology of Canadian weeds. 128. Leucanthemum vulgare Lam. Canadian Journal of Plant Science 84, 343-363.

Costin, A.B. (1954) A study of the ecosystems of the Monaro region of New South Wales. Government Printer: Sydney.

Costin, A.B., Gray, M., Totterdell, C.J. \& Wimbush D.J. (2000) Kosciuszko alpine flora. CSIRO Publishing: Collingwood.

Crawford, I. (1999) Unpublished flora data from BallalabaKrawarree Landcare group remnant vegetation survey.

Crawford, I. (2002a) Unpublished vegetation survey data, Voluntary Conservation Area survey program. National Parks and Wildlife Service, Far South Coast region, Merimbula.

Crawford, I. (2002b) Unpublished flora survey data from Bondi Gulf Nature Reserve. Collected for NSW National Parks and Wildlife Service, Merimbula.

Crawford, I. (2002c) Unpublished flora survey data from Coolumbooka Nature Reserve. Collected for NSW National Parks and Wildlife Service, Merimbula.

De Cáceres, M., Font, X. \& Oliva, F. (2008) Assessing species diagnostic value in large data sets: a comparison between phicoefficient and Ochiai index. Journal of Vegetation Science 19: 779-788.

De Cáceres, M., Font, X., Vicente, P. \& Oliva, F. (2009) Numerical reproduction of traditional classifications and automated vegetation identification. Journal of Vegetation Science 20: $620-628$.

Department of Environment and Climate Change (DECC) (2009) Strategy for vegetation type classification and mapping. NSW Department of Environment and Climate Change, Sydney. 
Department of Environment, Climate Change and Water (DECCW) (2010a) Unpublished survey data from alpine ash fire response monitoring sites. NSW Department of Environment, Climate Change and Water, Queanbeyan.

Department of Environment, Climate Change and Water (DECCW) (2010b) Vegetation condition monitoring in the Southern Rivers catchment - baseline establishment in autumn 2010. Final report to the Southern Rivers Catchment Management Authority.

Department of Mineral Resources (undated) Lithology GIS layer 1:250,000. NSW Department of Mineral Resources.

Doherty, M.D. (1996) Vegetation survey and mapping of Mundoonen Nature Reserve. Unpublished report to NSW National Parks and Wildlife Service, Queanbeyan district. CSIRO Division of Wildlife and Ecology, Canberra.

Doherty, M.D. (1997a) Vegetation survey and mapping of Brindabella National Park and adjacent crown lands. Report to the NSW National Parks and Wildlife Service, Queanbeyan district. CSIRO Division of Wildlife and Ecology, Canberra.

Doherty, M.D. (1997b) Vegetation survey and mapping of Tinderry Nature Reserve. Unpublished report to NSW National Parks and Wildlife Service, Queanbeyan district. CSIRO Division of Wildlife and Ecology, Canberra.

Doherty, M.D. (1998) Vegetation survey and mapping of Burrinjuck Nature Reserve. Unpublished report for NSW National Parks and Wildlife Service, Queanbeyan, by CSIRO Division of Wildlife and Ecology, Canberra.

Doherty, M.D. (2004) Preliminary assessment of the impact of the January 2003 wildfires on the flora and vegetation of Brindabella National Park, Bimberi Nature Reserve and Burrinjuck Nature Reserve, NSW. CSIRO Division of Wildlife and Ecology, Canberra.

Doherty, M.D., Robertson, G., Corcoran, D. \& Wright, G. (2011) Cool temperate rainforest in the Pilot wilderness area, Kosciuszko National Park: distribution, composition and impact of the 2003 fires. Cunninghamia 12: 119-127.

EcoGIS (2004) Final report: mapping of vegetation ecosystems in new and existing conservation reserves, South West Slopes region 2002-2004 version 2. Report to National Parks and Wildlife Service South West Slopes region.

EcoLogical (2008) Editing Mitchell landcapes (Project No. 092019) - final report. Report to NSW Department of Environment and Climate Change by EcoLogical Australia Pty. Ltd, Sutherland.

Environment ACT (2006) National recovery plan for natural temperate grassland of the southern tablelands (NSW and ACT): an endangered ecological community. Environment ACT, Canberra.

ESCAVI (2003) National Vegetation Information System Australian vegetation attribute manual version 6.0. Executive committee for Australian vegetation information. Department of Environment and Heritage, Canberra.

Fanning, F.D. \& Fatchen, T.J. (1990) The upper Wog Wog river catchment of Coolangubra and Nalbaugh State Forest (Mines road area), New South Wales: A fauna and flora survey. Forest resources series no.12, Forestry Commission of New South Wales.

Fanning, F.D. \& Rice, B. (1989) Natural resource survey of the northern portion of Rockton section, Bondi State Forest. Forest resources series no.7, Forestry Commission of New South Wales.

FGDC (2008) National Vegetation Classification Standard, version 2. Vegetation Subcommittee, Federal Geographic Data Committee, FGDC doc. no. FGDC-STD-005-2008.

Fisher, M. \& Ryan, K. (1994) Hawkesbury-Nepean Catchment vegetation mapping: explanatory notes for the Taralga and Oberon 1:100 000 map sheets. Ecology Section, National Herbarium, Royal Botanic Gardens, Sydney.
Floyd, A.G. (1990) Australian rainforests in New South Wales. Surrey Beatty and Sons Pty. Ltd. in association with the NSW National Parks and Wildlife Service.

Gellie, N.J.H. (2002) Unpublished flora survey data from Monga National Park. Collected for NSW National Parks and Wildlife Service Merimbula.

Gellie, N.J.H. (2005) Native vegetation of the southern forests: South Eastern Highlands, Australian Alps, South West Slopes and South East Corner bioregions. Cunninghamia 9: 219-254.

Gilmour, P.M. (1985) Vegetation survey of Deua National Park. Unpublished report to NSW National Parks and Wildlife Service, Narooma District.

Greening Australia (2011) Survey of southern sassafras (Atherosperma moschatum) in the Murphys Swamp area, Bogong Peak wilderness, Kosciuszko National Park. A report by Greening Australia capital region for the NSW Department of Environment, Climate Change and Water. Unpublished report. February 2011.

Grossman, D.H., Faber-Langendoen, D., Weakley, A.S., Anderson, M., Bourgeron, P., Crawford, R., Goodin, K., Landaal, S., Metzler, K., Patterson, K.D., Pyne, M., Reid, M. \& Sneddon, L. (1998) International classification of ecological communities: terrestrial vegetation of the United States. volume 1. The National Vegetation Classification System: development, status, and applications. The Nature Conservancy, Arlington, Virginia, USA.

Hancock, W.K. (1972) Discovering Monaro: A study of man's impact on his environment. Cambridge University Press, Cambridge.

Helman, C.E. (1983) Inventory analysis of southern New South Wales rainforest vegetation. MSc Thesis, University of New England, Armidale.

Helman, C.E. \& Gilmour, P.M. (1985) Treeless vegetation above 1,000 metres altitude in the A.C.T. Unpublished report. Conservation Council of the Southeast Region and Canberra: Canberra.

Helman, C.E., Gilmour, P.M., Osborne, W.S. \& Green, K. (1988) An ecological survey of the upper Cotter catchment wilderness area, Namadgi National Park, ACT. Unpublished report. Conservation Council of the South-east Region and Canberra, Canberra.

HO \& DUAP (1996) Regional Histories: regional histories of New South Wales. Heritage Office \& Department of Urban Affairs \& Planning, Sydney.

Hibberd, J. \& Taws, N. (1993) The long paddock revisited 15 years on: a comparative study of the condition and use of travelling stock reserves in the southern tablelands 1977-1993. Unpublished report for the Nature Conservation Council.

Hutchinson, M.F. (1989) A new objective method for spatial interpolation of meteorological variables from irregular networks applied to the estimation of monthly mean solar radiation, temperature, precipitation and wind-run. Technical memorandum 89/5, CSIRO Division of Water Resources, Canberra.

Ingwersen, F., Evans, O. \& Griffiths, B. (1974) Vegetation of the Ainslie-Majura Reserve. Conservation series no. 2, Department of the Capital Territory. Australian Government Publishing Service, Canberra.

Ingwersen, F. (2001) Sundry nameless ranges: The landscape ecology of the Naas - Gudgenby catchment. PhD Thesis, Australian National University, Canberra.

Johnston, L., Skinner, S. \& Sharp, S. (2008) Report to National Vegetation Inventory System: final deliverables. ACT Parks, Conservation and Lands Territory and Municipal Services. June 2008, Unpublished. 
Jurskis, V., Shields, R. \& Binns, D. (1995) Flora survey: Queanbeyan/Badja Environmental Impact Statement area, Southern region, New South Wales. Supporting document 3, Environmental Impact Statement for Queanbeyan and Badja management areas. Research division, State Forests of NSW, Beecroft.

Keith, D.A. (2004) Ocean shores to desert dunes: The native vegetation of New South Wales and the ACT. NSW Department of Environment and Conservation: Hurstville.

Keith, D.A. \& Auld, T.D. (2009) Dealing with threats: Integrating science and management. Ecological Management \& Restoration, 10: S79-S87.

Keith, D.A. \& Bedward, M. (1999) Native vegetation of the south east forests region, Eden, New South Wales. Cunninghamia 6: $1-218$.

Leigh, J.H. \& Holgate, M.D. (1979) The responses of the understorey of forests and woodlands of the southern tablelands to grazing and burning. Australian Journal of Ecology 4: 25-45.

Lennon, J. (1999) The international significance of the cultural values of the Australian alps. Report for the Cultural Heritage Working Group, Australian Alps Liaison Committee.

Lennon, J. (2003) The cultural significance of Australian alpine areas. In: Celebrating mountains: proceedings of an international year of mountains conference. November 25 - 28, 2002. Jindabyne - Australia. Australian Alps Liaison Committee, Canberra.

LPI (2006) New South Wales DTDB Landform Theme 9 x $7.5 \mathrm{k}$ Digital Elevation Models. 2006.10.10. NSW Land \& Property Information, Bathurst.

Lyons, M.T., Brooks, R.R. \& Craig, D.C. (1974) The influence of soil composition on the vegetation of the Coolac serpentinite belt in New South Wales. Journal and Proceedings of the Royal Society of New South Wales 107: 67-75.

Mackenzie, B.D.E., Tozer, M.G., Keith, D.A. \& Bradstock, R.A. (1998) The ecology and fire management of montane heathlands in Wadbilliga National Park. Unpublished report to Narooma district, NSW National Parks and Wildlife Service.

McDougall, K.L. (1978) The alpine vegetation of Mt Nelse, Victoria. BSc. Honours Thesis. La Trobe University, Melbourne.

McDougall, K.L. (1982) The alpine vegetation of the Bogong high plains. Environmental studies publication no. 357. Ministry for Conservation: Melbourne.

McDougall, K.L., Brookhouse, M. \& Broome, L.S. (2012) Dendroclimatological investigation of mainland Australia's only alpine conifer, Podocarpus lawrencei Hook.f. Dendrochronologia 30: 1-9.

McDougall, K.L. \& Walsh, N.G. (2002) The flora of Nungar plain, a treeless sub-alpine frost hollow in Kosciuszko National Park. Cunninghamia 7: 601-610.

McDougall, K.L. \& Walsh, N.G. (2007) Treeless vegetation of the Australian Alps. Cunninghamia 10: 1-57.

McVean, D.N. (1969) Alpine vegetation of the central Snowy Mountains of New South Wales. Journal of Ecology 57: 67-86.

Miles, J. (2001) Unpublished flora survey data from Tantawangalo and Yurramie. Collected for NSW National Parks and Wildlife Service, Merimbula.

Miles, J. (2002) Unpublished flora survey data from Coolangubra section of South East Forests National Park. Collected for NSW National Parks and Wildlife Service, Merimbula.

Miles, J. (2004) Unpublished flora survey data from National Parks and Wildlife Service Voluntary Conservation Area flora surveys. Collected for NSW National Parks and Wildlife Service, Merimbula.

Miles, J. (2005a) Vegetation re-mapping for Bungonia State Conservation Area, Bees Nest Nature Reserve and western Morton National Park. NGH Environmental report to NSW Department of Environment and Conservation.
Miles, J. (2005b) Vegetation survey and mapping of Merriangaah, Meringo and Quidong Nature Reserves north east of Bombala. Report by NGH Environmental to National Parks and Wildlife Service, Snowy Mountains region.

Miles, J. (2006) Unpublished vegetation survey data from Badja Swamp Nature Reserve, Frogs Hole State Conservation Area and Yurramie State Conservation Area. Collected for NSW Department of Environment and Climate Change, Queanbeyan.

Miles, J. (2007) Unpublished vegetation survey data from Monga National Park for vegetation mapping validation in undersampled reserves. Collected for NSW Department of Environment and Climate Change, Queanbeyan.

Miles, J. (2010a) Unpublished flora survey data from Nadgigomar Nature Reserve. Survey conducted for NSW National Parks and Wildlife Service, Nowra.

Miles, J. (2010b) Vegetation survey of Goulburn district reserves. Unpublished data collected for National Parks and Wildlife Service, Queanbeyan.

Miles, J. \& McPherson, P. (2004) Unpublished flora surveys from new nature reserves in the Cooma area: Dangelong, Coornartha, Good Good, Kybeyan, Macanally, Mount Clifford, Numeralla, Undoo and Wadjan. Survey conducted for NSW National Parks and Wildlife Service, Merimbula.

Miles, J. \& Robertson, G. (2008) Unpublished flora survey data from Kosciuszko NP including Byadbo wilderness, Geehi, Jounama, Long Plain and Tom Groggin. Collected for NSW Department of Environment and Climate Change, Queanbeyan.

Mitchell, P.B. (2003) New South Wales ecosystems database mapping unit descriptions. Unpublished report to the NSW National Parks and Wildlife Service, Hurstville.

Mulvaney, M., Boak, M., Priday, S., Hudson, K. \& Crane, M. (2005) The native vegetation of Gundagai shire. NSW Department of Environment and Conservation, Queanbeyan.

Naughton, M. \& Bourke, C.A. (2007) Primefact 694 - St John's Wort (Hypericum perforatum). NSW Department of Primary Industries, Orange.

Neldner, V.J. \& Butler, D.W. (2009) Is $500 \mathrm{~m}^{2}$ an effective plot size to sample floristic diversity for Queensland's vegetation? Cunninghamia 10: 513-519.

National Parks \& Wildlife Service (undated a) Unpublished data from various flora surveys including Bomaderry Creek, Burra Creek, Cecil Hoskins, Corramy, Murramarang, Nimmo, Robertson, Rodway, Throsby Park and Wogamia. Commissioned by NSW National Parks and Wildlife Service, Queanbeyan.

National Parks \& Wildlife Service (undated b) Unpublished flora survey data from the Riverina Highlands. Collected for the 'Southern Comprehensive Regional Assessment' forest ecosystem mapping project, National Parks and Wildlife Service Queanbeyan.

National Parks \& Wildlife Service (2003a) The bioregions of New South Wales: their biodiversity, conservation and history. NSW National Parks and Wildlife Service, Hurstville.

National Parks \& Wildlife Service (2003b) The native vegetation of the Warragamba Special Area. National Parks and Wildlife Service, Sydney.

Office of Environment and Heritage (NSW) (OEH) (unpublished a) Vegetation Information System Classification Database version 2.0 [URL: http://www.environment.nsw.gov.au/research/ Visclassification.htm]. Website accessed July 302012.

Office of Environment and Heritage (NSW) (OEH) (unpublished b) Soil landscapes of the upper Murrumbidgee catchment soil benchmarking project. NSW Office of Environment and Heritage, Parramatta.

Otýpková, Z. \& Chytrý, M. (2006) Effects of plot size on the ordination of vegetation samples. Journal of Vegetation Science 17: 465-472. 
Pickering, C.M. \& Armstrong, T. (2003) The potential impact of climate change on plant communities in the Kosciuskzo alpine zone. The Victorian Naturalist 120: 15-24.

Prober, S.M. \& Thiele, K.R. (2005) Restoring Australia's temperate grasslands and grassy woodlands: integrating function and diversity. Ecological Management \& Restoration 6: 16-27.

Rehwinkel, R. (unpublished) Revision of PATN analysis of grassland associations within the Natural Temperate Grassland Endangered Ecological Community in the Southern Tablelands of NSW. August 2009 [URL: http://www.gbwcmn.net.au/sites/ default/files/Revision_PATN_Rehwinkel09 .pdf]. Website accessed July 9 2012. NSW Department of Environment and Climate Change, Queanbeyan. Unpublished report.

Schaminée, J.H.J., Hennekens, S.M. \& Ozinga, W.A. (2007) Use of the ecological information system SynBioSys for the analysis of large databases. Journal of Vegetation Science 18: 463-470.

Sharp, S., McDonald, T., Kitchin, M. \& Dunford, M. (2007) Setting conservation targets for vegetation communities in the ACT. Final report to Natural Resource Management Council, June 2007. Research and Monitoring; Parks, Conservation and Lands, Canberra. Unpublished report.

Sivertsen, D. (2009) Native vegetation interim type standard. NSW Department of Environment and Climate Change, Sydney.

Steenbeeke, G.L. (1990) An investigation into the flora and vegetation of the middle Kowmung river valley, eastern NSW. Honours thesis, University of Sydney School of Biological Sciences.

Steenbeeke, G.L. (1996) Population dynamics and distribution of the rare shrub, Hakea 'species 2' (Kowmung river). MSc Thesis, University of Sydney.

Thackway, R., \& Cresswell, I.D. (1995) An interim biogeographic regionalisation for Australia: a framework for setting priorities in the National Reserves System cooperative program. Australian Nature Conservation Agency, Canberra.

Thomas, V., Gellie, N. \& Harrison, T. (2000) Forest ecosystem classification and mapping for the 'Southern Comprehensive Regional Assessment'. Report for the NSW CRA/RFA steering committee, Project no. NS 08/EH. NSW National Parks and Wildlife Service, Queanbeyan.

Tichý, L. (2002) JUICE, software for vegetation classification. Journal of Vegetation Science 13: 451-453.

Tindale, N.B. (1974) Tribal boundaries in Aboriginal Australia. Australian National University Press, Canberra.

Tindall, D., Pennay, C., Tozer, M., Turner, K. \& Keith, D. (2004) Native vegetation map report series no. 4. version 2.2. Araluen, Batemans Bay, Burragorang, Goulburn, Jervis Bay, Katoomba, Kiama, Moss Vale, Penrith, Port Hacking, Sydney, Taralga, Ulladulla and Wollongong 1:100,000 mapsheets. NSW Department of Environment and Conservation and NSW Department of Infrastructure, Planning and Natural Resources.
Togher, C. (1996) A report on the biodiversity and land management of the Abercrombie river catchment. National Parks Association Inc., Sydney.

Tolsma, A., Coates, F. \& Sutter, G. (2004) Recovery of Mountain Plum-Pine Shrubland After Fire (Cobberas). Arthur Rylah Institute for Environmental Research Technical Report No. 153. Department of Sustainability and Environment, Victoria.

Tozer, M.G. (2003) The native vegetation of the Cumberland Plain, western Sydney: systematic classification and field identification of communities. Cunninghamia 8: 1-75.

Tozer, M.G., Turner, K., Keith, D.A., Tindall, D., Pennay, C., Simpson, C., MacKenzie, B., Beukers, P. \& Cox, S. (2010) Native vegetation of southeast NSW: a revised classification and map for the coast and eastern tablelands. Cunninghamia 11: 359-406.

Turner, K. (2007) Unpublished field survey data collected from formal quadrats in wetlands in southeast New South Wales. NSW Department of Natural Resources, Wollongong.

Van Rees, H. \& Holmes, J.H.G. (1986) The botanical composition of the diet of free-ranging cattle on an alpine range in Australia. Journal of Range Management 39: 392-395.

Vivian, L.M. \& Cary, G.J. (2012) Relationship between leaf traits and fire-response strategies in shrub species of a mountainous region of south-eastern Australia. Annals of Botany 109: 197208.

Walker, J., \& Hopkins, M.S. (1990) Vegetation. In: McDonald, R.E., Isbell, R.F., Speight, J.R., Walker, J. \& Hopkins, M.S. eds. (1990) Australian soil and land survey field handbook, 2nd edition, pp. 58-77. Inkata Press, Melbourne and Sydney.

Walsh, N.G., Barley, R.H. \& Gullan, P.K. (1984) The alpine vegetation of Victoria (excluding the Bogong high plains), volume 1. Environmental studies publication no. 376. Department of Conservation, Forests and Lands: Melbourne.

Whinam, J. \& Chilcott, N. (2002) Floristic description and environmental relationships of Sphagnum communities in NSW and the ACT and their conservation management. Cunninghamia 7:463-500.

Williams, R.J., Wahren, C-H., Tolsma, A.D., Sanecki, G.M., Papst, W.A., Myers, B.A., McDougall, K.L., Heinze, D.A. \& Green, K. (2008) Large fires in Australian alpine landscapes: their part in the historical fire regime and their impacts on alpine biodiversity. International Journal of Wildland Fire 17: 793808.

Manuscript accepted 13 February 2013 


\section{Appendix 1: Plant community type descriptions for plant communities occurring in the upper Murrum- bidgee catchment area.}

\section{List of Contents}

\section{ALPINE COMPLEX}

\section{Class: Alpine Herbfields}

a6: Ranunculus millanii - Pratia surrepens - Carex gaudichaudiana herbfield of shallow depressions in the Australian Alps bioregion

a14: Poa costiniana - Carex gaudichaudiana subalpine valley grassland of the Australian Alps bioregion

a22: Poa fawcettiae - Celmisia costiniana - Craspedia maxgrayi grassland of the Australian Alps bioregion

a30: Poa hookeri - Poa clivicola - Oreomyrrhis argentea - Ranunculus graniticola grassland of the Australian Alps bioregion

a38: Themeda australis - Galium roddii - Leucochrysum alpinum grassland of steep limestone slopes in the Australian Alps bioregion

Class: Alpine Heaths

a33: Bossiaea foliosa - Cassinia monticola - Kunzea muelleri - Hovea montana heathland of the Australian Alps bioregion

a39: Epacris sp. - Pentachondra pumila - Poa fawcettiae heathland of the Australian Alps bioregion

a42: Epacris celata - Poa clivicola - Dillwynia palustris grassy heathland of the Australian Alps bioregion

a43: Bossiaea riparia - Themeda australis low open heathland of the Australian Alps bioregion

a46: Prostanthera cuneata - Orites lancifolius - Nematolepis ovatifolia heathland of the Australian Alps bioregion

a51: Podocarpus lawrencei - Rytidosperma alpicola - Brachyscome nivalis low open heathland of rock outcrops of the Australian Alps bioregion

a54: Podocarpus lawrence - Pimelea ligustrina subsp. ciliata heathland of screes and boulder-fields of the Australian Alps bioregion

g36: Leptospermum micromyrtus - Kunzea muelleri - Kunzea ericoides dry heathland on skeletal ridges primarily of the Namadgi region

Class: Alpine Bogs and Fens

a2: Baeckea gunniana - Epacris paludosa - Richea continentis - Sphagnum cristatum wet heathland of the Australian Alps bioregion (Bog)

a7: Ranunculus pimpinellifolius - Gonocarpus micranthus herbfield of wetland margins in the Australian Alps bioregion

a8: Carex gaudichaudiana - Myriophyllum pedunculatum - Deschampsia cespitosa sedgeland of the Australian Alps bioregion (Fen)

\section{RAINFORESTS}

\section{Class: Cool Temperate Rainforests}

g172: Black Sassafras temperate rainforest of wet sheltered slopes in the Australian Alps and Bondo subregion of the South Eastern Highlands bioregions

\section{WET SCLEROPHYLL FORESTS}

\section{Class: Montane Wet Sclerophyll Forests}

u40: Alpine Ash very tall wet sclerophyll open forest primarily of the Australian Alps bioregion

u53: Mountain Gum - Blackwood tall wet sclerophyll open forest primarily on granitoids of the Australian Alps and western South Eastern Highlands bioregions

u239: Alpine Ash - Mountain Gum \pm Snow Gum wet sclerophyll open forest of the Australian Alps and South Eastern Highlands bioregions

\section{Class: Southern Tableland Wet Sclerophyll Forests}

u52: Ribbon Gum - Robertson's Peppermint very tall wet sclerophyll open forest primarily of the Bondo subregion of the South Eastern Highlands and the northern Australian Alps bioregions

\section{Class: Southern Escarpment Wet Sclerophyll Forests}

p338: Brown Barrel wet sclerophyll very tall grass-herb open forest primarily of the Gourock and Tallaganda Ranges in the South Eastern Highlands bioregion 


\section{DRY SCLEROPHYLL FORESTS}

\section{Class: Southern Tableland Dry Sclerophyll Forests}

e24: Mountain Gum - Snow Gum very tall dry shrubby open forest primarily in the Kybeyan - Gourock subregion of the South Eastern Highlands bioregion

m31: Ribbon Gum - Snow Gum - Cassinia longifolia tall shrub-grass open forest of gullies in quartz-rich ranges in the Monaro and KybeyanGourock subregions of the South Eastern Highlands bioregion

m51: Brittle Gum - Scribbly Gum shrub-grass tall dry sclerophyll open forest on exposed quartz-rich slopes and ridges at primarily in the Monaro and Kybeyan - Gourock subregions of the South Eastern Highlands bioregion

p8: Silvertop Ash - Narrow-leaved Peppermint shrubby tall dry open forest primarily on sedimentary ridges of the eastern South Eastern Highlands bioregion

p10: Black She-oak - Silvertop Ash tall shrubby dry sclerophyll open forest primarily in the Bungonia subregion of the South Eastern Highlands bioregion

p9: Brittle Gum - Scribbly Gum shrubby tall dry open forest on infertile low ridges and hills primarily of the Bungonia subregion of the South Eastern Highlands bioregion

p14: Red Stringybark - Scribbly Gum - Rytidosperma pallidum tall grass-shrub dry sclerophyll open forest on loamy ridges of the central South Eastern Highlands bioregion

p23: Red Stringybark - Broad-leaved Peppermint tall dry sclerophyll grassy open forest on loamy rises primarily in the Bungonia subregion of the South Eastern Highlands bioregion

u18: Mealy Bundy - Broad-leaved Peppermint shrubby mid-high open forest on granite substrates primarily in the South Eastern Highlands u21: Broad-leaved Peppermint - Candlebark tall dry sclerophyll open forest of quartz-rich ranges of the upper South East Highlands and lower Australian Alps bioregions

u29: Apple Box - Broad-leaved Peppermint tall shrub-grass open forest primarily on granitoids of the South Eastern Highlands bioregion u105: Broad-leaved Peppermint - Brittle Gum - Red Stringybark tall shrub-grass dry sclerophyll open forest of lower ranges of the western South Eastern Highlands and upper South Western Slopes bioregions

u148: Red Stringybark - Red Box grass-forb tall open forest of the upper South Western Slopes and western South Eastern Highlands bioregions u150: Broad-leaved Peppermint - Mountain Gum shrubby tall open forest of the South Eastern Highlands and Australian Alps bioregions u152: Robertson's Peppermint - Red Stringybark very tall grass-forb sheltered open forest of the southwest South Eastern Highlands and upper South Western Slopes bioregions

u165: Robertson's Peppermint very tall shrubby open forest primarily of the Bondo subregion of the South Eastern Highlands bioregion u191: Black Cypress Pine - Brittle Gum tall dry open forest on hills primarily in the Cooma region

\section{Class: Upper Riverina Dry Sclerophyll Forests}

u43: Mealy Bundy - Acacia implexa - Allocasuarina verticillata - Ricinocarpos bowmanii tall grassy open woodland on serpentinite in the Coolac-Goobarragandra area primarily of the upper South Western Slopes bioregion

u66: Mealy Bundy - Red Stringybark grass-forb mid-high open forest of the South Eastern Highlands and Upper Slopes Subregion of the South Western Slopes bioregion

\section{HEATHLANDS}

\section{Class: Southern Montane Heaths}

e53: Allocasuarina nana shrubland on exposed skeletal ridges of primarily in the eastern South Eastern Highlands bioregion

\section{FORESTED WETLANDS}

\section{Class: Eastern Riverine Forests}

p32d: River She-oak riparian forest on sand/gravel alluvial soils along major watercourses of the South Eastern Highlands and upper South Western Slopes bioregions

p56: Leptospermum grandifolium - Hakea microcarpa - Lomatia myricoides riparian very tall shrubland of the eastern South Eastern Highlands bioregion

u181: Callistemon sieberi - Kunzea ericoides rocky riparian tall shrubland in the South Eastern Highlands and upper South Western Slopes bioregions 


\section{FRESHWATER WETLANDS}

\section{Class: Inland Riverine Forests}

u173: River Red Gum \pm Apple Box very tall grass-forb riparian woodland on alluvial flats in the South Eastern Highlands and upper South Western Slopes bioregions

\section{Class: Montane Bogs and Fens}

a9: Carex gaudichaudiana - Ranunculus amphitrichus - Phragmites australis aquatic herbfield of waterways in the Australian Alps and South Eastern Highlands bioregions

e59: Hakea microcarpa - Baeckea utilis - Leptospermum myrtifolium subalpine wet heathland on escarpment and eastern tableland ranges of the South Eastern Highlands bioregion

u193: Hakea microcarpa - Epacris breviflora - Epacris paludosa subalpine wet heathland of the Australian Alps and western South Eastern Highlands bioregions

\section{Class: Montane Lakes}

L12: Freshwater sedge-herb marsh of shallow, commonly inundated wetlands of the eastern South Eastern Highlands bioregion

L3: Freshwater sedge-herb marsh of shallow ephemeral lakes of the eastern South Eastern Highlands bioregion

L4: Freshwater sedge-herb marsh of deep semi-permanent and/or slightly saline wetlands of the eastern South Eastern Highlands bioregion

\section{GRASSY WOODLANDS}

\section{Class: Subalpine Woodlands}

a34: Weeping Snow Gum shrub-grass open woodland of the Australian Alps bioregion

u22: Mountain Gum - Snow Gum \pm Robertson's Peppermint grass-forb very tall woodland to open forest of the Australian Alps and South Eastern Highlands bioregions

u23: Snow Gum - Drumstick Heath - Leptospermum myrtifolium tall woodland to open forest of drainage depressions primarily of the South Eastern Highlands bioregion

u27: Snow Gum - Candlebark tall grassy woodland in frost hollows and gullies of the South Eastern Highlands bioregion

u28: Snow Gum - Mountain Gum - Daviesia mimosoides tall dry grass-shrub subalpine open forest of the Australian Alps and South Eastern Highlands bioregions

u118: Black Sallee grass-herb woodland in drainage depressions and moist valley flats in the South Eastern Highlands and Australian Alps bioregions

u158: Alpine Sallee shrub-grass subalpine mid-high woodland of the Australian Alps bioregion

u207: Jounama Snow Gum - Snow Gum shrubby mid-high woodland on granitoids primarily of the Namadgi region

\section{Class: Southern Tableland Grassy Woodlands}

p24: Yellow Box - Blakely's Red Gum tall grassy woodland on undulating sedimentary and acid-volcanic substrates in the Goulburn area of the South Eastern Highlands bioregion

u19: Blakely’s Red Gum - Yellow Box \pm White Box tall grassy woodland of the Upper South Western Slopes and western South Eastern Highlands bioregions

u20: Kurrajong - Bursaria spinosa - Themeda australis shrub-grass mid-high open woodland on limestone karsts in the Wee Jasper area u178: Yellow Box \pm Apple Box tall grassy woodland of the South Eastern Highlands bioregion

\section{Class: Tableland Clay Grassy Woodlands}

p220: Ribbon Gum - Snow Gum tableland flats tall grassy woodland primarily on granitoids in the Kybean - Gourock and Monaro subregions of the South Eastern Highlands bioregion

p520: Ribbon Gum very tall woodland on alluvial soils along drainage lines of the eastern South Eastern Highlands bioregion

u78: Snow Gum grassy mid-high woodland of the South Eastern Highlands bioregion

\section{GRASSLANDS}

\section{Class: Temperate Montane Grasslands}

r1: Sub-montane moist tussock grassland of the South Eastern Highlands bioregion

r2: Poa labillardierei - Themeda australis - Juncus sp. wet tussock grassland of footslopes, drainage lines and flats of the South Eastern Highlands bioregion

r3: Rytidosperma sp. - Themeda australis - Juncus sp. tussock grassland of occasionally wet sites of the South Eastern Highlands bioregion

r4: Lacustrine Grass-forbland of the South Eastern Highlands bioregion

r5: Rytidosperma sp. - Austrostipa bigeniculata - Chrysocephalum apiculatum tussock grassland of the South Eastern Highlands bioregion

r6: Dry tussock grassland of the Monaro in the South Eastern Highlands bioregion

r7: Themeda australis - Rytidosperma sp. - Poa sieberiana moist tussock grassland of the South Eastern Highlands bioregion

r8: Themeda australis - Lomandra filiformis - Aristida ramosa dry tussock grassland in the South Eastern Highlands bioregion 


\section{Plant community type descriptions}

Additional to text descriptions, tabulated floristic information, photographs and figures, each plant community contains tabulated summary information as follows:

Number of samples: Number of field samples assigned to a particular community and used to characterise species composition and habitat.

Richness [mean $( \pm S D)$ ]: Average richness of native species per plot sample within a particular plant community $( \pm 1$ standard deviation).

Slope (degrees): Approximate ground surface slope of samples assigned to a particular plant community, as: [(minimum) $25^{\text {th }}$ percentile $-75^{\text {th }}$ percentile (maximum) (from GIS; sample intersect with slope surface generated from $25 \mathrm{~m}$ digital elevation model).

Altitude ( $m$ asl): Approximate elevation of samples assigned to a particular plant community, as [(minimum) $25^{\text {th }}$ percentile $-75^{\text {th }}$ percentile (maximum) (from GIS; sample intersect with elevation surface generated from $25 \mathrm{~m}$ DEM).

Ave. Annual Rainfall ( $\mathrm{mm}$ ): Modelled average annual rainfall of plots assigned to a particular plant community, as [(minimum) $25^{\text {th }}$ percentile $-75^{\text {th }}$ percentile (maximum) (from GIS; sample intersect with climate surface generated using BioClim software).

Temp. Annual Range $\left({ }^{\circ} \mathrm{C}\right)$ : Modelled annual temperature range (mean maximum of warmest month minus mean minimum of coldest month) of samples assigned to a particular plant community, as [(minimum) 25 th percentile - 75th percentile (maximum)] (from GIS; sample intersect with climate surface generated using BioClim software).

\section{Formation: Alpine Complex}

\section{Class: Alpine Herbfields}

\section{a6: Ranunculus millanii - Lobelia surrepens - Carex gaudichaudiana herbfield of shallow depressions of the Australian Alps bioregion}

Scientific Name: Ranunculus millanii - Lobelia surrepens - Carex gaudichaudiana - Dichondra repens - Hydrocotyle sibthorpioides - Gonocarpus micranthus

$\begin{array}{ll}\text { Number of samples: } & 5 \\ \text { Richness [mean }( \pm \mathrm{SD})]: & 11(4) \\ \text { Slope (degrees): } & (1) 2-3(6) \\ \text { Altitude (m asl): } & (1156) 1268-1302(1527) \\ \text { Ave. Annual Rainfall }(\mathrm{mm}): & (1037) 1123-1564(1590) \\ \text { Temp. Annual Range }\left({ }^{\circ} \mathrm{C}\right): & (22.2) 23.3-24.2(24.3)\end{array}$

Vegetation Description: Community a6 is a wet low sedgeland/herbfield with characteristic species including Lobelia surrepens, Ranunculus millanii, Gonocarpus micranthus, Isolepis montivaga, Myriophyllum pedunculatum, Stackhousia pulvinaris and Lachnagrostis meionectes.

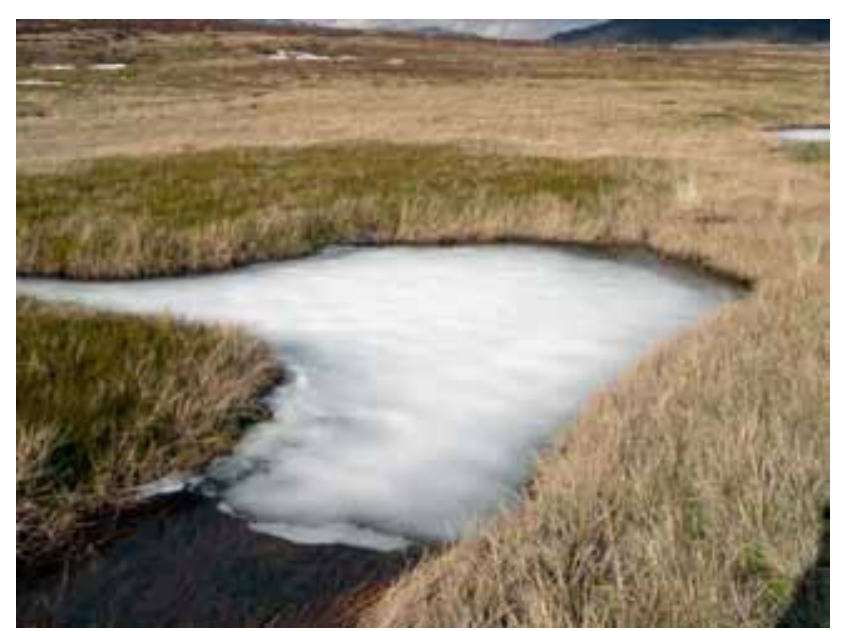

Plate a6: A depression in Poa fawcettiae grassland, the habitat of community a6; this example near Spencers Creek, Kosciuszko NP. The flora of this community is distinct from that of surrounding communities only a few cm away. The depressions are often waterfilled in spring and late autumn.

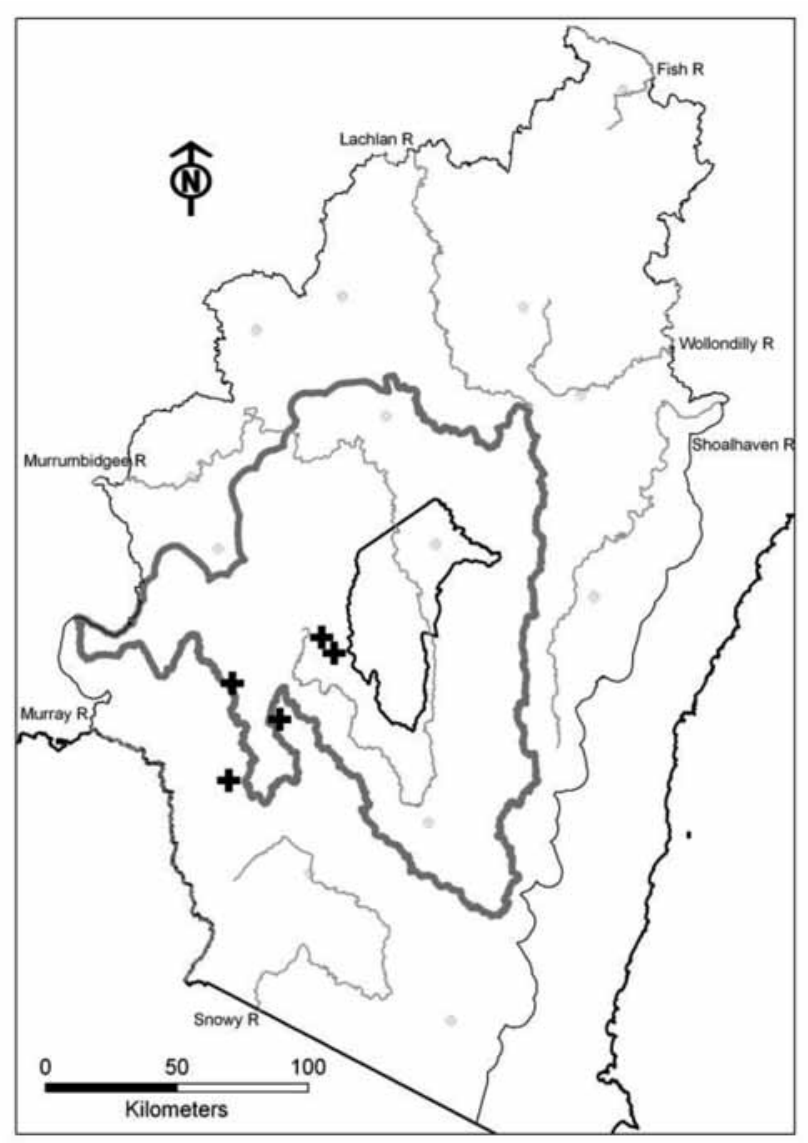

Fig. a6: Distribution of field samples assigned to plant community a6. 
Carex gaudichaudiana is usually present, particularly in deeper sections of the depressions where water tends to persist for longer periods.

This community occurs on the Bimberi Range (ACT), northern Kosciuszko NP and surrounds (e.g. Kiandra, Seventeen Flat, Broadway Plain, McPhersons Plain and Cooleman Plain) and a number of sites of suitable topography in Victoria where it is locally common. It is confined to, and highly characteristic of, seasonally inundated depressions of alpine and high subalpine areas. There appears to be no convincing explanation for the genesis of these formations. The depressions may be more or less linear and oriented across slopes or they may be nearly circular on almost flat ground. They are underlain by water-retentive soils, often derived from igneous parent material, and filled with water following snow-melt. By early summer they are usually empty of surface water, but soils remain moist through the season (sometimes filling again during heavy rains).

Individual examples of Community a6 are often only a few square metres in area, but there will generally be many within a grassland stand. The main grassland community in which this is expected is Community a30 [Poa hookeri - Poa clivicola-Oreomyrrhis argentea-Ranunculus graniticola grassland of the Australian Alps bioregion]. Less commonly, it is found amongst grassy heathland, such as Community a42 [Epacris celata - Poa clivicola - Dillwynia palustris grassy heathland of the Australian Alps bioregion].

\section{Characteristic Species:}

\section{Species}

Carex chlorantha

Carex gaudichaudiana

Dichondra repens

Gonocarpus micranthus

Hydrocotyle sibthorpioides

Hypericum japonicum

Isolepis fluitans

Isolepis montivaga

Isolepis spp.

Juncus brevibracteus

Lobelia surrepens

Luzula alpestris

Myriophyllum pedunculatum

Plantago alpestris

Plantago antarctica

Pultenaea fasciculata

Ranunculus millanii

Spiranthes australis

Asperula gunnii

Viola betonicifolia
C/A Freq C/A O FreqO Fid

$\begin{array}{lllll}3 & 40 & 1 & <1 & \mathrm{P} \\ 3 & 100 & 2 & 4 & \mathrm{P} \\ 1 & 80 & 2 & 21 & \mathrm{P} \\ 3 & 60 & 1 & 2 & \mathrm{P} \\ 2 & 80 & 2 & 4 & \mathrm{P} \\ 2 & 40 & 1 & 4 & \mathrm{P} \\ 1 & 20 & 2 & <1 & \mathrm{P} \\ 1 & 20 & 1 & <1 & \mathrm{P} \\ 1 & 40 & 1 & <1 & \mathrm{P} \\ 1 & 40 & 1 & <1 & \mathrm{P} \\ 3 & 80 & 2 & <1 & \mathrm{P} \\ 1 & 20 & 1 & <1 & \mathrm{P} \\ 1 & 20 & 1 & <1 & \mathrm{P} \\ 1 & 20 & 1 & <1 & \mathrm{P} \\ 1 & 20 & 1 & <1 & \mathrm{P} \\ 1 & 20 & 1 & <1 & \mathrm{P} \\ 2 & 80 & 1 & <1 & \mathrm{P} \\ 1 & 20 & 1 & <1 & \mathrm{P} \\ 1 & 40 & 1 & 5 & \mathrm{C} \\ 1 & 60 & 1 & 27 & \mathrm{C}\end{array}$

Threatened communities: Nil.

Equivalent vegetation types: Unit 8A [Pratia depression] and Unit 8B [Fen (Bog pool)] (McDougall 1982); Damp alpine heathland Subcommunity 10.1 (Walsh et al. 1984); Vegetation Type 9 (Helman \& Gilmour 1985); Community 6 [Lobelia surrepens - Ranunculus millanii herbfield] (McDougall \& Walsh 2007).

Frequently occurring weeds: Acetosella vulgaris (0.20), Poa pratensis (0.20), Rorippa palustris (0.20), Rumex conglomeratus (0.20), Taraxacum officinale (0.20), Trifolium repens $(0.20)$.

Threats: Trampling by livestock or feral horses may damage plants or soils but the threat is currently low.

Reservation status: Mostly in Kosciuszko NP as well as Namadgi NP, but some examples are on freehold or leasehold land west of Kosciuszko NP.

Extent of clearing: Nil.
References: Helman, C.E. \& Gilmour, P.M. (1985) Treeless vegetation above 1,000 metres altitude in the A.C.T. Unpublished report. Conservation Council of the Southeast Region and Canberra: Canberra; McDougall, K.L. (1982) The alpine vegetation of the Bogong high plains. Environmental studies publication no. 357. Ministry for Conservation: Melbourne; McDougall, K.L. \& Walsh, N.G. (2007) Treeless vegetation of the Australian Alps. Cunninghamia 10: 1-57; Walsh, N.G., Barley, R.H. \& Gullan, P.K. (1984) The alpine vegetation of Victoria (excluding the Bogong high plains), volume 1. Environmental studies publication no. 376. Department of Conservation, Forests and Lands: Melbourne.

\section{4: Poa costiniana - Carex gaudichaudiana subal- pine valley grassland of the Australian Alps biore- gion}

Scientific Name: Poa costiniana - Carex gaudichaudiana - Stellaria angustifolia - Asperula gunnii - Luzula modesta
Number of samples:
Richness [mean $( \pm \mathrm{SD})]$ :
Slope (degrees):
18 (6)
Altitude (m asl):
Ave. Annual Rainfall (mm):
Temp. Annual Range $\left({ }^{\circ} \mathrm{C}\right)$ :
(0) $1-6(14)$
(1008) 1237-1434 (1618)
(807) $1082-1468(1912)$
(21.7) $22.8-24.5(26.1)$

Vegetation Description: Community a14 is a grassland or occasionally open heathland confined to broad valley floors and seepage areas on gentle slopes. Dominant species vary between localities, but common components include herbaceous species such as Poa costiniana, which is usually dominant, Hookerochloa hookeriana, Baloskion australe, Carex gaudichaudiana, Empodisma minus and Stylidium montanum as well as shrubs including Epacris breviflora, Epacris gunnii and Hakea microcarpa. In the northern part of its range, including the ACT, Poa labillardierei is often dominant. Soils are typically sodden humified peats.

Community a14 is common from Bimberi, Brindabella and Scabby Ranges (ACT), through lower altitude plains within Kosciuszko NP (Kiandra and Tantangara areas, Mt. Selwyn, Tooma/Tumut Divide, Cooleman Plain, Happy Jacks Plain and Currango Plain). It also occurs in the more easterly ranges of Victoria (e.g. Mt. Wombargo-Cobberas area, Nunniong Plateau, Davies Plain and Dinner Plain). It commonly grades into Community a2 [Baeckea gunniana - Epacris paludosa - Richea continentis - Sphagnum cristatum wet heathland of the Australian Alps bioregion (Bog)] in areas with impeded drainage and Community a30 [Poa hookeri - Poa clivicola - Oreomyrrhis argentea - Ranunculus graniticola grassland of the Australian Alps bioregion] on drier sites.

\section{Characteristic Species:}

Species

C/A Freq C/A OFreqO Fid

Asperula gunnii

Baloskion australe

Brachyscome decipiens

Brachyscome obovata

Cardamine astoniae

Carex gaudichaudiana

Carex jackiana

Cassinia monticola

Craspedia crocata

Empodisma minus

Epacris gunnii

Epilobium billardierianum

Epilobium gunnianum

Hookerochloa hookeriana

Hydrocotyle algida

\section{$\begin{array}{llllll}1 & 74 & 1 & 4 & \mathrm{P}\end{array}$}

$\begin{array}{lllll}1 & 74 & 1 & 4 & \mathrm{P} \\ 1 & 30 & 1 & 2 & \mathrm{P}\end{array}$

$\begin{array}{lllll}1 & 26 & 1 & 2 & \mathrm{P}\end{array}$

$\begin{array}{lllll}1 & 30 & 1 & <1 & \mathrm{P}\end{array}$

$\begin{array}{lllll}1 & 39 & 1 & <1 & \mathrm{P}\end{array}$

$\begin{array}{lllll}2 & 91 & 2 & 3 & \mathrm{P}\end{array}$

$\begin{array}{lllll}2 & 91 & 2 & 3 & \mathrm{P} \\ 1 & 26 & 1 & <1 & \mathrm{P}\end{array}$

$\begin{array}{lllll}1 & 22 & 1 & 1 & \mathrm{P}\end{array}$

$\begin{array}{lllll}1 & 22 & 2 & <1 & \mathrm{P}\end{array}$

$\begin{array}{lllll}2 & 52 & 2 & 3 & \mathrm{P}\end{array}$

$\begin{array}{lllll}1 & 35 & 1 & 2 & \mathrm{P}\end{array}$

$\begin{array}{lllll}1 & 39 & 1 & 2 & \mathrm{P} \\ 1 & 43 & 1 & 1 & \mathrm{P}\end{array}$

$\begin{array}{lllll}1 & 43 & 1 & 1 & \mathrm{P} \\ 1 & 26 & 1 & <1 & \mathrm{P}\end{array}$


Hypericum japonicum

Luzula modesta

Montia australasica

Oreomyrrhis ciliata

Poa costiniana

Ranunculus graniticola

Ranunculus millanii

Ranunculus pimpinellifolius

Senecio gunnii

Stellaria angustifolia

39
61
35
43
100
48
30
35
39
61

1
1
1
2
1
2

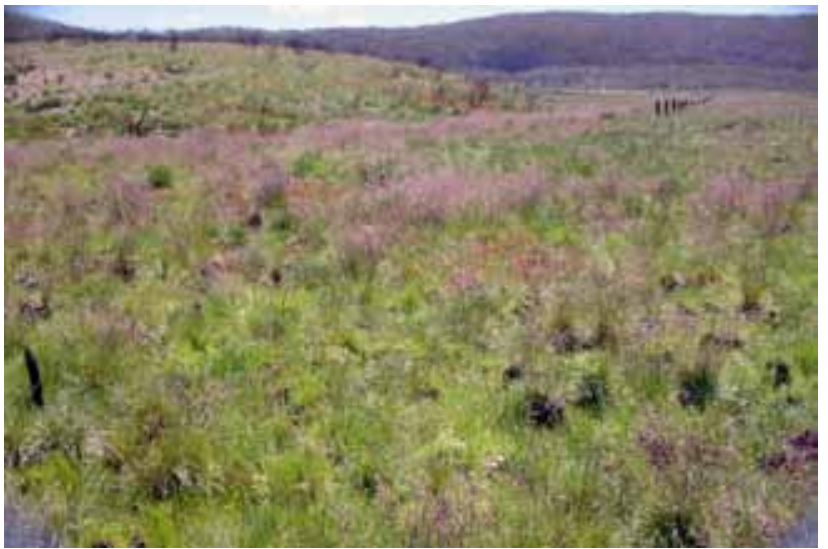

Plate a14: Community a14 is typically dominated by the tussocks of Poa costiniana and is common on drainage flats in the montane and subalpine zones of the Australian Alps. This example is at Rocky Plains on the Snowy Mountain Highway, east of Kiandra. (to excavation by feral pigs, causing thes to dry. Its greater fertility than surrounding vegetation and perma wetness makes the community especially vulnerable to weed invasion. Holcus lanatus, Anthoxanthum odoratum and Leucanthemum vulgare have formed extensive colonies at some sites and pose a great threat to this vegetation.

Reservation status: Well reserved, with almost all examples in NSW occurring within Kosciuszko NP.

Extent of clearing: Nil, but this community was probably degraded through decades of grazing in the $19^{\text {th }}$ and $20^{\text {th }}$ centuries.

References: Benson, J.S. (1994) The native grasslands of the Monaro region: southern tablelands of New South Wales. Cunninghamia 3: 609-650; Costin, A.B. (1954) A study of the ecosystems of the Monaro region of New South Wales. (Government Printer: Sydney); Helman, C.E., Gilmour, P.M., Osborne, W.S. \& Green, K. (1988) An ecological survey of the upper Cotter catchment wilderness area, Namadgi National Park, ACT. Unpublished report. Conservation Council of the South-east Region and Canberra, Canberra; McDougall, K.L. \& Walsh, N.G. (2007) Treeless vegetation of the Australian Alps. Cunninghamia 10: 1-57; Walsh, N.G., Barley, R.H. \& Gullan, P.K. (1984) The alpine vegetation of Victoria (excluding the Bogong high plains), volume 1. Environmental studies publication no. 376. Department of Conservation, Forests and Lands: Melbourne.

\section{a22: Poa fawcettiae - Celmisia costiniana - Cras- pedia maxgrayi grassland of the Australian Alps bioregion}

Scientific Name: Poa fawcettiae - Celmisia costiniana Craspedia maxgrayi - Euphrasia collina subsp. diversicolor - Pentachondra pumila

$\begin{array}{ll}\text { Number of samples: } & 25 \\ \text { Richness [mean }( \pm \text { SD)]: } & 20(4) \\ \text { Slope (degrees): } & (1) 4-18(22) \\ \text { Altitude (m asl): } & (1727) 1937-2083(2182) \\ \text { Ave. Annual Rainfall (mm): } & (2070) 2290-2560(2667) \\ \text { Temp. Annual Range }\left({ }^{\circ} \mathrm{C}\right): & (19.6) 20-20.6(21.6)\end{array}$

Vegetation Description: Community a22 is a grassland generally dominated by Poa fawcettiae, although Poa hiemata and Pentachondra pumila may be locally dominant. The main forbs include Celmisia costiniana and Craspedia maxgrayi. Species diversity is usually high (compared with other communities at similar elevation). Tall shrubs

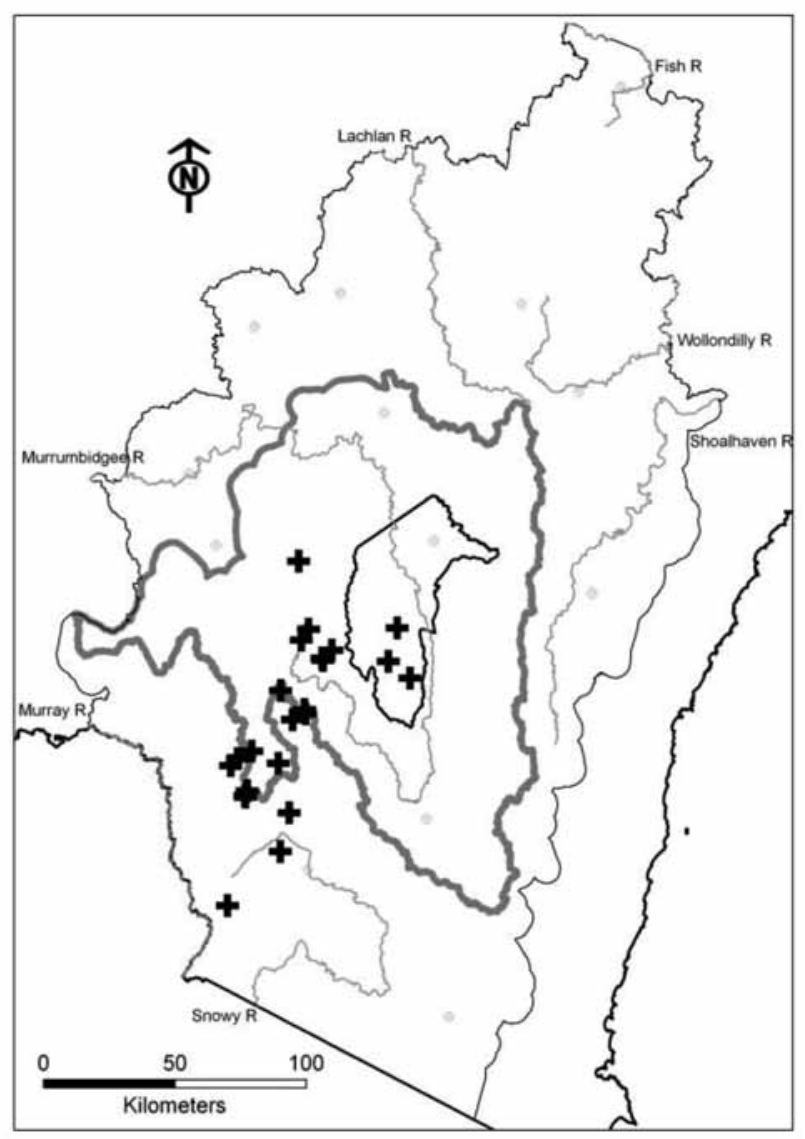

Fig. a14: Distribution of field samples assigned to this community. 
are rare. A species-poor variant of the community (Community 18 of McDougall \& Walsh 2007) is found on Mt. Jagungal and Mt. Twynam and is incorporated into the current plant community concept. On Mt. Twynam at least, it may be a result of assisted regeneration following severe erosion caused by cattle grazing. That area was the subject of major soil conservation works in the 1960s after grazing was removed.

Community a22 occurs on sites of low relief with deep soils (e.g. saddles and stream heads) between the Main Range and Mt. Jagungal in Kosciuszko NP. It is not known whether this community occurs in the upper Murrumbidgee catchment, being present on the southern and eastern fall of Mt. Jagungal, which marks the boundary of the catchment. Throughout its range, it grades into Community a46 [Prostanthera cuneata - Orites lancifolius - Nematolepis ovatifolia heathland of the Australian Alps bioregion]. The ecotone between these communities is large and it will often be difficult to map a boundary between them where the dominants of the heathland are scattered through the grassland.

\section{Characteristic Species:}

\section{Species} Acrothamnus montanus Australopyrum velutinum Brachyscome scapigera

Carex breviculmis

Carex hebes

Celmisia costiniana

Celmisia pugioniformis

Craspedia costiniana

Craspedia maxgrayi

Deyeuxia crassiuscula

Empodisma minus

Euphrasia collina subsp. diversicolor

Grevillea australis

Luzula alpestris

Luzula modesta

Lycopodium fastigiatum

Microseris lanceolata

Oreomyrrhis eriopoda

Pentachondra pumila

Pimelea alpina

Plantago euryphylla

Poa costiniana

Poa fawcettiae

Prasophyllum spp.

Ranunculus graniticola

Rytidosperma nudiflorum

Saxipoa saxicola

Scleranthus singuliflorus

Senecio pinnatifolius var. alpinus

Trisetum spicatum
Aciphylla glacialis Argyrotegium fordianum

Craspedia aurantia

Gentianella muelleriana subsp. alpestris

\section{C/A Freq C/AO FreqO Fid}

$\begin{array}{lll}1 & 32 & 1 \\ 1 & 48 & 1 \\ 1 & 32 & 1 \\ 1 & 20 & 1 \\ 1 & 20 & 1 \\ 1 & 92 & 1 \\ 1 & 36 & 1 \\ 2 & 76 & 1 \\ 1 & 24 & 1 \\ 1 & 44 & 1 \\ 1 & 28 & 1 \\ 1 & 72 & 1 \\ 1 & 20 & 1 \\ 1 & 20 & 2 \\ 1 & 52 & 1 \\ 1 & 40 & 1 \\ 1 & 20 & 2 \\ 1 & 28 & 1 \\ 1 & 20 & 1 \\ 1 & 28 & 1 \\ 1 & 76 & 1 \\ 1 & 76 & 1 \\ 1 & 44 & 1 \\ 1 & 60 & 1 \\ 1 & 24 & 1 \\ 3 & 48 & 2 \\ 3 & 60 & 2 \\ 1 & 36 & 1 \\ 2 & 20 & 1 \\ 1 & 88 & 1 \\ 1 & 40 & 1 \\ 1 & 20 & 1 \\ 1 & 52 & 1 \\ 1 & 72 & 1\end{array}$

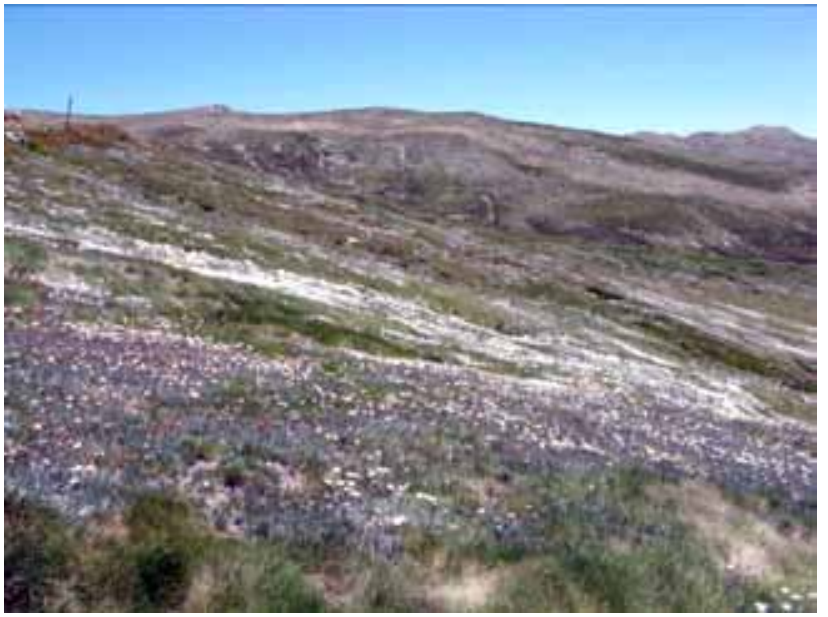

Plate a22: Community a22 is rare in the study area, found only near the summit of Mt Jagungal. This example is on the slopes of the Main Range of Kosciuszko NP.

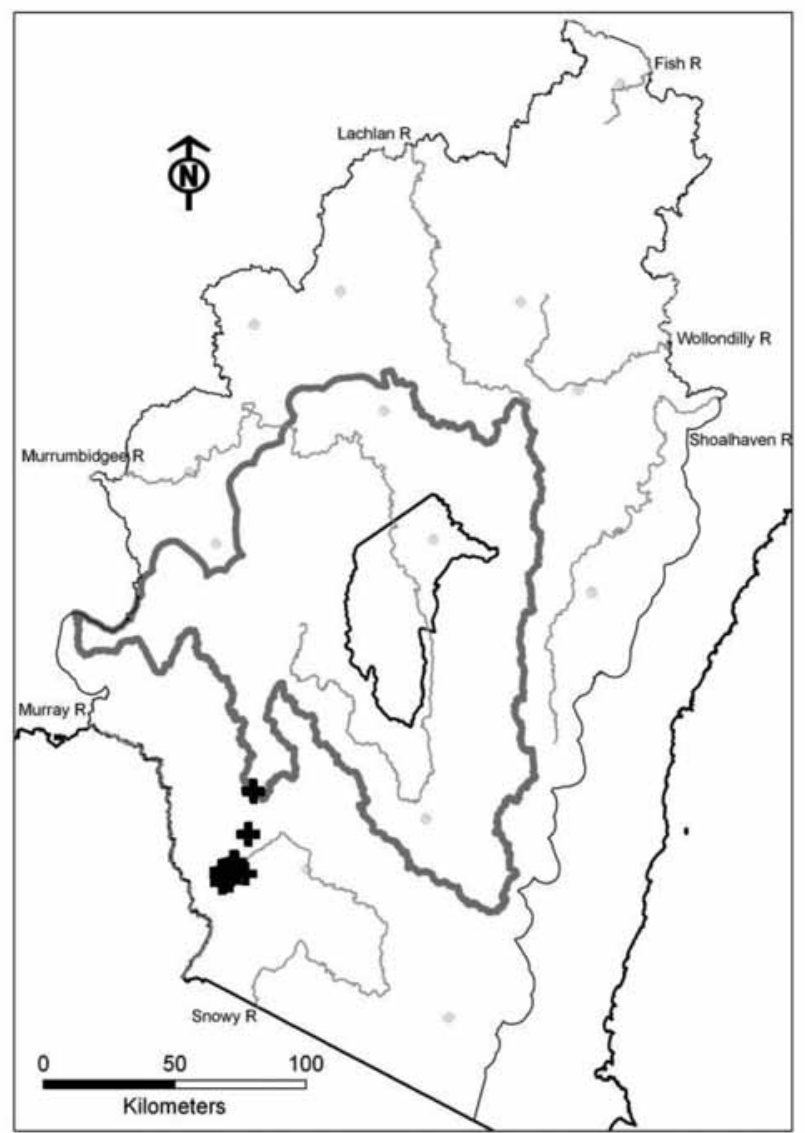

\section{Threatened communities: Nil.}

Equivalent vegetation types: part of Celmisia longifolia - Poa caespitosa alliance (Costin 1954); part of the Tall alpine herbfield of Costin et al. (2000); combination of Communities 18 [Poa fawcettiae Uncinia sulcata grassland] and 22 [Poa fawcettiae - Euphrasia collina grassland] (McDougall \& Walsh 2007).

Frequently occurring weeds: Acetosella vulgaris (0.46).

Threats: Chronological aerial photograph interpretation indicates that the area of this community has declined in the past 60 years because of encroachment by shrubs. It is uncertain if this is the result of climate

Fig. a22: Distribution of field samples assigned to this community. 22 
change or disturbance by sheep and cattle, as both factors may favour shrub establishment.

Reservation status: Entirely within Kosciuszko NP.

Extent of clearing: Nil, though formerly much of the community had been severely degraded by sheep and cattle grazing.

References: Costin, A.B. (1954) A study of the ecosystems of the Monaro region of New South Wales. (Government Printer: Sydney); Costin, A.B., Gray, M., Totterdell, C.J. \& Wimbush D.J. (2000) Kosciuszko alpine flora. (CSIRO Publishing: Collingwood); McDougall, K.L. \& Walsh, N.G. (2007) Treeless vegetation of the Australian Alps. Cunninghamia 10: 1-57.

\section{a30: Poa hookeri - Poa clivicola - Oreomyrrhis argentea - Ranunculus graniticola grassland of the Australian Alps bioregion}

Scientific Name: Poa hookeri - Poa clivicola - Oreomyrrhis argentea - Ranunculus graniticola - Geranium antrorsum

$\begin{array}{ll}\text { Number of samples: } & 54 \\ \text { Richness [mean }( \pm \mathrm{SD})]: & 28(6) \\ \text { Slope (degrees): } & (0) 2-8(22) \\ \text { Altitude (m asl): } & (1194) 1285-1397(1619) \\ \text { Ave. Annual Rainfall (mm): } & (969) 1186-1459(1814) \\ \text { Temp. Annual Range }\left({ }^{\circ} \mathrm{C}\right): & (21.7) 23.2-24.1(25)\end{array}$

Vegetation Description: Community a30 is a grassland characterised by a dense cover of one or often several species of Poa (mainly Poa clivicola, Poa costiniana, Poa hiemata or Poa hookeri but occasionally Poa petrophila or Poa phillipsiana) with numerous intertussock spaces containing a large range of herbaceous species. Tall shrubs such as Hakea microcarpa and Cassinia monticola may be present in this community and at times are abundant enough for the vegetation to be structurally an open heathland. Despite the greater shrub cover, such examples are floristically inseparable from surrounding grasslands. There is photographic evidence that these shrubs are recent invaders of the grassland community. Their invasion has probably been facilitated by past grazing disturbance, although climate change will also favour expansion of shrubs into frost hollows.

The component of this community dominated by Poa hookeri was regarded as a distinct community by McDougall \& Walsh (2007) and may well be so. In the places where it occurs (Kosciuszko NP north from the Happy Jacks area), it forms a mosaic with grassland dominated by other species, making it hard to collect homogeneous samples and increasing the likelihood of combination in the classification. In any case, the grasslands would be inseparable as a mapping unit. The Poa hookeri-dominated variant is characterised by dwarf tussocks of Poa hookeri and the closed cover of mat-forming herbs, shrubs and low shrubs (e.g. Calotis pubescens, Coprosma nivalis, Dillwynia prostrata, Pimelea biflora, Pultenaea fasciculata, Pultenaea polifolia, Rutidosis leiolepis).

Community a30 is the most common grassland of the treeless plains in Kosciuszko NP, occurring from the upper Thredbo Valley in the south to Emu Plain in the west, Cooleman Plain in the north and Snowy Plain in the east. It is the dominant community of large plains such as Kiandra, Happy Jacks and Long Plains and also occurs in the ACT at Cheyenne Flat and Bimberi (and probably elsewhere at high altitude). Its distribution is controlled by temperature and soil depth: low temperatures associated with cold air drainage in the growing season do not favour tall shrub and tree establishment. It is best expressed where soils are deep and on shallow soils it is replaced by heathlands and woodlands.

The lower edge of this community commonly adjoins Community a14 [Poa costiniana - Carex gaudichaudiana subalpine valley grassland of the Australian Alps bioregion] and its upper edge is usually Community u158 [Alpine Sallee shrub-grass subalpine mid-high woodland of the

Australian Alps bioregion]. Patches of Community a33 [Bossiaea foliosa - Cassinia monticola - Kunzea muelleri - Hovea montana heathland of the Australian Alps bioregion] and Community a34 [Weeping Snow Gum - Small-fruited Hakea - Blue Snow-grass grassy open woodland of the Australian Alps bioregion] may be found in a mosaic within the grassland.

\section{Characteristic Species:}

\section{Species}

Acaena echinata

Aciphylla simplicifolia Acrothamnus hookeri

Ajuga australis

Asperula gunnii

Asterolasia trymalioides

Australopyrum velutinum

Brachyscome aculeata

Brachyscome decipiens

Brachyscome scapigera

Cardamine lilacina

Carex breviculmis

Carex hebes

Celmisia pugioniformis

Craspedia coolaminica

Craspedia jamesii

Diuris monticola

Epilobium billardierianum

Erigeron bellidioides

Euphrasia collina subsp. paludosa 1

Festuca asperula

Geranium antrorsum

Grevillea australis

Hakea microcarpa

Hovea montana

Hovea aff. heterophylla (Kiandra)

Leptorhynchos elongatus

Leptorhynchos squamatus

Linum marginale

Luzula flaccida

Melicytus sp. 'Snowfields'

Microseris lanceolata

Oreomyrrhis argentea

Pimelea biflora

Pimelea linifolia subsp. caesia

Plantago antarctica

Plantago euryphylla

Poa clivicola

Poa hiemata

Poa hookeri

Poa costiniana

Poa fawcettiae

Poa petrophila

Poa phillipsiana

Podolepis jaceoides

Poranthera oreophila

Prasophyllum spp.

Pultenaea fasciculata

Pultenaea polifolia

Ranunculus graniticola

Rhodanthe anthemoides

Rhytidosporum alpinum

Rytidosperma spp.

Rutidosis leiolepis

Scleranthus biflorus

Scleranthus fasciculatus

Senecio pinnatifolius var. alpinus

Swainsona monticola

Trisetum spicatum

Xerochrysum subundulatum

\section{C/A Freq C/A O FreqO Fid}

$\begin{array}{llll}33 & 1 & 9 & \mathrm{P}\end{array}$

$\begin{array}{llll}33 & 1 & 2 & \mathrm{P}\end{array}$

$\begin{array}{llll}65 & 1 & 7 & \mathrm{P}\end{array}$

$\begin{array}{llll}26 & 1 & 8 & \mathrm{P}\end{array}$

$\begin{array}{llll}63 & 1 & 4 & \mathrm{P}\end{array}$

$\begin{array}{llll}15 & 2 & <1 & \mathrm{P}\end{array}$

$\begin{array}{llll}28 & 1 & <1 & \mathrm{P}\end{array}$

$\begin{array}{llll}33 & 1 & 2 & \mathrm{P}\end{array}$


Threatened communities: Nil.

Equivalent vegetation types: Vegetation Type 2 (Helman \& Gilmour 1985); Group 16 (Helman et al. 1988); Community 6 (Benson 1994); combination of Communities 30 [Poa hiemata - Poa clivicola grassland] and 31 [Poa hookeri grassland] (McDougall \& Walsh 2007).

Frequently occurring weeds: Acetosella vulgaris (0.59), Hypochaeris radicata $(0.59)$.

Threats: Despite its great spatial extent in conservation reserves, this community is one of the most threatened communities in the Alps and upper Murrumbidgee catchment. Patches of up to $100 \mathrm{~m}^{2}$ may be overturned by pigs causing the exposure of bare soil, a large reduction in the cover of Poa species, and an increase in disturbance tolerant species such as Geranium antrorsum, Drabastrum alpestre and Stellaria multiflora (McDougall \& Walsh 2002). Horses are commonly seen in this grassland and presumably selectively graze some of its species. Grassland forbs were found to be selectively grazed by cattle on the Bogong High Plains in Victoria (Van Rees \& Holmes 1986), so it is possible that horses are having a significant effect on species abundance and turnover. Investigation of horse diet is urgently required, given the high incidence of rare and threatened plant species in this community (McDougall \& Walsh 2007). Invasion by Leucanthemum vulgare is also a significant threat, with this weed spreading rapidly in recent years near Tantangara Dam. Based on its invasion ecology and impact elsewhere (Clements et al. 2004), the containment of this weed will be essential for the future survival of this community.

Reservation status: Mostly within Kosciuszko NP; some examples on freehold land at Snowy Plain (in the Southern Rivers CMA).

Extent of clearing: Nil, but probably highly degraded in places by domestic grazing and, at Kiandra, mining.

References: Benson, J.S. (1994) The native grasslands of the Monaro region: southern tablelands of New South Wales. Cunninghamia 3: 609650; Helman, C.E. \& Gilmour, P.M. (1985) Treeless vegetation above 1,000 metres altitude in the A.C.T. Unpublished report. Conservation Council of the Southeast Region and Canberra: Canberra; Helman, C.E., Gilmour, P.M., Osborne, W.S. \& Green, K. (1988) An ecological survey of the upper Cotter catchment wilderness area, Namadgi National Park, ACT. Unpublished report. Conservation Council of the South-east Region and Canberra, Canberra; McDougall, K.L. \& Walsh, N.G. (2002) The flora of Nungar plain, a treeless sub-alpine frost hollow in Kosciuszko National Park. Cunninghamia 7: 601-610; McDougall, K.L. \& Walsh, N.G. (2007) Treeless vegetation of the Australian Alps. Cunninghamia 10: 1-57; Van Rees, H. \& Holmes, J.H.G. (1986) The botanical composition of the diet of free-ranging cattle on an alpine range in Australia. Journal of Range Management 39: 392-395.

\section{a38: Themeda australis - Galium roddii - Leuc- ochrysum alpinum grassland of steep limestone slopes in the Australian Alps bioregion}

Scientific Name: Themeda australis - Galium roddii Leucochrysum alpinum - Cassinia ochracea - Xerochrysum viscosum

Number of samples:

Richness [mean $( \pm \mathrm{SD})]$ :

Slope (degrees):

Altitude (m asl):

Ave. Annual Rainfall (mm):

Temp. Annual Range $\left({ }^{\circ} \mathrm{C}\right)$ :

6

$15(4)$

(2) 14-27 (39)

(1185) 1207-1220 (1240)

(1080) 1081-1082 (1084)

(24.7) $24.7-24.8(24.8)$
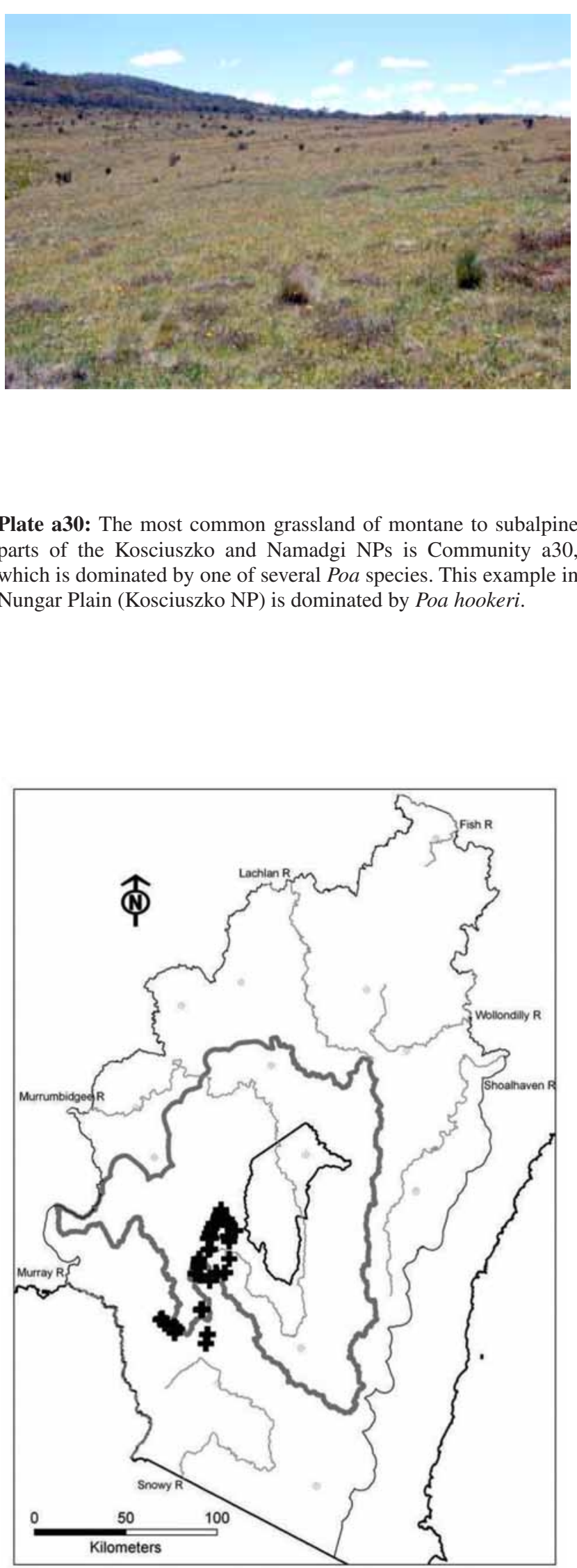

Fig. a30: Distribution of field samples assigned to this community.
Plate a30: The most common grassland of montane to subalpine parts of the Kosciuszko and Namadgi NPs is Community a30, which is dominated by one of several Poa species. This example in

Nungar Plain (Kosciuszko NP) is dominated by Poa hookeri.

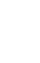

Vegetation Description: Community a38 is a grassland mainly dominated by Themeda australis and Poa fawcettiae, although plant cover is sometimes sparse amongst limestone outcrops. While shrub cover is generally low, there are occasional emergent shrubs of Cassinia ochracea, Grevillea lanigera and Hakea microcarpa. Several taxa 
otherwise uncommon in treeless vegetation in the Australian Alps grow in this community which are restricted to limestone landscapes (e.g. Bulbine glauca, Clematis leptophylla, Convolvulus angustissimus, Galium roddii, Xerochrysum viscosum).

This community is common on steep slopes in the Blue Waterholes area of Kosciuszko NP (Cave Creek), where it occurs on loose limestone scree and around rocky outcrops. Slopes in similar habitat at Yarrangobilly Caves about $25 \mathrm{~km}$ south of Blue Waterholes support small pockets of this community within a forested landscape.

\section{Characteristic Species:}

\section{Species}

Brachyscome rigidula

Carex breviculmis

Cassinia ochracea

Clematis leptophylla

Convolvulus angustissimus

Craspedia coolaminica

Galium roddii

Grevillea lanigera

Hakea microcarpa

Leucochrysum alpinum

Linum marginale

Muehlenbeckia axillaris

Picris angustifolia subsp merxmuelleri

Pimelea linifolia subsp. caesia 1

Poa fawcettiae

Rhodanthe anthemoides

Themeda australis

Vittadinia cuneata

Xerochrysum viscosum

\section{C/A Freq C/AO FreqO Fid}

$\begin{array}{llll}33 & 1 & 2 & \mathrm{P}\end{array}$

$\begin{array}{llll}100 & 1 & 13 & \mathrm{P}\end{array}$

$\begin{array}{llll}67 & 1 & <1 & \mathrm{P}\end{array}$

$\begin{array}{llll}33 & 1 & 2 & \mathrm{P}\end{array}$

$\begin{array}{llll}67 & 1 & 3 & \mathrm{P}\end{array}$

$\begin{array}{llll}50 & 1 & 2 & \mathrm{P}\end{array}$

$\begin{array}{llll}50 & 1 & <1 & \mathrm{P}\end{array}$

$\begin{array}{llll}33 & 1 & 3 & \mathrm{P}\end{array}$

$\begin{array}{llll}83 & 1 & 3 & \mathrm{P}\end{array}$

$\begin{array}{llll}100 & 1 & <1 & \mathrm{P}\end{array}$

$\begin{array}{llll}67 & 1 & 1 & \mathrm{P}\end{array}$

$\begin{array}{llll}33 & 1 & <1 & \mathrm{P}\end{array}$

$\begin{array}{llll}67 & 1 & 2 & \mathrm{P}\end{array}$

$\begin{array}{llll}83 & 1 & 2 & \mathrm{P} \\ 100 & 3 & 2 & \mathrm{P}\end{array}$

$\begin{array}{llll}100 & 3 & 2 & \mathrm{P}\end{array}$

$\begin{array}{llll}33 & 1 & 1 & \mathrm{P}\end{array}$

$\begin{array}{llll}100 & 2 & 21 & P\end{array}$

$\begin{array}{llll}67 & 1 & 2 & \mathrm{P}\end{array}$

$\begin{array}{lll}83 & 1 & 1\end{array}$

Threatened communities: Nil.

Equivalent vegetation types: Community 38 [Themeda triandra Leucochrysum albicans grassland] (McDougall \& Walsh 2007).

Frequently occurring weeds: Cerastium vulgare (0.33), Crepis capillaris (0.50), Echium vulgare (0.33), Hypochaeris radicata (0.67), Rosa rubiginosa (0.67), Sedum acre (0.67), Tragopogon dubius (0.67), Trifolium dubium (0.83).

Threats: The Cave Creek area has a high diversity of weeds, some of which are locally abundant. Sedum acre occupies a niche on rocky sites also occupied by the very restricted Galium roddii, which appears to be threatened as a result. Many of the weeds present in Cave Creek are locally dominant in similar habitat at Yarrangobilly Caves (e.g. Potentilla recta, Rosa rubiginosa, Tragopogon dubius, Verbascum thapsus). Control of these and other weed species may be required in the future. Control will be difficult, however, because the steep slopes of Cave Creek are unstable and frequent pedestrian traffic could have a significant impact on plants growing there.

Reservation status: Entirely within Kosciuszko NP.

Extent of clearing: Nil.

Reference: McDougall, K.L. \& Walsh, N.G. (2007) Treeless vegetation of the Australian Alps. Cunninghamia 10: 1-57.

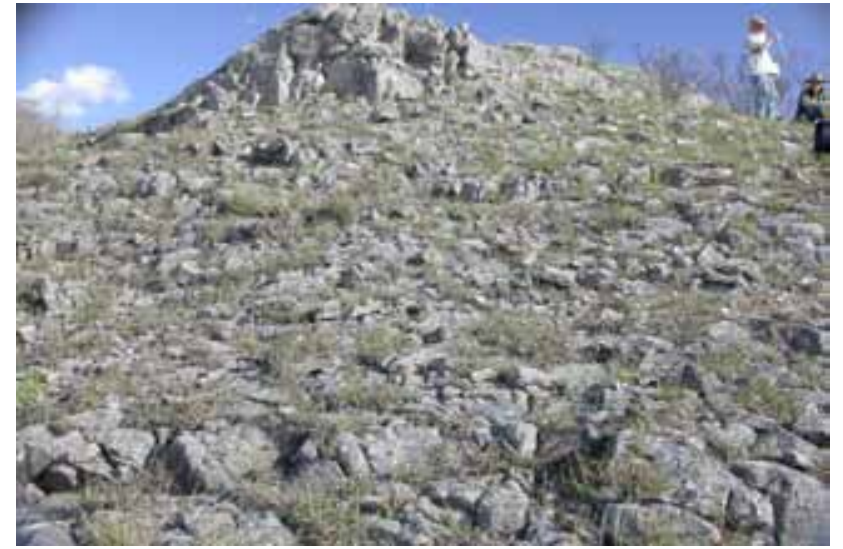

Plate a38: Community a38 is a grassland with scattered shrubs confined to karst areas at Yarrangobilly and Blue Waterholes in Kosciuszko NP. This photo was taken near Blue Waterholes one year after the 2003 fires which burnt all of the community.

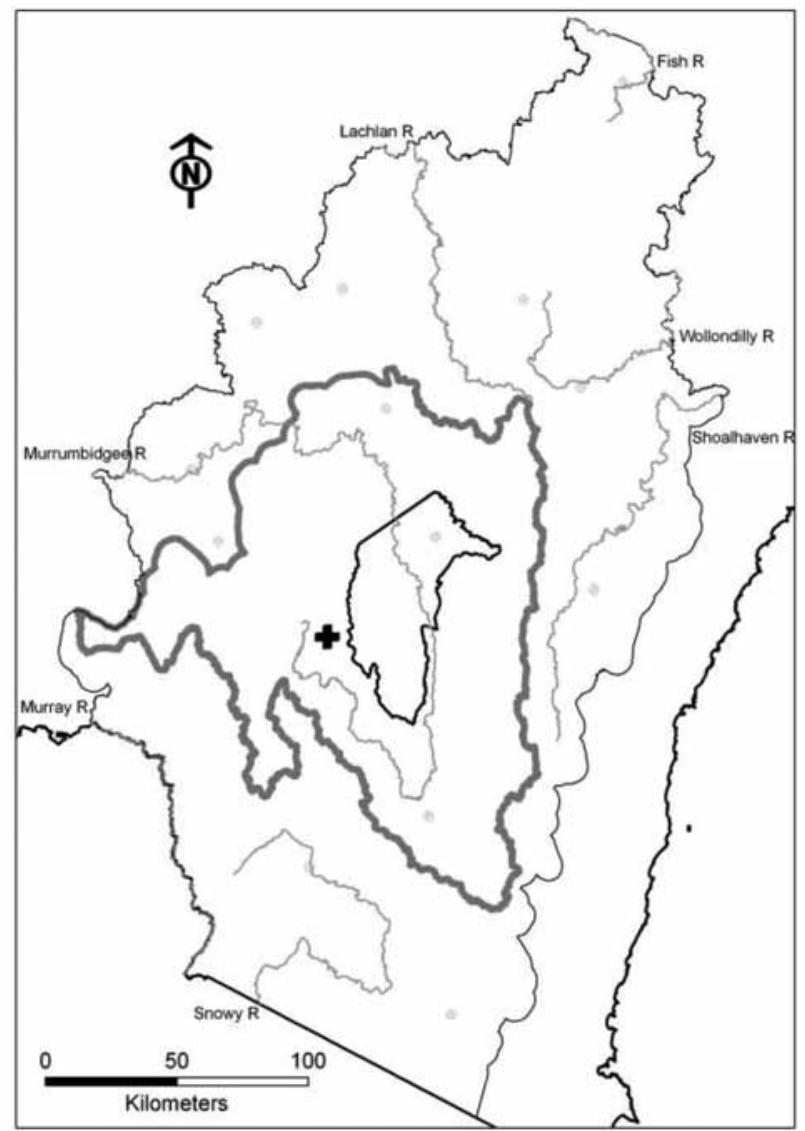

Fig. a38: Distribution of field samples assigned to this community. 


\section{Class: Alpine Heaths}

\section{a33: Bossiaea foliosa - Cassinia monticola - Kunzea muelleri - Hovea montana heathland of the Austral- ian Alps bioregion}

Scientific Name: Bossiaea foliosa - Cassinia monticola Epacris petrophila - Hovea montana - Kunzea muelleri Pimelea biflora / Poa hiemata

Number of samples:

36

Richness [mean $( \pm \mathrm{SD})]$ :

$26(5)$

Slope (degrees):

Altitude (m asl):

Ave. Annual Rainfall (mm):

Temp. Annual Range $\left({ }^{\circ} \mathrm{C}\right)$ :
(0) $3-10(21)$

(1241) 1330-1582 (1790)

(1144) $1506-1777(2050)$

(21.1) $21.8-23.3(24.1)$

Vegetation Description: Community a33 can occur as either a closed or open heathland dominated by shrubs 1 to 1.5 metres tall, such as Bossiaea foliosa, Epacris petrophila, Hovea montana, Cassinia monticola, Grevillea australis, Kunzea muelleri or Podolobium alpestre. Gaps between shrubs are commonly dominated by Poa clivicola, Poa fawcettiae or Poa phillipsiana, and occasionally Austrostipa nivicola, with many forbs characteristic of the adjoining grassland Community a30 [Poa hookeri - Poa clivicola - Oreomyrrhis argentea - Ranunculus graniticola grassland of the Australian Alps bioregion]. In the Murray catchment (e.g. upper Tooma River catchment), the heathland is commonly dominated by Bossiaea foliosa and despite the closed nature of this variant, the diversity of forbs and grasses is high. Dichelachne crinita, an uncommon species in the higher Alps, is a common component there.

Within the upper Murrumbidgee catchment, this community is abundant in Kosciuszko NP (e.g. Long Plain, Bullocks Hill, Currango Plain) and Namadgi NP (e.g. Mt. Bimberi, Mt. Murray, Mt. Gingera) It may be found in a mosaic with Community a30 [Poa hookeri - Poa clivicola - Oreomyrrhis argentea - Ranunculus graniticola grassland of the Australian Alps bioregion] but usually occupies the upper slopes of subalpine frost hollows.

Community a33 is a combination of three heathland Communities 33 , 35 and 36 of McDougall \& Walsh (2007). These communities may be separable floristically, each being influenced by the herbaceous composition of surrounding grassland communities. However, at their extremities the differences between them are minor and, for mapping purposes, they are likely to be indistinguishable.

\section{Characteristic Species:}

\section{Species}

Aciphylla simplicifolia Acrothamnus hookeri Asperula gunnii Bossiaea foliosa Brachyscome decipiens Brachyscome scapigera Brachyscome spathulata Cardamine lilacina Carex breviculmis Carex hebes

Cassinia monticola Celmisia pugioniformis Craspedia coolaminica Craspedia jamesii Empodisma minus Epacris gunnii

\section{C/A Freq C/A O FreqO Fid}

$\begin{array}{lll}1 & 72 & 1 \\ 1 & 33 & 1 \\ 1 & 58 & 1 \\ 2 & 31 & 2 \\ 1 & 25 & 1 \\ 1 & 25 & 1 \\ 1 & 33 & 1 \\ 1 & 39 & 1 \\ 1 & 92 & 1 \\ 1 & 22 & 1 \\ 1 & 56 & 1 \\ 1 & 42 & 1 \\ 1 & 28 & 1 \\ 1 & 75 & 1 \\ 1 & 25 & 2 \\ 1 & 33 & 1\end{array}$

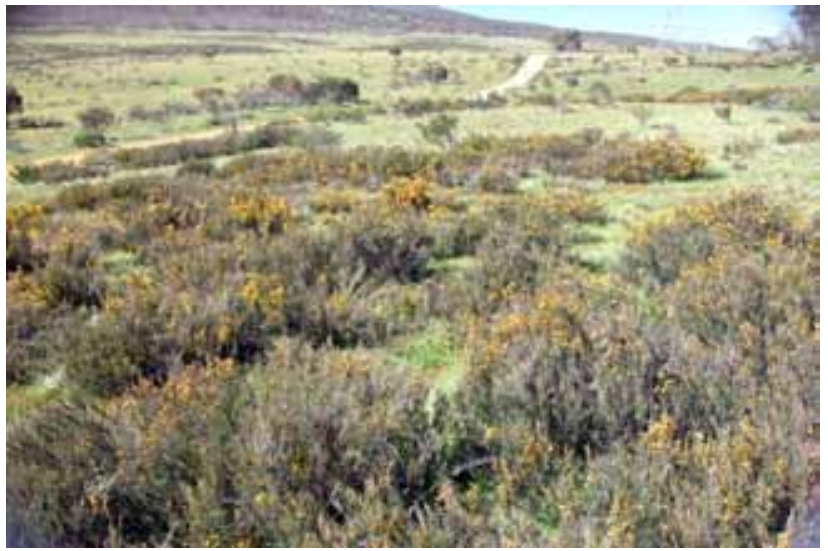

Plate a33: Community a33 is a common shrubland found in and around Kosciuszko and Namadgi NPs. The dominant may be one or more of several shrub species (Bossiaea foliosa in this photo taken in Long Plain (Kosciuszko NP), and the understorey is typically composed of grasses and forbs found in neighbouring grassland communities.

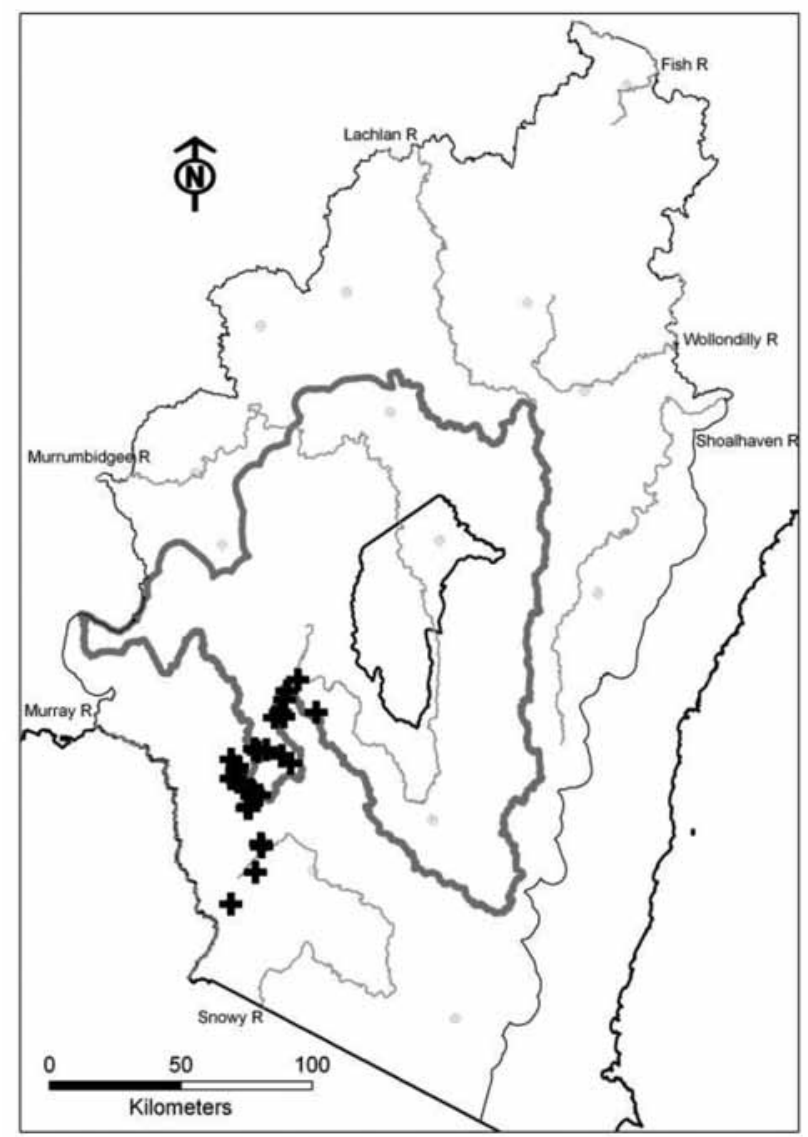

Fig. a33: Distribution of field samples assigned to this community. 
Erigeron bellidioides

Geranium antrorsum

Grevillea australis

Hakea microcarpa

Hovea montana

Kunzea muelleri

Leptorhynchos squamatus

Luzula modesta

Microseris lanceolata

Oreomyrrhis argentea

Pimelea biflora

Pimelea linifolia subsp. ceasia

Poa clivicola

Poa costiniana

Poa hiemata

Poranthera oreophila

Ranunculus graniticola

Scleranthus biflorus

Senecio pinnatifolius var. alpinus

Trisetum spicatum

Xerochrysum subundulatum
Euphrasia collina subsp. paludosa 1

$\begin{array}{llll}39 & 1 & <1 & \mathrm{P} \\ 31 & 1 & 2 & \mathrm{P} \\ 33 & 1 & 3 & \mathrm{P} \\ 50 & 2 & 1 & \mathrm{P} \\ 33 & 1 & 3 & \mathrm{P} \\ 50 & 1 & <1 & \mathrm{P} \\ 47 & 2 & <1 & \mathrm{P} \\ 61 & 1 & 2 & \mathrm{P} \\ 31 & 1 & 2 & \mathrm{P} \\ 69 & 1 & 6 & \mathrm{P} \\ 33 & 1 & <1 & \mathrm{P} \\ 36 & 1 & <1 & \mathrm{P} \\ 33 & 1 & 8 & \mathrm{P} \\ 28 & 3 & 2 & \mathrm{P} \\ 53 & 2 & 4 & \mathrm{P} \\ 53 & 3 & 1 & \mathrm{P} \\ 50 & 1 & 27 & \mathrm{P} \\ 83 & 1 & 3 & \mathrm{P} \\ 64 & 1 & 9 & \mathrm{P} \\ 44 & 1 & 3 & \mathrm{P} \\ 31 & 1 & 2 & \mathrm{P} \\ 47 & 1 & <1 & \mathrm{P}\end{array}$

\section{Threatened communities: Nil}

Equivalent vegetation types: Combination of Communities 33 [Northern Alps Hovea montana open heathland], 35 [Bossiaea foliosa - Epacris petrophila heathland] and 36 [Broadway Bossiaea foliosa closed heathland] (McDougall \& Walsh 2007); not clearly identified in other previous vegetation descriptions.

Frequently occurring weeds: Acetosella vulgaris (0.58), Hypochaeris radicata $(0.36)$.

Threats: This community is frequently used by feral horses. Although trampling and selective grazing undoubtedly occur, the overall effect is likely to be minimal, because most shrubs in this community are unpalatable and facultative resprouters; in addition, most palatable species will be found in adjoining grassland. The greatest threat appears to be invasion by Leucanthemum vulgare. In an example of several hectares near Tantangara Dam, this weed has a cover of about $80 \%$.

Reservation status: Mostly in conservation reserves (Kosciuszko NP, Bimberi NR, Namadgi NP), with small amounts on freehold land at Snowy Plain in the Southern Rivers CMA.

Extent of clearing: Probably negligible and this community appears to be expanding into grassland either because of past land use disturbance or climate change (or both).

Reference: McDougall, K.L. \& Walsh, N.G. (2007) Treeless vegetation of the Australian Alps. Cunninghamia 10: 1-57.

\section{a39: Epacris sp. - Pentachondra pumila - Poa fawc- ettiae heathland of the Australian Alps bioregion}

Scientific Name: Epacris sp. - Pentachondra pumila - Poa fawcettiae - Senecio pectinatus - Craspedia maxgrayi

$\begin{array}{ll}\text { Number of samples: } & 10 \\ \text { Richness [mean }( \pm \text { SD)]: } & 19(4) \\ \text { Slope (degrees): } & (2) 6-10(17) \\ \text { Altitude (m asl): } & (1729) 1936-2117(2147) \\ \text { Ave. Annual Rainfall (mm): } & (2095) 2327-2581(2634) \\ \text { Temp. Annual Range }\left({ }^{\circ} \mathrm{C}\right): & (19.7) 19.9-20.6(21.6)\end{array}$

Vegetation Description: Community a39 is a low heathland dominated by an undescribed Epacris species (Costin et al. 2000), Kunzea muelleri or occasionally Epacris petrophila. It occurs on the upper granite or phyllite slopes and summits of the Kosciuszko Main Range, with an outlier on the summit of Mt. Jagungal. Sites containing this community are generally rocky with shallow soil. An unusual feature of some stands is the presence of Baeckea gunniana, a species usually associated with moist sites. This species can sometimes be found layering over large granite boulders. The diversity and abundance of herb species is usually low. Rock and bare ground are common. This heathland has some floristic elements of Community 40 of McDougall \& Walsh (2007; Epacris gunnii - Chionohebe pulvinatus feldmark; e.g. Leucochrysum alpinum and Luzula australasica), but is far more diverse and lacking in low-growing species endemic to that community (Colobanthus pulvinatus, Ranunculus acrophilus, Chionohebe densifolia, Euphrasia collina subsp. lapidosa, Kelleria dieffenbachii).

On less exposed sites with deeper soil profiles, Community a39 often grades into Community a46 [Prostanthera cuneata - Orites lancifolius - Nematolepis ovatifolia heathland of the Australian Alps bioregion]. Community a39 is found in Murray and Southern Rivers catchments but may extend into the upper Murrumbidgee catchment area.

\section{Characteristic Species:}

Species

C/A Freq C/A O FreqO Fid

Aciphylla glacialis

Acrothamnus montanus

Brachyscome tenuiscapa

Carex breviculmis

Carex hebes

Celmisia costiniana

Craspedia aurantia

Craspedia costiniana

Craspedia maxgrayi

Deyeuxia carinata

Deyeuxia crassiuscula

Empodisma minus

Epacris sp. (sensu Costin et al. 2000)

Erigeron bellidioides

Erigeron nitidus

Euphrasia collina subsp. diversicolor

Gentianella muelleriana subsp. alpestris

Grevillea australis

Kunzea muelleri

Luzula alpestris

Microseris lanceolata

Oreomyrrhis eriopoda

Pentachondra pumila

Pimelea alpina

Poa costiniana

Poa fawcettiae

Poa hiemata

Prasophyllum spp.

Rytidosperma nudiflorum

Saxipoa saxicola

Senecio pectinatus var. major

Senecio pinnatifolius var. alpinus

Stackhousia pulvinaris

Trisetum spicatum

$\begin{array}{llll}30 & 1 & <1 & \mathrm{P} \\ 50 & 1 & 1 & \mathrm{P} \\ 20 & 1 & <1 & \mathrm{P} \\ 100 & 1 & 13 & \mathrm{P} \\ 30 & 1 & 1 & \mathrm{P} \\ 80 & 1 & 1 & \mathrm{P} \\ 60 & 1 & 1 & \mathrm{P} \\ 40 & 1 & <1 & \mathrm{P} \\ 70 & 1 & <1 & \mathrm{P} \\ 20 & 1 & <1 & \mathrm{P} \\ 30 & 1 & <1 & \mathrm{P} \\ 30 & 2 & 3 & \mathrm{P} \\ 90 & 1 & 2 & \mathrm{P} \\ 30 & 1 & 1 & \mathrm{P} \\ 30 & 1 & <1 & \mathrm{P} \\ 40 & 1 & 1 & \mathrm{P} \\ 30 & 1 & <1 & \mathrm{P} \\ 40 & 1 & 2 & \mathrm{P} \\ 30 & 2 & 1 & \mathrm{P} \\ 40 & 1 & <1 & \mathrm{P} \\ 60 & 1 & 7 & \mathrm{P} \\ 80 & 1 & 13 & \mathrm{P} \\ 70 & 1 & <1 & \mathrm{P} \\ 50 & 1 & 1 & \mathrm{P} \\ 40 & 2 & 5 & \mathrm{P} \\ 50 & 3 & 2 & \mathrm{P} \\ 20 & 2 & 2 & \mathrm{P} \\ 20 & 1 & <1 & \mathrm{P} \\ 60 & 1 & 2 & \mathrm{P} \\ 20 & 1 & <1 & \mathrm{P} \\ 40 & 1 & <1 & \mathrm{P} \\ 30 & 1 & 3 & \mathrm{P} \\ 20 & 1 & <1 & \mathrm{P} \\ 40 & 1 & 3 & \mathrm{P}\end{array}$

Threatened communities: Nil.

Equivalent vegetation types: Epacris serpyllifolia - Kunzea muelleri alliance (Costin 1954); a combination of the Epacris microphylla and Kunzea muelleri associations (McVean 1969); Community 39 [Kosciuszko alpine Epacris - Kunzea open heathland] (McDougall \& Walsh 2007).

Frequently occurring weeds: Acetosella vulgaris (0.30).

Threats: Some examples (e.g. summit of Mt. Kosciuszko) are subject to trampling pressure by tourists. The top stations of some lifts in NSW ski resorts are positioned within this community. The impact of these pressures on the overall community is currently low. 


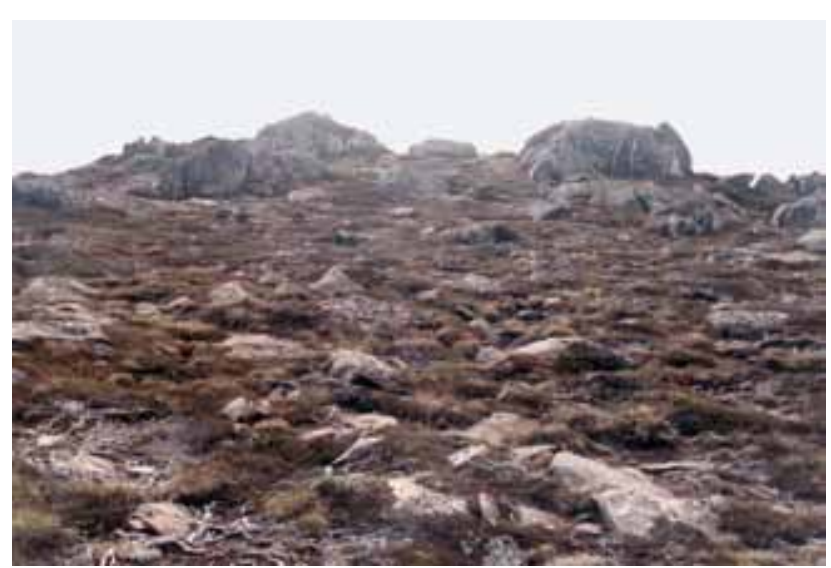

Plate a39: Community a39 is a low shrubland occurring on exposed sites in the Australian Alps, with a species-poor herbaceous component. This example is on the slopes of Mt Perisher, Kosciuszko NP.

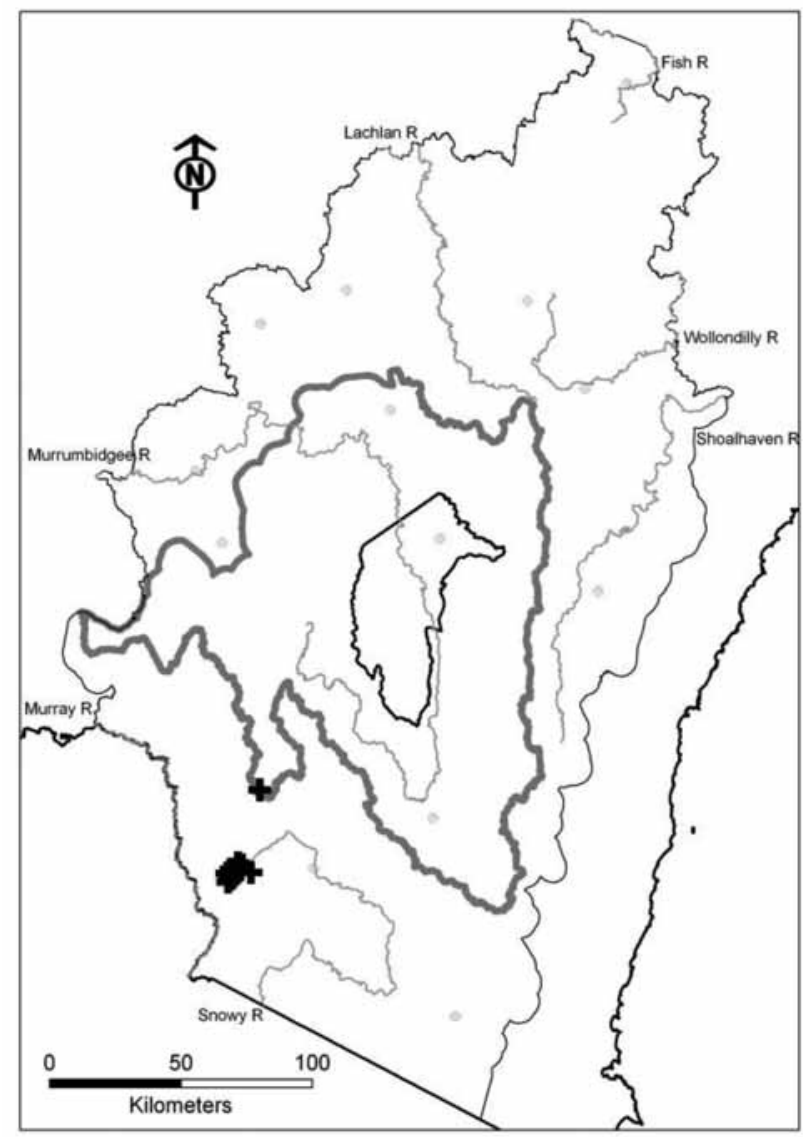

Fig. a39: Distribution of field samples assigned to this community.
Reservation status: Entirely within Kosciuszko NP.

Extent of clearing: Nil, but severely degraded by grazing prior to the 1950s.

References: Costin, A.B. (1954) A study of the ecosystems of the Monaro region of New South Wales. (Government Printer: Sydney); McDougall, K.L. \& Walsh, N.G. (2007) Treeless vegetation of the Australian Alps. Cunninghamia 10: 1-57; McVean, D.N. (1969) Alpine vegetation of the central Snowy Mountains of New South Wales. Journal of Ecology 57: 67-86.

\section{a42: Epacris celata - Poa clivicola - Dillwynia palustris grassy heathland of the Australian Alps bioregion}

Scientific Name: Epacris celata - Epacris gunnii / Poa clivicola - Deyeuxia gunniana - Cotula alpina - Lomandra aff. micrantha.
Number of samples:
3
Richness [mean $( \pm \mathrm{SD})]$ :
Slope (degrees):
Altitude ( $\mathrm{m}$ asl):
Ave. Annual Rainfall (mm):
Temp. Annual Range $\left({ }^{\circ} \mathrm{C}\right)$ :
(0) $0-2(3)$
(1153) 1153-1155 (1156)
(1367) 1369-1372 (1373)
(24.1) $24.2-24.2(24.2)$

Vegetation Description: Community a42 is a grassy heathland comprising very short plants of Epacris celata and Epacris gunnii. In stature and abundance, the shrubs are less prominent than the grasses (Poa clivicola, Poa sieberiana and Themeda australis), which makes the community appear more like a grassland than an open heathland. This community is not closely related to any of the other communities in the upper Murrumbidgee catchment. It is considered rare and isolated from other treeless vegetation in the Australian Alps bioregion.

This community is currently recorded only from McPhersons Plain, part of a high plateau on the western side of the Tumut Valley to the west of Kosciuszko NP. Considering that other treeless plains on the plateau nearby (Sparks Plain and Tomneys Plain) have not been surveyed, it is likely that it is not restricted to McPhersons Plain.

Adjoining communities include Community u22 [Mountain Gum - Snow Gum grass-forb very tall woodland to open forest of the Australian Alps and South Eastern Highlands bioregions] on upper slopes, Community a2 [Baeckea gunniana - Epacris paludosa - Richea continentis - Sphagnum cristatum wet heathland of the Australian Alps bioregion (Bog)] in areas of impeded drainage, and Community a14 [Poa costiniana - Carex gaudichaudiana subalpine valley grassland of the Australian Alps bioregion], as well as Community a9 [Carex gaudichaudiana - Ranunculus amphitrichus - Phragmites australis aquatic herbfield of waterways in the Australian Alps and South Eastern Highlands bioregions] along waterways. Examples of Community a6 [Ranunculus millanii - Lobelia surrepens - Carex gaudichaudiana herbfield of shallow depressions in the Australian Alps bioregion] are scattered within the community.

\section{Characteristic Species:}

Species

Asperula gunnii

Baloskion australe

Brachyscome decipiens

Brachyscome scapigera

Bulbine bulbosa

Caesia alpina

Carex hebes

Cotula alpina
C/A Freq C/A O FreqO Fid

$\begin{array}{llll}67 & 1 & 5 & \mathrm{P} \\ 33 & 1 & 2 & \mathrm{P} \\ 67 & 1 & 2 & \mathrm{P} \\ 100 & 1 & 2 & \mathrm{P} \\ 67 & 1 & 4 & \mathrm{P} \\ 33 & 1 & <1 & \mathrm{P} \\ 33 & 1 & 2 & \mathrm{P} \\ 100 & 1 & 1 & \mathrm{P}\end{array}$


Deyeuxia crassiuscula

Deyeuxia gunniana

Dillwynia palustris

Diuris monticola

Diuris spp.

Empodisma minus

Epacris celata

Epacris gunnii

Erigeron bellidioides

Euphrasia collina subsp. paludosa

Gonocarpus micranthus

Hakea microcarpa

Hydrocotyle sibthorpioides

Hypericum japonicum

Lomandra aff. micrantha

Oreobolus distichus

Pimelea biflora

Plantago euryphylla

Poa clivicola

Prasophyllum spp.

Pultenaea polifolia

Ranunculus graniticola

Stylidium montanum

Carex breviculmis

Luzula flaccida

Poa sieberiana

Poranthera oreophila

Themeda australis

33
100
33
33
33
67
100
100
33
100
67
67
67
67
67
33
33
33
67
67
33
100
100
67
67
67
67
67

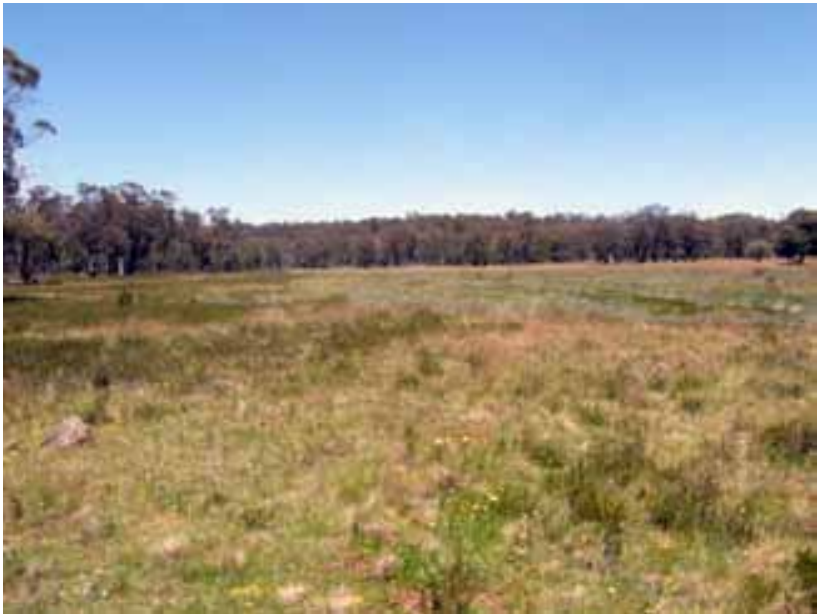

Plate a42: Community a42 at McPhersons Plain, Kosciuszko NP. It is a grassy heathland which may be dominated by Epacris spp. or Poa species depending on time since disturbance (e.g. by grazing). It is confined to the plains in and around Bago State Forest, between Talbingo and Tumbarumba.

\section{Threatened communities: Nil.}

Equivalent vegetation types: Community 42 [Epacris celata - Poa clivicola open heathland] (McDougall \& Walsh 2007).

Frequently occurring weeds: Cerastium vulgare (0.33), Holcus lanatus (0.33), Hypochaeris radicata (0.67), Poa pratensis (0.33), Trifolium repens (0.67).

Threats: Some of the community is the subject of a conservation agreement that fosters management of the vegetation for its significant biodiversity features. Despite this, the community is threatened overall by feral animals, stray domestic stock from neighbouring properties and future changes in land use.

Reservation status: Not present in a conservation reserve. McPhersons Plain is partly in a State Forest lease and partly freehold. Treeless plains nearby are freehold.

Extent of clearing: Nil, but probably locally degraded by historic grazing practices.

References: McDougall, K.L. \& Walsh, N.G. (2007) Treeless vegetation of the Australian Alps. Cunninghamia 10: 1-57.

\section{a43: Bossiaea riparia - Themeda australis low open heathland of the Australian Alps bioregion}

Scientific Name: Bossiaea riparia - Cryptandra amara Hakea microcarpa-Dillwynia prostrata / Themeda australis

Number of samples:

Richness [mean $( \pm \mathrm{SD})]$

3

Slope (degrees):

$23(5)$

Altitude (m asl):

(3) $6-12(15)$

Ave. Annual Rainfall (mm):

(1198) 1209-1254 (1289)

Temp. Annual Range $\left({ }^{\circ} \mathrm{C}\right)$ :

968) 971-980 (986)

(24.5) 24.7-24.9 (25)
Vegetation Description: Community a43 is an open heathland characterised by an extensive cover of a prostrate form of the shrub Bossiae riparia and much exposed rock. The associated flora is variable and may depend on the amount of soil present and the composition

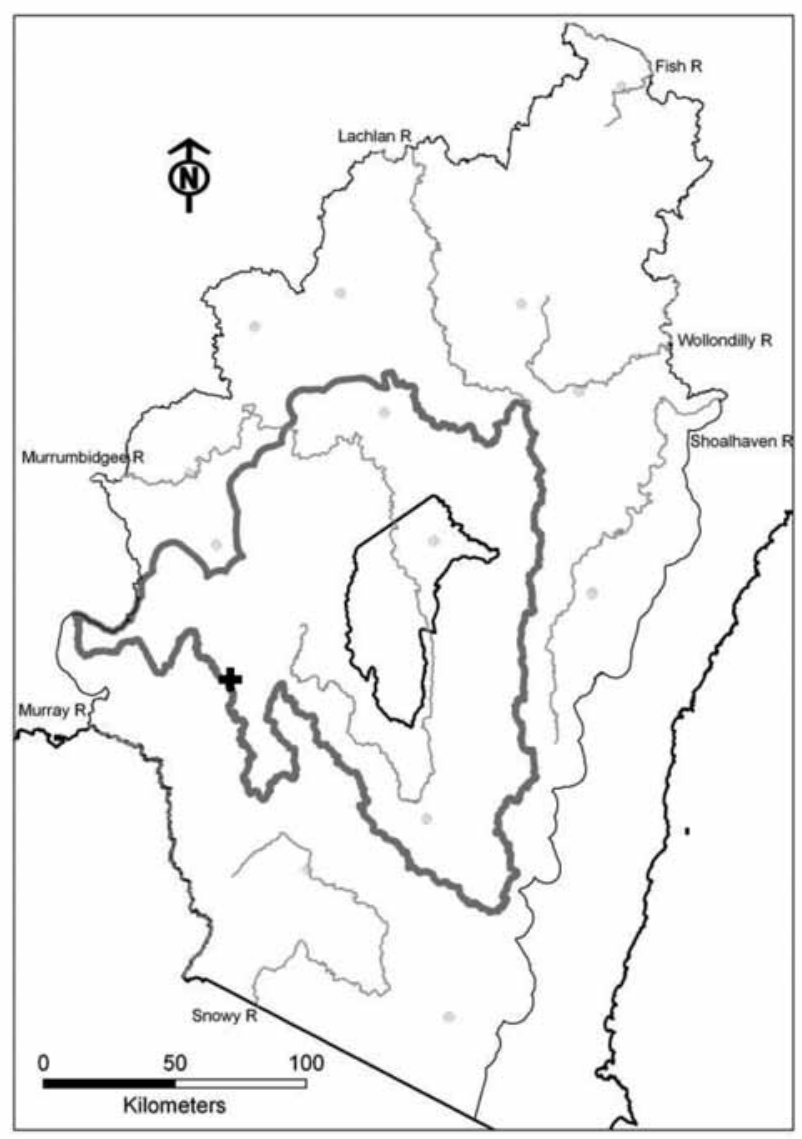

Fig. a42: Distribution of field samples assigned to this community. 
of surrounding communities. Despite its variability, the community has few affinities with other communities. Of communities present in treeless subalpine plains, five species were restricted to Community a43 or very rare elsewhere (Bossiaea riparia, Cryptandra amara, Daviesia mimosoides subsp. acris, Mirbelia oxylobioides, Patersonia sericea var. longifolia). Patersonia sericea var. longifolia is otherwise unknown in the Australian Alps bioregion.

This community is endemic to the upper Murrumbidgee catchment, being restricted to the rocky slopes above the upper Murrumbidgee River, and a few of its tributaries (in the vicinity of Currango Plain and Tantangara Dam). It possibly occurs at lower elevations in the Yaouk valley. It is typically found amongst Community a30 [Poa hookeri-Poa clivicola - Oreomyrrhis argentea - Ranunculus graniticola grassland of the Australian Alps bioregion] and sometimes in association with Community a34 [Weeping Snow Gum - Small-fruited Hakea - Blue Snow-grass grassy open woodland of the Australian Alps bioregion].

\section{Characteristic Species:}

\section{Species}

Agrostis venusta

Australopyrum velutinum

Austrostipa nivicola

Bossiaea riparia

Carex hebes

Cassinia monticola

Craspedia aurantia

Cryptandra amara

Dillwynia prostrata

Diuris monticola

Epilobium billardierianum

Festuca muelleri

Hakea microcarpa

Patersonia sericea var. longifolia

Pimelea linifolia subsp. caesia

Pimelea pauciflora

Poa clivicola

Poa hookeri

Podolepis jaceoides

Pultenaea subspicata

Rhodanthe anthemoides

Rutidosis leiolepis

Rytidosperma erianthum

Saxipoa saxicola

Senecio pinnatifolius var. alpinus

Themeda australis

Trisetum spicatum

Xerochrysum subundulatum

Carex breviculmis

Euchiton japonicus

Luzula flaccida
Calotis glandulosa

Luzula novae-cambriae

Microlaena stipoides

C/A Freq C/A O FreqO Fid

$\begin{array}{lllll}1 & 33 & 1 & <1 & \mathrm{P} \\ 1 & 33 & 1 & <1 & \mathrm{P} \\ 1 & 33 & 1 & <1 & \mathrm{P} \\ 2 & 100 & 1 & <1 & \mathrm{P} \\ 2 & 33 & 1 & <1 & \mathrm{P} \\ 1 & 33 & 1 & 2 & \mathrm{P} \\ 1 & 33 & 1 & 1 & \mathrm{P} \\ 1 & 33 & 1 & 2 & \mathrm{P} \\ 1 & 67 & 1 & 1 & \mathrm{P} \\ 4 & 67 & 2 & <1 & \mathrm{P} \\ 1 & 67 & 1 & <1 & \mathrm{P} \\ 1 & 67 & 1 & 2 & \mathrm{P} \\ 1 & 33 & 1 & <1 & \mathrm{P} \\ 1 & 100 & 1 & 3 & \mathrm{P} \\ 1 & 33 & 1 & <1 & \mathrm{P} \\ 2 & 33 & 2 & 1 & \mathrm{P} \\ 1 & 100 & 1 & 8 & \mathrm{P} \\ 1 & 33 & 1 & <1 & \mathrm{P} \\ 2 & 67 & 3 & 2 & \mathrm{P} \\ 3 & 33 & 3 & <1 & \mathrm{P} \\ 1 & 67 & 1 & 1 & \mathrm{P} \\ 2 & 33 & 2 & 2 & \mathrm{P} \\ 1 & 33 & 1 & 1 & \mathrm{P} \\ 2 & 33 & 2 & <1 & \mathrm{P} \\ 1 & 33 & 2 & 1 & \mathrm{P} \\ 1 & 33 & 1 & <1 & \mathrm{P} \\ 1 & 67 & 1 & 3 & \mathrm{P} \\ 1 & 100 & 2 & 21 & \mathrm{P} \\ 1 & 67 & 1 & 3 & \mathrm{P} \\ 1 & 33 & 1 & 1 & \mathrm{P} \\ 1 & 67 & 1 & 13 & \mathrm{C} \\ 1 & 67 & 1 & 15 & \mathrm{C} \\ 1 & 67 & 1 & 13 & \mathrm{C} \\ 1 & 67 & 2 & 34 & \mathrm{C}\end{array}$

Threatened communities: Nil.

Equivalent vegetation types: Community 43 [Bossiaea riparia dwarf heathland] (McDougall \& Walsh 2007).

Frequently occurring weeds: Acetosella vulgaris (0.33), Agrostis capillaris (0.33), Aira caryophyllea (0.33), Anthoxanthum odoratum (0.33), Hypericum perforatum (0.33), Hypochaeris radicata (1.00), Vulpia bromoides $(0.33)$.

Threats: None obvious.

Reservation status: All known examples occur within Kosciuszko NP.

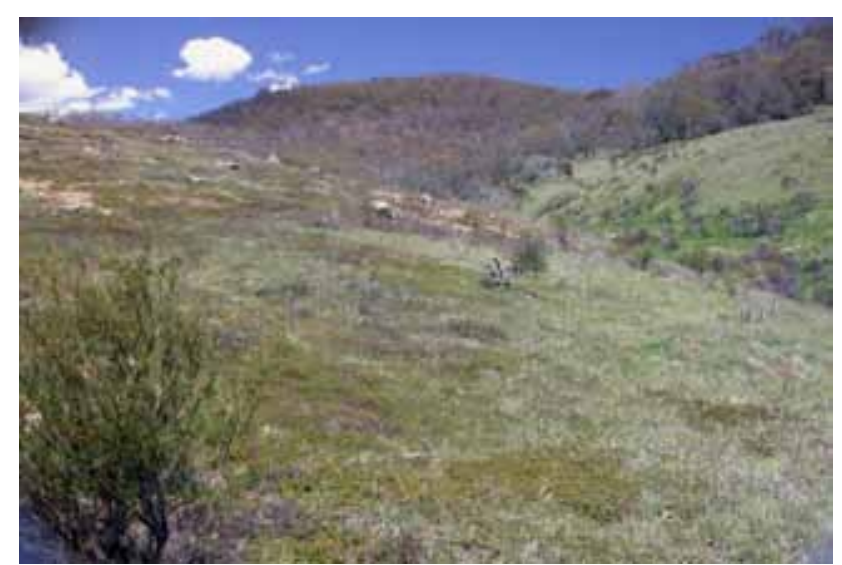

Plate a43: Community a43 (left hand side adjoining a30) is a low shrubland dominated by Bossiaea riparia and confined to the upper Murrumbidgee valley in the vicinity of Tantangara Dam (Kosciuszko NP, this photo) and Currango Plain.

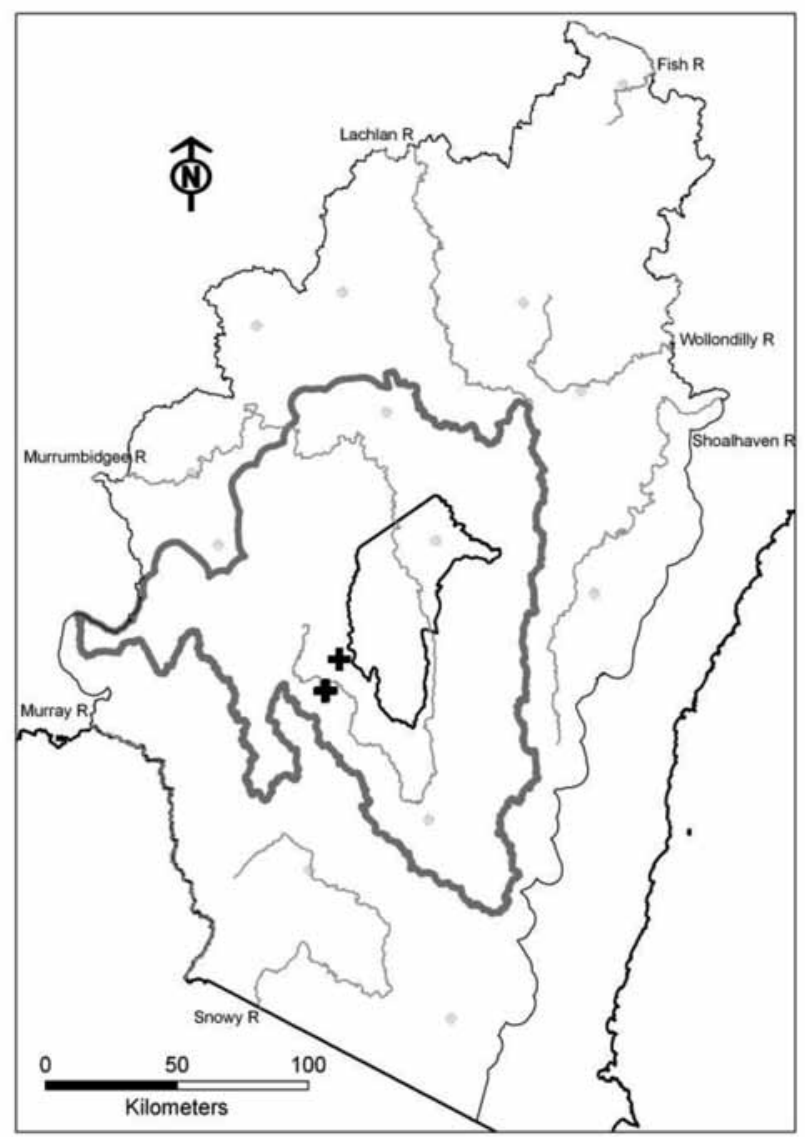

Fig. a43: Distribution of field samples assigned to this community. 
Extent of clearing: Unknown but probably nil. Many examples on the steep slopes of the Murrumbidgee River at Gulf Bend are sparsely vegetated and may be recovering from past disturbance associated with domestic grazing.

References: McDougall, K.L. \& Walsh, N.G. (2007) Treeless vegetation of the Australian Alps. Cunninghamia 10: 1-57.

\section{a46: Prostanthera cuneata - Orites lancifolius - Nematolepis ovatifolia heathland of the Australian Alps bioregion}

Scientific Name: Nematolepis ovatifolia - Orites lancifolius - Prostanthera cuneata - Olearia brevipedunculata Grevillea australis

$\begin{array}{ll}\text { Number of samples: } & 17 \\ \text { Richness [mean }( \pm \text { SD)]: } & 22(7) \\ \text { Slope (degrees): } & (1) 5-12(18) \\ \text { Altitude (m asl): } & (1635) 1749-1945(2009) \\ \text { Ave. Annual Rainfall (mm): } & (1851) 2075-2296(2438) \\ \text { Temp. Annual Range }\left({ }^{\circ} \mathrm{C}\right): & (20.2) 20.6-21.5(21.7)\end{array}$

Vegetation Description: Community a46 is a shrubland dominated by species such as Nematolepis ovatifolia, Orites lancifolia and/or Prostanthera cuneata. Other shrubs such as Grevillea australis, Hovea montana, Kunzea muelleri and Oxylobium ellipticum may be locally abundant. Shrub cover is sparse at its upper altitudinal limits and closed at its lower. Its distribution is scattered and common on the dry slopes of the Kosciuszko Main Range between Dead Horse Gap (near Thredbo) and Mt. Jagungal.

Community a46 is a combination of two shrub-dominated communities described by McDougall \& Walsh (2007), representing a continuum from near the treeline, where shrubs are tall and closed with a sparse herb cover, to the alpine zone, where shrubs are shorter and gaps between shrubs are filled with species characteristic of Community a22 [Poa fawcettiae - Celmisia costiniana - Craspedia maxgrayi grassland of the Australian Alps bioregion]. At their boundaries, these communities are probably inseparable. At its lower extent, community a46 grades into Community u158 [Alpine Sallee shrub-grass subalpine mid-high woodland of the Australian Alps bioregion].

There are outliers in the upper Murrumbidgee catchment in the upper Tumut valley and at Kiandra. The Kiandra example contains the northern-most population of Phebalium squamulosum subsp. alpinum.

\section{Characteristic Species:}

\section{Species}

Aciphylla simplicifolia Acrothamnus montanus Argyrotegium fordianum Asperula gunnii

Carex breviculmis

Celmisia costiniana

Celmisia pugioniformis

Craspedia aurantia

Deyeuxia crassiuscula

Empodisma minus

Erigeron bellidioides

Erigeron nitidus

Euphrasia collina subsp. diversicolor

Gonocarpus montanus

Grevillea australis

Leptorhynchos squamatus

Luzula alpestris

Luzula modesta

\section{C/A Freq C/A OFreqO Fid}

$\begin{array}{llll}24 & 1 & 2 & \mathrm{P} \\ 29 & 1 & 1 & \mathrm{P} \\ 24 & 1 & <1 & \mathrm{P} \\ 41 & 1 & 5 & \mathrm{P} \\ 82 & 1 & 13 & \mathrm{P} \\ 24 & 1 & 1 & \mathrm{P} \\ 47 & 1 & 2 & \mathrm{P} \\ 65 & 1 & 1 & \mathrm{P} \\ 24 & 1 & <1 & \mathrm{P} \\ 24 & 2 & 3 & \mathrm{P} \\ 35 & 1 & 1 & \mathrm{P} \\ 59 & 1 & <1 & \mathrm{P} \\ 29 & 1 & 1 & \mathrm{P} \\ 24 & 1 & 1 & \mathrm{P} \\ 82 & 1 & 1 & \mathrm{P} \\ 24 & 1 & 3 & \mathrm{P} \\ 24 & 1 & <1 & \mathrm{P} \\ 29 & 1 & 2 & \mathrm{P}\end{array}$

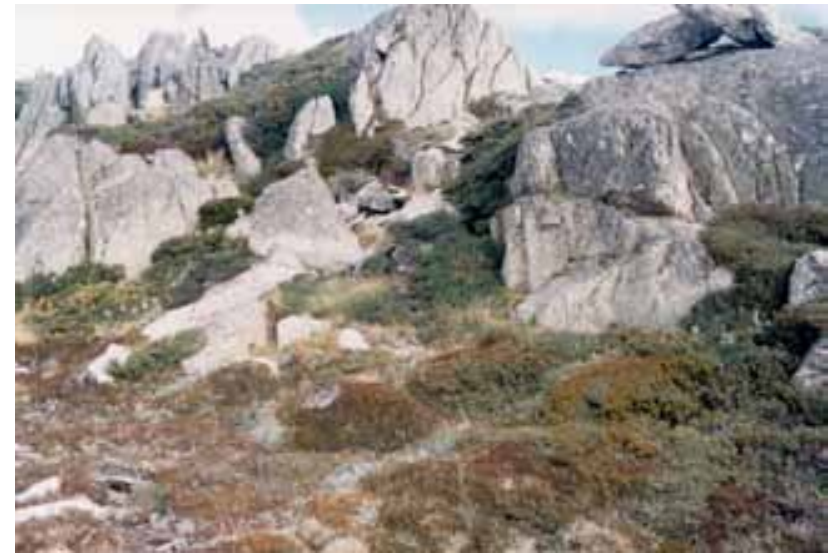

Plate a46: Sheltered sites with shallow soils and exposed rock at high elevation in Kosciuszko NP are typically shrub-dominated with a very sparse understorey of herbs; this example near Mt Blue Cow, Kosciuszko NP.

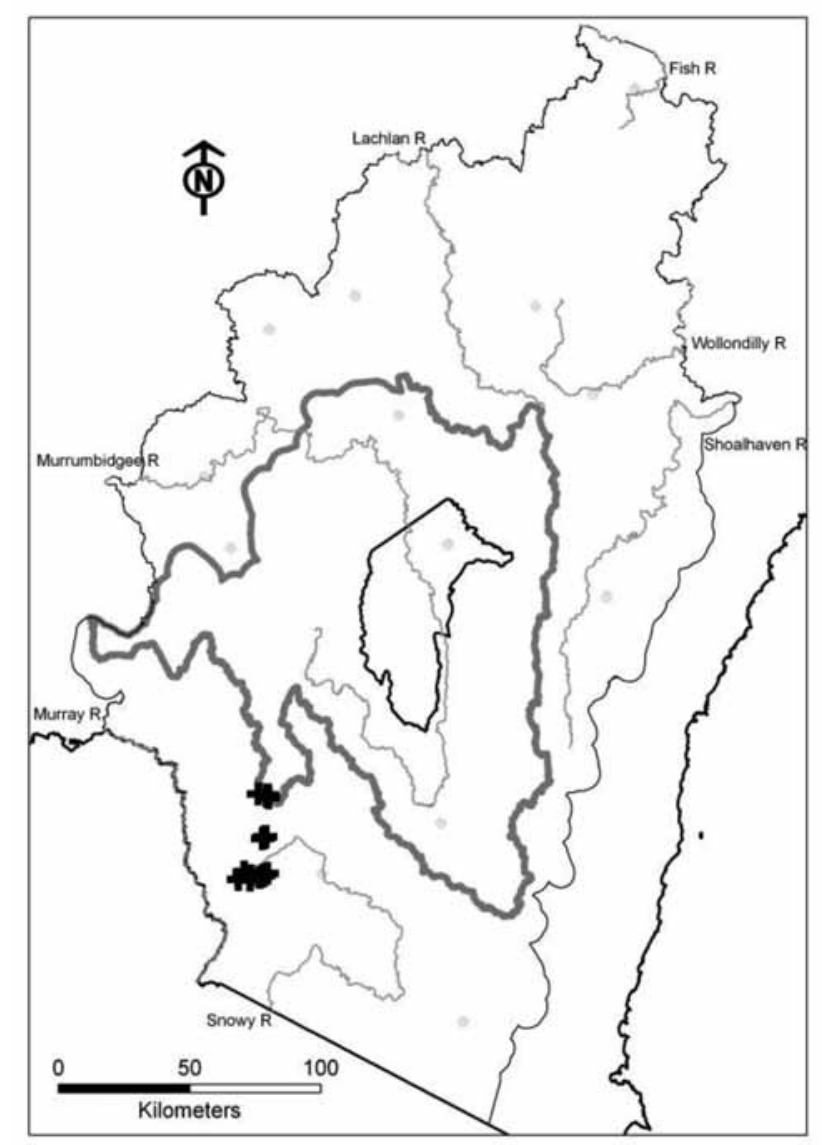

Fig. a46: Distribution of field samples assigned to this community. 
Lycopodium fastigiatum Melicytus sp. 'Snowfields'

Microseris lanceolata

Nematolepis ovatifolia

Olearia algida

Olearia brevipedunculata

Olearia phlogopappa

Oreomyrrhis eriopoda

Orites lancifolius

Oxylobium ellipticum

Pimelea alpina

Plantago euryphylla

Poa costiniana

Poa fawcettiae

Poa hiemata

Prostanthera cuneata

Ranunculus graniticola

Rytidosperma nudiflorum

Scleranthus biflorus

Senecio pinnatifolius var. alpinus

Trisetum spicatum

Viola betonicifolia

\section{Threatened communities: Nil.}

Equivalent vegetation types: part of Oxylobium ellipticum Podocarpus alpinus alliance (Costin 1954); Phebalium ovatifolium association (McVean 1969); part of Heath formation (Costin et al. 2000); combination of communities 23 [Grevillea australis Nematolepis ovatifolia open heathland] and 46 [Nematolepis ovatifolia - Prostanthera cuneata closed heathland] (McDougall \& Walsh 2007).

Frequently occurring weeds: Acetosella vulgaris (0.65).

Threats: None obvious. This community is apparently expanding either under the influence of climate change or because of past disturbance from grazing. Much of this community was burnt in 2003, but regeneration of most species seems to have occurred (Walsh \& McDougall 2005).

Reservation status: All within Kosciuszko NP.

Extent of clearing: Nil.

References: Costin, A.B. (1954) A study of the ecosystems of the Monaro region of New South Wales. (Government Printer: Sydney); Costin, A.B., Gray, M., Totterdell, C.J. \& Wimbush D.J. (2000) Kosciuszko alpine flora. (CSIRO Publishing: Collingwood); McDougall, K.L. \& Walsh, N.G. (2007) Treeless vegetation of the Australian Alps. Cunninghamia 10: 1-57; McVean, D.N. (1969) Alpine vegetation of the central Snowy Mountains of New South Wales. Journal of Ecology 57: $67-86$

\section{a51: Podocarpus lawrencei - Rytidosperma alpicola - Brachyscome nivalis low open heathland of rock outcrops of the Australian Alps bioregion}

Scientific Name: Podocarpus lawrencei - Grevillea australis / Rytidosperma alpicola - Brachyscome nivalis Polystichum proliferum

Number of samples:

Richness [mean $( \pm \mathrm{SD})]$ :

Slope (degrees):

Altitude (m asl):

Ave. Annual Rainfall (mm):

5

$22(7)$

(9) $15-22(30)$

(1911) 2029-2076 (2153)

Temp. Annual Range $\left({ }^{\circ} \mathrm{C}\right)$ :

(2316) 2322-2576 (2653)

(19.7) 20-20.2 (20.7)
Vegetation Description: Community a51 is a low sparse shrubland dominated by Rytidosperma alpicola, with sparse shrubs including Podocarpus lawrencei, Prostanthera cuneata, Melicytus sp. 'Snowfields'

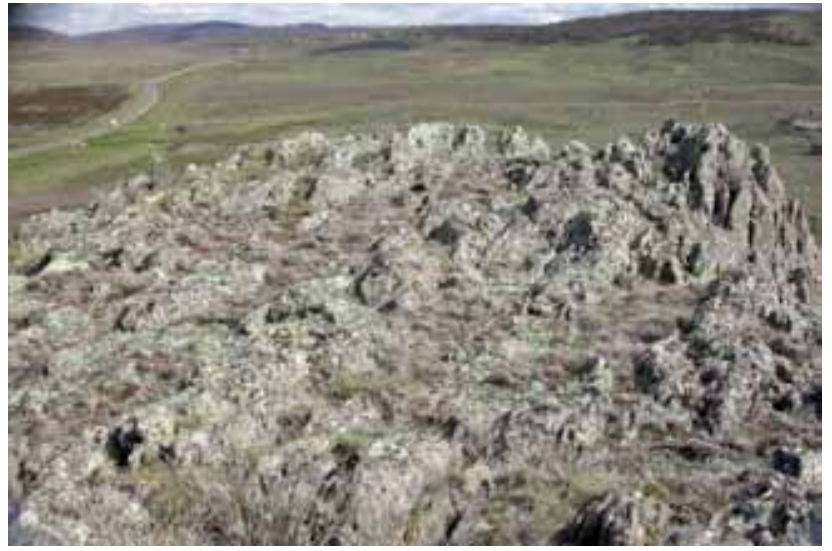

Plate a51: Rocky outcrops with skeletal soils in subalpine and alpine parts of Kosciuszko NP usually have a sparse cover of herbs and low shrubs. This example is at Kiandra in Kosciuszko NP where the shrub component was temporarily removed by the 2003 fire.

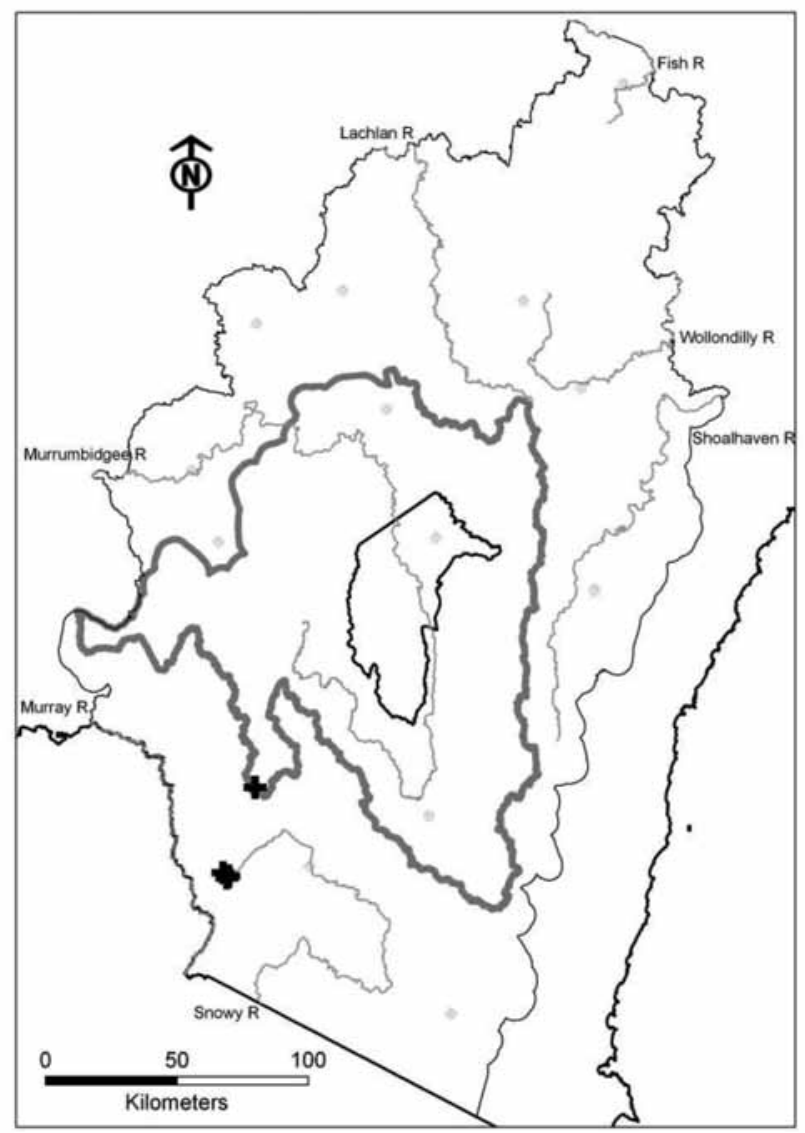

Fig. a51: Distribution of field samples assigned to this community. 
and Acrothamnus montanus. Plant cover is generally minimal. This community occurs on cliffs and other rocky outcrops from Mt. Buller in Victoria to Kiandra in NSW. It is especially common on the higher peaks of the Kosciuszko Main Range and the Mt. Jagungal area. Herbs and sedges such as Brachyscome nivalis, Brachyscome rigidula, Crassula sieberiana and Luzula novae-cambriae occur in most examples and are rarely found in other communities in the Australian Alps bioregion.

\section{Characteristic Species:}

\section{Species}

Aciphylla glacialis Acrothamnus montanus Argyrotegium fordianum Argyrotegium mackayi

Asperula pusilla

Brachyscome nivalis

Celmisia pugioniformis

Craspedia adenophora

Craspedia aurantia

Craspedia maxgrayi

Deyeuxia crassiuscula

Epilobium billardierianum

Erigeron nitidus

Ewartia nubigena

Gentianella muelleriana subsp. alpestris

Luzula novae-cambriae

Lycopodium fastigiatum

Melicytus sp. 'Snowfields'

Microseris lanceolata

Nematolepis ovatifolia

Olearia brevipedunculata

Oreomyrrhis brevipes

Oreomyrrhis eriopoda

Ozothamnus secundiflorus

Poa costiniana

Poa fawcettiae

Podocarpus lawrencei

Polystichum proliferum

Prostanthera cuneata

Rytidosperma alpicola

Rytidosperma nudiflorum

Saxipoa saxicola

Scleranthus singuliflorus

Senecio pectinatus var. major

Senecio pinnatifolius var. alpinus

Trisetum spicatum

Acaena novae-zelandiae

Carex breviculmis

Crassula sieberiana

Viola betonicifolia

\section{Threatened communities: Nil.}

Equivalent vegetation types: Brachycome nivalis - Danthonia alpicola alliance (Costin 1954); Poa hothamensis (rocky) grassland, Unit 13 (McDougall 1982); Brachyscome - Austrodanthonia tall alpine herbfield (Costin et al. 2000); Community 51 [Austrodanthonia alpicola - Grevillea australis open heathland] (McDougall \& Walsh 2007).

Frequently occurring weeds: Acetosella vulgaris (0.80), Hypochaeris radicata $(0.40)$.

Threats: Examples of this community occurring on cliffs above Blue Lake in Kosciuszko NP are possibly threatened by recreational rock climbers. Elsewhere, it may be damaged by tourists accessing rocky outcrops for better views, but the overall threat to the community from these activities is currently low.

Reservation status: Likely to be entirely within Kosciuszko NP.

\section{Extent of clearing: Nil.}

References: Costin, A.B. (1954) A study of the ecosystems of the Monaro region of New South Wales. (Government Printer: Sydney); Costin, A.B., Gray, M., Totterdell, C.J. \& Wimbush D.J. (2000) Kosciuszko alpine flora. (CSIRO Publishing: Collingwood); McDougall, K.L. (1982) The alpine vegetation of the Bogong high plains. Environmental studies publication no. 357. Ministry for Conservation: Melbourne; McDougall, K.L. \& Walsh, N.G. (2007) Treeless vegetation of the Australian Alps. Cunninghamia 10: 1-57.

\section{4: Podocarpus lawrencei-Pimelea ligustrina subsp. ciliata heathland of screes and boulder-fields of the Australian Alps bioregion}

\author{
Scientific Name: Podocarpus lawrencei - Pimelea ligustrina \\ subsp. ciliata / Polystichum proliferum

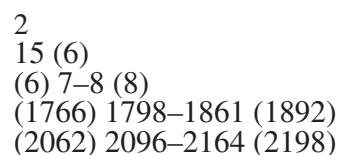

Vegetation Description: Community a54 is a closed shrubland dominated by Podocarpus lawrencei. It occurs in areas of minimal soil development and abundant boulders in the alpine and subalpine areas of Victoria (Bogong High Plains, Mt. Hotham area, Mt. Howitt, Mt. Buffalo, Cobberas and Crosscut Saw) and NSW (between Mt. Kosciuszko and Mt. Jagungal, and the steep slopes of the Tumut valley in the vicinity of Cabramurra). Scree slopes containing Podocarpus lawrencei in the ACT may also be referable to this community, but further sampling is required to confirm this. Examples have been recorded on metamorphic substrates, where Podocarpus lawrencei layers over large rock slabs, on granite boulder streams and outcrops and on basalt scree. The species composition of plots depends on the location of drainage features, which often pass under the boulders. Species characteristic of wetlands (e.g. Richea continentis) may therefore be found in damp parts of the community. Species richness is commonly low, and in sites with large rocks and no exposed soil there may be only a few species per plot.

This community is highly restricted and usually found in screes and bounder fields amongst Community u158 [Alpine Sallee shrubgrass subalpine mid-high woodland of the Australian Alps bioregion] or Community a46 [Prostanthera cuneata - Orites lancifolius Nematolepis ovatifolia heathland of the Australian Alps bioregion]. After the 2003 fires, the diversity of many burnt Podocarpus lawrence heathlands increased. Pelargonium helmsii, a species rarely recorded prior to 2003, was found to be common in many burnt Podocarpus lawrencei dominated heathlands in Kosciuszko NP. A population of Senecio velleioides, normally a wet sclerophyll forest species occurring from the central coast in NSW south to Tasmania, was located in this community two years after the fire at 1880 metres above sea level on Blue Cow Mountain. This was the first record for this species in treeless vegetation in the Australian Alps bioregion. The community is the primary habitat for the Mountain Pygmy-possum (Burramys parvus), an endangered marsupial.

\section{Characteristic Species:}

Species

Argyrotegium fordianum

Baeckea gunniana

Epilobium billardierianum

Erigeron nitidus

Grevillea australis

\section{C/A Freq C/A O FreqO Fid}

$\begin{array}{lllll}1 & 50 & 1 & <1 & \mathrm{P} \\ 2 & 50 & 2 & 1 & \mathrm{P} \\ 1 & 50 & 1 & 2 & \mathrm{P} \\ 1 & 100 & 1 & <1 & \mathrm{P} \\ 2 & 50 & 2 & 2 & \mathrm{P}\end{array}$




$\begin{array}{llllll}\text { Lycopodium fastigiatum } & 1 & 50 & 1 & <1 & \mathrm{P} \\ \text { Nematolepis ovatifolia } & 2 & 100 & 3 & <1 & \mathrm{P} \\ \text { Olearia brevipedunculata } & 1 & 50 & 1 & <1 & \mathrm{P} \\ \text { Olearia phlogopappa } & 1 & 50 & 1 & 3 & \mathrm{P} \\ \text { Orites lancifolius } & 2 & 100 & 3 & <1 & \mathrm{P} \\ \text { Pimelea axiflora subsp. alpina } & 1 & 50 & 1 & <1 & \mathrm{P} \\ \text { Pimelea ligustrina subsp. ciliata } & 1 & 100 & 1 & <1 & \mathrm{P} \\ \text { Poa hiemata } & 1 & 50 & 2 & 2 & \mathrm{P} \\ \text { Podocarpus lawrencei } & 4 & 100 & 2 & <1 & \mathrm{P} \\ \text { Polystichum proliferum } & 1 & 100 & 1 & 7 & \mathrm{P} \\ \text { Prostanthera cuneata } & 3 & 100 & 2 & <1 & \mathrm{P} \\ \text { Richea continentis } & 1 & 50 & 2 & <1 & \mathrm{P} \\ \text { Carex breviculmis } & 1 & 50 & 1 & 13 & \mathrm{C} \\ \text { Deyeuxia monticola } & 1 & 50 & 1 & 6 & \mathrm{C} \\ \text { Oreomyrrhis eriopoda } & 1 & 50 & 1 & 13 & \mathrm{C} \\ \text { Senecio gunnii } & 1 & 50 & 1 & 9 & \mathrm{C}\end{array}$

Threatened communities: Nil, but possibly eligible for listing.

Equivalent vegetation types: part of Oxylobium ellipticum - Podocarpus alpinus alliance (Costin 1954); Podocarpus lawrencei association (McVean 1969); Podocarpus heathland, Unit 1 (McDougall 1982); Podocarpus heathland, subcommunity 1.1 (Walsh et al. 1984); Community 54 [Podocarpus lawrencei closed heathland] (McDougall \& Walsh 2007).

Frequently occurring weeds: Acetosella vulgaris (0.5).

Threats: Surveys of regeneration following the 2003 fires suggest that recovery of many stands will be slow and patchy, and some may not recover at all in the short term. Basal regeneration of Podocarpus lawrencei has been observed in some populations in the ACT and the Cobberas in Victoria (Carey et al. 2003, Tolsma et al. 2004) but none appears to have occurred in Kosciuszko NP (Williams et al. 2008). Resprouting of partially burnt stems did occur throughout its range but it tended to be rare and much of the regeneration subsequently died. Seedlings were observed in the summer following the fire, but these have been rare or patchy at some sites.

Dendrochronological research on Podocarpus lawrencei indicates that plants are up to 400 years old (McDougall et al. 2012). Since the plants are obligate seeders (in NSW at least), catastrophic fires must be rare in this community. Too frequent fire is therefore a grave threat to this community and the Mountain Pygmy-possum.

Reservation status: All within Kosciuszko NP.

Extent of clearing: Nil.

References: Carey, A., Evans, M., Hann, P., Lintermans, M., MacDonald, T., Ormay, P., Sharp, S., Shorthouse, D. \& Webb, N. (2003) Wildfires in the ACT 2003: Report on initial impacts on natural ecosystems . Technical Report 17, Wildlife Research and Monitoring, Environment ACT, Canberra; Costin, A.B. (1954) A study of the ecosystems of the Monaro region of New South Wales. (Government Printer: Sydney); McDougall, K.L. (1982) The alpine vegetation of the Bogong high plains. Environmental studies publication no. 357. Ministry for Conservation: Melbourne; McDougall, K.L. \& Walsh, N.G. (2007) Treeless vegetation of the Australian Alps. Cunninghamia 10: 1-57; McDougall, K.L., Brookhouse, M. \& Broome, L.S. (2012) Dendroclimatological investigation of mainland Australia's only alpine conifer, Podocarpus lawrencei Hook.f. Dendrochronologia 30: 1-9; McVean, D.N. (1969) Alpine vegetation of the central Snowy Mountains of New South Wales. Journal of Ecology 57: 67-86; Tolsma, A., Coates, F. \& Sutter, G. (2004) Recovery of Mountain Plum-Pine Shrubland After Fire (Cobberas). Arthur Rylah Institute for Environmental Research Technical Report No. 153. Department of Sustainability and Environment, Victoria; Walsh, N.G., Barley, R.H. \& Gullan, P.K. (1984) The alpine vegetation of Victoria (excluding the Bogong high plains), volume 1. Environmental studies publication no. 376. Department of Conservation, Forests and Lands: Melbourne; Williams, R.J., Wahren, C-H., Tolsma, A.D., Sanecki, G.M., Papst, W.A., Myers, B.A., McDougall, K.L., Heinze, D.A. \& Green, K. (2008) Large fires in Australian alpine landscapes: their part in the historical fire regime and their impacts on alpine biodiversity. International Journal of Wildland Fire 17: 793-808.

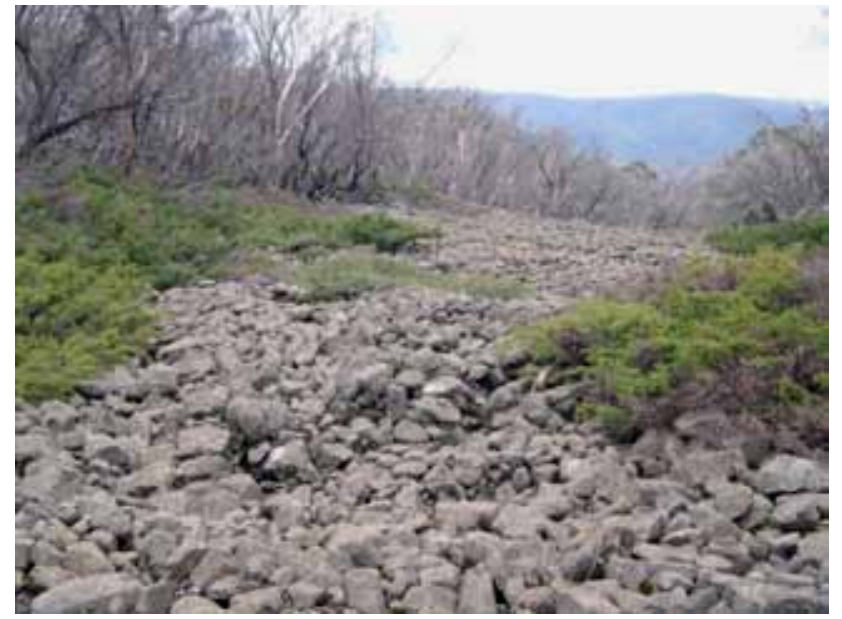

Plate a54: Periglacial activity has resulted in the deposition of extensive piles of boulders (of granite or basalt) in Kosciuszko NP. Community a54, dominated by Podocarpus lawrencei, is characteristic of this habitat; this example on basalt near Happy Jacks Plain.

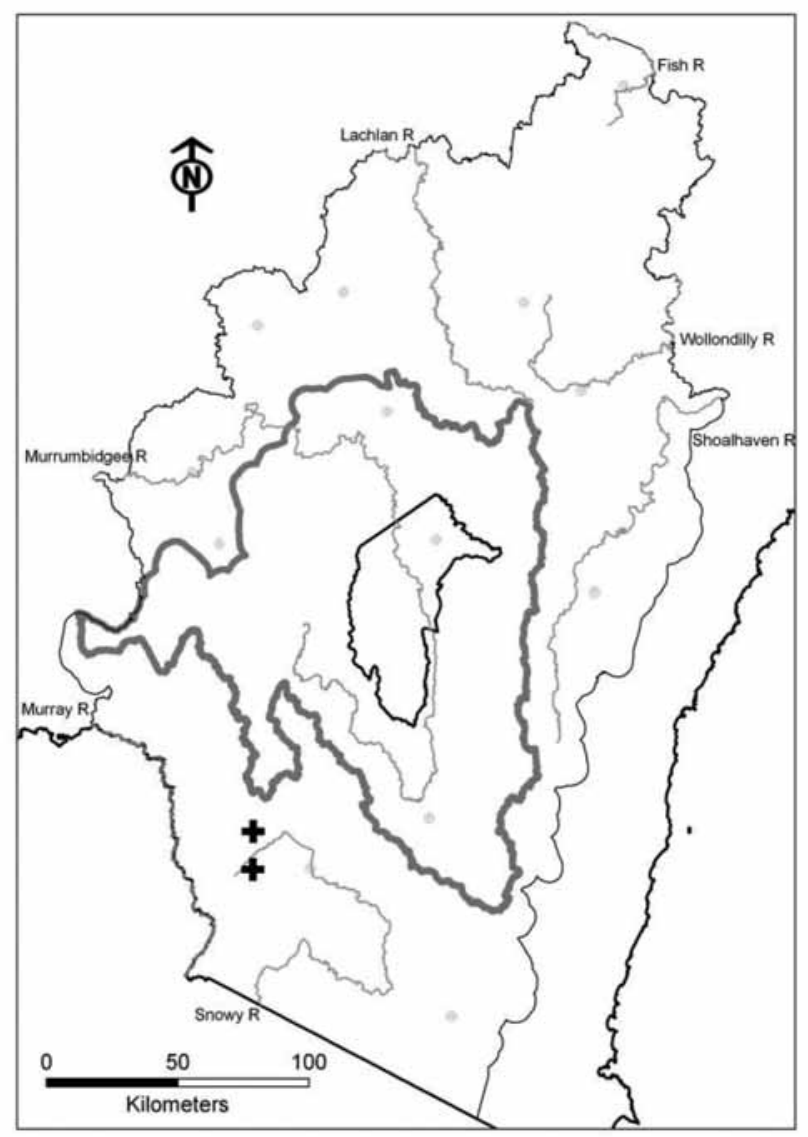

Fig. a54: Distribution of field samples assigned to this community. 


\section{g36: Leptospermum micromyrtus - Kunzea muelleri - Kunzea ericoides dry heathland on skeletal ridges primarily of the Namadgi region}

Scientific Name: Leptospermum micromyrtus - Kunzea muelleri - Kunzea ericoides / Carex breviculmis Gonocarpus tetragynus

Number of samples:

Richness [mean $( \pm$ SD)]:

Slope (degrees):

Altitude (m asl)

Ave. Annual Rainfall (mm):

Temp. Annual Range $\left({ }^{\circ} \mathrm{C}\right)$ :

15 (4)

(3) $11-23(30)$

(1123) 1370-1461 (1634)

(928) 1043-1137 (1357)

(22.1) 23.4-23.9 (25.2)

Vegetation Description: Community g36 is a dense shrubland interspersed with large expanses of unvegetated rock outcrop. Dominant species include Leptospermum micromyrtus, Kunzea ericoides, Calytrix tetragona, Kunzea muelleri and Leionema lamprophyllum. Epacris robusta and Oxylobium ellipticum may also be locally common, and Eucalyptus cinerea subsp. triplex is an emergent (up to 10 metres tall) at one site. Carex breviculmis, Veronica perfoliata, Gonocarpus tetragynus and Poa spp. are common ground cover elements. Species such as Pelargonium australe, Trachymene composita and the endangered Dampiera fusca are likely to be ephemeral components that increase in abundance after fire.

This community has been recorded on granite outcrops at Booroomba Rocks in the ACT, the NSW side of Mt. Coree on the NSW / ACT border (Brindabella NP) and in Yaouk NR in NSW. It was identified as Montane / Sub-Alpine Dry Rocky Shrubland by Gellie (2005). Modelling by Gellie (2005), which suggested that the community extends from the ACT to the higher parts of Kosciuszko NP to the south-west (in the vicinity of the Main Range), is not supported by subsequent plot sampling. While the exact distribution of this community is uncertain because of undersampling (a consequence of the remoteness of the areas in which it occurs), the distribution of one of its character species gives a clue to the likely distribution. The variant of Asterolasia trymalioides that occurs in this community is likely to be recognized at subspecific rank (K. McDougall, OEH, pers. comm.). It is found at Booroomba Rocks in Namadgi NP and granite outcrops along the ACT / NSW border (e.g. Mt. Kelly, Mt. Scabby) to Yaouk NR. This variant also occurs in Tinderry NR (Twin Peaks) in similar habitat and with many of the characteristic species listed below, however its relationship to this plant community has not been investigated through plot sampling.

\section{Characteristic Species:}

\section{Species}

Asterolasia aff. trymalioides

Baeckea utilis

Bulbine glauca

Callistemon pallidus

Calytrix tetragona

Carex breviculmis

Deyeuxia monticola

Epacris robusta

Kunzea ericoides

Kunzea muelleri

Leptospermum micromyrtus

Leptospermum namadgiensis

Leucopogon attenuatus

Oxylobium ellipticum

Pelargonium australe

Poa induta

Prostanthera decussata

Rytidosperma fulvum

Thelymitra spp.

\section{C/A Freq C/A O FreqO Fid}

$\begin{array}{lllll}25 & 2 & <1 & \mathrm{P} \\ & 25 & 2 & 2 & \mathrm{P} \\ 25 & 1 & <1 & \mathrm{P} \\ & 25 & 1 & <1 & \mathrm{P} \\ & 25 & 2 & 1 & \mathrm{P} \\ & 63 & 1 & 13 & \mathrm{P} \\ & 38 & 1 & 5 & \mathrm{P} \\ & 25 & 0 & 0 & \mathrm{P} \\ 3 & 75 & 2 & 4 & \mathrm{P} \\ & 75 & 2 & <1 & \mathrm{P} \\ & 88 & 1 & <1 & \mathrm{P} \\ 2 & 25 & 0 & 0 & \mathrm{P} \\ & 38 & 1 & 1 & \mathrm{P} \\ & 38 & 1 & 4 & \mathrm{P} \\ & 38 & 1 & <1 & \mathrm{P} \\ 2 & 38 & 3 & 6 & \mathrm{P} \\ 25 & 2 & <1 & \mathrm{P} \\ & 25 & 2 & 1 & \mathrm{P} \\ & 25 & 1 & 3 & \mathrm{P}\end{array}$

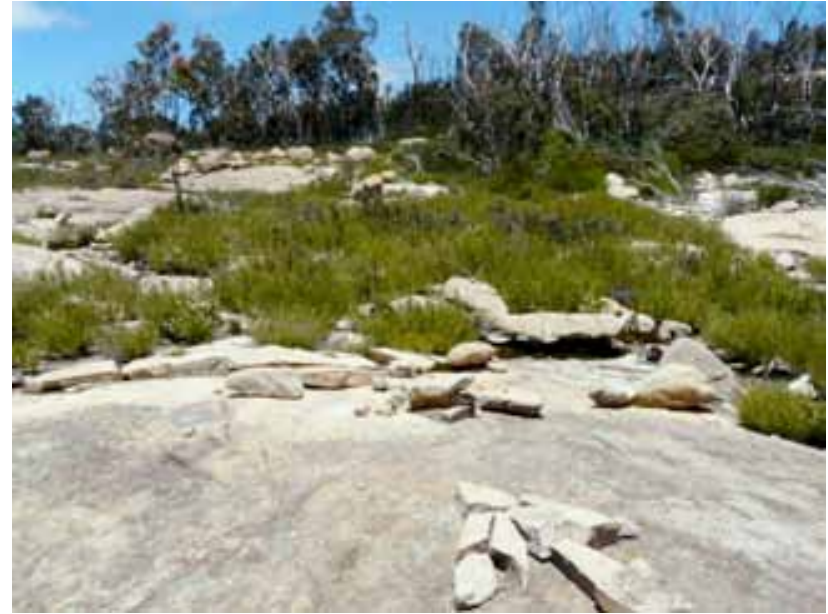

Plate g36: Community g36 is a shrubland of granite outcrops dominated by Leptospermum micromyrtus and Kunzea muelleri; This example is at Booroomba Rocks, Namadgi NP.

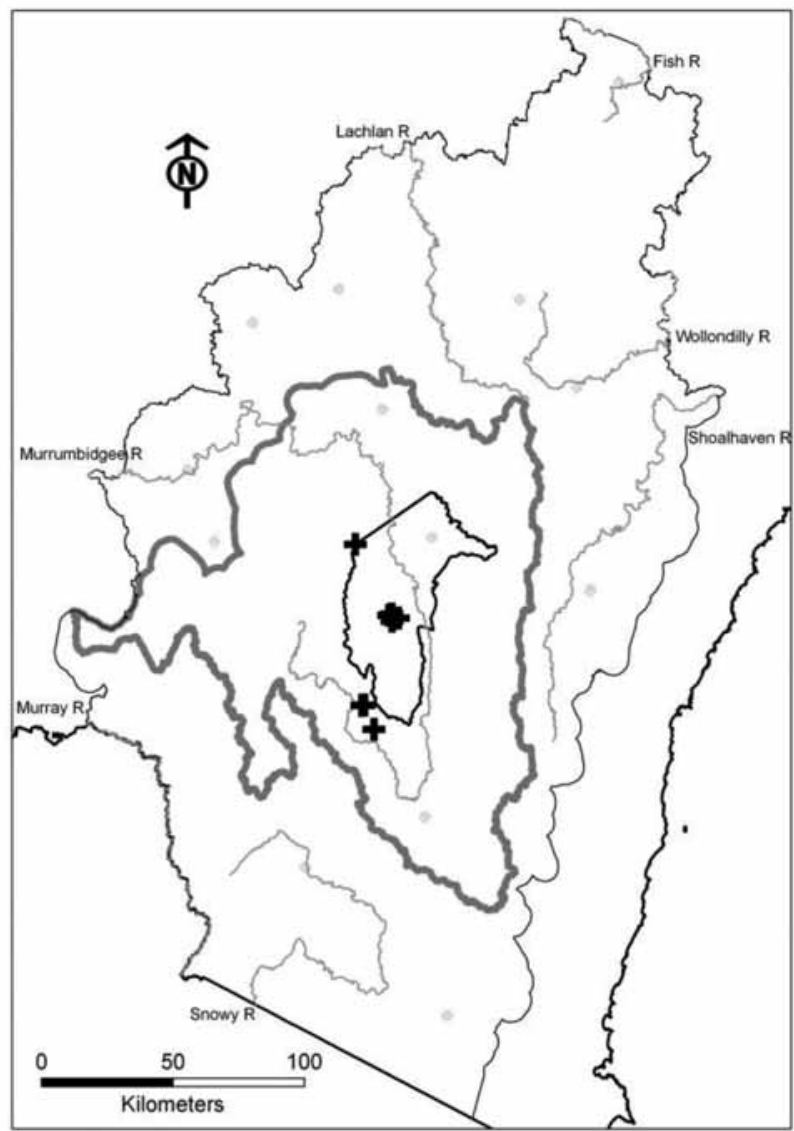

Fig. g36: Distribution of field samples assigned to this community 
Trachymene composita Veronica perfoliata Gonocarpus tetragynus

$\begin{array}{lllll}3 & 25 & 1 & <1 & \mathrm{P} \\ 1 & 38 & 1 & 4 & \mathrm{P} \\ 2 & 50 & 2 & 48 & \mathrm{C}\end{array}$

Threatened communities: Nil.

Equivalent vegetation types: Equivalent to Community VG36 [Montane / Sub-Alpine Dry Rocky Shrubland] (Gellie 2005).

Frequently occurring weeds: Hypochaeris glabra, Hypochaeris radicata, Vulpia bromoides, Vulpia myuros f. megalura (all 0.20).

Threats: Not considered to have any significant threats.

Reservation status: Likely to be entirely within conservation reserves; recorded from Namadgi NP, Brindabella NP and Yaouk NR.

Extent of clearing: Nil.

Reference: Gellie, N.J.H. (2005) Native vegetation of the southern forests: South Eastern Highlands, Australian Alps, South West Slopes and South East Corner bioregions. Cunninghamia 9: 219-254.

\section{Class: Alpine Bogs and Fens}

\section{a2: Baeckea gunniana - Epacris paludosa - Richea continentis - Sphagnum cristatum wet heathland of the Australian Alps bioregion (Bog)}

Scientific Name: Baeckea gunniana - Epacris paludosa - Richea continentis / Carex gaudichaudiana - Sphagnum cristatum

Number of samples:

Richness [mean ( \pm SD)]:

38

Slope (degrees):

Altitude (m asl):

Ave. Annual Rainfall (mm):

Temp. Annual Range $\left({ }^{\circ} \mathrm{C}\right)$ :

(0) 2-9 (20)

(1149) 1377-1741 (2004)

(999) 1383-2051 (2488)

(20.3) 21.5-23.6 (24.8)

Vegetation Description: Community a2 generally occurs as a low closed wet heathland dominated by Baeckea gunniana, Epacris paludosa and Richea continentis, with intervening areas dominated by Sphagnum cristatum and associated herbs (e.g. Astelia alpina, Astelia psychrocharis, Baloskion australe, Carex gaudichaudiana, Carpha nivicola, Celmisia spp. (Celmisia pugioniformis, Celmisia 'pulchella' ms., Celmisia tomentosa), Diplaspis nivis, Empodisma minus, Erigeron paludicola, Oreobolus distichus, Oschatzia cuneifolia and Poa costiniana. At lower elevations this community is generally dominated by shrubs such as Baeckea gunniana, Epacris paludosa, Richea continentis, Callistemon pityoides and Epacris breviflora, with Epacris glacialis becoming more frequent at higher elevations. It is found mainly in broad valleys, but also in seepage zones on slopes of low relief and along margins of smaller watercourses. Free water, either as pools or as slow-flowing streams is usually present.

This community is widespread from the Brindabella Ranges in the ACT through to Kosciuszko NP in NSW (and possibly extending into the South Eastern Highlands at lower altitudes). In Victoria it is known from The Cobberas and across the Bogong High Plains, with outlying examples on the Mt. Buffalo plateau. In the upper Murrumbidgee catchment, examples of this community are generally small, occurring in linear strips along creeks or as patches of less than 100 metres $^{2}$. Most are found in conservation reserves (Kosciuszko NP, Bimberi NR, Namadgi NP), with limited occurrences on State Forest and private land east of Tumbarumba.

\section{Characteristic Species:}

Species

C/A Freq C/A OFreqO Fid

Aciphylla simplicifolia

Asperula gunnii

Astelia psychrocharis

Baeckea gunniana

Baloskion australe

Brachyscome obovata

Carex gaudichaudiana

Carpha nivicola

Celmisia pugioniformis

Empodisma minus

Epacris glacialis

Epacris gunnii

Epacris paludosa

Epilobium gunnianum

Erigeron paludicola

Gonocarpus micranthus

Hakea microcarpa

Luzula modesta

Oreobolus distichus

Oreomyrrhis ciliata

Oschatzia cuneifolia

Poa costiniana

Ranunculus pimpinellifolius

Richea continentis

Rytidosperma nivicola

Sphagnum cristatum

$\begin{array}{llll}29 & 1 & 2 & \mathrm{P} \\ 45 & 1 & 4 & \mathrm{P} \\ 32 & 1 & <1 & \mathrm{P} \\ 79 & 2 & <1 & \mathrm{P} \\ 55 & 1 & 1 & \mathrm{P} \\ 39 & 1 & <1 & \mathrm{P} \\ 95 & 2 & 3 & \mathrm{P} \\ 29 & 1 & <1 & \mathrm{P} \\ 32 & 1 & 2 & \mathrm{P} \\ 97 & 2 & 2 & \mathrm{P} \\ 26 & 1 & <1 & \mathrm{P} \\ 24 & 1 & 2 & \mathrm{P} \\ 71 & 2 & <1 & \mathrm{P} \\ 39 & 1 & 1 & \mathrm{P} \\ 37 & 1 & <1 & \mathrm{P} \\ 29 & 1 & 2 & \mathrm{P} \\ 21 & 1 & 3 & \mathrm{P} \\ 53 & 1 & 2 & \mathrm{P} \\ 50 & 1 & <1 & \mathrm{P} \\ 50 & 1 & 2 & \mathrm{P} \\ 24 & 1 & <1 & \mathrm{P} \\ 95 & 2 & 4 & \mathrm{P} \\ 24 & 1 & 1 & \mathrm{P} \\ 61 & 1 & <1 & \mathrm{P} \\ 24 & 1 & <1 & \mathrm{P} \\ 89 & 2 & <1 & \mathrm{P}\end{array}$

Threatened communities: TSC Act 1995 - Montane Peatlands and Swamps of the New England Tableland, NSW North Coast, Sydney Basin, South East Corner, South Eastern Highlands and Australian Alps bioregions; EPBC Act 1999 - Alpine Sphagnum Bogs and Associated Fens.

Equivalent vegetation types: Epacris paludosa - Sphagnum cymbifolium alliance and Carex gaudichaudiana - Sphagnum cymbifolium alliance and Epacris breviflora - Blindia robusta alliance (Costin 1954); Sphagnum - Richea - Astelia association (McVean 1969); types 4a and 4b (Helman \& Gilmour 1985); groups 11 and 12 (Helman et al. 1988), combination of Community 2 [Richea continentis - Carpha nivicola - Sphagnum cristatum wet heathland] and Community 3 [Baeckea gunniana - Callistemon pityoides - Sphagnum cristatum wet heathland] (McDougall \& Walsh 2007).

Frequently occurring weeds: This community is generally low in weed diversity with the most common being Trifolium repens (0.07).

Threats: Historically this community was heavily degraded by cattle and sheep grazing, and by fire used for grazing management. Many examples were drained for water management during the Snowy Hydro Scheme and some were destroyed in early ski resort development. Damage still occurs as a result of trampling by feral horses, deer and pigs. Some freehold examples are still affected by domestic grazing practices.

Reservation status: Most examples of this community are in Kosciuszko NP and Namadgi NP. A few are in State Forest and freehold land adjoining Kosciuszko NP.

Extent of clearing: Not assessed. Very little has been cleared but all has been degraded.

References: Costin, A.B. (1954) A study of the ecosystems of the Monaro region of New South Wales. (Government Printer: Sydney); Helman, C.E. \& Gilmour, P.M. (1985) Treeless vegetation above 1,000 metres altitude in the A.C.T. Unpublished report. Conservation Council of the Southeast Region and Canberra: Canberra; Helman, C.E., Gilmour, P.M., Osborne, W.S. \& Green, K. (1988) An ecological survey of the upper Cotter catchment wilderness area, Namadgi National Park, ACT. Unpublished report. Conservation Council of the South-east Region and Canberra, Canberra; McDougall, K.L. \& Walsh, N.G. (2007) Treeless vegetation of the Australian Alps. Cunninghamia 10: 1-57. 


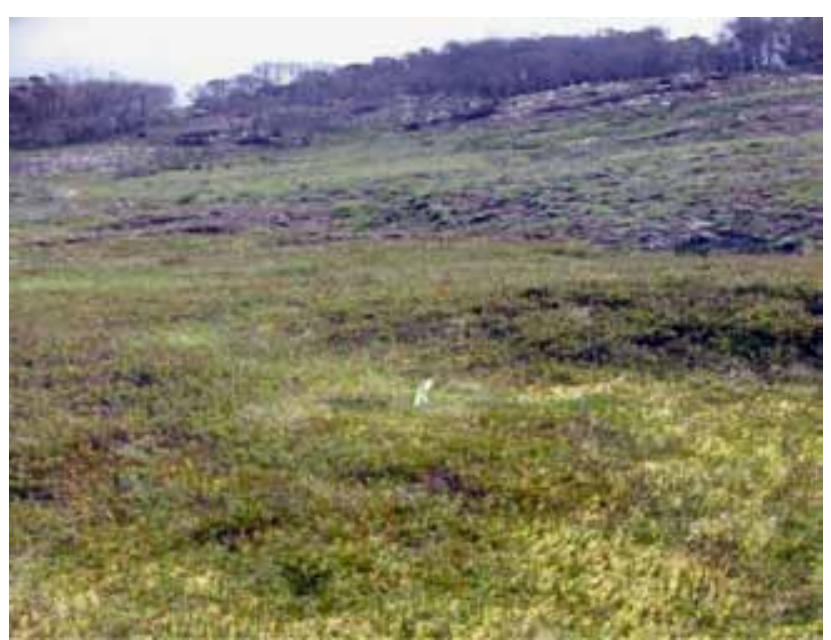

Plate a2: Community a2 (also known as bogs or peatlands) develops where drainage is impeded in the Australian Alps and surrounds. Examples may contain a range of tall or short shrubs but the moss and herbaceous layer is remarkably similar at most sites; this Richea continentis-dominated example near Mt Jagungal, Kosciuszko NP.

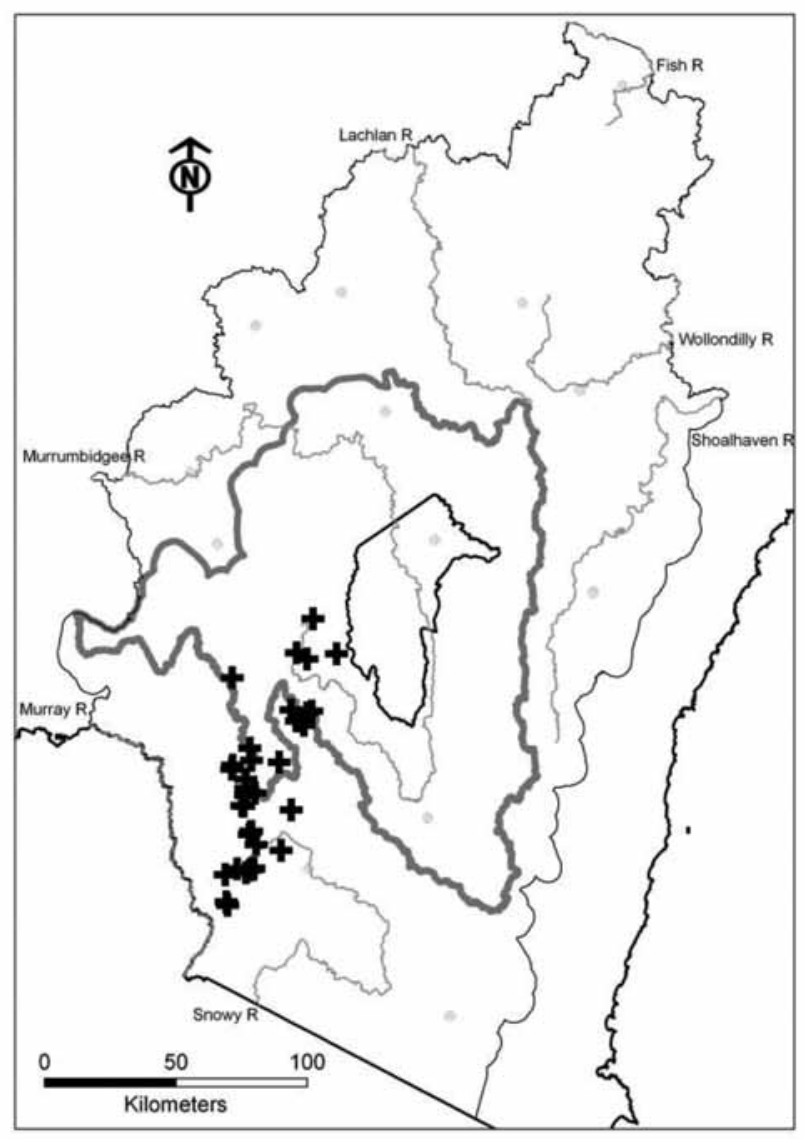

Fig. a2: Distribution of field samples assigned to this community.

\section{a7: Ranunculus pimpinellifolius - Gonocarpus micranthus herbfield of wetland margins in the Australian Alps bioregion}

Scientific Name: Ranunculus pimpinellifolius - Gonocarpus micranthus - Carex gaudichaudiana - Cotula alpina Hydrocotyle algida - Montia australasica

$\begin{array}{ll}\text { Number of samples: } & 2 \\ \text { Richness [mean }( \pm \mathrm{SD})]: & 20(8) \\ \text { Slope (degrees): } & (2) 4-7(9) \\ \text { Altitude (m asl): } & (1577) 1582-1591(1595) \\ \text { Ave. Annual Rainfall }(\mathrm{mm}): & (1775) 1817-1902(1944) \\ \text { Temp. Annual Range }\left({ }^{\circ} \mathrm{C}\right): & (21.8) 21.9-22(22)\end{array}$

Vegetation Description: Community a7 is a herbfield occuring in broad valleys or around seepage zones on flat ground anywhere in the subalpine zone where soils are relatively deep and permanently sodden (but not inundated); often found on sites with basaltic parent material. Forbs such as Hypericum japonicum, Ranunculus pimpinellifolius, Gonocarpus micranthus, Nertera granadensis and Epilobium curtisiae are the usual dominants and form a dense mat of overlapping foliage.

Examples of this community are often small (a few metres ${ }^{2}$ ) and adjoin Community a2 [Baeckea gunniana - Epacris paludosa - Richea continentis - Sphagnum cristatum wet heathland of the Australian Alps bioregion (Bog)]. It has been recorded from Boggy Plain near Tantangara, Long Plain and Bogong Plain near Mt. Jagungal (all in the upper Murrumbidgee catchment) but undoubtedly commonly occurs elsewhere within the subalpine area and possibly into the ACT. It is also found in the Victorian high country.

\section{Characteristic Species:}

Species
Agrostis venusta
Baeckea gunniana
Brachyscome tadgellii
Carex cephalotes
Carex echinata
Carex gaudichaudiana
Cotula alpina
Epilobium curtisiae
Epilobium gunnianum
Gonocarpus micranthus
Hydrocotyle algida
Isolepis subtilissima
Juncus falcatus
Luzula modesta
Montia australasica
Myriophyllum alpinum
Myriophyllum pedunculatum
Nertera granadensis
Olearia algida
Oreobolus pumilio
Oreomyrrhis ciliata
Poa costiniana
Ranunculus millanii
Ranunculus pimpinellifolius
Richea continentis
Rytidosperma nivicola
Acaena echinata
Hypericum japonicum

$\begin{array}{lllll}\text { C/A } & \text { Freq } & \text { C/A } & \text { OFreqO } & \text { Fid } \\ 1 & 50 & 1 & <1 & \mathrm{P} \\ 1 & 50 & 2 & 1 & \mathrm{P} \\ 1 & 50 & 1 & <1 & \mathrm{P} \\ 1 & 50 & 1 & <1 & \mathrm{P} \\ 1 & 50 & 1 & <1 & \mathrm{P} \\ 3 & 100 & 2 & 4 & \mathrm{P} \\ 2 & 100 & 1 & 1 & \mathrm{P} \\ 1 & 50 & 1 & <1 & \mathrm{P} \\ 1 & 100 & 1 & 1 & \mathrm{P} \\ 2 & 100 & 1 & 2 & \mathrm{P} \\ 2 & 100 & 1 & 1 & \mathrm{P} \\ 2 & 50 & 1 & <1 & \mathrm{P} \\ 2 & 50 & 1 & <1 & \mathrm{P} \\ 1 & 50 & 1 & 2 & \mathrm{P} \\ 2 & 100 & 1 & 1 & \mathrm{P} \\ 2 & 50 & 1 & <1 & \mathrm{P} \\ 1 & 50 & 1 & <1 & \mathrm{P} \\ 1 & 50 & 1 & <1 & \mathrm{P} \\ 1 & 50 & 1 & <1 & \mathrm{P} \\ 1 & 50 & 2 & <1 & \mathrm{P} \\ 2 & 100 & 1 & 2 & \mathrm{P} \\ 1 & 100 & 2 & 5 & \mathrm{P} \\ 1 & 100 & 1 & <1 & \mathrm{P} \\ 3 & 100 & 1 & 1 & \mathrm{P} \\ 1 & 50 & 2 & <1 & \mathrm{P} \\ 1 & 50 & 1 & <1 & \mathrm{P} \\ 1 & 50 & 1 & 9 & \mathrm{C} \\ 1 & 50 & 1 & 4 & \mathrm{C}\end{array}$

Threatened communities: TSC Act 1995 - Montane Peatlands and Swamps of the New England Tableland, NSW North Coast, Sydney Basin, South East Corner, South Eastern Highlands and Australian Alps bioregions. 


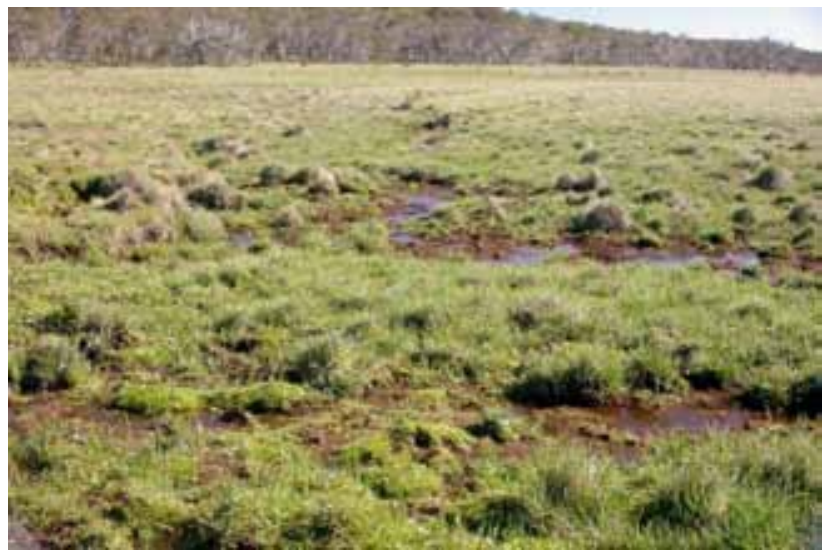

Plate a7: Community a7 is typically very small in extent, being found at the margins of various wetlands; this example at Long Plain in Kosciuszko NP.

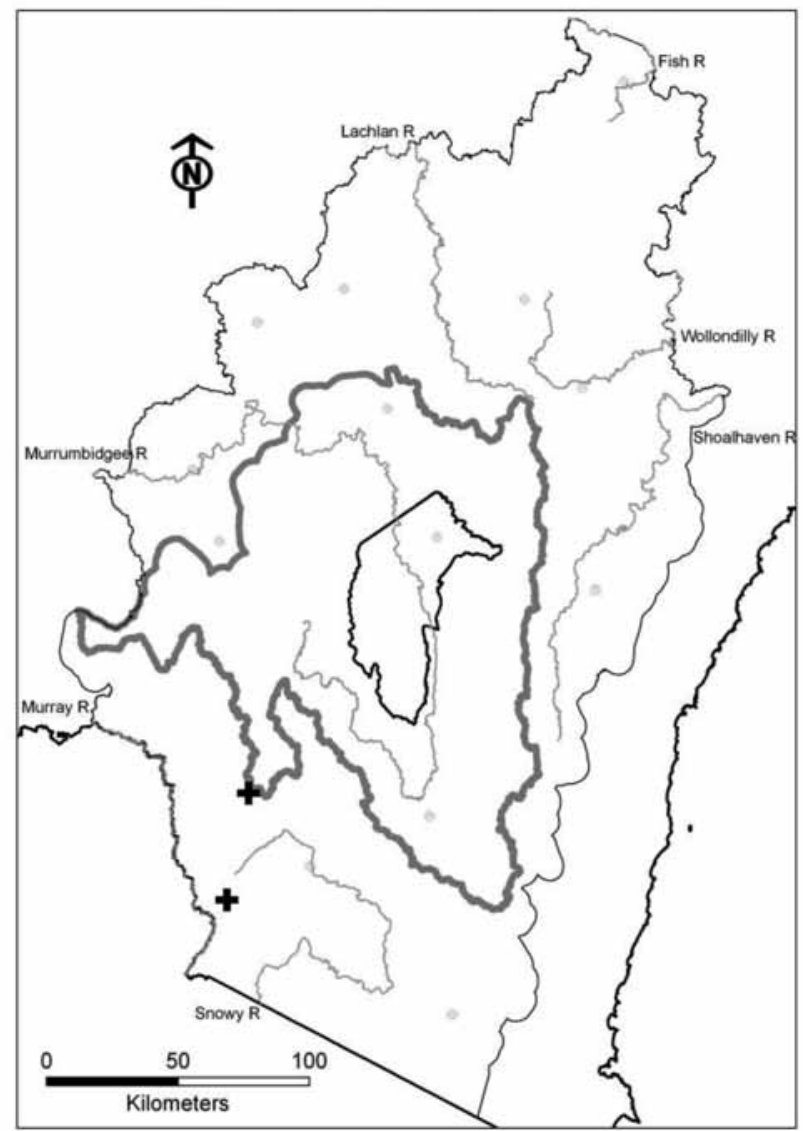

Fig. a7: Distribution of field samples assigned to this community.

Equivalent vegetation types: Community 7 [Hypericum japonicum Ranunculus pimpinellifolius herbfield] (McDougall \& Walsh 2007).

Frequently occurring weeds: Taraxacum officinale (0.5), Trifolium repens $(0.5)$.

Threats: A relatively high weed cover in plots (particularly Acetosella vulgaris, Cerastium glomeratum, Holcus lanatus and Trifolium repens) is indicative of past disturbance. Sites in NSW may be affected by pigs and are especially vulnerable to trampling by feral horses.

Reservation status: Possibly all within Kosciuszko NP.

Extent of clearing: Nil, but probably severely damaged by trampling when grazed by domestic stock.

Reference: McDougall, K.L. \& Walsh, N.G. (2007) Treeless vegetation of the Australian Alps. Cunninghamia 10: 1-57.

\section{a8: Carex gaudichaudiana-Myriophyllum pedun- culatum - Deschampsia cespitosa sedgeland of the Australian Alps bioregion (Fen)}

Scientific Name: Carex gaudichaudiana - Myriophyllum pedunculatum - Deschampsia cespitosa-Isolepis montivaga

$\begin{array}{ll}\text { Number of samples: } & 7 \\ \text { Richness [mean }( \pm \text { SD)]: } & 12(6) \\ \text { Slope (degrees): } & (1) 2-4(13) \\ \text { Altitude (m asl): } & (1281) 1559-1760(1920) \\ \text { Ave. Annual Rainfall (mm): } & (1525) 1758-2040(2405) \\ \text { Temp. Annual Range }\left({ }^{\circ} \mathrm{C}\right): & (20.7) 21.4-21.9(23.5)\end{array}$

Vegetation Description: Community a8 is a wet sedgeland (fen) dominated by the sedge Carex gaudichaudiana, making it one of the most immediately recognisable of alpine/subalpine communities. Typically, sites are inundated through most (if not all) summer with water depths up to approximately 15 centimetres. Examples tend to be species-poor but in some areas Brachyscome obovata, Carex echinata, Deschampsia cespitosa, Epilobium gunnianum, Isolepis montivaga and Myriophyllum pedunculatum are reasonably common. Sphagnum cristatum often occupies any ground raised slightly above the bed of the fen. Poa costiniana is a frequent component of this community but is typically present only at the margins of the zone of permanent inundation. This community is highly variable and poorly sampled.

This community is widespread in valleys and low saddles in Kosciuszko NP (extending into the alpine zone) and subalpine valleys of the ACT. It is known from Victoria where it is far less common. Examples in the upper Murrumbidgee catchment are often small and form part of a mosaic with Community a2 [Baeckea gunniana - Epacris paludosa - Richea continentis - Sphagnum cristatum wet heathland of the Australian Alps bioregion (Bog)] in areas of impeded drainage, and Community a14 [Poa constiniana - Carex gaudichaudiana subalpine valley grassland of the Australian Alps bioregion].

\section{Characteristic Species:}

\section{Species}

Asperula gunnii Baloskion australe Brachyscome obovata Cardamine astoniae Carex echinata Carex gaudichaudiana Carpha nivicola Deschampsia cespitosa Epilobium gunnianum Isolepis montivaga
C/A Freq C/A OFreqO Fid

$\begin{array}{llll}43 & 1 & 5 & \mathrm{P} \\ 43 & 1 & 2 & \mathrm{P} \\ 43 & 1 & 1 & \mathrm{P} \\ 29 & 1 & <1 & \mathrm{P} \\ 29 & 1 & <1 & \mathrm{P} \\ 100 & 2 & 4 & \mathrm{P} \\ 29 & 1 & <1 & \mathrm{P} \\ 57 & 1 & <1 & \mathrm{P} \\ 43 & 1 & 1 & \mathrm{P} \\ 29 & 1 & <1 & \mathrm{P}\end{array}$


Juncus falcatus

Luzula modesta

Montia australasica

Myriophyllum pedunculatum

Oreomyrrhis ciliata

Poa costiniana

Ranunculus pimpinellifolius

Richea continentis

Sphagnum cristatum

$\begin{array}{ll}1 & 29 \\ 1 & 29 \\ 1 & 29 \\ 1 & 57 \\ 2 & 29 \\ 1 & 71 \\ 2 & 29 \\ 1 & 29 \\ 2 & 57\end{array}$

$\begin{array}{ll}2 & <1 \\ 1 & 2 \\ 1 & 1 \\ 1 & <1 \\ 1 & 2 \\ 2 & 5 \\ 1 & 1 \\ 2 & <1 \\ 3 & 1\end{array}$

Threatened communities: TSC Act 1995 - Montane Peatlands and Swamps of the New England Tableland, NSW North Coast, Sydney Basin, South East Corner, South Eastern Highlands and Australian Alps bioregions; EPBC Act 1999 - Alpine Sphagnum Bogs and Associated Fens.

Equivalent vegetation types: Carex gaudichaudiana alliance (Costin 1954); Carex - Drepanocladus association (McVean 1969); Vegetation Type 6a (Helman \& Gilmour 1985); Fen (Costin et al. 2000); Community 8 [Fen] (McDougall \& Walsh 2007).

Frequently occurring weeds: No weeds have been recorded in plots in this community.

Threats: The weed Myosotis caespitosa, although not recorded in plots, is abundant at a few sites in Kosciuszko NP (e.g. Boggy Plain, Ogilvies Plain) and may threaten the integrity of this community.

Reservation status: Possibly all within Kosciuszko and Namadgi NPs.

Extent of clearing: Nil, but this community was probably highly degraded by domestic grazing. The dominant species, Carex gaudichaudiana, is noted for its high palatability (Van Rees \& Holmes 1986).

References: Costin, A.B. (1954) A study of the ecosystems of the Monaro region of New South Wales. (Government Printer: Sydney); Costin, A.B Helman, C.E. \& Gilmour, P.M. (1985) Treeless vegetation above 1,000 metres altitude in the A.C.T. Unpublished report. Conservation Council of the Southeast Region and Canberra: Canberra; McDougall, K.L. \& Walsh, N.G. (2007) Treeless vegetation of the Australian Alps. Cunninghamia 10: 1-57; McVean, D.N. (1969) Alpine vegetation of the central Snowy Mountains of New South Wales. Journal of Ecology 57: 67-86; Van Rees, H. \& Holmes, J.H.G. (1986) The botanical composition of the diet of free-ranging cattle on an alpine range in Australia. Journal of Range Management 39: 392-395.

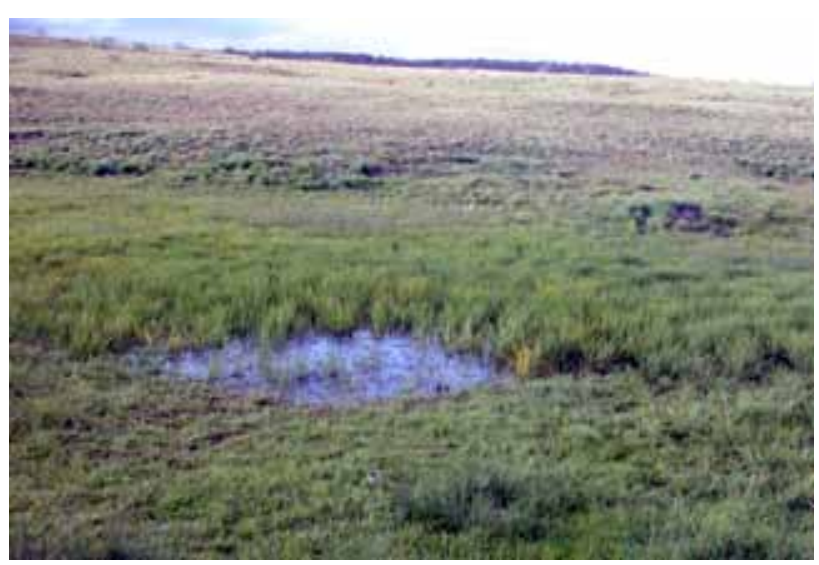

Plate a8: Subalpine and alpine areas where water lies for long periods are usually dominated by Carex gaudichaudiana. They are commonly known as fens. Species richness is a function of the duration of inundation.

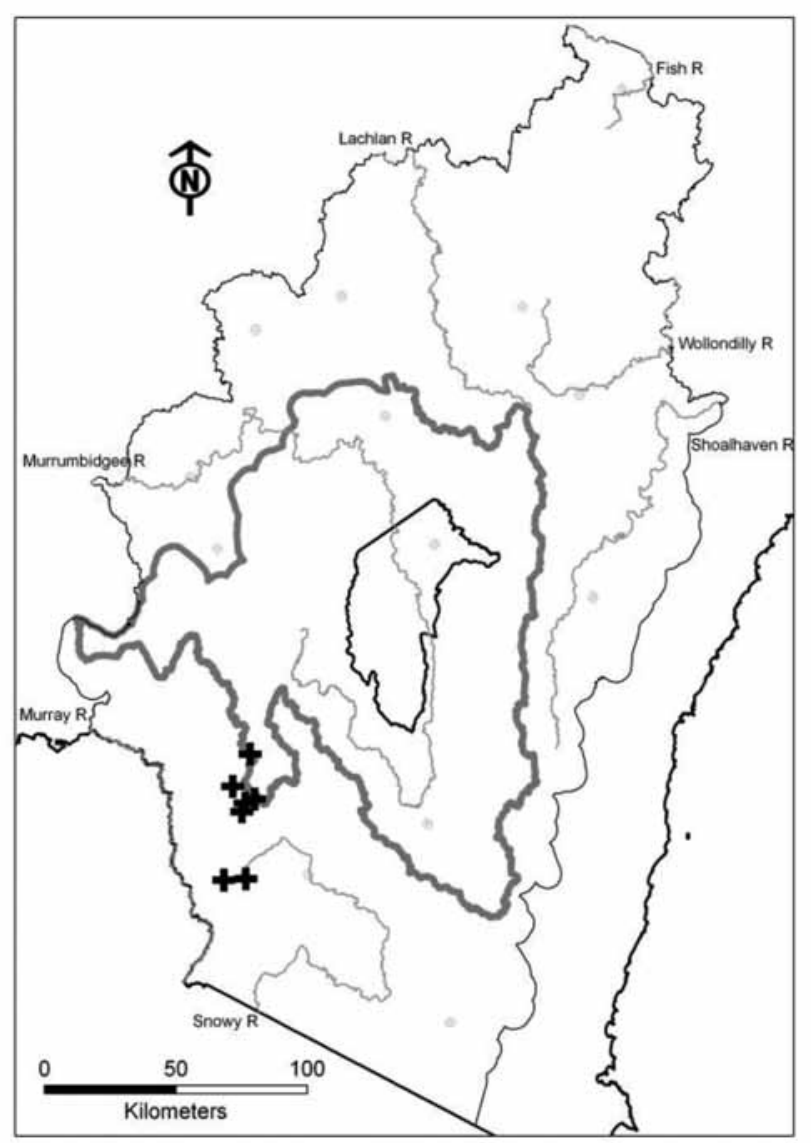

Fig. a8: Distribution of field samples assigned to this community. 


\section{Formation: Rainforests}

\section{Class: Cool Temperate Rainforests}

\section{g172: Black Sassafras temperate rainforest of wet sheltered slopes in the Australian Alps and Bondo subregion of the South Eastern Highlands biore- gions}

Scientific Name: Atherosperma moschatum - Dicksonia antarctica / Polystichum proliferum - Blechnum fluviatile Australina pusilla - Asplenium flabellifolium

Number of samples:

2

Richness [mean ( \pm SD)]:

Slope (degrees):

Altitude (m asl):

14 (3)

(8) 10-13 (14)

(1037) 1053-1084 (1099)

Ave. Annual Rainfall (mm):

(1104) 1126-1170 (1192)

Temp. Annual Range $\left({ }^{\circ} \mathrm{C}\right)$

\section{Characteristic Species:}

Species

C/A Freq C/A O FreqO Fid

$\begin{array}{llllllll}\text { Asplenium bulbiferum subsp. gracillimum } & 1 & 50 & 2 & <1 & \mathrm{P}\end{array}$ Asplenium flabellifolium

Atherosperma moschatum

Australina pusilla

Blechnum fluviatile

Dicksonia antarctica

Diplazium australe

Histiopteris incisa

Leptospermum grandifolium

Polystichum proliferum

Sambucus australasica

Sambucus gaudichaudiana

Tasmannia xerophila

Urtica incisa

Veronica subtilis

Viola hederacea

Eucalyptus delegatensis

Poa helmsii

Rubus parvifolius

Tasmannia lanceolata

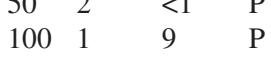

$\begin{array}{llll}100 & 3 & <1 \quad \mathrm{P}\end{array}$

$\begin{array}{llll}100 & 2 & 1 & \mathrm{P}\end{array}$

$\begin{array}{lllll}100 & 0 & 0 & \mathrm{P}\end{array}$

$\begin{array}{llll}100 & 3 & 2 & \mathrm{P}\end{array}$

$\begin{array}{llll}50 & 2 & <1 \quad \mathrm{P}\end{array}$

$\begin{array}{llll}50 & 1 & <1 & \mathrm{P}\end{array}$

$\begin{array}{llll}100 & 1 & 7 & \mathrm{P}\end{array}$

$\begin{array}{lll}50 & 2<1 \quad \mathrm{P}\end{array}$

$\begin{array}{llll}50 & 1 & <1 & \mathrm{P}\end{array}$

$\begin{array}{llll}50 & 1 & 2 & \mathrm{P}\end{array}$

$\begin{array}{llll}100 & 1 & 2 & \mathrm{P}\end{array}$

$\begin{array}{llll}50 & 1 & <1 & \mathrm{P}\end{array}$

$\begin{array}{llll}100 & 2 & 19 & \mathrm{P}\end{array}$

$\begin{array}{llll}50 & 3 & 5 & \mathrm{C}\end{array}$

$\begin{array}{llll}50 & 2 & 4 & \mathrm{C}\end{array}$

$\begin{array}{llll}50 & 1 & 11 & \mathrm{C}\end{array}$

$\begin{array}{llll}50 & 1 & 4 & \mathrm{C}\end{array}$ $\begin{array}{llll}50 & 3 & 2 & \mathrm{P}\end{array}$

Vegetation Description: Community $\mathrm{g} 172$ is a rare rainforest community to about 20 metres high, dominated by Atherosperma moschatum. The shrub layer is dominated by Dicksonia antarctica, with a sparse groundlayer dominated by Polystichum proliferum, Blechnum fluviatile, Australina pusilla, Asplenium flabellifolium, Urtica incisa and Viola hederacea.

This community occurs in deep east facing valleys and gorges, mainly as a narrow band along drainage lines usually only a few metres wide and often overtopped by the canopy of adjacent Community u40 [Alpine Ash tall wet sclerophyll open forest primarily of the Australian Alps bioregion], and occasionally, u52 [Ribbon Gum - Robertson's Peppermint very tall wet sclerophyll open forest primarily of the Bondo subregion of the South Eastern Highlands and the northern Australian Alps bioregions]. However, the structure and floristics of these communities are distinct and they do not intergrade.

Community g172 is found as isolated patches along creeks near Bogong Peaks (such as Stinking Creek and the upper Goobaragandra River), the Geehi Valley (Greening Australia 2011), and the Jacobs and Pinch River Gorges. While it is sampled only at higher elevations in the Murray catchment, within the study area it is found down to 700 metres above sea level, some 150 metres below the occurrence of Eucalyptus delegatensis. Stands in the Pinch River Gorge contain Elaeocarpus holopetalus (Doherty et al. 2011). A similar community also occurs in southern parts of Tallaganda SF east of the divide, and possibly in Gourock NP, although further sampling is required to quantify their relationship (J. Crooks, DPI, pers. comm.).

Fire is believed to have limited the extent of this community, as it is only found in locations that are protected from wildfires, which in the Australian Alps and Bondo subregion of the South Eastern Highlands are usually driven by strong north-westerly winds. Remnant stands do not seem to be burnt even in extreme events such as the 2003 wildfires that affected $70 \%$ of Kosciuszko NP.

Threatened communities: Nil, but given its highly restricted distribution and the potential for wildfires to effect this community, it is possibly eligible for listing.

Equivalent vegetation types: This community was identified by Gellie (2005) as Community VG172 [Kosciuszko Western Escarpment Cool Temperate Rainforest].

Frequently occurring weeds: No weeds were recorded within plot samples.

Threats: Climate change and an increased incidence of hot fires may reduce the extent of the community.

Reservation status: Within the Upper Murrumbidgee catchment all sites known are in Kosciuszko NP.

\section{Extent of clearing: Nil.}

References: Doherty, M.D., Robertson, G., Corcoran, D. \& Wright, G. (2011) Cool temperate rainforest in the Pilot wilderness area, Kosciuszko National Park: distribution, composition and impact of the 2003 fires. Cunninghamia 12: 119-127; Greening Australia (2011) Survey of southern sassafras (Atherosperma moschatum) in the Murphies Swamp area, Bogong Peak wilderness, Koskiuszko National Park. A report by Greening Australia capital region for the NSW Department of Environment, Climate Change and Water. Unpublished. February 2011; Gellie, N.J.H. (2005) Native vegetation of the southern forests: South Eastern Highlands, Australian Alps, South West Slopes and South East Corner bioregions. Cunninghamia 9: 219-254. 


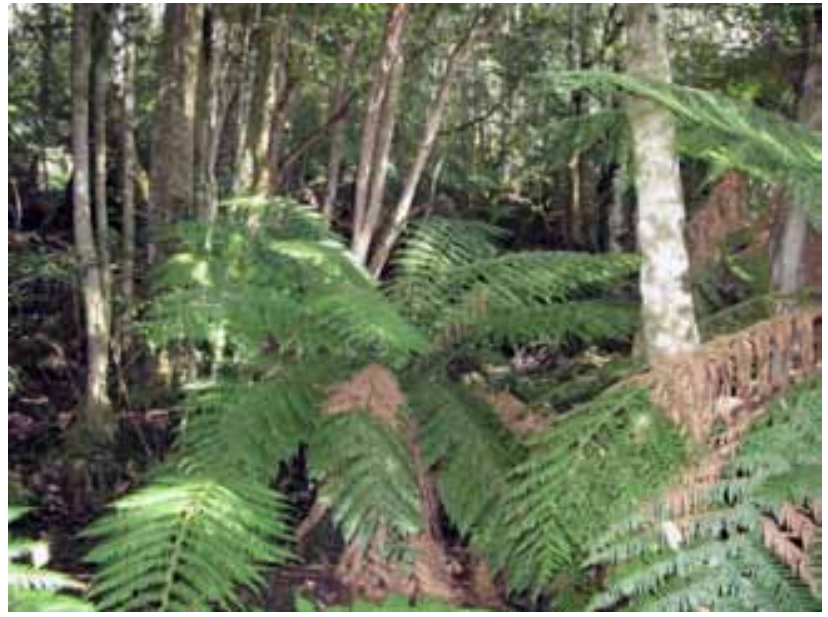

Plate g172: Beneath the canopy of community g172, with Dicksonia antarctica beneath Atherosperma moschatum. $2.4 \mathrm{~km}$ east of Tin Mine Hut, Pilot Wilderness, Kosciuszko NP.

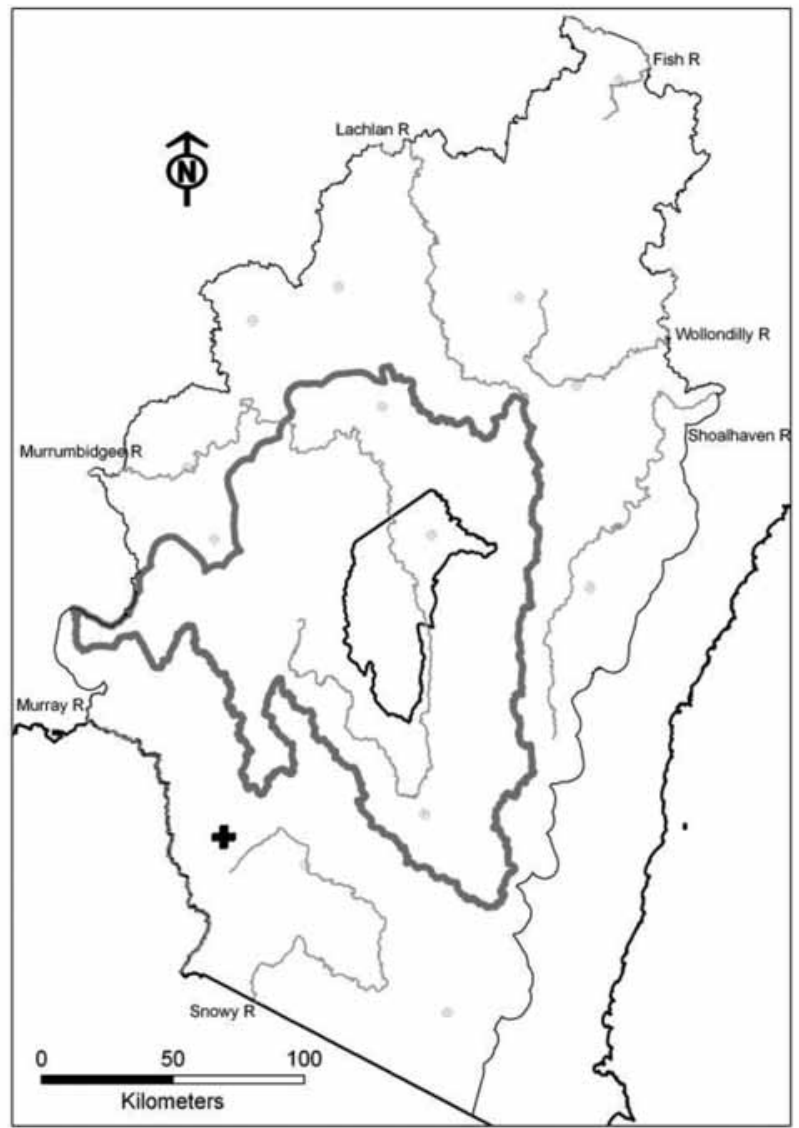

\section{Formation: Wet Sclerophyll Forests}

\section{Class: Montane Wet Sclerophyll Forests}

\section{u40: Alpine Ash very tall wet sclerophyll open for- est primarily of the Australian Alps bioregion}

Scientific Name: Eucalyptus delegatensis \pm Eucalyptus dalrympleana / Polyscias sambucifolia subsp. leptophylla Coprosma hirtella - Veronica derwentiana / Poa helmsii Stellaria pungens - Polystichum proliferum

$\begin{array}{ll}\text { Number of samples: } & 35 \\ \text { Richness [mean }( \pm \text { SD)]: } & 27(7) \\ \text { Slope (degrees): } & (1) 16-26(35) \\ \text { Altitude (m asl): } & (1021) 1163-1337(1504) \\ \text { Ave. Annual Rainfall }(\mathrm{mm}): & (1042) 1261-1533(1802) \\ \text { Temp. Annual Range }\left({ }^{\circ} \mathrm{C}\right): & (22.1) 23.2-24.6(25.2)\end{array}$

Vegetation Description: Community $\mathrm{u} 40$ is a very tall open forest dominated by Eucalyptus delegatensis, often with Eucalyptus dalrympleana occurring at low abundance. At maturity, this community ranges from $25 \mathrm{~m}$ to $45 \mathrm{~m}$ in height. The understorey is predominantly shrubby and of variable density depending on site condition and time since fire. It is typically dominated by Polyscias sambucifolia subsp. leptophylla, Tasmannia xerophila and Coprosma hirtella. Daviesia latifolia and Acacia obliquinervia occur in many sites in abundance after fire. Polystichum proliferum, Veronica derwentiana, Dianella tasmanica, Stellaria pungens, Viola betonicifolia and Poa helmsii are frequently occurring groundlayer taxa.

This community is found mainly from Cabramurra to The Pilot on the western side of the Kosciuszko Range, mostly on steep slopes. In the ACT, it is found in Namadgi NP at Bulls Head and above Smokers Gap. At higher altitudes the community may grade into Community u158 [Alpine Sallee shrub-grass subalpine mid-high woodland of the Australian Alps bioregion], and at lower elevations it may grade into Community u22 [Mountain Gum - Snow Gum grass-forb very tall woodland to open forest of the Australian Alps and South Eastern Highlands bioregions].

Eucalyptus delegatensis is killed by crown fires. Recruitment after hot fires is often prolific, with very high stand densities. Following a crown fire the vegetation is often dominated by shrubs of the genera Daviesia and Acacia for several years until trees grow sufficiently to exert site dominance. The vegetation is often extremely dense, with many thousands of tree stems per hectare. If fires occur at intervals of 20 years or less, young Eucalyptus delegatensis are unlikely to have flowered and developed seed. In these circumstances the vegetation may become a shrubland with scattered trees of Eucalyptus dalrympleana or Eucalyptus pauciflora subsp. pauciflora, which usually resprout after fire (G. Robertson, OEH, pers. comm.), presenting a succession to Community u53 [Mountain Gum - Blackwood tall wet sclerophyll open forest primarily on granitoids of the Australian Alps and western South Eastern Highlands bioregions] or Community u239 [Alpine Ash - Mountain Gum \pm Snow Gum wet sclerophyll open forest of the Australian Alps and South Eastern Highlands bioregions].

Fig. g172: Distribution of field samples assigned to this community. 


\section{Characteristic Species:}

Species

Acacia obliquinervia

Acaena novae-zelandiae

Asperula euryphylla

Bossiaea foliosa

Cassinia aculeata

Coprosma hirtella

Daviesia latifolia

Dianella tasmanica

Eucalyptus dalrympleana

Eucalyptus delegatensis

Galium polyanthum

Leucopogon gelidus

Olearia megalophylla

Olearia phlogopappa

Ozothamnus secundiflorus

Picris angustifolia

Poa ensiformis

Poa helmsii

Polyscias sambucifolia subsp. leptophylla

Polystichum proliferum

Prostanthera lasianthos

Rubus parvifolius

Senecio pinnatifolius var. lanceolatus

Stellaria pungens

Tasmannia xerophila

Veronica derwentiana

Viola betonicifolia

Viola hederacea

Clematis aristata
C/A Freq C/A O FreqO Fid

$\begin{array}{lllll}2 & 37 & 1 & 3 & \mathrm{P} \\ 1 & 51 & 1 & 27 & \mathrm{P} \\ 2 & 29 & 1 & <1 & \mathrm{P} \\ 2 & 29 & 2 & 4 & \mathrm{P} \\ 2 & 46 & 1 & 14 & \mathrm{P} \\ 2 & 86 & 1 & 11 & \mathrm{P} \\ 4 & 57 & 2 & 7 & \mathrm{P} \\ 2 & 71 & 1 & 16 & \mathrm{P} \\ 1 & 46 & 3 & 20 & \mathrm{P} \\ 3 & 91 & 3 & 4 & \mathrm{P} \\ 2 & 23 & 1 & 2 & \mathrm{P} \\ 1 & 26 & 1 & 2 & \mathrm{P} \\ 2 & 31 & 1 & 4 & \mathrm{P} \\ 1 & 54 & 1 & 2 & \mathrm{P} \\ 1 & 37 & 1 & <1 & \mathrm{P} \\ 1 & 20 & 1 & 2 & \mathrm{P} \\ 3 & 23 & 2 & 2 & \mathrm{P} \\ 3 & 80 & 1 & 3 & \mathrm{P} \\ 2 & 89 & 1 & 4 & \mathrm{P} \\ 2 & 80 & 1 & 7 & \mathrm{P} \\ 1 & 31 & 1 & 1 & \mathrm{P} \\ 2 & 71 & 1 & 11 & \mathrm{P} \\ 2 & 37 & 2 & <1 & \mathrm{P} \\ 2 & 83 & 2 & 31 & \mathrm{P} \\ 2 & 57 & 1 & 1 & \mathrm{P} \\ 2 & 80 & 1 & 6 & \mathrm{P} \\ 2 & 71 & 1 & 27 & \mathrm{P} \\ 1 & 40 & 2 & 18 & \mathrm{P} \\ 1 & 43 & 1 & 24 & \mathrm{C}\end{array}$

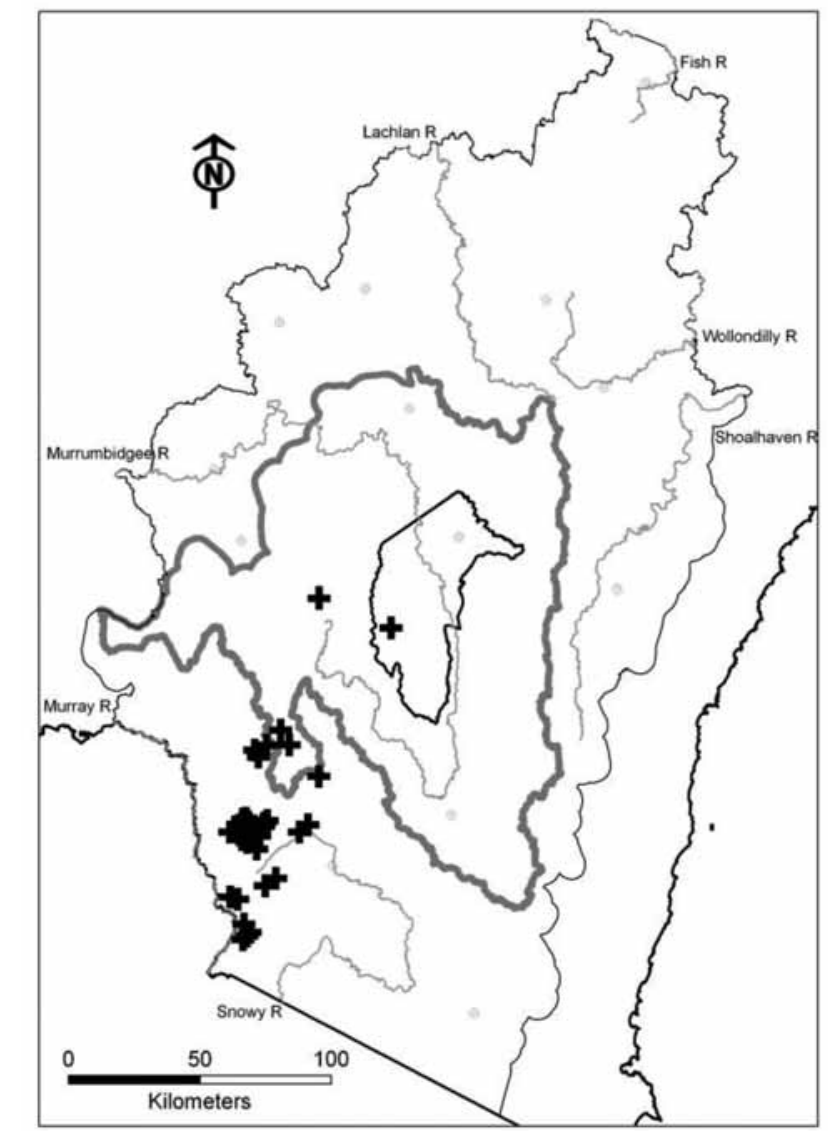

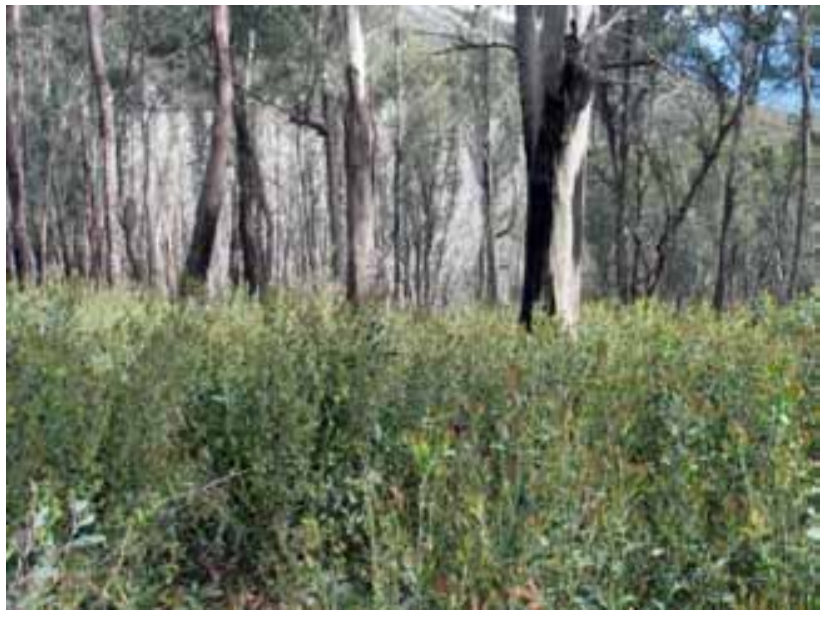

Plate u40: A burnt example of community u40, with a regenerating Daviesia latifolia understorey on the Alpine Way between Tom Groggin and Dead Horse Gap, Kosciuszko NP.

\section{Threatened communities: Nil}

Equivalent vegetation types: This community is defined by a large group of field survey plots, some of which (10) were also classified by Gellie (2005). Most of these were assigned to Community VG87 [Western Escarpment Moist Shrub/Herb/Grass Forest], with a smaller number classified as Community VG86 [Western Sub-alpine Moist Shrub Forest].

Frequently occurring weeds: The distribution of this community on public land is the primary reason for the low abundance of weed species within it. Disturbances most likely to allow weed invasion include logging (in State Forests), road construction and maintenance, and high intensity fire. Cirsium vulgare (0.17) was the most commonly recorded weed species from within this community.

Threats: Hot fires at intervals of less than 20 years are likely to eliminate the key canopy species, Eucalyptus delegatensis.

Reservation status: There are around 100,000 hectares of Eucalyptus delegatensis (all community types) in NSW, with about 80,000 hectares reserved in Kosciuszko NP and Brindabella NP (G. Robertson, OEH, pers. comm.).Most of the area not reserved occurs in Bago, Maragle and Ingebyra SFs..

Extent of clearing: This community has not been affected by clearing, although it is the subject of regenerative logging in State Forest tenure.

References:Gellie, N.J.H. (2005) Native vegetation of the southern forests: South Eastern Highlands, Australian Alps, South West Slopes and South East Corner bioregions. Cunninghamia 9: 219-254. 


\section{u53: Mountain Gum - Blackwood tall wet sclero- phyll open forest primarily on granitoids of the Australian Alps and western South Eastern High- lands bioregions}

Scientific Name: Eucalyptus dalrympleana \pm Eucalyptus delegatensis - Eucalyptus viminalis - Eucalyptus pauciflora subsp. pauciflora / Acacia melanoxylon / Leptospermum grandifolium - Epacris breviflora - Tasmannia lanceolata I Polystichum proliferum - Acaena novae-zelandiae Blechnum nudum

$\begin{array}{ll}\text { Number of samples: } & 18 \\ \text { Richness [mean }( \pm \mathrm{SD})]: & 34(12) \\ \text { Slope (degrees): } & (1) 8-18(26) \\ \text { Altitude (m asl): } & (924) 1101-1261(1368) \\ \text { Ave. Annual Rainfall }(\mathrm{mm}): & (895) 1020-1385(1506) \\ \text { Temp. Annual Range }\left({ }^{\circ} \mathrm{C}\right): & (23.3) 23.9-25.3(25.7)\end{array}$

Vegetation Description: Community u53 is a tall to very tall open forest dominated by Eucalyptus dalrympleana. The well developed midstorey is characterised by the tall shrub Acacia melanoxylon along with smaller shrubs such as Leptospermum grandifolium, Coprosma hirtella, Tasmannia lanceolata, Coprosma quadrifida, Baeckea utilis and Lomatia myricoides. The moist groundlayer is a diverse mix of ferns, forbs and grasses, including Acaena novae-zelandiae, Polystichum proliferum, Blechnum nudum, Carex appressa, Poa helmsii, Blechnum penna-marina subsp. alpina, Clematis aristata, Mentha laxiflora, Lagenophora stipitata, Stellaria pungens, Pteridium esculentum, Viola hederacea and Asperula scoparia.

This community is most common within northern parts of the Australian Alps bioregion, and adjacent high altitude regions of the western South Eastern Highlands bioregion. It is found through Namadgi NP, northern Kosciuszko NP and Bago SF. It occurs on a variety of aspects, bu favours sheltered locations - most often adjacent to drainage features. It is most common on granite, granodiorite or metasedimentary geologies. Co-occurring communities include Community u22 [Mountain Gum Snow Gum grass-forb very tall woodland to open forest of the Australian Alps and South Eastern Highlands bioregions] and Community u239 [Alpine Ash - Mountain Gum \pm Snow Gum wet sclerophyll open forest of the Australian Alps and South Eastern Highlands bioregions] which generally occupies more exposed locations. Narrow creeklines within Community u53 may be dominated by dense patches of Leptospermum grandifolium, a shrub of up to 4 metres in height.

\section{Characteristic Species:}

\section{Species}

Acacia melanoxylon

Acaena novae-zelandiae

Baeckea utilis

Blechnum minus

Blechnum nudum

Blechnum penna-marina subsp. alpina

Blechnum wattsii

Carex appressa

Clematis aristata

Coprosma hirtella

Coprosma quadrifida

Deyeuxia brachyathera

Epacris breviflora

Epilobium billardierianum subsp.

hydrophilum

Eucalyptus dalrympleana

Eucalyptus delegatensis

Eucalyptus viminalis

\begin{tabular}{|c|c|c|c|c|}
\hline $\mathrm{Cl}$ & Frec & C/A & FreqO & Fid \\
\hline 2 & 67 & $\begin{array}{l}\mathbf{U} \\
1\end{array}$ & 14 & $\mathrm{P}$ \\
\hline 2 & 72 & 1 & 27 & $\mathrm{P}$ \\
\hline 2 & 44 & 2 & 1 & $\mathrm{P}$ \\
\hline 2 & 39 & 1 & $<1$ & \\
\hline 3 & 67 & 2 & 3 & \\
\hline 2 & 61 & 1 & $<1$ & \\
\hline 2 & 28 & 2 & $<1$ & \\
\hline 2 & 67 & 1 & 7 & \\
\hline 1 & 61 & 1 & 24 & \\
\hline 1 & 72 & 1 & 11 & $\mathrm{P}$ \\
\hline 1 & 50 & 1 & 8 & $\mathrm{P}$ \\
\hline 1 & 28 & 1 & $<1$ & $\mathrm{P}$ \\
\hline 2 & 83 & 1 & 2 & $\mathrm{P}$ \\
\hline 2 & 44 & 1 & $<1$ & P \\
\hline 2 & 61 & 3 & 20 & \\
\hline 3 & 39 & 3 & 5 & \\
\hline 3 & 39 & 3 & 13 & \\
\hline
\end{tabular}

Gonocarpus micranthus

Gratiola peruviana

Isolepis subtilissima

Lagenophora stipitata

Leptinella filicula

Leptospermum grandifolium

Lomatia myricoides

Mentha laxiflora

Olearia phlogopappa

Poa helmsii

Polyscias sambucifolia subsp. leptophylla

Polystichum proliferum

Prostanthera lasianthos

Ranunculus lappaceus

Rubus parvifolius

Senecio biserratus

Senecio hispidulus

Tasmannia lanceolata

Veronica derwentiana

Pteridium esculentum

Stellaria pungens

Viola hederacea

$\begin{array}{llll}22 & 1 & 2 & \mathrm{P} \\ 22 & 1 & 1 & \mathrm{P} \\ 33 & 1 & <1 & \mathrm{P} \\ 56 & 1 & 17 & \mathrm{P} \\ 28 & 1 & 3 & \mathrm{P} \\ 100 & 2 & 1 & \mathrm{P} \\ 44 & 1 & 11 & \mathrm{P} \\ 61 & 2 & <1 & \mathrm{P} \\ 33 & 1 & 3 & \mathrm{P} \\ 67 & 2 & 3 & \mathrm{P} \\ 28 & 2 & 4 & \mathrm{P} \\ 72 & 1 & 7 & \mathrm{P} \\ 22 & 1 & 1 & \mathrm{P} \\ 39 & 1 & 11 & \mathrm{P} \\ 56 & 1 & 11 & \mathrm{P} \\ 22 & 1 & <1 & \mathrm{P} \\ 22 & 1 & 2 & \mathrm{P} \\ 72 & 1 & 3 & \mathrm{P} \\ 39 & 1 & 7 & \mathrm{P} \\ 44 & 2 & 27 & \mathrm{C} \\ 50 & 2 & 31 & \mathrm{C} \\ 44 & 2 & 18 & \mathrm{C}\end{array}$

\section{Threatened communities: Nil.}

Equivalent vegetation types: This community is most closely related to Community VG86 [Western Sub-alpine Moist Shrub Forest] described by Gellie (2005). Patches where Leptospermum grandifolium is dominant may represent VG84 [Montane Wet Heath/Herb Woodland] of Gellie (2005) but this wasn't identified as a distinct community in the current study, possibly because of undersampling. A Leptospermum grandifolium shrubland occurs in similar vegetation and landscape positions in the Victorian high country.

Frequently occurring weeds: The weeds most frequently recorded in this community are typical of those recorded in other wet forest communities of the region, and include Cirsium vulgare (0.22), Hypochaeris radicata (0.28) and Prunella vulgaris (0.33).

Threats: Where this community occurs in State Forest or on private land, impacts associated with logging are a potential threat to the overstorey and structure of the understorey. Grazing by feral herbivores may also impact upon this community, especially where it occurs within drainage features or adjacent to open woodland communities. As with all vegetation in extensively forested regions, frequent and intense fire represents a major threat to the distribution and composition of this community.

Reservation status: Recorded from survey plots within Kosciuszko NP and Namadgi NP; likely to be well reserved.

Extent of clearing: Considered minimal.

References: Gellie, N.J.H. (2005) Native vegetation of the southern forests: South Eastern Highlands, Australian Alps, South West Slopes and South East Corner bioregions. Cunninghamia 9: 219-254. 


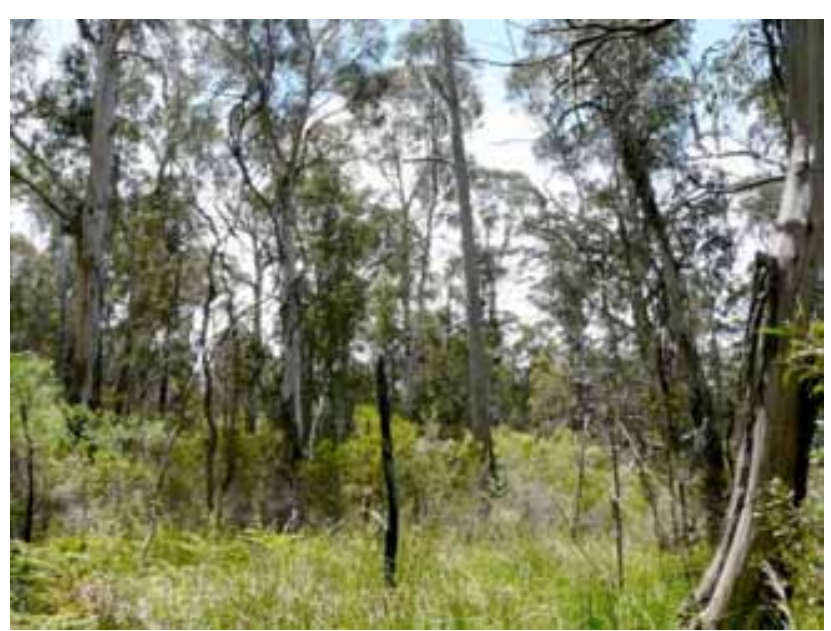

Plate u53: Community u53 dominated by tall Eucalyptus dalrympleana with a shrubby herbaceous understorey. Murray's Gap Trail, Namadgi NP.

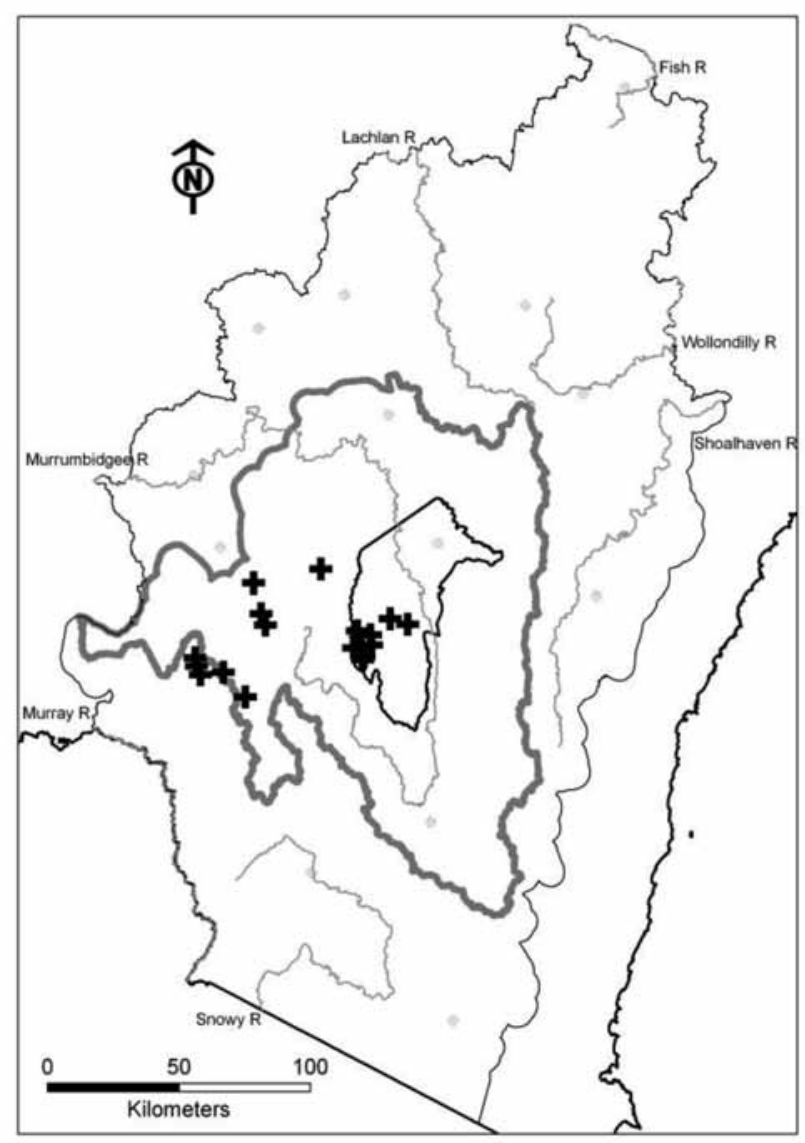

Fig. u53: Distribution of field samples assigned to this community.

\section{u239: Alpine Ash - Mountain Gum \pm Snow Gum wet sclerophyll open forest of the Australian Alps and South Eastern Highlands bioregions}

Scientific Name: Eucalyptus delegatensis - Eucalyptus dalrympleana \pm Eucalyptus pauciflora subsp. pauciflora / Coprosma hirtella - Lomatia myricoides - Olearia megalophylla / Asperula scoparia - Clematis aristata Stellaria pungens - Viola betonicifolia

$\begin{array}{ll}\text { Number of samples: } & 100 \\ \text { Richness [mean }( \pm \mathrm{SD})]: & 29(7) \\ \text { Slope (degrees): } & (1) 8-18(36) \\ \text { Altitude (m asl): } & (1006) 1179-1357(1526) \\ \text { Ave. Annual Rainfall (mm): } & (846) 1101-1365(1653) \\ \text { Temp. Annual Range }\left({ }^{\circ} \mathrm{C}\right): & (22.2) 23.5-24.5(25.3)\end{array}$

Vegetation Description: Community u 239 is a tall to very tall open forest dominated by Eucalyptus delegatensis and Eucalyptus dalrympleana. Eucalyptus pauciflora subsp. pauciflora is often present. The higher abundance of Eucalyptus dalrympleana and the presence of Eucalyptus pauciflora subsp. pauciflora and other species of drier sites indicate that this community occurs in drier habitats than Community u40 [Alpine Ash tall wet sclerophyll open forest primarily of the Australian Alps bioregion]. At maturity, this community ranges from $25 \mathrm{~m}$ to $45 \mathrm{~m}$ in height. Below the canopy it is often variable and may be grassy or shrubby, depending on site condition and fire history. The shrub layer is often a sparse cover of Coprosma hirtella, Acacia dealbata, Daviesia mimosoides and Lomatia myricoides. The groundlayer is a mixture of grasses, forbs and climbers (e.g. Poa sieberiana, Poa phillipsiana, Asperula scoparia, Stellaria pungens, Clematis aristata, Coronidium scorpiodes and Viola betonicifolia).

This community is found mainly from the Brindabella Range south to the Victorian border, but is more common north of Khancoban, mostly on steep slopes between 1,000 and 1,400 metres above sea level. In the Australian Alps bioregion it often grades into Community u158 [Alpine Sallee shrub-grass subalpine mid-high woodland of the Australian Alps bioregion], and at lower elevations this community grades into Community u22 [Mountain Gum - Snow Gum grass-forb very tall woodland to open forest of the Australian Alps and South Eastern Highlands bioregions]. In moister sheltered slopes at the southern edge of its range this community may grade into Community u40 [Alpine Ash tall wet sclerophyll open forest primarily of the Australian Alps bioregion].

For information on the fire ecology of Eucalyptus delegatensis dominated communites, refer to the description of Community u 40 .

\section{Characteristic Species:}

Species

Acacia dealbata

Acacia kettlewelliae

Acacia obliquinervia

Acaena novae-zelandiae

Arthropodium milleflorum

Asperula scoparia

Billardiera macrantha

Brachyscome spathulata

Caladenia alpina

Cassinia aculeata

Chiloglottis pluricallata

Chiloglottis valida

Clematis aristata

Coprosma hirtella

Coronidium scorpioides

Craspedia jamesii

\section{C/A Freq C/A OFreqO Fid}

$\begin{array}{llll}51 & 2 & 25 & \mathrm{P} \\ 5 & 1 & <1 & \mathrm{P} \\ 23 & 1 & 2 & \mathrm{P} \\ 45 & 1 & 27 & \mathrm{P} \\ 34 & 1 & 7 & \mathrm{P} \\ 85 & 2 & 20 & \mathrm{P} \\ 6 & 1 & <1 & \mathrm{P} \\ 38 & 1 & 10 & \mathrm{P} \\ 5 & 1 & <1 & \mathrm{P} \\ 39 & 1 & 13 & \mathrm{P} \\ 7 & 1 & <1 & \mathrm{P} \\ 14 & 1 & 2 & \mathrm{P} \\ 78 & 1 & 22 & \mathrm{P} \\ 85 & 1 & 9 & \mathrm{P} \\ 49 & 1 & 19 & \mathrm{P} \\ 20 & 1 & 3 & \mathrm{P}\end{array}$


Craspedia spp.

Daviesia latifolia

Daviesia mimosoides subsp.

mimosoides

Daviesia ulicifolia

Deyeuxia monticola

Deyeuxia rodwayi

Dianella tasmanica

Eucalyptus dalrympleana

Eucalyptus delegatensis

Eucalyptus pauciflora subsp.

pauciflora

Geranium potentilloides

Gonocarpus montanus

Lagenophora stipitata

Leptinella filicula

Leucopogon gelidus

Lobelia pedunculata

Lobelia puberula

Lomatia myricoides

Olearia erubescens

Olearia megalophylla

Olearia phlogopappa

Oxylobium ellipticum

Ozothamnus stirlingii

Ozothamnus thyrsoideus

Persoonia chamaepeuce

Persoonia subvelutina

Picris angustifolia

Picris angustifolia subsp. angustifolia

Platylobium montanum

Poa helmsii

Poa induta

Poa phillipsiana

Podolobium alpestre

Polyscias sambucifolia subsp.

leptophylla

Polystichum proliferum

Poranthera microphylla

Pterostylis monticola

Ranunculus plebeius

Ranunculus scapiger

Ranunculus spp.

Senecio diaschides

Senecio gunnii

Senecio linearifolius

Stackhousia monogyna

Stellaria pungens

Tasmannia lanceolata

Veronica derwentiana

Viola betonicifolia

Viola hederacea

Wahlenbergia gloriosa

Lomandra longifolia

Poa sieberiana

\begin{tabular}{|c|c|c|c|}
\hline 2 & 19 & 1 & 3 \\
\hline 3 & 26 & 2 & 6 \\
\hline & 36 & 2 & 9 \\
\hline & 32 & 1 & 9 \\
\hline & 22 & 1 & 5 \\
\hline 1 & 5 & 1 & 1 \\
\hline 1 & 48 & 1 & 15 \\
\hline 2 & 77 & 3 & 18 \\
\hline 4 & 96 & 3 & 2 \\
\hline 2 & 50 & 3 & 20 \\
\hline 1 & 43 & 1 & 12 \\
\hline 1 & 8 & 1 & 1 \\
\hline 1 & 40 & 1 & 17 \\
\hline 1 & 17 & 1 & 3 \\
\hline 1 & 15 & 1 & 2 \\
\hline 1 & 18 & 1 & 5 \\
\hline 1 & 11 & 1 & $<1$ \\
\hline 2 & 46 & 1 & 11 \\
\hline 1 & 45 & 1 & 11 \\
\hline 1 & 45 & 1 & 4 \\
\hline 1 & 16 & 1 & 3 \\
\hline 2 & 11 & 1 & 4 \\
\hline 2 & 9 & 1 & $<1$ \\
\hline 1 & 8 & 1 & 2 \\
\hline 1 & 22 & 1 & 11 \\
\hline 2 & 20 & 1 & $<1$ \\
\hline 1 & 10 & 1 & 2 \\
\hline 2 & 7 & 1 & 2 \\
\hline 2 & 29 & 2 & 10 \\
\hline 1 & 13 & 2 & 3 \\
\hline 2 & 14 & 3 & 6 \\
\hline 4 & 26 & 2 & 2 \\
\hline 1 & 9 & 2 & 2 \\
\hline 2 & 36 & 2 & 3 \\
\hline
\end{tabular}

Plate u239: Community u239 with an open shrub layer. Alpine Creek Fire Trail, northern Kosciuszko NP.

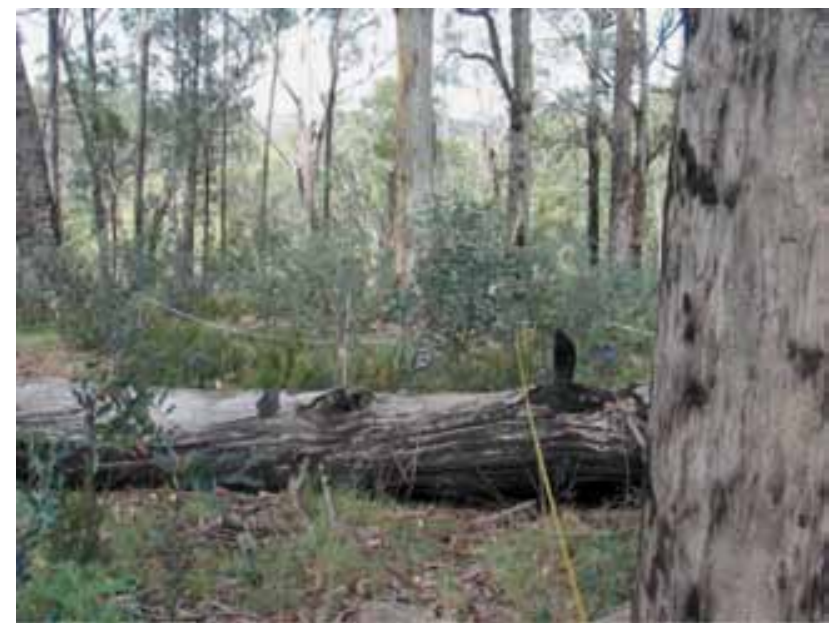

\section{Threatened communities: Nil}

Equivalent vegetation types: This community is defined by a very large group of field survey plots, some of which (22) were also classified by Gellie (2005). These were assigned to a wide variety of Forest Ecosystems and there is no direct equivalent - related types include Community VG102 [Brindabella Montane Dry Fern/Grass Forest] and Community VG86 [Western Sub-alpine Moist Shrub Forest].

Frequently occurring weeds: Weeds are generally uncommon in this community, most likely because it is remote from major anthropogenic disturbances. Weed species that were recorded in this community are typical of other wet forest communities and include Hypochaeris radicata (0.42) and Crepis capillaris (0.15), although both are generally found in low numbers.

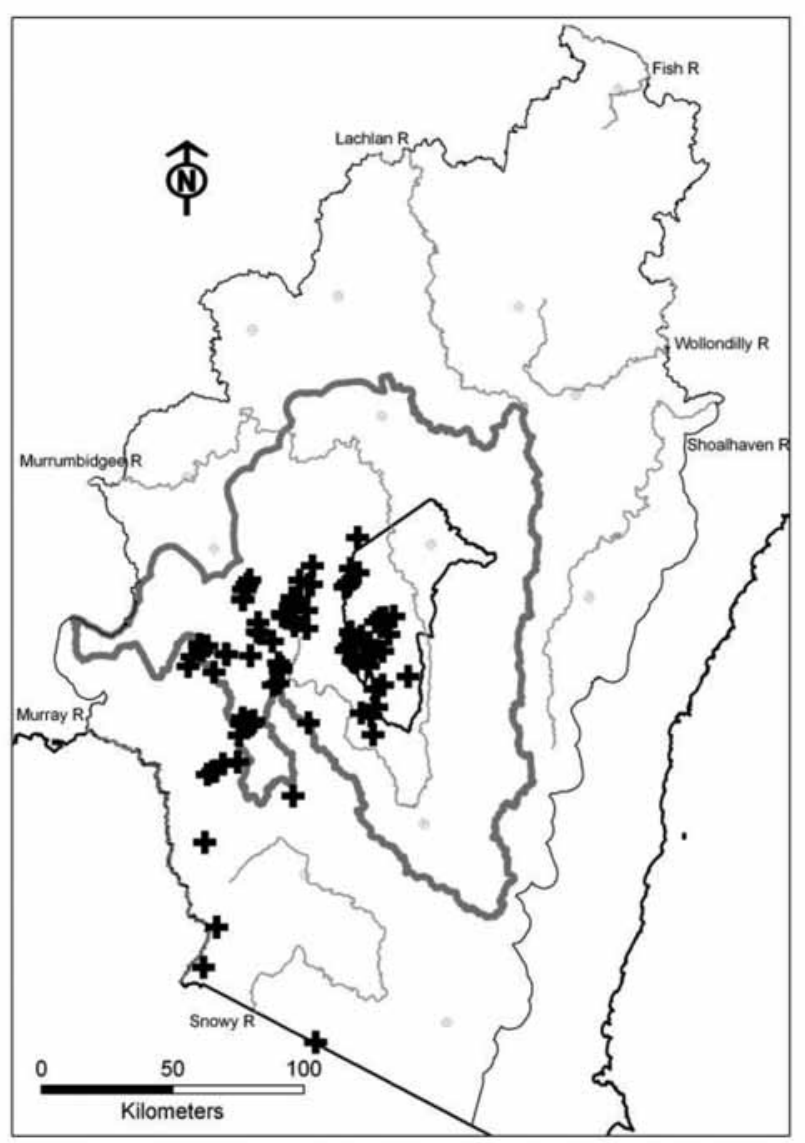

Fig. u239: Distribution of field samples assigned to this community. 
Threats: The greatest threat to this community is the combined effect of high fire intensity and frequency. Because Eucalyptus delegatensis is an obligate seeder (Vivian \& Cary 2012), hot fires at intervals of less than 20 years have the potential to eliminate the species (G. Robertson, $\mathrm{OEH}$, pers. comm.).

Reservation status: There are around 100,000 hectares of Eucalyptus delegatensis (all community types) in NSW, with about 80,000 hectares being reserved in Kosciuszko NP and Brindabella NP. Most of the area not reserved occurs in Bago, Maragle and Ingebyra SFs (G. Robertson, $\mathrm{OEH}$, pers. comm.).

Extent of clearing: This community has not been affected by clearing.

References: Gellie, N.J.H. (2005) Native vegetation of the southern forests: South Eastern Highlands, Australian Alps, South West Slopes and South East Corner bioregions. Cunninghamia 9: 219-254; Vivian, L.M. \& Cary, G.J. (2012) Relationship between leaf traits and fireresponse strategies in shrub species of a mountainous region of southeastern Australia. Annals of Botany 109: 197-208.

\section{Class: Southern Tableland Wet Sclerophyll Forests}

\section{u52: Ribbon Gum - Robertson's Peppermint very tall wet sclerophyll open forest primarily of the Bondo Subregion of the South Eastern Highlands and the northern Australian Alps bioregions}

Scientific Name: Eucalyptus viminalis - Eucalyptus radiata subsp. robertsonii / Acacia melanoxylon / Rubus parvifolius - Cassinia aculeata / Pteridium esculentum - Clematis aristata - Stellaria pungens

Number of samples: 85

Richness [mean $( \pm \mathrm{SD})]$ :

Slope (degrees):

Altitude (m asl):

Ave. Annual Rainfall (mm):

Temp. Annual Range $\left({ }^{\circ} \mathrm{C}\right)$ :

$$
\begin{aligned}
& 36 \text { (9) } \\
& \text { (2) } 12-21(36) \\
& \text { (426) } 804-1088(1249) \\
& \text { (739) } 1001-1189(1396) \\
& \text { (24) } 24.7-25.7(28.2)
\end{aligned}
$$

Vegetation Description: Community u52 is a very tall eucalypt forest dominated by Eucalyptus viminalis and Eucalyptus radiata subsp. robertsonii. Eucalyptus fastigata may be dominant in patches, which in the ACT can be found up to $1,320 \mathrm{~m}$ above sea level (M. Kitchin, ACT ESDD, pers. comm.). The shrub layer of this community is open and variable in height, typically including Acacia melanoxylon, Acacia dealbata, Cassinia aculeata, Lomatia myricoides and Coprosma quadrifida. The moist groundlayer is a mix of forbs, ferns, climbers and grasses including Pteridium esculentum, Clematis aristata, Stellaria pungens, Acaena novae-zelandiae, Lagenophora stipitata, Viola hederacea, Rubus parvifolius, Glycine clandestina, Asperula scoparia, Microlaena stipoides, Poa sieberiana, Geranium potentilloides and Hydrocotyle laxiflora.

This community is prevalent in Namadgi and Brindabella NPs, but extends east to Tinderry NR, and west through Kosciuszko NP to Bondo SF near Tumut. It occupies a variety of aspects, but is most common in sheltered environments. It occurs on a variety of geologies, including rhyolite, granite, granodiorite and meta-sediments. Associated communities are moist forests and subalpine woodlands of the Australian Alps and western South Eastern Highlands bioregions. These include Community u22 [Mountain Gum - Snow Gum grass-forb very tall woodland to open forest of the Australian Alps and South Eastern Highlands bioregions] which occurs at higher altitude, Community u150 [Broad-leaved Peppermint - Mountain Gum tall grass-forb open forest of the South Eastern Highlands and Australian Alps bioregions] on drier and more exposed sites, and Community u152 [Robertson's Peppermint - Red Stringybark very tall grass-forb sheltered open forest of the southwest South Eastern Highlands and upper South Western Slopes bioregions] also on drier sites.

\section{Characteristic Species:}

\section{Species}

Acacia dealbata

Acacia melanoxylon

Acaena novae-zelandiae

Adiantum aethiopicum

Asperula scoparia

Asplenium flabellifolium

Australina pusilla

Bedfordia arborescens

Blechnum minus

Blechnum nudum

Bursaria spinosa

Carex appressa

Cassinia aculeata

Clematis aristata

Coprosma hirtella

Coprosma quadrifida

Cynoglossum australe

Deyeuxia rodwayi

Dianella tasmanica

Dichondra repens

Drymophila cyanocarpa

Echinopogon ovatus

Epilobium billardierianum subsp. cinereum

Eucalyptus fastigata

Eucalyptus radiata subsp. robertsonii

Eucalyptus viminalis

Euchiton japonicus

Galium gaudichaudii

Galium polyanthum

Geranium potentilloides

Glycine clandestina

Gratiola peruviana

Gynatrix pulchella

Hydrocotyle laxiflora

Lagenophora stipitata

Leptinella filicula

Leptospermum juniperinum

Lobelia pedunculata

Lomatia myricoides

Luzula flaccida

Mentha diemenica

Microlaena stipoides

Olearia argophylla

Olearia erubescens

Olearia megalophylla

Olearia stellulata

Platylobium montanum

Poa helmsit

Poa tenera

Polystichum proliferum

Pomaderris aspera

Prostanthera lasianthos

Pteridium esculentum

Pterostylis coccina

Pterostylis decurva

Ranunculus lappaceus

Ranunculus plebeius

Rubus parvifolius

Senecio diaschides

Senecio linearifolius

Stellaria pungens
C/A Freq C/A O FreqO Fid

$\begin{array}{lllll}2 & 65 & 2 & 25 & \mathrm{P} \\ & 68 & 1 & 12 & \mathrm{P} \\ & 81 & 1 & 26 & \mathrm{P} \\ & 21 & 2 & 3 & \mathrm{P} \\ & 65 & 2 & 21 & \mathrm{P} \\ & 25 & 1 & 8 & \mathrm{P} \\ & 12 & 2 & 1 & \mathrm{P} \\ & 13 & 3 & 2 & \mathrm{P} \\ & 21 & 1 & <1 & \mathrm{P} \\ 2 & 19 & 2 & 3 & \mathrm{P} \\ 21 & 1 & 10 & \mathrm{P} \\ & 29 & 1 & 6 & \mathrm{P} \\ & 69 & 1 & 12 & \mathrm{P} \\ & 87 & 1 & 22 & \mathrm{P} \\ & 46 & 1 & 11 & \mathrm{P} \\ & 47 & 1 & 7 & \mathrm{P} \\ 1 & 12 & 1 & 4 & \mathrm{P} \\ 2 & 9 & 1 & <1 & \mathrm{P} \\ 1 & 45 & 1 & 16 & \mathrm{P} \\ 1 & 54 & 2 & 20 & \mathrm{P} \\ 1 & 7 & 1 & <1 & \mathrm{P} \\ 1 & 46 & 1 & 9 & \mathrm{P} \\ 16 & 1 & 5 & \mathrm{P}\end{array}$

213

563

$73 \quad 3$

361

221

$\begin{array}{ll}11 & 1\end{array}$

611

$69 \quad 1$

$\begin{array}{ll}18 & 1\end{array}$

162

592

$\begin{array}{ll}79 & 1\end{array}$

$\begin{array}{ll}15 & 1\end{array}$

72

$\begin{array}{ll}14 & 1\end{array}$

$60 \quad 1$

$26 \quad 1$

181

652

82

$25 \quad 1$

$120 \quad 1$

131

292

252

112

551

272

$\begin{array}{ll}7 & 1\end{array}$

892

121

71

$46 \quad 1$

131

$71 \quad 1$

$28 \quad 1$

$29 \quad 1$

852
6

11

12

1

$<1$ 


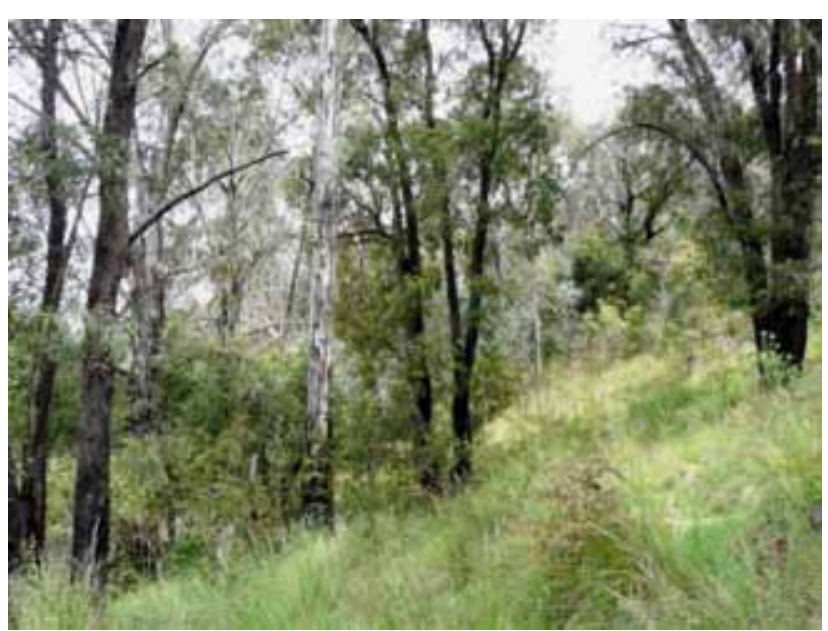

Plate u52: Community u52 dominated by Eucalyptus viminalis and Eucalyptus radiata subsp. robertsonii with scattered shrubs and a grassy understorey. Lower south-western slope of Mt. Tennent, Tennent Fire Trail, Namadgi NP.

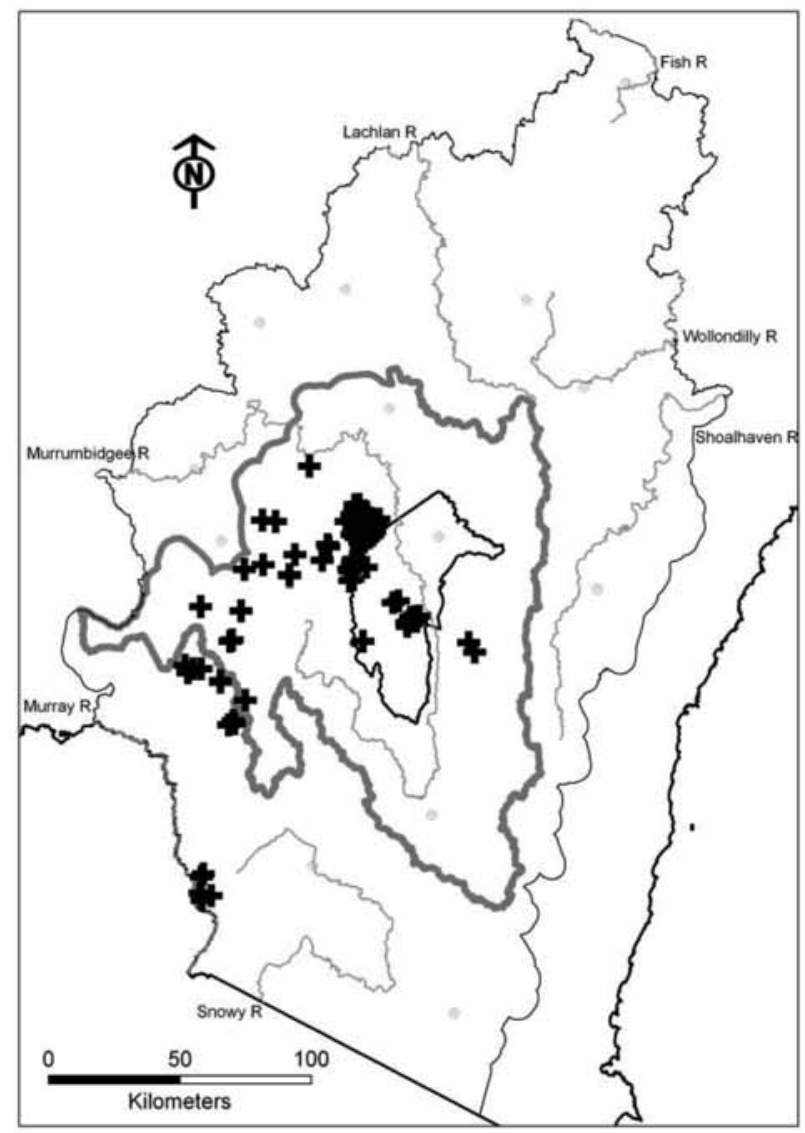

Urtica incisa

Veronica calycina

Veronica derwentiana

Viola hederacea

Lomandra longifolia

Poa sieberiana

$\begin{array}{lllll}1 & 15 & 1 & 2 & \mathrm{P} \\ 1 & 29 & 1 & 16 & \mathrm{P} \\ 1 & 11 & 1 & <1 & \mathrm{P} \\ 1 & 73 & 2 & 17 & \mathrm{P} \\ 1 & 48 & 2 & 42 & \mathrm{C} \\ 2 & 64 & 2 & 48 & \mathrm{C}\end{array}$

Threatened communities: Nil.

Equivalent vegetation types: Most similar to Community VCA 300 [Ribbon Gum-Narrow-leaved (Robertson's) Peppermint montane ferngrass tall open forest on deep clay loam soils in the upper NSW SWS bioregion and western Kosciuszko escarpment] (Benson et al. 2010) and represents a combination of Community VG82 [Western Montane Acacia Fern/Herb Forest], Community VG83 [Montane Riparian Moist Shrub/Grass/Herb Forest] and Community VG102 [Brindabella Montane Dry Fern/Grass Forest] (Gellie 2005).

Frequently occurring weeds: Cirsium vulgare (0.41) and Rosa rubiginosa $(0.24)$ are the most frequently recorded weeds form this community. The prevalence of Rosa rubiginosa, in particular, suggests widespread past disturbance to the canopy and/or the shrub layer.

Threats: As with other forest communities, frequent and intense fire is a significant potential threat to this community. Due to the open nature of the understorey in this community, the other major risk factor is damage associated with feral herbivores.

Reservation status: Likely to be well reserved. Recorded from survey plots in Bimberi NR, Black Andrew NR, Brindabella NP and SCA, Kosciuszko NP, Namadgi NP and Tinderry NR.

Extent of clearing: Likely to be minor.

References: Benson, J.S., Richards, P.G., Waller, S. \& Allen, C.B. (2010) New South Wales vegetation classification and assessment: Part 3. Plant communities of the NSW Brigalow Belt South, Nandewar and west New England bioregions and update of NSW Western Plains and South Western Slopes plant communities. Version 3 of the NSW VCA database. Cunninghamia 11: 457-579. Botanic Gardens Trust, Sydney; Gellie, N.J.H. (2005) Native vegetation of the southern forests: South Eastern Highlands, Australian Alps, South West Slopes and South East Corner bioregions. Cunninghamia 9: 219-254.

\section{Class: Southern Escarpment Wet Sclero phyll Forests}

\section{p338: Brown Barrel wet sclerophyll very tall grass- herb open forest primarily of the Gourock and Tallaganda Ranges in the South Eastern Highlands bioregion}

Scientific Name: Eucalyptus fastigata \pm Eucalyptus radiata subsp. radiata - Eucalyptus viminalis / Acacia dealbata - Leucopogon lanceolatus / Pteridium esculentum I Poa meionectes - Dianella tasmanica - Viola hederacea Stellaria pungens - Clematis aristata

$\begin{array}{ll}\text { Number of samples: } & 112 \\ \text { Richness [mean }( \pm \mathrm{SD})]: & 33(8) \\ \text { Slope (degrees): } & (0) 5-15(33) \\ \text { Altitude (m asl): } & (562) 907-1117(1353) \\ \text { Ave. Annual Rainfall }(\mathrm{mm}): & (759) 911-1005(1144) \\ \text { Temp. Annual Range }\left({ }^{\circ} \mathrm{C}\right): & (22.7) 23.7-24.7(25.8)\end{array}$

Fig. u52: Distribution of field samples assigned to this community. 
Vegetation Description: Community p338 is a very tall eucalypt forest dominated by Eucalyptus fastigata, Eucalyptus radiata subsp. radiata and Eucalyptus viminalis. The shrub layer is variable in height depending on local dominance, but typically includes Acacia dealbata, Leucopogon lanceolatus, Acacia melanoxylon, Coprosma quadrifida and Lomatia myricoides. The moist groundlayer is a mix of ferns, forbs and grasses including Pteridium esculentum, Poa meionectes, Dianella tasmanica, Viola hederacea, Stellaria pungens, Lagenophora stipitata, Poranthera microphylla, Gonocarpus tetragynus, Dichondra repens, Microlaena stipoides, Veronica calycina and Asperula scoparia. The climber Clematis aristata is often present.

This community is generally confined to the western fall of the coastal escarpment within the South Eastern Highlands bioregion. It is common in sheltered environments typically on granite or meta-sedimentary geologies, but is also recorded from granodiorite and basalt substrates. Associated communities are dry forests of the Great Dividing Range including Community p8 [Silvertop Ash - Narrow-leaved Peppermint shrubby tall dry open forest primarily on sedimentary ridges of the eastern South Eastern Highlands bioregion] and Community e24 [Mountain Gum - Snow Gum subalpine very tall dry shrubby open forest primarily in the Kybeyan - Gourock subregion of the South Eastern Highlands bioregion], which both occur in more exposed locations. In the ACT and west into the Brindabellas, Eucalyptus fastigata stands are considered part of Community u52 [Ribbon Gum - Robertson's Peppermint very tall wet sclerophyll open forest primarily of the Bondo Subregion of the South Eastern Highlands and northern Australian Alps bioregions] rather than Community p338.

\section{Characteristic Species:}

\section{Species}

Acacia dealbata

Acacia melanoxylon

Acaena novae-zelandiae

Acrothamnus hookeri

Acrotriche divaricata

Ajuga australis

Asperula scoparia

Blechnum cartilagineum

Brachyscome formosa

Chiloglottis pluricallata

Chiloglottis spp.

Choretrum candollei

Clematis aristata

Clematis spp.

Comesperma volubile

Coprosma quadrifida

Coronidium scorpioides

Cyathea australis

Desmodium gunnii

Dianella tasmanica

Dichondra repens

Drymophila cyanocarpa

Echinopogon ovatus

Eucalyptus cypellocarpa

Eucalyptus fastigata

Eucalyptus nitens

Eucalyptus obliqua

Eucalyptus radiata subsp. radiata

Eucalyptus viminalis

Galium leiocarpum

Geranium potentilloides

Glycine clandestina

Goodia lotifolia

Hakea eriantha

Helichrysum leucopsideum

Hydrocotyle acutiloba

Lagenophora stipitata

Leptinella filicula

Leucopogon lanceolatus

Lobelia puberula

Lomandra longifolia

Lomatia fraseri

Lomatia myricoides

Luzula flaccida

Microlaena stipoides

Olearia megalophylla

Persoonia silvatica

Plantago debilis

Poa ensiformis

Poa meionectes

Polyscias sambucifolia subsp. sambucifolia

Polystichum proliferum

Poranthera microphylla

Pteridium esculentum

Ranunculus pimpinellifolius

Rubus parvifolius

Schelhammera undulata

Senecio prenanthoides

Smilax australis

Stellaria pungens

Tasmannia lanceolata

Veronica calycina

Viola hederacea

Xerochrysum bracteatum

Gonocarpus tetragynus

\section{Threatened communities: Nil.}

\section{C/A Freq C/A O FreqO Fid}

$\begin{array}{lllll}2 & 61 & 2 & 25 & \mathrm{P} \\ 1 & 36 & 1 & 13 & \mathrm{P} \\ 2 & 54 & 1 & 27 & \mathrm{P} \\ 2 & 20 & 1 & 7 & \mathrm{P} \\ 2 & 9 & 1 & <1 & \mathrm{P} \\ 1 & 17 & 1 & 7 & \mathrm{P} \\ 2 & 56 & 2 & 21 & \mathrm{P} \\ 1 & 5 & 2 & 1 & \mathrm{P} \\ 2 & 4 & 2 & <1 & \mathrm{P} \\ 1 & 13 & 1 & <1 & \mathrm{P} \\ 1 & 10 & 2 & 1 & \mathrm{P} \\ 1 & 4 & 1 & <1 & \mathrm{P} \\ 1 & 72 & 1 & 22 & \mathrm{P} \\ 2 & 6 & 2 & <1 & \mathrm{P} \\ 1 & 7 & 1 & 1 & \mathrm{P} \\ 1 & 37 & 1 & 7 & \mathrm{P} \\ 2 & 54 & 1 & 19 & \mathrm{P} \\ 1 & 10 & 2 & 2 & \mathrm{P} \\ 2 & 7 & 2 & 1 & \mathrm{P} \\ 2 & 82 & 1 & 14 & \mathrm{P} \\ 2 & 57 & 2 & 19 & \mathrm{P} \\ 2 & 5 & 1 & <1 & \mathrm{P} \\ 1 & 23 & 1 & 10 & \mathrm{P} \\ 2 & 13 & 3 & 5 & \mathrm{P} \\ 3 & 70 & 3 & 4 & \mathrm{P} \\ 3 & 8 & 3 & <1 & \mathrm{P} \\ 3 & 17 & 3 & 3 & \mathrm{P} \\ 2 & 48 & 3 & 10 & \mathrm{P} \\ 3 & 43 & 3 & 12 & \mathrm{P} \\ 1 & 15 & 1 & 4 & \mathrm{P} \\ 2 & 32 & 1 & 12 & \mathrm{P} \\ 2 & 61 & 1 & 29 & \mathrm{P} \\ 1 & 8 & 1 & 1 & \mathrm{P} \\ 1 & 20 & 1 & 1 & \mathrm{P} \\ 1 & 6 & 1 & <1 & \mathrm{P} \\ 2 & 7 & 1 & 2 & \mathrm{P} \\ 2 & 71 & 1 & 15 & \mathrm{P} \\ 2 & 17 & 1 & 3 & \mathrm{P} \\ & & & & \end{array}$

Equivalent vegetation types: Community WSFp338 [Southern Range Wet Forest] (Tozer et al. 2010) and a combination of Community VG55 [Eastern Tableland Fern/Herb/Grass Moist Forest], Community VG56 [Tableland and Escarpment Moist Herb/Gern/Grass Forest] and Community VG95 [Tableland Acacia Moist Herb Forest] (Gellie 2005).

Frequently occurring weeds: Compared with many communities, this community is relatively undisturbed and consequently weed species are uncommon. Nonetheless the highly dispersable Hypochaeris radicata $(0.74)$ is present at low abundances in the majority of sites.

Threats: Because large areas of this community occur in State Forest, logging and its associated impacts may alter species composition and vegetation condition. Frequent and intense fire also has the potential to impact upon this community.

Reservation status: Likely to be well reserved. Recorded from survey plots in Badja Swamps NR, Bondi Gulf NR, Coolumbooka NR, Deua NP, Gourock NP, Monga NP and SCA, Southeast Forest NP, Tallaganda NP, Tallaganda SCA and Wadbilliga NP.

Extent of clearing: Not assessed, but likely to be minor due to its generally steep mountainous habitat.

References: Gellie, N.J.H. (2005) Native vegetation of the southern forests: South Eastern Highlands, Australian Alps, South West Slopes and South East Corner bioregions. Cunninghamia 9: 219-254; Tozer, M.G., Turner, K., Keith, D.A., Tindall, D., Pennay, C., Simpson, C., MacKenzie, B., Beukers, P. \& Cox, S. (2010) Native vegetation of southeast NSW: a revised classification and map for the coast and eastern tablelands. Cunninghamia 11: 359-406. 


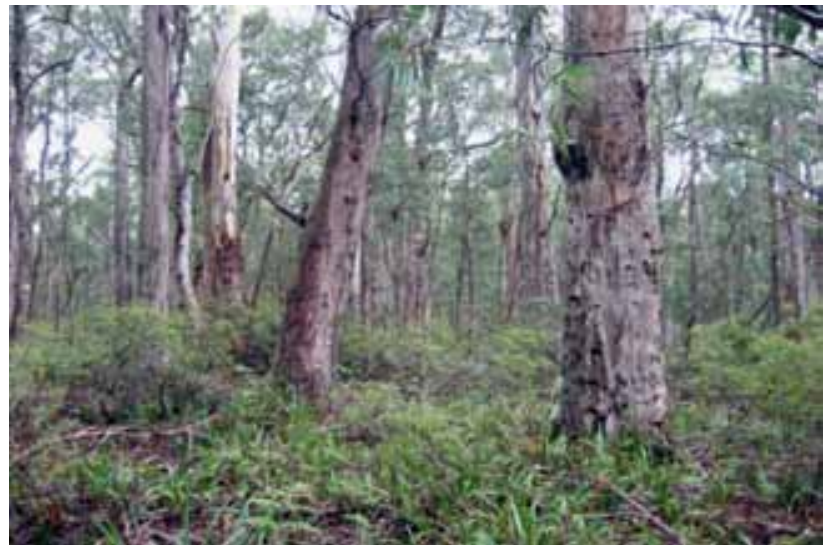

Plate p338: An example of Community p338 dominated by Eucalyptus fastigata, Eucalyptus radiata subsp. radiata and Eucalyptus cypellocarpa, with Leucopogon lanceolata, Dianella tasmanica and Pteridium esculentum in the understorey. Cattlemans Link Firetrail, South East Forests NP.

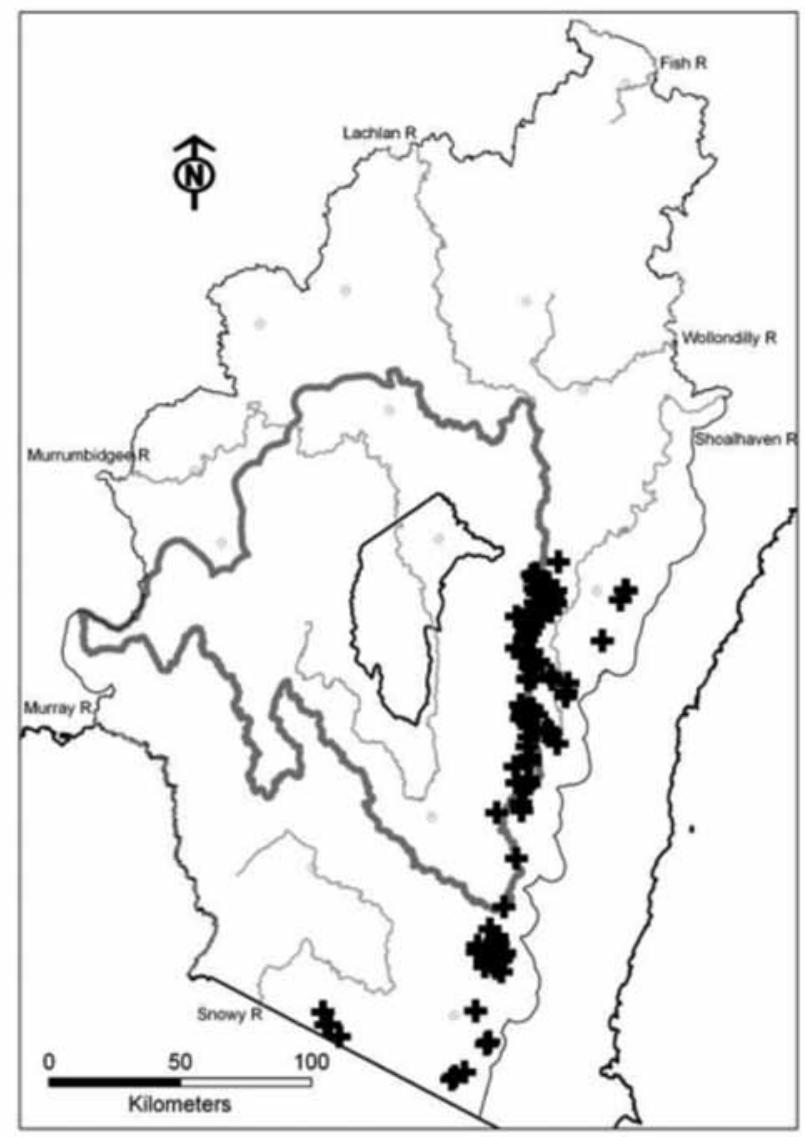

Fig. p338: Distribution of field samples assigned to this community
Formation: Dry Sclerophyll Forests

\section{Class: Southern Tableland Dry Sclerophyll Forests}

\section{e24: Mountain Gum - Snow Gum very tall dry shrubby open forest primarily in the Kybeyan - Gourock subregion of the South Eastern Highlands bioregion}

Scientific Name: Eucalyptus dalrympleana - Eucalyptus pauciflora subsp. pauciflora - Eucalyptus radiata subsp. radiata/Persoonia silvatica-Monotoca scoparia/Lomandra longifolia - Poa meionectes - Stylidium graminifolium sens. lat. - Dianella tasmanica

$\begin{array}{ll}\text { Number of samples: } & 30 \\ \text { Richness [mean }( \pm \mathrm{SD})]: & 25(8) \\ \text { Slope (degrees): } & (0) 2-8(21) \\ \text { Altitude (m asl): } & (758) 922-1147(1351) \\ \text { Ave. Annual Rainfall }(\mathrm{mm}): & (809) 879-1036(1120) \\ \text { Temp. Annual Range }\left({ }^{\circ} \mathrm{C}\right): & (22.7) 23.5-24.2(25.6)\end{array}$

Vegetation Description: Community e24 is a very tall dry shrubby open forest dominated by Eucalyptus dalrympleana, often with Eucalyptus pauciflora subsp. pauciflora or Eucalyptus radiata subsp. radiata. The shrub layer is generally patchy, with species such as Persoonia silvatica, Bossiaea foliosa, Monotoca scoparia, Daviesia ulicifolia and the tall shrubs Acacia dealbata and Exocarpos strictus. The groundlayer is usually sparse and dominated by leaf litter and woody debris, with patches of forbs including Lomanda longifolia, Stylidium graminifolium sens. lat., Dianella tasmanica and Gonocarpus tetragynus and grasses including Poa meionectes and Poa sieberiana.

This community is distributed along the western fall of the Great Dividing Range from Tallaganda NP in the north and extending south to the Bombala area. It is generally found on loamy forest soils of low fertility. This community generally occurs in a mosaic with Community p338 [Brown Barrel wet sclerophyll very tall grass-herb open forest primarily of the Gourock and Tallaganda Ranges in the South Eastern Highlands bioregion] occurring on more sheltered aspects on better soils. It is often increasingly dominated by Eucalyptus pauciflora subsp. pauciflora at higher altitude within its range.

Characteristic Species:

Species

C/A Freq C/A O FreqO Fid

Banksia marginata

Bossiaea foliosa

Choretrum pauciflorum

Daviesia ulicifolia

Dianella tasmanica

Eucalyptus dalrympleana

Eucalyptus pauciflora subsp. pauciflora

Eucalyptus radiata subsp. radiata

Exocarpos strictus

Gompholobium huegelii

Hovea linearis

Lomandra longifolia

Monotoca scoparia

Patersonia sericea var. sericea

Persoonia chamaepeuce

Persoonia silvatica

$\begin{array}{llll}30 & 1 & 3 & \mathrm{P} \\ 63 & 2 & 4 & \mathrm{P} \\ 20 & 1 & 3 & \mathrm{P} \\ 57 & 2 & 10 & \mathrm{P} \\ 67 & 1 & 16 & \mathrm{P} \\ 80 & 3 & 19 & \mathrm{P} \\ 60 & 3 & 21 & \mathrm{P} \\ 50 & 3 & 10 & \mathrm{P} \\ 40 & 1 & 12 & \mathrm{P} \\ 27 & 1 & 5 & \mathrm{P} \\ 47 & 1 & 13 & \mathrm{P} \\ 80 & 2 & 42 & \mathrm{P} \\ 60 & 1 & 14 & \mathrm{P} \\ 27 & 2 & 3 & \mathrm{P} \\ 33 & 1 & 11 & \mathrm{P} \\ 67 & 1 & 3 & \mathrm{P}\end{array}$


Poa meionectes

sambucifolia

Stylidium graminifolium sens. lat.

Acacia dealbata

Coronidium scorpioides

Gonocarpus tetragynus

Hibbertia obtusifolia

Lomandra multiflora
Polyscias sambucifolia subsp.

Microlaena stipoides

$\begin{array}{lllll}2 & 67 & 2 & 16 & \mathrm{P} \\ 2 & 20 & 1 & 1 & \mathrm{P} \\ & & & & \\ 2 & 70 & 1 & 25 & \mathrm{P} \\ 1 & 43 & 2 & 26 & \mathrm{C} \\ 2 & 40 & 1 & 20 & \mathrm{C} \\ 2 & 67 & 2 & 48 & \mathrm{C} \\ 1 & 40 & 1 & 35 & \mathrm{C} \\ 1 & 40 & 1 & 18 & \mathrm{C} \\ 1 & 57 & 2 & 34 & \mathrm{C}\end{array}$

Threatened communities: Components of this community may contain TSC Act 1995 - Tablelands Snow Gum, Black Sallee, Candlebark and Ribbon Gum Grassy Woodland in the South Eastern Highlands, Sydney Basin, South East Corner and NSW South Western Slopes bioregions.

Equivalent vegetation types: Community DSFe24 [Subalpine Dry Shrub Forest] (Tozer et al. 2010), with DSFe24 contains a moderate frequency of Eucalypus dives east of the study area. Some similarities with VG64 [South East Tableland Edge Shrub/Grass Dry Forest] (Gellie 2005).

Frequently occurring weeds: Weed species are uncommon throughout this community. The most commonly recorded species is Hypochaeris radicata $(0.37)$, which is a highly disperable species often found at low abundance in extensively forested environments.

Threats: There are very few threats to the long-term structure and composition of this community, largely because it is well reserved and it has limited value to forestry (BRS \& SFNSW, 1999). The biggest potential threat to this community is via frequent and intense fire, which may alter community floristics and structure over time.

Reservation status: Unknown, although examples of this community are found in Badja Swamps NR, Coolumbooka NR, Dangelong NR, Deua NP, Good Good NR, Gourock NP, South East Forest NP, Tallaganda NP, Tallaganda SCA and Wadbilliga NP.

Extent of clearing: Considered minimal.

References: BRS \& SFNSW (1999) A report on forest wood resources for Southern NSW CRA Region. Bureau of Rural Sciences and State Forests of NSW New South Wales Government, Sydney; Gellie, N.J.H. (2005) Native vegetation of the southern forests: South Eastern Highlands, Australian Alps, South West Slopes and South East Corner bioregions. Cunninghamia 9: 219-254; Tozer, M.G., Turner, K., Keith, D.A., Tindall, D., Pennay, C., Simpson, C., MacKenzie, B., Beukers, P. \& Cox, S. (2010) Native vegetation of southeast NSW: a revised classification and map for the coast and eastern tablelands. Cunninghamia 11: 359-406.

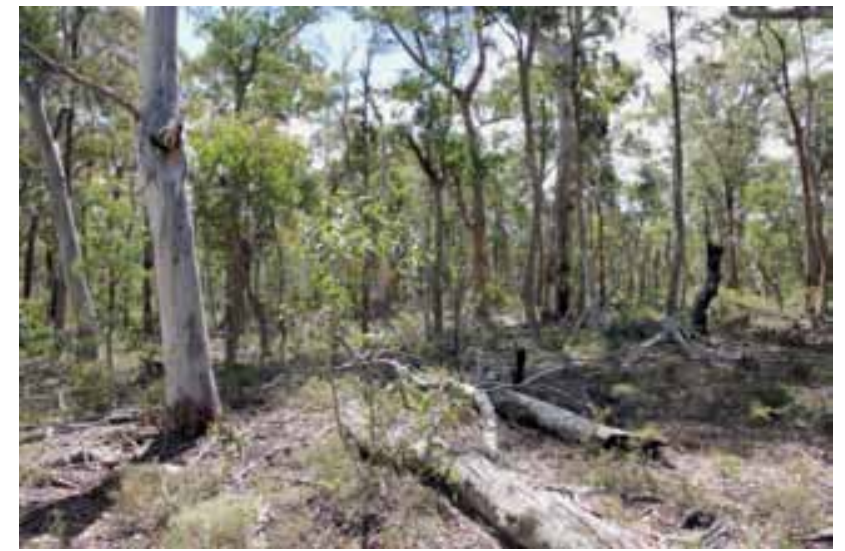

Plate 24: Community e24 dominated by Eucalyptus dalrympleana, with an open shrub layer of Bossiaea foliosa and a patchy understorey of Poa spp. and Microlaena stipoides var. stipoides. Plot UMC219, west of Glenbog SF.

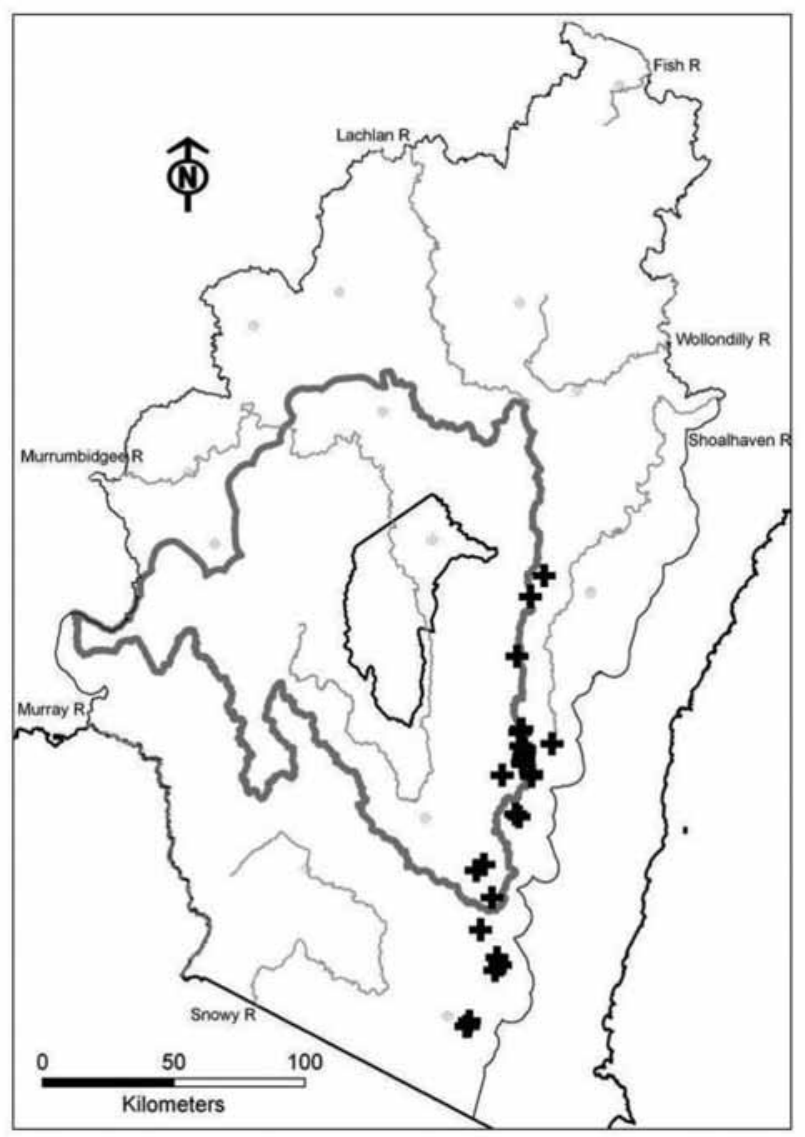

Fig. e24: Distribution of field samples assigned to this community. 


\section{m31: Ribbon Gum - Snow Gum - Cassinia longifo- lia tall shrub-grass open forest of gullies in quartz- rich ranges in the Monaro and Kybeyan-Gourock subregions of the South Eastern Highlands biore- gion}

Scientific Name: Eucalyptus viminalis - Eucalyptus pauciflora subsp. pauciflora / Cassinia longifolia - Acacia dealbata / Poa sieberiana - Elymus scaber - Gonocarpus tetragynus - Microlaena stipoides

$\begin{array}{ll}\text { Number of samples: } & 42 \\ \text { Richness [mean ( } \pm \text { SD)]: } & 35(10) \\ \text { Slope (degrees): } & (4) 7-15(25) \\ \text { Altitude (m asl): } & (721) 815-947(1112) \\ \text { Ave. Annual Rainfall (mm): } & (527) 586-694(846) \\ \text { Temp. Annual Range }\left({ }^{\circ} \mathrm{C}\right): & (23.8) 25.6-26.2(27.7)\end{array}$

Vegetation Description: Community $\mathrm{m} 31$ is a tall open forest to woodland dominated by Eucalyptus viminalis and Eucalyptus pauciflora subsp. pauciflora, frequently with Eucalyptus rubida as a co-dominant. A patchy to sparse shrub layer is commonly present, frequently including Cassinia longifolia and Acacia dealbata, with a groundlayer consisting of a moderately diverse range of grasses, forbs and hard-leaved low shrubs. Commonly occurring species include Poa sieberiana, Elymus scaber, Chrysocephalum semipapposum, Gonocarpus tetragynus, Euchiton japonicus, Hypericum gramineum, Acaena echinata, Microlaena stipoides, Hibbertia obtusifolia and Scleranthus biflorus.

Field plots assigned to this community were recorded from gullies and footslopes of minor watercourses on moderately low fertility siliceous substrates along eastern ranges of the tablelands from Tinderry NR south to Cooma and Nimmitabel, with a disjunct occurrence further south in the Merriangaah area. Many records are from the CoornarthaNumeralla-Countegany area. Within this range, this community is found primarily on Adaminaby Group sandstones but also from metamorphics (quartzite and schist) and Glenbog Granodiorite. This community is likely to be restricted to narrow areas of moist deeper soil along drainage lines, grading into Community u21 [Broad-leaved Peppermint - Candlebark tall dry sclerophyll open forest of quartz-rich ranges of the upper South East Highlands and lower Australian Alps bioregions] on sheltered footslopes and Community m51 [Brittle Gum - Scribbly Gum shrub-grass tall dry sclerophyll open forest on exposed quartz-rich slopes and ridges at primarily in the Monaro and Kybeyan - Gourock subregions of the South Eastern Highlands] on exposed stony slopes and ridges. As annual rainfall increases to the east and at higher altitudes, this community is replaced in similar moist sandy alluvium habitats by Community p520 [Ribbon Gum very tall woodland on alluvial soils along drainage lines of the eastern South Eastern Highlands bioregion].

\section{Characteristic Species:}

\section{Species}

Acacia dealbata

Acacia rubida

Acaena echinata

Acaena novae-zelandiae

Ajuga australis

Bossiaea buxifolia

Cassinia longifolia

Chrysocephalum semipapposum

Daucus glochidiatus

Desmodium varians

Dichondra repens

Echinopogon ovatus

Elymus scaber

\begin{tabular}{lllll}
\multicolumn{3}{c}{ C/A Freq } & \multicolumn{3}{c}{ C/A } & FreqO Fid \\
2 & 81 & 2 & 25 & $\mathrm{P}$ \\
2 & 29 & 1 & 6 & $\mathrm{P}$ \\
1 & 50 & 1 & 9 & $\mathrm{P}$ \\
2 & 52 & 1 & 27 & $\mathrm{P}$ \\
1 & 29 & 1 & 8 & $\mathrm{P}$ \\
1 & 33 & 1 & 7 & $\mathrm{P}$ \\
2 & 88 & 1 & 15 & $\mathrm{P}$ \\
2 & 55 & 1 & 4 & $\mathrm{P}$ \\
1 & 24 & 1 & 8 & $\mathrm{P}$ \\
1 & 36 & 1 & 12 & $\mathrm{P}$ \\
2 & 45 & 2 & 20 & $\mathrm{P}$ \\
1 & 43 & 1 & 10 & $\mathrm{P}$ \\
1 & 69 & 1 & 20 & $\mathrm{P}$
\end{tabular}

Epilobium billardierianum subsp.

cinereum

Eucalyptus pauciflora subsp. pauciflora

Eucalyptus rubida

Eucalyptus viminalis

Euchiton japonicus

Exocarpos strictus

Geranium neglectum

Hypericum gramineum

Leucopogon fletcheri subsp. brevisepalus

Melichrus urceolatus

Mirbelia oxylobioides

Oxalis spp.

Plantago varia

Poa sieberiana

Pultenaea procumbens

Rumex brownii

Rytidosperma racemosum

Scleranthus biflorus

Veronica perfoliata

Veronica plebeia

Viola betonicifolia

Glycine clandestina

Gonocarpus tetragynus

Hibbertia obtusifolia

Hydrocotyle laxiflora

Microlaena stipoides

Themeda australis

$\begin{array}{lllll}1 & 24 & 1 & 5 & \mathrm{P} \\ 3 & 64 & 3 & 20 & \mathrm{P} \\ 3 & 43 & 3 & 8 & \mathrm{P} \\ 3 & 71 & 3 & 12 & \mathrm{P} \\ 1 & 55 & 1 & 15 & \mathrm{P} \\ 1 & 31 & 1 & 12 & \mathrm{P} \\ 1 & 21 & 2 & 2 & \mathrm{P} \\ 1 & 55 & 1 & 25 & \mathrm{P} \\ 1 & 21 & 1 & 3 & \mathrm{P} \\ 1 & 43 & 1 & 13 & \mathrm{P} \\ 3 & 19 & 1 & 3 & \mathrm{P} \\ 1 & 21 & 1 & 3 & \mathrm{P} \\ 1 & 33 & 1 & 11 & \mathrm{P} \\ 2 & 74 & 2 & 48 & \mathrm{P} \\ 1 & 21 & 1 & 4 & \mathrm{P} \\ 1 & 38 & 1 & 9 & \mathrm{P} \\ 1 & 40 & 2 & 10 & \mathrm{P} \\ 1 & 40 & 1 & 10 & \mathrm{P} \\ 1 & 21 & 1 & 4 & \mathrm{P} \\ 1 & 19 & 1 & 6 & \mathrm{P} \\ 1 & 52 & 1 & 27 & \mathrm{P} \\ 1 & 45 & 1 & 29 & \mathrm{C} \\ 2 & 62 & 2 & 48 & \mathrm{C} \\ 1 & 45 & 1 & 35 & \mathrm{C} \\ 1 & 40 & 2 & 30 & \mathrm{C} \\ 2 & 55 & 2 & 34 & \mathrm{C} \\ 1 & 40 & 2 & 21 & \mathrm{C}\end{array}$

Threatened communities: Components of this community may contain TSC Act 1995- Tablelands Snow Gum, Black Sallee, Candlebark and Ribbon Gum Grassy Woodland in the South Eastern Highlands, Sydney Basin, South East Corner and NSW South Western Slopes bioregions.

Equivalent vegetation types: This community has no direct equivalent in the Forest Ecosystem classification of Gellie (2005), however it includes many of the plots that were assigned by those studies to Community VG73 [Eastern Tableland Dry Shrub/Grass Forest] and Community VG74 [South Eastern Tablelands Dry Shrub/Grass/Herb Forest].

Frequently occurring weeds: The greater diversity of weed species found in this community relative to other forested communities in the region might be attributed to the moist, deep soil on which it generally occurs. The most commonly recorded species were Acetosella vulgaris (0.21), Centaurium erythraea (0.28), Cirsium vulgare (0.18), Hypochaeris radicata (0.62), and Trifolium arvense (0.21), each of which is typical of pastoral environments. This may also indicate some past clearing and/or grazing by domestic stock in this community.

Threats: Although this community occupies relatively moist and productive sites, these generally occupy narrow zones within dry siliceous hills and ranges in dissected terrain. As a result this community is unlikely to have been extensively cleared, although larger examples of the type may have been historically thinned or cleared of trees to encourage pasture growth for grazing stock. Examples of this type on private land are likely to be subject to occasional ongoing light grazing. Its moister landscape position means this type is likely to be prone to ongoing weed invasion, particularly exotic pasture species spread by grazing animals.

Reservation status: Most of the plots assigned to this community were sampled in conservation reserves, including Coornartha NR, Dangelong NR, Macanally SCA, Merriangaah NR, Mount Clifford NR, Numeralla NR, Quidong NR, Strike-a-Light NR, Tinderry NR, Undoo NR and Wadjan NR.

Extent of clearing: Likely to be minor.

Reference: Gellie, N.J.H. (2005) Native vegetation of the southern forests: South Eastern Highlands, Australian Alps, South West Slopes and South East Corner bioregions. Cunninghamia 9: 219-254. 


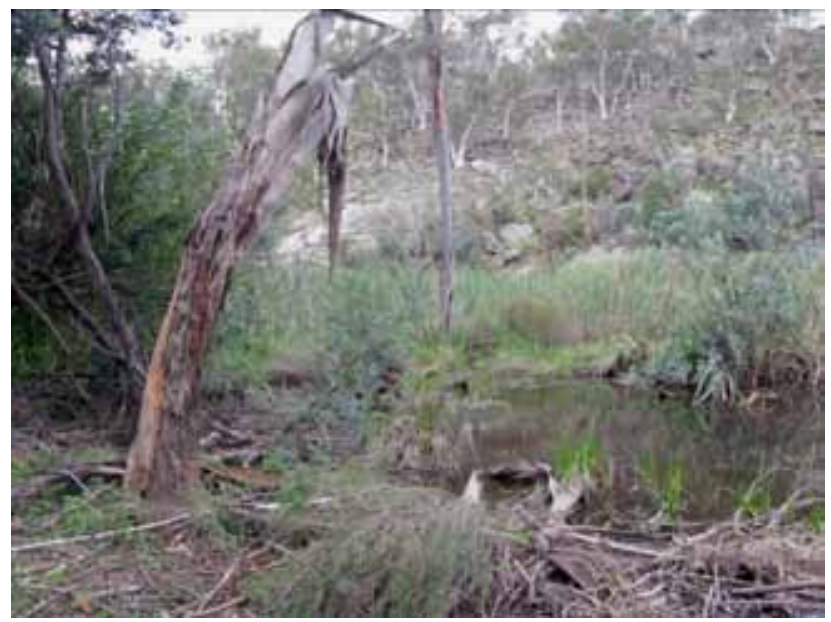

Plate m31: Community m31 beside the Murrumbidgee River near Cooma water filtration plant (plot UMC424), with Eucalyptus viminalis above scattered Acacia dealbata, Leptospermum obovatum and a moist riparian herbaceous groundcover.

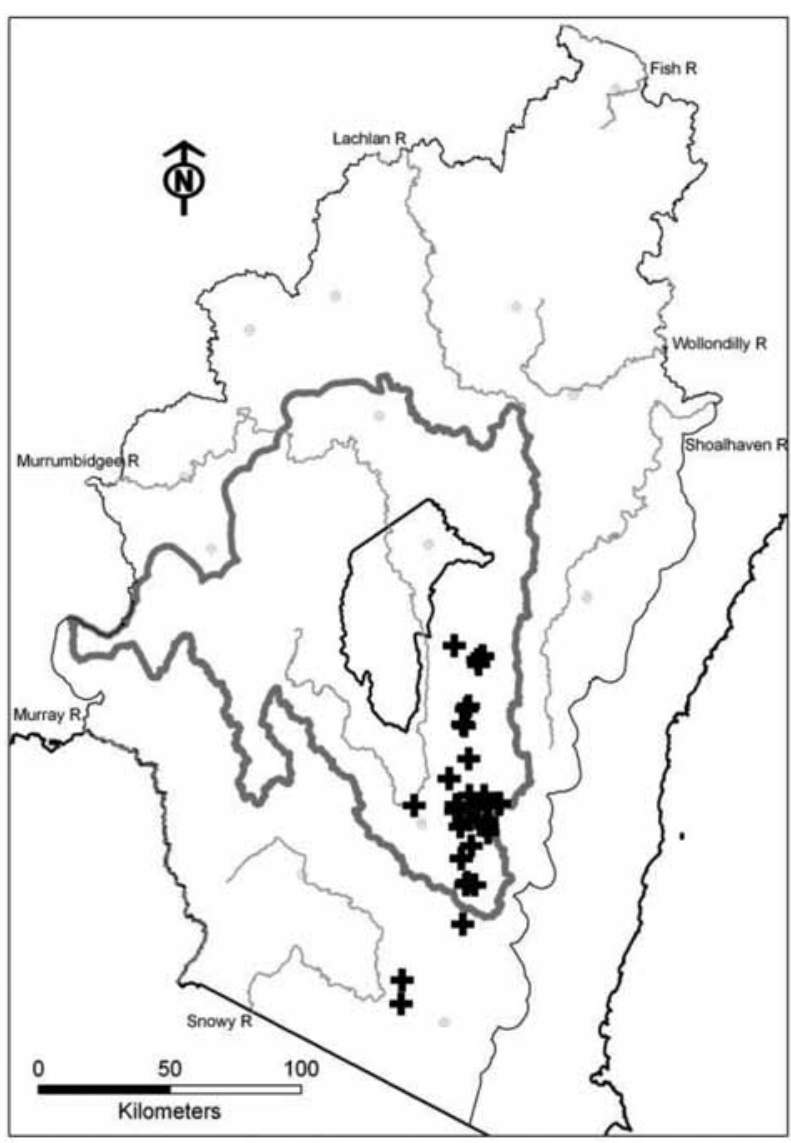

Fig. m31: Distribution of field samples assigned to this community. m51: Brittle Gum - Scribbly Gum shrub-grass tall dry sclerophyll open forest on exposed quartz-rich slopes and ridges at primarily in the Monaro and Kybeyan - Gourock subregions of the South Eastern Highlands bioregion

Scientific Name: Eucalyptus mannifera - Eucalyptus rossii - Eucalyptus macrorhyncha - Eucalyptus dives / Hibbertia obtusifolia - Melichrus urceolatus / Rytidosperma pallidum - Pultenaea procumbens - Dianella revoluta
Number of samples:
Richness [mean $( \pm \mathrm{SD})]$
Slope (degrees):
Altitude ( $\mathrm{m}$ asl):
Ave. Annual Rainfall $(\mathrm{mm})$ :
Temp. Annual Range $\left({ }^{\circ} \mathrm{C}\right)$ :

Vegetation Description: Community $\mathrm{m} 51$ is a tall eucalypt open forest to woodland with a canopy 10 to $15 \mathrm{~m}$ tall dominated by Eucalyptus mannifera and Eucalyptus rossii, commonly with Eucalyptus dives and/ or Eucalyptus macrorhyncha. Shrubs are absent to patchy and a sparse to moderate groundlayer is dominated by a relatively depauperate mix of low shrubs, forbs and grasses, including Hibbertia obtusifolia, Rytidosperma pallidum, Dianella revoluta, Pultenaea procumbens, Melichrus urceolatus and Brachyloma daphnoides.

This community is distributed from the Captains Flat and Burra areas in the north, south along the Tinderry Range and Black Range to Numeralla and Sunny Corner, with disjunct occurrences in the far south from Merriangaah and Quidong on Sherwins Range and Gibraltar Ridge. Within this range, Community m51 occurs on siliceous, moderate to low fertility substrates, occurring primarily on Adaminaby Group sediments (sandstones, siliceous siltstones and mudstones), but also on Jerangle and Cooma Metamorphics and Glenbog Granodiorite.

Community m51 may grade into Community u21 [Broad-leaved Peppermint - Candlebark tall dry sclerophyll open forest of quartz-rich ranges of the upper South East Highlands and lower Australian Alps bioregions] on deeper soils on footslopes and flats, and in sheltered gullies may be replaced by Community m31 [Ribbon Gum - Snow Gum - Cassinia longifolia tall shrub-grass open forest of gullies in quartz-rich ranges in the Monaro and Kybeyan-Gourock subregions of the South Eastern Highlands bioregion]. On similar exposed landscape positions with siliceous substrates north of Queanbeyan, this community is replaced by the related Community p14 [Red Stringybark - Scribbly Gum - Rytidosperma pallidum tall grass-shrub dry sclerophyll open forest on loamy ridges of the central South Eastern Highlands bioregion].

\section{Characteristic Species:}

Species

Acacia buxifolia

Acacia falciformis

Acacia gunnii

Acacia rubida

Bossiaea buxifolia

Brachyloma daphnoides

Brachyscome rigidula

Callitris endlicheri

Cassinia longifolia

Choretrum pauciflorum

Daviesia leptophylla

Daviesia mimosoides subsp. mimosoides

Dianella revoluta

Dillwynia sericea
C/A Freq C/A O FreqO Fid

$\begin{array}{llll}14 & 1 & 1 & \mathrm{P} \\ 26 & 2 & 7 & \mathrm{P} \\ 26 & 1 & 6 & \mathrm{P} \\ 46 & 1 & 5 & \mathrm{P} \\ 32 & 1 & 7 & \mathrm{P} \\ 62 & 1 & 16 & \mathrm{P} \\ 14 & 1 & 2 & \mathrm{P} \\ 16 & 2 & 1 & \mathrm{P} \\ 34 & 1 & 16 & \mathrm{P} \\ 14 & 1 & 3 & \mathrm{P} \\ 22 & 1 & 5 & \mathrm{P} \\ 24 & 2 & 9 & \mathrm{P} \\ & & & \\ 66 & 1 & 22 & \mathrm{P} \\ 24 & 1 & 4 & \mathrm{P}\end{array}$




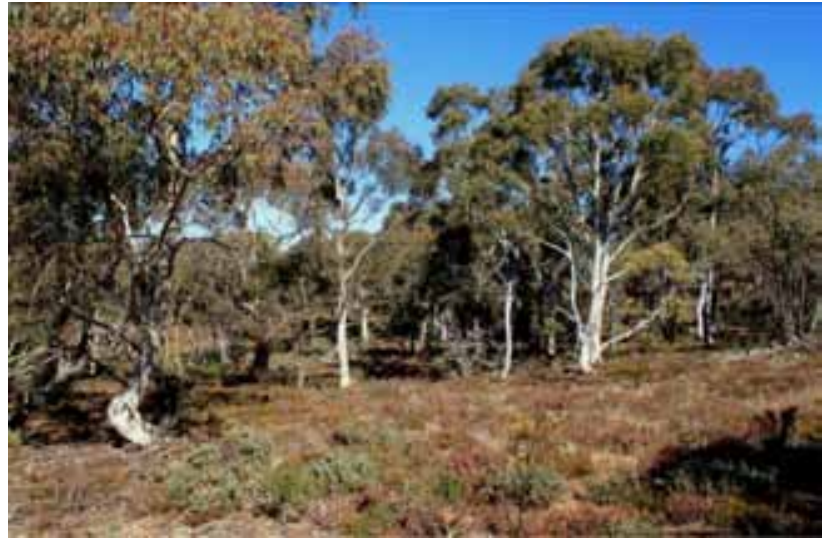

Plate m51: Eucalyptus mannifera with hardy shrub taxa typical of plant community m51, adjacent to Dangelong NR, Nimmitabel.
Eucalyptus dives

Eucalyptus macrorhyncha

Eucalyptus mannifera

Eucalyptus rossii

Hibbertia obtusifolia

Leucopogon ericoides

Leucopogon microphyllus

Melichrus urceolatus

Persoonia rigida

Platysace lanceolata

Pultenaea procumbens

Rytidosperma pallidum

Veronica perfoliata

Gonocarpus tetragynus

Lomandra longifolia

$\begin{array}{lllll}3 & 50 & 3 & 18 & \mathrm{P} \\ 3 & 46 & 3 & 15 & \mathrm{P} \\ 3 & 80 & 2 & 10 & \mathrm{P} \\ 3 & 58 & 3 & 7 & \mathrm{P} \\ & 84 & 1 & 34 & \mathrm{P} \\ 3 & 18 & 1 & <1 & \mathrm{P} \\ 22 & 2 & 1 & \mathrm{P} \\ 62 & 1 & 12 & \mathrm{P} \\ 50 & 1 & 2 & \mathrm{P} \\ 18 & 2 & 5 & \mathrm{P} \\ 66 & 1 & 4 & \mathrm{P} \\ 80 & 2 & 17 & \mathrm{P} \\ 22 & 1 & 4 & \mathrm{P} \\ 54 & 2 & 48 & \mathrm{C} \\ 58 & 2 & 42 & \mathrm{C}\end{array}$

Threatened communities: Nil.

Equivalent vegetation types: Community $\mathrm{m} 51$ has no direct equivalent in the Forest Ecosystem classification of Gellie (2005), however it includes a number of plots that were assigned to Community VG115 [South East Tablelands Dry Shrub/Tussock Grass Forest].

Frequently occurring weeds: Due to the relatively infertile substrate of this community it is generally low in diversity and abundance of weeds, with Hypochaeris radicata (0.07) being the most commonly recorded.

Threats: This community occupies relatively infertile and dry rocky slopes and is likely to have suffered only minor clearing across its range. Examples on private land may be subject to stock grazing, but are unlikely to support high stocking rates. Weed invasion is not a significant problem for this community.

Reservation status: Due to the infertile, steep, dry rocky habitat of this community, it is well represented in conservation reserves. This community has been sampled from many conservation reserves across its range, including Burra Creek NR, Yanununbeyan SCA, Tinderry NR, Mount Dowling NR, Macanally NR, Coornatha NR, Kybeyan NR and Merriangaah NR.

Extent of clearing: Only minor clearing likely.

Reference: Gellie, N.J.H. (2005) Native vegetation of the southern forests: South Eastern Highlands, Australian Alps, South West Slopes and South East Corner bioregions. Cunninghamia 9: 219-254.

\section{p8: Silvertop Ash - Narrow-leaved Peppermint shrubby tall dry open forest primarily on sedimen- tary ridges of the eastern South Eastern Highlands bioregion}

Scientific Name: Eucalyptus sieberi - Eucalyptus radiata subsp. radiata /Leucopogon lanceolatus - Persoonia linearis - Hibbertia obtusifolia-Pteridium esculentum/Gonocarpus tetragynus - Lomandra longifolia - Poa sieberiana

$\begin{array}{ll}\text { Number of samples: } & 83 \\ \text { Richness [mean }( \pm \mathrm{SD})]: & 26(8) \\ \text { Slope (degrees): } & (1) 6-17(31) \\ \text { Altitude (m asl): } & (648) 806-994(1190) \\ \text { Ave. Annual Rainfall }(\mathrm{mm}): & (694) 856-956(1069) \\ \text { Temp. Annual Range }\left({ }^{\circ} \mathrm{C}\right): & (22.6) 24.2-25.2(26.2)\end{array}$

Vegetation Description: Community p8 is a dry open forest with a tall tree canopy characteristically dominated by Eucalyptus sieberi, with or without other eucalypts of dry sites including Eucalyptus radiata subsp. radiata or Eucalyptus dives, and north of the upper Murrumbidee catchment, Eucalyptus blaxlandii. This community typically has an open understorey with a sparse complement of hard-leaved tall shrubs,

Fig. m51: Distribution of field samples assigned to this community. 
including Acacia terminalis, Persoonia linearis and Podolobium ilicifolium and shorter shrubs such as Leucopogon lanceolatus, Monotoca scoparia and the scrambling Billardiera scandens. The groundlayer is often dominated by leaf litter and rock, with sparse and scattered plant cover of Gonocarpus tetragynus, Pteridium esculentum, Lomandra longifolia, Poa sieberiana, Dianella revoluta and Hibbertia obtusifolia.

This community occurs primarily on dry exposed ridges and slopes with shallow to skeletal soils of moderately low to low soil fertility derived from a range of quartz-rich sedimentary, acid-volcanic and igneous substrates. It is found extensively on the eastern tablelands, from Jenolan south along the Kanangra Range to Mount Werong, Wiarborough, Wombeyan Caves, the Cookbundoon Range, Currawang, the Gourock, Butmaroo and Bendoura Ranges to the Kybeyan Range (Countegany), and east of Braidwood from Charleys Forest to Northangera and Monga. It extends further to the east beyond the current study area (see Tozer et al. 2010).

Community p8 is often associated with Community WSFp73 (described by Tozer et al. 2010) north of the study area, and Community p338 [Brown Barrel wet sclerophyll very tall grass-herb open forest primarily of the Gourock and Tallaganda Ranges in the South Eastern Highlands bioregion] in the south of its range. Both of these communities occur on deeper, moister soils of lower slopes and more sheltered aspects than Community p8.

\section{Characteristic Species:}

\section{Species}

Acacia falciformis

Acacia gunnii

Acacia obliquinervia

Acacia obtusifolia

Acacia terminalis

Acacia ulicifolia

Amperea xiphoclada

Austrostipa rudis

Banksia spinulosa var. spinulosa

Billardiera scandens

Bossiaea obcordata

Comesperma volubile

Dampiera purpurea

Daviesia ulicifolia

Dianella caerulea

Dianella revoluta

Eucalyptus blaxlandii

Eucalyptus radiata subsp. radiata

Eucalyptus sieberi

Eucalyptus smithii

Gonocarpus tetragynus

Goodenia bellidifolia

Goodenia hederacea subsp. hederacea

Goodenia spp.

Hakea dactyloides

Hakea eriantha

Hardenbergia violacea

Hibbertia diffusa

Hibbertia obtusifolia

Hibbertia serpyllifolia

Lepidosperma urophorum

Leucopogon lanceolatus

Lomandra filiformis subsp. coriacea

Lomandra glauca

Lomandra longifolia

Lomandra multiflora

Lomandra obliqua

Lomatia ilicifolia

Lomatia silaifolia

Monotoca scoparia

\section{C/A Freq C/A O FreqO Fid}

$\begin{array}{llll}1 & 28 & 2 & 7\end{array}$

$\begin{array}{llll}18 & 1 & 6\end{array}$

$\begin{array}{llll}1 & 12 & 2 & 3\end{array}$

$\begin{array}{llll}2 & 10 & 2 & 1\end{array}$

$\begin{array}{llll}2 & 34 & 1 & 3\end{array}$

$\begin{array}{lll}10 & 1 & 2\end{array}$

$\begin{array}{llll}2 & 19 & 1 & 1\end{array}$

$\begin{array}{llll}2 & 12 & 1 & 3\end{array}$

$\begin{array}{llll}2 & 34 & 2 & 1\end{array}$

$\begin{array}{llll}1 & 49 & 1 & 8 \\ 2 & 7 & 2 & <1\end{array}$

$\begin{array}{llll}1 & 7 & 1 & 1\end{array}$

$\begin{array}{llll}1 & 8 & 2 & <1\end{array}$

$\begin{array}{llll}2 & 22 & 2 & 10\end{array}$

$\begin{array}{llll}1 & 27 & 1 & 5\end{array}$

$\begin{array}{llll}2 & 52 & 1 & 22\end{array}$

$\begin{array}{llll}2 & 14 & 2 & <1\end{array}$

$\begin{array}{llll}3 & 58 & 3 & 10\end{array}$

$\begin{array}{llll}3 & 89 & 3 & 6\end{array}$

$\begin{array}{llll}3 & 10 & 1 & <1\end{array}$

$\begin{array}{llll}2 & 73 & 2 & 47\end{array}$

$\begin{array}{llll}1 & 6 & 2 & 1\end{array}$

$\begin{array}{lll}40 & 2 & 16\end{array}$

$\begin{array}{lll}6 & 1 & <1\end{array}$

$\begin{array}{lll}17 & 2\end{array}$

$\begin{array}{lll}10 & 1 & 2\end{array}$

$34 \quad 1 \quad 14$

$\begin{array}{lll}6 & 2 & <1\end{array}$

$\begin{array}{lll}77 & 1 & 34\end{array}$

$\begin{array}{lll}6 & 2<1\end{array}$

$\begin{array}{lll}19 & 2 & 1\end{array}$

$\begin{array}{lll}73 & 2 & 11\end{array}$

$\begin{array}{lll}36 & 2 & 18\end{array}$

$\begin{array}{lll}23 & 2 & 4\end{array}$

$\begin{array}{lll}67 & 2 & 42\end{array}$

$\begin{array}{lll}36 & 1 & 18\end{array}$

$\begin{array}{lll}24 & 2 & 3\end{array}$

$\begin{array}{lll}22 & 1 & 3\end{array}$

$\begin{array}{lll}22 & 2 & <1\end{array}$

$\begin{array}{llll}2 & 54 & 1 & 14\end{array}$
Patersonia glabrata

Patersonia sericea var. sericea

Persoonia laurina

Persoonia linearis

Phyllanthus hirtellus

Platysace ericoides

Podolobium ilicifolium

Polyscias sambucifolia subsp.

decomposita

Polyscias sambucifolia subsp.

sambucifolia

Pomax umbellata

Pteridium esculentum

Rhytidosporum procumbens

Rytidosperma fulvum

Tetratheca thymifolia

Xanthorrhoea concava

Poa sieberiana

\section{Threatened communities: Nil.}

Equivalent vegetation types: This community is equivalent to Community DSFp8 [Tableland Ridge Forest] identified by Tozer et al. (2010), with the addition of a small number of new plots from the Monga area and some minor reallocations of plots between this group and the closely related Community DSFp73. It includes a number of plots allocated by Gellie (2005) to Community VG59 [Eastern Tableland and Escarpment Shrub/Fern Dry Forest] and Community VG112 [Eastern Tablelands Dry Shrub Forest].

Frequently occurring weeds: Weeds are rare probably because the community occurs on soils of low fertility. The most commonly observed species were Hypochaeris radicata (0.1), Oxalis corniculata (0.03), Taraxacum officinale (0.03).

Threats: The steep, dissected, infertile habitat of this type is likely to have largely protected it from broadscale clearing. Parts of its range are within State Forest and private lands subject to logging and grazing. Weed invasion is not a significant threat.

Reservation status: Recorded from within Kanangra-Boyd NP, Blue Mountains NP, Mares Forest NP, Tallaganda NP and SCA, Monga NP and SCA, Budawang NP and Deua NP. Many other reserves have records of p8 immediately adjacent and are likely to contain areas of this type; these reserves include Tarlo River NP, Cookbundoon NR, Gourock NP and Wadbilliga NP.

Extent of clearing: Likely to be minor and scattered, largely restricted to slightly flatter or marginally more fertile examples and edges where this type adjoins habitats more suitable for agricultural development.

References: Gellie, N.J.H. (2005) Native vegetation of the southern forests: South Eastern Highlands, Australian Alps, South West Slopes and South East Corner bioregions. Cunninghamia 9: 219-254; Tozer, M.G., Turner, K., Keith, D.A., Tindall, D., Pennay, C., Simpson, C., MacKenzie, B., Beukers, P. \& Cox, S. (2010) Native vegetation of southeast NSW: a revised classification and map for the coast and eastern tablelands. Cunninghamia 11: 359-406. 


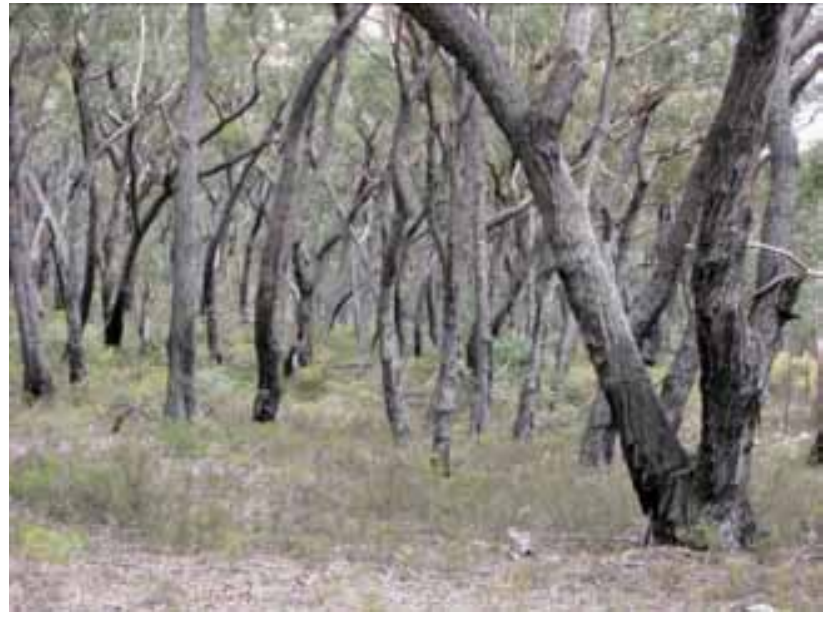

Plate p8: Community p8 with Eucalyptus sieberi and Eucalyptus radiata subsp. radiata over a diverse low shrub layer and sparse groundcover, Palerang Fire Trail, Tallaganda SCA.

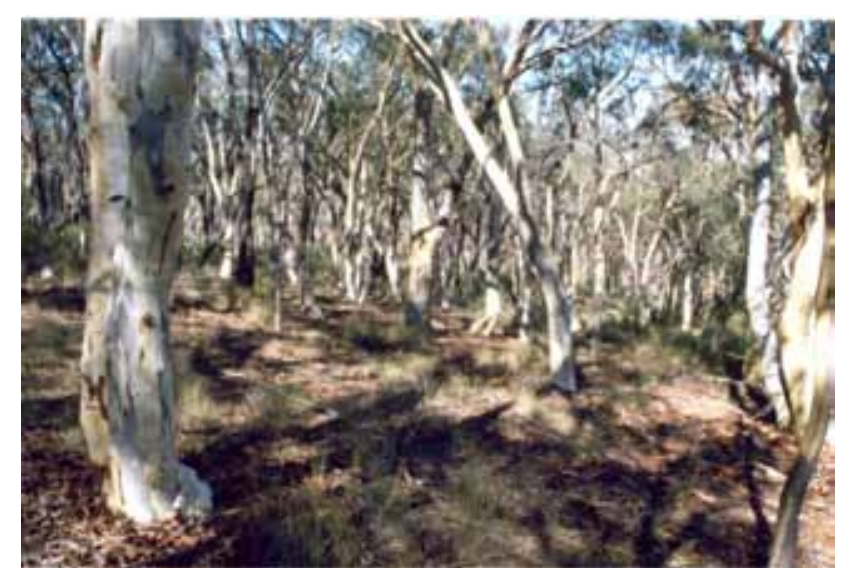

Plate p9: Community p9 with Eucalyptus rossii, Eucalyptus macrorhyncha and a sparse understorey dominated by Rytidosperma pallidum, on Governor's Hill above Goulburn (plot TOW005HQ).

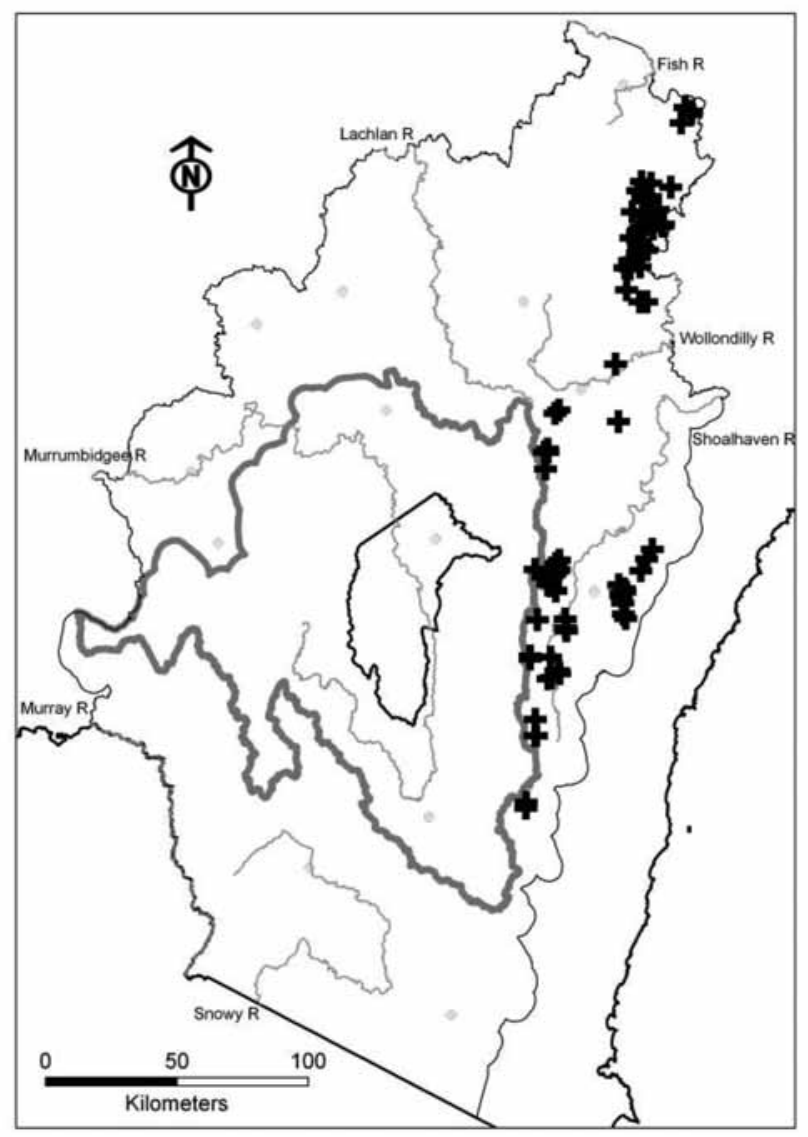

Fig. p8: Distribution of field samples assigned to this community.

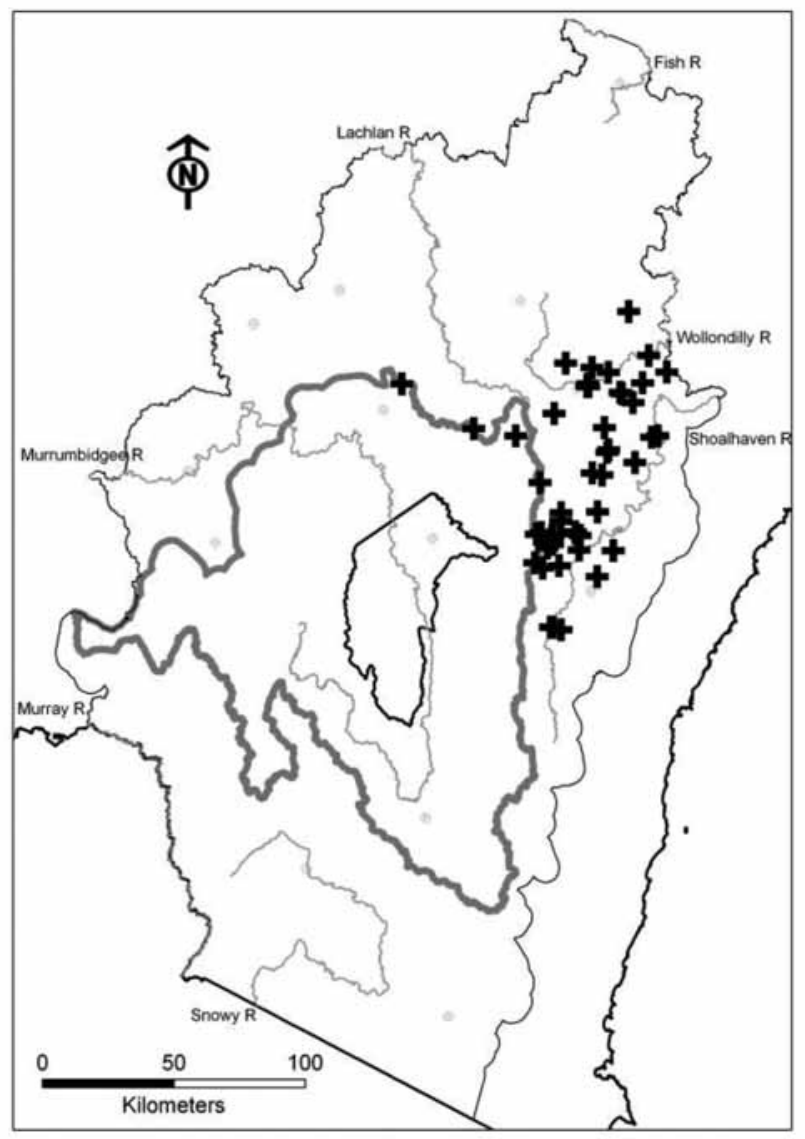

Fig. p9: Distribution of field samples assigned to this community. 


\section{p9: Brittle Gum - Scribbly Gum shrubby tall dry open forest on infertile low ridges and hills primar- ily of the Bungonia subregion of the South Eastern Highlands bioregion}

Scientific Name: Eucalyptus mannifera - Eucalyptus rossii / Allocasuarina littoralis / Melichrus urceolatus Brachyloma daphnoides - Hibbertia obtusifolia / Goodenia hederacea subsp. hederacea - Gonocarpus tetragynus Lomandra filiformis subsp. coriacea - Microlaena stipoides - Rytidosperma pallidum

Number of samples:

Richness [mean $( \pm \mathrm{SD})]$ :

Slope (degrees):

Altitude (m asl):

Ave. Annual Rainfall (mm):

51

$30(8)$

(0) 3-8 (20)

(560) 649-762 (918)

(669) 701-754 (893)

(24.7) 25.7-26.2 (26.6)

Vegetation Description: Community $\mathrm{p} 9$ is a tall, dry eucalypt woodland to open forest, with a tree canopy commonly dominated by Eucalyptus mannifera and/or Eucalyptus rossii, often associated with Eucalyptus dives and Eucalyptus macrorhyncha. A sparse to patchy small tree stratum of Allocasuarina littoralis is commonly present, above a sparse understorey of shrubs including Persoonia linearis, Acacia gunnii, Daviesia leptophylla and Kunzea ericoides. Groundlayer plants are generally sparse but reasonably diverse, including scattered low shrubs such as Brachyloma daphnoides, Dillwynia sericea, Hibbertia obtusifolia, Leucopogon virgatus, Lissanthe strigosa and Melichrus urceolatus, the grasses Aristida ramosa, Rytidosperma pallidum, Microlaena stipoides and Poa sieberiana and the forbs Dianella revoluta, Gonocarpus tetragynus, Goodenia hederacea subsp. hederacea, Lepidosperma gunnii, Lomandra filiformis subsp. coriacea, Lomandra multiflora, Opercularia diphylla, Hypericum gramineum and Lomandra longifolia.

This community occurs on soils of moderately low to low fertility, derived most commonly from sandstones, quartzites, conglomerates and shales of the Adaminaby, Mount Fairy and Lambie Groups, and in the Boro, Manar, Bungonia and Marulan areas, on acid volcanic and granitic substrates. This community extends from Big Hill west to Kingsdale, Yarra, Collector and Bellmount, south to Tarago, Butmaroo, Mulloon and Warri and east to Braidwood, Nadgigomar, Windellama, Bungonia, Marulan and Brayton. Within this range, p9 may grade into Community p10 [Black She-oak - Silvertop Ash tall shrubby dry sclerophyll open forest primarily in the Bungonia subregion of the South Eastern Highlands bioregion] on sheltered slopes and slightly deeper soils of hills and ridges, while on footslopes it may grade into Community p23 [Red Stringybark - Broad-leaved Peppermint tall dry sclerophyll grassy open forest on loamy rises primarily in the Bungonia subregion of the South Eastern Highlands bioregion]. To the west and north of its range it is replaced in similar habitats by the related Community p14 [Red Stringybark - Scribbly Gum - Rytidosperma pallidum tall grass-shrub dry sclerophyll open forest on loamy ridges of the central South Eastern Highlands bioregion].

\section{Characteristic Species:}

\section{Species}

Acacia gunnii

Allocasuarina littoralis

Aristida ramosa

Astroloma humifusum

Austrostipa mollis

Brachyloma daphnoides

Cheilanthes sieberi

Daviesia leptophylla
Dianella revoluta

Entolasia stricta

Eucalyptus macrorhyncha

Eucalyptus mannifera

Eucalyptus rossii

Gonocarpus tetragynus

Goodenia hederacea subsp. hederacea

Hibbertia obtusifolia

Hovea heterophylla

Kunzea ericoides

Laxmannia gracilis

Lepidosperma gunnii

Leucopogon virgatus

Lissanthe strigosa

Lomandra filiformis subsp. coriacea

Lomandra multiflora

Lomandra obliqua

Melichrus urceolatus

Microlaena stipoides

Opercularia diphylla

Patersonia sericea var. sericea

Persoonia linearis

Rhytidosporum procumbens

Rytidosperma pallidum

Rytidosperma spp.

Tricoryne elatior

Hypericum gramineum

Lomandra longifolia

Poa sieberiana
Dillwynia sericea

Eucalyptus dives

$\begin{array}{lllll}2 & 69 & 1 & 22 & \mathrm{P} \\ 1 & 29 & 1 & 4 & \mathrm{P} \\ 2 & 27 & 2 & 4 & \mathrm{P} \\ 3 & 52 & 3 & 18 & \mathrm{P} \\ 3 & 38 & 3 & 16 & \mathrm{P} \\ 3 & 65 & 3 & 10 & \mathrm{P} \\ 3 & 60 & 3 & 7 & \mathrm{P} \\ 2 & 85 & 2 & 47 & \mathrm{P} \\ 2 & 94 & 2 & 15 & \mathrm{P} \\ 2 & 63 & 1 & 34 & \mathrm{P} \\ 2 & 31 & 1 & 4 & \mathrm{P} \\ 2 & 25 & 2 & 4 & \mathrm{P} \\ 1 & 21 & 1 & <1 & \mathrm{P} \\ 2 & 50 & 1 & 4 & \mathrm{P} \\ 2 & 17 & 1 & 3 & \mathrm{P} \\ 2 & 29 & 1 & 7 & \mathrm{P} \\ 2 & 67 & 2 & 18 & \mathrm{P} \\ 2 & 58 & 1 & 18 & \mathrm{P} \\ 1 & 21 & 2 & 3 & \mathrm{P} \\ 1 & 71 & 1 & 12 & \mathrm{P} \\ 2 & 77 & 2 & 34 & \mathrm{P} \\ 2 & 38 & 2 & 3 & \mathrm{P} \\ 2 & 25 & 1 & 3 & \mathrm{P} \\ 1 & 52 & 1 & 10 & \mathrm{P} \\ 2 & 23 & 1 & 3 & \mathrm{P} \\ 3 & 54 & 2 & 17 & \mathrm{P} \\ 2 & 25 & 1 & 7 & \mathrm{P} \\ 2 & 21 & 1 & 4 & \mathrm{P} \\ 1 & 42 & 1 & 25 & \mathrm{C} \\ 2 & 42 & 2 & 42 & \mathrm{C} \\ 2 & 46 & 2 & 48 & \mathrm{C} \\ & & & & \end{array}$

Threatened communities: Nil.

Equivalent vegetation types: This community represents Community DSFp9 [Tableland Low Woodland] (Tozer et al. 2010) in the context of the upper Murrumbidgee catchment, based on an overlapping but different study area with additional field samples. There is no equivalent community in the classifications of Gellie (2005) as most of the plots in this group are recent samples from private land.

Frequently occurring weeds: Weed species are uncommon and their abundance is low in this community. The ubiquitous Hypochaeris radicata $(0.29)$ is the most frequently recorded species.

Threats: Frequent and high-intensity grazing, such as occurs in areas of rural-residential subdivision, threatens remnants of this community. Of particular concern is the disruption this causes to important ecological processes such as seed production and seedling establishment, which may ultimately lead to structural and compositional changes including local extinctions of sensitive plant species. Firewood collection is also likely to represent a threat to components of this community.

Reservation status: Recorded from Tarlo River NP, Belmount SCA, Nadgigomar NR and Scott NR.

Extent of clearing: This type has probably experienced widespread but relatively low clearing levels, with clearing likely to have affected lower hills and the lower edges of patches. Future clearing pressure on remaining examples is most likely in areas of rural-residential subdivision around larger towns.

References: Gellie, N.J.H. (2005) Native vegetation of the southern forests: South Eastern Highlands, Australian Alps, South West Slopes and South East Corner bioregions. Cunninghamia 9: 219-254; Tozer, M.G., Turner, K., Keith, D.A., Tindall, D., Pennay, C., Simpson, C., MacKenzie, B., Beukers, P. \& Cox, S. (2010) Native vegetation of southeast NSW: a revised classification and map for the coast and eastern tablelands. Cunninghamia 11: 359-406. 


\section{p10: Black She-oak - Silvertop Ash tall shrubby dry sclerophyll open forest primarily in the Bun- gonia subregion of the South Eastern Highlands bioregion}

Scientific Name: Allocasuarina littoralis - Eucalyptus sieberi - Eucalyptus agglomerata / Persoonia linearis - Hibbertia obtusifolia / Goodenia hederacea subsp. hederacea - Lomandra obliqua - Microlaena stipoides Pomax umbellata

Number of samples:

Richness [mean $( \pm \mathrm{SD})]$ :

Slope (degrees):

Altitude (m asl):

Ave. Annual Rainfall (mm):

$30(9)$

(0) $3-10(27)$

(589) 663-789 (919)

Temp. Annual Range $\left({ }^{\circ} \mathrm{C}\right)$ :

Vegetation Description: Community p10 is a dry tall open eucalypt forest with a canopy dominated by Eucalyptus sieberi and Eucalyptus agglomerata, usually with a sparse to dense small tree layer of Allocasuarina littoralis and scattered shrubs, including Acacia terminalis and Persoonia linearis. The groundlayer tends to be dominated by leaf litter, with a sparse scatter of grasses, sedges, forbs and low shrubs including Billardiera scandens, Entolasia stricta, Goodenia hederacea subsp. hederacea, Hibbertia obtusifolia, Lepidosperma gunnii, Lomandra multiflora, Lomandra obliqua, Microlaena stipoides and Pomax umbellata.

This community occurs on dry ridges and slopes, on soils of moderately low fertility derived predominantly from sedimentary and metasedimentary rocks of the Adaminaby, Lambie and Shoalhaven Groups and the Towrang and Gundary Beds, which are predominantly shales, sandstones, quartzites and conglomerates. It occurs from Greenwich Park and Chatsbury in the north, south to Larbert and Durran Durra, west to Collector and east beyond the study area boundary. While not sampled in the ACT, similar vegetation observed around Gibraltar Hill may be a western outlier or represent a variant of this community.

This community is often associated with other dry ridge forests across its range. It commonly occupies lower ridges and slopes of tableland hills, and may grade into Community p8 [Silvertop Ash - Narrowleaved Peppermint shrubby tall dry open forest] on high stony tableland ridges, while on lower slopes it is often replaced by Community $\mathrm{p} 9$ [Brittle Gum - Scribbly Gum shrubby tall dry open forest].

\section{Characteristic Species:}

\section{Species}

Acacia obtusifolia

Acacia terminalis

Allocasuarina littoralis

Banksia spinulosa var. spinulosa

Billardiera scandens

Brachyloma daphnoides

Caustis flexuosa

Daviesia leptophylla

Dianella revoluta

Entolasia stricta

Eucalyptus agglomerata

Eucalyptus globoidea

Eucalyptus rossii

Eucalyptus sieberi

Goodenia hederacea subsp. hederacea

Hakea dactyloides

Helichrysum leucopsideum

Hibbertia empetrifolia

Hibbertia obtusifolia

\section{C/A Freq C/A OFreqO Fid}

$\begin{array}{lllll}2 & 15 & 2 & 1 & \mathrm{P} \\ 1 & 53 & 2 & 3 & \mathrm{P} \\ 3 & 83 & 2 & 3 & \mathrm{P} \\ 2 & 17 & 2 & 2 & \mathrm{P} \\ 1 & 53 & 1 & 9 & \mathrm{P} \\ 1 & 34 & 1 & 16 & \mathrm{P} \\ 1 & 13 & 2 & <1 & \mathrm{P} \\ 2 & 26 & 1 & 5 & \mathrm{P} \\ 1 & 43 & 1 & 22 & \mathrm{P} \\ 2 & 53 & 1 & 3 & \mathrm{P} \\ 3 & 64 & 3 & 2 & \mathrm{P} \\ 3 & 25 & 3 & 2 & \mathrm{P} \\ 3 & 21 & 3 & 7 & \mathrm{P} \\ 3 & 83 & 3 & 7 & \mathrm{P} \\ 2 & 98 & 2 & 16 & \mathrm{P} \\ 2 & 23 & 2 & 3 & \mathrm{P} \\ 2 & 19 & 1 & <1 & \mathrm{P} \\ 2 & 17 & 2 & <1 & \mathrm{P} \\ 1 & 77 & 1 & 34 & \mathrm{P}\end{array}$

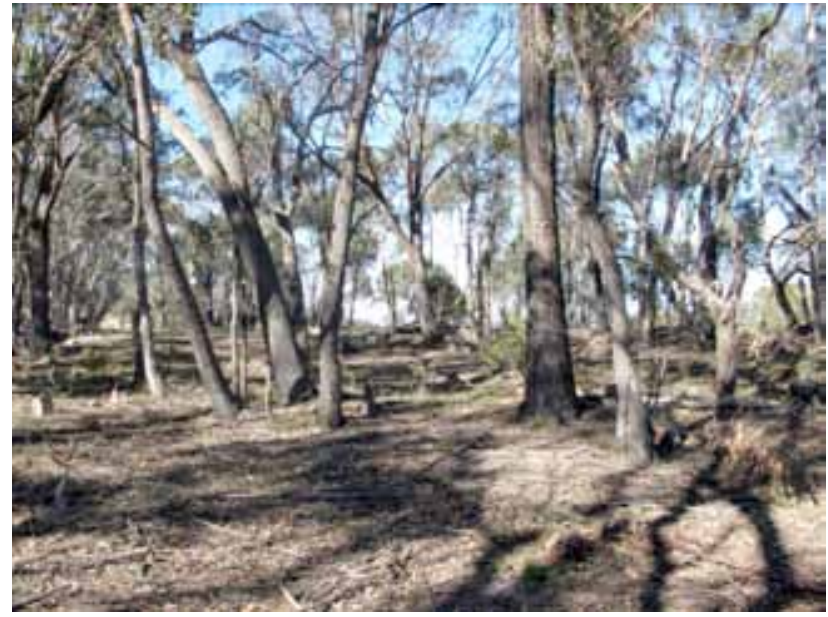

Plate p10: An example of Community p10 near Tiyces Lane, Towrang, with a canopy dominated by Eucalyptus sieberi, a very sparse understorey and groundcover dominated by leaf litter.

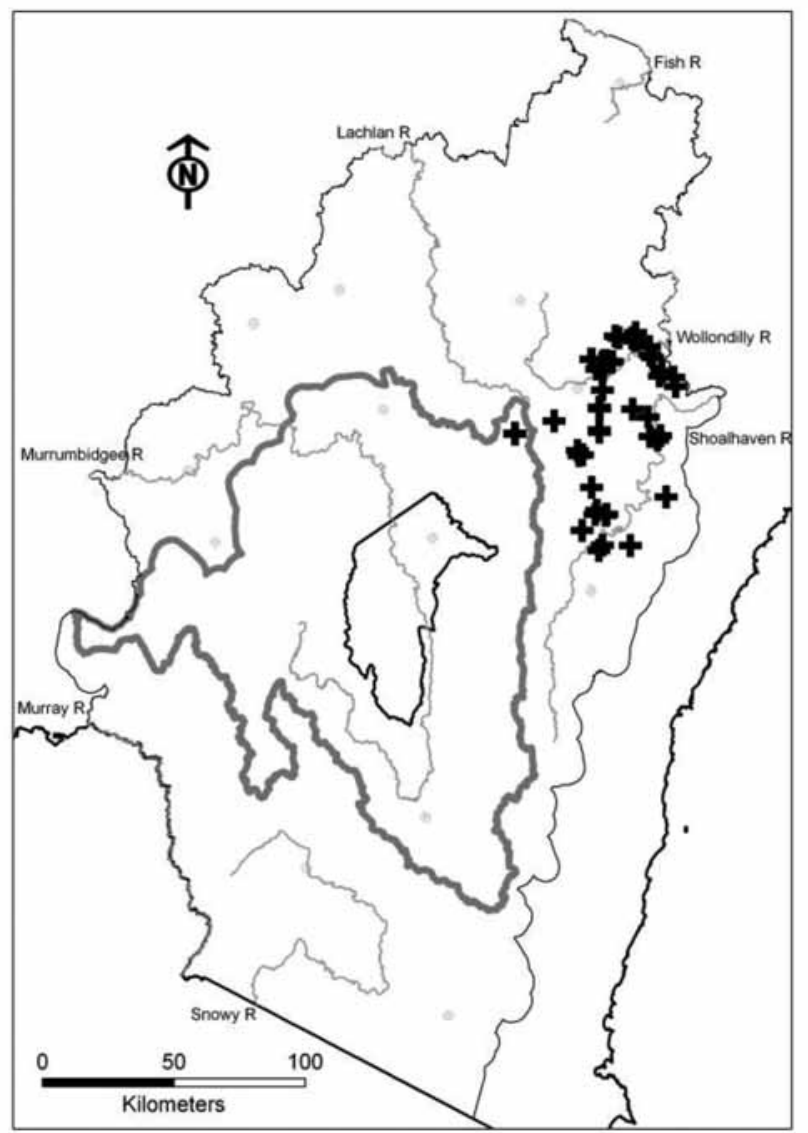

Fig. p10: Distribution of field samples assigned to this community. 
Lepidosperma gunnii

Lomandra glauca

Lomandra multiflora

Lomandra obliqua

Lomatia ilicifolia

Melichrus urceolatus

Microlaena stipoides

Monotoca scoparia

Opercularia aspera

Opercularia diphylla

Patersonia glabrata

Patersonia sericea var. longifolia

Patersonia sericea var. sericea

Persoonia linearis

Persoonia mollis subsp. livens

Platysace ericoides

Platysace lanceolata

Podolobium ilicifolium

Pomax umbellata

Rhytidosporum procumbens

Rytidosperma pallidum

Stypandra glauca

Xanthorrhoea concava

Gonocarpus tetragynus Lepidosperma urophorum

\begin{tabular}{|c|c|c|}
\hline 55 & 1 & 4 \\
\hline 15 & 2 & 1 \\
\hline 23 & 2 & 4 \\
\hline 51 & 1 & 18 \\
\hline 70 & 2 & 2 \\
\hline 30 & 1 & 3 \\
\hline 43 & 1 & 13 \\
\hline 57 & 2 & 34 \\
\hline 32 & 1 & 15 \\
\hline 19 & 1 & 3 \\
\hline 21 & 2 & 3 \\
\hline 28 & 2 & 1 \\
\hline 23 & 2 & $<1$ \\
\hline 38 & 2 & 3 \\
\hline 92 & 1 & 9 \\
\hline 13 & 1 & 1 \\
\hline 30 & 2 & $<1$ \\
\hline 25 & 2 & 5 \\
\hline 26 & 2 & 3 \\
\hline 66 & 2 & 4 \\
\hline 49 & 1 & 2 \\
\hline 40 & 2 & 17 \\
\hline 49 & 2 & 5 \\
\hline 30 & 2 & $<1$ \\
\hline 45 & 2 & 48 \\
\hline
\end{tabular}

Threatened communities: Nil.

Equivalent vegetation types: Community p10 represents a slight westward extension of Community DSFp10 [Eastern Tablelands Dry Forest $]$ identified by Tozer et al. (2010), with the addition of new plots from Collector and recently acquired reserves around Goulburn. This community extends beyond the current study area's eastern boundary. It has floristic affinities with VG15 [North East Tableland Dry Shrub Forest] of Gellie (2005).

Frequently occurring weeds: Because this community occurs on poor soils, weeds are infrequent. The ubiquitous Hypochaeris glabra (0.09) is the most frequently recorded weed species in this community.

Threats: This community is commonly found as remnant patches of woody vegetation on poor soils on hills and ridges in rural landscapes where communities of better soils have been cleared. Some of its original extent is likely to have been cleared, and most remnants on private land are likely to be subject to ongoing light grazing. Where this community occurs on public land, frequent hazard reduction burning has the potential to eliminate important structural elements, such as the Allocasuarina littoralis dominated midstorey.

Reservation status: This community is known to occur in Tarlo River NP, Cookbundoon NR, Pomaderris NR, Bungonia SCA, Morton NP (western edge) and Nadgigomar NR.

Extent of clearing: This community is only likely to have undergone minor clearing across its range, predominantly at the edges of patches where it adjoins areas of slightly deeper and/or more fertile soils.

References: Gellie, N.J.H. (2005) Native vegetation of the southern forests: South Eastern Highlands, Australian Alps, South West Slopes and South East Corner bioregions. Cunninghamia 9: 219-254; Tozer, M.G., Turner, K., Keith, D.A., Tindall, D., Pennay, C., Simpson, C., MacKenzie, B., Beukers, P. \& Cox, S. (2010) Native vegetation of southeast NSW: a revised classification and map for the coast and eastern tablelands. Cunninghamia 11: 359-406.

\section{p14: Red Stringybark - Scribbly Gum - Ryti- dosperma pallidum tall grass-shrub dry sclerophyll open forest on loamy ridges of the central South Eastern Highlands bioregion}

Scientific Name: Eucalyptus macrorhyncha - Eucalyptus rossii \pm Eucalyptus mannifera / Hibbertia obtusifolia - Brachyloma daphnoides - Daviesia leptophylla / Rytidosperma pallidum - Gonocarpus tetragynus - Poa sieberiana

Number of samples:

Richness [mean $( \pm \mathrm{SD})]$ :

Slope (degrees):

Altitude (m asl):

Ave. Annual Rainfall (mm):

Temp. Annual Range $\left({ }^{\circ} \mathrm{C}\right)$ :

165

$27(8)$

(0) 5-16 (51)

(504) 703-856 (1157)

(603) 712-790 (918)

(24.1) $25.8-26.6(28.1)$

Vegetation Description: Community p14 is a tall open eucalypt forest dominated by Eucalyptus macrorhyncha and Eucalyptus rossii, often with Eucalyptus mannifera, Eucalyptus goniocalyx, Eucalyptus dives or Eucalyptus polyanthemos. The shrub layer is patchy and generally includes Hibbertia obtusifolia, Brachyloma daphnoides, Daviesia leptophylla, Acacia gunnii and Hovea linearis and occasionally Melichrus urceolatus, Monotoca scoparia, Persoonia rigida and Gompholobium huegellii. The climbing or prostrate subshrub Hardenbergia violacea is often present. The groundlayer is also generally patchy and dominated by grasses such as Rytidosperma pallidum and Poa sieberiana and a variety of forbs including Lomandra filiformis subsp. coriacea, Dianella revoluta, Lomandra multiflora, Gonocarpus tetragynus and Goodenia hederacea subsp. hederacea.

This community is widely distributed, occurring within the Murrumbidgee catchment mostly in areas north of the Wee Jasper and Captains Flat areas to Oberon in the Central West catchment. It grades into communities such as Community m51 [Brittle Gum - Scribbly Gum shrub-grass tall dry sclerophyll open forest on exposed quartz-rich slopes and ridges at primarily in the Monaro and Kybeyan - Gourock subregions of the South Eastern Highlands] south of Queanbeyan, as well as Community p23 [Red Stringybark - Broad-leaved Peppermint tall dry sclerophyll grassy open forest on loamy rises primarily in the Bungonia subregion of the South Eastern Highlands bioregion] and Community p24 [Yellow Box - Blakely's Red Gum tall grassy woodland on undulating sedimentary and acid-volcanic substrates in the Goulburn area of the South Eastern Highlands bioregion] on more gently undulating sites with loamy soils.

\section{Characteristic Species:}

Species

C/A Freq C/A OFreqO Fid

Acacia buxifolia

Acacia decurrens

Acacia falciformis

Acacia genistifolia

Acacia gunnii

Acacia lanigera

Astrotricha ledifolia

Brachyloma daphnoides

Caladenia carnea

Cassinia arcuata

Cheiranthera linearis

Comesperma ericinum

Daviesia leptophylla

Dianella revoluta

Dillwynia phylicoides

Dillwynia sericea

Dillwynia sieberi

$\begin{array}{lllll}1 & 8 & 1 & 1 & \mathrm{P}\end{array}$

$\begin{array}{lllll}1 & 6 & 2 & 1 & \mathrm{P}\end{array}$

$\begin{array}{lllll}1 & 15 & 2 & 7 & \mathrm{P}\end{array}$

$\begin{array}{lllll}2 & 11 & 1 & 1 & \mathrm{P}\end{array}$

$\begin{array}{lllll}1 & 44 & 1 & 4 & \mathrm{P}\end{array}$

$\begin{array}{lllll}1 & 4 & 0 & 0 & \mathrm{P}\end{array}$

$\begin{array}{lllll}1 & 4 & 1 & <1 & \mathrm{P}\end{array}$

$\begin{array}{lllll}2 & 62 & 1 & 14 & \mathrm{P}\end{array}$

$\begin{array}{lllll}1 & 4 & 1 & 1 & \mathrm{P}\end{array}$

$\begin{array}{lllll}1 & 8 & 2 & 1 & \mathrm{P}\end{array}$

$\begin{array}{lllll}1 & 13 & 1 & <1 & \mathrm{P}\end{array}$

$\begin{array}{lllll}2 & 3 & 1 & <1 & \mathrm{P}\end{array}$

$\begin{array}{lllll}2 & 51 & 1 & 3 & \mathrm{P}\end{array}$

$\begin{array}{lllll}1 & 63 & 1 & 20 & \mathrm{P}\end{array}$

$\begin{array}{lllll}2 & 16 & 2 & 1 & \mathrm{P}\end{array}$

$\begin{array}{lllll}1 & 26 & 1 & 3 & \mathrm{P}\end{array}$

$\begin{array}{lllll}1 & 26 & 1 & 3 & \mathrm{P} \\ 1 & 4 & 1 & <1 & \mathrm{P}\end{array}$ 
Dillwynia spp.

Drosera auriculata

Eucalyptus dives

Eucalyptus goniocalyx

Eucalyptus macrorhyncha

Eucalyptus mannifera

Eucalyptus polyanthemos

Eucalyptus praecox

Eucalyptus rossii

Genoplesium spp.

Glossodia major

Gompholobium huegelii

Gompholobium minus

Gonocarpus tetragynus

Goodenia bellidifolia

Goodenia hederacea subsp. hederacea

Hakea decurrens subsp. decurrens

Hardenbergia violacea

Hibbertia calycina

Hibbertia obtusifolia

Hibbertia riparia

Hibbertia spp.

Hovea heterophylla

Hovea linearis

Leptospermum multicaule

Leucopogon virgatus

Lomandra filiformis subsp. coriacea

Lomandra multiflora

Melichrus urceolatus

Monotoca scoparia

Olearia microphylla

Patersonia sericea var. sericea

Persoonia rigida

Phyllanthus hirtellus

Poa sieberiana

Pomax umbellata

Pterostylis spp.

Pultenaea microphylla

Pultenaea procumbens

Pultenaea subspicata

Rhytidosporum procumbens

Rytidosperma fulvum

Rytidosperma pallidum

Senecio tenuiflorus

Stypandra glauca

Styphelia triflora

Tetratheca spp.

Thelymitra spp.

Thysanotus patersonii

Wahlenbergia gracilis
Diuris sulphurea

\begin{tabular}{|c|c|c|c|}
\hline 2 & 4 & 1 & $<1$ \\
\hline 1 & 5 & 1 & 1 \\
\hline 1 & 8 & 1 & 2 \\
\hline 3 & 30 & 3 & 18 \\
\hline 2 & 34 & 3 & 2 \\
\hline 3 & 86 & 3 & 12 \\
\hline 3 & 51 & 2 & 9 \\
\hline 3 & 22 & 3 & 2 \\
\hline 3 & 2 & 0 & 0 \\
\hline 3 & 66 & 3 & 4 \\
\hline 1 & 4 & 1 & $<1$ \\
\hline 1 & 3 & 1 & $<1$ \\
\hline 1 & 20 & 1 & 4 \\
\hline 1 & 5 & 1 & 1 \\
\hline 2 & 84 & 2 & 46 \\
\hline 2 & 8 & 2 & 1 \\
\hline 2 & 67 & 2 & 15 \\
\hline 2 & 2 & 1 & $<1$ \\
\hline 1 & 34 & 1 & 13 \\
\hline 1 & 6 & 2 & $<1$ \\
\hline 1 & 89 & 1 & 32 \\
\hline 1 & 11 & 1 & $<1$ \\
\hline 1 & 4 & 1 & $<1$ \\
\hline 2 & 13 & 1 & 4 \\
\hline 1 & 40 & 1 & 12 \\
\hline 2 & 5 & 2 & $<1$ \\
\hline 1 & 15 & 1 & 3 \\
\hline 2 & 61 & 2 & 17 \\
\hline 1 & 45 & 1 & 17 \\
\hline 1 & 37 & 1 & 12 \\
\hline 1 & 31 & 1 & 14 \\
\hline 1 & 4 & 2 & $<1$ \\
\hline 1 & 9 & 2 & 3 \\
\hline 1 & 21 & 1 & 2 \\
\hline 1 & 8 & 1 & 1 \\
\hline 2 & 73 & 2 & 47 \\
\hline 1 & 12 & 2 & 5 \\
\hline 1 & 19 & 1 & 5 \\
\hline 2 & 11 & 1 & $<1$ \\
\hline 1 & 11 & 1 & 4 \\
\hline 1 & 7 & 2 & 2 \\
\hline 1 & 14 & 1 & 3 \\
\hline 3 & 8 & 2 & 1 \\
\hline 3 & 74 & 2 & 15 \\
\hline 2 & 7 & 1 & 2 \\
\hline 1 & 17 & 2 & 5 \\
\hline 1 & 8 & 1 & $<1$ \\
\hline 1 & 2 & 1 & $<1$ \\
\hline 1 & 11 & 1 & 2 \\
\hline 1 & 5 & 1 & $<1$ \\
\hline 2 & 12 & 1 & 6 \\
\hline
\end{tabular}

\section{Threatened communities: Nil.}

Equivalent vegetation types: This community represents Community DSF p14 [Western Tablelands Dry Forest] as described by Tozer et al. (2010), with a western range extension into the upper Murrumbidgee catchment. The relationship between Community p14 and communities identified by Benson et al. (2010) with similar structural dominants outside the upper Murrumbidgee catchment (such as VCA 290, VCA 349 and VCA 351) requires resolution through further sampling and analysis.

Frequently occurring weeds: As with other communities occurring on soils of low fertility, weeds are an uncommon component of this community. Hypochaeris glabra (0.14), Hypochaeris radicata (0.29) are the most frequently recorded weeds, which is not surprising given the dispersive nature and colonising potential of these species.

Threats: This community is generally found on undulating terrain, and in close proximity to intensively managed farmland. As a consequence, moderate areas have been cleared and used for grazing. Where intensive

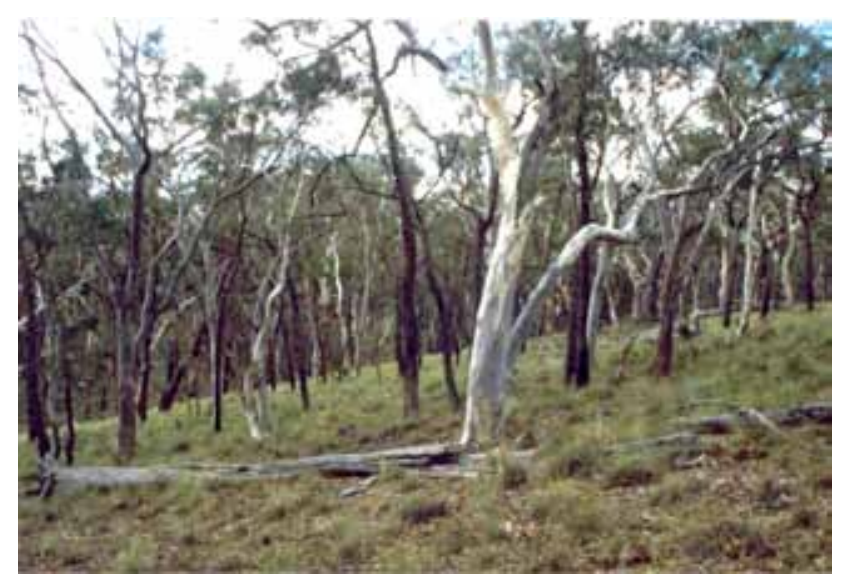

Plate p14: Community p14 with Eucalyptus macrorhyncha, Eucalyptus mannifera, Eucalyptus rossii and groundcover dominated by Rhytidosperma pallidum, above Soldiers Gully near Burra Burra Creek (plot RIC002LQ).

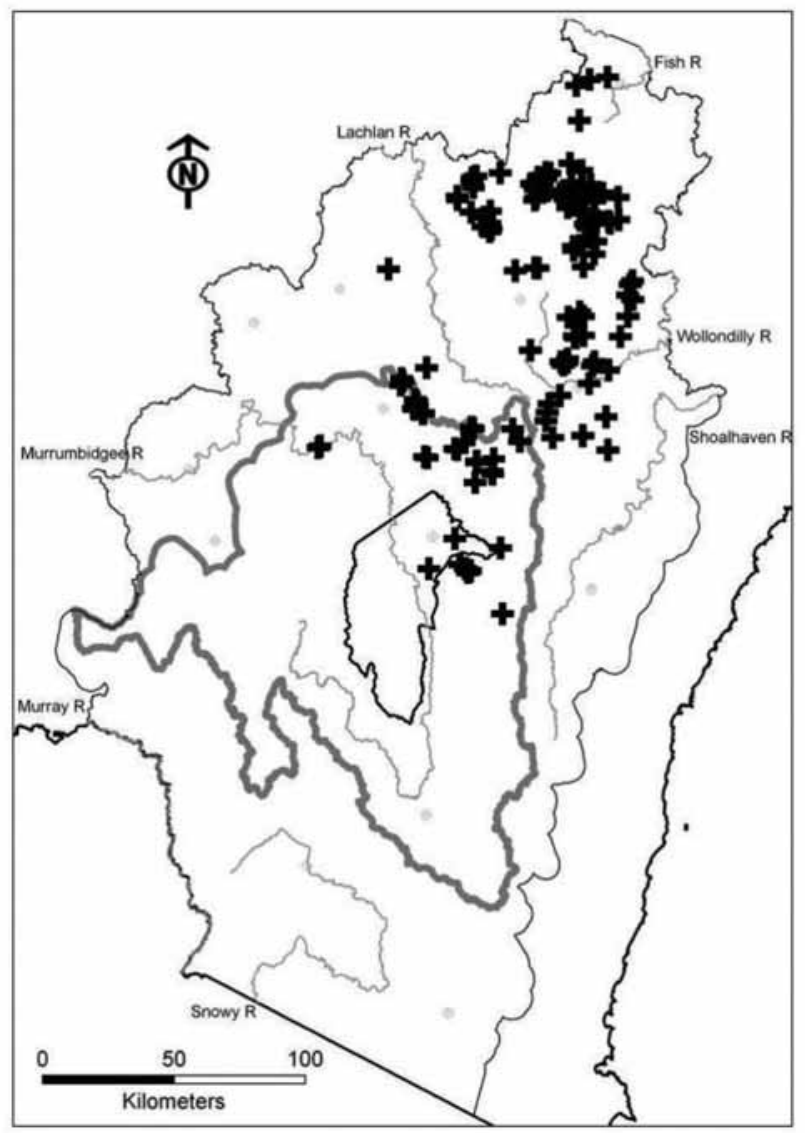

Fig. p14: Distribution of field samples assigned to this community. 
grazing occurs, this has the potential to compromise community structure and species richness. On private property the collection of fallen timber for firewood is likely to be a threat to populations of ground-dwelling fauna.

Reservation status: Considered to be moderately well reserved. Examples of this community are found in Abercrombie River NP, Back Arm NR, Bango NR, Belmount SCA, Gillindich NR, Keverstone NP, McLeods Creek NR, Morton NP, Mundoonen NR, Razorback NR, Tarlo River NP, Wee Jasper NR and Yanununbeyan NP.

Extent of clearing: Although this community generally occurs on nutrient deficient lithosols on low undulating hills, it is moderately cleared due to its broad extent and occurrence on gentle slopes.

References: Benson, J.S., Richards, P.G., Waller, S. \& Allen, C.B. (2010) New South Wales vegetation classification and assessment: Part 3. Plant communities of the NSW Brigalow Belt South, Nandewar and west New England bioregions and update of NSW Western Plains and South Western Slopes plant communities. Version 3 of the NSW VCA database. Cunninghamia 11: 457-579. Botanic Gardens Trust, Sydney; Tozer, M.G., Turner, K., Keith, D.A., Tindall, D., Pennay, C., Simpson, C., MacKenzie, B., Beukers, P. \& Cox, S. (2010) Native vegetation of southeast NSW: a revised classification and map for the coast and eastern tablelands. Cunninghamia 11: 359-406.

\section{p23: Red Stringybark - Broad-leaved Peppermint tall dry sclerophyll grassy open forest on loamy rises primarily in the Bungonia subregion of the South Eastern Highlands bioregion}

Scientific Name: Eucalyptus macrorhyncha - Eucalyptus dives / Melichrus urceolatus - Hibbertia obtusifolia Hardenbergia violacea / Microlaena stipoides - Lomandra filiformis subsp. coriacea - Hydrocotyle laxiflora Gonocarpus tetragynus - Themeda australis - Poa sieberiana
Number of samples:

Richness [mean $( \pm \mathrm{SD})]$ :

Slope (degrees):

Altitude (m asl):

Ave. Annual Rainfall (mm):

Temp. Annual Range $\left({ }^{\circ} \mathrm{C}\right)$ :

$$
\begin{aligned}
& 86 \\
& 36 \text { (9) } \\
& \text { (0) } 3-11(37) \\
& (531) 661-856(1118) \\
& (664) 700-790(940) \\
& \text { (24) } 25.5-26.3(28.3)
\end{aligned}
$$

Vegetation Description: Community p23 is a tall open forest or woodland most commonly dominated by Eucalyptus macrorhyncha and Eucalyptus dives, often with a mix of other eucalypts including Eucalyptus bridgesiana, Eucalyptus mannifera and Eucalyptus melliodora. Taller shrubs are frequently absent, but some plots have a sparse small tree layer of acacias and a sparse to patchy shrub stratum. The groundlayer is commonly moderate to dense, with the most frequent taxa being Lomandra filiformis subsp. coriacea and a mix of grasses (e.g. Microlaena stipoides, Themeda australis, Poa sieberiana), low shrubs (Hibbertia obtusifolia, Melichrus urceolatus), and forbs (Gonocarpus tetragynus, Goodenia hederacea subsp. hederacea, Hydrocotyle laxiflora, Hypericum gramineum and Oxalis perennans).

This community occupies gently undulating to hilly country in the northeastern Southern Tablelands, and is recorded from an area bounded by Tuena, Arkstone and Paling Yards in the north; Crooked Corner, Lost River, Bannister, Parkesbourne, Collector and Tarago in the southwest; and Larbert, Braidwood and Tomboye in the southeast. It extends to the east beyond the current study area boundary on similar undulating tableland country. Plots assigned to this type are commonly on sandy soils of intermediate depth and moderately low to low fertility derived from substrates including Adaminaby and Lambie Group sedimentary rocks and various granitic and acid volcanic rocks.

The floristic composition of Community p23 is intermediate between vegetation of drier hills with shallow soil, and vegetation of gentle slopes and flats with deeper soils and better groundwater availability. On gentler slopes and flats this type may grade into p24 [Yellow Box - Blakely's Red Gum tall grassy woodland on undulating sedimentary and acid-volcanic substrates in the Goulburn area of the South Eastern Highlands bioregion], while on steeper slopes with shallower soils it is generally replaced by dry sclerophyll forest types such as p9 [Brittle Gum - Scribbly Gum shrubby tall dry open forest on infertile low ridges and hills primarily of the Bungonia subregion of the South Eastern Highlands bioregion] or p14 [Red Stringybark - Scribbly Gum - Rytidosperma pallidum tall grass-shrub dry sclerophyll open forest on loamy ridges of the central South Eastern Highlands bioregion]. The majority of plots allocated to this community are from private land subject to regular stock grazing, fencepost cutting and other disturbances, which may help to explain the highly variable shrub and canopy composition of this type.

\section{Characteristic Species:}

Species

C/A Freq C/A OFreqO Fid

Acacia decurrens

Acacia genistifolia

Acaena echinata

Aristida jerichoensis var. jerichoensis 2

Aristida ramosa

Astroloma humifusum

Austrostipa densiflora

Austrostipa mollis

Austrostipa rudis

Austrostipa scabra

Bossiaea buxifolia

Bossiaea prostrata

Cassinia arcuata

Cassinia laevis

Cheilanthes sieberi

Chrysocephalum apiculatum

Cymbonotus lawsonianus

Daviesia latifolia

Dianella longifolia

Dichelachne micrantha

Dillwynia sericea

Echinopogon caespitosus

Einadia nutans

Elymus scaber

Eucalyptus blakelyi

Eucalyptus bridgesiana

Eucalyptus cinerea

Eucalyptus dives

Eucalyptus macrorhyncha

Eucalyptus mannifera

Eucalyptus melliodora

Galium gaudichaudii

Geranium solanderi

Glycine microphylla

Gonocarpus tetragynus

Goodenia hederacea subsp.

hederacea

Hardenbergia violacea

Hibbertia obtusifolia

Hovea heterophylla

Hydrocotyle laxiflora

Hypericum gramineum

Indigofera australis

Juncus filicaulis

Juncus subsecundus

Lagenophora gracilis

Laxmannia gracilis

Lissanthe strigosa

Lomandra filiformis subsp. coriacea 2

Lomandra multiflora

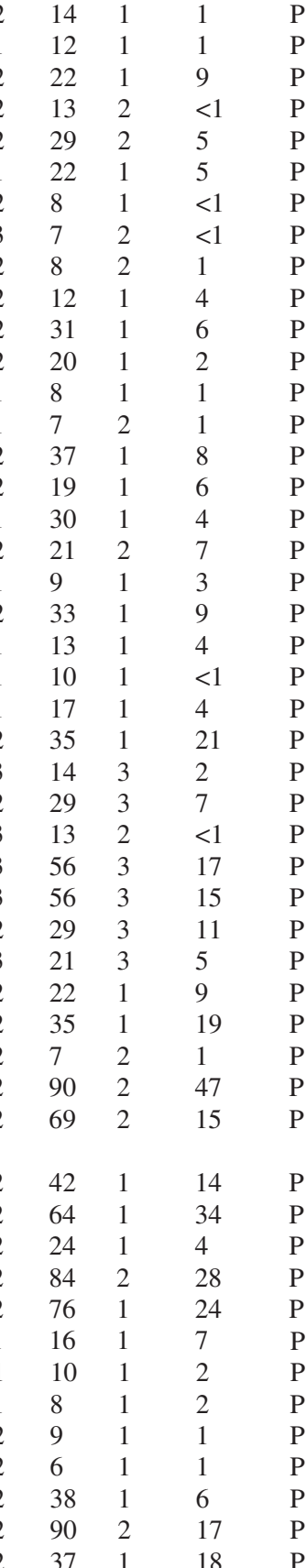


Luzula densiflora Melichrus urceolatus

Microlaena stipoides

Opercularia diphylla

Oxalis perennans

Ozothamnus diosmifolius

Panicum effusum

Pimelea curviflora

Plantago gaudichaudii

Pultenaea microphylla

Rytidosperma laeve

Rytidosperma monticola

Rytidosperma racemosum

Rytidosperma tenuius

Solenogyne dominii

Solenogyne gunnii

Thelymitra spp.

Themeda australis

Thysanotus patersonii

Tricoryne elatior

Veronica plebeia

Wahlenbergia gracilis

Poa sieberiana
Opercularia aspera

Opercularia hispida

Pterostylis spp.

$\begin{array}{lllll}1 & 22 & 1 & 5 & \mathrm{P} \\ 2 & 60 & 1 & 12 & \mathrm{P} \\ 2 & 93 & 2 & 33 & \mathrm{P} \\ 2 & 16 & 1 & 3 & \mathrm{P} \\ 2 & 23 & 2 & 3 & \mathrm{P} \\ 2 & 12 & 1 & 2 & \mathrm{P} \\ 2 & 70 & 1 & 12 & \mathrm{P} \\ 1 & 7 & 1 & <1 & \mathrm{P} \\ 1 & 10 & 1 & 3 & \mathrm{P} \\ 2 & 29 & 1 & 6 & \mathrm{P} \\ 2 & 12 & 1 & 1 & \mathrm{P} \\ 1 & 19 & 1 & 6 & \mathrm{P} \\ 2 & 9 & 1 & 1 & \mathrm{P} \\ 2 & 23 & 2 & 3 & \mathrm{P} \\ 2 & 6 & 2 & 1 & \mathrm{P} \\ 2 & 44 & 2 & 10 & \mathrm{P} \\ 2 & 10 & 2 & <1 & \mathrm{P} \\ 1 & 13 & 1 & 3 & \mathrm{P} \\ 2 & 13 & 1 & 5 & \mathrm{P} \\ 1 & 10 & 1 & 2 & \mathrm{P} \\ 2 & 62 & 2 & 20 & \mathrm{P} \\ 2 & 10 & 1 & <1 & \mathrm{P} \\ 2 & 29 & 1 & 3 & \mathrm{P} \\ 2 & 34 & 1 & 5 & \mathrm{P} \\ 1 & 19 & 1 & 6 & \mathrm{P} \\ 2 & 57 & 2 & 48 & \mathrm{C}\end{array}$

Threatened communities: Components of this community may be considered part of TSC Act 1995 - White Box Yellow Box Blakely's Red Gum Woodland and EPBC Act 1999 - White Box Yellow Box Blakely's Red Gum Grassy Woodland and Derived Native Grassland.

Equivalent vegetation types: This community represents Community GWp23 [Tableland Hills Grassy Woodland] (Tozer et al. 2010) in the context of this study, based on an overlapping but different study area with additional field samples from the tablelands and slopes.

Frequently occurring weeds: The weeds Acetosella vulgaris $(0.35)$ and Hypochaeris radicata $(0.61)$ are relatively common in this community, reflecting its proximity to land managed for grazing.

Threats: Frequent and high-intensity grazing, such as occurs in areas of rural-residential subdivision, threatens remnants of this community. Of particular concern is the disruption this causes to important ecological processes such as seed production and seedling establishment, which may ultimately lead to structural and compositional changes including local extinctions of sensitive plant species. Firewood collection is also likely to represent a threat to components of this community.

Reservation status: The distribution of this community generally corresponds with freehold land and this community is not well represented in the conservation reserve system. Small areas are present in the newer reserves of Gillindich NR, Mares Forest NP and Oakdale NR and immediately adjacent to Abercrombie River NP and Bungonia NP, none of which occur within the upper Murrumbidgee catchment.

Extent of clearing: This community has probably experienced widespread though only moderate levels of clearing, because it tends to occupy habitats of intermediate utility for agricultural development. Clearing is likely to have disproportionately affected examples on better soils, but also along the edges of patches on poorer soils. Future clearing pressure on remaining examples is most likely in areas of ruralresidential subdivision around larger towns.

Reference: Tozer, M.G., Turner, K., Keith, D.A., Tindall, D., Pennay, C., Simpson, C., MacKenzie, B., Beukers, P. \& Cox, S. (2010) Native vegetation of southeast NSW: a revised classification and map for the coast and eastern tablelands. Cunninghamia 11: 359-406.

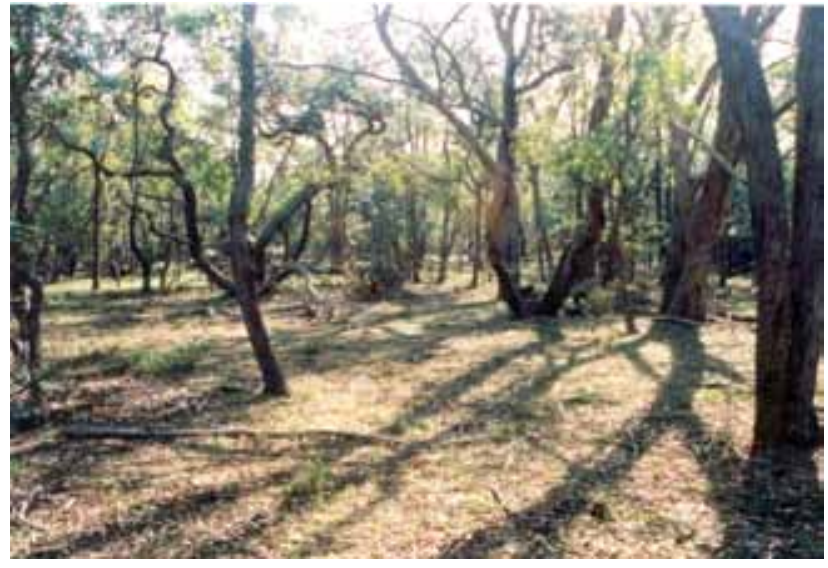

Plate p23: Community p23 on "Arthursleigh", west of Canyonleigh, with Eucalyptus dives, Eucalyptus macrorhyncha and a grazed grassy groundcover (plot CAN039LQ).

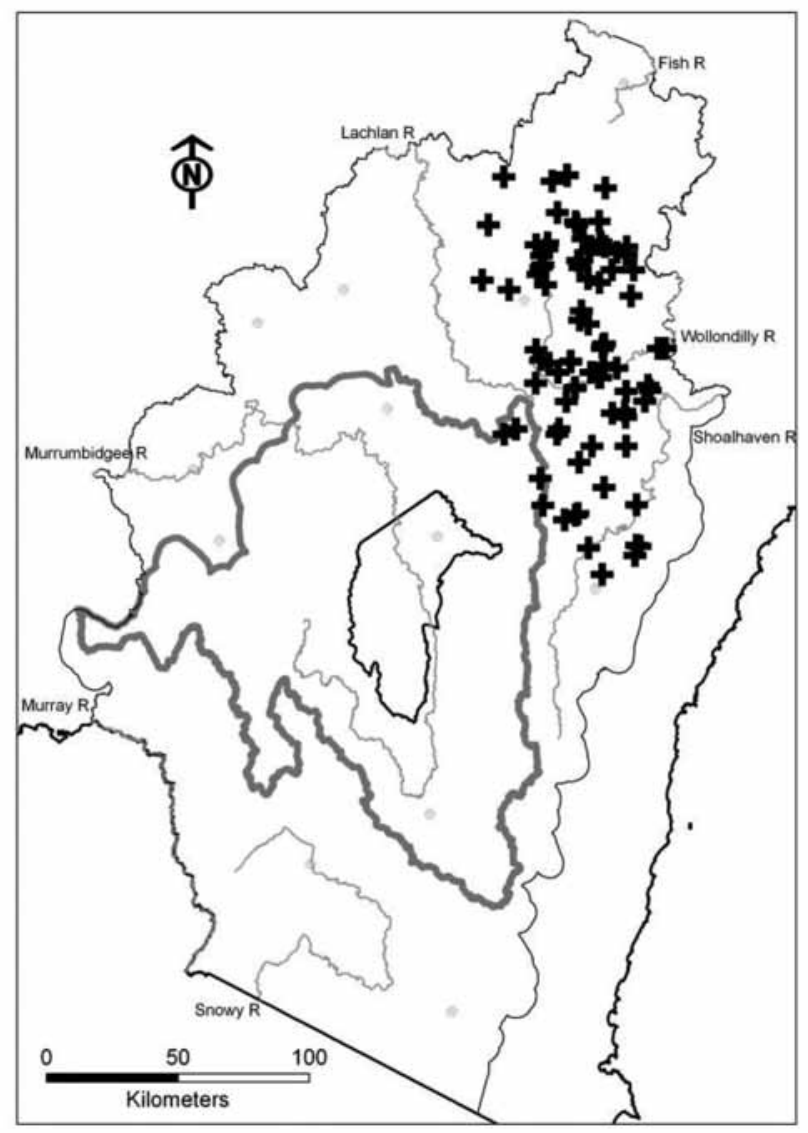

Fig. p23: Distribution of field samples assigned to this community. 


\section{u18: Mealy Bundy - Broad-leaved Peppermint shrubby mid-high open forest on granite substrates primarily in the Namadgi region}

Scientific Name: Eucalyptus nortonii - Eucalyptus dives / Cassinia longifolia - Hibbertia obtusifolia - Olearia tenuifolia / Gonocarpus tetragynus - Dichelachne micrantha - Wahlenbergia stricta - Hydrocotyle laxiflora

Number of samples:

Richness [mean $( \pm \mathrm{SD})]$ :

17

Slope (degrees):

$26(7)$

Altitude (m asl):

(8) $15-23(35)$

Ave. Annual Rainfall (mm):

(730) 818-978 (1318)

Temp. Annual Range $\left({ }^{\circ} \mathrm{C}\right)$

(735) $789-958(1072)$
(24.1) $25.5-26(26.3)$

Vegetation Description: Community u18 is a mid-high open forest dominated by Eucalyptus nortonii and Eucalyptus dives, with occasional occurrences of dense stands of Callitris endlicheri occurring in either the canopy or midstorey. The shrub layer is generally dense and may be dominated by taxa including Cassinia longifolia, Olearia tenuifolia, Brachyloma daphnoides, Kunzea ericoides, Calytrix tetragona and/or Acacia falciformis. The groundlayer is usually sparse and frequently includes the forbs Gonocarpus tetragynus, Wahlenbergia stricta and Hydrocotyle laxiflora and the low shrub Hibbertia obtusifolia. Dichelachne micrantha is the most common grass, with occasional occurrences of Rytidosperma pallidum and Rytidosperma pilosum.

This community was sampled in the ACT, primarily in Namadgi NP in the Mount Tennant area and slopes around Blue Gum Creek, however it may potentially occur in other parts of the Brindabella Ranges including in NSW on earthy sands derived from granite substrates. In Namadgi NP it grades into communities such as Community u150 [Broad-leaved Peppermint - Mountain Gum tall grass-forb open forest of the South Eastern Highlands and Australian Alps bioregions], Community u29 [Apple Box - Broad-leaved Peppermint tall shrub-grass woodland primarily on granitoids of the South Eastern Highlands bioregion], Community u66 [Mealy Bundy - Red Stringybark grass-herb mid-high open forest of the South Eastern Highlands and Upper Slopes subregion of the South Western Slopes bioregion] and Community u27 [Snow Gum - Candlebark tall grassy woodland in frost hollows and gullies of the South Eastern Highlands bioregion].

\section{Characteristic Species:}

Species

\section{C/A Freq C/A OFreqO Fid}

Acacia falciformis Brachyloma daphnoides Bursaria spinosa Callitris endlicheri Calytrix tetragona Cassinia longifolia Cheilanthes austrotenuifolia Dichelachne micrantha

Dillwynia sericea

Dodonaea viscosa

Eucalyptus dives

Eucalyptus nortonii

Hibbertia obtusifolia

Kunzea ericoides

Leucopogon attenuatus

Olearia tenuifolia

Oxalis exilis

Pomax umbellata

Pultenaea procumbens

Senecio quadridentatus

Stypandra glauca

Thysanotus tuberosus

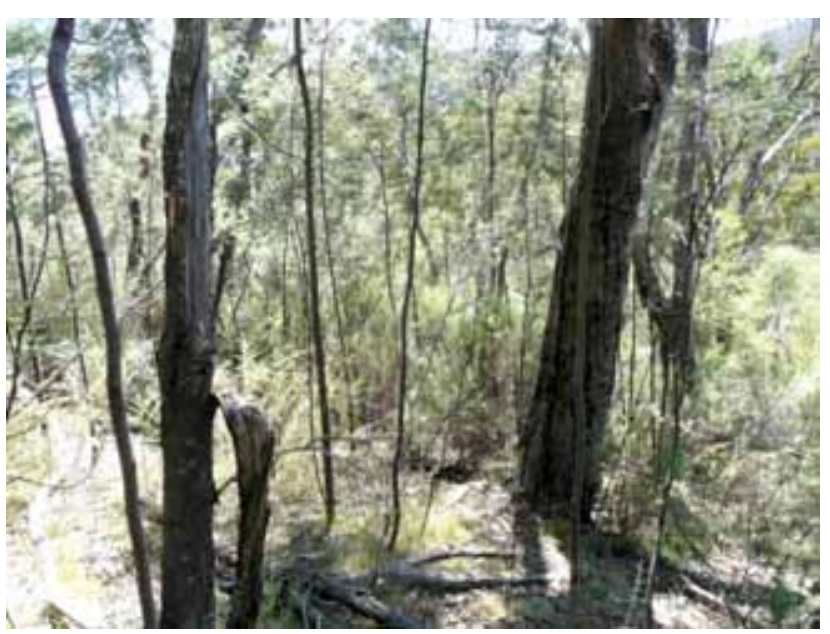

Plate u18: Community u18 showing Eucalyptus nortonii and shrubs including Cassinia longifolia and Acacia dealbata, with the ground layer covered with leaf litter. Bluegum Ck., Namadgi NP.

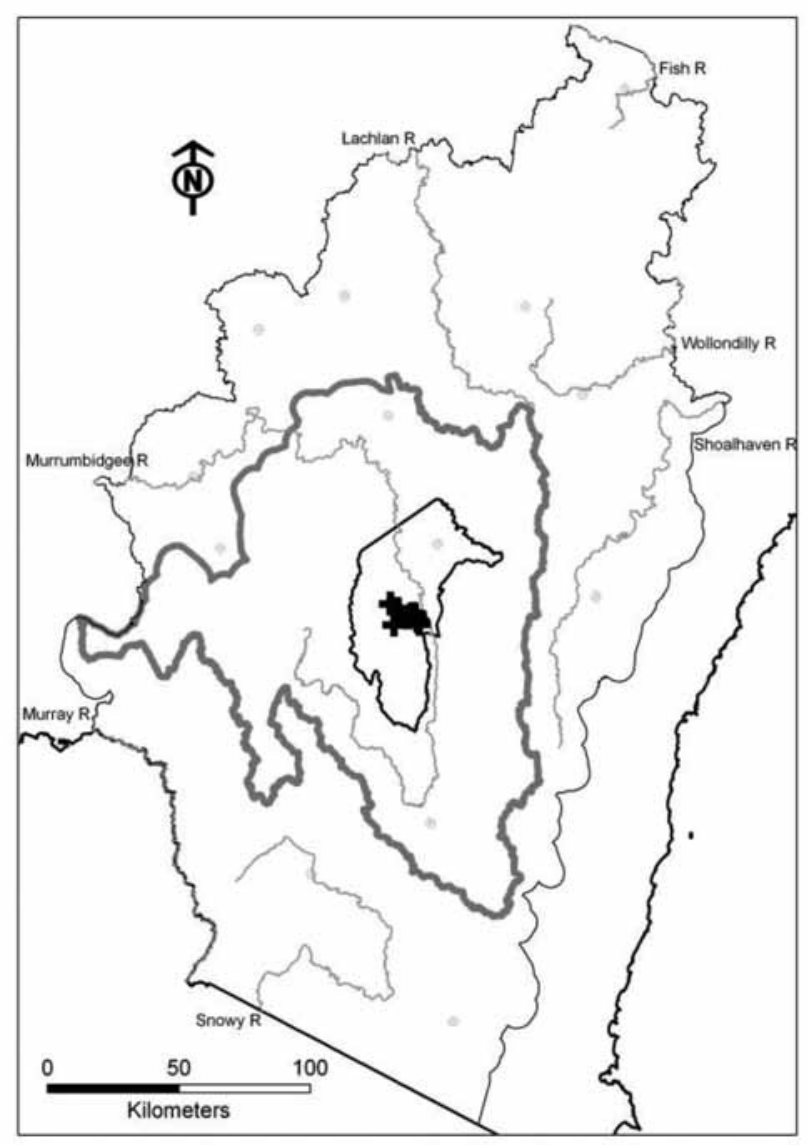

Fig. u18: Distribution of field samples assigned to this community. 
Wahlenbergia stricta Dianella revoluta Glycine clandestina Gonocarpus tetragynus Hydrocotyle laxiflora Hypericum gramineum Lomandra longifolia

Threatened communities: Nil.

Equivalent vegetation types: This community has affinities with Community VG79 [Montane Dry Shrub/Tussock Grass Forest] (Gellie (2005).

Frequently occurring weeds: This community is largely confined to the conservation reserve system and has not experienced significan weed invasion. The weeds Hypochaeris glabra (0.41) and Hypochaeris radicata (0.76) are common, although not abundant within this community.

Threats: This community appears to be well reserved within the ACT, and is unlikely to have been significantly cleared in the past. Given the tenure on which it occurs, future significant clearing is unlikely. Minor threats include herbaceous weed invasion and grazing by feral goats.

Reservation status: All known examples of this community occur in Namadgi NP, however there may be other examples on unsampled private land in surrounding areas.

Extent of clearing: Given its landscape position and its high reservation status, clearing rates in this plant community are likely to be low.

Reference: Gellie, N.J.H. (2005) Native vegetation of the southern forests: South Eastern Highlands, Australian Alps, South West Slopes and South East Corner bioregions. Cunninghamia 9: 219-254.

\section{u21: Broad-leaved Peppermint - Candlebark tall dry sclerophyll open forest of quartz-rich ranges of the upper South East Highlands and lower Austral- ian Alps bioregions}

Scientific Name: Eucalyptus dives - Eucalyptus rubida / Acacia dealbata / Hibbertia obtusifolia - Brachyloma daphnoides - Bossiaea buxifolia / Rytidosperma pallidum Gonocarpus tetragynus - Poa sieberiana

$\begin{array}{ll}\text { Number of samples: } & 45 \\ \text { Richness [mean }( \pm \text { SD)]: } & 33(9) \\ \text { Slope (degrees): } & (2) 8-14(29) \\ \text { Altitude (m asl): } & (745) 909-1074(1189) \\ \text { Ave. Annual Rainfall }(\mathrm{mm}): & (574) 667-764(900) \\ \text { Temp. Annual Range }\left({ }^{\circ} \mathrm{C}\right): & (24.5) 25.5-26.2(26.6)\end{array}$

Vegetation Description: Community u 21 is a tall eucalypt woodland to open forest to woodland, with a canopy dominated by Eucalyptus dives and/or Eucalyptus rubida, often with Eucalyptus bridgesiana cooccuring. Eucalyptus rubida tends to be the most prevalent tree species in this community in the ACT. There may be a scattered to patchy stratum of tall shrubs, commonly including Acacia dealbata, Cassinia longifolia and/or Acacia rubida. A sparse groundlayer is dominated by a mix of low shrubs such as Hibbertia obtusifolia, Brachyloma daphnoides, Bossiaea buxifolia, Pultenaea procumbens and Melichrus urceolatus, forbs including Gonocarpus tetragynus, Dianella revoluta, Hypericum gramineum, and Lomandra longifolia and tussock grasses such as Rytidosperma pallidum and Poa sieberiana.

This community is widely distributed in the higher parts of the South East Corner bioregion and lower slopes of the Australian Alps bioregion. In the east, it occurs from Captains Flat south through Tinderry, Strikea-Light and Mount Dowling NRs to Numeralla and Sunny Corner. The community is absent from the southern Monaro basalts but reappears on the ranges in the far south from Merriangaah and Tombong, west to Byadbo and the Suggan Buggan Range. In the north-west, plots run from northeast Namadgi NP (lower slopes of Booroomba Creek) south along Boboyan Road to the lower slopes of Yaouk Bill Range and Murrumbucca.

Within this range, Community u21 generally occurs on broad ridge crests and broad gentle slopes with moderately-low fertility soils of intermediate depth, with records primarily from Adaminaby Group and Yalmy Group sediments (sandstones, mudstones, shales) and from granites and granodiorites (including Shannons Flat Suite, Clear Range Suite and Glenbog Suite). In the east of its range, it may grade into Community m51 [Brittle Gum - Scribbly Gum shrub-grass tall dry sclerophyll open forest on exposed quartz-rich slopes and ridges at primarily in the Monaro and Kybeyan - Gourock subregions of the South Eastern Highlands] on shallower soils on dry, exposed north and west-facing slopes and ridges, while in sheltered gullies and on sheltered south-facing slopes it may be replaced by Community m31 [Ribbon Gum - Snow Gum - Cassinia longifolia tall shrub-grass open forest of gullies in quartz-rich ranges in the Monaro and KybeyanGourock subregions of the South Eastern Highlands bioregion]. In the western part of its range it tends to grade into Community u29 [Apple Box - Broad-leaved Peppermint tall shrub-grass woodland primarily on granitoids of the South Eastern Highlands bioregion] on steep exposed slopes with shallower soil or Community u52 [Ribbon GumRobertson's Peppermint very tall wet sclerophyll open forest primarily of the Bondo Subregion of the South Eastern Highlands and northern Australian Alps bioregions] on moist sheltered slopes and gullies. In frost hollows at higher elevations it may be replaced by Community u27 [Snow Gum - Candlebark tall grassy woodland in frost hollows and gullies of the South Eastern Highlands bioregion].

\section{Characteristic Species:}

Species

C/A Freq C/A O FreqO Fid

Acacia dealbata

Acacia gunnii

Acacia rubida

Astroloma humifusum

Bossiaea buxifolia

Brachyloma daphnoides

Cassinia longifolia

Dichelachne rara

Dillwynia sericea

Eucalyptus bridgesiana

Eucalyptus dives

Eucalyptus rubida

Galium gaudichaudii

Gonocarpus tetragynus

Hibbertia obtusifolia

Hovea heterophylla

Hovea linearis

Hypericum gramineum

Indigofera australis

Leucopogon fletcheri subsp.

brevisepalus

Lomandra multiflora

Melichrus urceolatus

Mirbelia oxylobioides

Pimelea curviflora

Pultenaea procumbens

Rytidosperma pallidum

Rytidosperma spp.

Stackhousia monogyna

Wahlenbergia communis

Wahlenbergia spp.

Wahlenbergia stricta

Lomandra longifolia

Poa sieberiana

$\begin{array}{llll}60 & 2 & 25 & \mathrm{P} \\ 22 & 1 & 6 & \mathrm{P} \\ 36 & 1 & 6 & \mathrm{P} \\ 24 & 1 & 5 & \mathrm{P} \\ 64 & 1 & 6 & \mathrm{P} \\ 73 & 1 & 16 & \mathrm{P} \\ 62 & 1 & 16 & \mathrm{P} \\ 27 & 1 & 8 & \mathrm{P} \\ 24 & 1 & 4 & \mathrm{P} \\ 38 & 3 & 7 & \mathrm{P} \\ 89 & 3 & 17 & \mathrm{P} \\ 82 & 3 & 8 & \mathrm{P} \\ 31 & 1 & 9 & \mathrm{P} \\ 80 & 2 & 47 & \mathrm{P} \\ 96 & 1 & 34 & \mathrm{P} \\ 20 & 1 & 4 & \mathrm{P} \\ 53 & 1 & 13 & \mathrm{P} \\ 56 & 1 & 25 & \mathrm{P} \\ 22 & 1 & 7 & \mathrm{P} \\ 40 & 1 & 3 & \mathrm{P}\end{array}$

$\begin{array}{llll}49 & 1 & 18 & \mathrm{P}\end{array}$

$\begin{array}{llll}58 & 1 & 12 & \mathrm{P}\end{array}$

$\begin{array}{lllll}3 & 18 & 1 & 3 & \mathrm{P}\end{array}$

$\begin{array}{lllll}1 & 38 & 1 & 6 & \mathrm{P}\end{array}$

$\begin{array}{lllll}2 & 53 & 1 & 4 & \mathrm{P}\end{array}$

$\begin{array}{lllll}2 & 84 & 2 & 17 & \mathrm{P}\end{array}$

$\begin{array}{lllll}1 & 22 & 1 & 7 & \mathrm{P}\end{array}$

$\begin{array}{lllll}1 & 36 & 1 & 12 & \mathrm{P}\end{array}$

$\begin{array}{lllll}1 & 22 & 1 & 5 & \mathrm{P}\end{array}$

$\begin{array}{lllll}1 & 42 & 1 & 18 & \mathrm{P}\end{array}$

$1-44-2-42$

$\begin{array}{lllll}1 & 44 & 2 & 42 & C \\ 1 & 60 & 2 & 48 & C\end{array}$ $\begin{array}{lllll}1 & 18 & 1 & 5 & \mathrm{P}\end{array}$ 


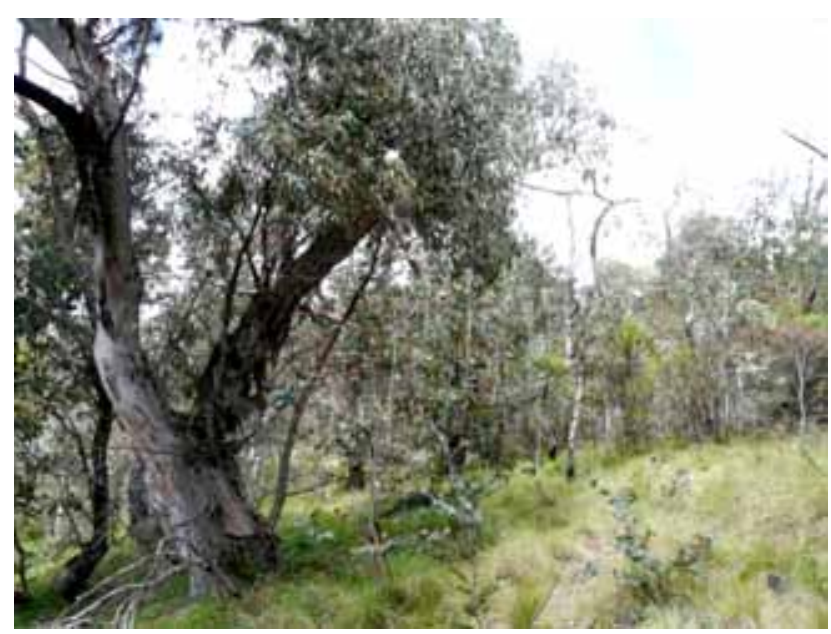

Plate u21: Community u21 showing Eucalyptus rubida with patches of Bursaria spinosa and Cassinia longifolia, and regenerating eucalypts in open grassy patches. Southern end of Bushfords Flats, Mt. Tennent Fire Trail, Namadgi NP.

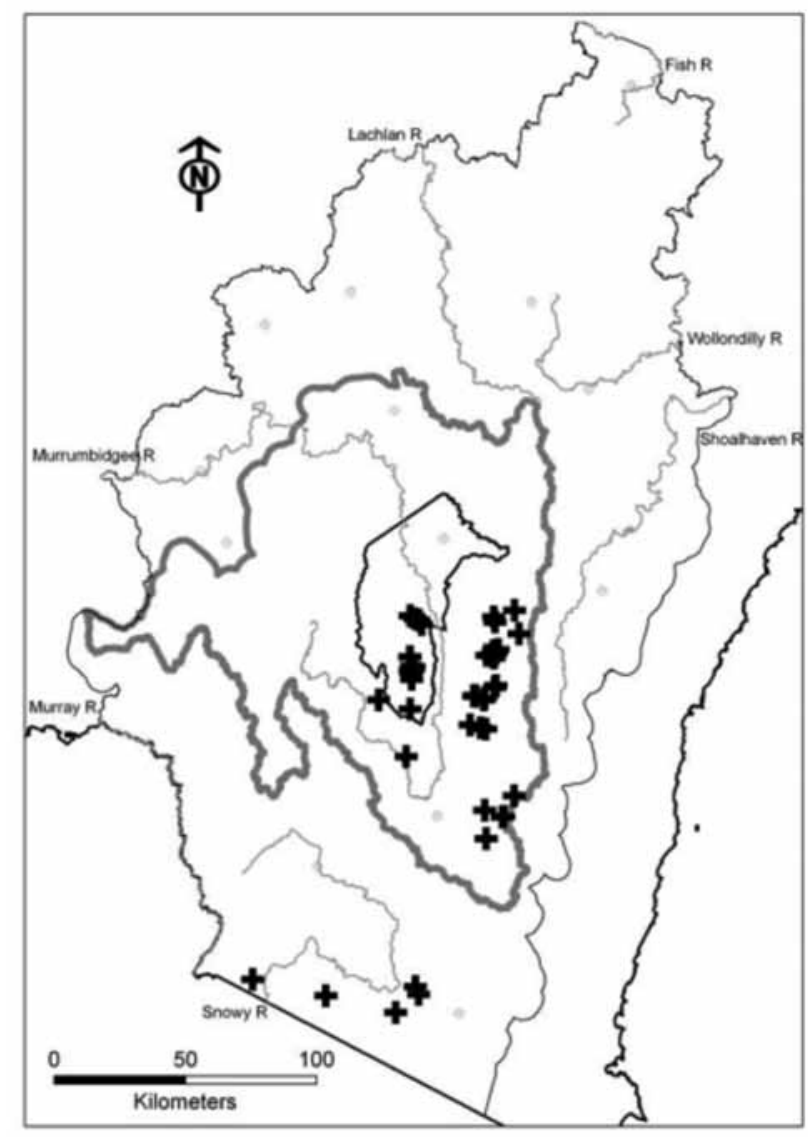

Fig. u21: Distribution of field samples assigned to this community.
Threatened communities: Examples may be part of the TSC Act Tablelands Snow Gum, Black Sallee, Candlebark and Ribbon Gum Grassy Woodland in the South Eastern Highlands, Sydney Basin, South East Corner and NSW South Western Slopes bioregions.

Equivalent vegetation types: Community u21 has no directly equivalent community in the classification of Gellie (2005). Most of the plots defining this community were not classified by Gellie (2005), and the small number of common plots were assigned in that classification to either VG74 [South Eastern Tablelands Dry Shrub/Grass/Herb Forest $]$ or VG75 [Tablelands Shrub/Tussock Grass Forest]. Other plots which defined VG74 and VG75 were assigned by the present study to related groups $\mathrm{m} 31$ and $\mathrm{m} 51$.

Frequently occurring weeds: Weeds do not feature prominantly in this community, although the common pasture weeds Centaurium erythraea and Hypochaeris radicata are present in a high proportion of sites (0.43).

Threats: The habitat of this community is generally not attractive to agricultural development, and it is unlikely to have been widely cleared. Where this community occurs on freehold land, incidental clearing for firewood and fenceposts represents a minor threat, as does grazing by feral herbivores.

Reservation status: NSW reserves known to contain this type include Yanununbeyan SCA, Tinderry NR, Burnt School NR, Strike-a-Light NR, Yaouk NR, Numeralla NR, Kybeyan NR, Merriangah NR, Meringo NR, Quidong NR, and south-eastern Kosciuszko NP. Within the ACT, samples of this community are distributed through eastern Namadgi NP.

Extent of clearing: Where the community occurs on relatively fertile soil, it is likely that moderate levels of clearing have occurred for pastoral development.

Reference: Gellie, N.J.H. (2005) Native vegetation of the southern forests: South Eastern Highlands, Australian Alps, South West Slopes and South East Corner bioregions. Cunninghamia 9: 219-254.

\section{u29: Apple Box - Broad-leaved Peppermint tall shrub-grass open forest primarily on granitoids of the South Eastern Highlands bioregion}

Scientific Name: Eucalyptus bridgesiana - Eucalyptus dives \pm Eucalyptus nortonii - Eucalyptus melliodora / Bursaria spinosa - Cassinia longifolia / Elymus scaber Poa sieberiana - Gonocarpus tetragynus
Number of samples:

Richness [mean $( \pm \mathrm{SD})]$ :

Altitude (m asl):

Ave. Annual Rainfall (mm):

Temp. Annual Range $\left({ }^{\circ} \mathrm{C}\right)$ :
Slope (degrees):

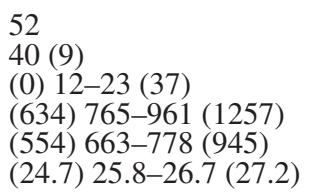

Vegetation Description: Community u29 is a tall eucalypt woodland to open forest characterised by the presence of Eucalyptus bridgesiana, Eucalyptus dives, Eucalyptus nortonii and/or Eucalyptus melliodora on granite hills with a shrubby/grassy/herbaceous understorey. Shrub species include Cassinia longifolia, Bursaria spinosa and Acacia dealbata. The groundlayer is herbaceous with the main grass species being Poa sieberiana, Elymus scaber and Themeda australis and forbs including Hydrocotyle laxiflora, Gonocarpus tetragynus, Glycine clandestina, Hypericum gramineum, Desmodium varians, Geranium solanderi, Galium gaudichaudii and Plantago varia. The dominant tree species may vary from site to site.

This community occurs primarily on granitoids in eastern parts of the Namadgi region (e.g. Booth Range), extending southward to the Snowy Mountains in Kosciuzsko NP, around Merriangaah NR and Puapong, and east to Captains Flat. In the ACT and adjacent ranges it occurs in a 
mosaic with Community u21 [Broad-leaved Peppermint-Candlebark tall dry sclerophyll open forest of quartz-rich ranges of the upper South East Highlands and lower Australian Alps bioregions], and grades downslope into Community u27 [Snow Gum - Candlebark tall grassy woodland in frost hollows and gullies of the South Eastern Highlands].

\section{Characteristic Species:}

\section{Species}

Acacia dealbata

Acaena ovina

Acrotriche serrulata

Ajuga australis

Asperula conferta

Asplenium flabellifolium

Austrostipa scabra

Bossiaea buxifolia

Bothriochloa macra

Brachyscome rigidula

Bursaria spinosa

Carex inversa

Cassinia longifolia

Cheilanthes sieberi

Chrysocephalum semipapposum

Clematis leptophylla

Crassula sieberiana

Cullen microcephalum

Cymbonotus lawsonianus

Cymbonotus spp.

Cynoglossum australe

Cynoglossum suaveolens

Daucus glochidiatus

Desmodium varians

Dichelachne micrantha

Dichelachne spp.

Dodonaea viscosa

Echinopogon cheelii

Echinopogon spp.

Elymus scaber

Epilobium billardierianum subsp.

billardierianum

Eucalyptus bridgesiana

Eucalyptus dives

Eucalyptus melliodora

Eucalyptus nortonii

Euchiton sphaericus

Galium gaudichaudii

Geranium solanderi

Glycine clandestina

Gonocarpus tetragynus

Hydrocotyle laxiflora

Hypericum gramineum

Indigofera australis

Kunzea ericoides

Lepidosperma laterale

Lomandra filiformis subsp. filiformis

Luzula spp.

Panicum effusum

Pimelea curviflora

Plantago varia

Pleurosorus rutifolius

Poa sieberiana

Rumex browni

Rytidosperma penicillatum

Rytidosperma spp.

Schoenus apogon

Senecio quadridentatus

Solenogyne dominii

Solenogyne gunnii

\section{C/A Freq C/A OFreqO Fid}

$\begin{array}{ll}56 & 2 \\ 54 & 1 \\ 37 & 1 \\ 21 & 1 \\ 42 & 1 \\ 29 & 1 \\ 13 & 1 \\ 21 & 1 \\ 27 & 1 \\ 17 & 1 \\ 85 & 1 \\ 46 & 1 \\ 81 & 1 \\ 40 & 1 \\ 17 & 1 \\ 17 & 1 \\ 33 & 1 \\ 19 & 1 \\ 15 & 1 \\ 54 & 1 \\ 21 & 1 \\ 13 & 1 \\ 54 & 1 \\ 69 & 1 \\ 37 & 1 \\ 19 & 1 \\ 38 & 1 \\ 13 & 1 \\ 17 & 1 \\ 87 & 1 \\ 13 & 1 \\ 1\end{array}$

$25 \quad \mathrm{P}$

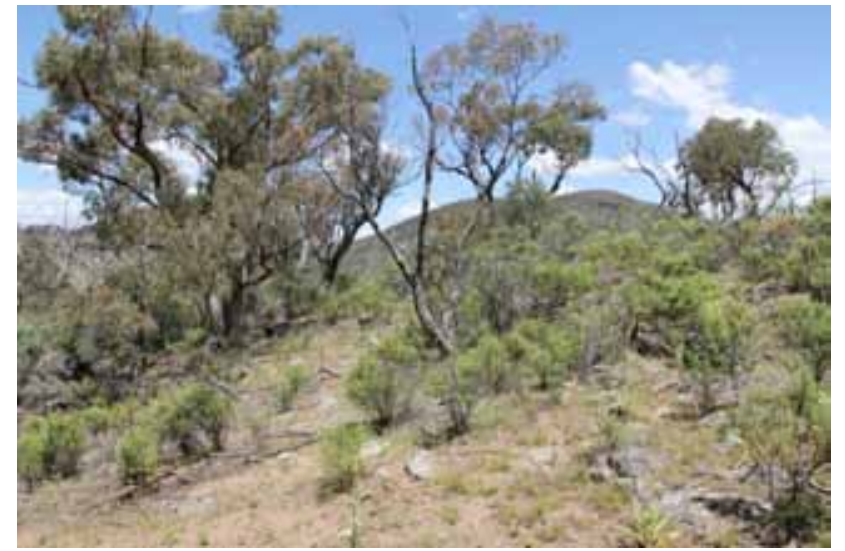

Plate u29: Community u29 with an open canopy of Eucalyptus bridgesiana, scattered Cassinia longifolia and a grassy understorey of Austrostipa scabra and Panicum effusum. Plot UMC136, north of Bullenamang Gap, Murrumbucca.

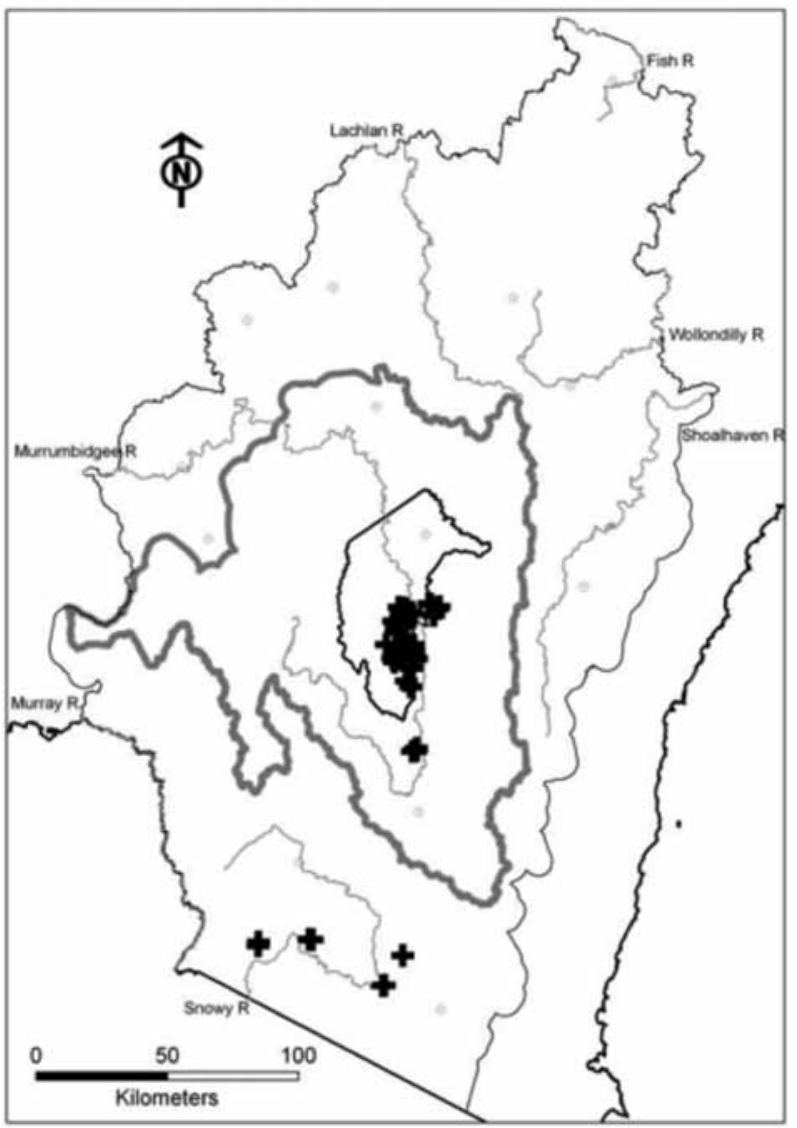

Fig. u29: Distribution of field samples assigned to this community. 
Sorghum leiocladum

Vittadinia cuneata

Vittadinia muelleri

Wahlenbergia communis

Wahlenbergia spp.

Wahlenbergia stricta

Hibbertia obtusifolia

Lomandra longifolia
Themeda australis

$\begin{array}{lllll}1 & 19 & 1 & <1 & \mathrm{P} \\ 1 & 54 & 2 & 20 & \mathrm{P} \\ 1 & 23 & 1 & 2 & \mathrm{P} \\ 2 & 15 & 1 & 2 & \mathrm{P} \\ 1 & 52 & 1 & 4 & \mathrm{P} \\ 1 & 17 & 1 & 5 & \mathrm{P} \\ 2 & 48 & 1 & 18 & \mathrm{P} \\ 1 & 44 & 1 & 35 & \mathrm{C} \\ 1 & 56 & 2 & 42 & \mathrm{C}\end{array}$

Threatened communities: Nil.

Equivalent vegetation types: Nil, although there are some affinities with VG81 [Eastern Dry Shrub/Herb/Grass Forest] identified by Gellie (2005).

Frequently occurring weeds: The diverse mix of weeds recorded within the community reflects its distribution over freehold grazing land. The most commonly recorded species are Centaurium erythraea (0.62), Cirsium vulgare (0.37), Hypochaeris glabra (0.25), Hypochaeris radicata (0.58), Lysimachia arvensis (0.35), Oxalis corniculata (0.5), Petrorhagia nanteuilii (0.33), Rosa rubiginosa (0.42), Trifolium arvense (0.63), Trifolium campestre (0.46), Verbascum thapsus subsp. thapsus (0.23).

Threats: Due to its distribution and landscape position, the main threat to this community is likely to be from selective timber removal and grazing by domestic and feral herbivores. Where grazing intensity is not carefully controlled, weed infestation may also occur.

Reservation status: Unknown, although examples of this community are found in Kosciuszko NP, Merriangaah NR, Namadgi NP and Stony Creek NR.

Extent of clearing: Likely to be minor as it occurs on poor soils on hills, although remnants on freehold land may be subject to selective tree removal for on-farm purposes.

Reference: Gellie, N.J.H. (2005) Native vegetation of the southern forests: South Eastern Highlands, Australian Alps, South West Slopes and South East Corner bioregions. Cunninghamia 9: 219-254.

\section{u105: Broad-leaved Peppermint - Brittle Gum - Red Stringybark tall shrub-grass dry sclerophyll open forest of lower ranges of the western South Eastern Highlands and upper South Western Slopes bioregions}

Scientific Name: Eucalyptus dives - Eucalyptus macrorhyncha - Eucalyptus mannifera / Acacia rubida / Hibbertia obtusifolia - Platylobium montanum Hardenbergia violacea / Poa sieberiana - Gonocarpus tetragynus - Lomandra longifolia

Number of samples:

74

Richness [mean $( \pm \mathrm{SD})]$ :

30 (10)

Slope (degrees):

Altitude (m asl):

Ave. Annual Rainfall (mm):

Temp. Annual Range $\left({ }^{\circ} \mathrm{C}\right)$ :

(0) 11-24 (30)

(396) 647-861 (1078)

(848) 996-1188 (1249)

(24.7) $25.2-27.1(28.3)$

Vegetation Description: Community u105 is a tall dry sclerophyll open forest dominated by Eucalyptus dives, Eucalyptus mannifera and Eucalyptus macrorhyncha with a sparse to patchy layer of shrubs including Acacia rubida and Cassinia longifolia. A diverse complement of low shrubs commonly includes Hibbertia obtusifolia, Monotoca scoparia, Platylobium montanum and/or Persoonia chamaepeuce. A groundlayer of tussock grasses, forbs and sprawling twiners, most frequently including Rytidosperma pallidum, Poa sieberiana, Dianella revoluta, Gonocarpus tetragynus, Hardenbergia violacea, Hovea linearis, Lomandra longifolia and Stylidium graminifolium sens. lat. is typically present.

This community is commonly recorded from dry rocky ridges and exposed west-facing upper slopes with shallow soils of moderate to moderately low fertility derived from a wide variety of substrates including rhyolite, tuff, sandstone, shale, granite, granodiorite, psammite and conglomerate. Plots assigned to this type are closely tied to the Bondo subregion and are distributed around the northern and western rims of the Snowy Mountains, associated with lower foothill ranges, ridges of major valleys and outlying western ridgelines. Plots were recorded from Burrinjuck, Wee Jasper, the margins of the Brindabella Range, the Snubba Range from Wereboldera to Talbingo, east of Talbingo Reservoir on lower slopes above the Tumut River, on the southwestern lower slopes of the Kosciuszko massif from Jagumba Range to Khancoban, Geehi and Tom Groggin, and on outlying lower western ridgelines at Downfall, Carabost, Mundaroo and Tumbarumba. It may also occur in the Cotter River area of the ACT.

Community u105 grades into various communities across its range. In sheltered areas of deeper moister soil such as gullies and footslopes it may be replaced by Community u152 [Robertson's Peppermint - Red Stringybark very tall grass-forb sheltered open forest of the southwest South Eastern Highlands and upper South Western Slopes bioregions]. In the north of its range, at higher altitudes it may grade into Community u150 [Broad-leaved Peppermint - Mountain Gum tall grass-forb open forest of the South Eastern Highlands and Australian Alps bioregions], particularly in the Brindabella ranges, while at lower altitudes and decreasing rainfall from Burrinjuck east it may grade into Community p14 [Red Stringybark - Scribbly Gum - Rytidosperma pallidum tall grass-shrub dry sclerophyll open forest on loamy ridges of the central South Eastern Highlands bioregion]. To the west as rainfall declines and altitude falls, it is gradually replaced on lower ridgelines by Community u148 [Red Stringybark - Red Box grass-forb tall open forest of the upper South Western Slopes and western South Eastern Highlands bioregions].

\section{Characteristic Species:}

\section{Species}

\section{C/A Freq C/A O FreqO Fid}

Acacia buxifolia

Acacia gunnii

Acacia rubida

Acacia ulicifolia

Acrotriche serrulata

Astrotricha ledifolia

Austrostipa rudis

Billardiera scandens

Boronia nana

Cassinia longifolia

Cassytha pubescens

Cheiranthera linearis

Choretrum pauciflorum

Daviesia leptophylla

Dianella revoluta

Dichelachne sieberiana

Dillwynia phylicoides

Eriochilus cucullatus

Eucalyptus dives

Eucalyptus globulus subsp. bicostata 1

Eucalyptus goniocalyx

Eucalyptus macrorhyncha

Eucalyptus mannifera

Eucalyptus nortonii

Eucalyptus radiata subsp. robertsonii 1

Gompholobium huegelii

Gonocarpus tetragynus

Grevillea lanigera

Grevillea ramosissima

$\begin{array}{llll}14 & 1 & 1 & \mathrm{P} \\ 22 & 1 & 6 & \mathrm{P} \\ 50 & 1 & 5 & \mathrm{P} \\ 9 & 1 & 2 & \mathrm{P} \\ 32 & 1 & 11 & \mathrm{P} \\ 14 & 1 & <1 & \mathrm{P} \\ 22 & 2 & 3 & \mathrm{P} \\ 30 & 1 & 9 & \mathrm{P} \\ 6 & 1 & <1 & \mathrm{P} \\ 42 & 1 & 16 & \mathrm{P} \\ 19 & 1 & 2 & \mathrm{P} \\ 10 & 1 & 1 & \mathrm{P} \\ 11 & 1 & 3 & \mathrm{P} \\ 20 & 1 & 5 & \mathrm{P} \\ 65 & 1 & 21 & \mathrm{P} \\ 16 & 2 & 5 & \mathrm{P} \\ 22 & 2 & 2 & \mathrm{P} \\ 9 & 1 & <1 & \mathrm{P} \\ 86 & 3 & 16 & \mathrm{P} \\ 8 & 3 & <1 & \mathrm{P} \\ 17 & 3 & 4 & \mathrm{P} \\ 76 & 3 & 14 & \mathrm{P} \\ 72 & 3 & 10 & \mathrm{P} \\ 15 & 3 & 3 & \mathrm{P} \\ 22 & 3 & 9 & \mathrm{P} \\ 23 & 1 & 4 & \mathrm{P} \\ 89 & 2 & 47 & \mathrm{P} \\ 16 & 1 & 3 & \mathrm{P} \\ 7 & 1 & <1 & \mathrm{P}\end{array}$


Hardenbergia violacea Hibbertia obtusifolia

Hovea linearis

Indigofera australis

Lepidosperma laterale

Leptospermum brevipes

Leucopogon attenuatus

Leucopogon fletcheri subsp.

brevisepalus

Leucopogon virgatus

Lomandra filiformis subsp. coriacea 1

Lomandra filiformis subsp. filiformis 1

Lomandra longifolia

Melichrus urceolatus

Monotoca scoparia

Omphacomeria acerba

Persoonia chamaepeuce

Pimelea glauca

Platylobium montanum

Poa sieberiana

Poa tenera

Pultenaea spinosa

Rytidosperma pallidum

Stackhousia monogyna

Stylidium graminifolium sens. lat.

Tetratheca bauerifolia

Thelymitra pauciflora

Xanthorrhoea glauca subsp.

angustifolia

$\begin{array}{lll}1 & 72 & 1 \\ 1 & 93 & 1 \\ 1 & 57 & 1 \\ 1 & 31 & 1 \\ 1 & 22 & 1 \\ 1 & 7 & 2 \\ 1 & 9 & 1 \\ 1 & 13 & 1\end{array}$

$\begin{array}{ll}13 & \mathrm{P} \\ 33 & \mathrm{P} \\ 12 & \mathrm{P} \\ 6 & \mathrm{P} \\ 9 & \mathrm{P} \\ <1 & \mathrm{P} \\ 1 & \mathrm{P} \\ 3 & \mathrm{P} \\ & \\ 3 & \mathrm{P} \\ 18 & \mathrm{P} \\ 16 & \mathrm{P} \\ 42 & \mathrm{P} \\ 13 & \mathrm{P} \\ 14 & \mathrm{P} \\ <1 & \mathrm{P} \\ 10 & \mathrm{P} \\ <1 & \mathrm{P} \\ 9 & \mathrm{P} \\ 47 & \mathrm{P} \\ 2 & \mathrm{P} \\ <1 & \mathrm{P} \\ 17 & \mathrm{P} \\ 12 & \mathrm{P} \\ 24 & \mathrm{P} \\ 6 & \mathrm{P} \\ <1 & \mathrm{P} \\ <1 & \mathrm{P}\end{array}$

Plate u105: Community u105, beside Stony Creek firetrail in Wereboldera SCA (near plot SWSWRB05) with Eucalyptus dives and Eucalyptus mannifera over a diverse layer of tough low shrubs, twiners and grasses.

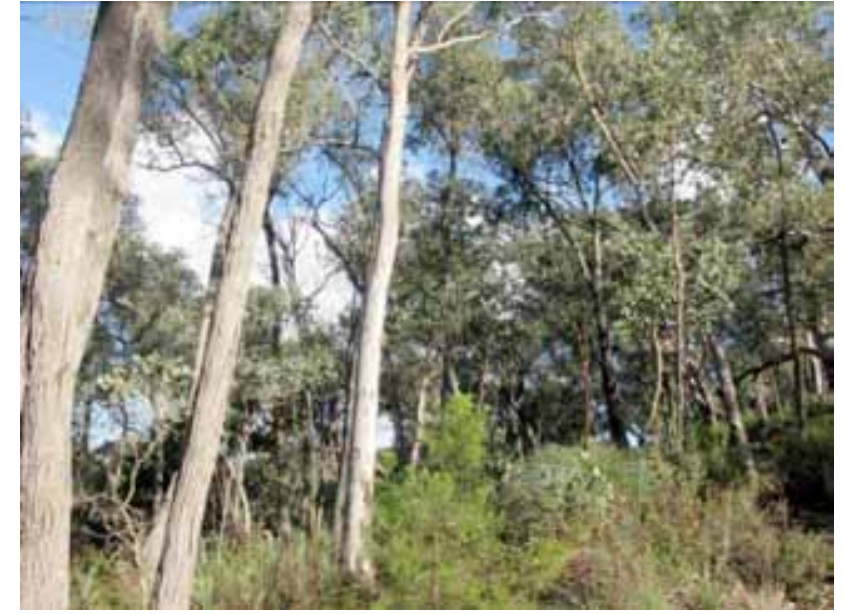

\section{Threatened communities: Nil.}

Equivalent vegetation types: This community is defined by a large number of field survey plots, including many plots from forested public lands which were classified by Gellie (2005). Strongly related Forest Ecosystems include VG110 [Tablelands Dry Shrub/Grass Forest] (23 plots in common), VG108 [Western Tablelands Dry Herb/Grass Forest] (15 plots in common) and VG109 [Widespread Tablelands Dry Shrub/ Tussock Grass Forest] (5 plots in common). The relationship between Community u105 and communities identified by Benson et al. (2010) with similar structural dominants (such as VCA 351) requires resolution through further sampling and analysis.

Frequently occurring weeds: The common pasture weeds Centaurium erythraea (0.26) and Hypochaeris radicata (0.24) were the most frequently recorded weed species in this community.

Threats: This community is generally found on ridges and steep country which are generally not suitable for agriculture. As a consequence, it is unlikely to have been widely cleared. Examples on private land may be subject to occasional light rough-country grazing, selective tree removal and firewood collection.

Reservation status: Recorded from plots in Burrinjuck NR, Wereboldera SCA, Brindabella NP and SCA, Bimberi NR, Downfall $\mathrm{NR}$, Bogandyera NR and at numerous locations on the western edge of Kosciuszko NP.

Extent of clearing: Unlikely to have been widely cleared.

References: Benson, J.S., Richards, P.G., Waller, S. \& Allen, C.B (2010) New South Wales vegetation classification and assessment: Part 3. Plant communities of the NSW Brigalow Belt South, Nandewar and west New England bioregions and update of NSW Western Plains and South Western Slopes plant communities. Version 3 of the NSW VCA database. Cunninghamia 11: 457-579. Botanic Gardens Trust, Sydney; Gellie, N.J.H. (2005) Native vegetation of the southern forests: South Eastern Highlands, Australian Alps, South West Slopes and South East Corner bioregions. Cunninghamia 9: 219-254.

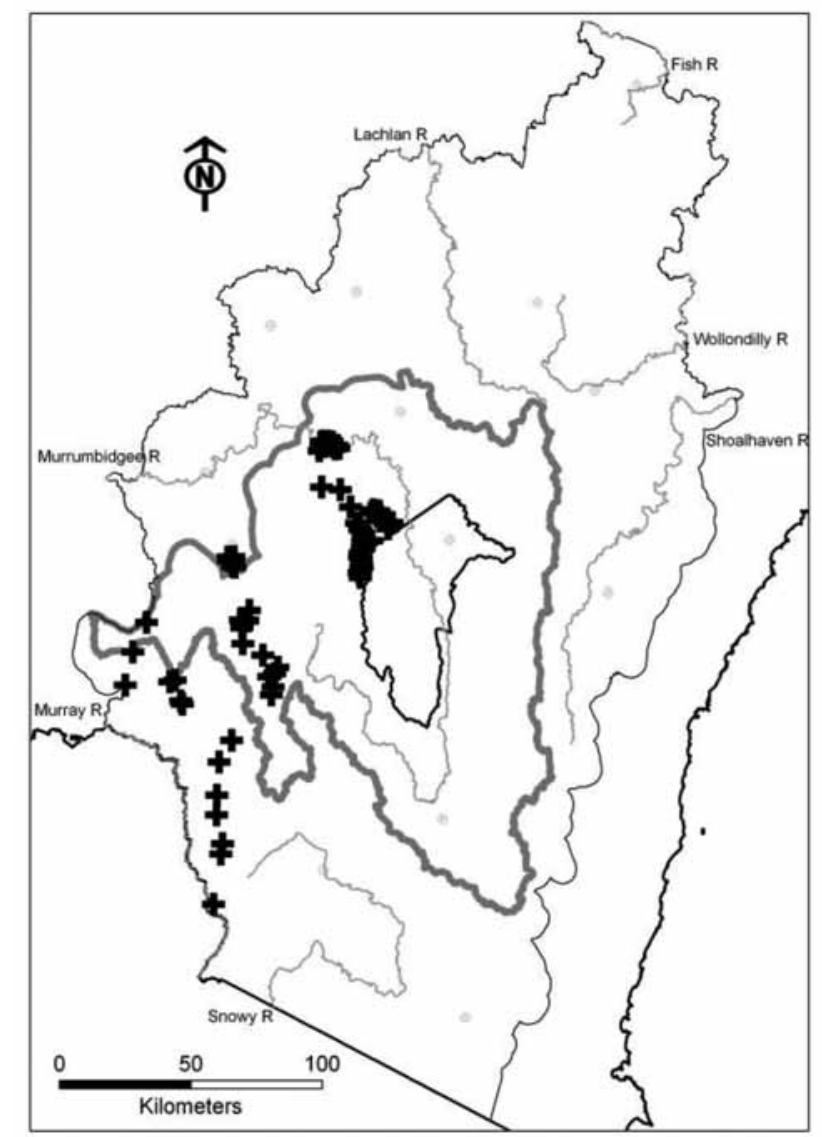

Fig. u105: Distribution of field samples assigned to this community. 


\section{u148: Red Stringybark - Red Box grass-forb tall open forest of the upper South Western Slopes and western South Eastern Highlands bioregions}

Scientific Name: Eucalyptus macrorhyncha - Eucalyptus polyanthemos / Hibbertia obtusifolia / Poa sieberiana - Gonocarpus tetragynus - Lomandra filiformis subsp. coriacea - Hydrocotyle laxiflora - Rytidosperma pilosum Elymus scaber

$\begin{array}{ll}\text { Number of samples: } & 64 \\ \text { Richness [mean }( \pm \mathrm{SD})]: & 32(9) \\ \text { Slope (degrees): } & (1) 7-19(30) \\ \text { Altitude (m asl): } & (293) 441-552(837) \\ \text { Ave. Annual Rainfall }(\mathrm{mm}): & (713) \text { 846-961 (1201) } \\ \text { Temp. Annual Range }\left({ }^{\circ} \mathrm{C}\right): & (25.5) 26.3-28.2(28.8)\end{array}$

Vegetation Description: Community u148 is a tall eucalypt forest dominated by Eucalyptus macrorhyncha and Eucalyptus polyanthemos, occasionally with Eucalyptus goniocalyx, Eucalyptus nortonii or Eucalyptus blakelyi. The shrub layer ranges from sparse to dense, most frequently including Brachyloma daphnoides, Xanthorrhoea glauca subsp. angustifolia and the low shrub Melichrus urceolatus within a diverse suite of sclerophyllous shrub taxa occurring across the range of this community. The ground cover is open to dense and dominated by grasses such as Poa sieberiana, Rytidosperma pilosum, Elymus scaber and Microlaena stipoides, and forbs including Gonocarpus tetragynus, Hydrocotyle laxiflora, Lomandra filiformis subsp. coriacea, Lomandra filiformis subsp. filiformis, Daucus glochidiatus and Wahlenbergia stricta.

This community is widely distributed across the western half of the South Eastern Highlands and into the upper Slopes of the NSW South Western Slopes within the Murrumbidgee catchment. It occurs as far east as Yass, and westwards in a band through Tumut and southwards towards the Murray River. It grades into communities such as Community u19 [Blakely's Red Gum - Yellow Box \pm White Box tall grassy woodland of the Upper South Western Slopes and western South Eastern Highlands bioregions] in more fertile areas, Community p14 [Red Stringybark - Scribbly Gum - Rytidosperma pallidum tall grassshrub dry sclerophyll open forest on loamy ridges of the central South Eastern Highlands bioregion] on poorer soils in the north-eastern extent of its range, and Community u105 [Broad-leaved Peppermint - Brittle Gum - Red Stringybark tall shrub-grass dry sclerophyll open forest of lower ranges of the western South Eastern Highlands and upper South Western Slopes bioregions] on poorer soils in the western extent of its range.

\section{Characteristic Species:}

Species

Acacia buxifolia

Acacia implexa

Acacia ulicifolia

Bothriochloa macra

Brachychiton populneus

Brachyloma daphnoides

Brunonia australis

Cassinia longifolia

Cheilanthes austrotenuifolia

Cheilanthes sieberi

Cheiranthera linearis

Cynoglossum suaveolens

Daucus glochidiatus

Dichelachne crinita

Dichelachne hirtella

Dichelachne sieberiana
C/A Freq C/A OFreqO Fid

$\begin{array}{lllll}1 & 9 & 1 & 1 & \mathrm{P} \\ 1 & 16 & 1 & 2 & \mathrm{P} \\ 2 & 19 & 1 & 1 & \mathrm{P} \\ 2 & 11 & 1 & 3 & \mathrm{P} \\ 1 & 17 & 1 & 2 & \mathrm{P} \\ 2 & 36 & 1 & 16 & \mathrm{P} \\ 2 & 20 & 1 & <1 & \mathrm{P} \\ 1 & 34 & 1 & 16 & \mathrm{P} \\ 1 & 17 & 1 & 3 & \mathrm{P} \\ 1 & 44 & 1 & 8 & \mathrm{P} \\ 1 & 22 & 1 & <1 & \mathrm{P} \\ 1 & 11 & 1 & 3 & \mathrm{P} \\ 1 & 56 & 1 & 7 & \mathrm{P} \\ 2 & 13 & 1 & 3 & \mathrm{P} \\ 2 & 16 & 1 & 1 & \mathrm{P} \\ 2 & 30 & 2 & 5 & \mathrm{P}\end{array}$

Dodonaea viscosa

Drosera auriculata

Elymus scaber

Eucalyptus albens

Eucalyptus blakelyi

Eucalyptus goniocalyx

Eucalyptus macrorhyncha

Eucalyptus nortonii

Eucalyptus polyanthemos

Eucalyptus sideroxylon

Geranium solanderi

Glycine clandestina

Gonocarpus tetragynus

Hibbertia obtusifolia

Hydrocotyle laxiflora

Hypericum gramineum

Lomandra filiformis subsp. coriacea 2

Lomandra filiformis subsp.

filiformis

Lomandra spp.

Luzula densiflora

Melichrus urceolatus

Microtis unifolia

Oxalis perennans

Poa sieberiana

Pultenaea spinosa

Rytidosperma pilosum

Scutellaria humilis

Senecio bathurstianus

Senecio prenanthoides

Senecio quadridentatus

Senecio tenuiflorus

Stypandra glauca

Thelymitra spp.

Tricoryne elatior

Wahlenbergia stricta

Wurmbea dioica

Xanthorrhoea glauca subsp.

angustifolia

Microlaena stipoides

Threatened communities: Nil.

Equivalent vegetation types: No clear equivalent, but has similarities with VG119 [Western Tablelands Dry Shrub/Grass Forest] defined by Gellie (2005). It also displays characteristics of VCA 290 [Red Stringybark - Red Box - Long-leaved Box - Inland Scribbly Gum tussock grass-shrub low open forest on hills in the southern part of the NSW South-western Slopes bioregion] (Benson et al. 2010) and probably represents the more fertile end of this community.

Frequently occurring weeds: This community is characterised by an abundance of weed species, reflecting its distribution on freehold land, and the effect of domestic stock grazing on the groundlayer. The most commonly recorded weed species are Aira elegantissima (0.31), Briza maxima (0.86), Briza minor (0.45), Cirsium vulgare (0.31), Hypericum perforatum (0.37), Hypochaeris glabra (0.37), Hypochaeris radicata (0.55), Lysimachia arvensis $(0.33)$, Orobanche minor $(0.35)$, Petrorhagia nanteuilii (0.51), Trifolium angustifolium (0.45), Trifolium arvense (0.45) and Trifolium campestre (0.41).

Threats: The biggest threat to this community is weed infestation and grazing, which often occur in unison. Clearing is unlikely to represent a significant threat, although selective tree removal does occur, which may induce changes to structure and species composition.

Reservation status: Examples of this community are found in Bango NR, Bogandyera NR, Burrinjuck NR, Downfall NR, Ellerslie NR, Kosciuszko NP, Minjary NP, Mudjarn NR, Mulligans Flat NR, Mundoonen NR, Oak Creek NR, Tumblong SCA and Wereboldera SCA. 


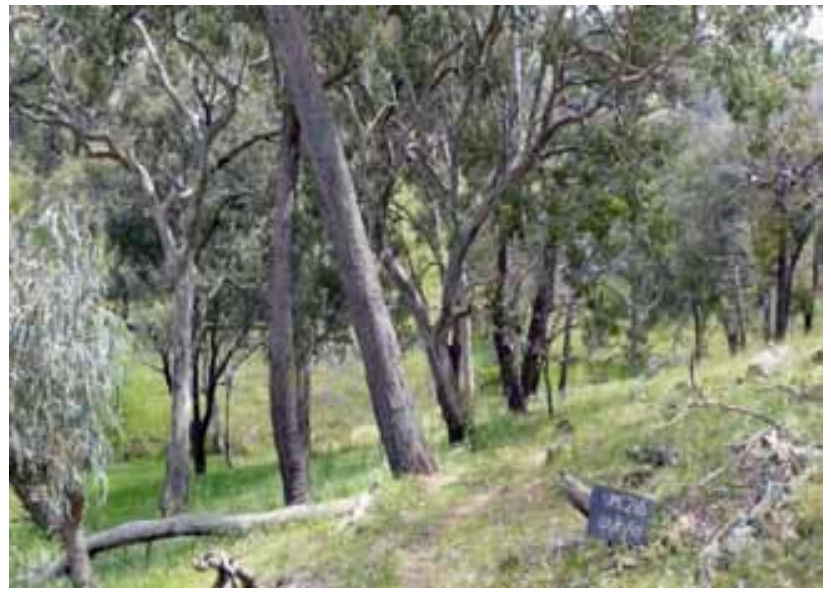

Plate u148: Community u148, in crown reserve above Lake Burrinjuck approximately $2.5 \mathrm{~km}$ north of Taemas Bridge, plot UMC216.

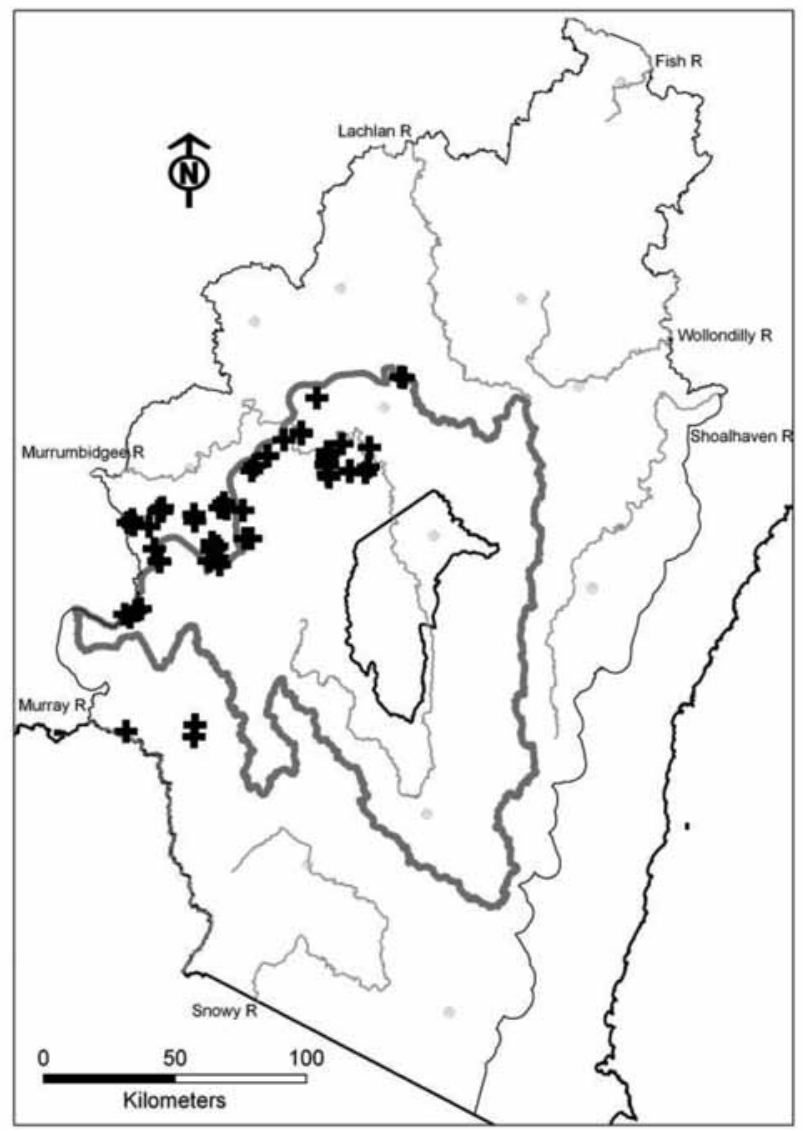

Extent of clearing: Likely to be moderate.

References: Benson, J.S., Richards, P.G., Waller, S. \& Allen, C.B. (2010) New South Wales vegetation classification and assessment: Part 3. Plant communities of the NSW Brigalow Belt South, Nandewar and west New England bioregions and update of NSW Western Plains and South Western Slopes plant communities. Version 3 of the NSW VCA database. Cunninghamia 11: 457-579. Botanic Gardens Trust, Sydney; Gellie, N.J.H. (2005) Native vegetation of the southern forests: South Eastern Highlands, Australian Alps, South West Slopes and South East Corner bioregions. Cunninghamia 9: 219-254.

\section{u150: Broad-leaved Peppermint - Mountain Gum shrubby tall open forest of the South Eastern High- lands and Australian Alps bioregions}

Scientific Name: Eucalyptus dives - Eucalyptus dalrympleana / Acacia dealbata / Daviesia mimosoides subsp. mimosoides - Hibbertia obtusifolia - Monotoca scoparia - Persoonia chamaepeuce - Tetratheca bauerifolia / Lomandra longifolia - Gonocarpus tetragynus - Poa sieberiana

$\begin{array}{ll}\text { Number of samples: } & 73 \\ \text { Richness [mean }( \pm \mathrm{SD})]: & 24(6) \\ \text { Slope (degrees): } & (1) 6-17(37) \\ \text { Altitude (m asl): } & (826) 1072-1230(1490) \\ \text { Ave. Annual Rainfall }(\mathrm{mm}): & (690) 870-1054(1181) \\ \text { Temp. Annual Range }\left({ }^{\circ} \mathrm{C}\right): & (23.1) 24.3-25.2(25.6)\end{array}$

Vegetation Description: Community u150 is a shrubby tall dry open forest dominated by Eucalyptus dives and Eucalyptus dalrympleana. The well defined midstorey typically includes Monotoca scoparia, Daviesia mimosoides subsp. mimosoides and Acacia dealbata. Shorter shrubs often include Hibbertia obtusifolia, Persoonia chamaepeuce, Tetratheca bauerifolia and Brachyloma daphnoides. The sparse groundlayer generally includes Lomandra longifolia, Gonocarpus tetragynus, Stylidium graminifolium sens. lat., Poa sieberiana, Dianella revoluta, Goodenia hederacea subsp. hederacea, Hovea linearis, Rytidosperma pallidum, Poranthera microphylla and Stellaria pungens.

This is a widespread community, occurring from Tallaganda NP and Kybean SCA in the eastern part of the study area, through Tinderry NR, Namadgi NP to Brindabella NP in the west. It is most common on metasedimentary and granite geologies, usually on lower slopes. This community often forms a mosaic with other dry montane forests and subalpine woodlands including Community u22 [Mountain Gum - Snow Gum grass-forb very tall woodland to open forest of the Australian Alps and South Eastern Highlands bioregions], Community u52 [Ribbon Gum - Robertson's Peppermint very tall wet sclerophyll open forest primarily of the Bondo Subregion of the South Eastern Highlands and northern Australian Alps bioregions] and, in the south of the study area, Community m31 [Ribbon Gum - Snow Gum - Cassinia longifolia tall shrub-grass open forest of gullies in quartz-rich ranges in the Monaro and Kybeyan-Gourock subregions of the South Eastern Highlands bioregion].

Fig. u148: Distribution of field samples assigned to this community. 


\section{Characteristic Species:}

Species

\section{C/A Freq C/A O FreqO Fid}

\section{Acacia gunnii}

Acrotriche serrulata

Brachyloma daphnoides

Cassytha pubescens

Choretrum pauciflorum

mimosoides

Daviesia ulicifolia

Deyeuxia quadriseta

Dianella revoluta

Eucalyptus dalrympleana

Eucalyptus dives

Eucalyptus radiata subsp. robertsonii 3

Eucalyptus rubida

Exocarpos strictus

Gonocarpus tetragynus

Grevillea lanigera

Hibbertia obtusifolia

Hovea linearis

Lomandra longifolia

Monotoca scoparia

Oxylobium ellipticum

Persoonia chamaepeuce

Persoonia silvatica

Pimelea linifolia

Poa sieberiana

Stylidium graminifolium sens. lat.

Tetratheca bauerifolia

Veronica perfoliata

Acacia dealbata

\section{$\begin{array}{lllll}1 & 19 & 1 & 6 & \mathrm{P}\end{array}$}

$25 \quad 1$

$49 \quad 1$

$\begin{array}{ll}49 & 1 \\ 8 & 1\end{array}$

$25 \quad 1$

$\begin{array}{lll}1 & 68 & 2\end{array}$

11

16

2

2

8

$29 \quad 2$

191

$51 \quad 1$

$\begin{array}{ll}67 & 3\end{array}$

853

$10 \mathrm{P}$

$22 \mathrm{P}$

19 P

$17 \quad \mathrm{P}$

9 P

$8 \mathrm{P}$

$12 \mathrm{P}$

$47 \quad \mathrm{P}$

3 P

$33 \quad \mathrm{P}$

$12 \quad \mathrm{P}$

$41 \mathrm{P}$

13 P

$4 \quad \mathrm{P}$

$10 \mathrm{P}$

$3 \mathrm{P}$

$8 \quad \mathrm{P}$

$48 \quad \mathrm{P}$

$24 \mathrm{P}$

$6 \mathrm{P}$

$4 \quad \mathrm{P}$
Daviesia mimosoides subsp.

Threatened communities: Nil.

Equivalent vegetation types: Amalgamates VG103 [Western Montane Dry Fern/Grass Forest], VG105 [ACT Montane Dry Shrub Forest] and VG107 [Central Tableland/ACT Montane Dry Shrub Forest], which are very closely related Vegetation Groups previously described by Gellie (2005).

Frequently occurring weeds: The low abundance of weed species reflects the landuse history and current tenure of this community. Only the most dispersive and widespread weed species were recorded, such as Centaurium erythraea (0.08) and Hypochaeris radicata (0.17).

Threats: Frequent and intense fire has the potential to affect the structural and floristic integrity of this vegetation community. The naturally open midstorey and canopy may make this community attractive to grazing by feral herbivores.

Reservation status: Likely to be reasonably well reserved; most of the plots assigned to this community were located in conservation reserves, including Namadgi NP, Bimberi NR, Bondi Gulf NR, Brindabella NP and SCA, Dangelong NR, Nimmo NR, Scabby Range NR, Tallaganda NP, Tinderry NR, Yanununbeyan NP and Yaouk NR.

Extent of clearing: Not assessed, but likely to be minimal.

Reference: Gellie, N.J.H. (2005) Native vegetation of the southern forests: South Eastern Highlands, Australian Alps, South West Slopes and South East Corner bioregions. Cunninghamia 9: 219-254.

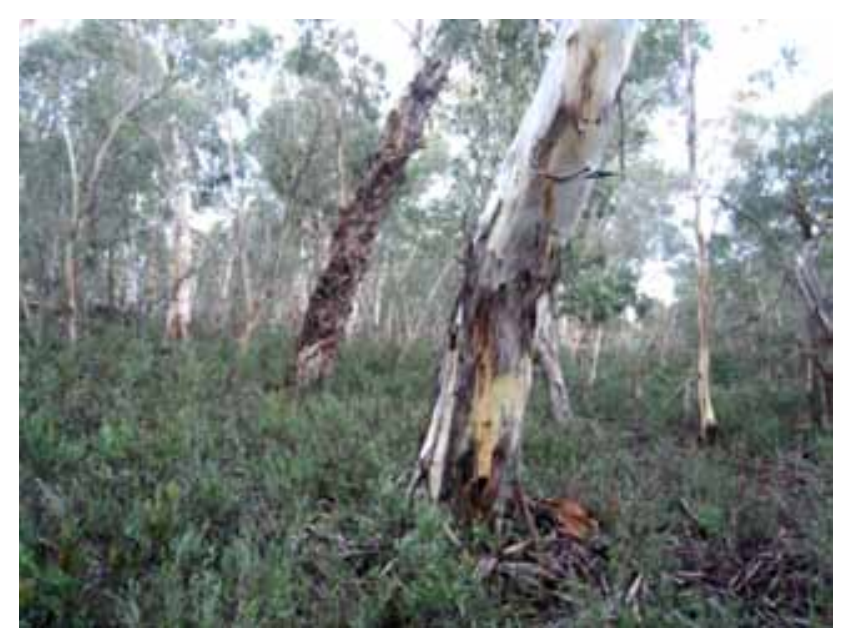

Plate u150: Community u150 dominated by Eucalyptus dalrympleana with sparse Eucalyptus pauciflora and a shrubby understorey of Daviesia mimosoides. Coolumbooka NR near Bombala.

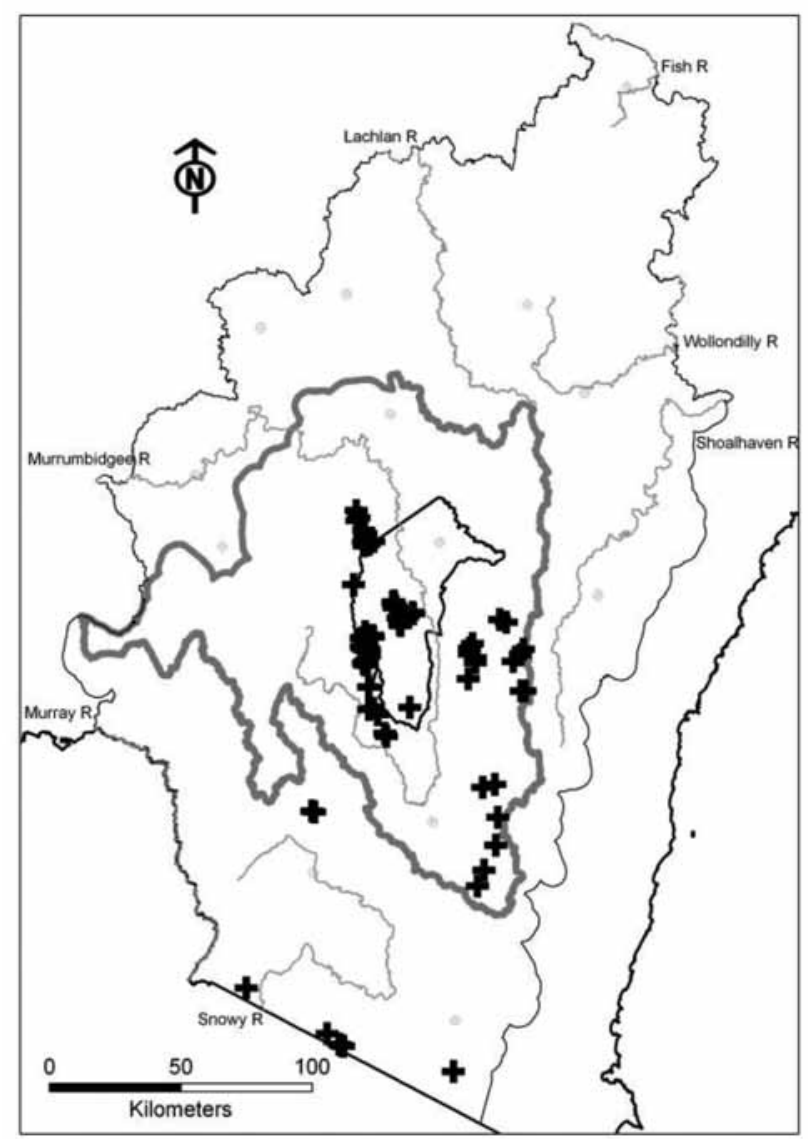

Fig. u150: Distribution of field samples assigned to this community. 


\section{u152: Robertson's Peppermint - Red Stringybark very tall grass-forb sheltered open forest of the southwest South Eastern Highlands and upper South Western Slopes bioregions}

Scientific Name: Eucalyptus radiata subsp. robertsonii - Eucalyptus macrorhyncha / Acacia dealbata / Pteridium esculentum - Hibbertia obtusifolia / Poa sieberiana Microlaena stipoides - Hydrocotyle laxiflora - Gonocarpus tetragynus - Geranium solanderi-Acaena novae-zelandiae

Number of samples:

Richness [mean ( \pm SD)]:

Slope (degrees):

Altitude (m asl):

Ave. Annual Rainfall (mm):

101

$44(12)$

(1) 5-17 (38)

(309) 619-817 (1085)

(825) 963-1177 (1312)

Temp. Annual Range $\left({ }^{\circ} \mathrm{C}\right)$ :

(24.5) 25.8-27.5 (28.6)

Vegetation Description: Community u 152 is a very tall open eucalypt forest with canopy commonly dominated by Eucalyptus radiata subsp. robertsonii and Eucalyptus macrorhyncha, less frequently with Eucalyptus bridgesiana, Eucalyptus dives or Eucalyptus viminalis. Patches within this community may be dominated by Eucalyptus globulus subsp. bicostata. Plots assigned to this group commonly contains a sparse layer of scattered shrubs and small trees including Acacia dealbata and Acacia melanoxylon, with a patchy to continuous groundlayer of grasses including Poa sieberiana, Microlaena stipoides, Elymus scaber and Themeda australis, the fern Pteridium esculentum and a diverse mix of forbs including Acaena novae-zelandiae, Dichondra repens, Euchiton japonicus, Geranium solanderi, Glycine clandestina, Gonocarpus tetragynus, Hydrocotyle laxiflora, Hypericum gramineum, Lomandra filiformis subsp. filiformis, Plantago varia Senecio prenanthoides, Viola betonicifolia and Wahlenbergia stricta Low shrubs such as Hibbertia obtusifolia and Platylobium montanum are often present.

This community is found on moist sheltered slopes and gullies along lower western margins of the Snowy Mountains and further west on lower outlying ranges. It is commonly recorded from soils of intermediate fertility derived from a wide variety of substrates including granodiorite, granite, rhyolite, sandstone, tuff, psammite and shale. Plots are distributed around the northern and western rims of the Snowy Mountains, associated with lower foothills of the ranges and major valleys and outlying lower western ranges. Records occur from Burrinjuck and lower slopes of the Brindabellas in the north, west and south to Bungongo, Wee Jasper, Billapaloola and Argalong; south along Snubba Range and lower slopes of the upper Goobarragandra and Tumut Rivers; western footslopes of the Bago Range at Courabyra, Tumbarumba and Maragle; to the far south along lower slopes of the upper Murray gorge to Khancoban and Tom Groggin; and on lower ranges to the west including Ellerslie, Downfall and Munderoo.

Community u152 generally occurs on more sheltered slopes and footslopes with somewhat deeper, moister soils than the related Community u105 [Broad-leaved Peppermint - Brittle Gum - Red Stringybark tall shrub-grass dry sclerophyll open forest of lower ranges of the western South Eastern Highlands and upper South Western Slopes bioregions]. At higher altitudes with cooler winters and increasing rainfall it may be replaced by Community u22 [Mountain Gum - Snow Gum grass-forb very tall woodland to open forest of the Australian Alps and South Eastern Highlands bioregions] or Community u52 [Ribbon Gum - Robertson's Peppermint very tall wet sclerophyll open forest primarily of the Bondo Subregion of the South Eastern Highlands and northern Australian Alps bioregions], while at lower elevations on the margins of undulating slopes country it may grade into Community u148 [Red Stringybark - Red Box grass-forb tall open forest of the upper South Western Slopes and western South Eastern Highlands bioregions] or Community u29 [Apple Box-Broad-leaved Peppermint tall shrub-grass woodland primarily on granitoids of the South Eastern Highlands bioregion].

\section{Characteristic Species:}

Species

C/A Freq C/A O FreqOFid

Acacia dealbata

Acacia melanoxylon

Acaena echinata

Acaena novae-zelandiae

Acaena ovina

Acrotriche serrulata

Ajuga australis

Ammobium craspedioides

Amyema pendulum

Asperula conferta

Asperula scoparia

Boronia nana

Brunonia australis

Bulbine bulbosa

Burchardia umbellata

Caladenia carnea

Carex breviculmis

Carex incomitata

Cassinia aculeata

Cassinia longifolia

Cheilanthes austrotenuifolia

Chiloglottis trapeziformis

Corybas spp.

Cymbonotus preissianus

Cynoglossum suaveolens

Daucus glochidiatus

Desmodium varians

Dichelachne crinita

Dichelachne sieberiana

Dichondra repens

Dipodium roseum

Diuris sulphurea

Drosera auriculata

Drosera spp.

Echinopogon intermedius

Echinopogon ovatus

Elymus scaber

Epilobium billardierianum subsp.

cinereum

Eucalyptus bridgesiana

Eucalyptus dives

Eucalyptus globulus subsp. bicostata

Eucalyptus macrorhyncha

Eucalyptus radiata subsp. robertsonii

Eucalyptus viminalis

Euchiton japonicus

Exocarpos cupressiformis

Galium ciliare

Galium gaudichaudii

Galium leiocarpum

Geranium solanderi

Glossodia major

Glycine clandestina

Gompholobium huegelii

Gonocarpus tetragynus

Grevillea rosmarinifolia

Hardenbergia violacea

Hibbertia obtusifolia

Hovea linearis

Hydrocotyle laxiflora

Hypericum gramineum

Leptospermum continentale

Lomandra filiformis subsp. coriacea

Lomandra filiformis subsp. filiformis

Luzula densiflora

Luzula flaccida

Mentha diemenica

Microlaena stipoides

\begin{tabular}{|c|c|c|}
\hline 66 & 2 & 25 \\
\hline 42 & 1 & 13 \\
\hline 49 & 1 & 8 \\
\hline 73 & 1 & 26 \\
\hline 5 & 1 & $<1$ \\
\hline 50 & 1 & 10 \\
\hline 23 & 1 & 7 \\
\hline 5 & 1 & $<1$ \\
\hline 13 & 1 & 2 \\
\hline 29 & 1 & 10 \\
\hline 35 & 2 & 22 \\
\hline 9 & 1 & $<1$ \\
\hline 4 & 2 & $<1$ \\
\hline 30 & 1 & 3 \\
\hline 7 & 1 & $<1$ \\
\hline 19 & 1 & $<1$ \\
\hline 30 & 1 & 12 \\
\hline 11 & 1 & $<1$ \\
\hline 29 & 1 & 13 \\
\hline 38 & 1 & 16 \\
\hline 11 & 1 & 3 \\
\hline 6 & 1 & $<1$ \\
\hline 5 & 1 & $<1$ \\
\hline 47 & 1 & 5 \\
\hline 10 & 1 & 3 \\
\hline 26 & 1 & 8 \\
\hline 32 & 1 & 12 \\
\hline 10 & 1 & 3 \\
\hline 19 & 2 & 5 \\
\hline 54 & 2 & 20 \\
\hline 13 & 1 & $<1$ \\
\hline 7 & 1 & 1 \\
\hline 25 & 1 & 2 \\
\hline 4 & 1 & $<1$ \\
\hline 10 & 1 & $<1$ \\
\hline 41 & 1 & 9 \\
\hline 56 & 1 & 20 \\
\hline 28 & 1 & 4 \\
\hline 37 & 3 & 6 \\
\hline 34 & 3 & 18 \\
\hline 13 & 1 & $<1$ \\
\hline 60 & 3 & 14 \\
\hline 68 & 3 & 7 \\
\hline 24 & 3 & 12 \\
\hline 54 & 1 & 14 \\
\hline 20 & 1 & 3 \\
\hline 5 & 2 & $<1$ \\
\hline 26 & 1 & 9 \\
\hline 12 & 1 & 4 \\
\hline 69 & 1 & 18 \\
\hline 4 & 1 & $<1$ \\
\hline 82 & 1 & 28 \\
\hline 13 & 1 & 4 \\
\hline 81 & 2 & 47 \\
\hline 5 & 1 & $<1$ \\
\hline 26 & 1 & 14 \\
\hline 66 & 1 & 34 \\
\hline 24 & 1 & 13 \\
\hline 81 & 2 & 28 \\
\hline 68 & 1 & 24 \\
\hline 10 & 1 & 1 \\
\hline 38 & 2 & 18 \\
\hline 59 & 1 & 15 \\
\hline 17 & 1 & 5 \\
\hline 47 & 1 & 12 \\
\hline 17 & 1 & 2 \\
\hline 82 & 2 & 33 \\
\hline
\end{tabular}




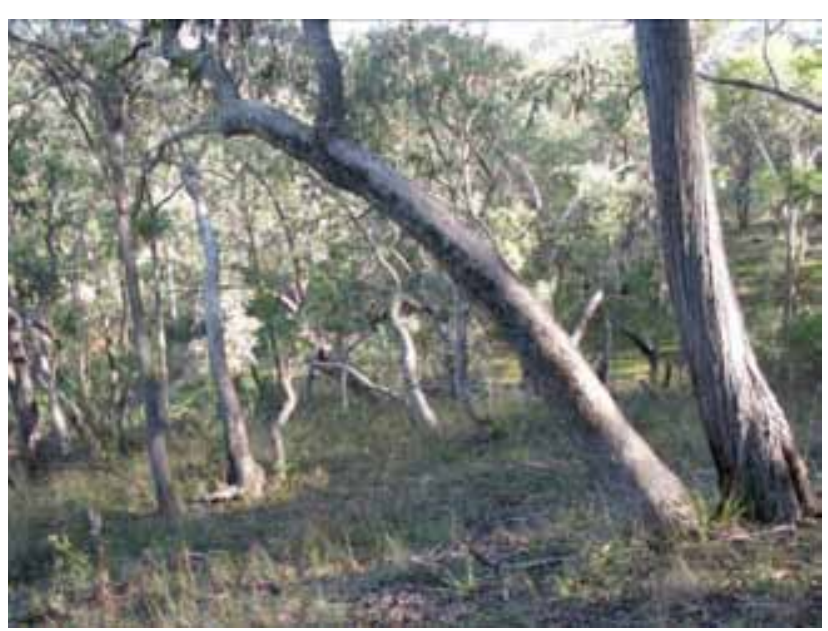

Plate u152: Community u152 on the footslope above Stony Creek, Wereboldera SCA, with Eucalyptus bridgesiana and Eucalyptus macrorhyncha over a scattered low shrubs and a grassy groundcover.

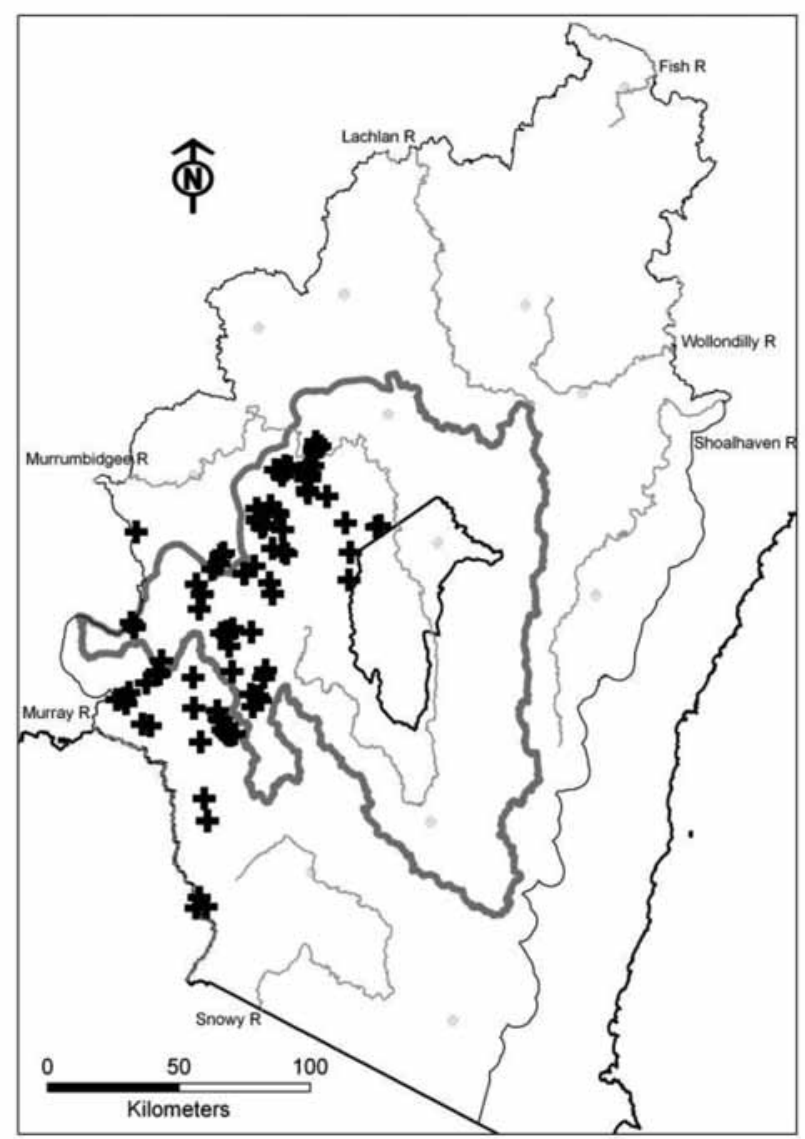

Fig. u152: Distribution of field samples assigned to this community.
Microtis unifolia

Ophioglossum lusitanicum

Oxalis exilis

Oxalis perennans

Oxalis radicosa

Pimelea curviflora

Plantago varia

Platylobium montanum

Poa helmsii

Poa sieberiana

Polygala japonica

Pteridium esculentum

Pterostylis longifolia

Pterostylis nutans

Pterostylis pedunculata

Pultenaea juniperina

Pultenaea polifolia

Ranunculus lappaceus

Ranunculus pachycarpus

Ranunculus scapiger

Ranunculus sessiliflorus

Rytidosperma penicillatum

Rytidosperma pilosum

Rytidosperma racemosum

Scutellaria humilis

Senecio bathurstianus

Senecio diaschides

Senecio prenanthoides

Senecio tenuiflorus

Stackhousia monogyna

Thelymitra pauciflora

Themeda australis

Thysanotus tuberosus

Veronica calycina

Viola betonicifolia

Wahlenbergia stricta

Wurmbea dioica

Stellaria pungens

Threatened communities: Nil.

Equivalent vegetation types: The most strongly related Forest Ecosystems of Gellie (2005) are VG93 [Western Tablelands Herb/Grass Dry Forest] (29 shared plots) and VG94 [South West Slopes Acacia Dry Herb/Grass Forest] (8 plots). Community u152 has affinities with VCA 295 [Robertson's Peppermint - Broad-leaved Peppermint - Norton's Box - stringybark shrub-fern open forest of the NSW South Western Slopes and South Eastern Highlands bioregions] (Benson et al. 2010).

Frequently occurring weeds: Although this community is most common on public land (State Forest and Conservation Reserve), its proximity to land used for domestic stock grazing is reflected in the weed species most commonly recorded. These include Centaurium erythraea (0.42), Cirsium vulgare (0.32), Hypericum perforatum (0.31), Hypochaeris radicata (0.78), Rosa rubiginosa (0.31) and Hypericum perforatum $(0.30)$.

Threats: Most surveyed occurrences of this community are on slopes and foothills of steep country with relatively low suitability for agriculture, and these situations are unlikely to have been widely cleared. It is more likely that some clearing has occurred on the margins of private land where gentler footslopes were considered suitable for pasture development and grazing. Areas in State Forests may be subject to logging and to fire regimes associated with silvicultural management, which may modify vegetation structure and floristic composition over time. Surveyed examples have not been subject to widespread weed invasion, but areas subject to disturbance by grazing animals or vehicles, including logged forests, may be more prone to invasion by weeds. This community is found within the altitude and rainfall band prefered by Hypericum perforatum $->500 \mathrm{~m}$ altitude and $>600 \mathrm{~mm}$ rainfall; Naughton \& Bourke 2007) and may be prone to invasion by this weed. 
Reservation status: Recorded from plots within Burrinjuck NR, Brindabella NP and SCA, Bimberi NR, Wereboldera SCA, Ellerslie NR, Downfall NR, Courabyra NR, Bogandyera NR, Clarkes Hill NR and at numerous locations on the western edge of Kosciuszko NP.

Extent of clearing: In the eastern part of its range (in the foothills of the Kosciuszko main range), this community is unlikely to have been widely cleared. In the western part of its range, where it occurs more often on undulating private land it may have been subject to moderate levels of clearing for pasture development.

References: Benson, J.S., Richards, P.G., Waller, S. \& Allen, C.B. (2010) New South Wales vegetation classification and assessment: Part 3. Plant communities of the NSW Brigalow Belt South, Nandewar and west New England bioregions and update of NSW Western Plains and South Western Slopes plant communities. Version 3 of the NSW VCA database. Cunninghamia 11: 457-579. Botanic Gardens Trust, Sydney; Gellie, N.J.H. (2005) Native vegetation of the southern forests: South Eastern Highlands, Australian Alps, South West Slopes and South East Corner bioregions. Cunninghamia 9: 219-254; Naughton, M. \& Bourke, C.A. (2007) Primefact 694 - St John's Wort (Hypericum perforatum). NSW Department of Primary Industries, Orange.

\section{u165: Robertson's Peppermint very tall shrubby open forest primarily of the Bondo subregion of the South Eastern Highlands}

Scientific Name: Eucalyptus radiata subsp. robertsonii / Platylobium montanum - Hibbertia obtusifolia - Olearia erubescens - Persoonia chamaepeuce - Pteridium esculentum / Lomandra longifolia - Gonocarpus tetragynus - Poa sieberiana

$\begin{array}{ll}\text { Number of samples: } & 23 \\ \text { Richness [mean }( \pm \mathrm{SD})]: & 28(9) \\ \text { Slope (degrees): } & (3) 6-20(30) \\ \text { Altitude (m asl): } & (497) 751-1032(1174) \\ \text { Ave. Annual Rainfall }(\mathrm{mm}): & (836) 989-1249(1383) \\ \text { Temp. Annual Range }\left({ }^{\circ} \mathrm{C}\right): & (24.3) 25-26.8(28.2)\end{array}$

Vegetation Description: Community u 165 is a very tall eucalypt open forest dominated by Eucalyptus radiata subsp. robertsonii, occasionally with other eucalypts including Eucalyptus dives, Eucalyptus dalrympleana or Eucalyptus viminalis. The shrub layer ranges from dense to sparse, with shrubs including Platylobium montanum, Olearia erubescens, Persoonia chamaepeuce, Monotoca scoparia, Exocarpos strictus and Hibbertia obtusifolia. Daviesia latifolia is abundant in recently burnt patches of forest. The ground cover is open to dense and dominated by forbs such as Lomandra longifolia and Gonocarpus tetragynus, with Poa sieberiana being the dominant grass species. The climber Clematis aristata is often present.

This community is distributed primarily in western sections of Kosciuszko NP, extending northwards to the Brindabella ranges and south to the Geehi valley in the Murray catchment. It grades into communities such as Community u105 [Broad-leaved Peppermint Brittle Gum - Red Stringybark tall shrub-grass dry sclerophyll open forest of lower ranges of the western South Eastern Highlands and upper South Western Slopes bioregions], Community u239 [Alpine Ash - Mountain Gum \pm Snow Gum wet sclerophyll open forest of the Australian Alps and South Eastern Highlands bioregions], Community u22 [Mountain Gum - Snow Gum grass-forb very tall woodland to open forest of the Australian Alps and South Eastern Highlands bioregions] and in the Brindabellas, Community u52 [Ribbon Gum - Robertson's Peppermint very tall wet sclerophyll open forest primarily of the Bondo Subregion of the South Eastern Highlands and northern Australian Alps bioregions]. This community may extend further west into the NSW South Western Slopes bioregion.

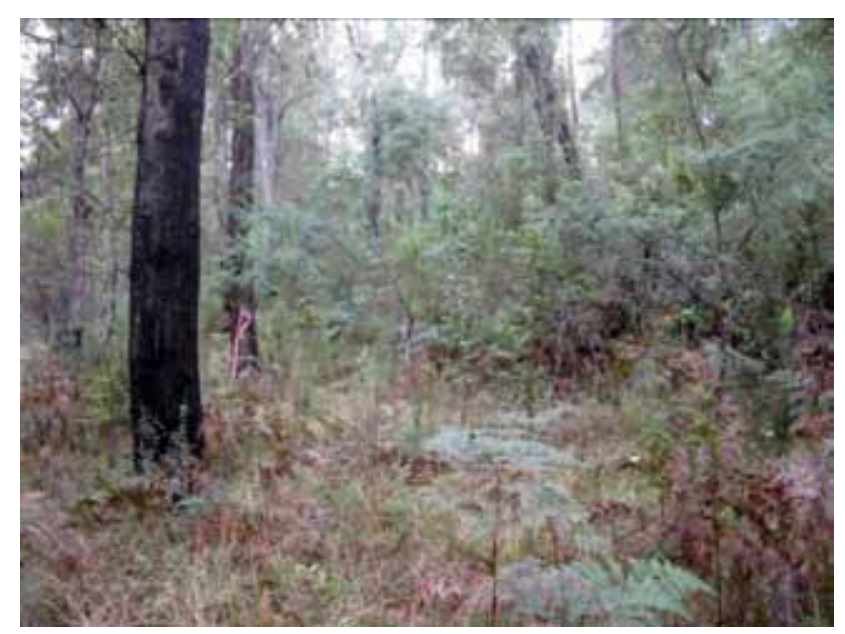

Plate u165: Community u165 beside the Alpine Way south of Geehi Flat (near plot SZ27011M), with a canopy dominated by Eucalyptus radiata subsp. robertsonii above patches of Acacia dealbata and Pomaderris lanigera and a groundcover dominated by Pteridium esculentum and Poa sieberiana.

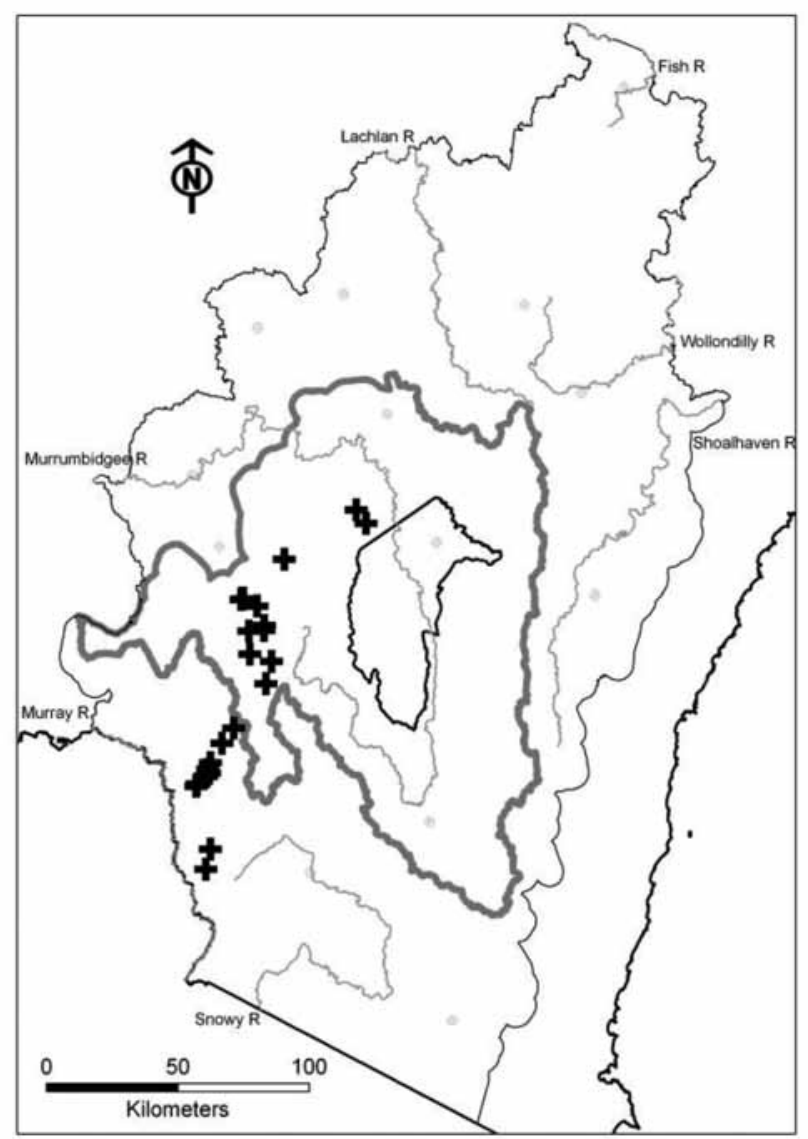

Fig. u165: Distribution of field samples assigned to this community. 


\section{Characteristic Species:}

Species

Acacia rubida

Asperula scoparia

Brachyscome spathulata

Caladenia gracilis

Cassinia uncata

Clematis aristata

Coprosma hirtella

Coprosma quadrifida

Corybas spp.

Craspedia jamesii

Daviesia latifolia

Eucalyptus radiata subsp. robertsonii 3

Exocarpos strictus

Gonocarpus tetragynus

Hibbertia obtusifolia

Lomandra longifolia

Monotoca scoparia

Olearia erubescens

Persoonia chamaepeuce

Pimelea linifolia

Platylobium montanum

Pteridium esculentum

Tetratheca bauerifolia

Poa sieberiana

Viola betonicifolia

\section{Threatened communities: Nil.}

Equivalent vegetation types: This community is most similar to VCA 295 [Robertson's Peppermint - Broad-leaved Peppermint - Norton's Box - stringybark shrub-fern open forest of the NSW South Western Slopes and South Eastern Highlands bioregions] (Benson et al. 2010). It incorporates VG106 [Montane Dry Shrub/Tussock Forest] of Gellie (2005)

Frequently occurring weeds: As with many other forested communities, Hypochaeris radicata $(0.3)$ is the most frequently recorded species.

Threats: There are few threats to the structure or composition of this community, however a future increase in fire frequency may alter the community structure and floristic composition.

Reservation status: Examples of this community are recorded from Brindabella NP and Kosciuszko NP.

Extent of clearing: Considered likely to be minor, although some areas have been cleared for pastoral land or Pinus radiata plantations. Selective logging may also have affected the age-structure of the community in some areas.

References: Benson, J.S., Richards, P.G., Waller, S. \& Allen, C.B. (2010) New South Wales vegetation classification and assessment: Part 3. Plant communities of the NSW Brigalow Belt South, Nandewar and west New England bioregions and update of NSW Western Plains and South Western Slopes plant communities. Version 3 of the NSW VCA database. Cunninghamia 11: 457-579. Botanic Gardens Trust, Sydney; Gellie, N.J.H. (2005) Native vegetation of the southern forests: South Eastern Highlands, Australian Alps, South West Slopes and South East Corner bioregions. Cunninghamia 9: 219-254.

\section{u191: Black Cypress Pine - Brittle Gum tall dry open forest on hills primarily in the Cooma region}

Scientific Name: Callitris endlicheri-Eucalyptus mannifera / Bossiaea buxifolia - Cassinia longifolia - Brachyloma daphnoides / Crassula sieberiana - Oxalis perennans Austrostipa scabra-Chrysocephalum semipapposum

$\begin{array}{ll}\text { Number of samples: } & 14 \\ \text { Richness [mean }( \pm \mathrm{SD})]: & 33(10) \\ \text { Slope (degrees): } & (0) 6-12(26) \\ \text { Altitude (m asl): } & (652) 805-910(996) \\ \text { Ave. Annual Rainfall }(\mathrm{mm}): & (507) 518-540(614) \\ \text { Temp. Annual Range }\left({ }^{\circ} \mathrm{C}\right): & (26.3) 26.9-27.5(27.6)\end{array}$

Vegetation Description: Community u191 is a tall dry open forest to woodland, with a canopy dominated by Callitris endlicheri and Eucalyptus mannifera and occasional Eucalyptus viminalis. The shrub layer is generally sparse and commonly includes Brachyloma daphnoides, Cassinia longifolia and Bossiaea buxifolia, often with dense patches of young Callitris endlicheri. Groundlayer vegetation is generally patchy due to high levels of litter or surface rock, with scattered large tussocks of Rytidosperma pallidum, and frequent forbs of low cover including Crassula sieberiana, Oxalis perennans, Chrysocephalum semipapposum, Gonocarpus tetragynus, grasses including Austrostipa scabra, Rytidosperma spp. and Elymus scaber, the sedge Carex breviculmis and the fern Cheilanthes austrotenuifolia.

Community u191 primarily occurs on earthy sands and lithosols derived from metasediments in hills around Cooma including Mount Gladstone and Binjura NR, extending north along Clear Range and steep lower slopes above the Murrumbidgee River. It is also recorded from steep slopes of the Molonglo River gorge near Queanbeyan. Around Cooma and Clear Range this community grades into Community m51 [Brittle Gum - Scribbly Gum shrub-grass tall dry sclerophyll open forest on exposed quartz-rich slopes and ridges at primarily in the Monaro and Kybeyan - Gourock subregions of the South Eastern Highlands] and Community u178 [Yellow Box \pm Apple Box tall grassy woodland of the South Eastern Highlands] on more fertile soils lines down slope. Around Queanbeyan it grades into Community u66 [Mealy Bundy Red Stringybark grass-herb mid-high open forest of the South Eastern Highlands and Upper Slopes Subregion of the South Western Slopes bioregion].

\section{Characteristic Species:}

Species

Acacia mearnsii

Aristida ramosa

Austrostipa densiflora

Austrostipa scabra

Bossiaea buxifolia

Bothriochloa macra

Brachyloma daphnoides

Callitris endlicheri

Carex breviculmis

Cassinia longifolia

Cheilanthes austrotenuifolia

Chrysocephalum apiculatum

Chrysocephalum semipapposum

Crassula sieberiana

Daucus glochidiatus

Desmodium varians

Dichelachne spp.

Einadia nutans

Elymus scaber

Eucalyptus mannifera

Euchiton involucratus
C/A Freq C/A O FreqO Fid

$\begin{array}{lllll}1 & 36 & 2 & 3 & \mathrm{P} \\ 1 & 43 & 2 & 5 & \mathrm{P} \\ 1 & 21 & 1 & 1 & \mathrm{P} \\ 1 & 79 & 2 & 4 & \mathrm{P} \\ 1 & 64 & 1 & 7 & \mathrm{P} \\ 1 & 29 & 1 & 3 & \mathrm{P} \\ 1 & 64 & 1 & 16 & \mathrm{P} \\ 2 & 86 & 3 & 1 & \mathrm{P} \\ 1 & 64 & 1 & 13 & \mathrm{P} \\ 1 & 64 & 1 & 16 & \mathrm{P} \\ 1 & 64 & 1 & 3 & \mathrm{P} \\ 1 & 43 & 1 & 6 & \mathrm{P} \\ 1 & 79 & 1 & 4 & \mathrm{P} \\ 1 & 93 & 1 & 5 & \mathrm{P} \\ 1 & 43 & 1 & 8 & \mathrm{P} \\ 1 & 43 & 1 & 12 & \mathrm{P} \\ 1 & 21 & 1 & 2 & \mathrm{P} \\ 1 & 36 & 1 & 4 & \mathrm{P} \\ 1 & 71 & 1 & 21 & \mathrm{P} \\ 3 & 57 & 3 & 11 & \mathrm{P} \\ 1 & 64 & 1 & 3 & \mathrm{P}\end{array}$


Grevillea lanigera

Lissanthe strigosa

Lomandra filiformis

Luzula densiflora

Mirbelia oxylobioides

Oxalis perennans

Poa phillipsiana

Rytidosperma spp.

Senecio quadridentatus

Themeda australis

Vittadinia cuneata

Vittadinia muelleri

Wahlenbergia communis

Wahlenbergia gracilis

Wahlenbergia stricta

Xerochrysum viscosum

Gonocarpus tetragynus

Hydrocotyle laxiflora

Poa sieberiana

Rytidosperma pallidum

$\begin{array}{lllll}1 & 29 & 1 & 3 & \mathrm{P} \\ 1 & 50 & 1 & 7 & \mathrm{P} \\ 1 & 21 & 1 & 2 & \mathrm{P} \\ 1 & 36 & 1 & 6 & \mathrm{P} \\ 1 & 21 & 1 & 3 & \mathrm{P} \\ 1 & 86 & 1 & 13 & \mathrm{P} \\ 1 & 29 & 3 & 3 & \mathrm{P} \\ 1 & 71 & 1 & 7 & \mathrm{P} \\ 1 & 29 & 1 & 6 & \mathrm{P} \\ 1 & 57 & 2 & 21 & \mathrm{P} \\ 1 & 36 & 1 & 2 & \mathrm{P} \\ 1 & 21 & 1 & 2 & \mathrm{P} \\ 1 & 29 & 1 & 5 & \mathrm{P} \\ 1 & 36 & 1 & 6 & \mathrm{P} \\ 1 & 57 & 1 & 19 & \mathrm{P} \\ 1 & 29 & 1 & 1 & \mathrm{P} \\ 1 & 71 & 2 & 48 & \mathrm{C} \\ 1 & 43 & 2 & 30 & \mathrm{C} \\ 1 & 57 & 2 & 48 & \mathrm{C} \\ 3 & 43 & 2 & 18 & \mathrm{C}\end{array}$

Plate u191: Eucalyptus mannifera with regenerating and mature Callitris endlicheri and a patchy layer of Rytidosperma pallidum and leaf litter is characteristic of Community u191, as with this example at plot UMC125, Murrumbidgee gorge in Binjura NR north of Cooma.

Equivalent vegetation types: This community was identified from field survey plots completed for the current study, and there is no equivalent Forest Ecosystem identified by Gellie (2005). It is possibly related to VG79 [Montane Dry Shrub/Tussock Grass Forest].

Frequently occurring weeds: This community often contains abundant weed populations, reflecting its susceptibility to over-grazing by domestic, feral or native herbivores. The most commonly recorded species were Acetosella vulgaris (0.29), Echium vulgare (0.36), Eragrostis curvula (0.21), Erophila verna (0.64), Hypericum perforatum (0.29), Hypochaeris glabra (0.29), Hypochaeris radicata (0.57), Linaria arvensis (0.57), Lysimachia arvensis (0.21), Pentaschistis airoides (0.43), Petrorhagia nanteuilii (0.64), Trifolium arvense (0.64) and Vulpia myuros $f$. megalura (0.36).

Threats: Due to the landscape position and infertile soils, the main threat to this community is considered to be over-grazing by domestic, feral or native herbivores. This in turn may facilitate weed invasion. Where the community occurs in close proximity to urban centres, high fire frequency has the potential to impact upon species composition, structure and habitat features such as fallen timber.

Reservation status: This community is sampled from Binjura NR and Molonglo Gorge NR. It is likely to occur in Bullen Range NR and Gigerline NR in the ACT and is known to occur at Scottsdale Reserve (Bush Heritage Australia) north of Bredbo.

Extent of clearing: Likely to be minor as it occurs on low nutrient soils on hills.

References: Gellie, N.J.H. (2005) Native vegetation of the southern forests: South Eastern Highlands, Australian Alps, South West Slopes and South East Corner bioregions. Cunninghamia 9: 219-254.

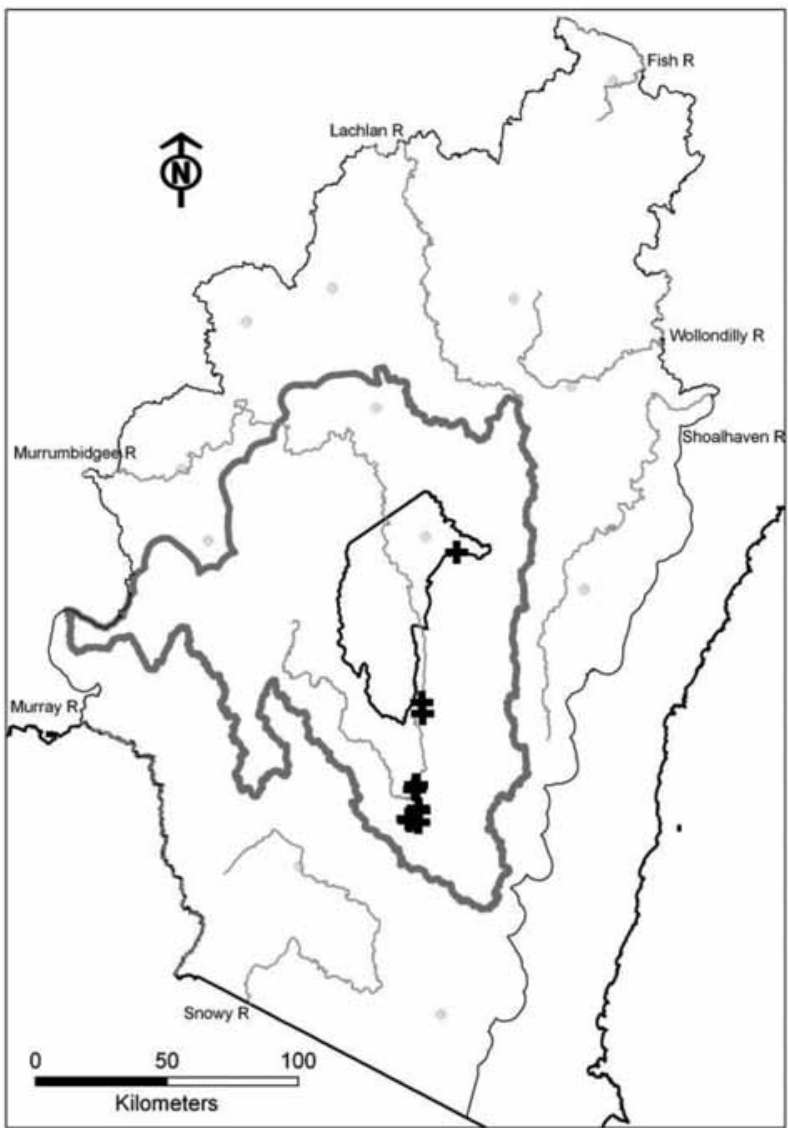

Fig. u191: Distribution of field samples assigned to this community. 


\section{Class: Upper Riverina Dry Sclerophyll Forests}

\section{u43: Mealy Bundy - Acacia implexa - Allocasuari- na verticillata - Ricinocarpos bowmanii tall grassy open woodland on serpentinite in the Coolac- Goobarragandra area primarily of the upper South Western Slopes bioregion}

Scientific Name: Eucalyptus nortonii / Allocasuarina verticillata - Acacia implexa / Ricinocarpos bowmanii Xanthorrhoea glauca subsp. angustifolia / Rytidosperma pilosum - Austrostipa scabra - Themeda australis

Number of samples:

Richness [mean $( \pm \mathrm{SD})]$

Slope (degrees):

Altitude (m asl):

Ave. Annual Rainfall (mm): 4 34 (2)

(9) 14-15 (25)

(237) 505-644 (694)

(687) 972-1083 (1148)

Temp. Annual Range $\left({ }^{\circ} \mathrm{C}\right)$ :

Vegetation Description: Community $\mathrm{u} 43$ is restricted to Cooolac serpentinite, and generally characterised by scattered or isolated Eucalyptus nortonii and Acacia implexa within a sparse to patchy tall shrub layer of Allocasuarina verticillata. Frequently, Allocasuarina verticillata can be the dominant woody species. Distinctive scattered Xanthorrhoea glauca subsp. angustifolia and low Ricinocarpos bowmanii are often present. The groundlayer commonly contains a high diversity of grass taxa including Rytidosperma pilosum, Austrostipa scabra, Bothriochloa macra, Themeda australis, Poa sieberiana, Panicum effusum, Rytidosperma racemosum and Elymus scaber. Plots and observations suggest that this vegetation is also characterised by the presence of Ptilotus species, plants typically found in drier environments west of the study area. Other common groundlayer plants include Carex breviculmis, Lomandra filiformis, Daucus glochidiatus, Senecio quadridentatus, Scutellaria humilis, Tricoryne elatior, Dichondra repens, Cheilanthes sieberi, Pleurosorus rutifolius, Convolvulus angustissimus and Clematis microphylla. Field observations suggest that tree and shrub cover are patchy on the Coolac serpentinite, where this community may occur as a woodland, shrubland or grassland. Patchiness in woody plant cover in this community may result from properties of the serpentinite landscape, past clearing events, or a combination of both.

This distinctive community is restricted to soils derived from the Coolac serpentinite formation, a narrow north-south belt of mixed intrusive/ metamorphic ultramafic rocks running from east of Coolac/Pettits south along the Mooney Mooney and Honeysuckle Ranges through Gobarralong, Brungle Creek, Wyangle to Goobarragandra. These soils are relatively rich in magnesium and iron-group elements (cobalt, chromium, iron, manganese and nickel) and poor in calcium and potassium, conditions which inhibit the growth of some plant species (Lyons et al. 1974). Average annual rainfall along the Honeysuckle Range is moderately high but local conditions may be harsh and dry; soils along this steep-sided range are commonly shallow to skeletal with much exposed rock, and west-facing slopes are likely to experience high summer evaporation rates.

\section{Characteristic Species:}

Species

C/A Freq C/A OFreqO Fid

Acacia decora

Acacia implexa

Acacia penninervis

Allocasuarina verticillata

Austrostipa densiflora

Austrostipa rudis

Austrostipa scabra

Bothriochloa macra

Carex breviculmis

Cheilanthes sieberi

Clematis microphylla

Convolvulus angustissimus

Crassula sieberiana

Daucus glochidiatus

Dichanthium sericeum

Eucalyptus nortonii

Goodenia spp.

Hibbertia calycina

Oxalis exilis

Panicum effusum

Pleurosorus rutifolius

Ptilotus spp.

Ptilotus semilanatus

Ricinocarpos bowmanii

Rytidosperma monticola

Rytidosperma pilosum

Rytidosperma setaceum

Schoenus apogon

Scutellaria humilis

Senecio bathurstianus

Senecio quadridentatus

Themeda australis

Thysanotus patersonii

Tricoryne elatior

Wahlenbergia gracilenta

Wahlenbergia luteola

Xanthorrhoea glauca subsp.

angustifolia

Dichondra repens

Elymus scaber

Gonocarpus tetragynus

Hovea linearis

Hydrocotyle laxiflora

Lomandra filiformis subsp. coriacea

Lomandra filiformis subsp. filiformis 2

Oxalis perennans

Poa sieberiana

Rumex brownii

Rytidosperma racemosum

$\begin{array}{llll}25 & 1 & <1 \quad \mathrm{P}\end{array}$

$\begin{array}{llll}100 & 1 & 2 & \mathrm{P}\end{array}$

$\begin{array}{llll}25 & 2 & <1 \quad \mathrm{P}\end{array}$

$<1 \quad \mathrm{P}$

$1 \quad \mathrm{P}$

$<1 \quad \mathrm{P}$

$4 \quad \mathrm{P}$

$3 \quad \mathrm{P}$

$13 \quad \mathrm{P}$

$9 \quad \mathrm{P}$

$<1 \quad \mathrm{P}$

3 P

$6 \quad \mathrm{P}$

Threatened communities: Nil, but may be eligible for listing.

Equivalent vegetation types: Identified by Mulvaney et al. (2005) as Serpentine Woodland, and by Benson et al. (2010) as VCA 301 [Drooping Sheoke - Ricinocarpus bowmannii - grasstree tall open shrubland of the Coolac - Tumut Serpentinite Belt].

Frequently occurring weeds: Grazed areas of this community are widely invaded by common south-western slopes exotic pasture plants. The following exotic plant taxa were recorded in $30 \%$ or more of plots assigned to this type: Acetosella vulgaris (0.5), Avena barbata (0.5), Briza maxima (1.00), Bromus diandrus (0.75), Bromus hordeaceus (0.5), Carthamus lanatus (0.5), Hypericum perforatum (0.75), Hypochaeris glabra (0.5), Petrorhagia nanteuilii (1), Rosa rubiginosa (0.5), Rostraria cristata (0.5), Sonchus oleraceus (0.5), Trifolium angustifolium (0.75), Trifolium arvense (0.5), Trifolium campestre (0.5), Trifolium dubium (0.5), Trifolium glomeratum (0.5). 


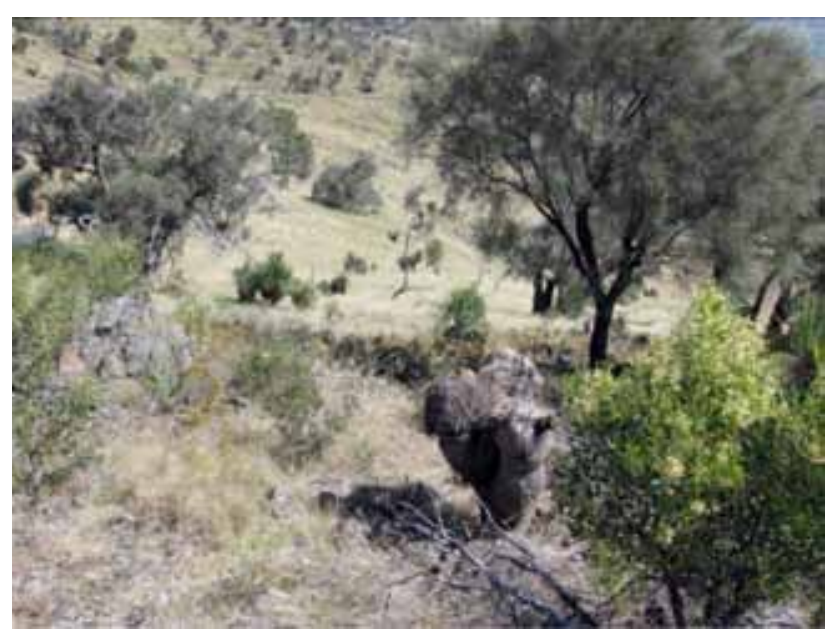

Plate u43: Community u43 with scattered Allocasuarina verticillata, Eucalyptus nortonii and Acacia decora growing on a serpentinite substrate. Honeysuckle Range, plot UMC418.

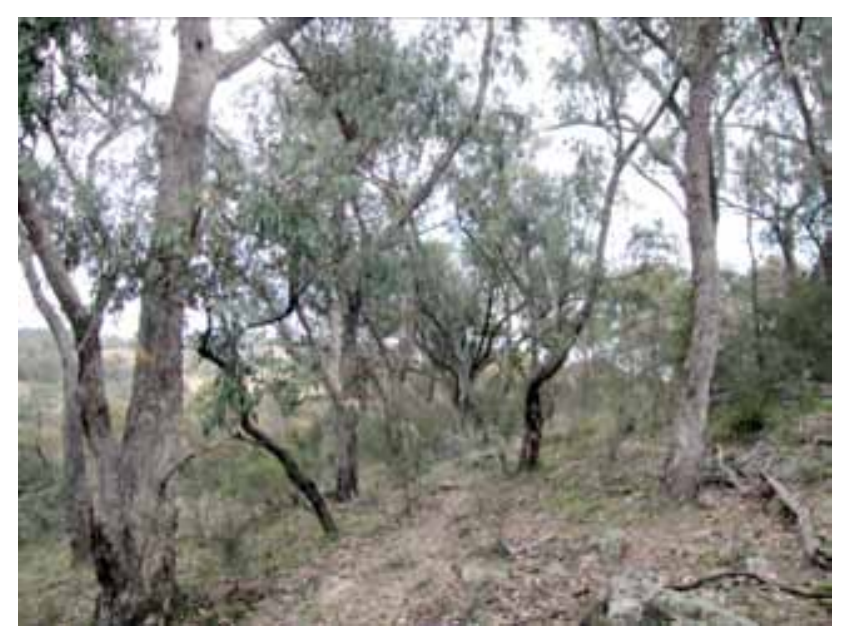

Plate u66: Community u66 dominated by Eucalyptus nortonii with a patchy shrub and ground layer. Isaacs Ridge NR, ACT.

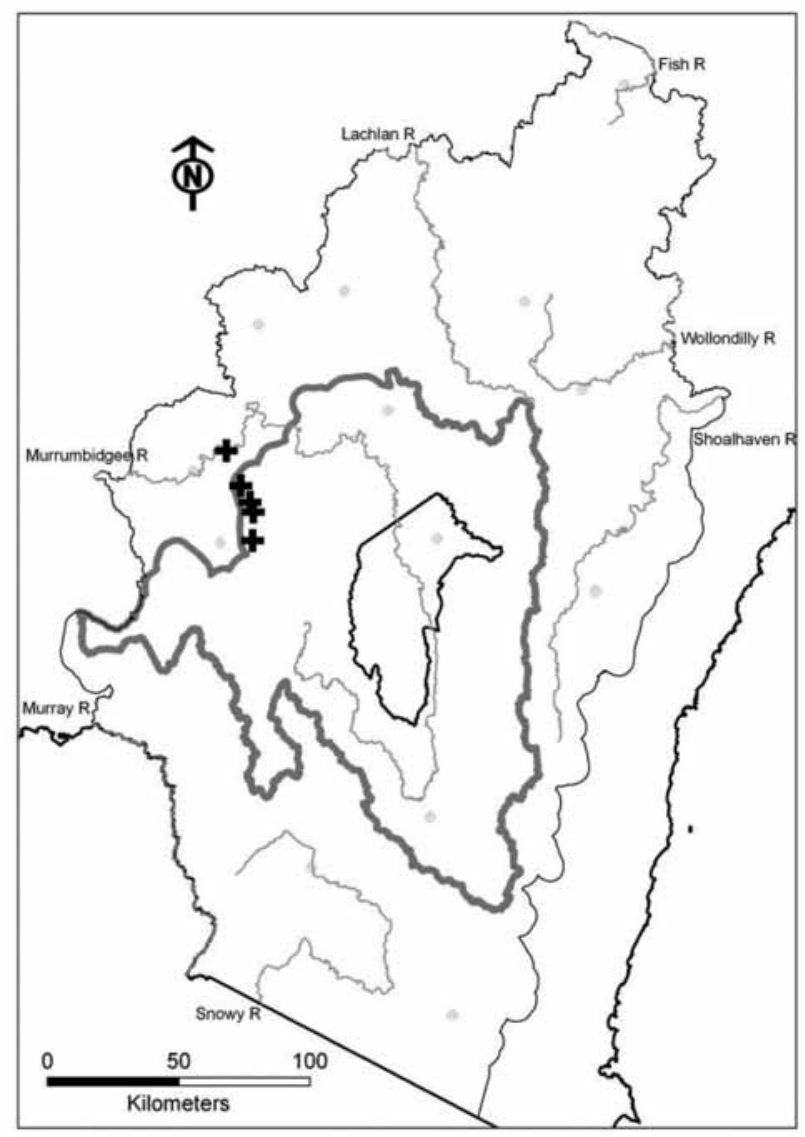

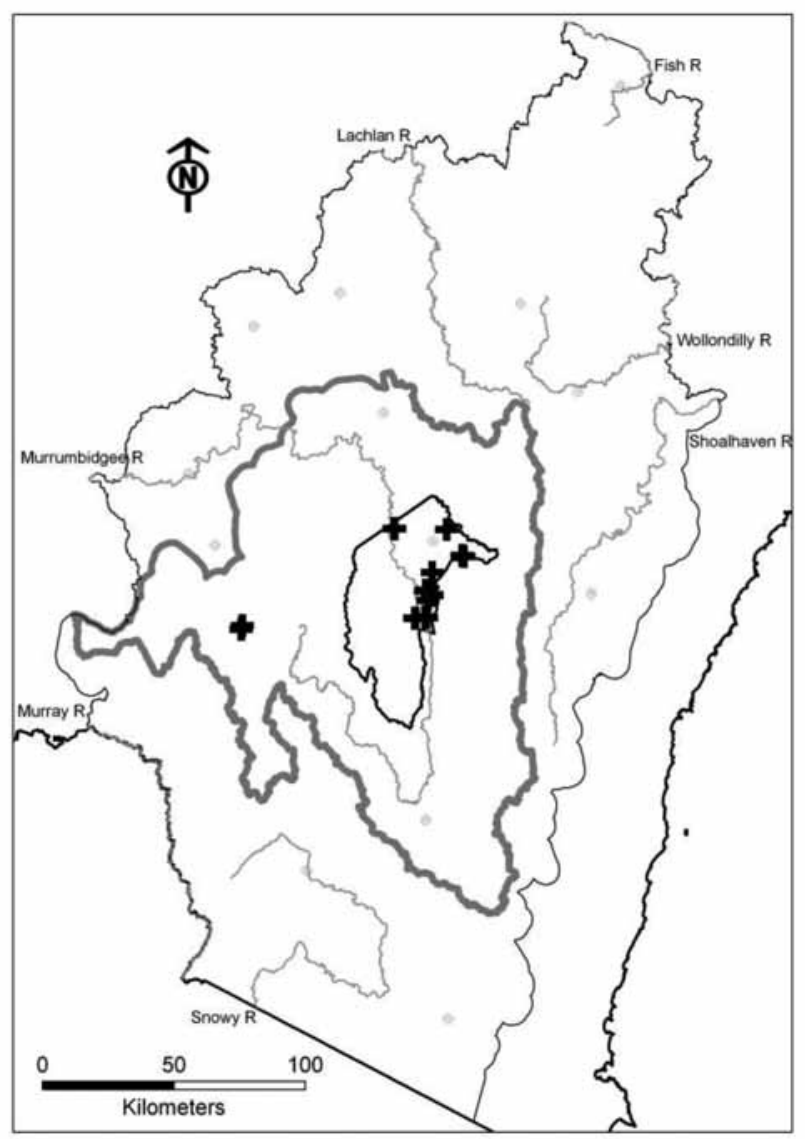

Fig. u43: Distribution of field samples assigned to this community.

Fig. u66: Distribution of field samples assigned to this community. 
Threats: Community u43 is grazed by stock across most of its extent, and some areas have been subject to clearing of tree or shrub layers. Mineral prospecting and mining may have local impacts; past mining took place at Tumut Gold Mine and McAlpine Mine, and significant areas of serpentinite are covered by current mineral exploration licences.

Reservation status: Not represented in any conservation reserves. Small areas exist in two TSRs, at the north and south ends of its range; a larger area is within Red Hill SF (which may be subject to a grazing lease); the remainder is private freehold.

Extent of clearing: Uncertain. Further investigation is required into the causes of the sparse tree and shrub cover observed across this landscape; whether it is partially due to the influence of serpentinite on plant growth, or is an artefact of historic clearing for pasture development. Some areas may have been cleared, but it is also possible that some areas are naturally open.

References: Benson, J.S., Richards, P.G., Waller, S. \& Allen, C.B. (2010) New South Wales vegetation classification and assessment: Part 3. Plant communities of the NSW Brigalow Belt South, Nandewar and west New England bioregions and update of NSW Western Plains and South Western Slopes plant communities. Version 3 of the NSW VCA database. Cunninghamia 11: 457-579. Botanic Gardens Trust, Sydney; Lyons, M.T., Brooks, R.R. \& Craig, D.C. (1974) The influence of soil composition on the vegetation of the Coolac serpentinite belt in New South Wales. Journal and Proceedings of the Royal Society of New South Wales 107: 67-75; Mulvaney, M., Boak, M., Priday, S., Hudson, K. \& Crane, M. (2005) The native vegetation of Gundagai shire. NSW Department of Environment and Conservation, Queanbeyan.

\section{u66: Mealy Bundy - Red Stringybark grass-forb mid-high open forest of the South Eastern High- lands and Upper Slopes Subregion of the South Western Slopes bioregion}

Scientific Name: Eucalyptus nortonii \pm Eucalyptus macrorhyncha - Eucalyptus polyanthemos / Cassinia longifolia - Hibbertia obtusifolia / Poa sieberiana - Daucus glochidiatus - Cheilanthes austrotenuifolia

$\begin{array}{ll}\text { Number of samples: } & 16 \\ \text { Richness [mean }( \pm \mathrm{SD})]: & 41(10) \\ \text { Slope (degrees): } & (8) 12-19(28) \\ \text { Altitude (m asl): } & (443) 613-740(812) \\ \text { Ave. Annual Rainfall }(\mathrm{mm}): & (611) 672-724(1076) \\ \text { Temp. Annual Range }\left({ }^{\circ} \mathrm{C}\right): & (25.8) 26.3-27.1(27.5)\end{array}$

Vegetation Description: Community u66 is a mid-high open woodland to open forest characterised by Eucalyptus nortonii often with Eucalyptus macrorhyncha or Eucalyptus polyanthemos, and occasionally with Brachychiton populneus or Callitris endlicheri. Allocasuarina verticillata and Acacia implexa may be present in low abundance in the midstorey, along with shrubs including Cassinia longifolia, Bursaria spinosa, Pimelea curviflora and Hibbertia obtusifolia. The groundlayer is generally patchy with grasses including Poa sieberiana, Rytidosperma spp. and Austrostipa scabra and forbs including Hydrocotyle laxiflora, Daucus glochidiatus, Acaena ovina, Geranium solanderi, Gonocarpus tetragynus, Lomandra filiformis subsp. filiformis and Wahlenbergia stricta. The fern Cheilanthes austrotenuifolia and sedge Carex appressa may be present.

Community u66 is located mainly on low hills of sandstone and acidvolcanic (ignimbrite, rhyolite, tuff) substrates within the northern ACT and surrounds, with further occurrences sampled from steep slopes around Talbingo to the west. It is likely that this community requires greater floristic sampling to refine its description. Around Canberra, it generally occurs on slightly less fertile soils than Community u29 [Apple Box - Broad-leaved Peppermint tall shrub-grass woodland primarily on granitoids of the South Eastern Highlands bioregion] and
Community u178 [Yellow Box \pm Apple Box tall grassy woodland of the South Eastern Highlands]. Around Talbingo it grades into Community u148 [Red Stringybark - Red Box grass-forb tall open forest of the upper South Western Slopes and western South Eastern Highlands bioregions].

\section{Characteristic Species:}

Species

C/A Freq C/A OFreqO Fid

Acacia implexa

Acaena ovina

Ajuga australis

Allocasuarina verticillata

Austrostipa scabra

Bothriochloa macra

Brachychiton populneus

Bursaria spinosa

Callitris endlicheri

Carex inversa

Cassinia longifolia

Cheilanthes austrotenuifolia

Cheilanthes sieberi

Clematis leptophylla

Crassula sieberiana

Cymbonotus lawsonianus

Cynoglossum suaveolens

Daucus glochidiatus

Desmodium varians

Dodonaea viscosa

Eucalyptus nortonii

Eucalyptus polyanthemos

Euchiton sphaericus

Galium gaudichaudii

Geranium solanderi

Hibbertia obtusifolia

Hydrocotyle laxiflora

Kunzea ericoides

Lepidosperma laterale

Lomandra filiformis subsp. filiformis

Luzula densiflora

Oxalis perennans

Pimelea curviflora

Plantago varia

Poa sieberiana

Pterostylis nana

Pultenaea procumbens

Rumex brownii

Rytidosperma spp.

Scutellaria humilis

Senecio quadridentatus

Vittadinia cuneata

Wahlenbergia spp.

Wahlenbergia stricta

Wurmbea dioica

Glycine clandestina

Gonocarpus tetragynus

Hypericum gramineum

Senecio prenanthoides

\begin{tabular}{|c|c|c|}
\hline 31 & 1 & 2 \\
\hline 69 & 1 & 8 \\
\hline 31 & 1 & 8 \\
\hline 38 & 1 & $<1$ \\
\hline 56 & 2 & 4 \\
\hline 31 & 1 & 3 \\
\hline 31 & 1 & 2 \\
\hline 63 & 1 & 10 \\
\hline 31 & 2 & 1 \\
\hline 63 & 1 & 8 \\
\hline 75 & 1 & 16 \\
\hline 69 & 1 & 3 \\
\hline 50 & 1 & 9 \\
\hline 50 & 1 & 1 \\
\hline 56 & 1 & 5 \\
\hline 38 & 1 & 5 \\
\hline 44 & 1 & 3 \\
\hline 75 & 1 & 8 \\
\hline 56 & 1 & 12 \\
\hline 25 & 1 & 2 \\
\hline 63 & 3 & 3 \\
\hline 31 & 3 & 3 \\
\hline 50 & 1 & 7 \\
\hline 50 & 1 & 10 \\
\hline 69 & 1 & 19 \\
\hline 75 & 1 & 34 \\
\hline 100 & 2 & 29 \\
\hline 38 & 2 & 4 \\
\hline 63 & 1 & 9 \\
\hline 69 & 1 & 16 \\
\hline 38 & 1 & 6 \\
\hline 56 & 1 & 13 \\
\hline 50 & 1 & 6 \\
\hline 44 & 1 & 11 \\
\hline 94 & 2 & 48 \\
\hline 31 & 1 & $<1$ \\
\hline 31 & 1 & 4 \\
\hline 38 & 1 & 9 \\
\hline 63 & 1 & 7 \\
\hline 31 & 1 & 1 \\
\hline 50 & 1 & 5 \\
\hline 31 & 1 & 2 \\
\hline 25 & 1 & 5 \\
\hline 69 & 1 & 18 \\
\hline 38 & 1 & 3 \\
\hline 56 & 1 & 29 \\
\hline 69 & 2 & 48 \\
\hline 56 & 1 & 25 \\
\hline 50 & 1 & 19 \\
\hline
\end{tabular}

\section{Threatened communities: Nil.}

Equivalent vegetation types: No obvious equivalent communities. There are a number of similar VCA plant communities including VCA 294, 297, 306, 310, 311 and 316 (Benson et al. 2010).

Frequently occurring weeds: This community is widely distributed across freehold (leasehold in the ACT) grazing land, and has experienced substantial disturbance and subsequent weed invasion. Weed species typical of the grazing environments of the Southern Tablelands and South Western Slopes are prevalent within this community, most notably 


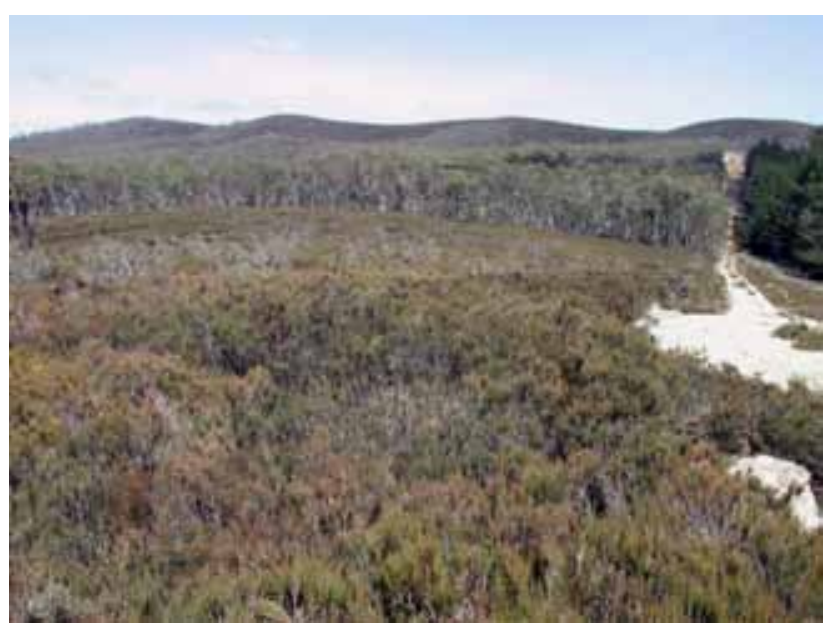

Plate e53: Community e53 in foreground, characterised by dense thickets of Allocasuarina nana. Coolumbooka NR.

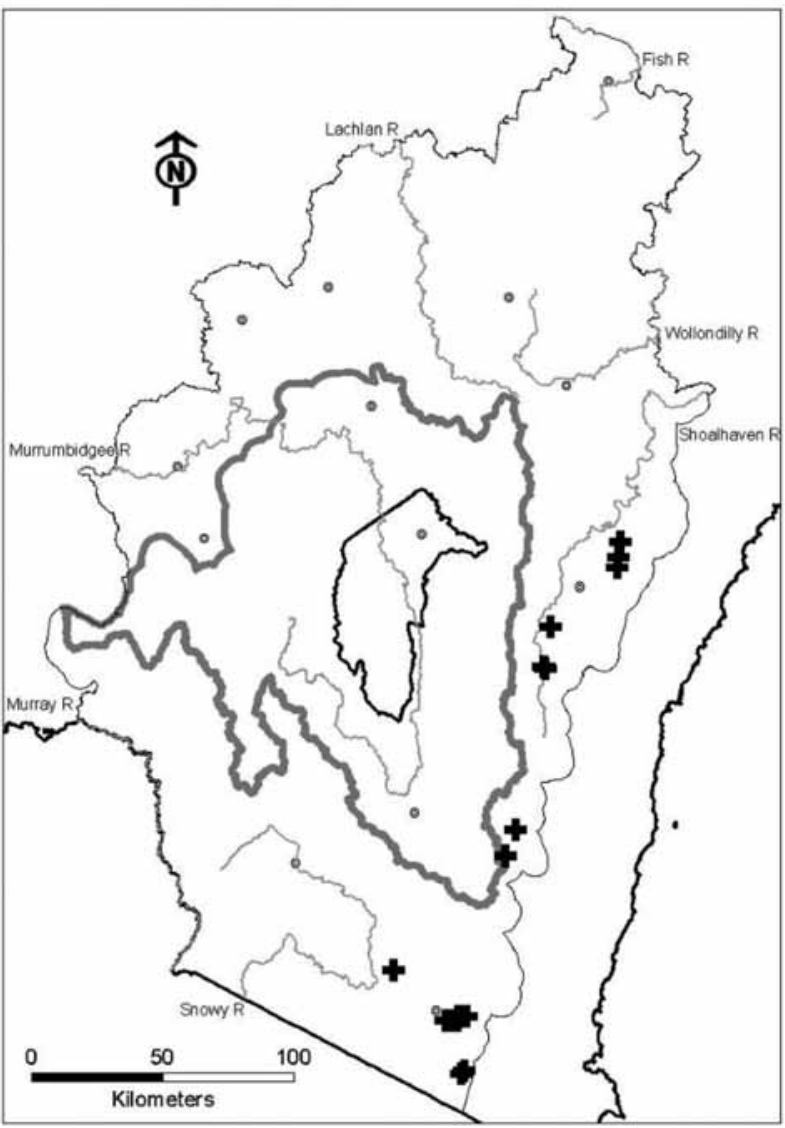

Fig. e53: Distribution of field samples assigned to this community.
Aira elegantissima (0.38), Briza minor (0.31), Bromus diandrus (0.38), Hypericum perforatum (0.38), Hypochaeris radicata (0.75), Lysimachia arvensis (0.31), Orobanche minor (0.31), Petrorhagia nanteuilii (0.5), Rosa rubiginosa (0.44), Sonchus oleraceus $(0.31)$, Trifolium arvense (0.88), Trifolium campestre (0.5), Trifolium glomeratum (0.31) and Vulpia myuros (0.44).

Threats: Grazing continues to degrade this community, reducing native species diversity and encouraging weed invasion. It is also likely that minor to moderate clearing still occurs, along with the removal of fallen timber for firewood.

Reservation status: Examples of this community are found in Kosciuszko NP and Namadgi NP as well as Isaac Ridge, Mt. Majura, Rob Roy Reserve and Tuggeranong Hill Reserve (parts of Canberra Nature Park).

Extent of clearing: Likely to be moderately cleared where it occurs on lower slopes or in close proximity to fertile farming country.

References: Benson, J.S., Richards, P.G., Waller, S. \& Allen, C.B. (2010) New South Wales vegetation classification and assessment: Part 3. Plant communities of the NSW Brigalow Belt South, Nandewar and west New England bioregions and update of NSW Western Plains and South Western Slopes plant communities. Version 3 of the NSW VCA database. Cunninghamia 11: 457-579. Botanic Gardens Trust, Sydney.

\section{Formation: Heathlands}

\section{Class: Southern Montane Heaths}

\section{e53: Allocasuarina nana shrubland on exposed skeletal ridges primarily in the eastern South East- ern Highlands bioregion}

Scientific Name: Allocasuarina nana - Brachyloma daphnoides / Lomandra glauca - Gonocarpus tetragynus Stylidium graminifolium sens. lat.
Number of samples:
Richness [mean $( \pm \mathrm{SD})]$
Slope (degrees):
Altitude (m asl):
Ave. Annual Rainfall (mm):
Temp. Annual Range $\left({ }^{\circ} \mathrm{C}\right)$ :

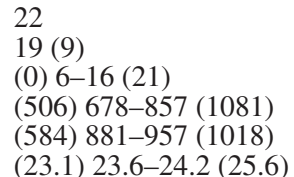

Vegetation Description: Community e53 is a dense shrubland to 1.5 metres tall (but often less that 0.5 metres) dominated by Allocasuarina nana and Brachyloma daphnoides, with Hakea dactyloides frequently occurring as an emergent to 3 metres tall. Epacris impressa, Dampiera spp. and prostrate shrubs including Isopogon prostratus and Mirbelia platylobioides are also common. Where breaks in the dense shrub layer occur, patches of grasses and sedges are common, including Rytidosperma pallidum, Lomandra glauca and Lepidosperma tortuosum, along with forbs including Stylidium graminifolium sens. lat., Gonocarpus tetragynus and Patersonia sericea var. longifolia. The Endangered (TSC Act 1995) Westringia kydrensis and Dampiera fusca are known to occur in this community, as are the rare Euryomyrtus denticulata and Haloragodendron monospermum. Species diversity appears to increase further north of the upper Murrumbidgee catchment. Occasionally, sparse to isolated emergent Eucalyptus dives or other eucalypts from adjacent forest communities may be present.

Community e53 is defined by data from sites extending from Coolumbooka NR (east of Bombala) to north of Mongarlowe. Within the upper Murrumbidgee catchment, it is known to occur on exposed 
slopes and ridges in Dangelong NR south of Numeralla, and may occur further north within the catchment in similar situations on the western fall of the Great Divide. It occurs on skeletal sandy loams derived from metasediments, acid volcanics or granitoids, and is likely to occur in exposed areas associated with Community p9 [Brittle Gum - Scribbly Gum shrubby tall dry open forest] and Community e24 [Mountain Gum - Snow Gum subalpine very tall dry shrubby open forest primarily in the Kybeyan - Gourock subregion of the South Eastern Highlands bioregion], and possibly other communities on ridge country in the east of the upper Murrumbidgee catchment.

\section{Characteristic Species:}

Species

Allocasuarina nana Austrostipa pubinodis Brachyloma daphnoides Cassytha glabella

Dampiera spp.

Entolasia stricta

Epacris impressa

Gompholobium huegelii

Gompholobium minus

Hakea dactyloides

Isopogon prostratus

Lepidosperma gunnii

Lepidosperma tortuosum

Lomandra glauca

Mirbelia platylobioides

Patersonia sericea var. longifolia

Platysace lanceolata

Rytidosperma pallidum

Rytidosperma tenuius

Stylidium graminifolium sens. lat.

Gonocarpus tetragynus

\section{Threatened communities: Nil.}

Equivalent vegetation types: This community is equivalent to HLe53 [Southern Montane Heath] described by Tozer et al. (2010), and overlaps with the communities VG134 [Eastern Tablelands Dry Heath] and VG135 [Southern Escarpment (Wadbilliga) Moist Heath] identified by Gellie (2005), with the latter type defined by additional dominant species including Kunzea sp. 'Wadbilliga' and Banksia canei.

Frequently occurring weeds: No exotic taxa have been recorded from this community, probably due to its occurrence on exposed and infertile substrates.

Threats: Because this community occurs on soils of low fertility and in exposed situations, clearing has been minimal. Grazing threats are likely to be minimal due to a dominance of relatively unpalatable species and difficulty of stock penetrating its dense shrubby layer. Infrequent fire may be changing the structure and composition of this community, with observations suggesting an optimum burn frequency of once every 10 -25 years (J. Miles, pers. comm.). Too frequent fire may affect the occurrence of obligate seeders.

Reservation status: While the distribution within the upper Murrumbidee catchment is unknown, all known examples are conserved in Dangelong NR. To the east of the upper Murrumbidgee catchment, more than $50 \%$ of the esimated pre-clearing extent of Community e53 (as defined by Tozer et al. 2010) is considered to be reserved.

Extent of clearing: Due to its occurrence in exposed locations and on soils of low fertility, this community is considered to be largely intact (Tozer et al. 2010).

References: Gellie, N.J.H. (2005) Native vegetation of the southern forests: South Eastern Highlands, Australian Alps, South West Slopes and South East Corner bioregions. Cunninghamia 9: 219-254; Tozer,
M.G., Turner, K., Keith, D.A., Tindall, D., Pennay, C., Simpson, C. MacKenzie, B., Beukers, P. \& Cox, S. (2010) Native vegetation of southeast NSW: a revised classification and map for the coast and eastern tablelands. Cunninghamia 11: 359-406.

\section{Formation: Forested Wetlands}

\section{Class: Eastern Riverine Forests}

\section{p32d: River She-oak riparian forest on sand/gravel alluvial soils along major watercourses of the South Eastern Highlands and upper South Western Slopes bioregions}

\author{
Scientific Name: Casuarina cunninghamiana / Acacia \\ dealbata / Microlaena stipoides - Dichondra repens \\ - Lomandra longifolia - Echinopogon ovatus - Poa \\ labillardierei
}

\author{
Number of samples: \\ Richness [mean $( \pm \mathrm{SD})]$ : \\ Slope (degrees): \\ Altitude ( $\mathrm{m}$ asl): \\ Ave. Annual Rainfall (mm): \\ Temp. Annual Range $\left({ }^{\circ} \mathrm{C}\right)$ :
}

15

28 (8)

(0) 5-26 (36)

(259) 507-622 (702)

(688) 697-728 (909)

(25.5) 26.3-27.6 (28.6)

Vegetation Description: Community p32d is characterised by a tall tree canopy of Casuarina cunninghamiana. The shrub layer is often sparse and may include scattered Acacia dealbata, Bursaria spinosa or Kunzea ericoides, and patches of young Casuarina cunninghamiana plants. Groundlayer is often dominated by bare soil/rock and thick litter of Casuarina cunninghamiana branchlets, and a dense tree canopy often contributes to a shady moist ground environment. Groundlayer plants may be sparse or patchy, and frequent species include Dichondra repens, Echinopogon ovatus, Geranium solanderi, Microlaena stipoides, Poa labillardierei, Rumex brownii, Hydrocotyle laxiflora, Lomandra longifolia and a variety of small ferns and sedges.

This community occurs across the study area on major rivers and streams including the Murrumbidgee, Abercrombie, Tarlo and Wollondilly Rivers. Plots assigned to Community p32d by the current study were recorded from the Retreat and Abercrombie Rivers in the north of the study area to lower altitudes on rivers in the ACT, on the Murrumbidgee River below Burrinjuck Dam and along the Goodradigbee River. This community occurs on river gravel, cobbles and coarse sandy alluvium along permanent and semi-permanent watercourses in relatively narrow confined channels subject to high-velocity flows. On meandering tableland watercourses with deeper, finer-grained alluvial silts and loams, it is replaced by Community u173 [River Red Gum \pm Apple Box very tall grass-forb riparian woodland on alluvial flats in the South Eastern Highlands and upper South Western Slopes bioregions]. To the west of the study area where major rivers cut through deep fine-grained silts and loams and sand lenses on broad river flats, it is replaced on riverbanks by a mixed River Red Gum - River She-oak community (e.g. see Mulvaney et al. 2005), which occurs in the study area on broad sandy flats on the Murrumbidgee at Jugiong and Gobarralong in the South Western Slopes. A similar but distinct River She-oak dominated community with increasing elements of moist eucalypt forest and rainforest in the midstorey and groundlayer (FoWp32 described by Tozer et al. 2010) occurs to the east of the study area in coastal escarpment streams. 


\section{Characteristic Species:}

Species

Adiantum aethiopicum

Asplenium flabellifolium

Bursaria spinosa

Carex spp.

Casuarina cunninghamiana

Cheilanthes sieberi

Dichondra repens

Echinopogon ovatus

Eucalyptus bridgesiana

Geranium solanderi

Kunzea ericoides

Microlaena stipoides

Pellaea falcata

Plantago debilis

Poa labillardierei

Rumex brownii

Rytidosperma racemosum

Senecio quadridentatus

Urtica incisa

Acacia dealbata

Acaena novae-zelandiae

Hydrocotyle laxiflora

Lomandra longifolia

Stellaria pungens

\section{C/A Freq C/A OFreqO Fid}

$\begin{array}{ll}1 & 38 \\ 1 & 44 \\ 1 & 50 \\ 2 & 25 \\ 4 & 100 \\ 1 & 38 \\ 2 & 81 \\ 1 & 63 \\ 1 & 31 \\ 1 & 56 \\ 3 & 38 \\ 2 & 94 \\ 1 & 25 \\ 2 & 25 \\ 1 & 50 \\ 1 & 63 \\ 2 & 38 \\ 2 & 38 \\ 1 & 38 \\ 2 & 56 \\ 2 & 50 \\ 2 & 56 \\ 2 & 75 \\ 2 & 50 \\ & \end{array}$

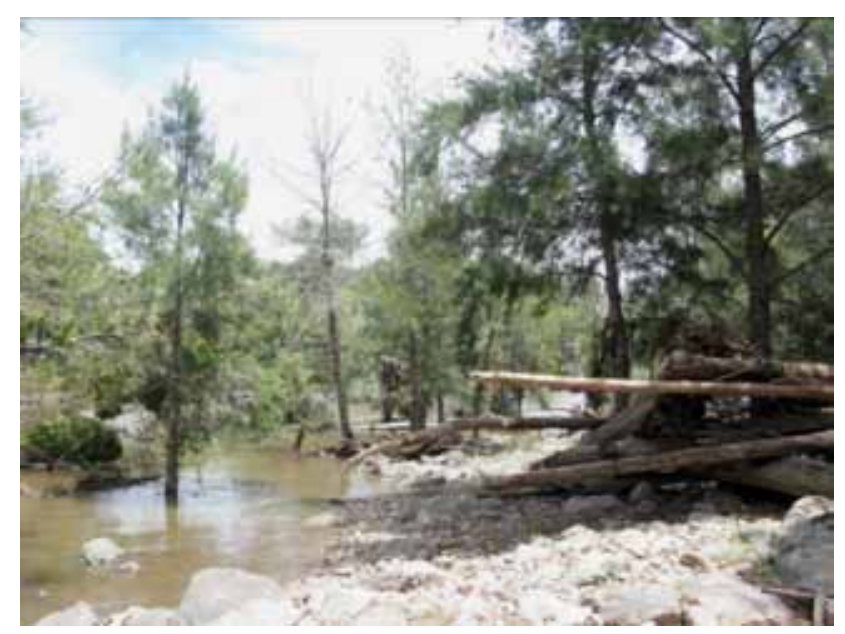

Plate p32d: Community p32d on the Murrumbidgee River beside Nanangroe Road (plot UMC404), dominated by Casuarina cunninghamiana with woody debris from December 2010 floods.

\section{Threatened communities: Nil.}

Equivalent vegetation types: This community is closely related to FoWp32 [Riverbank Forest] described by Tozer et al. (2010) for the coast and tablelands. The inclusion of additional tableland and slopes field samples in the current study area indicates that a split is warranted between the moist Casuarina cunninghamiana forests of the coast and coastal escarpments with their rainforest and wet sclerophyll elements, and the drier Casuarina cunninghamia forests of the tablelands and slopes containing elements of adjacent dry forests and woodlands. Community p32d also represents a dry subset of VG53 [Riparian Acacia Shrub/Grass/Herb Forest] described by Gellie (2005), and is described by Benson et al. (2010) as VCA 85 [River Oak forest and woodland wetland of the NSW South-western Slopes and South Eastern Highlands bioregions].

Frequently occurring weeds: This community is susceptible to invasion by a wide variety of exotic plant species. The following taxa were recorded from $30 \%$ or more of plots assigned to this community: Acetosella vulgaris (0.57), Cirsium vulgare (0.36), Conyza bonariensis (0.43), Euphorbia peplus (0.36), Holcus lanatus (0.36), Hypochaeris radicata (0.71), Lysimachia arvensis (0.43), Modiola caroliniana (0.43), Plantago lanceolata (0.36), Prunella vulgaris (0.43), Rosa rubiginosa (0.43), Rubus fruticosus sp. agg. (0.5), Sonchus oleraceus (0.79).

Threats: Generally not cleared, as it tends to be restricted to a narrow band of relatively infertile sand/gravel/cobble alluvium subject to frequent flooding. In some tableland rural environments a narrow strip of this community may be the only extant woody vegetation. However, many examples of this community across all tenures are degraded by weed invasion, and examples on private land are commonly subject to frequent stock grazing.

Reservation status: Plots were recorded from Abercrombie River NP, Brindabella SCA, Burrinjuck NR, Razorback NR and Tarlo River NP in NSW, and Woodstock NR, Stony Creek NR, Bullen Range NR and Kambah Pool Recreation Area in the ACT. Likely to occur in many other conservation reserves along permanent watercourses in dissected country.

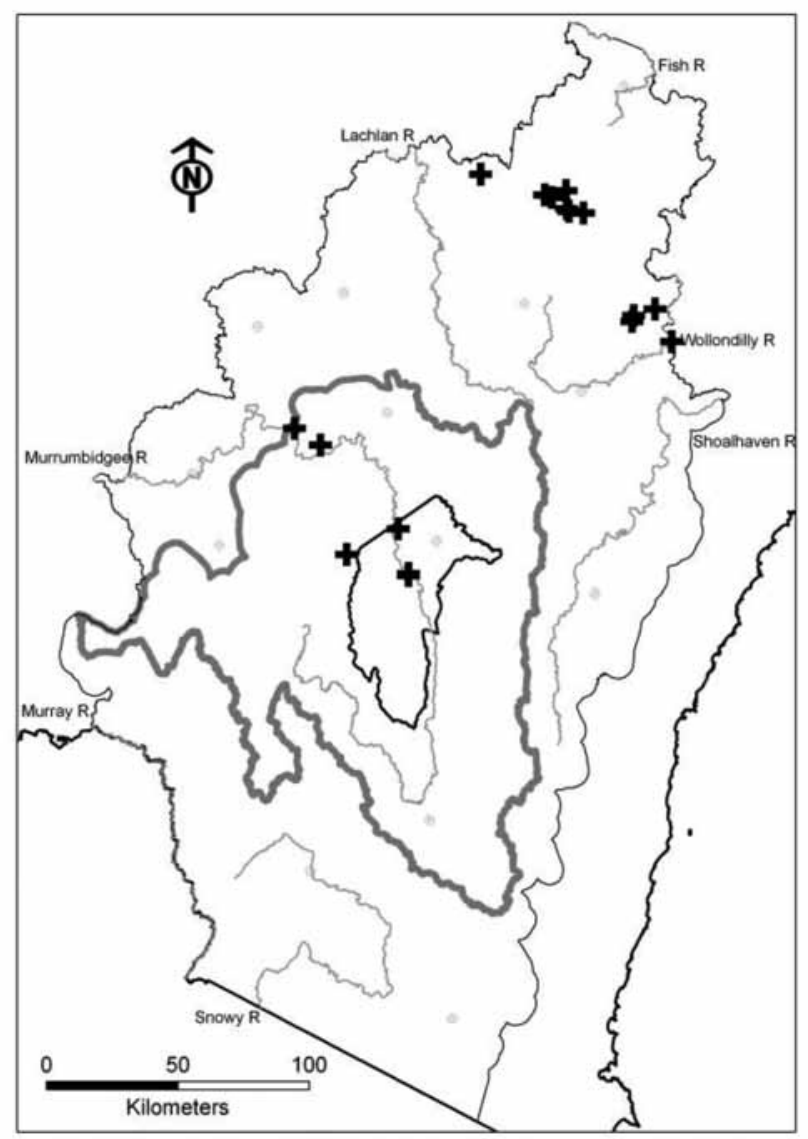

Extent of clearing: Generally minor.

Fig. p32d: Distribution of field samples assigned to this community. 
References: Benson, J.S., Richards, P.G., Waller, S. \& Allen, C.B. (2010) New South Wales vegetation classification and assessment: Part 3. Plant communities of the NSW Brigalow Belt South, Nandewar and west New England bioregions and update of NSW Western Plains and South Western Slopes plant communities. Version 3 of the NSW VCA database. Cunninghamia 11: 457-579. Botanic Gardens Trust, Sydney; Gellie, N.J.H. (2005) Native vegetation of the southern forests: South Eastern Highlands, Australian Alps, South West Slopes and South East Corner bioregions. Cunninghamia 9: 219-254; Tozer, M.G., Turner, K., Keith, D.A., Tindall, D., Pennay, C., Simpson, C., MacKenzie, B., Beukers, P. \& Cox, S. (2010) Native vegetation of southeast NSW: a revised classification and map for the coast and eastern tablelands. Cunninghamia 11: 359-406.

\section{p56: Leptospermum grandifolium - Hakea mi- crocarpa - Lomatia myricoides very tall riparian shrubland of the eastern South Eastern Highlands bioregion}

Scientific Name: Leptospermum grandifolium - Hakea microcarpa - Lomatia myricoides - Leptospermum obovatum / Carex gaudichaudiana - Poa labillardierei Scirpus polystachyus

Number of samples:

Richness [mean ( \pm SD)]:

Slope (degrees):

Altitude (m asl):

Ave. Annual Rainfall (mm):

Temp. Annual Range $\left({ }^{\circ} \mathrm{C}\right)$ :

9

24 (5)

(1) 3-6 (21)

(505) 721-916 (993)

(605) 710-916 (1032)

(23.2) 24.2-25.9 (26.5)

Vegetation Description: Community p56 is a distinctive riparian shrubland that occurs in a narrow band along beds and lower terraces of rivers and major streams of the eastern southern tablelands where substrates are dominated by exposed bedrock with shallow to skeletal pockets of coarse sand, gravel or cobble alluvium. A tree layer is often absent, or exists as scattered small individuals of from adjacent plant communities including Eucalyptus viminalis and Eucalyptus pauciflora subsp. pauciflora. A characteristic dense to patchy layer of low to tall shrubs is commonly dominated by Hakea microcarpa, Leptospermum grandifolium, Leptospermum obovatum, Lomatia myricoides and other riparian taxa. Groundlayer ranges from dense to patchy depending on flood disturbance and levels of bare rock and open water cover; areas of exposed sandy soil are commonly bound by tussocks of Poa labillardierei, Lomandra longifolia and Carex appressa and soft herbs including Epilobium spp., Hydrocotyle sibthorpioides and Acaena novae-zelandiae, while flow-lines, pools and wet banks contain a mix of aquatic and semi-aquatic plants commonly including Carex gaudichaudiana, Juncus, Ranunculus and Myriophyllum spp. and tall clumps of Scirpus polystachyus.

This community is recorded from eastern tableland streams subject to frequent high-velocity flows, including the upper Shoalhaven and upper Tuross Rivers, Bredbo River, Big Badja River, Maclaughlin River, Bombala River, Dragon Swamp Creek and White Rock River, and is likely to occur on other streams across this range with suitable rocky alluvial habitat. Where deeper sandy alluvial deposits develop, this community is replaced by Community p520 [Ribbon Gum very tall woodland on alluvial soils along drainage lines of the eastern South Eastern Highlands bioregion]. Further to the west on similar shallow sand/gravel/cobble alluvium it is replaced by Community u 181 [Callistemon sieberi - Kunzea ericoides rocky riparian tall shrubland in the South Eastern Highlands and upper South Western Slopes bioregions].

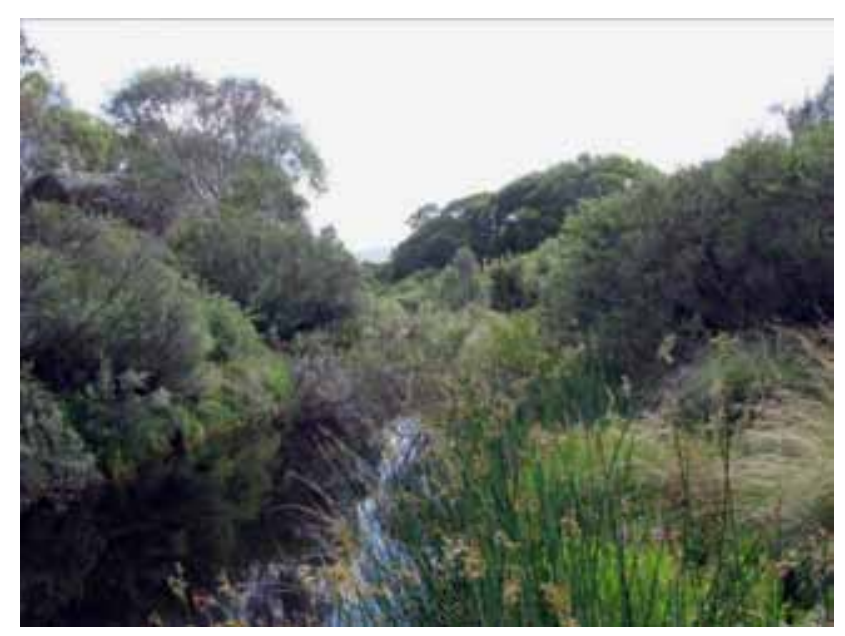

Plate p56: Community p56 with Leptospermum obovatum and a diverse array of grasses, sedges, rushes and forbs fringing the Bredbo River south of Jerangle, Frogs Hollow TSR (plot UMC425).

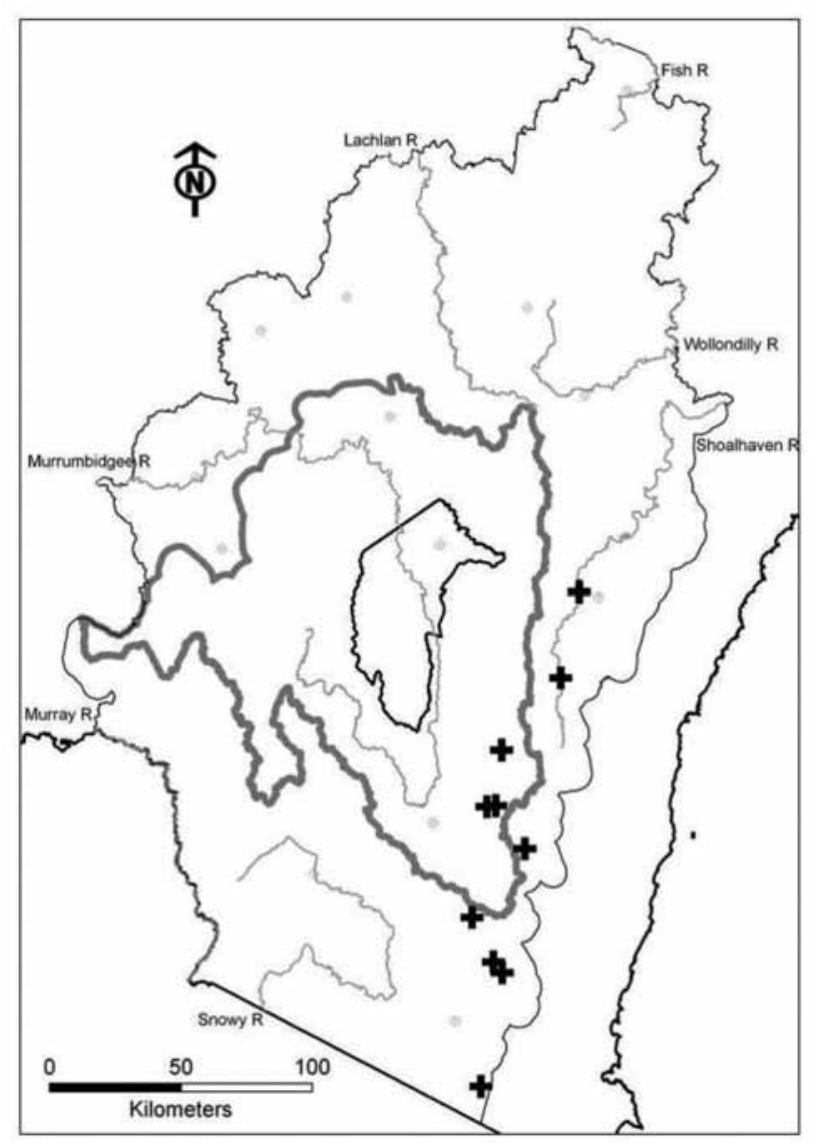

Fig. p56: Distribution of field samples assigned to this community. 


\section{Characteristic Species:}

Species

Acacia siculiformis

Blechnum minus

Callistemon subulatus

Carex gaudichaudiana

Elatine gratioloides

Epilobium spp.

Eucalyptus viminalis

Grevillea lanigera

Hakea microcarpa

Hydrocotyle sibthorpioides

Hypericum japonicum

Juncus falcatus

Juncus gregiflorus

Leptospermum grandifolium

Leptospermum lanigerum

Leptospermum obovatum

Lomatia myricoides

Micrantheum hexandrum

Myriophyllum spp.

Ozothamnus ferrugineus

Persicaria prostrata

Poa labillardierei

Pultenaea altissima

Ranunculus amphitrichus

Schoenoplectus validus

Scirpus polystachyus

Typha orientalis

Acaena novae-zelandiae

Elymus scaber
Carex appressa

Lomandra longifolia

\section{C/A Freq C/A OFreqO Fid}

$\begin{array}{lllll}2 & 22 & 1 & <1 & \mathrm{P} \\ 2 & 22 & 1 & 1 & \mathrm{P} \\ 2 & 33 & 1 & <1 & \mathrm{P} \\ 2 & 44 & 1 & 7 & \mathrm{P} \\ 3 & 89 & 2 & 4 & \mathrm{P} \\ 1 & 33 & 1 & <1 & \mathrm{P} \\ 2 & 67 & 1 & 1 & \mathrm{P} \\ 1 & 67 & 3 & 13 & \mathrm{P} \\ 2 & 44 & 1 & 3 & \mathrm{P} \\ 2 & 78 & 1 & 3 & \mathrm{P} \\ 2 & 44 & 2 & 4 & \mathrm{P} \\ 2 & 44 & 1 & 4 & \mathrm{P} \\ 2 & 22 & 1 & <1 & \mathrm{P} \\ 2 & 22 & 1 & <1 & \mathrm{P} \\ 3 & 67 & 3 & 2 & \mathrm{P} \\ 5 & 22 & 2 & <1 & \mathrm{P} \\ 3 & 56 & 1 & <1 & \mathrm{P} \\ 2 & 56 & 1 & 12 & \mathrm{P} \\ 1 & 22 & 1 & <1 & \mathrm{P} \\ 2 & 33 & 2 & <1 & \mathrm{P} \\ 1 & 22 & 2 & <1 & \mathrm{P} \\ 1 & 22 & 2 & 1 & \mathrm{P} \\ 2 & 89 & 2 & 10 & \mathrm{P} \\ 1 & 33 & 1 & <1 & \mathrm{P} \\ 1 & 44 & 2 & <1 & \mathrm{P} \\ 2 & 22 & 1 & <1 & \mathrm{P} \\ 2 & 67 & 1 & <1 & \mathrm{P} \\ 1 & 22 & 0 & 0 & \mathrm{P} \\ 2 & 44 & 1 & 28 & \mathrm{C} \\ 1 & 44 & 1 & 21 & \mathrm{C} \\ 2 & 56 & 2 & 42 & \mathrm{C}\end{array}$

Threatened communities: Nil.

Equivalent vegetation types: This community is equivalent to FrWp56 [Shoalhaven Riparian Scrub] identified by Tozer et al. (2010), with the addition of a new plot from the Bredbo River.

Frequently occurring weeds: This riparian community is relatively moist and is subject to frequent disturbance by flooding, so is prone to invasion by a variety of exotic plant species. The following taxa were recorded from $30 \%$ or more of plots assigned to this community: Acetosella vulgaris (0.33), Anthoxanthum odoratum (0.33), Holcus lanatus (0.67), Hypochaeris radicata (0.44), Plantago lanceolata (0.33), Prunella vulgaris $(0.56)$.

Threats: Weed invasion is likely to be the main ongoing threat to this community, particularly invasive perennial weeds such as Rubus fruticosus spp. agg. and Hypericum perforatum with the ability to survive major floods and gradually dominate the riparian zone and displace native plants.

Reservation status: Recorded from Deua NP and South East Forest $\mathrm{NP}$, also likely to occur in many other conservation reserves along the eastern tableland ranges.

Extent of clearing: Likely to be very minor due to its rocky, floodprone habitat.

References: Tozer, M.G., Turner, K., Keith, D.A., Tindall, D., Pennay, C., Simpson, C., MacKenzie, B., Beukers, P. \& Cox, S. (2010) Native vegetation of southeast NSW: a revised classification and map for the coast and eastern tablelands. Cunninghamia 11: 359-406.

\title{
u181: Callistemon sieberi - Kunzea ericoides rocky riparian tall shrubland in the South Eastern High- lands and upper South Western Slopes bioregions
}

Scientific Name: Callistemon sieberi - Kunzea ericoides Acacia rubida-Bursaria spinosa / Rumex brownii-Lythrum hyssopifolia - Lomandra longifolia

\author{
Number of samples: \\ Richness [mean $( \pm \mathrm{SD})]$ : \\ Slope (degrees): \\ Altitude ( $\mathrm{m}$ asl): \\ Ave. Annual Rainfall (mm): \\ Temp. Annual Range $\left({ }^{\circ} \mathrm{C}\right)$ :
}

10

$25(6)$

(360) 462-607 (749)

Vegetation Description: Community u181 is characteristically a tall to low riparian shrubland, with a patchy to dense layer of shrubs commonly dominated by Callistemon sieberi and Kunzea ericoides with scattered Acacia rubida and Bursaria spinosa. Scattered emergent or flood-stunted trees sometimes occur. Ground cover tends to be dominated by exposed rock and bare sand/gravel alluvium, with scattered or patchy low moisture-loving plants including sedge and rush tussocks of Lomandra longifolia, Juncus spp. and Carex appressa, with forbs including Lythrum hyssopifolia, Rumex brownii, Persicaria spp. and Epilobium spp. and grasses such as Rytidosperma racemosum, Microlaena stipoides and Elymus scaber. Eucalyptus camaldulensis may be found as part of or adjacent to this community, where it is at the eastern edge of its range.

This community has been recorded from the Murrumbidgee River (around Michelago, Gigerline and Greenway), the Molonglo gorge and a Queanbeyan River tributary, in Yass River gorge and tributaries (Bogolong Creek), and on the Goobarragandra River east of Tumut. It was also observed on Lerida Creek near Gunning, and may occur elsewhere across western parts of the study area in suitable rocky riparian habitats. This community appears to be restricted to riparian areas of exposed rocky substrate with skeletal or shallow pockets of gravelly soil along western tableland streams, often in confined gorges through hilly country but also on small bedrock reefs exposed in streams through undulating tableland/slopes country.

\section{Characteristic Species:}

Species

Acacia dawsonii

Acacia rubida

Alternanthera denticulata

Bursaria spinosa

Callistemon sieberi

Callitris endlicheri

Calytrix tetragona

Carex appressa

Cassinia spp.

Cheilanthes sieberi

Dodonaea viscosa subsp.

angustissima

Epilobium spp.

Eucalyptus camaldulensis

Juncus spp.

Juncus usitatus

Kunzea ericoides

Leptospermum obovatum

Lespedeza juncea subsp. sericea

Lythrum hyssopifolia

Paspalum distichum

Persicaria hydropiper
C/A Freq C/A O FreqO Fid

$\begin{array}{lllll}1 & 20 & 1 & <1 & \mathrm{P} \\ 2 & 70 & 1 & 6 & \mathrm{P} \\ 1 & 20 & 1 & <1 & \mathrm{P} \\ 1 & 60 & 1 & 10 & \mathrm{P} \\ 2 & 100 & 2 & <1 & \mathrm{P} \\ 2 & 40 & 3 & 1 & \mathrm{P} \\ 2 & 30 & 2 & 1 & \mathrm{P} \\ 1 & 50 & 1 & 7 & \mathrm{P} \\ 1 & 20 & 1 & 1 & \mathrm{P} \\ 1 & 50 & 1 & 9 & \mathrm{P} \\ 1 & 50 & 1 & <1 & \mathrm{P} \\ & & & & \\ 1 & 20 & 1 & 1 & \mathrm{P} \\ 3 & 20 & 4 & <1 & \mathrm{P} \\ 1 & 30 & 1 & 2 & \mathrm{P} \\ 1 & 20 & 1 & <1 & \mathrm{P} \\ 2 & 90 & 2 & 4 & \mathrm{P} \\ 1 & 20 & 3 & <1 & \mathrm{P} \\ 2 & 30 & 1 & <1 & \mathrm{P} \\ 1 & 60 & 1 & <1 & \mathrm{P} \\ 2 & 20 & 2 & <1 & \mathrm{P} \\ 2 & 20 & 1 & <1 & \mathrm{P}\end{array}$


Persicaria prostrata Pomaderris angustifolia Rumex brownii Rytidosperma racemosum Acacia dealbata Elymus scaber Geranium solanderi Lomandra longifolia Microlaena stipoides Poa labillardierei Themeda australis

$\begin{array}{llll}2 & 20 & 2 & 1 \\ 1 & 20 & 1 & <1 \\ 1 & 70 & 1 & 9 \\ 2 & 50 & 2 & 10 \\ 1 & 40 & 2 & 26 \\ 2 & 50 & 1 & 21 \\ 1 & 50 & 1 & 19 \\ 2 & 60 & 2 & 42 \\ 2 & 50 & 2 & 34 \\ 2 & 40 & 2 & 10 \\ 1 & 50 & 2 & 21\end{array}$

$\mathrm{P}$
$\mathrm{P}$
$\mathrm{P}$
$\mathrm{P}$
$\mathrm{C}$
$\mathrm{C}$
$\mathrm{C}$
$\mathrm{C}$
$\mathrm{C}$
$\mathrm{C}$
$\mathrm{C}$

Threatened communities: Nil.

Equivalent vegetation types: This community has no equivalent Forest Ecosystem (Gellie 2005), however some plots were originally part of VG82 [Montane Acacia Fern/Herb Forest]. It appears to have affinities with VCA 333 [Bottlebrush riparian shrubland wetland of the northern NSW South-western Slopes and southern Brigalow Belt South bioregions] (Benson et al. 2010).

Frequently occurring weeds: Community u181 occurs along stream channels where moist conditions and frequent flooding and grazing disturbance allow the arrival, survival and reproduction of a wide variety of exotic plants. The following exotic species were recorded from $30 \%$ or more of the plots assigned to this type: Acetosella vulgaris (0.60), Avena fatua (0.30), Briza maxima (0.30), Briza minor (0.50), Bromus diandrus (0.50), Bromus hordeaceus (0.30), Conyza bonariensis (0.40), Crataegus monogyna (0.30), Cynara cardunculus (0.40), Cynosurus echinatus (0.40), Cyperus eragrostis (0.40), Dactylis glomerata (0.30), Hypericum perforatum (0.80), Hypochaeris glabra (0.40), Hypochaeris radicata (0.50), Juncus bufonius (0.30), Lysimachia arvensis (0.70), Paspalum dilatatum (0.30), Petrorhagia nanteuilii (0.60), Plantago lanceolata (0.90), Polycarpon tetraphyllum (0.40), Rosa rubiginosa (0.60), Rubus fruticosus spp. agg. (0.70), Rumex crispus (0.40), Sanguisorba minor (0.30), Sonchus asper (0.30), Sonchus oleraceus (0.30), Trifolium angustifolium (0.40), Trifolium arvense (0.70), Trifolium campestre (0.50), Vulpia myuros $f$. megalura (0.70).

Threats: Unlikely to have been widely cleared. Examples on freehold land are likely to be grazed except where streambanks have been protected by fencing. The habitat of this community is moist and subject to occasional flooding disturbance and it is highly prone to invasion by riparian weeds and exotic plants of adjacent pasture lands.

Reservation status: Plots of this community sampled in the ACT were located in Bullen Range NR, Molonglo Gorge NR and Gigerline NR. None of the plots from NSW assigned to this type were located in a conservation reserve; however plot distribution suggests that it may possibly occur in a range of reserves containing suitable rocky riparian habitat including Cuumbeun NR, northern Kosciuszko NP, Hattons Corner NR and Burrinjuck NP. This community was sampled and observed in a few TSRs.

Extent of clearing: Although restricted to moist riparian habitats, the rocky substrate of this type means it is unlikely to have been widely cleared.

References: Benson, J.S., Richards, P.G., Waller, S. \& Allen, C.B. (2010) New South Wales vegetation classification and assessment: Part 3. Plant communities of the NSW Brigalow Belt South, Nandewar and west New England bioregions and update of NSW Western Plains and South Western Slopes plant communities. Version 3 of the NSW VCA database. Cunninghamia 11: 457-579. Botanic Gardens Trust, Sydney; Gellie, N.J.H. (2005) Native vegetation of the southern forests: South Eastern Highlands, Australian Alps, South West Slopes and South East Corner bioregions. Cunninghamia 9: 219-254.

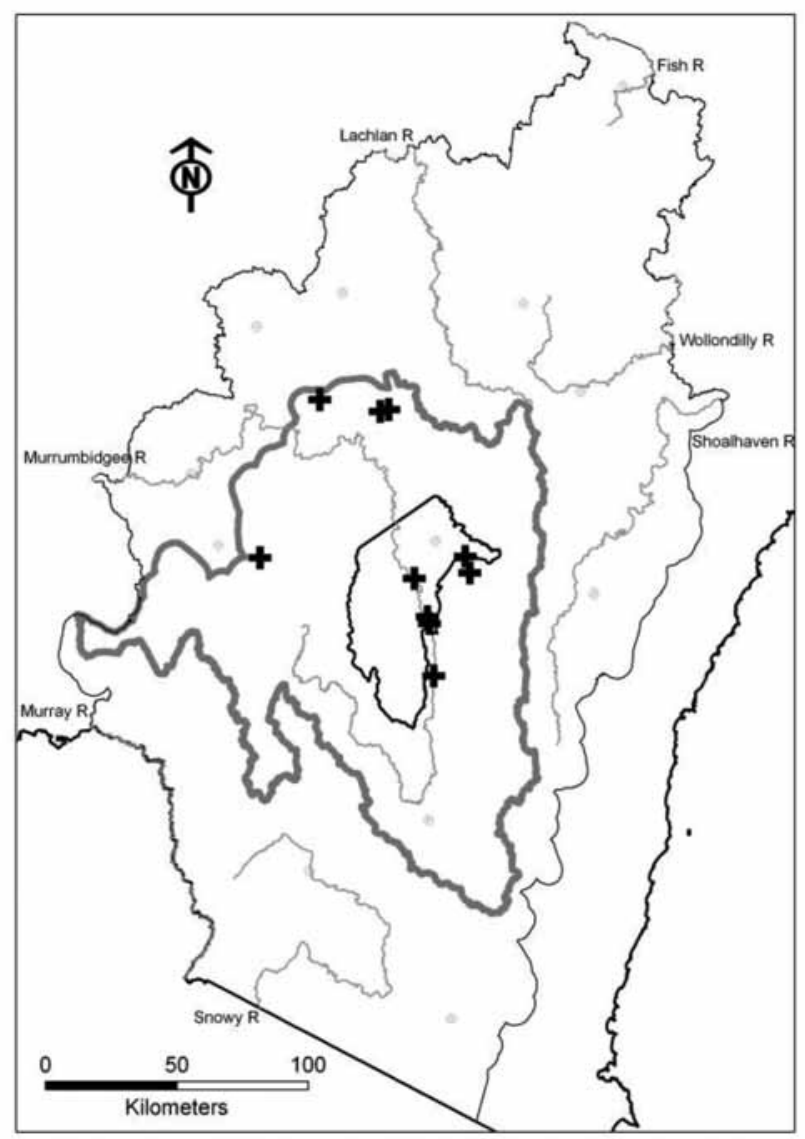

Plate u181: Community u181 on a scoured rocky bank of the Goobragandra River (plot UMC414), with a diverse array of shrubs, sedges, grasses and forbs surviving in skeletal soil pockets, dominated by Callistemon sieberi.

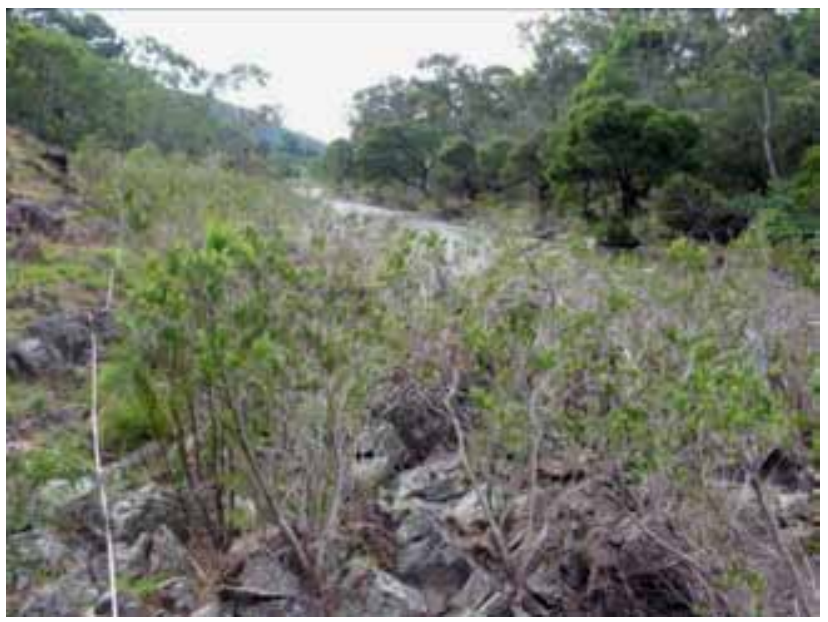




\section{Class: Inland Riverine Forests}

\section{u173: River Red Gum \pm Apple Box very tall grass- forb riparian woodland on alluvial flats in the South Eastern Highlands and upper South Western Slopes bioregions}

Scientific Name: Eucalyptus camaldulensis \pm Eucalyptus bridgesiana / Carex appressa - Geranium solanderi Themeda australis - Microlaena stipoides - Lythrum hyssopifolia

$\begin{array}{ll}\text { Number of samples: } & 6 \\ \text { Richness [mean }( \pm \mathrm{SD})]: & 16(10) \\ \text { Slope (degrees): } & (1) 2-8(13) \\ \text { Altitude (m asl): } & (286) 451-570(769) \\ \text { Ave. Annual Rainfall }(\mathrm{mm}): & (643) 654-753(867) \\ \text { Temp. Annual Range }\left({ }^{\circ} \mathrm{C}\right): & (26.6) 26.7-27.8(27.8)\end{array}$

Vegetation Description: Community u173 is a woodland to open forest characterised by an open, tall to very tall canopy of Eucalyptus camaldulensis and/or Eucalyptus bridgesiana above occasional scattered tall shrubs of Acacia deanei. A moderately dense, moist groundlayer commonly includes patches of grasses such as Themeda australis, Microlaena stipoides and Rytidosperma racemosum and forbs including Lythrum hyssopifolia, Geranium solanderi and Rumex brownii. Streambanks and overflow pools often support tall clumps of Carex appressa, Juncus gregiflorus and Typha domingensis, while calmer pools and wet exposed muddy banks may contain Myriophyllum crispatum and other aquatic plants.

This community is found on moderately fertile alluvial flats of meandering creeks and rivers of the western tablelands and upper slopes. It has been very widely cleared and remnants are often heavily disturbed. In the current study, based on only six survey plots, it is recorded along tributaries of the upper Lachlan River (at Lade Vale, Rye Park and Wheeo Creek) and the Murrumbidgee River (sampled on Yass River flats near Murrumbateman and a Tumut River tributary at Brungle, and observed on Jugiong Creek at Childowla Road TSR).

Within its range, Community u173 may be replaced by Community u181 [Callistemon sieberi - Kunzea ericoides rocky riparian tall shrubland in the South Eastern Highlands and upper South Western Slopes bioregions] in confined reaches of streams where alluvium is reduced to skeletal pockets over bedrock. On sections of stream with increased flow velocity and sand/gravel/cobble alluvium, it may be replaced by Community p32d [Casuarina cunninghamiana dry forest on sand/gravel alluvial soils along major watercourses of the South Eastern Highlands and upper South Western Slopes bioregions]. On riparian flats of the lower slopes and plains to the west of the current study area, Community u173 will grade into other River Red Gum dominated communities, such as the River Red Gum Forest described by Mulvaney et al. (2005) from Gundagai Shire.

\section{Characteristic Species:}

Species

Acacia deanei

Carex appressa

Eucalyptus bridgesiana

Eucalyptus camaldulensis

Juncus gregiflorus

Lythrum hyssopifolia

Myriophyllum crispatum

Typha domingensis

Geranium solanderi

Microlaena stipoides

Themeda australis
C/A Freq C/A O FreqO Fid

$\begin{array}{llll}33 & 1 & 1 & \mathrm{P} \\ 100 & 1 & 7 & \mathrm{P} \\ 50 & 3 & 7 & \mathrm{P} \\ 83 & 3 & <1 & \mathrm{P} \\ 33 & 1 & <1 & \mathrm{P} \\ 50 & 1 & <1 & \mathrm{P} \\ 33 & 2 & <1 & \mathrm{P} \\ 33 & 3 & <1 & \mathrm{P} \\ 50 & 1 & 19 & \mathrm{C} \\ 50 & 2 & 34 & \mathrm{C} \\ 50 & 2 & 21 & \mathrm{C}\end{array}$

Threatened communities: Nil, although it is highly rare / threatened within the region and may be eligible for listing.

Equivalent vegetation types: Plots allocated to this type include both plots within the broader analysis area classified by Gellie (2005) as VG43 [Western Slopes Riparian Moist Sedge Woodland], to which Community u173 has some affinities. It also has some affinities with VCA 79 [River Red Gum shrub/grass riparian tall woodland or open forest wetland mainly in the Upper Slopes subregion of the NSW South Western Slopes bioregion and western South East Highlands bioregion] (Benson et al. 2010).

Frequently occurring weeds: This community is restricted to moist, moderately fertile alluvial soils and is often heavily grazed and subject to occasional flooding disturbance, so is prone to invasion by a wide variety of exotic plant species. The following exotic plant species were recorded from $30 \%$ or more of the plots assigned to this type: Acetosella vulgaris (0.50), Bromus diandrus (0.33), Bromus hordeaceus (0.33), Cirsium vulgare (0.33), Cynosurus echinatus (0.50), Holcus lanatus (0.83), Hypochaeris radicata (0.50), Lolium perenne (0.33), Paspalum dilatatum (0.50), Phalaris aquatica (0.50), Rosa rubiginosa (0.33), Rubus fruticosus spp. agg. (0.33), Rumex crispus (0.33) and Trifolium campestre (0.33). Streambanks throughout much of the original extent of this type have been invaded by or are planted with exotic willow trees (Salix spp.).

Threats: The productive alluvial flats occupied by this community have been very widely cleared and converted to exotic pasture and/or are regularly cropped. Many surviving remnants are likely to be subject to ongoing stock grazing and invasion by weeds. Changes to stream hydrology in some catchments resulting from dams, changed runoff rates and bed-lowering may lead to long-term shifts in the composition of remnants of this community.

Reservation status: Only one plot assigned to this community is located in a conservation reserve (Burrinjuck NR). This community was also sampled and observed in a few TSRs.

Extent of clearing: Whilst limited in natural distribution, this community has been very widely cleared for agricultural development.

References: Benson, J.S., Richards, P.G., Waller, S. \& Allen, C.B. (2010) New South Wales vegetation classification and assessment: Part 3. Plant communities of the NSW Brigalow Belt South, Nandewar and west New England bioregions and update of NSW Western Plains and South Western Slopes plant communities. Version 3 of the NSW VCA database. Cunninghamia 11: 457-579. Botanic Gardens Trust, Sydney; Gellie, N.J.H. (2005) Native vegetation of the southern forests: South Eastern Highlands, Australian Alps, South West Slopes and South East Corner bioregions. Cunninghamia 9: 219-254; Mulvaney, M., Boak, M., Priday, S., Hudson, K. \& Crane, M. (2005) The native vegetation of Gundagai shire. NSW Department of Environment and Conservation, Queanbeyan. 


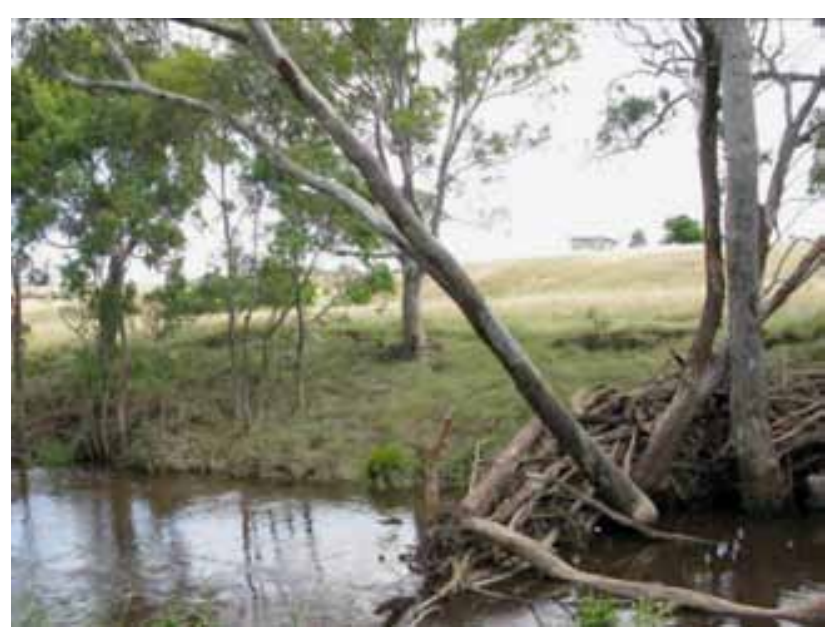

Plate u173: Community u173 as a narrow band of Eucalyptus camaldulensis over Poa labillardiere $i$ var. labillardiere $i$ and various sedges, on alluvial sediments along the Yass River at the Greenwood Road crossing (plot UMC405).

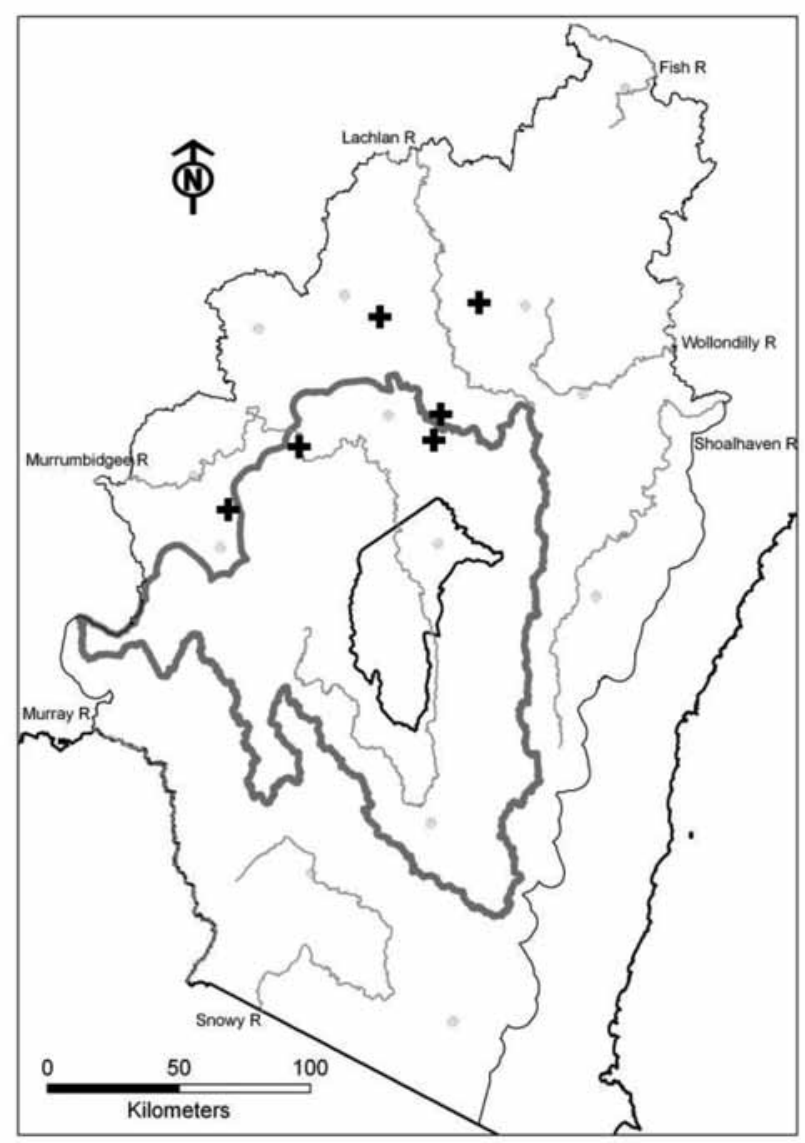

Fig. u173: Distribution of field samples assigned to this community.

\section{Formation: Freshwater Wetlands}

\section{Class: Montane Bogs and Fens}

\section{9: Carex gaudichaudiana-Ranunculus amphitri- chus - Phragmites australis aquatic herbfield of wa- terways in the Australian Alps and South Eastern Highlands bioregions}

Scientific Name: Carex gaudichaudiana - Ranunculus amphitrichus - Carex appressa - Phragmites australis Hydrocotyle tripartita - Epilobium pallidiflorum - Lythrum salicaria

$\begin{array}{ll}\text { Number of samples: } & 6 \\ \text { Richness [mean }( \pm \mathrm{SD})]: & 9(3) \\ \text { Slope (degrees): } & (0) 0-1(2) \\ \text { Altitude (m asl): } & (975) 978-1065(1150) \\ \text { Ave. Annual Rainfall }(\mathrm{mm}): & (772) 978-1304(1366) \\ \text { Temp. Annual Range }\left({ }^{\circ} \mathrm{C}\right): & (24.2) 25.2-25.6(26.5)\end{array}$

Vegetation Description: Community a9 is a highly variable aquatic herbfield community that, with further sampling, may represent more than one community. It includes true aquatic species with fully submerged (e.g. Myriophyllum alpinum), floating (e.g. Nymphoides montana) or emergent foliage (e.g. Carex gaudichaudiana), as well as semi-aquatic species capable of growing as submergents for extended periods (e.g. Lilaeopsis polyantha, Lythrum salicaria, Montia australasica, Ranunculus pimpinellifolius). Phragmites australis or Carex gaudichaudiana may fringe such vegetation. Plant cover is sporadic and sometimes only one or a few species will be present.

This community occurs in and adjacent to permanent waterways (e.g. upper reaches of the Murrumbidgee River and its tributaries), in deeper pools along intermittent streams (e.g. Nungar Creek and McPhersons Plain in NSW, Sheep Station Creek and Grassy Creek in the ACT, and in Victoria), and broad flooded creek flats (e.g. Micalong Swamp in Bondo SF).

\section{Characteristic Species:}

Species

C/A Freq C/A O FreqO Fid

Carex appressa

Carex gaudichaudiana

Epilobium pallidiflorum

Hydrocotyle tripartita

Lilaeopsis polyantha

Lythrum salicaria

Montia australasica

Myriophyllum variifolium

Phragmites australis

Ranunculus amphitrichus

Ranunculus pimpinellifolius

Stellaria angustifolia

Threatened communities: Nil.

Equivalent vegetation types: Community 9 [Aquatic] (McDougall \& Walsh 2007).

Frequently occurring weeds: Weeds are generally not prevalent in this community, suggesting a high degree of ecosystem stability. Even so, the moisture dependent Holcus lanatus (0.33), Myosotis discolor 


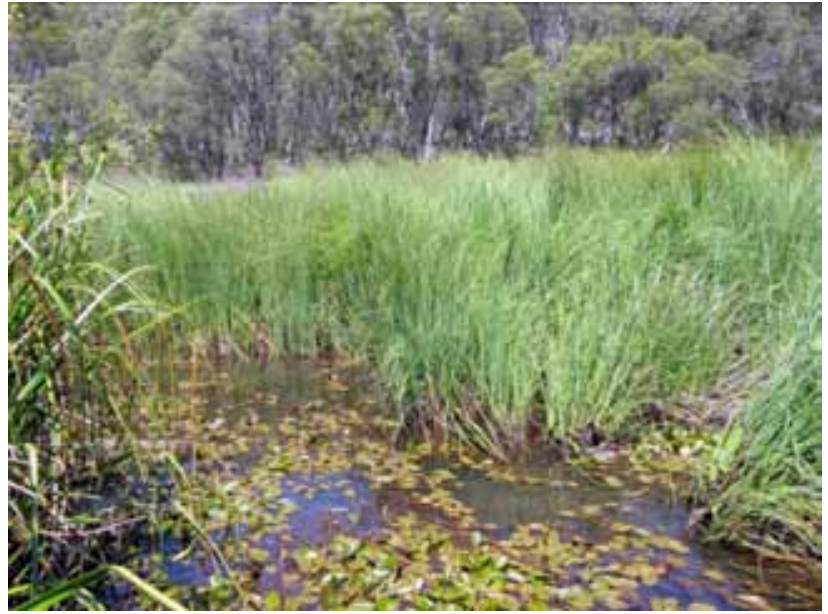

Plate a9: Dense Carex gaudichaudiana with occasional patches containing a diversity of floating and submerged aquatic plants is typical of Community a9. In this example at Micalong Swamp (plot UMC416), patches of Potamogeton tricarinatus can be seen.

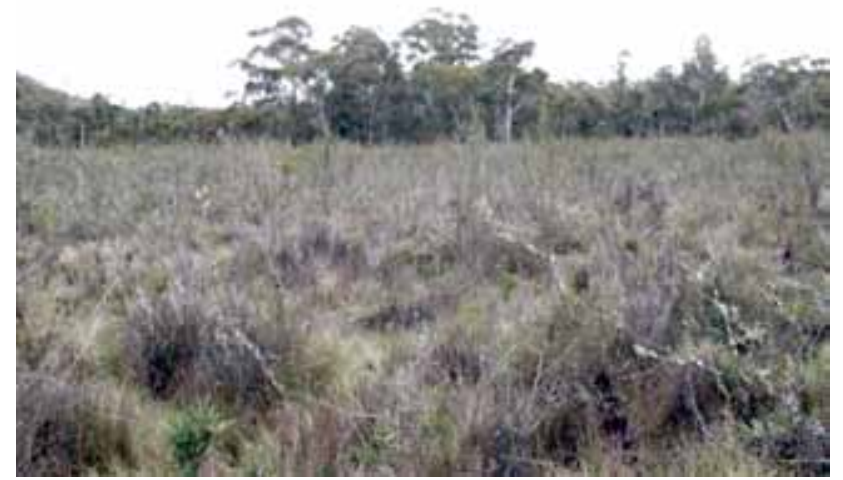

Plate e59: Scattered Hakea microcarpa and Baeckea utilis growing amongst Empodisma minus and a diversity of moisture-loving herbs is typical of Community e59, as with this example (plot UMC024B) at the headwaters of Roberts Ck, Tinderry NR.

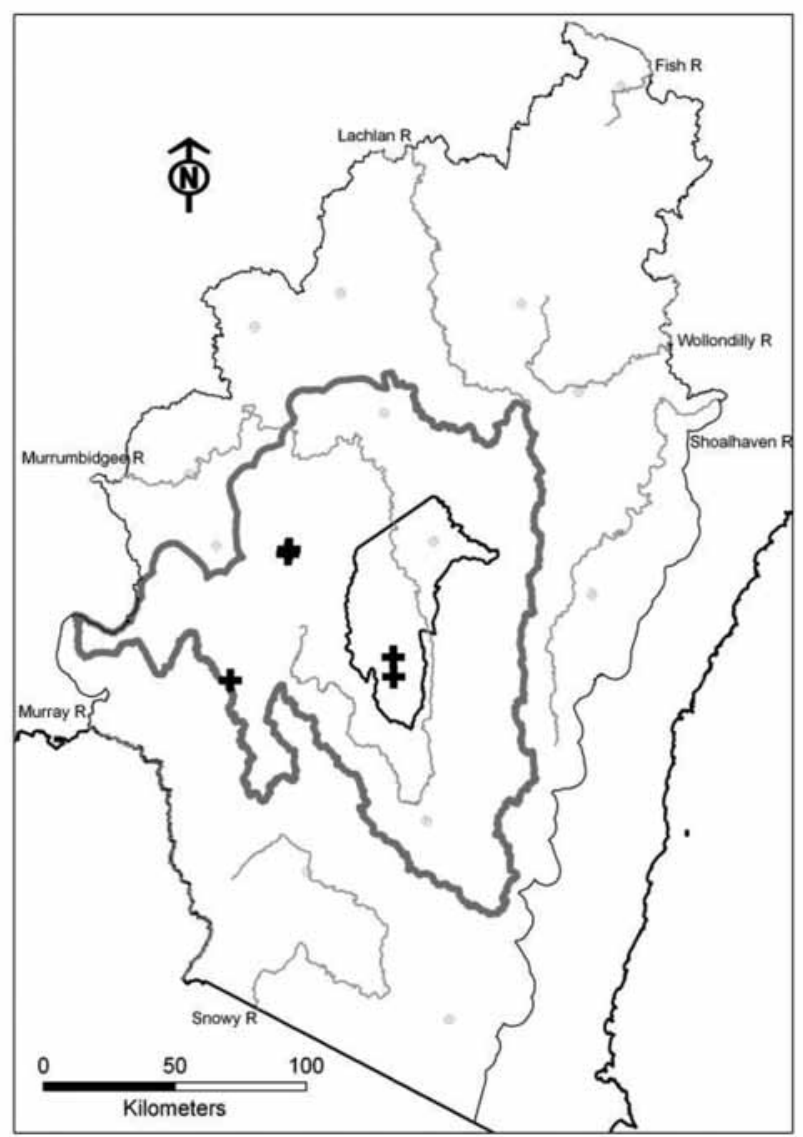

Fig. a9: Distribution of field samples assigned to this community.

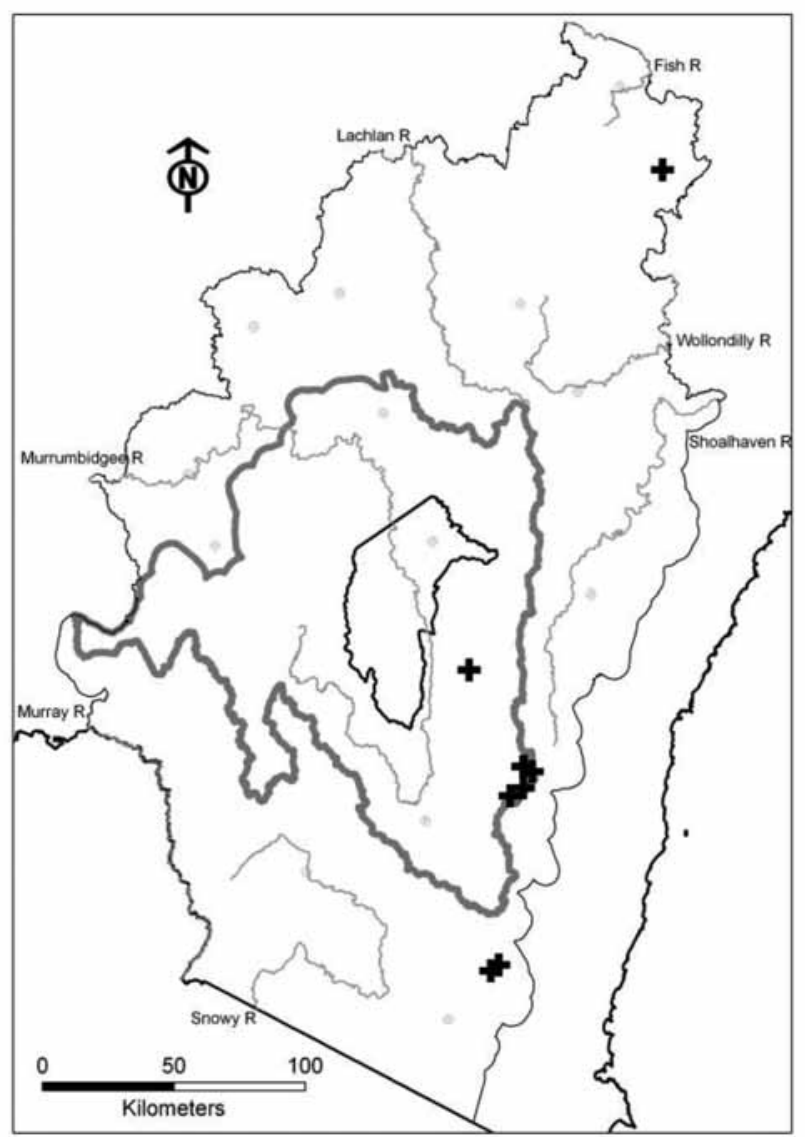

Fig. e59: Distribution of field samples assigned to this community. 
(0.33) and Myosotis laxa subsp. caespitosa (0.5) were recorded in a reasonable number of plots.

Threats: Some trampling of creek edges by horses has been observed in the vicinity of this community. It is possible however that some sites formerly supporting this community have been degraded by past domestic grazing to the extent that they are no longer floristically analogous. The weed Myosotis laxa subsp. caespitosa is locally dominant in some examples (e.g. Cooleman Plain in Kosciuszko NP and McPhersons Plain east of Tumbarumba) and may threaten the integrity of this community. Flood events and drought presumably lead to great fluctuation in species composition over time. The effect of deliberate large releases of water for environmental flows from Tantangara Dam is unknown but worth investigating, as the community is well developed below the dam. The establishment of commercial timber plantations in the catchment of these sites also has the potential to compromise their hydrology.

Reservation status: Present in Kosciuszko NP and Namadgi NP, with non-reserved examples being on State Forest and freehold land.

Extent of clearing: Unknown.

References: McDougall, K.L. \& Walsh, N.G. (2007) Treeless vegetation of the Australian Alps. Cunninghamia 10: 1-57.

\section{e59: Hakea microcarpa - Baeckea utilis - Lepto- spermum myrtifolium subalpine wet heathland on escarpment and eastern tableland ranges of the South Eastern Highlands bioregion}

Scientific Name: Hakea microcarpa - Baeckea utilis Leptospermum myrtifolium - Epacris breviflora / Empodisma minus - Hydrocotyle sibthorpioides - Baloskion australe Hypericum japonicum

$\begin{array}{ll}\text { Number of samples: } & 10 \\ \text { Richness [mean }( \pm \mathrm{SD})]: & 28(7) \\ \text { Slope (degrees): } & (0) 1-4(6) \\ \text { Altitude (m asl): } & (937) 953-1059(1187) \\ \text { Ave. Annual Rainfall }(\mathrm{mm}): & (747) 958-1047(1082) \\ \text { Temp. Annual Range }\left({ }^{\circ} \mathrm{C}\right): & (22.6) 23.6-24.2(25)\end{array}$

Vegetation Description: Community e59 is a sub-alpine bog heathland characterised by an open (to occasionally closed) shrub stratum to approximately 1.5 metres tall, commonly dominated by Baeckea utilis, Leptospermum myrtifolium and Epacris paludosa and comprising many other species commonly found in the community of similar landscape position in the Australian Alps bioregion [i.e. Community a2: Baeckea gunniana - Epacris paludosa - Richea continentis - Sphagnum cristatum wet heathland of the Australian Alps bioregion (Bog)], such as Carex gaudichaudiana, Epacris breviflora, Empodisma minus, Luzula modesta and Oreomyrrhis ciliata. Sphagnum cristatum often occurs as isolated clumps beneath shrubs or at the margins where a permanent supply of water permits. The community is often fringed by eucalypts (e.g. Eucalyptus dalrympleana, Eucalyptus pauciflora subsp. pauciflora, Eucalyptus stellulata), and moisture-loving grasses such as Poa labillardierei may be locally abundant.

This community occurs on peats and humified peat soils developed on alluvium in the bottoms of broad, flat valleys along the Great Dividing Range and coastal escarpment ranges. It may extend westward into the ACT (G. Baines, ACT ESDD, pers. comm.).

\section{Characteristic Species:}

Species

C/A Freq C/A O FreqO Fid

Allittia cardiocarpa

Asperula gunnii

Baeckea utilis

Baloskion australe

Brachyscome scapigera

Carex spp.

Cotula alpina

Craspedia variabilis

Empodisma minus

Epacris breviflora

Epacris microphylla

Epacris paludosa

Geranium neglectum

Gonocarpus micranthus

Hakea microcarpa

Hookerochloa hookeriana

Hydrocotyle sibthorpioides

Hypericum japonicum

Hypoxis hygrometrica

Juncus sarophorus

Leptospermum continentale

Leptospermum myrtifolium

Lindsaea linearis

Luzula modesta

Mitrasacme serpyllifolia

Oreobolus oxycarpus subsp. oxycarpus 3

Oreomyrrhis ciliata

Patersonia fragilis

Ranunculus pimpinellifolius

Stackhousia viminea

Stellaria angustifolia

Utricularia dichotoma

Velleia montana

Veronica subtilis

Viola caleyana

Xerochrysum palustre

Euchiton japonicus

Poa labillardierei

$\begin{array}{llll}30 & 1 & <1 & \mathrm{P} \\ 50 & 1 & 5 & \mathrm{P} \\ 70 & 2 & 1 & \mathrm{P} \\ 60 & 1 & 2 & \mathrm{P} \\ 30 & 1 & 2 & \mathrm{P} \\ 30 & 1 & 2 & \mathrm{P} \\ 50 & 1 & 1 & \mathrm{P} \\ 50 & 1 & 5 & \mathrm{P} \\ 80 & 2 & 3 & \mathrm{P} \\ 50 & 1 & 2 & \mathrm{P} \\ 20 & 1 & 1 & \mathrm{P} \\ 40 & 2 & 1 & \mathrm{P} \\ 40 & 2 & 2 & \mathrm{P} \\ 40 & 1 & 2 & \mathrm{P} \\ 100 & 1 & 3 & \mathrm{P} \\ 20 & 1 & <1 & \mathrm{P} \\ 80 & 2 & 4 & \mathrm{P} \\ 60 & 1 & 3 & \mathrm{P} \\ 20 & 1 & <1 & \mathrm{P} \\ 40 & 1 & <1 & \mathrm{P} \\ 30 & 1 & 2 & \mathrm{P} \\ 70 & 1 & 3 & \mathrm{P} \\ 20 & 1 & <1 & \mathrm{P} \\ 30 & 1 & 2 & \mathrm{P} \\ 60 & 1 & <1 & \mathrm{P} \\ 20 & 1 & <1 & \mathrm{P} \\ 40 & 1 & 2 & \mathrm{P} \\ 20 & 2 & <1 & \mathrm{P} \\ 40 & 1 & 1 & \mathrm{P} \\ 20 & 1 & <1 & \mathrm{P} \\ 30 & 1 & 1 & \mathrm{P} \\ 20 & 1 & <1 & \mathrm{P} \\ 40 & 1 & <1 & \mathrm{P} \\ 20 & 1 & <1 & \mathrm{P} \\ 30 & 1 & <1 & \mathrm{P} \\ 40 & 1 & 1 & \mathrm{P} \\ 40 & 2 & 10 & \mathrm{C} \\ & & & \end{array}$

Threatened communities: TSC Act 1995 - Montane Peatlands and Swamps of the New England Tableland, NSW North Coast, Sydney Basin, South East Corner, South Eastern Highlands and Australian Alps bioregions.

Equivalent vegetation types: Related to FrWe59 [Southeast Sub-alpine Bog] (Tozer et al. 2010) and Floristic Group 4 [Shrubby herbaceous Sphagnum peatlands] (Whinam \& Chilcott 2002).

Frequently occurring weeds: The presence of domestic stock in sites on freehold and State Forest land is the likely cause of weed invasion in the community. Many sites within the conservation reserve system were also historically grazed, with the legacy of that land management expressed through the continued presence of exotic plant species. The most commonly recorded species in this community were Cirsium vulgare (0.40), Hypochaeris radicata (0.50), Taraxacum officinale (0.30) and Trifolium repens $(0.30)$.

Threats: Some examples on State Forest and freehold land are grazed by cattle. This community is especially sensitive to trampling damage and further degradation can be expected on these tenures. Grazing, trampling and wallowing by deer occurs on all tenures but the degree of this disturbance is unknown. Frequent burning may destroy this community by damaging Sphagnum and peats, which causes drying of the soil and is likely to lead to the establishment of species more commonly found on drier sites. Rooting by feral pigs disturbs the groundlayer, and is associated with declining local populations of some species as well as the incursion of exotic plant species. 
Reservation status: Likely to be approximately evenly distributed in National Parks and Nature Reserves, State Forest and freehold. Recorded from survey plots in Badja Swamps NR, Deua NP, KanangraBoyd NP and South East Forest NP.

Extent of clearing: Tozer et al. (2010) indicate that about $70 \%$ of this community has been cleared or heavily degraded by grazing.

References: Tozer, M.G., Turner, K., Keith, D.A., Tindall, D., Pennay, C., Simpson, C., MacKenzie, B., Beukers, P. \& Cox, S. (2010) Native vegetation of southeast NSW: a revised classification and map for the coast and eastern tablelands. Cunninghamia 11: 359-406; Whinam, J. \& Chilcott, N. (2002) Floristic description and environmental relationships of Sphagnum communities in NSW and the ACT and their conservation management. Cunninghamia 7:463-500.

\section{u193: Hakea microcarpa - Epacris breviflora -} Epacris paludosa subalpine wet heathland of the Australian Alps and western South Eastern Highlands bioregions

Scientific Name: Eucalyptus camphora subsp. humeana / Hakea microcarpa - Epacris breviflora - Epacris paludosa / Empodisma minus - Carex gaudichaudiana - Asperula gunnii - Gonocarpus micranthus

Number of samples:

Richness [mean $( \pm \mathrm{SD})]$ :

Slope (degrees):

Altitude ( $\mathrm{m}$ asl):

Ave. Annual Rainfall (mm):

Temp. Annual Range $\left({ }^{\circ} \mathrm{C}\right)$ :

14

28 (7)

(0) $1-8(13)$

(790) 1002-1188 (1439)

(847) 936-1331 (1495)

(23) $23.8-25.6(26)$

Vegetation Description: Community u193 is a swampy heathland to 2 metres in height, typically dominated by Baeckea utilis, Epacris breviflora, Epacris paludosa and/or Hakea microcarpa. The ground cover is usually a dense cover of Empodisma minus and sedges (Carex spp., Eleocharis spp.) interspersed with herbs such as Gonocarpus micranthus, Hydrocotyle sibthorpioides, Poa costiniana, Poa labillardierei and Ranunculus pimpinellifolius. Carex gaudichaudiana may be abundant in areas of open water within the community. Sphagnum cristatum may also be present.

This community is distributed between the Brindabella Ranges and the Tumbarumba area. It is largely a treeless, shrub-dominated wetland apart from scattered or fringing Eucalyptus camphora subsp. humeana to 5 metres in height at some sites. Floristically and structurally it is similar to low altitude examples of Community a2 [Baeckea gunniana - Epacris paludosa - Richea continentis - Sphagnum cristatum wet heathland of the Australian Alps bioregion (Bog)], which typically occurs on broad frost hollows where it is bordered by grassland. Upslope, this community adjoins woodland or forest dominated by Eucalyptus pauciflora subsp. pauciflora, Eucalyptus stellulata or Eucalyptus dalrympleana. Examples range in size from tens of square metres where fed by permanent springs to several hectares on flat sections of streams. Soils are peaty.

\section{Characteristic Species:}

\section{Species}

Asperula gunnii

Baeckea gunniana

Baeckea utilis

Baloskion australe

Brachyscome scapigera

Carex appressa

Carex gaudichaudiana
C/A Freq C/A OFreqO Fid

$\begin{array}{lllll}2 & 71 & 1 & 5 & \mathrm{P} \\ 2 & 21 & 1 & 1 & \mathrm{P} \\ 3 & 57 & 2 & 1 & \mathrm{P} \\ 2 & 64 & 1 & 2 & \mathrm{P} \\ 1 & 21 & 1 & 2 & \mathrm{P} \\ 2 & 50 & 1 & 7 & \mathrm{P} \\ 3 & 79 & 2 & 4 & \mathrm{P}\end{array}$

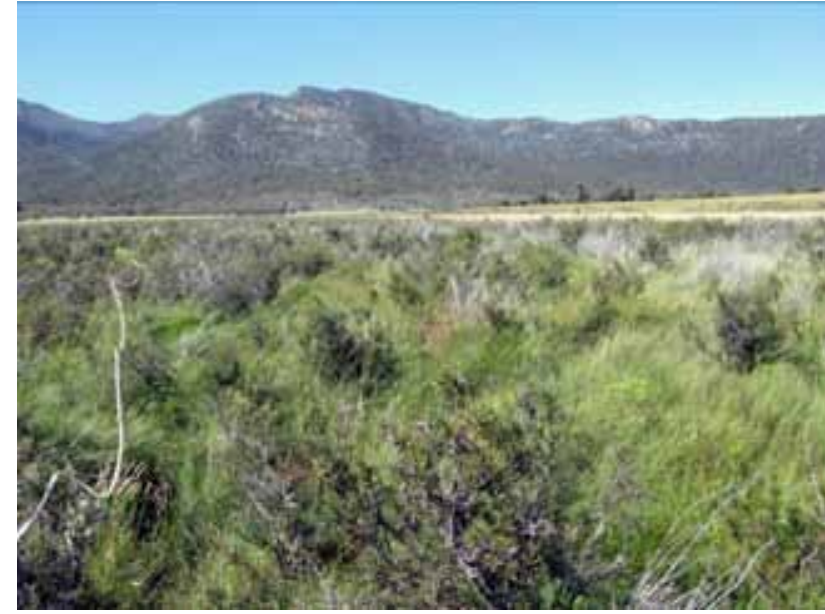

Plate u193: Community u193 with Hakea microcarpa, Baeckea utilis and Carex gaudichaudiana in Yaouk Creek Swamp, Scabby Range Nature Reserve (plot UMC421).

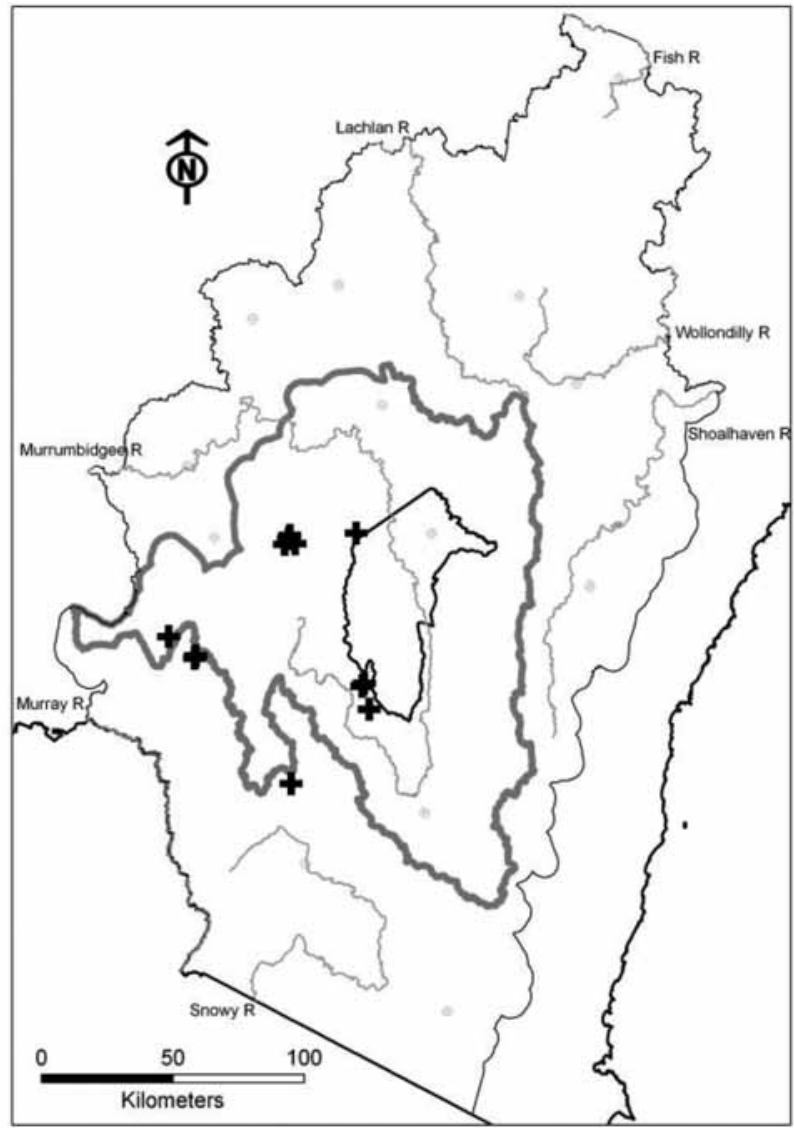

Fig. u193: Distribution of field samples assigned to this community. 
Comesperma retusum

Deyeuxia gunniana

Eleocharis gracilis

Eleocharis sphacelata

Empodisma minus

Epacris breviflora

Epacris paludosa

Epilobium billardierianum subsp.

hydrophilum

Epilobium gunnianum

Eucalyptus camphora subsp.

humeana

Gratiola peruviana

Hakea microcarpa

Hydrocotyle algida

Hydrocotyle sibthorpioides

Hypericum japonicum

Hypoxis hygrometrica

Juncus falcatus

Juncus fockei

Lachnagrostis filiformis

Lobelia pedunculata

Lobelia surrepens

Luzula ovata

Myriophyllum crispatum

Oreomyrrhis ciliata

Pimelea bracteata

Poa costiniana

Poa labillardierei

Ranunculus pimpinellifolius

Senecio glomeratus

Stellaria angustifolia

Veronica subtilis
Gonocarpus micranthus

Luzula modesta

$\begin{array}{lllll}1 & 36 & 1 & <1 & \mathrm{P} \\ 2 & 21 & 1 & <1 & \mathrm{P} \\ 2 & 29 & 2 & <1 & \mathrm{P} \\ 2 & 21 & 3 & <1 & \mathrm{P} \\ 4 & 71 & 2 & 3 & \mathrm{P} \\ 2 & 86 & 1 & 2 & \mathrm{P} \\ 3 & 57 & 2 & 1 & \mathrm{P} \\ 2 & 21 & 1 & <1 & \mathrm{P}\end{array}$

$121 \quad 1 \quad 1$
$<1 \quad \mathrm{P}$

$2 \quad \mathrm{P}$

$\mathrm{P}$
$\mathrm{P}$

$\mathrm{P}$
$\mathrm{P}$

$\mathrm{P}$

$\mathrm{P}$

$\mathrm{P}$

$\mathrm{P}$

$\mathrm{P}$

$\begin{array}{ll}<1 & \mathrm{P} \\ 4 & \mathrm{P}\end{array}$

$5 \quad \mathrm{P}$

$<1 \quad \mathrm{P}$

$2 \quad \mathrm{P}$

$<1 \quad \mathrm{P}$

$<1 \quad \mathrm{P}$

$2 \quad \mathrm{P}$

$<1 \quad \mathrm{P}$

$5 \quad \mathrm{P}$

$10 \quad \mathrm{P}$

$1 \quad \mathrm{P}$

$<1 \quad \mathrm{P}$

$1 \quad \mathrm{P}$

$<1 \quad \mathrm{P}$

Threatened communities: TSC Act 1995 - Montane Peatlands and Swamps of the New England Tableland, NSW North Coast, Sydney Basin, South East Corner, South Eastern Highlands and Australian Alps bioregions.

Equivalent vegetation types: Community u193 has an affinity with VG124 [Western Montane/Sub-alpine Wet Heath/Herb Grass Woodland] and includes western elements of VG123 [Montane/Subalpine Wet Heath/Bog] (Gellie 2005). The new community concept appears to be a largely treeless wetland (apart from scattered or fringing Eucalyptus camphora subsp. humeana) related to Community a2 [Baeckea gunniana - Epacris paludosa - Richea continentis Sphagnum cristatum wet heathland of the Australian Alps bioregion (Bog)], which occurs mostly at higher altitude. Western examples may have some affinities with VCA 285 [Broad-leaved Sally grass - sedge woodland on valley flats and swamps in the NSW South-western Slopes and adjoining South Eastern Highlands bioregions] (Benson et al. 2010).

Frequently occurring weeds: Disturbance by cattle (whether historic or more recent) is the likely reason for the high frequency with which some weeds were recorded from this community. As with other freshwater wetland communities, Holcus lanatus (0.75), Hypochaeris radicata $(0.50)$ and Trifolium repens $(0.33)$ were the most frequently recorded weeds.

Threats: All examples are threatened by feral horse grazing and trampling. Cattle grazing is permitted in many State Forest examples. Although most vascular plants in this community are facultative resprouters and well-adapted to fire, Sphagnum cristatum and the peat soils beneath may be damaged by single fire events. Additionally, fire regimes that repeatedly cause such damage before natural recovery occurs will destroy the system through drying, which facilitates stream entrenchment and allows species of drier systems to invade. Low montane wetlands are far more susceptible to weed invasion than similar systems at high altitude. Exotic grasses such as Holcus lanatus can become abundant and dominating following disturbance. Exotic Juncus species (e.g. Juncus effusus, Juncus articulatus) and Salix cinerea may be future threats to the integrity of this community.

Reservation status: Recorded in Brindabella NP, Scabby Range NR, Yaouk NR and the western edge of Kosciuszko NP, but mostly occurs in State Forest and on freehold land.

Extent of clearing: Unknown and probably negligible but all examples have a history of grazing, which is likely to have severely degraded this community.

References: Benson, J.S., Richards, P.G., Waller, S. \& Allen, C.B. (2010) New South Wales vegetation classification and assessment: Part 3. Plant communities of the NSW Brigalow Belt South, Nandewar and west New England bioregions and update of NSW Western Plains and South Western Slopes plant communities. Version 3 of the NSW VCA database. Cunninghamia 11: 457-579. Botanic Gardens Trust, Sydney; Gellie, N.J.H. (2005) Native vegetation of the southern forests: South Eastern Highlands, Australian Alps, South West Slopes and South East Corner bioregions. Cunninghamia 9: 219-254.

\section{Class: Montane Lakes}

\section{L12: Freshwater sedge-herb marsh of shallow, commonly inundated wetlands of the eastern South Eastern Highlands bioregion}

Scientific Name: Eleocharis acuta - Amphibromus nervosus - Lachnagrostis filiformis \pm Eleocharis pusilla / Glossostigma elatinoides - Ranunculus inundatus Hydrocotyle sibthorpioides / Myriophyllum simulans Potamogeton tricarinatus

Number of samples:

Richness [mean $( \pm \mathrm{SD})]$ :

Slope (degrees):

Altitude (m asl):

Ave. Annual Rainfall (mm):

Temp. Annual Range $\left({ }^{\circ} \mathrm{C}\right)$ :

29

17 (6)

(0) $0-1$ (4)

(708) 773-1035 (1239)

(530) 584-744 (879)

(24.1) 24.8-26.3 (26.8)

Vegetation Description: Community L12 occupies frequentlyinundated wetlands and is commonly dominated by the tall emergent spike-sedge Eleocharis acuta accompanied by scattered Amphibromus nervosus and Lachnagrostis filiformis. A variety of other tall emergents present at varying frequency include Eleocharis pusilla, Juncus australis, Eleocharis sphacelata and/or Carex tereticaulis. Some new plots assigned to this group include Triglochin procera and Glyceria australis, at times as co-dominant emergents. A layer of low herbaceous wetland plants commonly sprawls along wetland margins, frequently dominated by Hydrocotyle sibthorpioides, Glossostigma elatinoides and Ranunculus inundatus, with a diversity of other low wetland forbs at lower frequencies on the margins and spreading across standing water by rhizomes or stolons. Standing water is commonly occupied by floating/submerged aquatic taxa Myriophyllum simulans and Potamogeton tricarinatus and less commonly Potamogeton ochreatus, Myriophyllum caput-medusae, and occasionally the tiny gypsy floaters Azolla filiculoides, Lemna disperma or Wolffia australiana.

Community L12 is generally known from alluvium derived from a variety of substrates including basalt, granite, granodiorite and sedimentary rocks. Most samples are from Monaro lakes, in an area bounded by Cootralantra in the north, Hilltop and Ingebirah in the west, south to Bombala and east to Nimmitabel. Recent plot samples extend the range of this tableland wetland complex far to the north, with samples from Molonglo Lagoon east of Queanbeyan, along the Collector Creek chainof-ponds system above Lake George, from swamps at Rowes Lagoon and Wet Lagoon, and from Burra Burra Lake on basalt north of Taralga. 
Also added to this group are plots from frequently-inundated river-flat wetlands on the Monaro - beside the Bombala River near Bibbenluke and the Murrumbidgee River east of Adaminaby.

This community is partly defined from whole-lake samples collected by Benson \& Jacobs (1994) and is closely alligned with their Communities 1 and 2. The species list below is based on data from a combination of 22 whole-lake samples and seven plot samples assigned to this group.

\section{Characteristic Species:}

Species

\section{C/A Freq C/A OFreqO Fid}

Amphibromus nervosus

Carex tereticaulis

Centipeda cunninghamii

Crassula helmsii

Eleocharis acuta

Eleocharis pusilla

Eleocharis sphacelata

Euchiton sphaericus

Glossostigma elatinoides

Hydrocotyle sibthorpioides

Isolepis platycarpa

Juncus australis

Juncus radula

Lachnagrostis filiformis

Limosella australis

Lobelia surrepens

Marsilea costulifera

Montia australasica

Myriophyllum caput-medusae

Myriophyllum simulans

Persicaria prostrata

Potamogeton ochreatus

Potamogeton tricarinatus

Ranunculus diminutus

Ranunculus inundatus

Stellaria angustifolia

$\begin{array}{lllll}2 & 86 & 2 & <1 & \mathrm{P} \\ 2 & 21 & 1 & <1 & \mathrm{P} \\ 1 & 21 & 2 & <1 & \mathrm{P} \\ 2 & 31 & 3 & <1 & \mathrm{P} \\ 2 & 38 & 3 & <1 & \mathrm{P} \\ 4 & 93 & 3 & 1 & \mathrm{P} \\ 3 & 48 & 2 & <1 & \mathrm{P} \\ 3 & 28 & 2 & <1 & \mathrm{P} \\ 2 & 28 & 1 & 7 & \mathrm{P} \\ 3 & 62 & 2 & <1 & \mathrm{P} \\ 3 & 72 & 2 & 4 & \mathrm{P} \\ 4 & 24 & 3 & <1 & \mathrm{P} \\ 2 & 38 & 1 & 1 & \mathrm{P} \\ 2 & 31 & 1 & <1 & \mathrm{P} \\ 3 & 83 & 1 & 4 & \mathrm{P} \\ 2 & 28 & 3 & 1 & \mathrm{P} \\ 2 & 24 & 2 & <1 & \mathrm{P} \\ 3 & 34 & 3 & <1 & \mathrm{P} \\ 1 & 24 & 1 & 1 & \mathrm{P} \\ 3 & 21 & 3 & <1 & \mathrm{P} \\ 4 & 66 & 2 & <1 & \mathrm{P} \\ 2 & 31 & 2 & <1 & \mathrm{P} \\ 2 & 28 & 3 & <1 & \mathrm{P} \\ 3 & 79 & 4 & <1 & \mathrm{P} \\ 2 & 24 & 3 & 1 & \mathrm{P} \\ 2 & 76 & 1 & <1 & \mathrm{P} \\ 1 & 24 & 1 & 1 & \mathrm{P}\end{array}$

Brachyscome radicans

Threatened communities: EPBC Act 1999 - Upland Wetlands of the New England Tablelands and the Monaro Plateau.

Equivalent vegetation types: This community represents a revision of marsh communities 1 and 2 [Shallow freshwater sedge-herb marshes] identified by Benson \& Jacobs (1994), with the extension of this combined type to the north with the addition of wetland plot samples from the broader Southern Tablelands, and into floodplain marshes. This community is related to FrWp57 [Tableland Swamp Meadow] identified by Tozer et al. (2010).

Frequently occurring weeds: The widespread aquatic weeds Juncus articulatus (0.45) and Rumex crispus $(0.48)$ were the most common weeds observed in this community.

Threats: These shallow herbaceous tableland wetlands exist in specialised habitats of concentrated moisture and nutrients with high agricultural productivity potential. As such they have been subject to widespread, intensive disturbances including draining, exotic pasture introductions, heavy stock grazing and cropping. Remaining undrained examples located within highly modified rural catchments may be subject to increased frequency of eutrophication and invasion by exotic plants at various stages of their wetting/drying cycles.

Reservation status: No records of this community occur on conservation reserves.

Extent of clearing: The original extent of these herbaceous wetlands is likely to have been greatly reduced across their range by widespread draining, cropping and exotic pasture establishment.

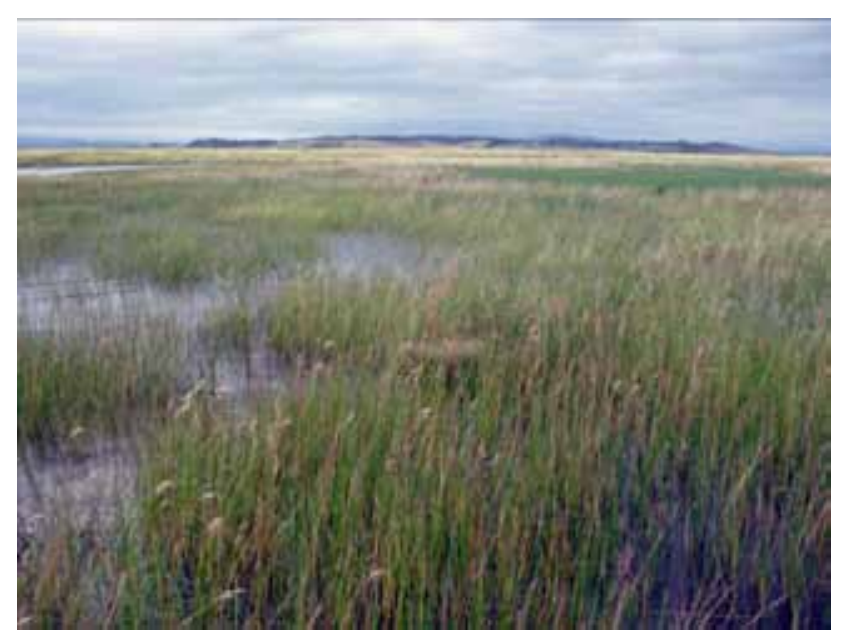

Plate L12: Community L12 on Molonglo Lagoon north of Hoskinstown (plot UMC419) dominated by Eleocharis acuta and Schoenoplectus pungens over floating/submerged aquatic species.

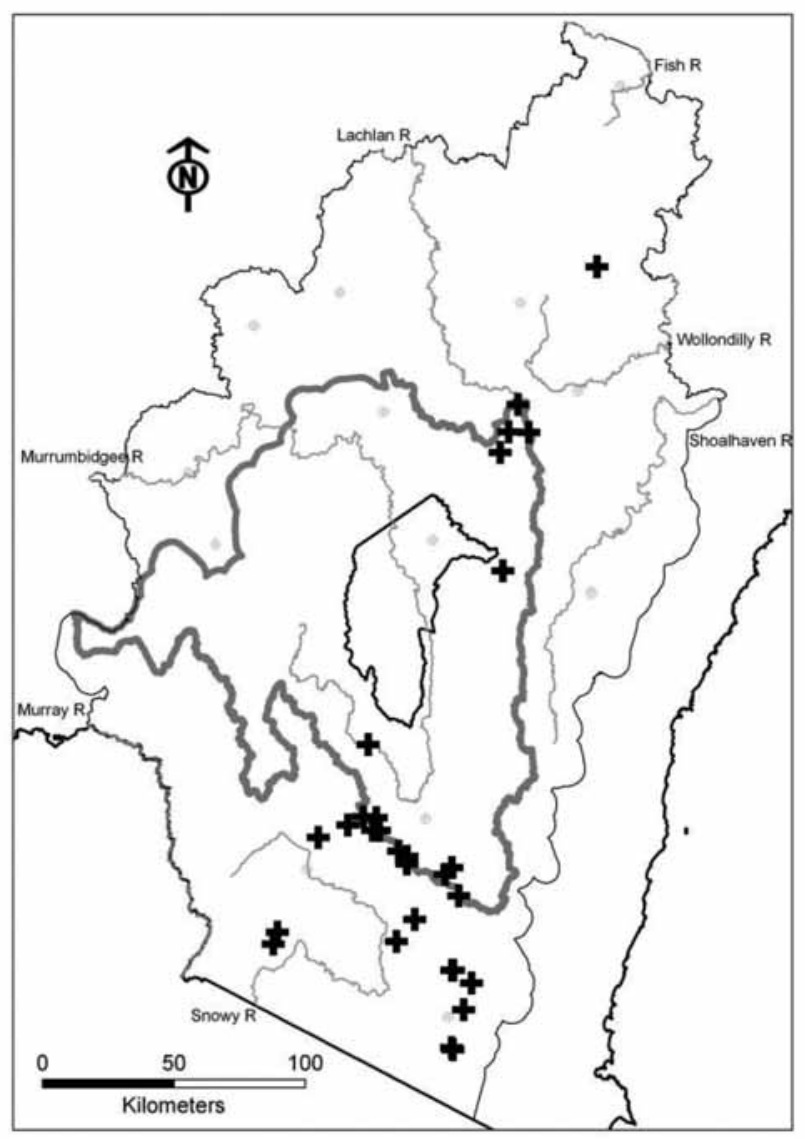

Fig. rL12: Distribution of field samples assigned to this community 
References: Benson, J.S. \& Jacobs, S.W.L. (1994) Plant communities of the Monaro lakes. Cunninghamia 3: 651-676; Tozer, M.G., Turner, K., Keith, D.A., Tindall, D., Pennay, C., Simpson, C., MacKenzie, B., Beukers, P. \& Cox, S. (2010) Native vegetation of southeast NSW: a revised classification and map for the coast and eastern tablelands. Cunninghamia 11: 359-406.

\section{L3: Freshwater sedge-herb marsh of shallow ephemeral lakes of the eastern South Eastern High- lands bioregion}

Scientific Name: Lachnagrostis filiformis - Eleocharis acuta - Isolepis platycarpa / Centipeda cunninghamii - Limosella australis - Persicaria prostrata \pm Ranunculus diminutus / Potamogeton ochreatus \pm Potamogeton tricarinatus

$\begin{array}{ll}\text { Number of samples: } & 13 \\ \text { Richness [mean }( \pm \mathrm{SD})]: & 10(4) \\ \text { Slope (degrees): } & (0) 0-1(4) \\ \text { Altitude (m asl): } & (744) 916-1003(1012) \\ \text { Ave. Annual Rainfall }(\mathrm{mm}): & (512) 521-586(758) \\ \text { Temp. Annual Range }\left({ }^{\circ} \mathrm{C}\right): & (24.6) 25.5-26.6(27.1)\end{array}$

Vegetation Description: Community L3 is recorded from shallow lakes formed on basalt substrates on the Monaro. Although only sampled from the Monaro, other small ephemeral wetlands matching this community may occur (or occurred prior to dusturbance) further north along the tablelands, for example smaller lakes/lagoons in the Lake Bathurst and Breadalbane areas.

This community is recorded from lakes which are generally small in area, shallow and ephemeral ("probably dry for most of the year" Benson \& Jacobs 1994), and some may be moderately saline. Common dominant native plants are ubiquitous, resilient perennial wetland species including the tufted plants Eleocharis acuta, Lachnagrostis filiformis and Isolepis platycarpa, prostrate forbs such as Centipeda cunninghamii, Limosella australis and Persicaria prostrata, and the highly vagile annual aquatic pondweed Potamogeton ochreatus. These wetlands tend to have relatively low native species richness.

Community L3 is defined entirely from whole-lake samples collected by Benson \& Jacobs (1994) and therefore is closely alligned with Community 3 as described in that study.

\section{Characteristic Species:}

Species

C/A Freq C/A OFreqO Fid

Amphibromus nervosus

Carex bichenoviana

Centipeda cunninghamii

Crassula helmsii

Eleocharis acuta

Eleocharis pusilla

Glossostigma elatinoides

Isolepis platycarpa

Lachnagrostis filiformis

Limosella australis

Marsilea costulifera

Myriophyllum verrucosum

Persicaria prostrata

Potamogeton ochreatus

Potamogeton tricarinatus

Puccinellia stricta

Ranunculus diminutus

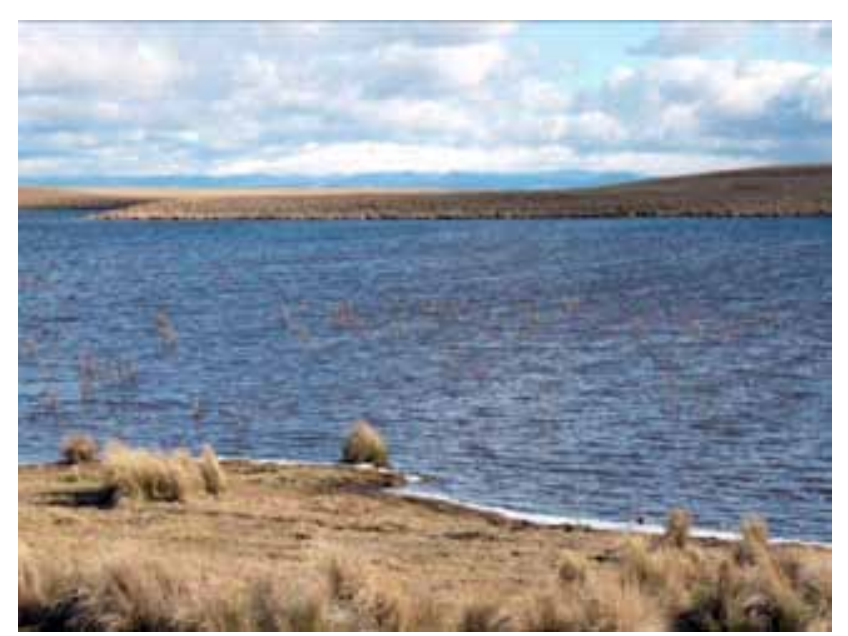

Plate L3: An inundated example of Community L3 in a basalt depression on Maffra Road approximately $16 \mathrm{~km}$ south of Cooma. This photo was taken in the same location as plot MWP166, although almost 20 years later.

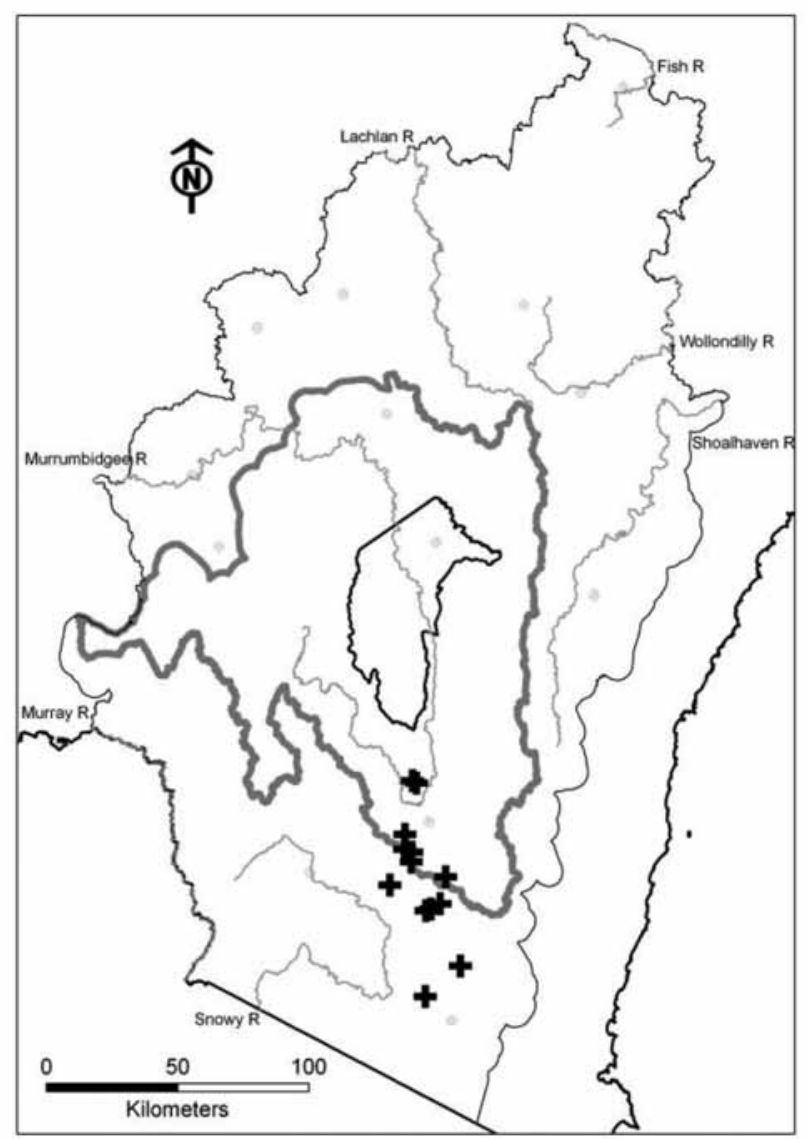

Fig. L3: Distribution of field samples assigned to this community. 


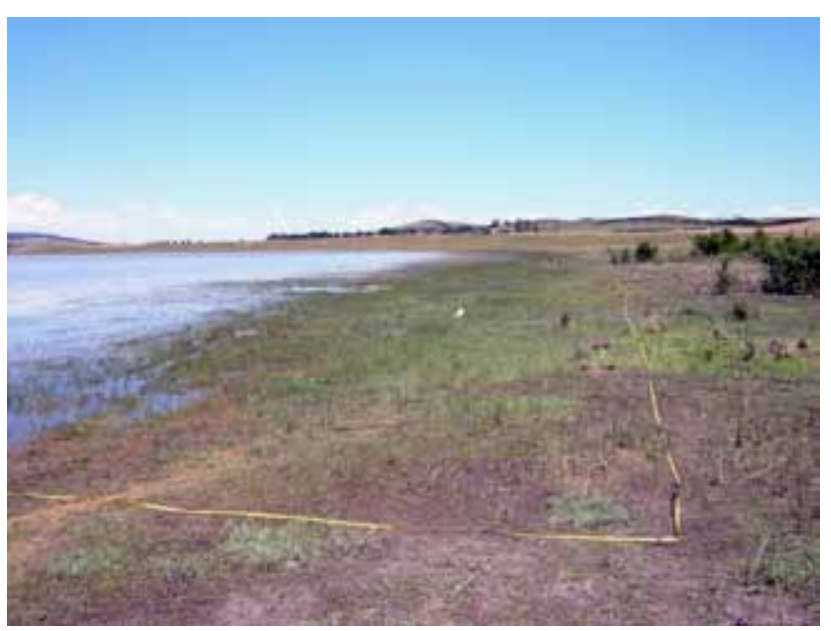

Plate L4: Community L4 on the Little Morass, adjoining the Morass and Lake Bathurst, with the drying lake margin supporting a diverse suite of wetland and moist edge species (plot KT_LAKBB).

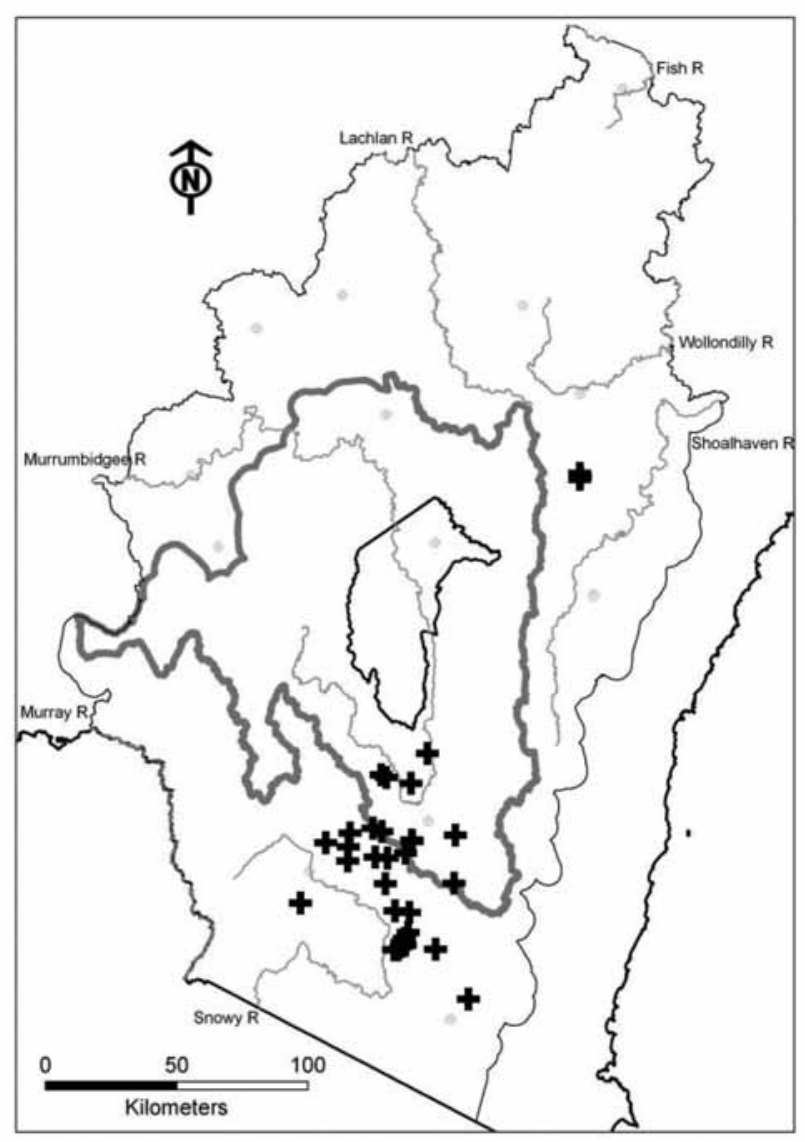

Fig. L4: Distribution of field samples assigned to this community.
Threatened communities: EPBC Act 1999 - Upland Wetlands of the New England Tablelands and the Monaro Plateau.

Equivalent vegetation types: Equivalent to Community 3 [Shallow ephemeral freshwater herb-grass marsh] of Benson \& Jacobs (1994).

Frequently occurring weeds: The weed species recorded from within this community are typical of degraded moist-terrestrial and ephemeral-aquatic environments, and include Holcus lanatus (0.31), Persicaria maculosa (0.31), Rumex crispus (0.23) and Veronica anagallis-aquatica (0.23).

Threats: These ephemeral herbaceous tableland lakes are specialised habitats of concentrated moisture and nutrients with high agricultural productivity potential, so have been subject to widespread, intensive disturbances equivalent to clearing including draining, exotic pasture plant introductions, heavy stock grazing and cropping. Remaining undrained examples located within highly modified rural catchments may be subject to increased frequency of eutrophication and invasion by exotic plants at various stages of their wetting/drying cycles.

Reservation status: No records of this community occur on conservation reserves.

Extent of clearing: The original extent of these herbaceous wetlands is likely to have been greatly reduced across their range by widespread draining, cropping and exotic pasture establishment.

Reference: Benson, J.S. \& Jacobs, S.W.L. (1994) Plant communities of the Monaro lakes. Cunninghamia 3: 651-676.

\section{L4: Freshwater sedge-herb marsh of deep semi- permanent and/or slightly saline wetlands of the eastern South Eastern Highlands bioregion}

Scientific Name: Lachnagrostis filiformis - Carex bichenoviana - Eleocharis acuta \pm Eleocharis pusilla / Ranunculus diminutus - Limosella australis - Crassula helmsii \pm Persicaria prostrata / Lepilaena bilocularis

$\begin{array}{ll}\text { Number of samples: } & 32 \\ \text { Richness [mean }( \pm \text { SD)]: } & 13(5) \\ \text { Slope (degrees): } & (0) 0-0(4) \\ \text { Altitude (m asl): } & (672) 874-987(1165) \\ \text { Ave. Annual Rainfall }(\mathrm{mm}): & (505) 531-650(799) \\ \text { Temp. Annual Range }\left({ }^{\circ} \mathrm{C}\right): & (24.5) 25.7-26.7(27.6)\end{array}$

Vegetation Description: Tableland lakes containing community L4 are generally large in area, deep and contain permanent water ("rarely dry") (Benson \& Jacobs 1994). Some are moderately saline at least during drying phases. Common native species of these wetlands and their margins include tall emergents Eleocharis acuta, Carex bichenoviana, Lachnagrostis filiformis and Juncus vaginatus, a mixed low forbs layer including Crassula helmsii, Limosella australis, Ranunculus diminutus and Persicaria prostrata, and aquatic taxa commonly dominated by the submerged Lepilaena bilocularis.

This community occurs on alluvium derived from a variety of substrates including basalt, granite, granodiorite and sedimentary rocks. Monaro Lake samples range from Dangelong, Bililingra and Dry Plain in the north, southwest to Cootralantra, Hill Top and Moonbah, and east to Bungarby, Bibbenluke and Rock Flat. Recent plot samples from the Morass and little Morass (beside Lake Bathurst) extend the range of this wetland complex far to the north. This type may also occur on other large but currently unsampled tableland lakes including some of those in the Breadalbane area.

Community L4 is largely defined from whole-lake samples collected by Benson \& Jacobs (1994) and is closely alligned with Community 4 as described in that study. The species list below is based on data from a combination of 29 whole-lake samples and three plot samples assigned to this group. 


\section{Characteristic Species:}

Species

Carex bichenoviana

Carex tereticaulis

Chenopodium glaucum

Crassula helmsii

Eleocharis acuta

Eleocharis pusilla

Hydrocotyle sibthorpioides

Isolepis platycarpa

Juncus australis

Juncus vaginatus

Lachnagrostis filiformis

Lepilaena bilocularis

Limosella australis

Myriophyllum verrucosum

Persicaria prostrata

Potamogeton ochreatus

Puccinellia stricta

Ranunculus diminutus

Schoenoplectus pungens

\section{C/A Freq C/A OFreqO Fid}

$\begin{array}{lllll}3 & 84 & 2 & <1 & \mathrm{P} \\ 3 & 34 & 1 & <1 & \mathrm{P} \\ 2 & 31 & 3 & <1 & \mathrm{P} \\ 3 & 75 & 2 & <1 & \mathrm{P} \\ 3 & 72 & 3 & 1 & \mathrm{P} \\ 2 & 41 & 2 & <1 & \mathrm{P} \\ 2 & 25 & 2 & 4 & \mathrm{P} \\ 3 & 22 & 3 & <1 & \mathrm{P} \\ 1 & 25 & 1 & 1 & \mathrm{P} \\ 1 & 38 & 1 & <1 & \mathrm{P} \\ 3 & 88 & 1 & 3 & \mathrm{P} \\ 4 & 66 & 0 & 0 & \mathrm{P} \\ 3 & 84 & 2 & <1 & \mathrm{P} \\ 3 & 22 & 2 & <1 & \mathrm{P} \\ 2 & 44 & 2 & <1 & \mathrm{P} \\ 3 & 28 & 3 & <1 & \mathrm{P} \\ 2 & 34 & 2 & <1 & \mathrm{P} \\ 3 & 97 & 2 & <1 & \mathrm{P} \\ 2 & 25 & 2 & <1 & \mathrm{P}\end{array}$

Threatened communities: EPBC Act 1999 - Upland Wetlands of the New England Tablelands and the Monaro Plateau.

Equivalent vegetation types: Represents a modification and extension of Community 4 [Deep freshwater sedge-herb marsh] of Benson \& Jacobs (1994).

Frequently occurring weeds: Common weeds of this community include those that characterise other ephemeral wetland communities in the region, and include Cirsium vulgare (0.16), Juncus articulatus (0.41), Juncus bufonius (0.25) and Rumex crispus (0.47). Hordeum marinum (0.5), a species unique to saline environments was also recorded within this community.

Threats: This tableland wetland type generally occupies deeper, more permanent lakes than L12 and L3, so is less prone to draining, grazing and conversion to exotic pasture or cropping. However, Benson \& Jacobs (1994) reported at least one example of a large Monaro lake drained by a channel cut through an adjacent hill. Some examples of this community are located within highly modified rural catchments, and may be subject to increased frequency of eutrophication and invasion by exotic plants at various stages of their wetting/drying cycles. Climate change impacts on this community will depend on its effects on the length and frequency of inundation of these wetlands.

Reservation status: No records of this community occur on conservation reserves.

Extent of clearing: The original extent of these herbaceous wetlands is likely to have been greatly reduced across their range by widespread draining, cropping and exotic pasture establishment.

Reference: Benson, J.S. \& Jacobs, S.W.L. (1994) Plant communities of the Monaro lakes. Cunninghamia 3: 651-676.

\section{Formation: Grassy Woodlands}

\author{
Class: Subalpine Woodlands
}

\section{a34: Weeping Snow Gum shrub-grass open wood- land of the Australian Alps bioregion}

Scientific Name: Eucalyptus lacrimans / Hakea microcarpa - Pimelea linifolia subsp. caesia / Poa phillipsiana

$\begin{array}{ll}\text { Number of samples: } & 6 \\ \text { Richness [mean }( \pm \mathrm{SD})]: & 25(1) \\ \text { Slope (degrees): } & (1) 3-11(16) \\ \text { Altitude (m asl): } & (1241) 1321-1351(1416) \\ \text { Ave. Annual Rainfall (mm): } & (1012) 1089-1251(1499) \\ \text { Temp. Annual Range }\left({ }^{\circ} \mathrm{C}\right): & (23.2) 23.7-24(24.6)\end{array}$

Vegetation Description: Community a34 is mid-high open woodland with a very sparse canopy dominated by Eucalyptus lacrimans to a height of about 5 metres. The understorey ranges from grass-dominated (most commonly Poa phillipsiana) to shrub-dominated (mostly Hakea microcarpa). Several species that are uncommon on the treeless plains of Kosciuszko NP were recorded in this community including Daviesia ulicifolia, Dichelachne rara, Grevillea lanigera, Lepidosperma curtisiae, Lomandra longifolia var. exilis, Phebalium squamulosum subsp. ozothamnoides and Tetratheca bauerifolia.

This community occurs only in Kosciuszko NP on isolated knolls and low ridges of frost hollows between Long and Nungar Plains in Kosciuszko NP (including the Kiandra area and Currango Plain). It is especially prominent on the slopes of the Murrumbidgee River at Gulf Bend, below Tantangara Dam. This community is considered distinct from vegetation containing Eucalyptus lacrimans around Adaminaby, where the understorey is dominated by Themeda australis and contains many elements of the Monaro Plains grassland communities such as Community r6 [Dry Tussock Grassland of the Monaro in the South Eastern Highlands bioregion]. Further sampling is required to quantify the existence of this plant community.

\section{Characteristic Species:}

Species

C/A Freq C/A OFreqO Fid

Acrothamnus hookeri

Asperula gunnii

Austrostipa nivicola

Bossiaea foliosa

Carex breviculmis

Craspedia coolaminica

Craspedia jamesii

Dillwynia prostrata

Eucalyptus lacrimans

Geranium antrorsum

Hakea microcarpa

Hovea aff. heterophylla (Kiandra)

Leptorhynchos squamatus

Linum marginale

Microseris lanceolata

Olearia myrsinoides

Pimelea linifolia

Poa clivicola

Poa phillipsiana

Poranthera microphylla

Ranunculus graniticola

Rytidosperma spp.

Scleranthus biflorus

$\begin{array}{llll}67 & 1 & 8 & \mathrm{P} \\ 67 & 1 & 5 & \mathrm{P} \\ 33 & 1 & <1 & \mathrm{P} \\ 50 & 2 & 4 & \mathrm{P} \\ 83 & 1 & 13 & \mathrm{P} \\ 50 & 1 & 2 & \mathrm{P} \\ 83 & 1 & 4 & \mathrm{P} \\ 33 & 3 & <1 & \mathrm{P} \\ 83 & 3 & <1 & \mathrm{P} \\ 50 & 1 & 3 & \mathrm{P} \\ 100 & 1 & 3 & \mathrm{P} \\ 33 & 1 & <1 & \mathrm{P} \\ 33 & 1 & 3 & \mathrm{P} \\ 33 & 1 & 1 & \mathrm{P} \\ 67 & 1 & 7 & \mathrm{P} \\ 33 & 1 & <1 & \mathrm{P} \\ 100 & 1 & 8 & \mathrm{P} \\ 50 & 3 & 2 & \mathrm{P} \\ 83 & 3 & 3 & \mathrm{P} \\ 83 & 1 & 27 & \mathrm{P} \\ 67 & 1 & 4 & \mathrm{P} \\ 50 & 1 & 7 & \mathrm{P} \\ 67 & 1 & 10 & \mathrm{P}\end{array}$




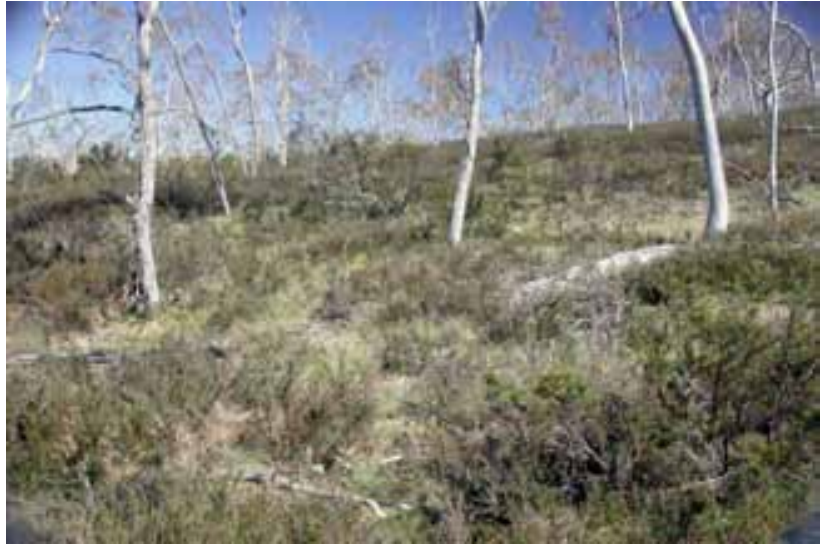

Plate a34: Eucalyptus lacrimans is a sparse dominant of Community a34, which is confined to Kosciuszko NP (this example at Long Plain). The understorey may be shrubby or grassy.

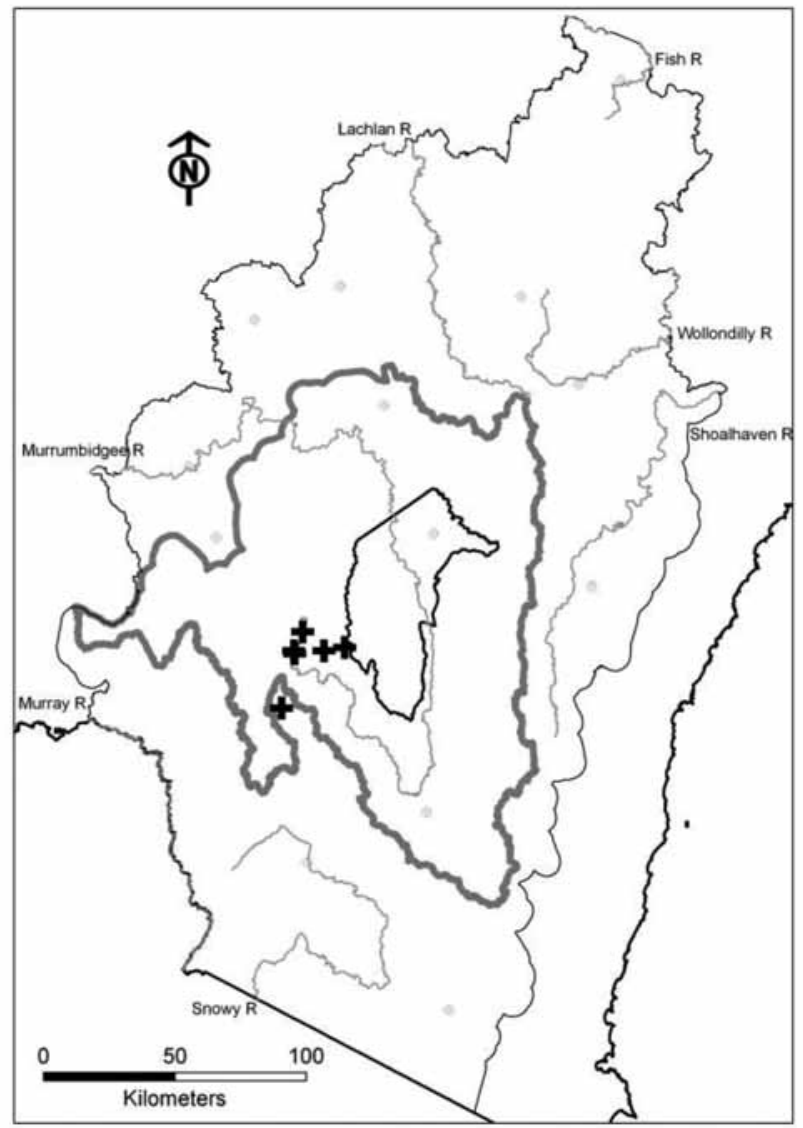

Fig. a34: Distribution of field samples assigned to this community.

$\begin{array}{llllll}\text { Scleranthus fasciculatus } & 2 & 33 & 1 & 1 & \mathrm{P} \\ \text { Senecio pinnatifolius var. alpinus } & 1 & 33 & 1 & 3 & \mathrm{P} \\ \text { Trisetum spicatum } & 1 & 83 & 1 & 3 & \mathrm{P} \\ \text { Elymus scaber } & 1 & 50 & 1 & 21 & \mathrm{C} \\ \text { Stylidium graminifolium sens. lat } & 1 & 50 & 1 & 25 & \mathrm{C}\end{array}$

Threatened communities: Nil.

Equivalent vegetation types: Community 34 [Eucalyptus lacrimans low open woodland] (McDougall \& Walsh 2007).

Frequently occurring weeds: The weeds Acetosella vulgaris $(0.50)$, Cerastium vulgare $(0.33)$ and Hypochaeris radicata $(0.67)$ are the most frequently recorded from this community, indicating past grazing disturbance.

Threats: The majority of sites contain dead trees of Eucalyptus lacrimans, with little or no recruitment of this species. The reason for the decline of the over-storey warrants investigation, but may be attributed in some way to the recent extended drought. This community is also highly localized, making it vulnerable to stochastic disturbance events.

Reservation status: Entirely within Kosciuszko NP.

Extent of clearing: Unknown. Large areas of Eucalyptus pauciflora subsp. pauciflora were cleared in the vicinity of this community in the early $20^{\text {th }}$ Century to increase the grazing capacity of the land. The sparse nature of Eucalyptus lacrimans stands may have saved it from that fate.

Reference: McDougall, K.L. \& Walsh, N.G. (2007) Treeless vegetation of the Australian Alps. Cunninghamia 10: 1-57.

\section{u22: Mountain Gum - Snow Gum \pm Robertson's Peppermint grass-forb very tall woodland to open forest of the Australian Alps and South Eastern Highlands bioregions}

Scientific Name: Eucalyptus dalrympleana - Eucalyptus pauciflora subsp. pauciflora \pm Eucalyptus radiata subsp. robertsonii / Acacia dealbata / Poa sieberiana - Stellaria pungens - Viola betonicifolia - Lomandra longifolia

Number of samples:

224

Richness [mean $( \pm \mathrm{SD})]$

(11)

Slope (degrees):

Altitude (m asl):

Ave. Annual Rainfall (mm):

(0) 6-16 (35)

Temp. Annual Range $\left({ }^{\circ} \mathrm{C}\right)$ :

(462) 1109-1294 (1694)

(701) 1075-1326 (1688)

(22.2) 23.7-24.7 (28.2)

Vegetation Description: Community $\mathrm{u} 22$ is a very tall grassy woodland to open forest dominated by Eucalyptus dalrympleana and Eucalyptus pauciflora subsp. pauciflora, occasionally with Eucalyptus radiata subsp. robertsonii. The shrub layer is generally sparse or absent with minor occurrences of Acacia dealbata, Coprosma hirtella, Olearia erubescens and Platylobium montanum. The understorey is characterised by a dense grassy / herbaceous cover, and is usually dominated by Poa sieberiana, infrequently with Dichelachne sieberiana or Rytidosperma pallidum. Common forbs include Stellaria pungens, Viola betonicifolia, Lomandra longifolia, Acaena novae-zelandiae. Asperula scoparia, Glycine clandestina, Clematis aristida, Stylidium graminifolium sens. lat., Poranthera microphylla, Coronidium scorpioides and Wahlenbergia stricta.

This community is distributed from south of Batlow in the BagoMaragle area, through northern Kosciuszko, Brindabella and Namadgi NPs, and extending eastwards to the Tinderry Ranges. It is found mainly on sandy-loam soils derived from granitoids. It grades into Community u239 [Alpine Ash - Mountain Gum \pm Snow Gum wet sclerophyll open 
forest of the Australian Alps and South Eastern Highlands bioregions] except in the Tinderry Ranges where it often grades into u150 [Broadleaved Peppermint - Mountain Gum tall grass-forb open forest of the South Eastern Highlands and Australian Alps bioregions]. In the Brindabella ranges, it may grade into Community u52 [Ribbon GumRobertson's Peppermint very tall wet sclerophyll open forest primarily of the Bondo Subregion of the South Eastern Highlands and northern Australian Alps bioregions] on sheltered slopes, and Community u 27 [Snow Gum - Candlebark tall grassy woodland in frost hollows and gullies of the South Eastern Highlands bioregion] in frost hollows downslope.

\section{Characteristic Species:}

\section{Species}

\section{Acacia dealbata}

Acacia melanoxylon

Acacia pravissima

Acaena echinata

Acaena novae-zelandiae

Acrothamnus hookeri

Acrotriche serrulata

Arthrochilus huntianus

Arthropodium milleflorum

Arthropodium Snowy R. catchment

Asperula scoparia

Brachyscome aculeata

Brachyscome spathulata

Bulbine bulbosa

Caladenia alpina

Caladenia gracilis

Calotis scabiosifolia var. integrifolia

Carex breviculmis

Cassinia aculeata

Chiloglottis valida

Clematis aristata

Coprosma hirtella

Coronidium scorpioides

Craspedia spp.

Craspedia variabilis

Cullen tenax

Cymbonotus preissianus

Cynoglossum australe

Daviesia latifolia

Daviesia mimosoides subsp.

mimosoides

Daviesia ulicifolia

Deyeuxia monticola

Deyeuxia quadriseta

Deyeuxia rodwayi

Dianella tasmanica

Dichelachne hirtella

Dichelachne inaequiglumis

Dichelachne sieberiana

Dipodium roseum

Dipodium spp.

Elymus scaber

Epacris breviflora

Epilobium billardierianum subsp.

cinereum

Eucalyptus dalrympleana

Eucalyptus pauciflora subsp.

pauciflora

Eucalyptus radiata subsp. robertsonii 3

Euchiton japonicus

Euphrasia collina subsp. paludosa

Euphrasia collina subsp. speciosa

Exocarpos strictus

Festuca asperula

\section{C/A Freq C/A O FreqO Fid}

\begin{tabular}{|c|c|c|c|}
\hline 2 & 58 & 2 & 24 \\
\hline 1 & 24 & 1 & 13 \\
\hline 1 & 8 & 1 & $<1$ \\
\hline 1 & 20 & 1 & 8 \\
\hline 2 & 74 & 1 & 24 \\
\hline 1 & 25 & 1 & 7 \\
\hline 1 & 23 & 1 & 10 \\
\hline 1 & 2 & 1 & $<1$ \\
\hline 1 & 29 & 1 & 7 \\
\hline 2 & 17 & 2 & $<1$ \\
\hline 2 & 75 & 1 & 18 \\
\hline 1 & 9 & 1 & 2 \\
\hline 1 & 41 & 1 & 9 \\
\hline 1 & 13 & 1 & 4 \\
\hline 1 & 3 & 1 & $<1$ \\
\hline 1 & 4 & 1 & 1 \\
\hline 1 & 12 & 1 & 2 \\
\hline 2 & 26 & 1 & 12 \\
\hline 2 & 37 & 1 & 12 \\
\hline 2 & 16 & 1 & 2 \\
\hline 1 & 72 & 1 & 20 \\
\hline 1 & 52 & 1 & 9 \\
\hline 1 & 55 & 1 & 17 \\
\hline 2 & 16 & 1 & 3 \\
\hline 1 & 39 & 1 & 3 \\
\hline 2 & 4 & 1 & $<1$ \\
\hline 1 & 24 & 1 & 5 \\
\hline 1 & 10 & 1 & 3 \\
\hline 2 & 33 & 2 & 5 \\
\hline 3 & 23 & 2 & 8 \\
\hline 2 & 31 & 1 & 9 \\
\hline 2 & 22 & 1 & 4 \\
\hline 1 & 11 & 1 & 4 \\
\hline 1 & 7 & 2 & $<1$ \\
\hline 1 & 32 & 2 & 15 \\
\hline 1 & 4 & 1 & 1 \\
\hline 2 & 22 & 2 & 5 \\
\hline 2 & 24 & 2 & 4 \\
\hline 1 & 3 & 1 & $<1$ \\
\hline 1 & 1 & 1 & $<1$ \\
\hline 2 & 33 & 1 & 20 \\
\hline 1 & 7 & 2 & 2 \\
\hline 1 & 19 & 1 & 4 \\
\hline 3 & 86 & 2 & 15 \\
\hline 3 & 82 & 3 & 17 \\
\hline 3 & 36 & 3 & 7 \\
\hline 1 & 31 & 1 & 14 \\
\hline 1 & 9 & 1 & 2 \\
\hline 1 & 2 & 1 & $<1$ \\
\hline 1 & 29 & 1 & 11 \\
\hline 1 & 11 & 1 & $<1$ \\
\hline
\end{tabular}

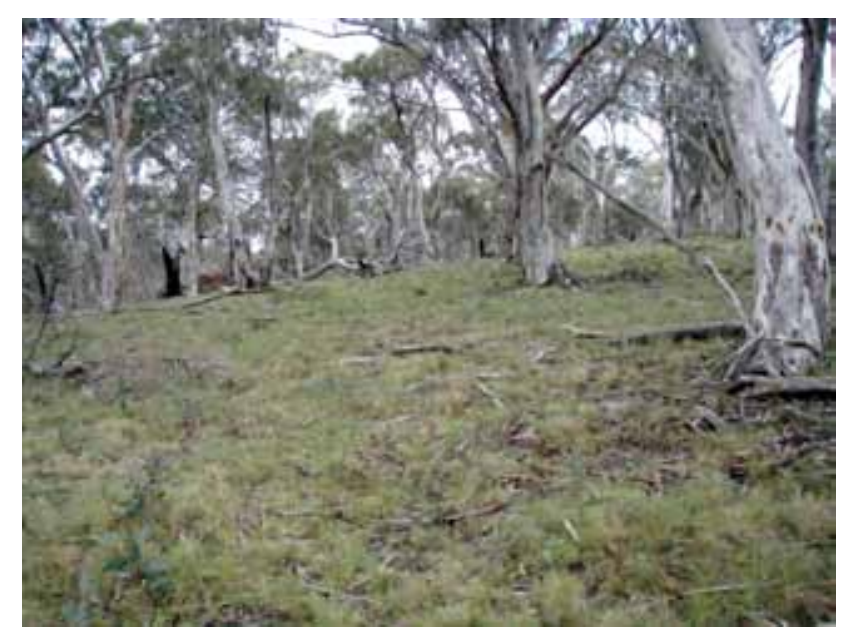

Plate u22: An example of Community u22 containing Eucalyptus pauciflora subsp. pauciflora with a grassy understorey dominated by Poa sieberiana. Plot UMCPG06, north of Brayshaw's Hut, eastern boundary of Kosciuszko NP.

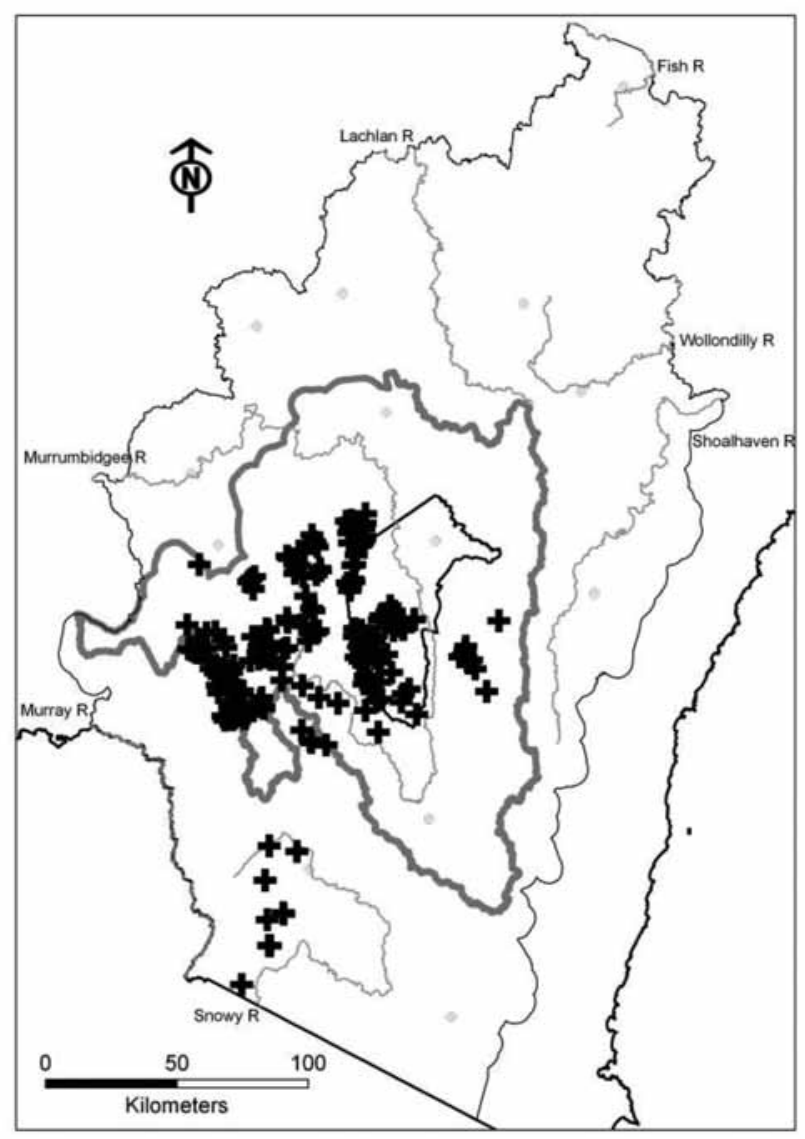

Fig. u22: Distribution of field samples assigned to this community. 
Galium ciliare

Gastrodia sesamoides

Gentianella sylvicola

Geranium potentilloides

Geranium solanderi

Glycine clandestina

Gonocarpus tetragynus

Hookerochloa eriopoda

Hovea asperifolia

Lachnagrostis aemula

Lagenophora stipitata

Leptinella filicula

Leucopogon gelidus

Lobelia gibbosa

Lobelia pedunculata

Lomandra filiformis subsp. filiformis

Lomandra longifolia

Lomatia myricoides

Lotus australis

Luzula flaccida

Myosotis australis

Olearia erubescens

Olearia megalophylla

Oreomyrrhis eriopoda

Ozothamnus thyrsoideus

Persoonia chamaepeuce

Persoonia subvelutina

Picris angustifolia

Platylobium montanum

Poa induta

Poa sieberiana

Poa tenera

Podolepis hieracioides

Polyscias sambucifolia

Poranthera microphylla

Pterostylis coccina

Pterostylis decurva

Pterostylis fischii

Pterostylis monticola

Pultenaea juniperina

Ranunculus lappaceus

Ranunculus plebeius

Ranunculus scapiger

Rytidosperma pilosum

Senecio biserratus

Senecio diaschides

Senecio gunnii

Senecio linearifolius

Senecio prenanthoides

Stackhousia monogyna

Stellaria pungens

Stylidium graminifolium sens. lat.

Tasmannia lanceolata

Tetratheca bauerifolia

Tetratheca ciliata

Thysanotus tuberosus

Veronica calycina

Veronica derwentiana

Veronica perfoliata

Viola betonicifolia

Wahlenbergia gloriosa

Wahlenbergia stricta
Galium polyanthum

Microseris lanceolata

\begin{tabular}{|c|c|c|}
\hline 5 & 2 & $<1$ \\
\hline 5 & 1 & 2 \\
\hline 3 & 1 & $<1$ \\
\hline 4 & 1 & $<1$ \\
\hline 40 & 1 & 11 \\
\hline 33 & 1 & 18 \\
\hline 75 & 1 & 26 \\
\hline 48 & 2 & 48 \\
\hline 13 & 2 & 1 \\
\hline 1 & 0 & 0 \\
\hline 6 & 1 & $<1$ \\
\hline 43 & 1 & 15 \\
\hline 14 & 1 & 2 \\
\hline 6 & 1 & 2 \\
\hline 4 & 1 & $<1$ \\
\hline 25 & 1 & 3 \\
\hline 33 & 1 & 15 \\
\hline 78 & 2 & 40 \\
\hline 25 & 1 & 11 \\
\hline 2 & 1 & $<1$ \\
\hline 42 & 1 & 11 \\
\hline 15 & 1 & 6 \\
\hline 2 & 1 & $<1$ \\
\hline 52 & 1 & 9 \\
\hline 16 & 1 & 4 \\
\hline 42 & 1 & 11 \\
\hline 6 & 1 & 2 \\
\hline 41 & 1 & 9 \\
\hline 5 & 1 & 1 \\
\hline 10 & 1 & 1 \\
\hline 43 & 2 & 8 \\
\hline 17 & 2 & 5 \\
\hline 88 & 2 & 45 \\
\hline 8 & 2 & 2 \\
\hline 5 & 1 & $<1$ \\
\hline 20 & 2 & 4 \\
\hline 57 & 1 & 25 \\
\hline 6 & 1 & $<1$ \\
\hline 8 & 1 & $<1$ \\
\hline 1 & 1 & $<1$ \\
\hline 12 & 1 & $<1$ \\
\hline 4 & 3 & $<1$ \\
\hline 46 & 1 & 8 \\
\hline 10 & 1 & 3 \\
\hline 4 & 1 & 1 \\
\hline 19 & 2 & 8 \\
\hline 3 & 1 & $<1$ \\
\hline 21 & 1 & 4 \\
\hline 25 & 1 & 8 \\
\hline 10 & 1 & 5 \\
\hline 38 & 1 & 18 \\
\hline 33 & 1 & 11 \\
\hline 88 & 2 & 27 \\
\hline 63 & 1 & 23 \\
\hline 9 & 1 & 3 \\
\hline 17 & 1 & 6 \\
\hline 10 & 1 & $<1$ \\
\hline 11 & 1 & 3 \\
\hline 49 & 1 & 14 \\
\hline 35 & 1 & 5 \\
\hline 8 & 1 & 4 \\
\hline 85 & 1 & 23 \\
\hline 8 & 1 & 2 \\
\hline 54 & 1 & 16 \\
\hline
\end{tabular}

Threatened communities: Parts of this community may contain TSC Act 1995 - Tablelands Snow Gum, Black Sallee, Candlebark and Ribbon Gum Grassy Woodland in the South Eastern Highlands, Sydney Basin, South East Corner and NSW South Western Slopes bioregions.
Equivalent vegetation types: This community has affinities with VG97 [Montane Acacia Dry/ Shrub/Herb/Grass Forest] and VG100 [ACT Montane Dry Shrub/Grass Forest] (Gellie 2005).

Frequently occurring weeds: Weed species were not common within this community, with only Hypochaeris radicata $(0.66)$ present in the majority of sites.

Threats: Community u 22 is well reserved across its range. Extensive areas also occur within the State Forest estate, where selective logging has had some impact upon the overstorey. The impact of logging is an ongoing, albeit minor threat to the floristic integrity of this community. Inappropriate fire regimes represent a greater potential threat through its capacity to alter community floristics and structure over time.

Reservation status: The majority of examples of this community are found in Kosciuszko NP and Namadgi NR, and it is also known from Bimberi NR, Brindabella NP, Burnt School NR, Scabby Range NR, Tinderry NR, Yanununbeyan NP and Yaouk NR.

Extent of clearing: Likely to be minimal. Patches closer to the valley floor are more likely to have been cleared on freehold land.

Reference: Gellie, N.J.H. (2005) Native vegetation of the southern forests: South Eastern Highlands, Australian Alps, South West Slopes and South East Corner bioregions. Cunninghamia 9: 219-254.

\section{u23: Snow Gum - Epacris breviflora - Leptosper- mum myrtifolium tall woodland to open forest of drainage depressions primarily of the South East- ern Highlands bioregion}

Scientific Name: Eucalyptus pauciflora subsp. paucifloraEucalyptus dalrympleana - Eucalyptus stellulata / Epacris breviflora - Leptospermum myrtifolium - Baeckea utilis / Acaena novae-zelandiae - Stylidium graminifolium sens. lat. - Poa sieberiana - Coronidium scorpioides

Number of samples:
Richness [mean $( \pm \mathrm{SD})]$ :
Slope (degrees):
Altitude (m asl):
Ave. Annual Rainfall $(\mathrm{mm})$ :
Temp. Annual Range $\left({ }^{\circ} \mathrm{C}\right)$ :

17

44 (12)

(1) 2-8 (17)

(577) 1100-1230 (1375)

(742) 876-1235 (1423)

(23.8) 24-25.2 (27.8)

Vegetation Description: Community u23 is a swampy tall eucalypt woodland to open forest dominated by Eucalyptus pauciflora subsp. pauciflora, Eucalyptus dalrympleana and Eucalyptus stellulata. The well developed shrub layer is dominated by Epacris breviflora, Leptospermum myrtifolium, Baeckea utilis, Hakea microcarpa and Olearia erubescens. Low shrubs include Persoonia chamaepeuce, Acrothamnus hookeri, Acrotriche serrulata and Grevillea lanigera. The diverse groundlayer is typical of subalpine woodland communities and includes Poa sieberiana, Elymus scaber, Hookerochloa eriopoda, Poa helmsii, Acaena novae-zelandiae, Stylidium graminifolium sens. lat., Coronidium scorpioides, Asperula scoparia, Viola betonicifolia, Carex appressa, Hydrocotyle sibthorpioides, Hypericum japonicum, Ranunculus lappaceus, Lomandra longifolia, Poranthera microphylla, Stellaria pungens and Arthropodium milleflorum.

This is a widespread community within the study area, extending from Tallaganda NP in the east to Maragle SF in the west. The majority of plot locations occur within the central part of its range, especially in Tinderry NR, Namadgi NP and Kosciuszko NP. It is confined to sheltered locations in montane environments, generally adjacent to, or within drainage depressions. Although it is most common on granite, it also occurs on basalt and metasediments. A number of widespread montane communities occur in association with this community, including Community u22 [Mountain Gum - Snow Gum grass-forb very tall woodland to open forest of the Australian Alps and South Eastern 
Highlands bioregions], Community u27 [Snow Gum - Candlebark tall grassy woodland in frost hollows and gullies of the South Eastern Highlands bioregion ], Community u239 [Alpine Ash - Mountain Gum \pm Snow Gum wet sclerophyll open forest of the Australian Alps and South Eastern Highlands bioregions] and Community u150 [Broadleaved Peppermint - Mountain Gum tall grass-forb open forest of the South Eastern Highlands and Australian Alps bioregions].

\section{Characteristic Species:}

\section{Species}

Acaena novae-zelandiae Arthropodium milleflorum Asperula gunnii

Asperula scoparia

Baeckea utilis

Baloskion australe

Blechnum penna-marina subsp. alpina

Bossiaea foliosa

Brachyscome spathulata

Bulbine bulbosa

Carex appressa

Chiloglottis valida

Coronidium scorpioides

Deyeuxia quadriseta

Empodisma minus

Epacris breviflora

Eucalyptus dalrympleana

Eucalyptus pauciflora subsp. pauciflora 382

Eucalyptus stellulata

Gonocarpus micranthus

Grevillea lanigera

Hakea microcarpa

Haloragis heterophylla

Hookerochloa eriopoda

Hydrocotyle sibthorpioides

Hypericum japonicum

Juncus australis

Leptospermum grandifolium

Leptospermum lanigerum

Leptospermum myrtifolium

Olearia erubescens

Olearia megalophylla

Oxylobium ellipticum

Poa helmsii

Poa labillardierei

Ranunculus lappaceus

Rytidosperma penicillatum

Schoenus apogon

Stylidium graminifolium sens. lat.

Veronica subtilis

Elymus scaber

Euchiton japonicus

Gonocarpus tetragynus

Lomandra longifolia

Poa sieberiana

Poranthera microphylla

Stellaria pungens

Viola betonicifolia

\section{C/AFreq C/A O FreqO Fid}

$\begin{array}{lllll}2 & 100 & 1 & 27 & \mathrm{P}\end{array}$

$\begin{array}{lllll}1 & 41 & 1 & 8 & \mathrm{P}\end{array}$

$\begin{array}{lllll}2 & 24 & 1 & 5 & \mathrm{P}\end{array}$

$\begin{array}{llll}59 & 2 & 22 & \mathrm{P}\end{array}$

$\begin{array}{lllll}3 & 65 & 2 & 1 & \mathrm{P}\end{array}$

$\begin{array}{lllll}2 & 24 & 1 & 2 & \mathrm{P}\end{array}$

$\begin{array}{lllll}2 & 24 & 2 & 1 & \mathrm{P}\end{array}$

$\begin{array}{lllll}3 & 24 & 2 & 4 & \mathrm{P}\end{array}$

$\begin{array}{lllll}1 & 41 & 1 & 11 & \mathrm{P}\end{array}$

$\begin{array}{lllll}2 & 24 & 1 & 4 & \mathrm{P}\end{array}$

$\begin{array}{lllll}2 & 53 & 1 & 7 & \mathrm{P}\end{array}$

$\begin{array}{lllll}1 & 24 & 1 & 2 & \mathrm{P}\end{array}$

$\begin{array}{lllll}2 & 71 & 1 & 20 & \mathrm{P}\end{array}$

$\begin{array}{lllll}1 & 24 & 1 & 4 & \mathrm{P}\end{array}$

$\begin{array}{lllll}2 & 29 & 2 & 3 & \mathrm{P}\end{array}$

$\begin{array}{lllll}2 & 94 & 1 & 2 & \mathrm{P}\end{array}$

$\begin{array}{lllll}2 & 76 & 3 & 20 & \mathrm{P}\end{array}$

$\begin{array}{lllll}2 & 82 & 3 & 21 & \mathrm{P}\end{array}$

$\begin{array}{lllll}2 & 53 & 2 & 3 & \mathrm{P}\end{array}$

$\begin{array}{lllll}2 & 41 & 1 & 2 & \mathrm{P}\end{array}$

$\begin{array}{lll}2 & 29 & 1\end{array}$

$\begin{array}{lll}2 & 41 & 1\end{array}$

$\begin{array}{lll}3 & 24 & 1\end{array}$

$\begin{array}{lll}3 & 35 & 2\end{array}$

$\begin{array}{lll}2 & 53 & 2\end{array}$

$\begin{array}{lll}2 & 53 & 1\end{array}$

$\begin{array}{lll}2 & 24 & 1\end{array}$

$\begin{array}{lll}3 & 24 & 3\end{array}$

$\begin{array}{lll}4 & 24 & 2\end{array}$

$\begin{array}{lll}2 & 88 & 1\end{array}$

$\begin{array}{lll}1 & 41 & 1\end{array}$

$\begin{array}{lll}1 & 24 & 1\end{array}$

$\begin{array}{lll}4 & 24 & 1\end{array}$

$\begin{array}{lll}2 & 35 & 2\end{array}$

$\begin{array}{lll}3 & 35 & 2\end{array}$

$\begin{array}{lll}2 & 53 & 1\end{array}$

2424

$\begin{array}{lll}2 & 29 & 1\end{array}$

$\begin{array}{lll}2 & 88 & 1\end{array}$

$\begin{array}{lll}2 & 24 & 1\end{array}$

$\begin{array}{lll}2 & 41 & 1\end{array}$

$\begin{array}{lll}2 & 41 & 1\end{array}$

$2 \quad 41 \quad 2$

$\begin{array}{lll}1 & 47 & 2\end{array}$

$\begin{array}{lll}2 & 71 & 2\end{array}$

$247 \quad 1$

$2 \begin{array}{lll}2 & 47 & 2\end{array}$

$1 \quad 59 \quad 1$

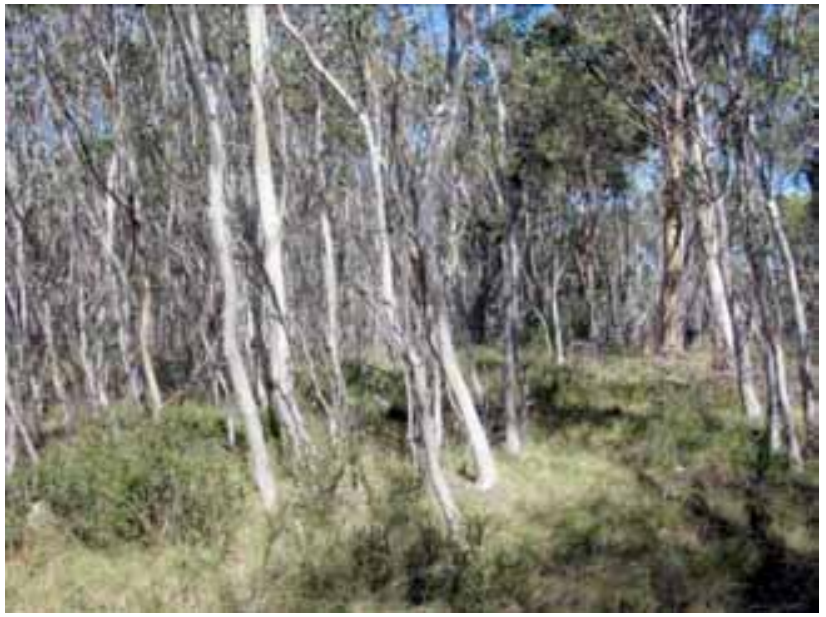

Plate u23: Community u23 in headwaters of Little Glory Hole Creek beside Yarrangobilly Caves exit road, Kosciuszko NP, showing regenerating Eucalyptus pauciflora and a grass-shrub understorey.

Threatened communities: Parts of this community may contain TSC Act 1995 - Tablelands Snow Gum, Black Sallee, Candlebark and Ribbon Gum Grassy Woodland in the South Eastern Highlands, Sydney Basin, South East Corner and NSW South Western Slopes bioregions.

Equivalent vegetation types: Most similar to VG124 [Western Montane/Sub-alpine Wet Heath/Herb Grass Woodland] and VG146 [Tableland Dry Herb/Grass Woodland] (Gellie 2005).

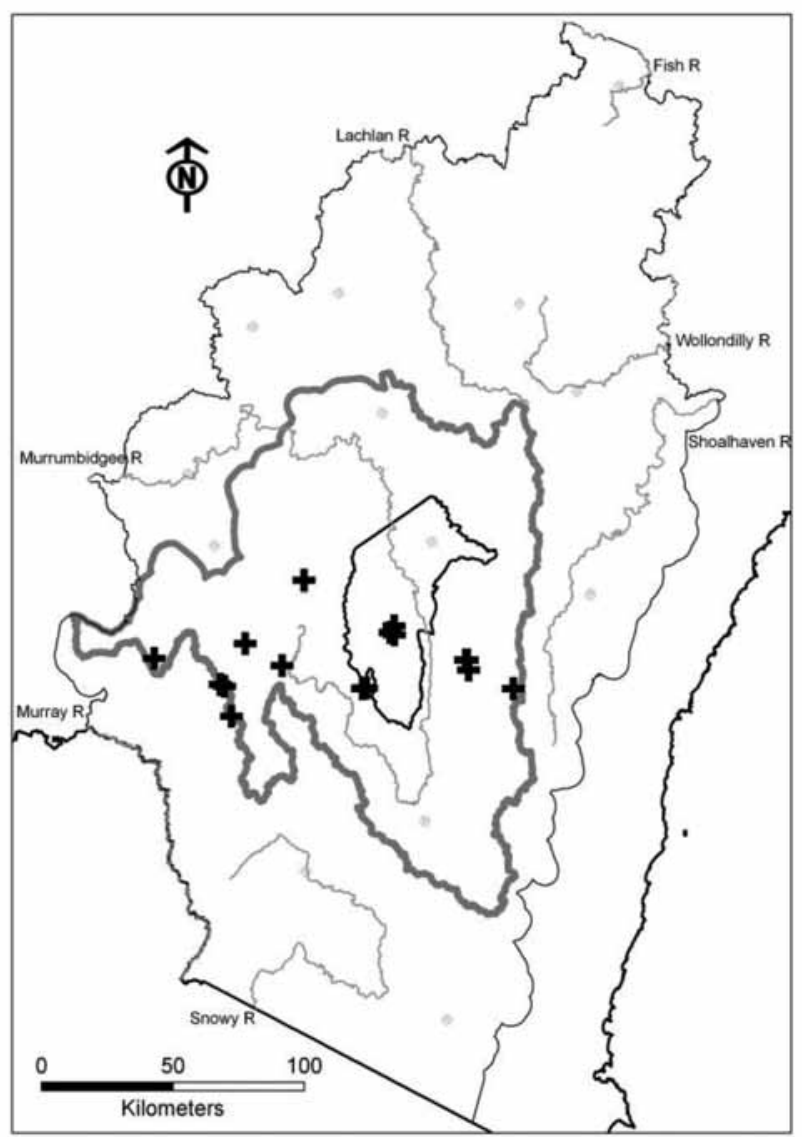

Fig. u23: Distribution of field samples assigned to this community. 
Frequently occurring weeds: The weeds of this community are typical of other grassy woodlands in the South Eastern Highlands, suggesting past and possibly ongoing disturbance by grazing. This community also occurs in riparian environments, which are often subject to colonisation by weeds. The most common weeds recorded from this community include Acetosella vulgaris (0.23), Centaurium erythraea (0.23) Cerastium vulgare (0.31), Crepis capillaris (0.31), Holcus lanatus (0.54), Hypochaeris radicata (0.77), Mimulus moschatus (0.31), Prunella vulgaris (0.69), Rosa rubiginosa (0.23), Trifolium dubium (0.23) and Trifolium repens $(0.46)$.

Threats: Although much of this community occurs on public land, it is not immune from disturbance or degradation. In many examples, weed invasion threatens ground and shrub layer structure and composition. Grazing by feral, and in some areas, native herbivores may exacerbate this problem. Because the community generally occurs within extensively forested regions, it is also at risk from frequent and intense fire, which may influence floristic and structural composition over time.

Reservation status: Likely to be well reserved, and is known to occur in Kosciuszko NP, Namadgi NP, Scabby Range NR, Tallaganda NP and Tinderry NR.

Extent of clearing: Negligible.

Reference: Gellie, N.J.H. (2005) Native vegetation of the southern forests: South Eastern Highlands, Australian Alps, South West Slopes and South East Corner bioregions. Cunninghamia 9: 219-254.

\section{u27: Snow Gum - Candlebark tall grassy woodland in frost hollows and gullies of the South Eastern Highlands bioregion}

Scientific Name: Eucalyptus pauciflora subsp. pauciflora Eucalyptus rubida \pm Eucalyptus dives / Acacia dealbata / Poa induta - Poa sieberiana - Glycine clandestina-Gonocarpus tetragynus

Number of samples:

Richness [mean $( \pm \mathrm{SD})]$ :

Slope (degrees):

Altitude (m asl):

Ave. Annual Rainfall (mm):

$42(8)$

(1) $7-20(34)$

(890) 1088-1331 (1558)

(656) 783-988 (1253)

Temp. Annual Range $\left({ }^{\circ} \mathrm{C}\right)$ :

Vegetation Description: Community u27 us a tall grassy woodland to open forest dominated by Eucalyptus pauciflora subsp. pauciflora often with Eucalyptus rubida, and occasionally with Eucalyptus dives or Eucalyptus viminalis. The shrub layer is generally sparse or absent with Acacia dealbata and Cassinia longifolia being the only frequently occurring shrub species, along with occasional occurrences of small shrubs such as Acrotriche serrulata and Hibbertia obtusifolia. Daviesia ulicifolia may be present in sites which have been burnt in the last 20 30 years. The understorey is characterised by dense grassy / herbaceous cover, and is dominated by grasses such as Poa induta, Poa sieberiana, Elymus scaber, Dichelachne rara and Themeda australis. Forbs include Glycine clandestina, Gonocarpus tetragynus, Lomandra longifolia, Asperula scoparia, Viola betonicifolia, Stellaria pungens, Senecio gunnii, Euchiton sphaericus, Luzula spp. and Acaena novae-zelandiae.

Plot records indicate that Community u 27 is distributed mostly on mid to lower slopes on ranges and frost hollow depressions in the Namadgi region and adjacent granitic ranges. However, it is poorly sampled throughout its range and is considered to occur in the Monaro between Bredbo, Bombala and Berridale. In the Namadgi region, it generally occurs in valley floors and lower slopes associated with dry montane forests including Community u22 [Mountain Gum - Snow Gum grassforb very tall woodland to open forest of the Australian Alps and South Eastern Highlands bioregions], Community u29 [Apple Box-Broadleaved Peppermint tall shrub-grass woodland primarily on granitoids of

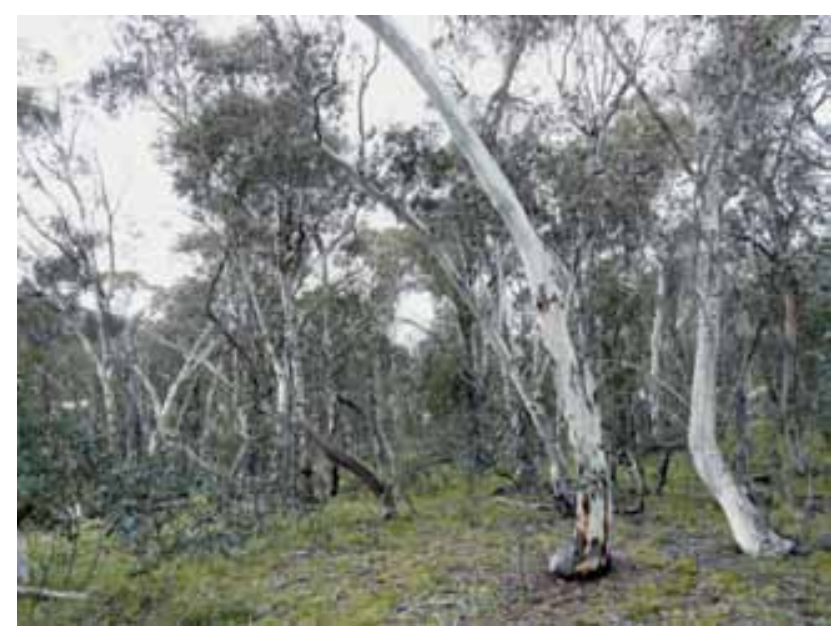

Plate u27: Community u27 with Eucalyptus rubida, Eucalyptus pauciflora and Poa spp. dominated grassy groundlayer near Mt Clear Camp ground track southern Naas Valley, ACT.

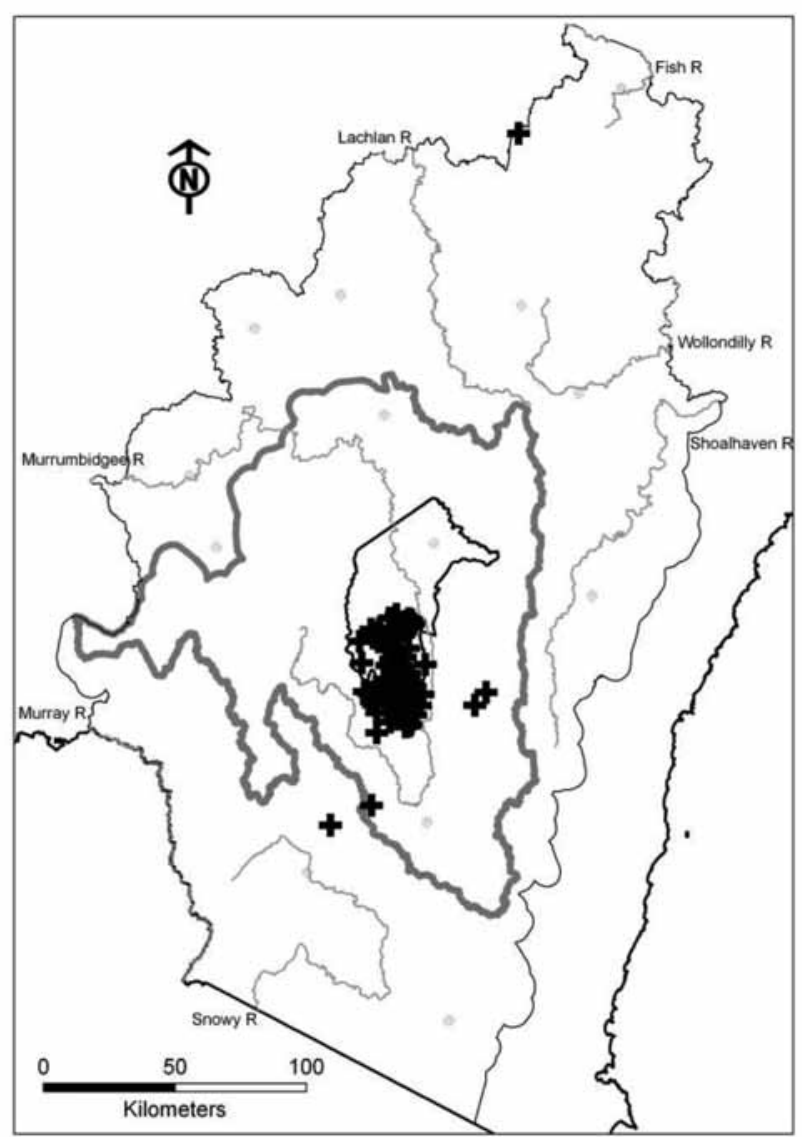

Fig. u27: Distribution of field samples assigned to this community. 
the South Eastern Highlands bioregion] and Community u150 [Broadleaved Peppermint - Mountain Gum tall grass-forb open forest of the South Eastern Highlands and Australian Alps bioregions].

This community is primarily characterised by plots sampled in the ACT. Further sampling of such vegetation in NSW will be useful to better define character species across its range.

\section{Characteristic Species:}

\section{Species}

Acacia dealbata

Acaena novae-zelandiae

Acaena ovina

Acrothamnus hookeri

Acrotriche serrulata

Ajuga australis

Arthropodium milleflorum

Asperula scoparia

Asplenium flabellifolium

Bossiaea buxifolia

Brachyscome aculeata

Brachyscome rigidula

Brachyscome spathulata

Bursaria spinosa

Calotis scabiosifolia var. integrifolia

Carex inversa

Cassinia longifolia

Cassinia quinquefaria

Chrysocephalum semipapposum

Craspedia spp.

Craspedia variabilis

Cullen microcephalum

Cymbonotus preissianus

Cymbonotus spp.

Cynoglossum australe

Cynoglossum suaveolens

Daviesia mimosoides subsp.

mimosoides

Daviesia ulicifolia

Deyeuxia monticola

Dichelachne micrantha

Dichelachne rara

Dichondra repens

Echinopogon cheelii

Elymus scaber

Epilobium billardierianum subsp.

billardierianum

Eucalyptus dives

Eucalyptus pauciflora subsp.

pauciflora

Eucalyptus rubida

Eucalyptus stellulata

Eucalyptus viminalis

Euchiton sphaericus

Exocarpos strictus

Galium gaudichaudii

Galium polyanthum

Geranium obtusisepalum

Geranium potentilloides

Geranium solanderi

Glycine clandestina

Gonocarpus tetragynus

Goodenia pinnatifida

Hibbertia obtusifolia

Hovea linearis

Hypericum gramineum

Indigofera australis

Leucopogon fletcheri subsp.

brevisepalus

\section{C/AFreq C/A O FreqO Fid}

\begin{tabular}{|c|c|c|c|c|c|}
\hline 2 & 67 & 2 & 25 & $\mathrm{P}$ & $\begin{array}{l}\text { Pimelea treyvaudii } \\
\text { Plantago varia }\end{array}$ \\
\hline 1 & 63 & 1 & 27 & $\mathrm{P}$ & Poa induta \\
\hline 1 & 49 & 1 & 7 & $\mathrm{P}$ & Poa sieberiana \\
\hline 1 & 23 & 1 & 7 & $\mathrm{P}$ & Pultenaea procumbens \\
\hline 1 & 44 & 1 & 10 & $\mathrm{P}$ & Ranunculus lappaceus \\
\hline 1 & 33 & 1 & 7 & $\mathrm{P}$ & Rytidosperma penicillatum \\
\hline 1 & 28 & 1 & 8 & $\mathrm{P}$ & Schoenus apogon \\
\hline 2 & 69 & 2 & 21 & $\mathrm{P}$ & Scleranthus biflorus \\
\hline 1 & 21 & 1 & 8 & $\mathrm{P}$ & Scleranthus diander \\
\hline 1 & 21 & 1 & 7 & $\mathrm{P}$ & Senecio gunnii \\
\hline 1 & 14 & 1 & 2 & $\mathrm{P}$ & Senecio quadridentatus \\
\hline 1 & 11 & 1 & 2 & $\mathrm{P}$ & Solenogyne gunnii \\
\hline 1 & 32 & 1 & 10 & $\mathrm{P}$ & Stackhousia monogyna \\
\hline 1 & 25 & 1 & 10 & $\mathrm{P}$ & Stellaria pungens \\
\hline 1 & 29 & 1 & 2 & $\mathrm{P}$ & Stylidium graminifolium sens. lat. \\
\hline 1 & 46 & 1 & 7 & $\mathrm{P}$ & Themeda australis \\
\hline 2 & 60 & 1 & 15 & $P$ & Veronica calycina \\
\hline 2 & 4 & 1 & $<1$ & $\mathrm{P}$ & Veronica derwentiana \\
\hline 1 & 13 & 1 & 4 & $P$ & Viola betonicifolia \\
\hline 1 & 18 & 1 & 3 & $\mathrm{P}$ & Wahlenbergia gloriosa \\
\hline 1 & 15 & 1 & 5 & $\mathrm{P}$ & Wahlenbergia graniticola \\
\hline 1 & 25 & 1 & 2 & $\mathrm{P}$ & Wahlenbergia stricta \\
\hline
\end{tabular}

Linum marginale Lomandra longifolia

Lotus australis

Luzula spp.

Mirbelia oxylobioides

Olearia erubescens

Oreomyrrhis eriopoda

Oxylobium ellipticum

Ozothamnus stirlingii

Persoonia chamaepeuce

Pimelea linifolia

Pimelea treyvaudii

Poa sieberian

Pultenaea procumben

Schoenus apogon

Scleranthus bifloru

Senecio quadridentatus
Lomandra filiformis subsp. filiformis

$\begin{array}{lllll}1 & 6 & 1 & 1 & \mathrm{P} \\ 1 & 36 & 1 & 15 & \mathrm{P} \\ 2 & 75 & 2 & 41 & \mathrm{P} \\ 1 & 4 & 1 & <1 & \mathrm{P} \\ 1 & 63 & 1 & 4 & \mathrm{P} \\ 1 & 12 & 1 & 3 & \mathrm{P} \\ 1 & 25 & 1 & 12 & \mathrm{P} \\ 1 & 55 & 1 & 12 & \mathrm{P} \\ 1 & 13 & 2 & 4 & \mathrm{P} \\ 1 & 6 & 1 & <1 & \mathrm{P} \\ 1 & 23 & 1 & 11 & \mathrm{P} \\ 1 & 31 & 1 & 8 & \mathrm{P} \\ 2 & 10 & 1 & <1 & \mathrm{P} \\ 1 & 57 & 1 & 10 & \mathrm{P} \\ 3 & 80 & 2 & 3 & \mathrm{P} \\ 3 & 78 & 2 & 47 & \mathrm{P} \\ 1 & 19 & 1 & 4 & \mathrm{P} \\ 1 & 23 & 1 & 10 & \mathrm{P} \\ 1 & 33 & 1 & 3 & \mathrm{P} \\ 1 & 15 & 1 & 5 & \mathrm{P} \\ 1 & 36 & 1 & 9 & \mathrm{P} \\ 1 & 20 & 1 & 1 & \mathrm{P} \\ 1 & 63 & 1 & 7 & \mathrm{P} \\ 2 & 21 & 1 & 5 & \mathrm{P} \\ 1 & 14 & 1 & 5 & \mathrm{P} \\ 1 & 51 & 1 & 11 & \mathrm{P} \\ 3 & 59 & 2 & 30 & \mathrm{P} \\ 1 & 50 & 1 & 25 & \mathrm{P} \\ 1 & 56 & 2 & 20 & \mathrm{P} \\ 1 & 47 & 1 & 15 & \mathrm{P} \\ 1 & 26 & 1 & 6 & \mathrm{P} \\ 1 & 75 & 1 & 26 & \mathrm{P} \\ 1 & 8 & 1 & 2 & \mathrm{P} \\ 1 & 9 & 2 & <1 & \mathrm{P} \\ 1 & 59 & 1 & 17 & \mathrm{P}\end{array}$

Threatened communities: TSC Act 1995 - Tablelands Snow Gum, Black Sallee, Candlebark and Ribbon Gum Grassy Woodland in the South Eastern Highlands, Sydney Basin, South East Corner and NSW South Western Slopes bioregions.

Equivalent vegetation types: No equivalent communities, defined by plots not used in previous classifications. May have affinities with VG100 [ACT Montane Dry Shrub/Grass Forest] from Gellie (2005)

Frequently occurring weeds: Common weeds of the pastoral districts of the South Eastern Highlands are a feature in this community, namely Acetosella vulgaris (0.23), Centaurium erythraea (0.51), Cirsium vulgare (0.25), Crepis capillaris (0.27) and Hypochaeris radicata (0.67).

Threats: Widespread historic clearing of this community has resulted in it becoming severely fragmented. This in turn has resulted in a disruption to essential ecological processes and has facilitated secondary disturbances such as over-grazing, weed invasion and the incursion of feral animals. Within existing remnants, weed invasion represents a major threat to ground and shrub layer species, especially where the community occurs on freehold land subject to grazing by domestic stock, Grazing by feral, and in some areas, native herbivores has a similar effect. Where the community occurs within extensively forested areas, frequent and intense fire may affect its structural and floristic composition. Within farming districts, canopy dieback is widespread.

Reservation status: Although this community was only sampled within in the ACT Reserve system, it is distributed across large parts of the South Eastern Highlands bioregion. Many examples of this community are found in Namadgi NP but it is also known from Burnt School NR, Kosciuszko NP, Scabby Range NR, Strike-a-Light NR and Yaouk NR.

Extent of clearing: Likely to be variable, with clearing rates of this community in valley floors being considerably higher than upslope. 


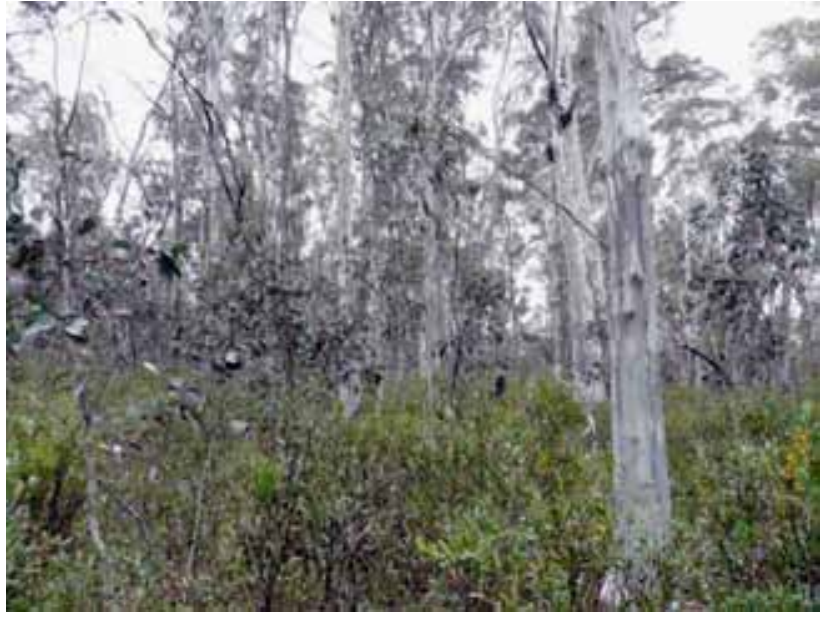

Plate u28: Community u28 at Smokers trail in Namadgi NP with Eucalyptus dalrympleana and Eucalyptus pauciflora and shrubs including Daviesia mimosoides and Coprosma hirtella.

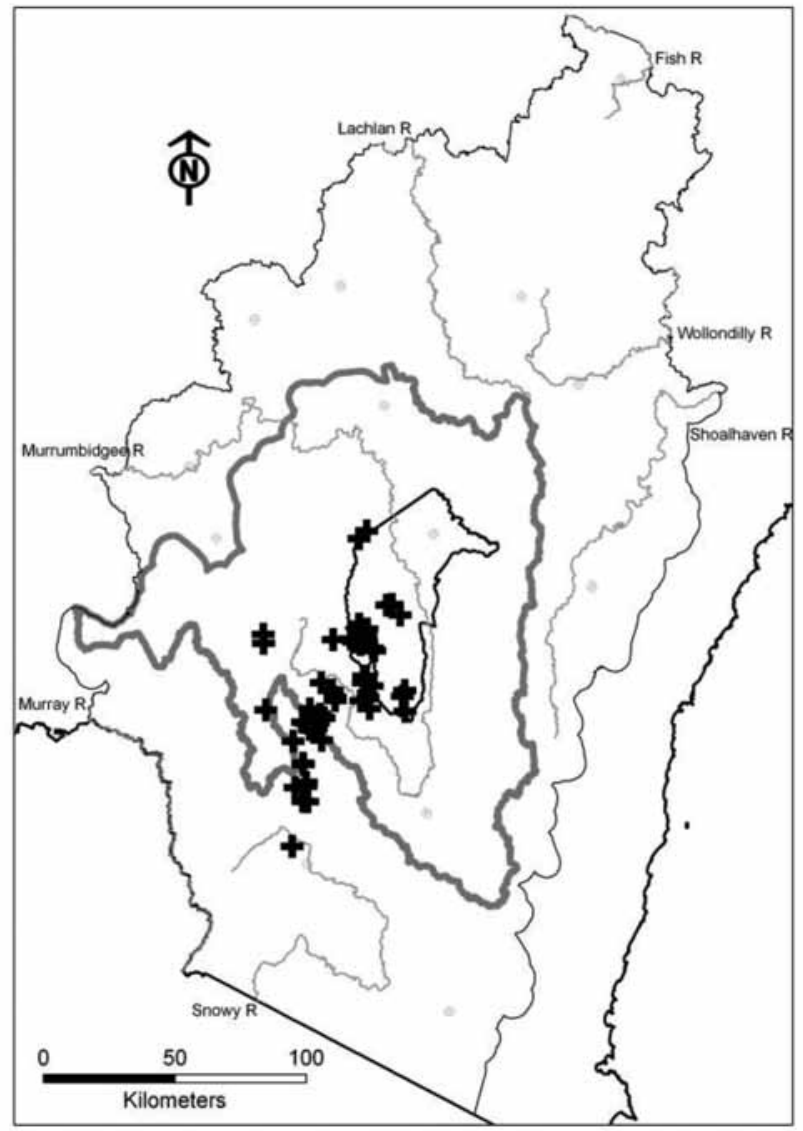

Fig. u28: Distribution of field samples assigned to this community.

\section{u28: Snow Gum - Mountain Gum - Daviesia mi- mosoides tall dry grass-shrub subalpine open forest of the Australian Alps and South Eastern High- lands bioregions}

Scientific Name: Eucalyptus pauciflora subsp. pauciflora - Eucalyptus dalrympleana \pm Eucalyptus rubida / Daviesia mimosoides subsp. mimosoides - Persoonia chamaepeuce I Poa sieberiana - Stellaria pungens - Lomandra longifolia

$\begin{array}{ll}\text { Number of samples: } & 54 \\ \text { Richness [mean }( \pm \mathrm{SD})]: & 24(7) \\ \text { Slope (degrees): } & (0) 6-17(42) \\ \text { Altitude (m asl): } & (978) 1181-1391(1582) \\ \text { Ave. Annual Rainfall }(\mathrm{mm}): & (737) 965-1129(1587) \\ \text { Temp. Annual Range }\left({ }^{\circ} \mathrm{C}\right): & (22.3) 23.7-24.8(25.7)\end{array}$

Vegetation Description: Community u28 is a tall eucalypt woodland to open forest dominated by Eucalyptus pauciflora subsp. pauciflora and Eucalyptus dalrympleana. The shrubby midstorey is dominated by Daviesia mimosoides subsp. mimosoides, Pimelea linifolia, Daviesia ulicifolia, Veronica perfoliata, Olearia erubescens and Exocarpos strictus. Low shrubs include Persoonia chamaepeuce, Hibbertia obtusifolia and Tetratheca bauerifolia. The diverse groundlayer shares affinities with other subalpine woodlands and includes Poa sieberiana, Stellaria pungens, Lomandra longifolia, Goodenia hederacea subsp. hederacea, Stylidium graminifolium sens. lat., Poranthera microphylla, Viola betonicifolia, Senecio gunnii, Gonocarpus tetragynus and Asperula scoparia.

This community is largely restricted to Namadgi NR, Kosciuszko NP and Scabby Range NR within the Australian Alps bioregion. Smaller occurrences also occur in adjacent parts of the South Eastern Highlands bioregion. It is generally confined to sheltered locations on metasedimentary and granite geologies. Communities with which Community u28 is associated are those characteristic of similar environments, including Community u22 [Mountain Gum - Snow Gum grass-forb very tall woodland to open forest of the Australian Alps and South Eastern Highlands bioregions], Community u27 [Snow Gum - Candlebark tall grassy woodland in frost hollows and gullies of the South Eastern Highlands bioregion], Community u239 [Alpine Ash - Mountain Gum \pm Snow Gum wet sclerophyll open forest of the Australian Alps and South Eastern Highlands bioregions] and Community u150 [Broad-leaved Peppermint - Mountain Gum tall grass-forb open forest of the South Eastern Highlands and Australian Alps bioregions].

Characteristic Species:

Species

C/AFreq C/A OFreqO Fid

Acacia obliquinervia

Bossiaea foliosa

Brachyscome spathulata

Caladenia gracilis

Daviesia mimosoides subsp. mimosoides 2

Daviesia ulicifolia

Deyeuxia monticola

Eucalyptus dalrympleana

Eucalyptus pauciflora subsp. pauciflora 3

Eucalyptus rubida

Exocarpos strictus

Goodenia hederacea subsp. hederacea

Grevillea lanigera

Leucopogon fletcheri subsp.

brevisepalus

Lomandra longifolia

$\begin{array}{lllll}2 & 17 & 2 & 3 & \mathrm{P} \\ 2 & 20 & 2 & 4 & \mathrm{P} \\ 1 & 26 & 1 & 11 & \mathrm{P} \\ 1 & 17 & 1 & 1 & \mathrm{P} \\ 2 & 67 & 2 & 8 & \mathrm{P} \\ 2 & 48 & 2 & 9 & \mathrm{P} \\ 1 & 19 & 1 & 5 & \mathrm{P} \\ 3 & 65 & 3 & 19 & \mathrm{P} \\ 3 & 94 & 3 & 20 & \mathrm{P} \\ 2 & 31 & 3 & 8 & \mathrm{P} \\ 2 & 31 & 1 & 12 & \mathrm{P} \\ 1 & 67 & 2 & 16 & \mathrm{P} \\ 2 & 17 & 1 & 3 & \mathrm{P} \\ 1 & 24 & 1 & 3 & \mathrm{P} \\ & & & & \\ 1 & 74 & 2 & 42 & \mathrm{P}\end{array}$




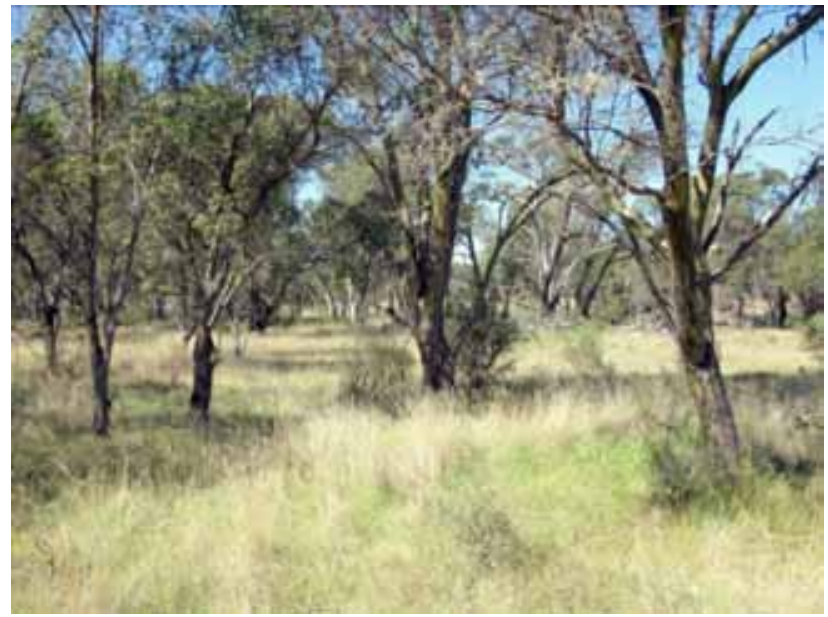

Plate u118: Community u118 with Eucalyptus stellulata and a diverse grass/forb groundcover, near Spicers Creek firetrail east of Yarrangobilly, Kosciuszko NP (near plot UMCPG09).

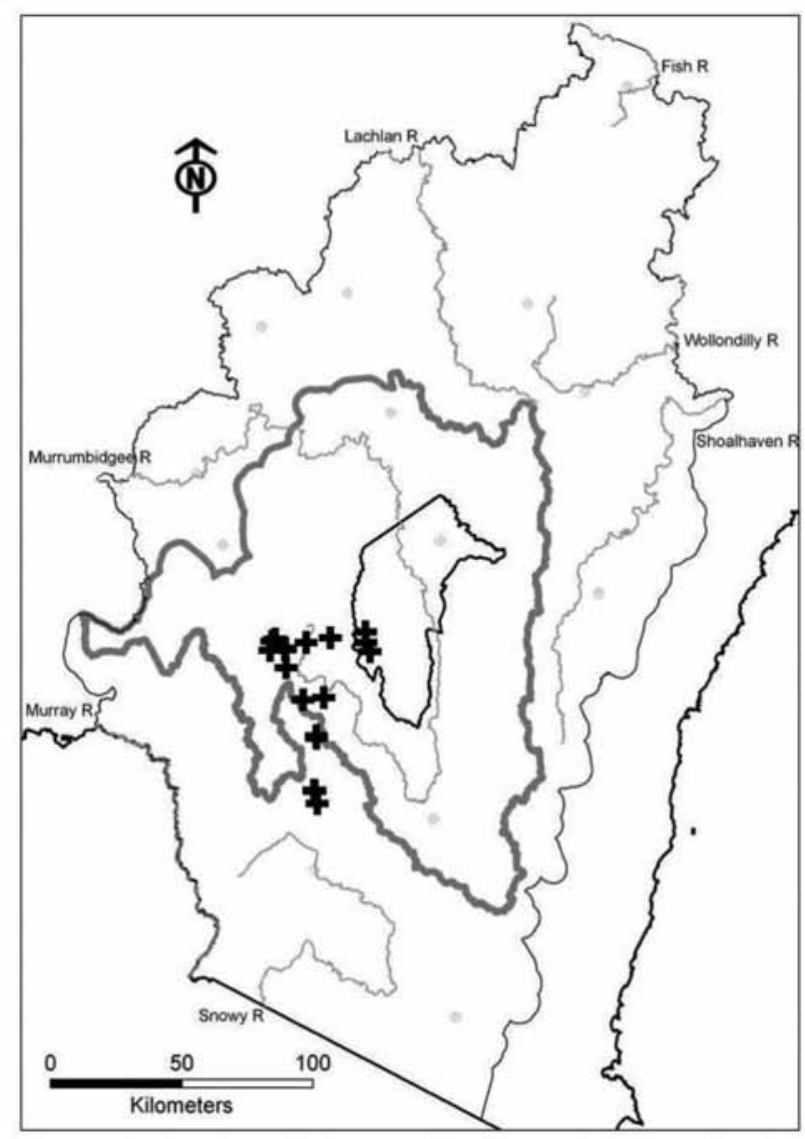

Fig. u118: Distribution of field samples assigned to this community.
Lomatia myricoides

Olearia erubescens

Oxylobium ellipticum

Ozothamnus thyrsoideus

Persoonia chamaepeuce

Pimelea linifolia

Poa sieberiana

Podolobium alpestre

Poranthera microphylla

Senecio gunnii

Stellaria pungens

Stylidium graminifolium sens. lat

Tetratheca bauerifolia

Veronica perfoliata

Hibbertia obtusifolia

Viola betonicifolia

$\begin{array}{lllll}1 & 28 & 1 & 11 & \mathrm{P} \\ 1 & 33 & 1 & 12 & \mathrm{P} \\ 1 & 26 & 1 & 4 & \mathrm{P} \\ 1 & 30 & 1 & 2 & \mathrm{P} \\ 1 & 67 & 1 & 10 & \mathrm{P} \\ 1 & 50 & 1 & 8 & \mathrm{P} \\ 2 & 93 & 2 & 47 & \mathrm{P} \\ 2 & 20 & 2 & 2 & \mathrm{P} \\ 1 & 48 & 1 & 27 & \mathrm{P} \\ 1 & 33 & 1 & 9 & \mathrm{P} \\ 1 & 76 & 2 & 31 & \mathrm{P} \\ 1 & 54 & 1 & 25 & \mathrm{P} \\ 1 & 35 & 1 & 7 & \mathrm{P} \\ 1 & 33 & 1 & 4 & \mathrm{P} \\ 1 & 54 & 1 & 34 & \mathrm{C} \\ 1 & 41 & 1 & 27 & \mathrm{C}\end{array}$

Threatened communities: Grassy examples of this community at lower altitudes may be the TSC Act 1995 - Tablelands Snow Gum, Black Sallee, Candlebark and Ribbon Gum Grassy Woodland in the South Eastern Highlands, Sydney Basin, South East Corner and NSW South Western Slopes bioregions.

Equivalent vegetation types: Mostly defined by new plots, but may have some similarity to VG98 [Western Montane Moist Shrub Forest] (Gellie 2005).

Frequently occurring weeds: Hypochaeris radicata $(0.27)$ is the most commonly recorded weed in this community, which probably reflects both minor past disturbance, and the colonising capacity of that species.

Threats: Although this community is largely confined to public land, the impacts of grazing by feral herbivores and inappropriate fire regimes have the potential to alter its condition.

Reservation status: This community is likely to be well reserved, with examples occurring in Brindabella SCA, Kosciuszko NP, Namadgi NP, Scabby Range NR and Yaouk NR.

Extent of clearing: Considered to be minor.

Reference: Gellie, N.J.H. (2005) Native vegetation of the southern forests: South Eastern Highlands, Australian Alps, South West Slopes and South East Corner bioregions. Cunninghamia 9: 219-254.

\section{u118: Black Sallee grass-herb woodland in drain-} age depressions and moist valley flats in the South Eastern Highlands and Australian Alps bioregions

Scientific Name: Eucalyptus stellulata / Rubus parvifolius - Pimelea pauciflora / Stellaria pungens - Acaena ovina Asperula scoparia - Acaena novae-zelandiae - Dichondra repens - Poranthera microphylla

Number of samples:

Richness [mean $( \pm \mathrm{SD})]$ :

Slope (degrees):

Altitude ( $\mathrm{m}$ asl):

Ave. Annual Rainfall (mm):

Temp. Annual Range $\left({ }^{\circ} \mathrm{C}\right)$ :
20

$34(7)$

(0) 3-10 (32)

(972) 1026-1172 (1400)

(749) 982-1227 (1340)

(23.5) $25.1-25.7(26.1)$
Vegetation Description: Community u118 is a eucalypt woodland characterised by a tall canopy of Eucalyptus stellulata, with occasional occurrences of Eucalyptus pauciflora subsp. pauciflora and/or Eucalyptus rubida. A layer of low to medium shrubs may be present, as scattered individuals to dense patches, commonly including Pimelea pauciflora, Epacris breviflora, Hakea microcarpa, Acacia siculiformis and Grevillea lanigera. The groundlayer is generally dense to continuous, with a diverse layer of forbs and low shrubs commonly including Acaena novae-zelandiae, Acaena ovina, Acrothamnus hookeri, 
Dichondra repens, Geranium solanderi, Poranthera microphylla, Rubus parvifolius, Stellaria pungens, Themeda australis, Viola betonicifolia covering the ground between tall tussocks of grasses such as Poa sieberiana, Poa labillardierei, Poa phillipsiana, Poa helmsii and sedges including Carex appressa.

Community u118 is recorded from moist footslopes of drainage depressions and margins of broad cold-air drainage flats on sandy soils, from the Upper Cotter area in the ACT, west to Yarrangobilly, south to Providence Portal, Eucumbene and Nimmo. It is also known to occur in areas east to Captains Flat and west into the Upper Slopes subregion of the South Western Slopes bioregion. This community is considered under-sampled across its geographic range.

In similar habitats at lower altitudes to the east of its range, this community may be replaced by Community r2 [Poa labillardierei Themeda australis - Juncus sp. wet tussock grassland of footslopes drainage lines and flats of the South Eastern Highlands bioregion], while in swampier sites it may grade into Community u23 [Snow Gum - Epacris breviflora - Leptospermum myrtifolium tall woodland to open forest of drainage depressions primarily of the South Eastern Highlands bioregion] with a greater component of moisture-loving shrubs, sedges and grasses.

\section{Characteristic Species:}

\section{Species}

Acacia siculiformis

Acaena novae-zelandiae

Acaena ovina

Acrothamnus hookeri

Asperula scoparia

Bulbine bulbosa

Carex appressa

Carex inversa

Cullen microcephalum

Cymbonotus preissianus

Dichelachne micrantha

Dichondra repens

Epacris breviflora

Epilobium billardierianum subsp.

cinereum

Eucalyptus rubida

Eucalyptus stellulata

Geranium antrorsum

Geranium solanderi

Geum urbanum

Grevillea lanigera

Hakea microcarpa

Luzula densiflora

Mirbelia oxylobioides

Pimelea pauciflora

Poa helmsii

Poa labillardierei

Poa phillipsiana

Poranthera microphylla

Ranunculus lappaceus

Rubus parvifolius

Scleranthus fasciculatus

Senecio gunnit

Solenogyne gunnii

Stellaria pungens

Veronica gracilis

Poa sieberiana

Themeda australis

Viola betonicifolia
Oxylobium ellipticum

\section{C/A Freq C/A O FreqO Fid}

\begin{tabular}{|c|c|c|}
\hline 33 & 1 & $<1$ \\
\hline 67 & 1 & 27 \\
\hline 76 & 1 & 7 \\
\hline 57 & 1 & 7 \\
\hline 67 & 2 & 22 \\
\hline 29 & 1 & 4 \\
\hline 48 & 1 & 7 \\
\hline 29 & 1 & 8 \\
\hline 24 & 1 & 2 \\
\hline 38 & 1 & 6 \\
\hline 33 & 1 & 10 \\
\hline 62 & 2 & 20 \\
\hline 33 & 1 & 2 \\
\hline 29 & 1 & 5 \\
\hline 38 & 3 & 9 \\
\hline 100 & 2 & 3 \\
\hline 33 & 1 & 3 \\
\hline 48 & 1 & 19 \\
\hline 24 & 1 & $<1$ \\
\hline 33 & 1 & 3 \\
\hline 38 & 1 & 3 \\
\hline 24 & 1 & 6 \\
\hline 24 & 1 & 3 \\
\hline 24 & 1 & 4 \\
\hline 57 & 1 & $<1$ \\
\hline 29 & 2 & 3 \\
\hline 33 & 2 & 10 \\
\hline 24 & 2 & 3 \\
\hline 62 & 1 & 27 \\
\hline 33 & 1 & 11 \\
\hline 62 & 1 & 11 \\
\hline 29 & 1 & 1 \\
\hline 33 & 1 & 9 \\
\hline 33 & 1 & 5 \\
\hline 90 & 2 & 31 \\
\hline 24 & 1 & 1 \\
\hline 57 & 2 & 48 \\
\hline 48 & 2 & 21 \\
\hline 48 & 1 & 27 \\
\hline
\end{tabular}

Threatened communities: TSC Act 1995 - Tablelands Snow Gum, Black Sallee, Candlebark and Ribbon Gum Grassy Woodland in the
South Eastern Highlands, Sydney Basin, South East Corner and NSW South Western Slopes bioregions.

Equivalent vegetation types: VCA 303 [Black Sally grassy low woodland in valleys in the Upper Slopes subregion of the NSW Southwestern Slopes bioregion and western South Eastern Highlands bioregion] (Benson et al. 2010). No obvious equivalents from other numerical classifications.

Frequently occurring weeds: This vegetation is restricted to moist footslopes and alluvial margins, a relatively productive habitat prone to invasion by a range of exotic plant taxa. Although all plots are from conservation reserves, most of these high-country areas were historically seasonally grazed, and many common pasture weeds were recorded from more than $30 \%$ of plots assigned to this community: Acetosella vulgaris (0.75), Anthoxanthum odoratum (0.30), Centaurium erythraea (0.30), Cirsium vulgare (0.60), Crepis capillaris (0.70), Holcus lanatus (0.75), Hypochaeris radicata (0.80), Rosa rubiginosa (0.35), Taraxacum officinale (0.35), Trifolium campestre (0.45), Trifolium repens $(0.70)$.

Threats: Some areas of this community at lower altitudes are likely to have been drowned by water impoundments of the Snowy scheme. However, the majority of its distribution is within conservation reserves (Kosciuszko NP and Namadgi NP). Grazed examples are likely to be prone to invasion by a range of exotic pasture plants and other weeds, due to moister habitat.

Reservation status: Recorded from Namadgi NP, Kosciuszko NP and Nimmo NR but probably extending into freehold land at Snowy Plain in the Southern Rivers CMA.

Extent of clearing: Extent of clearing unknown; some examples in deeper valley floors will have been drowned by major dams.

Reference: Benson, J.S., Richards, P.G., Waller, S. \& Allen, C.B. (2010) New South Wales vegetation classification and assessment: Part 3. Plant communities of the NSW Brigalow Belt South, Nandewar and west New England bioregions and update of NSW Western Plains and South Western Slopes plant communities. Version 3 of the NSW VCA database. Cunninghamia 11: 457-579. Botanic Gardens Trust, Sydney.

\section{u158: Alpine Sallee shrub-grass subalpine mid-high woodland of the Australian Alps bioregion}

Scientific Name: Eucalyptus pauciflora subsp. niphophila / Tasmannia xerophila - Bossiaea foliosa - Hovea montana / Stellaria pungens - Oreomyrris eriopoda - Asperula scoparia
Number of samples:

Richness [mean $( \pm \mathrm{SD})]$

Slope (degrees):

Altitude (m asl):

Ave. Annual Rainfall (mm)

Temp. Annual Range $\left({ }^{\circ} \mathrm{C}\right)$ :
16

28 (6)

(2) $9-14(23)$

(1398) 1541-1634 (1907)

(1499) 1550-1649 (1910)

(21.1) 22-22.2 (23)
Vegetation Description: Community u158 is a mid-high woodland dominated by Eucalyptus pauciflora subsp. niphophila. The understorey is characterised by a discontinuous, though occasionally well-developed shrub layer often to 2 metres tall, dominated by Bossiaea foliosa, Tasmannia xerophila, Podolobium alpestre, Olearia phlogopappa and Pimelea ligustrina subsp. ciliata. The groundlayer is a mix of shrubs, grasses and forbs including Hovea montana, Acrothamnus hookeri, Acrothamnus montanus, Poa phillipsiana, Stellaria pungens, Asperula scoparia, Oreomyrris eriopoda, Coronidium scorpioides, Senecio gunnii, Arthropodium milleflorum, Carex breviculmis, Gonocarpus montanus, Goodenia hederacea subsp. alpestris, Stylidium graminifolium sens. lat and Microseris lanceolata.

Community u158 is largely confined to the Australian Alps bioregion, although small areas may be present in adjacent parts of the South Eastern Highlands bioregion. The community is widespread near the altitudinal limit of trees, and may be found in the vicinity of Thredbo, Charlottes 


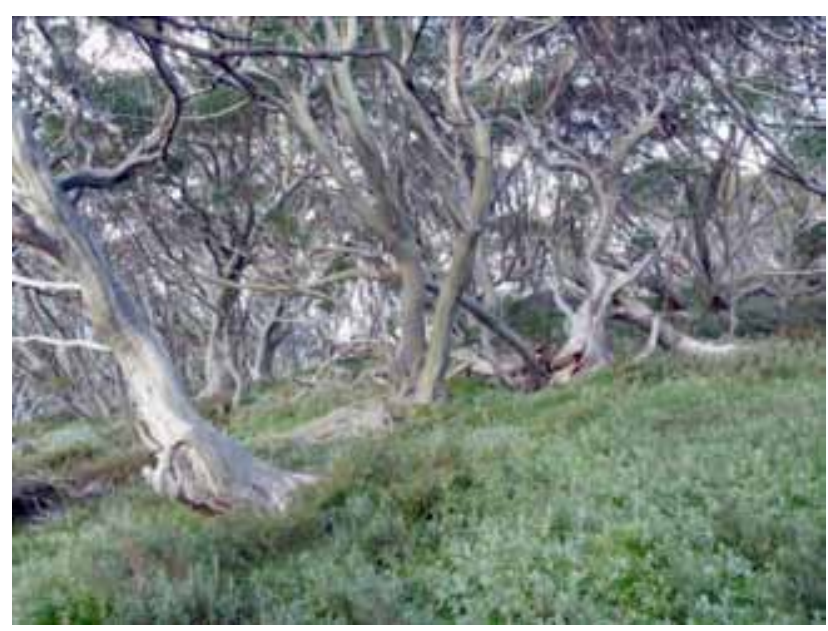

Plate u158: Community u158 in the hills above Charlottes Pass, dominated by stunted Eucalyptus pauciflora subsp. niphophila and an understorey of Helichrysum rutidolepis, Olearia algida and Phebalium squamulosum spp. ozothamnoides.

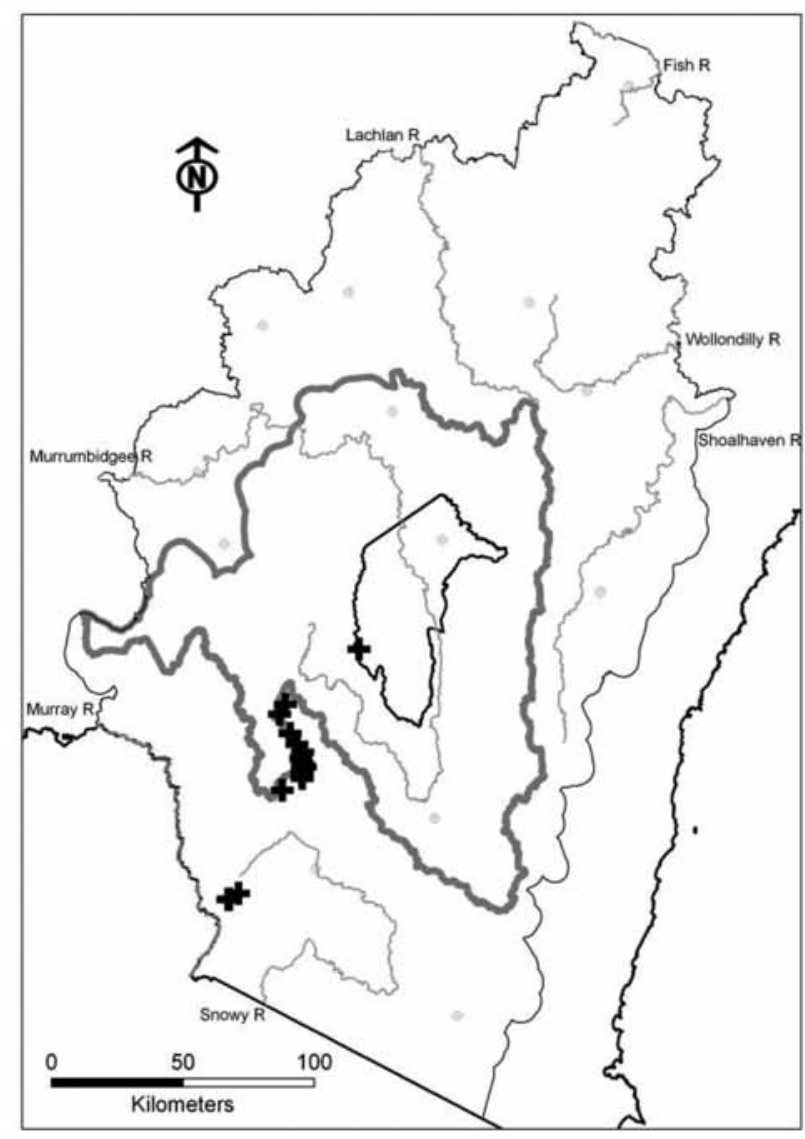

Fig. u158: Distribution of field samples assigned to this community.
Pass and Kiandra, and on the highest ranges in the ACT. It typically occurs on meta-sedimentary geologies, but is also found on granite and basalt. At its upper altitudinal limit, co-occurring communities include those typical of the alpine zone, especially Community a46 [Prostanthera cuneata - Orites lancifolius - Nematolepis ovatifolia heathland of the Australian Alps bioregion]. Elsewhere, the community occurs in association with Community u28 [Snow Gum - Mountain Gum - Daviesia mimosoides tall dry grass-shrub subalpine open forest of the Australian Alps and South Eastern Highlands bioregions] and in sheltered valleys, Community u40 [Alpine Ash tall wet sclerophyll open forest primarily of the Australian Alps bioregion].

\section{Characteristic Species:}

Species

C/AFreq C/A OFreqOFid

Acaena novae-zelandiae

Aciphylla simplicifolia

Acrothamnus hookeri

Acrothamnus montanus

Arthropodium milleflorum

Asperula scoparia

Bossiaea foliosa

Brachyscome spathulata

Brachyscome spp.

Caladenia alpina

Carex breviculmis

Celmisia spp.

Coronidium scorpioides

Craspedia spp.

Eucalyptus pauciflora subsp. niphophila

Gonocarpus montanus

Goodenia hederacea subsp. alpestris

Hovea montana

Lobelia pedunculata

Luzula densiflora

Microseris lanceolata

Olearia phlogopappa

Oreomyrrhis ciliata

Oreomyrrhis eriopoda

Ozothamnus thyrsoideus

Pimelea ligustrina subsp. ciliata

Poa phillipsiana

Podolepis robusta

Podolobium alpestre

Ranunculus graniticola

Senecio gunnii

Stellaria pungens

Stylidium graminifolium sens. lat

Tasmannia xerophila

$\begin{array}{lllll}1 & 44 & 1 & 28 & \mathrm{C}\end{array}$

$\begin{array}{lllll}1 & 38 & 1 & 2 & \mathrm{P}\end{array}$

$\begin{array}{lllll}1 & 56 & 1 & 8 & \mathrm{P}\end{array}$

$\begin{array}{lllll}2 & 25 & 1 & 1 & \mathrm{P}\end{array}$

$\begin{array}{lllll}1 & 50 & 1 & 8 & \mathrm{P}\end{array}$

$\begin{array}{lllll}1 & 69 & 2 & 22 & \mathrm{P}\end{array}$

$\begin{array}{lllll}3 & 75 & 2 & 4 & \mathrm{P}\end{array}$

$\begin{array}{lllll}1 & 44 & 1 & 11 & \mathrm{P}\end{array}$

$\begin{array}{lllll}1 & 25 & 1 & 1 & \mathrm{P}\end{array}$

$\begin{array}{lllll}1 & 44 & 1 & <1 & \mathrm{P}\end{array}$

$\begin{array}{lllll}1 & 50 & 1 & 13 & \mathrm{P}\end{array}$

$\begin{array}{lllll}2 & 25 & 1 & <1 & \mathrm{P}\end{array}$

$\begin{array}{lllll}2 & 63 & 1 & 20 & \mathrm{P}\end{array}$

$\begin{array}{lllll}2 & 50 & 1 & 4 & \mathrm{P}\end{array}$

$\begin{array}{lllll}3 & 94 & 2 & <1 & \mathrm{P}\end{array}$

$\begin{array}{lllll}1 & 50 & 1 & 1 & \mathrm{P}\end{array}$

$\begin{array}{lllll}1 & 50 & 2 & 16 & \mathrm{P}\end{array}$

$\begin{array}{lllll}1 & 69 & 1 & 1 & \mathrm{P}\end{array}$

$\begin{array}{lllll}1 & 44 & 1 & 5 & \mathrm{P}\end{array}$

$\begin{array}{lllll}1 & 31 & 1 & 6 & \mathrm{P}\end{array}$

$\begin{array}{lllll}1 & 50 & 1 & 7 & \mathrm{P}\end{array}$

$\begin{array}{lllll}2 & 44 & 1 & 3 & \mathrm{P}\end{array}$

$\begin{array}{lllll}1 & 31 & 1 & 2 & \mathrm{P}\end{array}$

$\begin{array}{lllll}1 & 69 & 1 & 13 & \mathrm{P}\end{array}$

$\begin{array}{lllll}1 & 25 & 1 & 2 & \mathrm{P}\end{array}$

$\begin{array}{lllll}1 & 25 & 1 & <1 & \mathrm{P}\end{array}$

$\begin{array}{lllll}3 & 31 & 2 & 3 & \mathrm{P}\end{array}$

$\begin{array}{lllll}1 & 25 & 1 & <1 & \mathrm{P}\end{array}$

$\begin{array}{lllll}1 & 50 & 2 & 2 & \mathrm{P}\end{array}$

$\begin{array}{lllll}1 & 38 & 1 & 4 & \mathrm{P}\end{array}$

$\begin{array}{lllll}1 & 63 & 1 & 9 & \mathrm{P}\end{array}$

$\begin{array}{lllll}1 & 94 & 2 & 31 & \mathrm{P}\end{array}$

$\begin{array}{lllll}1 & 50 & 1 & 25 & \mathrm{C}\end{array}$

Threatened communities: Nil.

Equivalent vegetation types: This community amalgamates VG128 [Sub Alpine Dry Shrub/Herb Woodland] with VG130 [Sub-Alpine Shrub/Grass Woodland], closely related communities previously described by Gellie (2005).

Frequently occurring weeds: The legacy of past clearing and cattle grazing is reflected in the presence and frequency with which common pastoral weeds were recorded. The most common weeds in this community are Acetosella vulgaris (0.81), Hypochaeris radicata (0.75) and Taraxacum officinale (0.38).

Threats: The threats facing this community are not unlike those experienced by other communities in the higher parts of Kosciuszko NP. The development of ski resorts and associated infrastructure, including ski runs resulted in significant clearing of the over-storey in some areas. Depending on the future expansion of ski fields, clearing may represent a future threat. Where the community occurs in close proximity to roads or tracks, invasion by exotic plant species including Ox-eye 
Daisy (Leucanthemum vulgare), Sweet Vernal Grass (Anthoxanthum odoratum) and Orange Hawkweed (Hieracium aurantiacum subsp. carpathicola) is occurring. Grazing by feral herbivores, in particular horses, not only facilitates weed invasion via soil disturbance, but also affects groundlayer structre and species composition. Perhaps the most dramatic of all threats faced by this community is that of high fire frequency and intensity.

Reservation status: Almost entirely within conservation reserves, including Kosciuszko NP and Namadgi NP.

Extent of clearing: Historically, this community was extensively cleared to increase the area of optimal grazing land in leases. The extent of clearing is unknown but judging from historic aerial photography would have been many thousands of hectares. In most places, trees have re-invaded since the removal of grazing from Kosciuszko NP in the 1950s and 60s. In a few places, however, repeated tree removal and burning have changed this community into a disclimax shrubland.

Reference: Gellie, N.J.H. (2005) Native vegetation of the southern forests: South Eastern Highlands, Australian Alps, South West Slopes and South East Corner bioregions. Cunninghamia 9: 219-254.

\section{u207: Jounama Snow Gum - Snow Gum shrubby mid-high woodland on granitoids primarily of the Namadgi region}

Scientific Name: Eucalyptus pauciflora subsp. debeuzevillei - Eucalyptus pauciflora subsp. pauciflora / Podolobium alpestre - Veronica perfoliata - Tasmannia xerophila / Poa sieberiana - Viola betonicifolia - Stellaria pungens Coronidium scorpioides

$\begin{array}{ll}\text { Number of samples: } & 24 \\ \text { Richness [mean }( \pm \mathrm{SD})]: & 24(6) \\ \text { Slope (degrees): } & (3) 12-22(32) \\ \text { Altitude (m asl): } & (1543) 1581-1680(1745) \\ \text { Ave. Annual Rainfall }(\mathrm{mm}): & (1186) 1271-1402(1735) \\ \text { Temp. Annual Range }\left({ }^{\circ} \mathrm{C}\right): & (21.7) 22.2-22.7(23)\end{array}$

Vegetation Description: Community u207 is a mid-high shrubby woodland dominated by Eucalyptus pauciflora subsp. debeuzevillei and Eucalyptus pauciflora subsp. pauciflora. The shrubby understorey is generally diverse, often including Veronica perfoliata, Tasmannia xerophila, Podolobium alpestre, Daviesia ulicifolia, Oxylobium ellipticum, Olearia phlogopappa and Polyscias sambucifolia subsp. leptophylla. Acrothamnus hookeri may be present. The groundlayer is a diverse mix of grasses and herbs, many of which occur in other high altitude communities. Typical species include Poa sieberiana, Stellaria pungens, Viola betonicifolia, Coronidium scorpioides, Senecio gunnii, Asperula scoparia, Geranium potentilloides, Poranthera microphylla, Brachyscome spathulata, Acaena novae-zelandiae, Celmisia tomentella, Oreomyrris eriopoda, Dianella tasmanica, Wahlenbergia gloriosa and Arthropodium milleflorum.

This community is almost entirely confined to the Upper Cotter and Yaouk Creek catchments of Namadgi NP and adjacent NSW parts of Kosciuszko NP, Bimberi NR and Scabby Range NR in the Australian Alps bioregion. It occurs in exposed locations at high altitude, primarily but not exclusively on northerly aspects. Although it is most common on granite, it is also known from metasedimentary geologies. A number of widespread montane communities occur in association with this community, including Community u22 [Mountain Gum - Snow Gum grass-forb very tall woodland to open forest of the Australian Alps and South Eastern Highlands bioregions], Community u23 [Snow Gum - Epacris breviflora - Leptospermum myrtifolium tall woodland to open forest of drainage depressions primarily of the South Eastern Highlands bioregion], Community u28 [Snow Gum - Mountain Gum - Daviesia mimosoides tall dry grass-shrub subalpine open forest of the Australian Alps and South Eastern Highlands bioregions] and

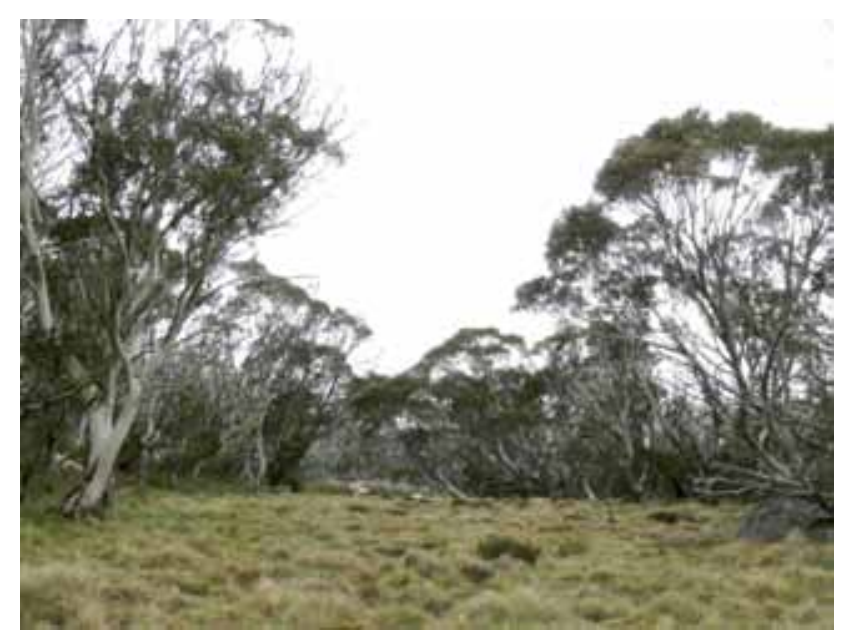

Plate u207: Eucalyptus pauciflora subsp. debeuzevillei with open Poa sieberiana patches characteristic of community u207. Southeast of Snowy Flats off Mt. Franklin Road, Namadgi NP.

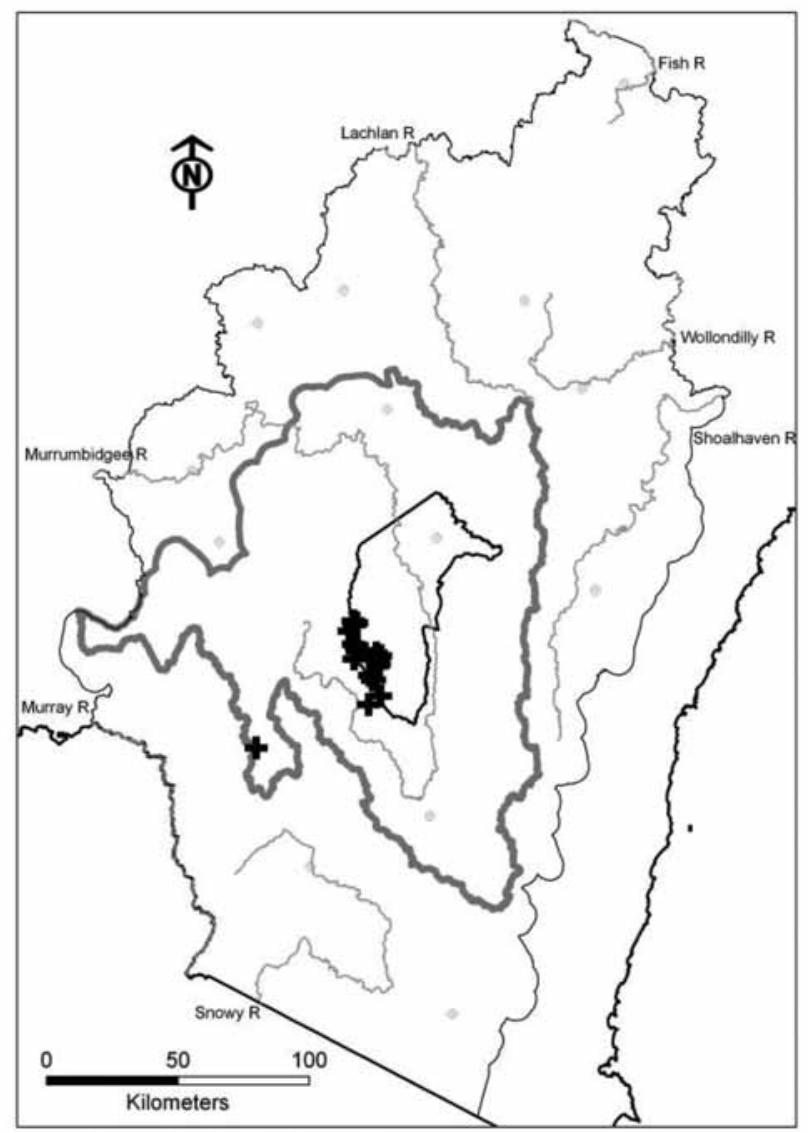

Fig. u207: Distribution of field samples assigned to this community. 
Community u53 [Mountain Gum - Blackwood tall wet sclerophyll open forest primarily on granitoids of the Australian Alps and western South Eastern Highlands bioregions].

\section{Characteristic Species:}

Species

Acacia obliquinervia

Acrothamnus hookeri

Asperula scoparia

Brachyscome aculeata

Brachyscome spathulata

Celmisia tomentella

Coronidium scorpioides

Craspedia spp.

Daviesia ulicifolia

Eucalyptus pauciflora subsp.

debeuzevillei

Geranium potentilloides

Leucopogon gelidus

Olearia megalophylla

Olearia phlogopappa

Oxylobium ellipticum

Ozothamnus thyrsoideus

Picris angustifolia subsp. angustifolia

Podolepis robusta

Podolobium alpestre

Polyscias sambucifolia subsp.

leptophylla

Senecio gunnii

Stellaria pungens

Tasmannia xerophila

Veronica derwentiana

Veronica perfoliata

Viola betonicifolia

Wahlenbergia gloriosa

Eucalyptus pauciflora subsp. pauciflora

Poa sieberiana

Poranthera microphylla

\section{C/AFreq C/A OFreqO Fid}

$\begin{array}{lllll}2 & 21 & 1 & 3 & \mathrm{P} \\ 2 & 46 & 1 & 8 & \mathrm{P} \\ 2 & 58 & 2 & 22 & \mathrm{P} \\ 1 & 33 & 1 & 2 & \mathrm{P} \\ 2 & 38 & 1 & 11 & \mathrm{P} \\ 2 & 33 & 1 & <1 & \mathrm{P} \\ 2 & 75 & 1 & 19 & \mathrm{P} \\ 2 & 33 & 1 & 4 & \mathrm{P} \\ 2 & 46 & 1 & 10 & \mathrm{P} \\ 4 & 54 & 1 & <1 & \mathrm{P}\end{array}$

$\begin{array}{lllll}2 & 50 & 1 & 13 & \mathrm{P}\end{array}$

29

421

421

46

$229 \quad 1$

21

211

542

$3 \quad 382$

$\begin{array}{ll}75 & 1\end{array}$

882

501

33

541

92

29

42

$\begin{array}{lll}3 & 71 & 2\end{array}$

$246 \quad 1$

\section{Class: Southern Tableland Grassy Woodlands}

\section{p24: Yellow Box - Blakely's Red Gum tall grassy woodland on undulating sedimentary and acid-vol- canic substrates in the Goulburn area of the South Eastern Highlands bioregion}

Scientific Name: Eucalyptus melliodora \pm Eucalyptus blakelyi - Eucalyptus mannifera - Eucalyptus dives / Acacia decurrens /Lissanthe strigosa - Pimelea curviflora / Lomandra filiformis subsp. coriacea - Microlaena stipoides - Poa sieberiana Gonocarpus tetragynus

$\begin{array}{ll}\text { Number of samples: } & 28 \\ \text { Richness [mean }( \pm \mathrm{SD})]: & 29(9) \\ \text { Slope (degrees): } & (0) 2-4(9) \\ \text { Altitude (m asl): } & (615) 647-705(815) \\ \text { Ave. Annual Rainfall }(\mathrm{mm}): & (654) 670-697(734) \\ \text { Temp. Annual Range }\left({ }^{\circ} \mathrm{C}\right): & (25.7) 26.1-26.6(26.7)\end{array}$

Vegetation Description: Community p24 is a tall grassy open eucalypt woodland, with a medium to low tree canopy commonly containing Eucalyptus blakelyi and/or Eucalyptus melliodora, with other tableland eucalypts occurring less frequently including Eucalyptus dives, Eucalyptus mannifera, Eucalyptus macrorhyncha and Eucalyptus rubida. A sparse to patchy shrub stratum may be present, commonly with tall Acacia decurrens and smaller dry shrubs including Acacia genistifolia and Daviesia latifolia. The groundlayer in this community is generally dominated by a diverse suite of grasses including Microlaena stipoides, Poa sieberiana, Themeda australis and various Aristida, Rytidosperma, Austrostipa and Dichelachne species. A rich mix of forbs includes Lomandra filiformis subsp. coriacea, Chrysocephalum apiculatum, Lomandra multiflora, Einadia nutans, Hydrocotyle laxiflora, Gonocarpus tetragynus, Goodenia hederacea subsp. hederacea, Plantago debilis and Dianella revoluta. A sparse scatter of low tough shrubs (commonly Lissanthe strigosa, Melichrus urceolatus, Pimelea curviflora and Bossiaea buxifolia is often present.

This community is defined from field survey plots scattered across the relatively low, dry saddle of the great divide around Goulburn. Plots assigned to this community are located in an area bounded by Woodhouselee, Gundaroo, Manar, Kooringaroo and Canyonleigh (and extending east of the study area), and occur on gently undulating tableland country on relatively deep soils of moderately low fertility derived from volcanic rocks (porphyry, rhyolites and tuffs) and from ancient sediments/metasediments (greywacke, limestone, shale, siltstone, quartzite including Gundary and Towrang beds and various Adaminaby group strata).

Community p24 commonly grades into Community p23 [Red Stringybark - Broad-leaved Peppermint tall dry sclerophyll grassy open forest on loamy rises primarily in the Bungonia subregion of the South Eastern Highlands bioregion] on footslopes of hilly country with shallower soils, or into Community u78 [Snow Gum grassy mid-high woodland of the South Eastern Highlands bioregion] in cooler situations and/or with increasing elevation. In similar rolling country to the west with decreasing rainfall, this community is replaced by Community u 19 [Blakely's Red Gum - Yellow Box \pm White Box tall grassy woodland of the Upper South Western Slopes and western South Eastern Highlands bioregions]. 


\section{Characteristic Species:}

Species

Acacia decurrens

Acacia genistifolia

Aristida ramosa

Aristida vagans

Asperula conferta

Austrostipa scabra

Bossiaea buxifolia

Cassinia arcuata

Cassinia laevis

Cheilanthes sieberi

Chrysocephalum apiculatum

Chrysocephalum semipapposum

Dichelachne micrantha

Einadia nutans

Eucalyptus blakelyi

Eucalyptus melliodora

Goodenia hederacea subsp. hederacea

Hydrocotyle laxiflora

Juncus usitatus

Lissanthe strigosa

Lomandra filiformis subsp. coriacea

Lomandra multiflora

Melichrus urceolatus

Microlaena stipoides

Opercularia aspera

Pimelea curviflora

Plantago debilis

Poa sieberiana

Pterostylis spp.

Rytidosperma laeve

Rytidosperma racemosum

Themeda australis

Tricoryne elatior

Wahlenbergia luteola

Dianella revoluta

Gonocarpus tetragynus

\section{C/AFreq C/A O FreqO Fid}

$\begin{array}{lll}46 & 1 & 1 \\ 39 & 1 & 1 \\ 29 & 2 & 5 \\ 21 & 2 & 1 \\ 39 & 1 & 11 \\ 25 & 2 & <1 \\ 29 & 1 & 7 \\ 25 & 1 & 1 \\ 21 & 2 & 1 \\ 29 & 1 & 9 \\ 61 & 1 & 6 \\ 21 & 1 & 4 \\ 29 & 1 & 10 \\ 50 & 1 & 4 \\ 36 & 3 & 2 \\ 54 & 3 & 5 \\ 50 & 2 & 16 \\ 61 & 2 & 29 \\ 21 & 1 & <1 \\ 64 & 1 & 6 \\ 93 & 2 & 18 \\ 54 & 1 & 18 \\ 39 & 1 & 13 \\ 82 & 2 & 34 \\ 36 & 1 & 3 \\ 54 & 1 & 6 \\ 46 & 2 & 4 \\ 79 & 2 & 48 \\ 21 & 1 & 6 \\ 32 & 2 & 4 \\ 21 & 2 & <1 \\ 64 & 2 & 21 \\ 36 & 1 & 4 \\ 29 & 1 & 1 \\ 43 & 1 & 22 \\ 68 & 2 & 48 \\ & & \\ & \\ 2\end{array}$

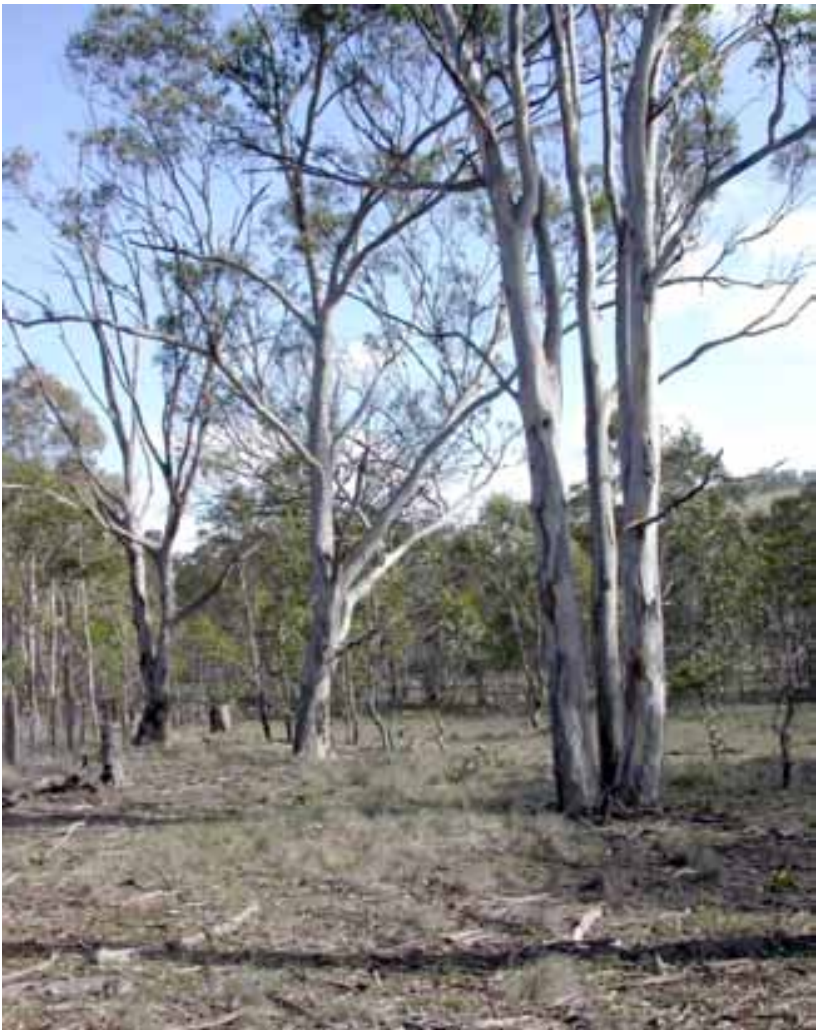

Plate p24: Grazed and partially cleared example of Community p24 on a crown reserve east of Tarlo River NP (plot CAN038LQ).

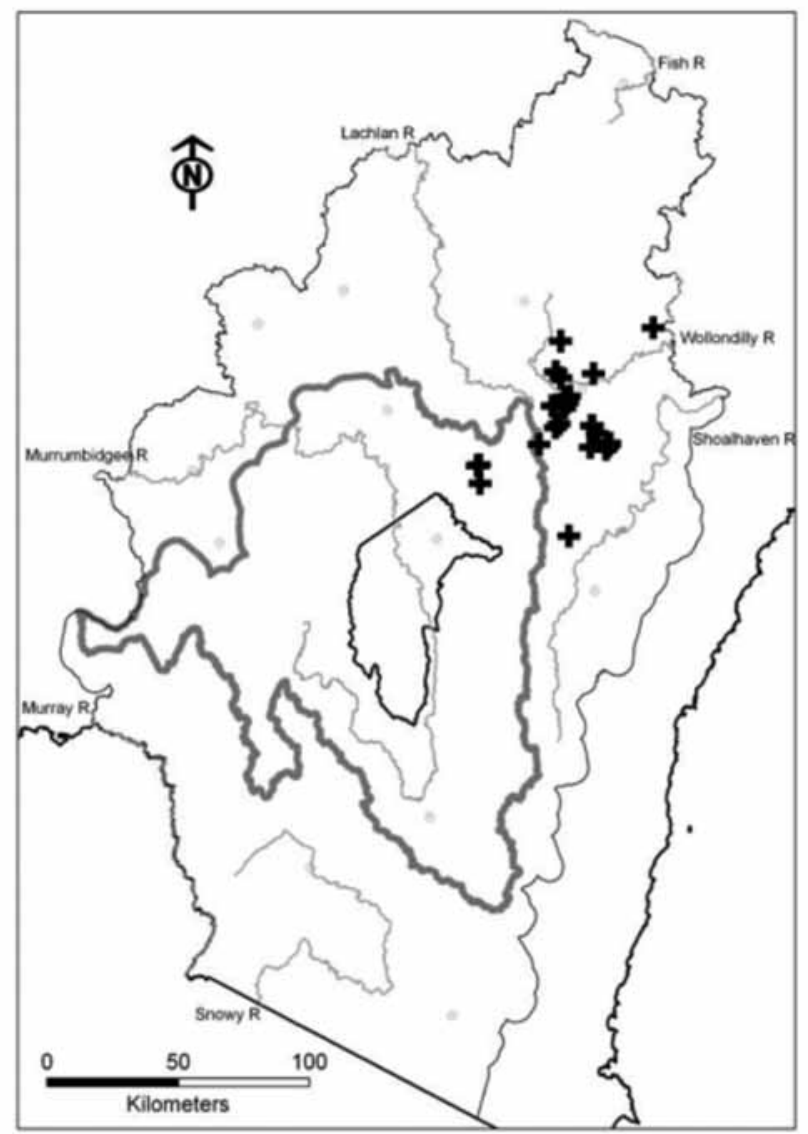

Fig. p24: Distribution of field samples assigned to this community

Threatened communities: This community is part of TSC Act 1995 - White Box Yellow Box Blakely's Red Gum Woodland and EPBC Act 1999 - White Box Yellow Box Blakely's Red Gum Grassy Woodland and Derived Native Grassland.

Equivalent vegetation types: Represents GWp24 [Tableland Grassy Box - Gum Woodland] (Tozer et al. 2010) in the context of the upper Murrumbidgee catchment, and includes a westward extension with the addition of new plots near Gundaroo. The current study area included some 63 of the 80 plots assigned to GWp24 by Tozer et al. (2010). There are no related Forest Ecosystems, with this community defined almost entirely by plots which were not classified by Gellie (2005).

Frequently occurring weeds: Weeds recorded in this community are typical of those found in other over-grazed grassy woodlands of the South Eastern Highlands bioregion. The most frequently recorded species are Arctotheca calendula (0.25), Briza maxima (0.21), Bromus catharticus (0.21), Dactylis glomerata (0.25), Hypochaeris radicata (0.63), Paspalum dilatatum (0.29), Plantago lanceolata (0.33) and Rosa rubiginosa (0.33).

Threats: This community occurs on undulating tableland country that was historically developed for stock grazing by the clearing of trees and shrubs and widespread conversion of groundlayer to pastures dominated by exotic annual grasses and legumes. Remnants are often regularly grazed and subject to ongoing invasion by exotic plants and feral animals. The condition of remnants adjacent to or within urban centres is generally declining because of recreational disturbances, firewood removal, over-grazing by domestic, feral and native herbivores and severe weed invasion. Urban and rural-residential development is also responsible for recent and predicted future clearing of remnant vegetation. 
Reservation status: Due to the agriculturally desirable habitat of this community, it is very poorly represented in conservation reserves. The only samples from a conservation reserve are at the margins of cleared country in McLeod's Creek NR near Gundaroo.

Extent of clearing: The broad geographic distribution of small remnants and isolated paddock trees suggest that historically, this community was extensively cleared.

References: Gellie, N.J.H. (2005) Native vegetation of the southern forests: South Eastern Highlands, Australian Alps, South West Slopes and South East Corner bioregions. Cunninghamia 9: 219-254; Tozer, M.G., Turner, K., Keith, D.A., Tindall, D., Pennay, C., Simpson, C., MacKenzie, B., Beukers, P. \& Cox, S. (2010) Native vegetation of southeast NSW: a revised classification and map for the coast and eastern tablelands. Cunninghamia 11: 359-406.

\section{u19: Blakely's Red Gum - Yellow Box \pm White Box tall grassy woodland of the Upper South Western Slopes and western South Eastern Highlands biore- gions}

Scientific Name: Eucalyptus blakelyi - Eucalyptus melliodora \pm Eucalyptus albens / Microlaena stipoides - Rytidosperma racemosum-Elymus scaber-Themeda australis-Austrostipa scabra

$\begin{array}{ll}\text { Number of samples: } & 28 \\ \text { Richness [mean }( \pm \mathrm{SD})]: & 26(10) \\ \text { Slope (degrees): } & (0) 2-5(29) \\ \text { Altitude }(\mathrm{m} \text { asl): } & (267) 469-593(811) \\ \text { Ave. Annual Rainfall }(\mathrm{mm}): & (646) 681-829(1023) \\ \text { Temp. Annual Range }\left({ }^{\circ} \mathrm{C}\right): & (25.6) 26.7-28.1(29)\end{array}$

Vegetation Description: Community u19 is a tall grassy eucalypt woodland dominated by Eucalyptus blakelyi and/or Eucalyptus melliodora with occasional occurrences of Eucalyptus albens. In the western part of its range, Eucalyptus albens can be the dominant eucalypt. The shrub layer is sparse or absent and generally contains regenerating eucalypts, Acacia implexa and/or Acacia dealbata. The groundlayer is dominated by grasses including Microlaena stipoides, Elymus scaber, Themeda australis, Rytidosperma racemosum, Bothriochloa macra and Poa sieberiana, with degraded areas generally dominated by less palatable robust species such as Bothriochloa macra and Austrostipa scabra. Forbs include Hydrocotyle laxiflora, Rumex brownii, Geranium solanderi, Oxalis perennans, Lomandra filiformis subsp. coriacea and Tricoryne elatior. Relatively undisturbed sites tend to have a wide variety of forbs including Microtis unifolia, Arthropodium minus, Dichopogon fimbriatus and Wurmbea dioica.

This community occurs on flat and undulating fertile soils from north of Crookwell in the east to west of Tumut in the Upper Slopes subregion of the NSW South Western Slopes bioregion. Plot analysis post this study suggests that community u19 is also present in the northern ACT. To the east, it may grade into Community p24 [Yellow BoxBlakely's Red Gum tall grassy woodland on undulating sedimentary and acid-volcanic substrates in the Goulburn area of the South Eastern Highlands bioregion] and Community u178 [Yellow Box \pm Apple Box tall grassy woodland of the South Eastern Highlands] to the south-east in the ACT. West of the study area, this community grades into a number of Box-Gum woodland associations including the closely related VCA 277 [Blakely's Red Gum - Yellow Box grassy tall woodland of the NSW South-western Slopes bioregion] and, primarily in the South Western Slopes bioregion, the Eucalyptus albens dominated VCA 266 [White Box grassy woodland in the Upper Slopes subregion of the NSW Southwestern Slopes bioregion] described by Benson et al. (2010).

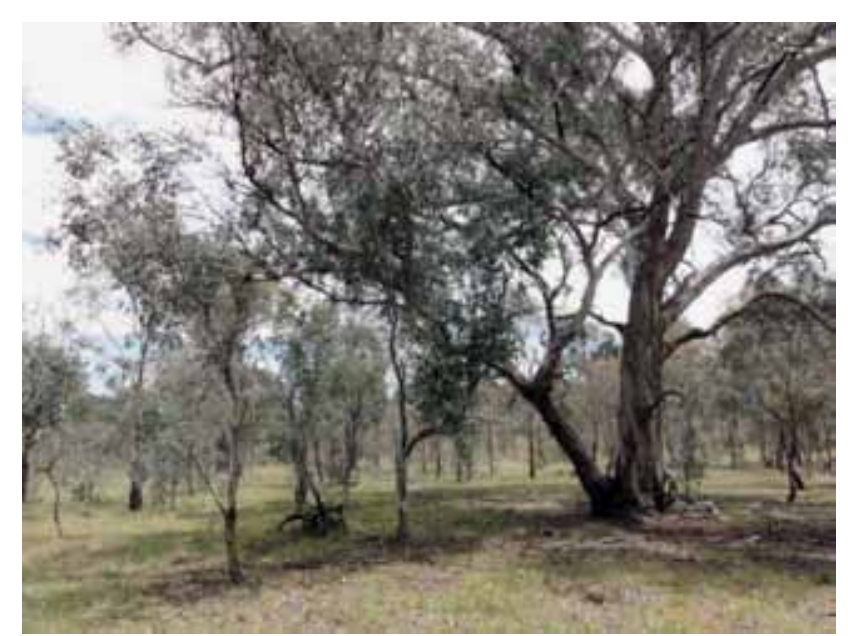

Plate u19: Community u19 with Eucalyptus melliodora and a grassy understorey of Themeda australis and Rytidosperma racemosum. Goorooyaroo NR.

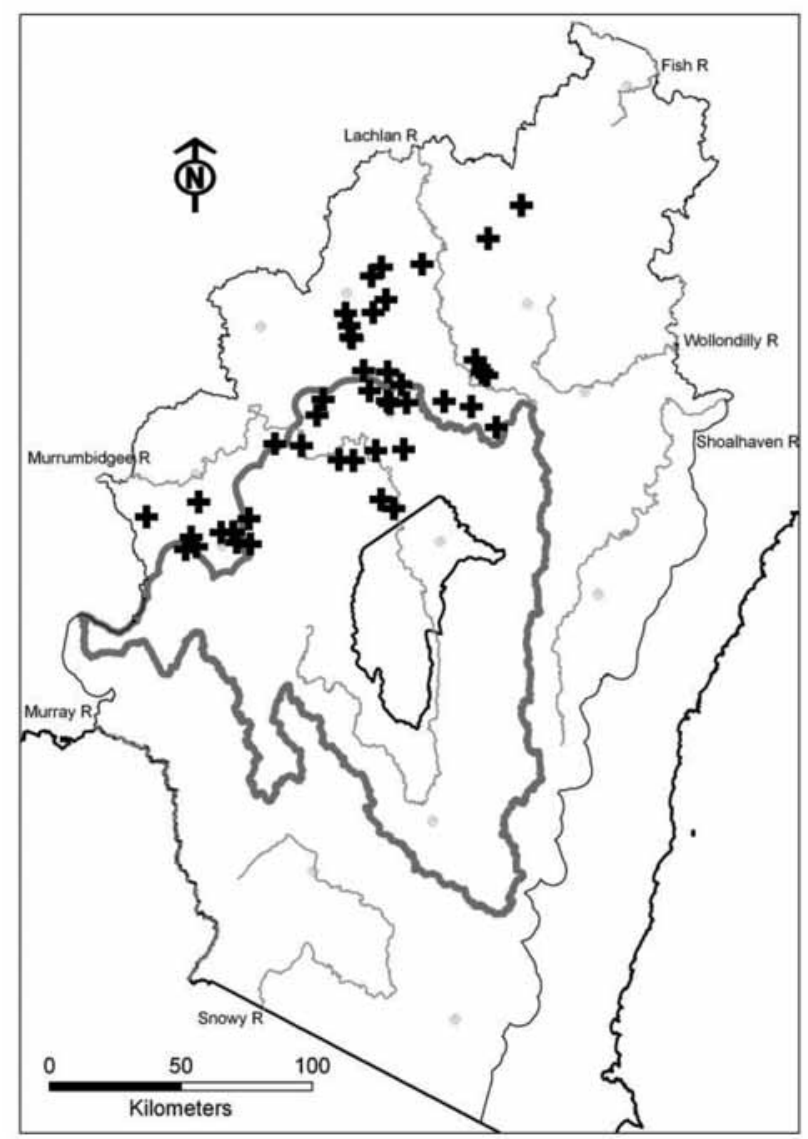

Fig. u19: Distribution of field samples assigned to this community. 


\section{Characteristic Species:}

Species

Acaena echinata

Aristida ramosa

Arthropodium minus

Austrostipa scabra

Bothriochloa macra

Carex inversa

Convolvulus angustissimus

Crassula sieberiana

Dichopogon fimbriatus

Drosera peltata

Elymus scaber

Eucalyptus albens

Eucalyptus blakelyi

Eucalyptus melliodora

Geranium solanderi

Hydrocotyle laxiflora

Microlaena stipoides

Microtis unifolia

Oxalis perennans

Panicum effusum

Rumex brownii

Rytidosperma erianthum

Rytidosperma pilosum

Schoenus apogon

Solenogyne dominii

Themeda australis

Tricoryne elatior

Wurmbea dioica

Poa sieberiana
Lomandra filiformis subsp. coriacea

Rytidosperma racemosum

Gonocarpus tetragynus

\section{C/AFreq C/A OFreqO Fid}

$\begin{array}{lllll}1 & 29 & 1 & 9 & \mathrm{P} \\ 2 & 46 & 2 & 5 & \mathrm{P} \\ 1 & 29 & 1 & 1 & \mathrm{P} \\ 2 & 46 & 1 & 4 & \mathrm{P} \\ 2 & 57 & 1 & 3 & \mathrm{P} \\ 1 & 36 & 1 & 8 & \mathrm{P} \\ 1 & 25 & 1 & 3 & \mathrm{P} \\ 1 & 21 & 1 & 5 & \mathrm{P} \\ 1 & 29 & 1 & <1 & \mathrm{P} \\ 1 & 21 & 1 & 1 & \mathrm{P} \\ 2 & 75 & 1 & 21 & \mathrm{P} \\ 4 & 32 & 3 & <1 & \mathrm{P} \\ 3 & 61 & 2 & 2 & \mathrm{P} \\ 3 & 57 & 3 & 5 & \mathrm{P} \\ 1 & 61 & 1 & 19 & \mathrm{P} \\ 1 & 68 & 2 & 29 & \mathrm{P} \\ 1 & 50 & 2 & 19 & \mathrm{P} \\ 3 & 86 & 2 & 34 & \mathrm{P} \\ 1 & 32 & 1 & 4 & \mathrm{P} \\ 1 & 57 & 1 & 13 & \mathrm{P} \\ 1 & 29 & 1 & 3 & \mathrm{P} \\ 1 & 68 & 1 & 9 & \mathrm{P} \\ 2 & 32 & 1 & <1 & \mathrm{P} \\ 2 & 29 & 2 & 9 & \mathrm{P} \\ 2 & 50 & 2 & 10 & \mathrm{P} \\ 1 & 32 & 1 & 5 & \mathrm{P} \\ 1 & 39 & 1 & 3 & \mathrm{P} \\ 3 & 54 & 2 & 21 & \mathrm{P} \\ 1 & 50 & 1 & 3 & \mathrm{P} \\ 1 & 25 & 1 & 3 & \mathrm{P} \\ 1 & 43 & 2 & 48 & \mathrm{C} \\ 1 & 57 & 2 & 48 & \mathrm{C}\end{array}$

Threatened communities: This community is part of the TSC Act 1995 - White Box Yellow Box Blakely's Red Gum Woodland; EPBC Act 1999 - White Box Yellow Box Blakely's Red Gum Grassy Woodland and Derived Native Grassland; and NC Act 1980 - Yellow Box/Red Gum Grassy Woodland.

Equivalent vegetation types: This community is most similar to VCA 277 [Blakely's Red Gum - Yellow Box grassy tall woodland of the NSW Southwestern Slopes bioregion] (Benson et al. 2010) and is similar to a number of communities described by Gellie (2005) including VG116, VG117, VG154 and VG160. At the western edge of its range, there may be areas dominated by Eucalyptus albens, and in this instance it will be most akin to VCA 266 [White Box grassy woodland in the Upper Slopes subregion of the NSW South-western Slopes bioregion] (Benson et al. 2010).

Frequently occurring weeds: Most remnants of this community are found on freehold land and actively managed as a source of food and shelter for domestic stock. As a consequence of this, many remnants are now infested with common pasture weeds including Briza maxima (0.63), Briza minor (0.67), Bromus diandrus (0.56), Bromus molliformis (0.59), Cirsium vulgare (0.48), Cynosurus echinatus (0.37), Echium plantagineum (0.33), Hypericum perforatum (0.7), Hypochaeris glabra (0.52), Hypochaeris radicata (0.7), Lolium perenne (0.44), Lysimachia arvensis (0.33), Orobanche minor (0.41), Petrorhagia nanteuilii (0.59), Plantago lanceolata (0.48), Romulea rosea var. australis (0.33), Rosa rubiginosa (0.33), Sherardia arvensis (0.44), Trifolium angustifolium (0.63), Trifolium arvense (0.52), Trifolium campestre (0.56), Trifolium dubium (0.48), Trifolium striatum (0.41), Trifolium subterraneum (0.52) and Vulpia muralis (0.37).

Threats: Because this community naturally occurs on soils of high fertility, it has experienced high levels of clearing. Remnants are often subjected to ongoing grazing by domestic stock, the addition of fertiliser and exotic pasture species, firewood removal and invasion by weed and pest species. The extent of disturbance has severely compromised the condition of most remnants of this community across its range. As a result, there are very few examples with an intact over-storey, high native plant species richness, low exotic weed species richness and abundance, over-storey regeneration and high structural integrity.

Reservation status: Poorly conserved. Examples are found in Burrinjuck NR, as well as Dunlop NR and Goorooyaroo NR in the ACT.

Extent of clearing: Known to be highly cleared. Due to continued and intense grazing, large areas containing healthy, regenerating overstorey species are rare.

References: Benson, J.S., Richards, P.G., Waller, S. \& Allen, C.B. (2010) New South Wales vegetation classification and assessment: Part 3. Plant communities of the NSW Brigalow Belt South, Nandewar and west New England bioregions and update of NSW Western Plains and South Western Slopes plant communities. Version 3 of the NSW VCA database. Cunninghamia 11: 457579. Botanic Gardens Trust, Sydney; Gellie, N.J.H. (2005) Native vegetation of the southern forests: South Eastern Highlands, Australian Alps, South West Slopes and South East Corner bioregions. Cunninghamia 9: 219-254.

\section{u20: Brachychiton populneus - Bursaria spinosa - Themeda australis shrub-grass mid-high open wood- land on limestone karsts in the Wee Jasper area}

Scientific Name: Brachychiton populneus - Eucalyptus bridgesiana / Grevillea iaspicula - Bursaria spinosa / Themeda australis - Poa sieberiana - Imperata cylindrica

$\begin{array}{ll}\text { Number of samples: } & 3 \\ \text { Richness [mean ( } \pm \text { SD)]: } & 35(6) \\ \text { Slope (degrees): } & (1) 3-8(12) \\ \text { Altitude (m asl): } & (375) 377-407(436) \\ \text { Ave. Annual Rainfall }(\mathrm{mm}): & (850) 851-875(897) \\ \text { Temp. Annual Range }\left({ }^{\circ} \mathrm{C}\right): & (26.2) 26.4-26.5(26.5)\end{array}$

Vegetation Description: Community u20 is a mid-high open woodland with sparsely scattered trees of Brachychiton populneus and Eucalyptus bridgesiana with occasional Eucalyptus albens and Eucalyptus melliodora. It has a moderately dense tall shrub layer commonly dominated by Bursaria spinosa. Other co-occurring shrub species include Grevillea iaspicula (Critically Endangered under the TSC Act 1995), Dodonaea viscosa, Rubus parviflora, Indigophora signata, Discaria pubescens and Olearia spp.. There is often a dense grassy groundlayer dominated by Themeda australis and Poa sieberiana. Other groundlayer species include Imperata cylindrica, Microlaena stipoides, Bulbine glauca, Cymbopogon refractus, Sorghum leiocladum and Rytidosperma spp. While many of the taxa recorded in ths community are regionally uncommon, the presence of Imperata cylindrica is notable in that it generally known primarily from the coast and the Nandewar bioregion.

This community is highly restricted in distribution, being endemic to limestone karst formations from just south of Wee Jasper to Lake Burrinjuck. The soil is a skeletal to shallow red-brown loam. Driven by geology rather than landform, it occurs on all aspects and the terrain varies from flat to gently sloping to very steep. At some sites within the karst there are large sinkholes or low cliffs where components of the vegetation grow on almost vertical limestone formations.

\section{Characteristic Species:}

Species

\section{C/A Freq C/A OFreqO Fid \\ C/A Freq C/A OFreqO Fid}

Arthropodium milleflorum Arthropodium minus Asperula ambleia Bothriochloa macra Brachychiton populneus Bulbine glauca

Bursaria spinosa Carex incomitata

$\begin{array}{lllll}1 & 100 & 1 & 8 & \mathrm{P} \\ 1 & 33 & 1 & 1 & \mathrm{P} \\ 1 & 33 & 1 & <1 & \mathrm{P} \\ 1 & 100 & 1 & 3 & \mathrm{P} \\ 2 & 100 & 1 & 2 & \mathrm{P} \\ 1 & 100 & 1 & <1 & \mathrm{P} \\ 2 & 100 & 1 & 10 & \mathrm{P} \\ 1 & 33 & 1 & 1 & \mathrm{P}\end{array}$




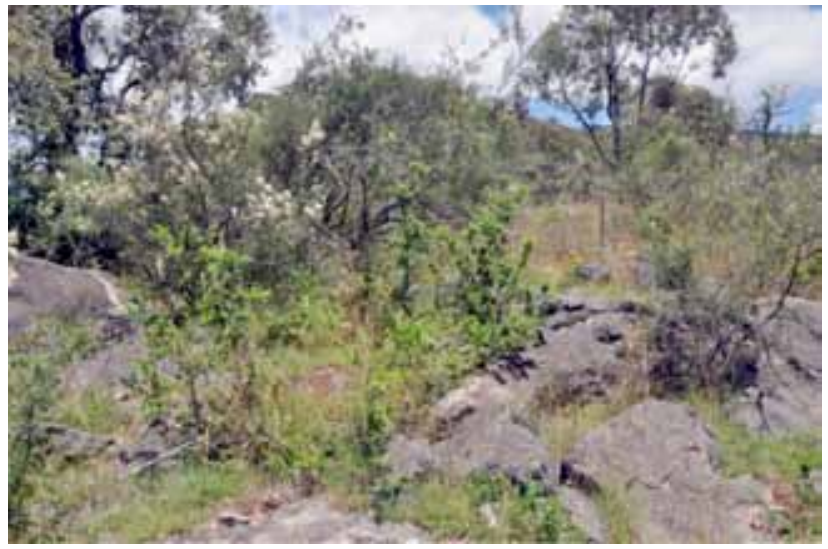

Plate u20: Community u20 with Grevillea iaspicula on limestone outcrops in foreground, on private property $2 \mathrm{~km}$ south of Wee Jasper.

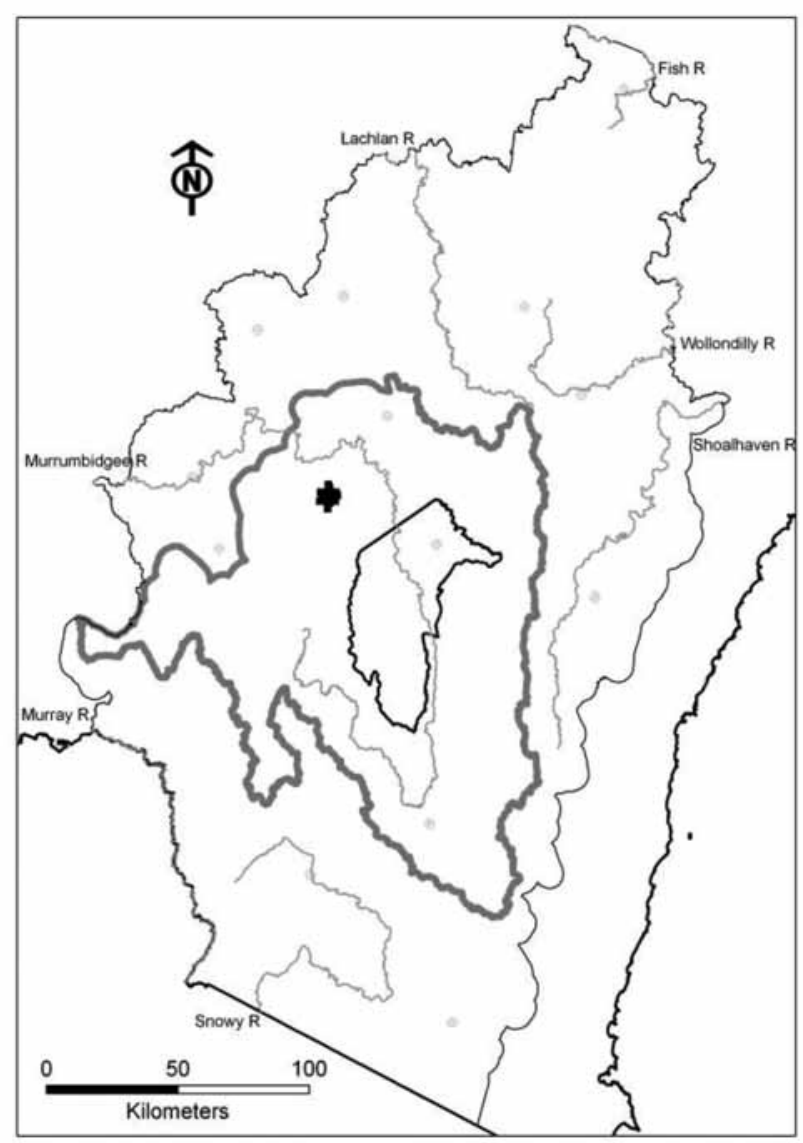

Fig. u20: Distribution of field samples assigned to this community.
Clematis microphylla

Convolvulus angustissimus

Correa reflexa

Daucus glochidiatus

Dianella longifolia

Discaria pubescens

Dodonaea viscosa

Elymus scaber

Eucalyptus bridgesiana

Geranium solanderi

Glycine clandestina

Glycine tabacina

Hydrocotyle laxiflora

Imperata cylindrica

Indigofera adesmiifolia

Microtis spp.

Olearia spp.

Pleurosorus rutifolius

Poa sieberiana

Senecio quadridentatus

Themeda australis

Wahlenbergia spp.

Desmodium varians

Dichondra repens

Rubus parvifolius

Rytidosperma racemosum
Echinopogon cheelii

Grevillea iaspicula

$\begin{array}{llll}67 & 1 & <1 & \mathrm{P} \\ 67 & 1 & 3 & \mathrm{P} \\ 33 & 1 & <1 & \mathrm{P} \\ 100 & 1 & 8 & \mathrm{P} \\ 67 & 1 & 3 & \mathrm{P} \\ 33 & 1 & <1 & \mathrm{P} \\ 67 & 1 & 2 & \mathrm{P} \\ 33 & 1 & 1 & \mathrm{P} \\ 100 & 1 & 21 & \mathrm{P} \\ 67 & 3 & 7 & \mathrm{P} \\ 100 & 1 & 19 & \mathrm{P} \\ 100 & 1 & 30 & \mathrm{P} \\ 67 & 1 & 4 & \mathrm{P} \\ 100 & 0 & 0 & \mathrm{P} \\ 100 & 2 & 30 & \mathrm{P} \\ 100 & 2 & <1 & \mathrm{P} \\ 67 & 1 & <1 & \mathrm{P} \\ 33 & 1 & <1 & \mathrm{P} \\ 33 & 1 & <1 & \mathrm{P} \\ 67 & 1 & <1 & \mathrm{P} \\ 100 & 2 & 48 & \mathrm{P} \\ 67 & 1 & 6 & \mathrm{P} \\ 100 & 2 & 21 & \mathrm{P} \\ 67 & 1 & 5 & \mathrm{P} \\ 67 & 1 & 12 & \mathrm{C} \\ 67 & 2 & 21 & \mathrm{C} \\ 67 & 1 & 11 & \mathrm{C} \\ 67 & 2 & 10 & \mathrm{C} \\ & & & \end{array}$

Threatened communities: Not currently listed, but possibly eligible for listing as Critically Endangered due to its highly restricted distribution and current / historic threats. Areas with Eucalyptus albens or Eucalyptus melliodora and a grassy understorey are considered part of TSC Act 1995 - White Box Yellow Box Blakely's Red Gum Woodland and EPBC Act 1999 - White Box Yellow Box Blakely's Red Gum Grassy Woodland and Derived Native Grassland.

Equivalent vegetation types: Nil. Poory sampled community.

Frequently occurring weeds: This community appears to be highly susceptible to weed invasion. Weeds were abundant at most sites, demonstrating the extent of past grazing disturbance, and also the sensitivity of the community to that disturbance. The most common weeds recorded were Briza minor (0.33), Bromus diandrus (0.33), Bromus molliformis (0.33), Bromus tectorum (0.67), Carthamus lanatus (1.00), Centaurium erythraea (1.00), Cerastium glomeratum (0.33), Chondrilla juncea (0.67), Cirsium vulgare (0.33), Cotoneaster glaucophyllus (0.33), Cynosurus echinatus (0.33), Hypericum perforatum (1.00), Hypochaeris radicata (0.67), Lactuca serriola (1.00), Lysimachia arvensis (0.67), Petrorhagia nanteuilii (0.33), Pyracantha angustifolia (0.33), Rosa rubiginosa (1.00), Rubus fruticosus sp. agg. (1.00), Torilis nodosa (0.67), Trifolium angustifolium (0.33), Trifolium arvense (0.33), Trifolium campestre (0.33) and Vulpia myuros $f$. megalura (0.33), all of which are widespread throughout the region.

Threats: Highly threatened and few relatively intact examples remain. Previous clearing and heavy grazing by domestic stock have almost completely destroyed the tree and shrub layer from all but the most rocky sites where stock have had difficulty gaining access. Some of the sites which have escaped intensive stock grazing are now heavily invaded by Rubus fruticosus sp. agg. and Rosa rubiginosa and other exotic shrubs such as Cotoneaster spp. and Photinia serratifolia. Many sites also have significant infestations of Hypericum perforatum on their margins where there has been greater disturbance due to grazing.

Reservation status: Extremely poorly represented within conservation reserves. A small area of one to two hectares occurs in Burrinjuck NR on the southern shores of Lake Burrinjuck. Unfortunately the shrub and groundlayer in this part of the reserve have been significantly degraded due to feral goat browsing.

Extent of clearing: It is estimated that over $90 \%$ of karst habitat has been cleared in the region, with only approximately 10 hectares remaining in reasonably intact condition. 


\section{u178: Yellow Box - Apple Box tall grassy woodland of the South Eastern Highlands}

Scientific Name: Eucalyptus melliodora - Eucalyptus bridgesiana / Austrostipa scabra - Themeda australis Panicum effusum - Chrysocephalum apiculatum - Oxalis perennans

Number of samples:

Richness [mean $( \pm \mathrm{SD})]$ :

Slope (degrees):

Altitude (m asl):

Ave. Annual Rainfall (mm):

Temp. Annual Range $\left({ }^{\circ} \mathrm{C}\right)$ :

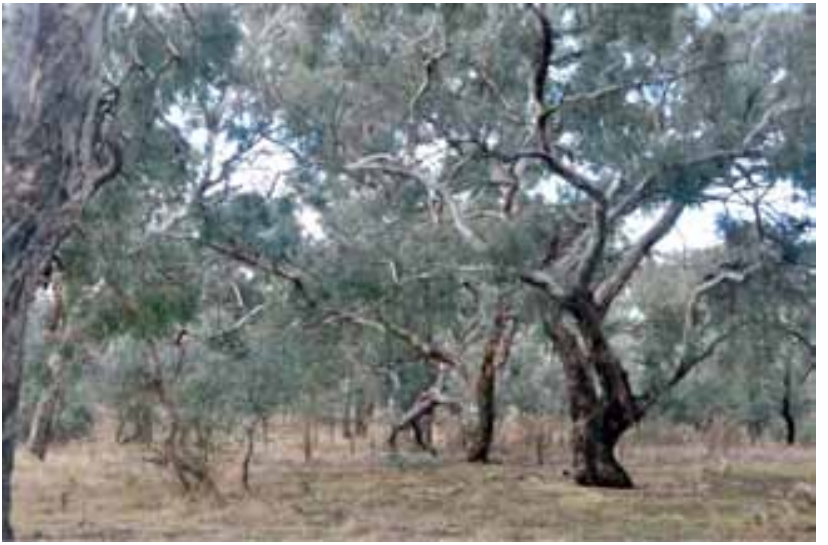

Vegetation Description: Community u178 is a tall grassy eucalypt woodland characterised by Eucalyptus melliodora and/or Eucalyptus bridgesiana, occasionally with Eucalyptus blakelyi along creeklines and in moist depressions. In the southern extent of its range scattered occurrences of Eucalyptus rubida are increasingly common. Whilst often containing a mix of these species, some examples may be dominated entirely by Eucalyptus melliodora or Eucalyptus bridgesiana. The shrub layer is sparse or absent and may include Acacia dealbata, with low shrubs such as Melichrus urceolatus, Astroloma humifusum and Cryptandra amara occurring on less fertile sites. The groundlayer is dense and dominated by herbaceous taxa, with grasses including Themeda australis, Austrostipa scabra, Poa sieberiana, Panicum effusum and Elymus scaber. Forbs include Oxalis perennans, Hydrocotyle laxiflora, Acaena ovina, Desmodium varians, Chrysocephalum apiculatum, Cymobonotus lawsonianus, Geranium solanderi and Glycine tabacina.

This community occurs from the Lake George area south to Michelago / Bredbo. It is generally found on fertile valley soils, although it may extend upslope. It is likely to have been widely distributed throughout the northern half of the ACT prior to urban expansion. In the ACT and surrounds, it often occurs downslope of less fertile communities such as Community u66 [Mealy Bundy - Red Stringybark grass-herb mid-high open forest of the South Eastern Highlands and Upper Slopes subregion of the South Western Slopes bioregion] and Community p14 [Red Stringybark - Scribbly Gum - Rytidosperma pallidum tall grass-shrub dry sclerophyll open forest on loamy ridges of the central South Eastern Highlands bioregion]. Further south around Bredbo, it often occurs downslope of Community u29 [Apple Box-Broad-leaved Peppermint tall shrub-grass woodland primarily on granitoids of the South Eastern Highlands bioregion].

\section{Characteristic Species:}

\section{Species}

Acaena ovina

Aristida ramosa

Arthropodium minus

Asperula conferta

Astroloma humifusum

Austrostipa bigeniculata

Austrostipa scabra

Bothriochloa macra

Bulbine bulbosa

Carex inversa

Cheilanthes sieberi

Chrysocephalum apiculatum

Chrysocephalum semipapposum

Convolvulus angustissimus

Crassula sieberiana

Cymbonotus lawsonianus

Cynoglossum suaveolens

Daucus glochidiatus

Desmodium varians

Dichelachne micrantha

\section{C/AFreq C/A O FreqO Fid}

$\begin{array}{llll}79 & 1 & 7 & \mathrm{P} \\ 33 & 2 & 5 & \mathrm{P} \\ 24 & 1 & 1 & \mathrm{P} \\ 36 & 1 & 11 & \mathrm{P} \\ 21 & 1 & 5 & \mathrm{P} \\ 27 & 2 & <1 & \mathrm{P} \\ 82 & 2 & 3 & \mathrm{P} \\ 45 & 1 & 3 & \mathrm{P} \\ 24 & 1 & 4 & \mathrm{P} \\ 33 & 1 & 8 & \mathrm{P} \\ 39 & 1 & 9 & \mathrm{P} \\ 70 & 1 & 5 & \mathrm{P} \\ 21 & 1 & 4 & \mathrm{P} \\ 39 & 1 & 3 & \mathrm{P} \\ 55 & 1 & 5 & \mathrm{P} \\ 67 & 1 & 4 & \mathrm{P} \\ 30 & 1 & 3 & \mathrm{P} \\ 64 & 1 & 8 & \mathrm{P} \\ 79 & 1 & 12 & \mathrm{P} \\ 33 & 1 & 10 & \mathrm{P}\end{array}$

Plate u178: An example of Community u178 dominated by Eucalyptus melliodora with a grassy understorey, Campbell Park, Canberra.

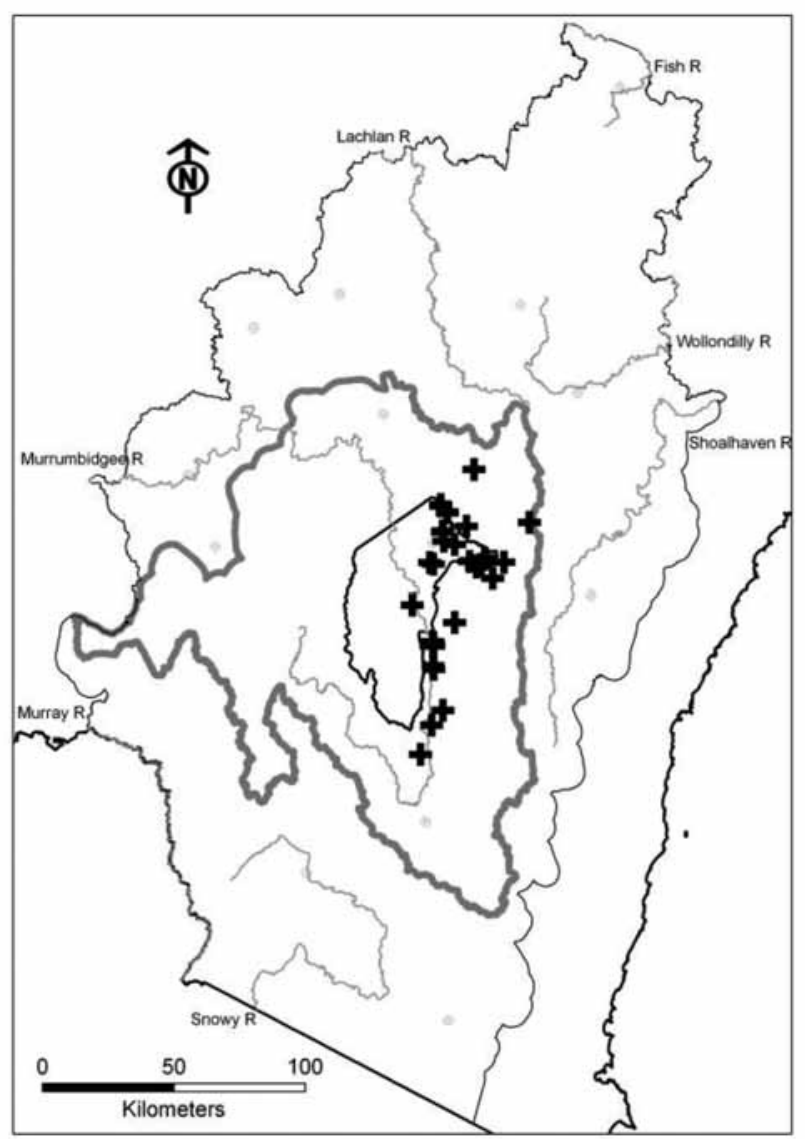

Fig. u178: Distribution of field samples assigned to this community. 
Einadia nutans

Elymus scaber

Enneapogon nigricans

Eryngium ovinum

Eucalyptus blakelyi

Eucalyptus melliodora

Euchiton involucratus

Euchiton sphaericus

Geranium solanderi

Glycine tabacina

Hydrocotyle laxiflora

Hypericum gramineum

Leptorhynchos squamatus

Lomandra filiformis

Lomandra multiflora

Melichrus urceolatus

Oxalis perennans

Panicum effusum

Pimelea curviflora

Plantago gaudichaudii

Plantago varia

Poa sieberiana

Rumex brownii

Rytidosperma spp.

Schoenus apogon

Sebaea ovata

Senecio quadridentatus

Solenogyne dominii

Themeda australis

Tricoryne elatior

Triptilodiscus pygmaeus

Vittadinia cuneata

Vittadinia muelleri

Wahlenbergia communis

Wahlenbergia spp.

Wurmbea dioica

Microlaena stipoides
Eucalyptus bridgesiana

Euchiton spp.

Gonocarpus tetragynus

$\begin{array}{lllll}1 & 48 & 1 & 4 & \mathrm{P} \\ 1 & 61 & 1 & 21 & \mathrm{P}\end{array}$

$\begin{array}{lllll}1 & 27 & 1 & <1 & \mathrm{P}\end{array}$

$\begin{array}{llllll}1 & 21 & 1 & <1 & \mathrm{P}\end{array}$

$\begin{array}{lllll}2 & 21 & 3 & 2 & \mathrm{P}\end{array}$

$\begin{array}{lllll}3 & 52 & 3 & 7 & \mathrm{P}\end{array}$

$\begin{array}{lllll}3 & 58 & 3 & 5 & \mathrm{P}\end{array}$

$\begin{array}{lllll}1 & 33 & 1 & 3 & \mathrm{P}\end{array}$

$\begin{array}{lllll}1 & 24 & 1 & 7 & \mathrm{P}\end{array}$

$\begin{array}{lllll}1 & 24 & 1 & <1 & \mathrm{P}\end{array}$

$\begin{array}{lllll}1 & 67 & 1 & 19 & \mathrm{P}\end{array}$

$\begin{array}{lllll}1 & 61 & 1 & 3 & \mathrm{P}\end{array}$

$\begin{array}{lllll}1 & 88 & 2 & 29 & \mathrm{P}\end{array}$

$\begin{array}{lllll}1 & 67 & 1 & 25 & \mathrm{P}\end{array}$

$\begin{array}{lllll}1 & 33 & 1 & 3 & \mathrm{P}\end{array}$

$\begin{array}{lllll}1 & 48 & 1 & 2 & \mathrm{P}\end{array}$

$\begin{array}{lllll}1 & 42 & 1 & 18 & \mathrm{P}\end{array}$

$\begin{array}{lllll}1 & 48 & 1 & 13 & \mathrm{P}\end{array}$

$\begin{array}{lllll}1 & 85 & 1 & 13 & \mathrm{P}\end{array}$

$\begin{array}{lllll}1 & 67 & 1 & 3 & \mathrm{P}\end{array}$

$\begin{array}{lllll}1 & 39 & 1 & 6 & \mathrm{P}\end{array}$

$\begin{array}{lllll}1 & 27 & 1 & 1 & \mathrm{P}\end{array}$

$\begin{array}{lllll}1 & 58 & 1 & 11 & \mathrm{P}\end{array}$

$\begin{array}{lllll}1 & 76 & 2 & 48 & \mathrm{P}\end{array}$

$\begin{array}{lllll}1 & 67 & 1 & 9 & \mathrm{P}\end{array}$

$\begin{array}{lllll}2 & 52 & 1 & 7 & \mathrm{P}\end{array}$

$\begin{array}{lllll}1 & 33 & 1 & 5 & \mathrm{P}\end{array}$

$\begin{array}{llllll}1 & 21 & 1 & <1 & \mathrm{P}\end{array}$

$\begin{array}{lllll}1 & 33 & 1 & 5 & \mathrm{P}\end{array}$

$\begin{array}{lllll}1 & 58 & 1 & 3 & \mathrm{P}\end{array}$

$\begin{array}{lllll}2 & 79 & 2 & 20 & \mathrm{P}\end{array}$

$\begin{array}{lllll}1 & 36 & 1 & 4 & \mathrm{P}\end{array}$

$\begin{array}{llllll}1 & 30 & 1 & <1 & \mathrm{P}\end{array}$

$\begin{array}{lllll}1 & 21 & 1 & 2 & \mathrm{P}\end{array}$

$\begin{array}{llllll}1 & 58 & 1 & 1 & \mathrm{P}\end{array}$

$\begin{array}{lllll}1 & 45 & 1 & 4 & \mathrm{P}\end{array}$

$\begin{array}{llllll}1 & 48 & 1 & 5 & \mathrm{P}\end{array}$

$\begin{array}{lllll}1 & 45 & 1 & 2 & \mathrm{P}\end{array}$

$\begin{array}{lllll}1 & 64 & 2 & 48 & \mathrm{C} \\ 1 & 55 & 2 & 34 & \mathrm{C}\end{array}$

Threatened communities: This community is part of the TSC Act 1995 - White Box Yellow Box Blakely's Red Gum Woodland; EPBC Act 1999 - White Box Yellow Box Blakely's Red Gum Grassy Woodland and Derived Native Grassland; NC Act 1980 - Yellow Box/Red Gum Grassy Woodland.

Equivalent vegetation types: This community is mostly made up of new plots but includes some plots which were used to define VG160 [Western Slopes Dry Grass Woodland] (Gellie 2005).

Frequently occurring weeds: The most frequently recorded weeds are also those found in other over-grazed grassy woodlands of the South Eastern Highlands bioregion, including Acetosella vulgaris (0.31), Centaurium erythraea (0.53), Hypochaeris radicata $(0.81)$, Linaria arvensis (0.31), Petrorhagia nanteuilii (0.88), Plantago lanceolata (0.38), Rosa rubiginosa (0.59), Trifolium arvense (0.81), Trifolium campestre (0.38) and Vulpia myuros f. megalura (0.44).

Threats: This vegetation type has been extensively cleared for various agricultural purposes, including cropping and grazing. In the ACT, urban development was, and continues to be the catalyst for further clearing of this community. Because of its distribution on the flat, fertile and wellwatered parts of the landscape, most remaining remnants are subject to intensive domestic stock grazing and weed invasion. As a consequence the majority of remnants now contain a depauperate native groundlayer and shrub/midstorey.

Reservation status: Unknown, although small patches of this community are occur in the Mt. Majura, Mt. Ainslie and Mugga Mugga sections of Canberra Nature Park, and Stony Creek NR in NSW. Very small remnants may be present in Mulligans Flat NR and Goorooyarroo NR.
Extent of clearing: Not fully assessed, but given its occurrence on fertile soils and distribution across urban and peri-urban areas it is considered to be one of the most highly cleared and modified components of the Box-Gum alliance.

Reference: Gellie, N.J.H. (2005) Native vegetation of the southern forests: South Eastern Highlands, Australian Alps, South West Slopes and South East Corner bioregions. Cunninghamia 9: 219-254.

\section{Class: Tableland Clay Grassy Woodlands}

\section{p220: Ribbon Gum - Snow Gum tableland flats tall grassy woodland primarily on granitoids in the Kybean - Gourock and Monaro subregions of the South Eastern Highlands bioregion}

Scientific Name: Eucalyptus viminalis - Eucalyptus pauciflora subsp. pauciflora / Microlaena stipoides - Themeda australis - Poa labillardierei - Glycine clandestina - Dichondra repens - Gonocarpus tetragynus

$\begin{array}{ll}\text { Number of samples: } & 52 \\ \text { Richness [mean }( \pm \mathrm{SD})]: & 40(9) \\ \text { Slope (degrees): } & (0) 2-10(18) \\ \text { Altitude (m asl): } & (585) 729-950(1125) \\ \text { Ave. Annual Rainfall }(\mathrm{mm}): & (677) 820-901(1006) \\ \text { Temp. Annual Range }\left({ }^{\circ} \mathrm{C}\right): & (23.5) 24.5-25.6(26.2)\end{array}$

Vegetation Description: Community p220 is a tall grassy woodland dominated by Eucalyptus pauciflora subsp. pauciflora and Eucalyptus viminalis, occasionally with Eucalyptus radiata subsp. radiata. The shrub layer is sparse or absent, with occasional occurrences of Acacia melanoxylon, Rubus parvifolius and low shrubs such as Hibbertia obtusifolia and Bossiaea buxifolia. The groundlayer is dense and dominated by grasses such as Microlaena stipoides, Themeda australis, Poa labillardierei, Elymus scaber and Poa meionectes, with forbs including Glycine clandestina, Dichondra repens, Gonocarpus tetragynus, Hypericum gramineum, Hydrocotyle laxiflora, Acaena novae-zelandiae and Desmodium varians.

This community occurs primarily on granitic soils on flat to gently undulating terrain east of the Great Dividing Range from Braidwood south to Bombala area, and westward to Tinderry NR. Along drainage lines this community may grade into the floristically similar Community p520 [Ribbon Gum very tall woodland on alluvial soils along drainage lines of the eastern South Eastern Highlands bioregion].

\section{Characteristic Species:}

Species

C/A Freq C/A OFreqO Fid

Acacia melanoxylon

Acaena novae-zelandiae

Acrotriche serrulata

Ajuga australis

Austrostipa rudis

Bossiaea buxifolia

Carex spp.

Cymbonotus lawsonianus

Cynoglossum australe

Desmodium gunnii

Desmodium varians

Dianella longifolia

Dichelachne inaequiglumis

Dichondra repens

Einadia nutans

$\begin{array}{lllll}1 & 50 & 1 & 13 & \mathrm{P}\end{array}$

$\begin{array}{lllll}1 & 50 & 1 & 13 & \mathrm{P} \\ 2 & 63 & 1 & 27 & \mathrm{P}\end{array}$

$\begin{array}{lllll}1 & 40 & 1 & 11 & \mathrm{P}\end{array}$

$\begin{array}{lllll}2 & 31 & 1 & 7 & \mathrm{P}\end{array}$

$\begin{array}{llll}15 & 1 & 3 & P\end{array}$

$\begin{array}{llll}46 & 1 & 6 & P\end{array}$

$\begin{array}{llll}13 & 1 & 2 & P\end{array}$

$\begin{array}{llll}17 & 1 & 5 & \mathrm{P}\end{array}$

$\begin{array}{llll}27 & 2 & 1 & P\end{array}$

$\begin{array}{llll}42 & 1 & 12 & \mathrm{P}\end{array}$

$\begin{array}{llll}31 & 1 & 2 & P\end{array}$

$\begin{array}{lllll}2 & 33 & 2 & 6 & \mathrm{P}\end{array}$

$\begin{array}{lllll}2 & 77 & 2 & 20 & \mathrm{P}\end{array}$ $\begin{array}{llll}15 & 1 & 4 & \mathrm{P}\end{array}$

$\begin{array}{lllll}2 & 17 & 1 & 4 & \mathrm{P}\end{array}$


Elymus scaber

Eucalyptus pauciflora subsp pauciflora

Eucalyptus radiata subsp. radiata

Eucalyptus stellulata

Eucalyptus viminalis

Euchiton japonicus

Geranium solanderi

Glycine clandestina

Gonocarpus tetragynus

Hovea heterophylla

Hovea linearis

Hydrocotyle laxiflora

Hypericum gramineum

Lomandra longifolia

Lomandra multiflora

Microlaena stipoides

Oxalis spp.

Panicum effusum

Poa labillardierei

Poa meionectes

Pteridium esculentum

Pultenaea subspicata

Rubus parvifolius

Rytidosperma laeve

Rytidosperma pilosum

Scleranthus biflorus

Senecio prenanthoides

Solenogyne gunnii

Themeda australis

Veronica calycina

Veronica plebeia

Wahlenbergia spp.

Hibbertia obtusifolia

Poa sieberiana
Viola betonicifolia

$\begin{array}{lllll}1 & 48 & 1 & 21 & \mathrm{P} \\ 3 & 79 & 3 & 20 & \mathrm{P} \\ 3 & 27 & 3 & 11 & \mathrm{P} \\ 1 & 15 & 2 & 3 & \mathrm{P} \\ 3 & 85 & 3 & 12 & \mathrm{P} \\ 2 & 33 & 1 & 15 & \mathrm{P} \\ 2 & 40 & 1 & 19 & \mathrm{P} \\ 2 & 77 & 1 & 29 & \mathrm{P} \\ 2 & 73 & 2 & 47 & \mathrm{P} \\ 1 & 23 & 1 & 4 & \mathrm{P} \\ 2 & 33 & 1 & 13 & \mathrm{P} \\ 2 & 60 & 2 & 29 & \mathrm{P} \\ 1 & 67 & 1 & 25 & \mathrm{P} \\ 2 & 63 & 2 & 42 & \mathrm{P} \\ 1 & 44 & 1 & 18 & \mathrm{P} \\ 2 & 88 & 2 & 33 & \mathrm{P} \\ 2 & 21 & 1 & 3 & \mathrm{P} \\ 1 & 13 & 1 & 3 & \mathrm{P} \\ 3 & 62 & 2 & 9 & \mathrm{P} \\ 2 & 52 & 2 & 16 & \mathrm{P} \\ 2 & 52 & 2 & 27 & \mathrm{P} \\ 2 & 13 & 2 & 2 & \mathrm{P} \\ 2 & 52 & 1 & 11 & \mathrm{P} \\ 2 & 19 & 2 & 4 & \mathrm{P} \\ 2 & 29 & 2 & 9 & \mathrm{P} \\ 1 & 40 & 1 & 9 & \mathrm{P} \\ 2 & 52 & 1 & 19 & \mathrm{P} \\ 1 & 15 & 1 & 5 & \mathrm{P} \\ 2 & 79 & 2 & 20 & \mathrm{P} \\ 2 & 44 & 1 & 16 & \mathrm{P} \\ 1 & 25 & 1 & 6 & \mathrm{P} \\ 2 & 48 & 1 & 27 & \mathrm{P} \\ & 17 & 1 & 5 & \mathrm{P} \\ & 50 & 1 & 34 & \mathrm{C} \\ & 40 & 2 & 48 & \mathrm{C} \\ & & & & \\ 2 & & & & \\ 2 & & 16 & \end{array}$

Threatened communities: This community is part of the TSC Act 1995 - Tablelands Snow Gum, Black Sallee, Candlebark and Ribbon Gum Grassy Woodland in the South Eastern Highlands, Sydney Basin, South East Corner and NSW South Western Slopes bioregions.

Equivalent vegetation types: This community is largely equivalent to GWp220 [Southern Tableland Flats Forest] (Tozer et al. 2010).

Frequently occurring weeds: Remnants of this community are generally restricted to freehold grazing land. The most frequently encountered weeds are therefore those that are typical of other grassy woodlands in the South Eastern Highlands bioregion, including Acetosella vulgaris (0.37), Cirsium vulgare (0.27), Holcus lanatus (0.25), Hypochaeris radicata (0.92), and Rosa rubiginosa (0.27).

Threats: This formerly widespread community has historically been the target of extensive clearing for pastoral development. The community is now highly fragmented, generally only existing in small remnants or as secondary grassland. Remaining examples are subject to grazing pressures, weed invasion, firewood collection and.occasional small-scale clearing. Canopy dieback is a significant problem across much of the range of this community.

Reservation status: Likely to be poorly reserved. Examples of this community are found in Badja Swamps NR, Coolumbooka NR, Deua NP, Monga SCA and Tinderry NR.

Extent of clearing: This community has been widely cleared across its range primarily for pastoral development.

Reference: Tozer, M.G., Turner, K., Keith, D.A., Tindall, D., Pennay, C., Simpson, C., MacKenzie, B., Beukers, P. \& Cox, S. (2010) Native vegetation of southeast NSW: a revised classification and map for the coast and eastern tablelands. Cunninghamia 11: 359-406.

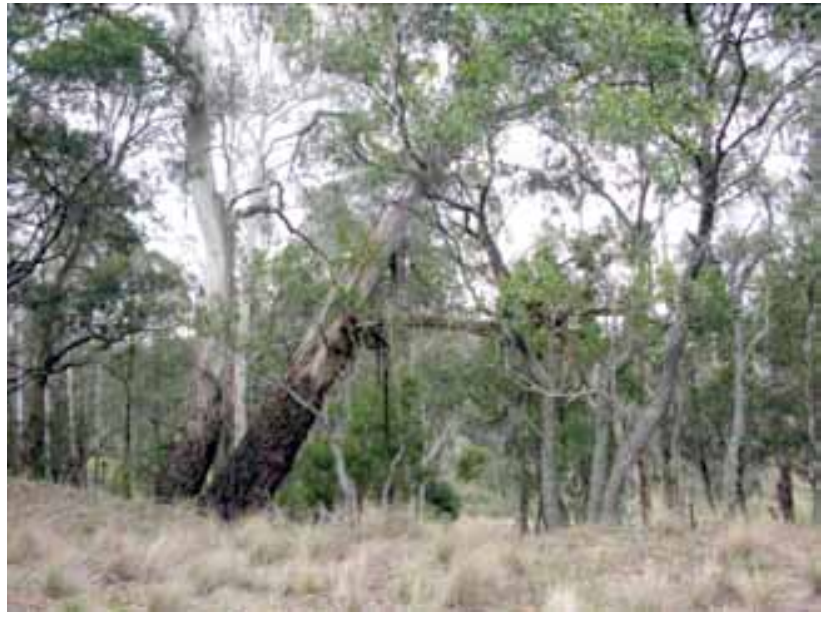

Plate p220: Community p220 beside Araluen Road near Reidsdale, with Eucalyptus viminalis and Acacia melanoxylon over a grassy groundcover dominated by Poa labillardierei var. labillardierei.

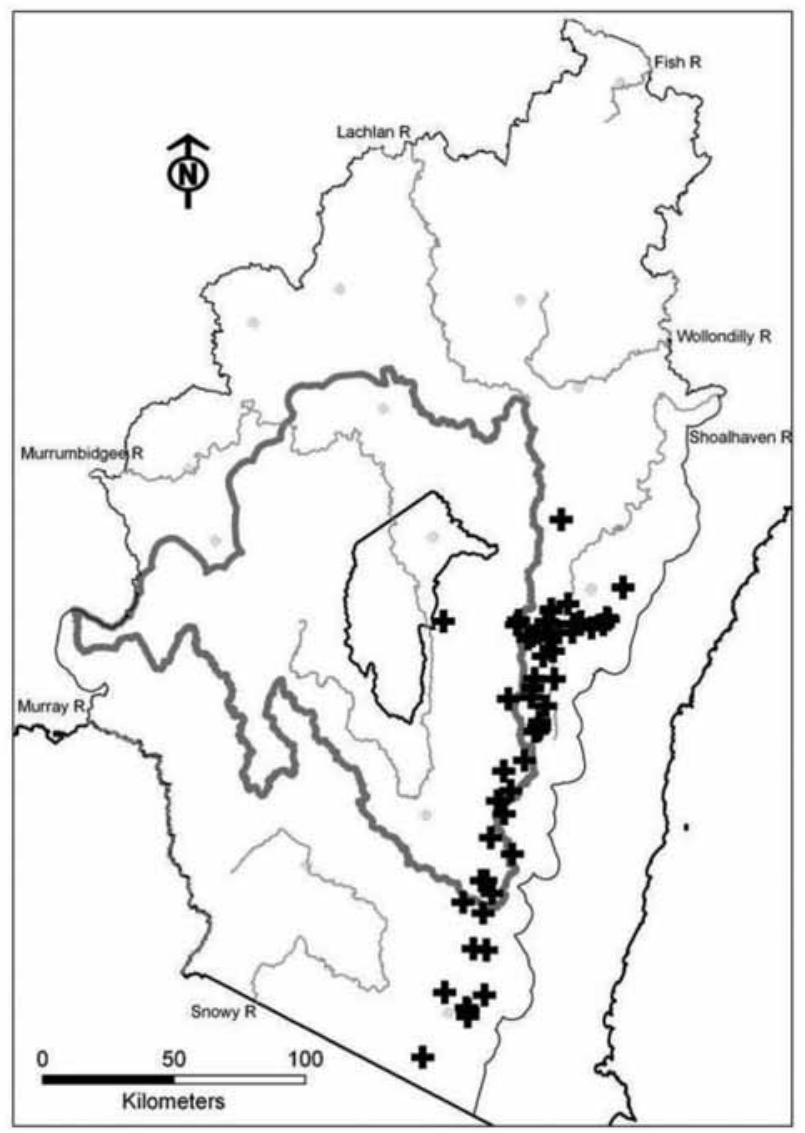

Fig. p220: Distribution of field samples assigned to this community. 


\section{p520: Ribbon Gum very tall woodland on alluvial soils along drainage lines of the eastern South East- ern Highlands bioregion}

Scientific Name: Eucalyptus viminalis \pm Eucalyptus stellulata - Eucalyptus pauciflora subsp. pauciflora / Microlaena stipoides - Poa labillardierei - Dichondra repens - Acaena novae-zelandiae

$\begin{array}{ll}\text { Number of samples: } & 42 \\ \text { Richness [mean }( \pm \mathrm{SD})]: & 33(11) \\ \text { Slope (degrees): } & (0) 3-8(19) \\ \text { Altitude }(\mathrm{m} \text { asl): } & (551) 641-860(1140) \\ \text { Ave. Annual Rainfall }(\mathrm{mm}): & (639) 702-856(968) \\ \text { Temp. Annual Range }\left({ }^{\circ} \mathrm{C}\right): & (23.7) 24.8-26.1(26.5)\end{array}$

Vegetation Description: Community p520 is a very tall woodland to open forest characterised by Eucalyptus viminalis, sometimes with Eucalyptus stellulata, Eucalyptus pauciflora subsp. pauciflora or Eucalyptus rubida. Occasionally, Eucalyptus aggregata may be present. The shrub layer is sparse or absent, with infrequent groves of Acacia melanoxylon, Acacia mearnsii, Lomatia myricoides or Leptospermum myrtifolium. The groundlayer is dense and dominated by grasses such as Microlaena stipoides, Poa labillardierei and Echinopogon ovatus, with forbs including Acaena novae-zelandiae, Dichondra repens, Hydrocotyle laxiflora, Stellaria pungens and Geranium solanderi.

This community is distributed on alluvial flats across eastern parts of the South Eastern Highlands bioregion, from the Abercrombie River in the north to east of the Bredbo - Cooma area. Although unsampled further west, it is likely to occur in sandy lenses and creek flats along the Murrumbidgee River corridor in the ACT. It generally occurs on creek flats and coarse sandy alluvial soils along drainage channels. Away from the riparian zone, it commonly grades into Community p220 [Ribbon Gum - Snow Gum tableland flats tall grassy woodland primarily on granitoids in the Kybean - Gourock and Monaro subregions of the South Eastern Highlands bioregion] or, in steeper country, numerous dry sclerophyll forest types.

\section{Characteristic Species:}

\section{Species}

Acacia mearnsii Acaena novae-zelandiae

Carex appressa

Carex inversa

Desmodium varians

Dichondra repens

Echinopogon ovatus

Einadia nutans

Eucalyptus rubida

Eucalyptus stellulata

Eucalyptus viminalis

Geranium solanderi

Glycine clandestina

Glycine tabacina

Hydrocotyle laxiflora

Lomandra longifolia

Microlaena stipoides

Oreomyrrhis eriopoda

Oxalis perennans

Poa labillardierei

Poranthera microphylla

Rubus parvifolius

Rumex brownii

Rytidosperma racemosum

Solenogyne gunni

Stellaria pungens

Veronica plebeia

Viola betonicifolia

\section{C/A Freq C/A OFreqO Fid}

$\begin{array}{lll}19 & 2 & 3 \\ 79 & 1 & 27 \\ 45 & 1 & 6 \\ 29 & 1 & 8 \\ 36 & 1 & 12 \\ 83 & 2 & 20 \\ 45 & 1 & 10 \\ 24 & 1 & 4 \\ 26 & 3 & 9 \\ 38 & 2 & 3 \\ 62 & 3 & 12 \\ 52 & 1 & 19 \\ 45 & 1 & 29 \\ 21 & 1 & 3 \\ 62 & 2 & 29 \\ 45 & 2 & 42 \\ 95 & 2 & 33 \\ 45 & 1 & 13 \\ 36 & 1 & 13 \\ 69 & 2 & 9 \\ 48 & 1 & 27 \\ 36 & 1 & 11 \\ 48 & 1 & 9 \\ 43 & 2 & 10 \\ 19 & 1 & 5 \\ 57 & 2 & 31 \\ 26 & 1 & 6 \\ 48 & 1 & 27\end{array}$

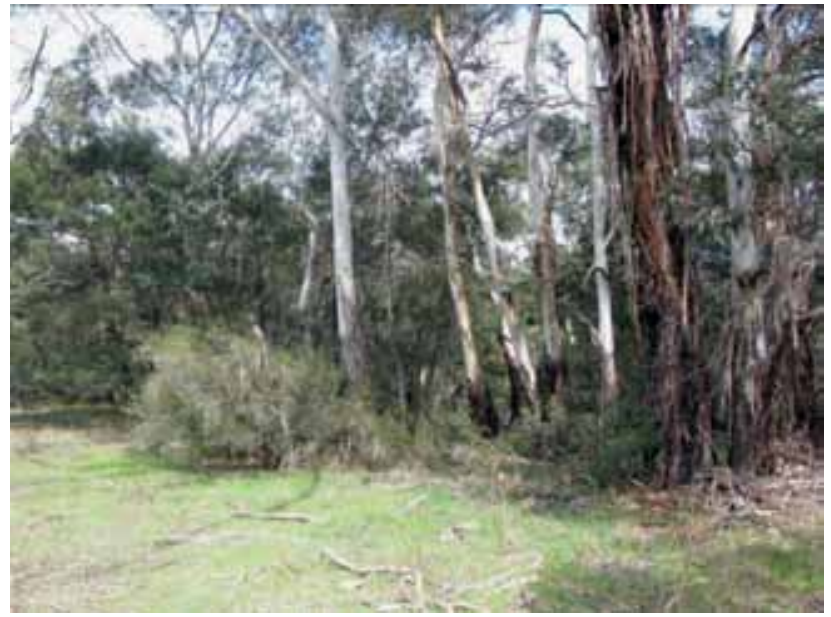

Plate p520: Community p520, Doughboy TSR (near plot MAN021A), with Eucalyptus viminalis and Eucalyptus stellulata over scattered Acacia mearnsii and a diverse grass/forb groundcover.

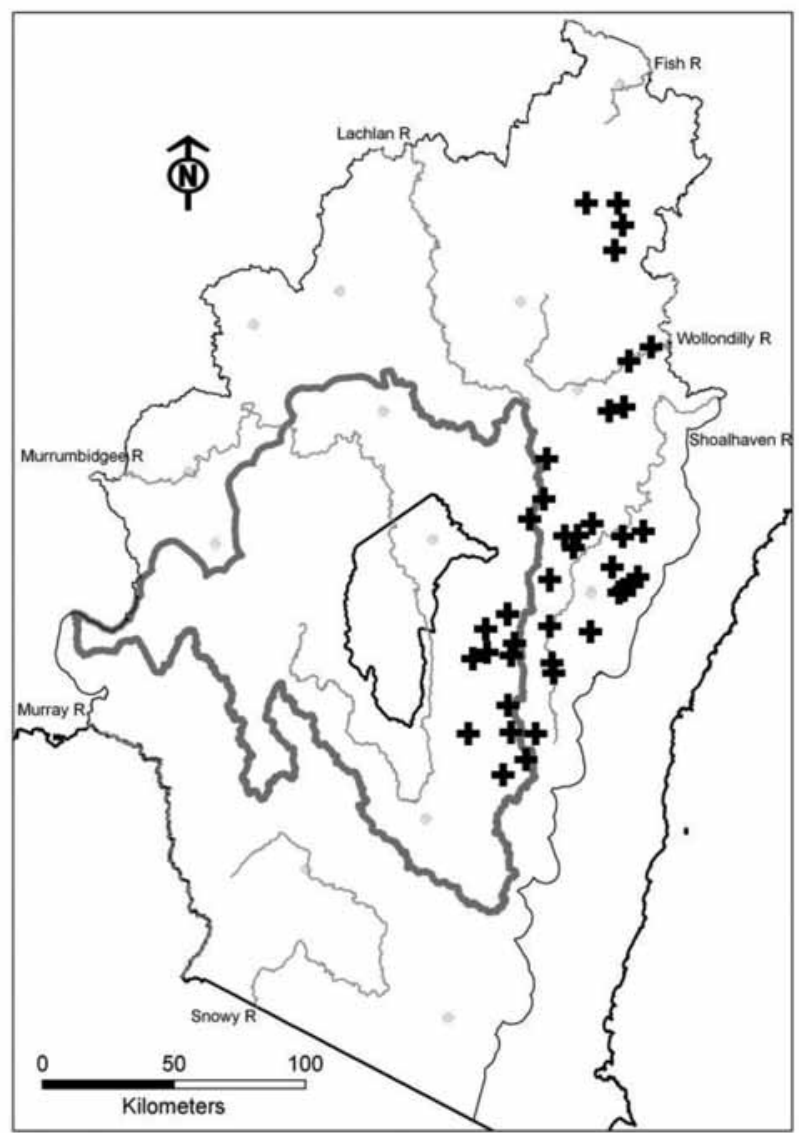

Fig. p520: Distribution of field samples assigned to this community. 
Threatened communities: This community is part of the TSC Act 1995 - Tablelands Snow Gum, Black Sallee, Candlebark and Ribbon Gum Grassy Woodland in the South Eastern Highlands, Sydney Basin, South East Corner and NSW South Western Slopes bioregions.

Equivalent vegetation types: This community is similar to GWp520 [Tableland Swamp Flats Forest] (Tozer et al. 2010), with the community described in this study containing a higher frequency of Eucalyptus stellulata and Eucalyptus rubida, and less Eucalyptus pauciflora ssp. pauciflora.

Frequently occurring weeds: Although examples of this community are found on public land, the majority of remnants occur on freehold grazing land. As with most grassy woodlands on this tenure, weeds are a major component of the remnant vegetation, the most common of which are Acetosella vulgaris (0.55), Cirsium vulgare (0.74), Holcus lanatus (0.5), Hypochaeris radicata (0.79), Plantago lanceolata (0.47), Rosa rubiginosa (0.42), Rubus ulmifolius (0.37) and Trifolium repens (0.32).

Threats: Community p520 was extensively cleared because it occupied relatively fertile alluvial soils suitable for agriculture. Examples on sandy alluvial lenses may be subject to less clearing pressure. Remnants are generally small and isolated, subject to ongoing degradation from domestic stock grazing, weed invasion, firewood collection and small-scale clearing.

Reservation status: Unknown, although examples are found in drainage areas in Abercrombie River NP, Badja Swamps NR, Blue Mountains NP, Deua NP, Gourock NP, Kanangra-Boyd NP, Macanally SCA, Monga SCA, Mount Dowling NR, Quidong NR, Tallaganda NP, Tinderry NR, Wiarborough NR and Yanununbeyan SCA.

Extent of clearing: This community has been widely cleared across its range primarily for pastoral development.

Reference: Tozer, M.G., Turner, K., Keith, D.A., Tindall, D., Pennay, C., Simpson, C., MacKenzie, B., Beukers, P. \& Cox, S. (2010) Native vegetation of southeast NSW: a revised classification and map for the coast and eastern tablelands. Cunninghamia 11: 359-406.

\section{u78: Snow Gum grassy mid-high woodland of the South Eastern Highlands bioregion}

Scientific Name: Eucalyptus pauciflora subsp. pauciflora \pm Eucalyptus bridgesiana / Astroloma humifusum - Hibbertia obtusifolia / Themeda australis - Microlaena stipoides - Poa sieberiana - Chrysocephalum apiculatum

$\begin{array}{ll}\text { Number of samples: } & 27 \\ \text { Richness [mean }( \pm \mathrm{SD})]: & 31(8) \\ \text { Slope (degrees): } & (0) 1-4(8) \\ \text { Altitude (m asl): } & (584) 683-792(940) \\ \text { Ave. Annual Rainfall }(\mathrm{mm}): & (641) 699-798(874) \\ \text { Temp. Annual Range }\left({ }^{\circ} \mathrm{C}\right): & (24.3) 25.6-26.2(26.8)\end{array}$

Vegetation Description: Community u78 is a mid-high grassy woodland dominated by Eucalyptus pauciflora subsp. pauciflora occasionally with Eucalyptus bridgesiana. The shrub layer is sparse or absent, with infrequent occurrences of low shrubs such as Pimelea curviflora, Astroloma humifusum, and Hibbertia obtusifolia at low abundance. The groundlayer is dense and dominated by grasses such as Themeda australis, Microlaena stipoides, Poa sieberiana, Elymus scaber, Aristida ramosa and Rytidosperma racemosum. Forb species include Chrysocephalum apiculatum, Gonocarpus tetragynus, Hypericum gramineum, Lomandra filiformis subsp. coriacea, Acaena echinata and Asperula conferta. Heavily grazed remnants may be dominated by less-palatable species such as Aristida ramosa, Rytidosperma spp. and Bothriochloa macra.

Community $\mathrm{u} 78$ occurs on flat to undulating clay landscapes from the Crookwell area south to the Braidwood area. It is mostly found on private grazing land and as such has been highly modified and cleared across its range. It grades into tableland grassland communities such as Community 7 [ Themeda australis - Rytidosperma sp. - Poa sieberiana

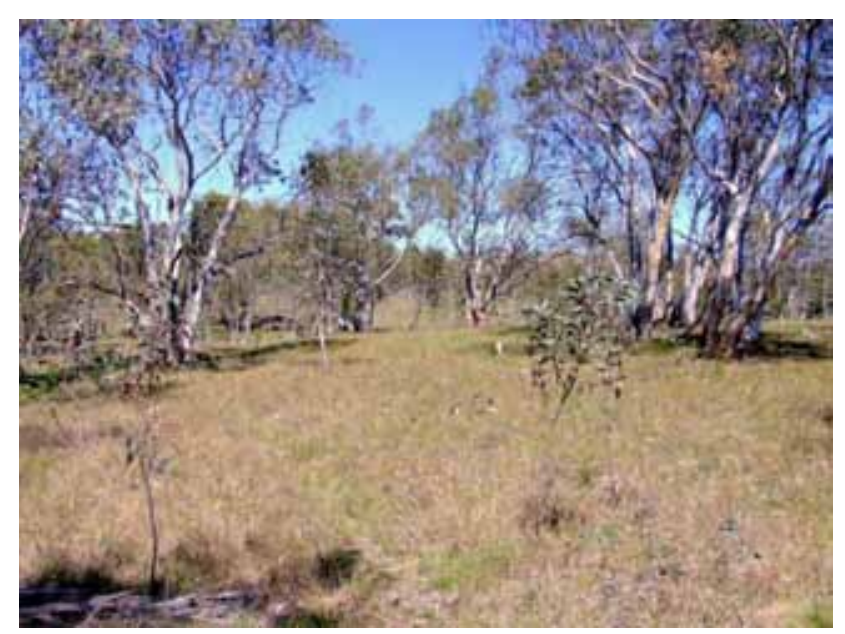

Plate u78: Community u78 with mature and regenerating Eucalyptus pauciflora ssp. pauciflora, and a mix of grasses and forbs.

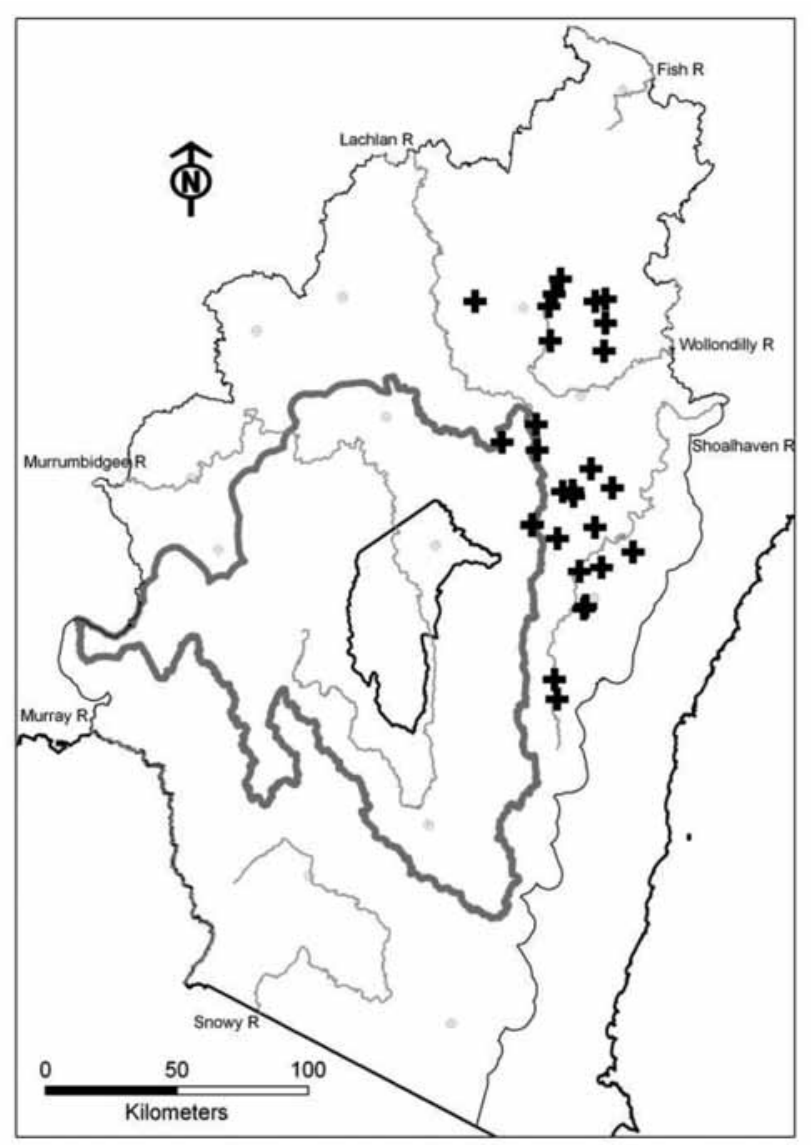

Fig. u78: Distribution of field samples assigned to this community. 
moist tussock grassland of the South Eastern Highlands bioregion], which can also contain scattered occurrences of Eucalyptus pauciflora subsp. pauciflora at low abundance.

\section{Characteristic Species:}

Species

Acaena echinata

Aristida ramosa

Asperula conferta

Bothriochloa macra

Calocephalus citreus

Carex inversa

Chrysocephalum apiculatum

Dichelachne micrantha

Einadia nutans

Elymus scaber

Eryngium ovinum

Eucalyptus bridgesiana

Eucalyptus pauciflora subsp. pauciflora

Hypericum gramineum

Lomandra filiformis subsp. coriacea

Microlaena stipoides

Oxalis exilis

Pimelea curviflora

Plantago varia

Poa labillardierei

Rytidosperma pilosum

Rytidosperma racemosum

Scleranthus biflorus

Solenogyne gunnil

Themeda australis

Tricoryne elatior

Wahlenbergia communis

Wahlenbergia luteola

Gonocarpus tetragynus

Hydrocotyle laxiflora

Poa sieberiana
Astroloma humifusum

Panicum effusum

Rytidosperma laeve

\section{C/AFreq C/A OFreqO Fid}

$\begin{array}{lllll}1 & 52 & 1 & 9 & \mathrm{P} \\ 2 & 48 & 2 & 5 & \mathrm{P} \\ 1 & 44 & 1 & 10 & \mathrm{P} \\ 1 & 33 & 1 & 5 & \mathrm{P} \\ 1 & 26 & 1 & 3 & \mathrm{P} \\ 2 & 22 & 1 & <1 & \mathrm{P} \\ 2 & 37 & 1 & 8 & \mathrm{P} \\ 2 & 67 & 1 & 6 & \mathrm{P} \\ 1 & 33 & 1 & 10 & \mathrm{P} \\ 1 & 26 & 1 & 4 & \mathrm{P} \\ 1 & 59 & 1 & 21 & \mathrm{P} \\ 1 & 22 & 1 & <1 & \mathrm{P} \\ 2 & 26 & 3 & 7 & \mathrm{P} \\ 3 & 89 & 3 & 20 & \mathrm{P} \\ & & & & \\ 2 & 59 & 1 & 25 & \mathrm{P} \\ 2 & 59 & 2 & 18 & \mathrm{P} \\ 3 & 96 & 2 & 34 & \mathrm{P} \\ 2 & 22 & 1 & 5 & \mathrm{P} \\ 2 & 41 & 1 & 3 & \mathrm{P} \\ 2 & 37 & 1 & 6 & \mathrm{P} \\ 2 & 37 & 1 & 11 & \mathrm{P} \\ 2 & 37 & 2 & 10 & \mathrm{P} \\ 2 & 26 & 2 & 4 & \mathrm{P} \\ 2 & 30 & 2 & 9 & \mathrm{P} \\ 2 & 44 & 2 & 10 & \mathrm{P} \\ 2 & 37 & 1 & 10 & \mathrm{P} \\ 1 & 22 & 1 & 5 & \mathrm{P} \\ 3 & 100 & 2 & 20 & \mathrm{P} \\ 2 & 41 & 1 & 4 & \mathrm{P} \\ 1 & 26 & 1 & 5 & \mathrm{P} \\ 2 & 26 & 1 & 1 & \mathrm{P} \\ 2 & 63 & 2 & 48 & \mathrm{C} \\ 2 & 44 & 2 & 30 & \mathrm{C} \\ 3 & 74 & 2 & 48 & \mathrm{C}\end{array}$

Threatened communities: This community is part of the TSC Act 1995 - Tablelands Snow Gum, Black Sallee, Candlebark and Ribbon Gum Grassy Woodland in the South Eastern Highlands, Sydney Basin, South East Corner and NSW South Western Slopes bioregions.

Equivalent vegetation types: Given the lack of adequate previous woodland classifications, there are no clear equivalent communities. There are some affinities with p22 [Frost Hollow Grassy Woodland] and p24 [Tableland Grassy Box-Gum Woodland] as described by Tozer et al. (2010).

Frequently occurring weeds: This community is generally confined to private properties where grazing of domestic stock is the primary landuse. Typcial weeds are those associated with this landuse and include Acetosella vulgaris (0.62), Centaurium erythraea (0.23), Cirsium vulgare (0.23), Crataegus monogyna (0.23), Hypochaeris radicata (0.85), Plantago lanceolata (0.58) and Rosa rubiginosa (0.46). Where pasture improvement has occurred Dactylis glomerata (0.23), Holcus lanatus (0.23) and Paspalum dilatatum (0.23) are more common.

Threats: This community was extensively cleared because it occurred on land well-suited to agricultural development. The community is now highly fragmented and remnants are subject to grazing pressures, weed invasion, firewood collection, and occasionally small-scale clearing.

Reservation status: This community is poorly reserved. Examples occur in Oakdale NR.

Extent of clearing: Clearing of this vegetation type is known to be high across its known range due to pastoral development.

Reference: Tozer, M.G., Turner, K., Keith, D.A., Tindall, D., Pennay, C., Simpson, C., MacKenzie, B., Beukers, P. \& Cox, S. (2010) Native vegetation of southeast NSW: a revised classification and map for the coast and eastern tablelands. Cunninghamia 11: 359-406.

\section{Formation: Grasslands}

\section{Class: Temperate Montane Grasslands}

Note: Grasslands were classified through a separate analysis (Rehwinkel unpub.) to that of the woody and alpine communities, and as such $\mathrm{CA} / \mathrm{O}$ (cover/abundance of taxa recorded in other communities), Freq $\mathrm{O}$ (frequency of taxa recorded in other communities) and Fid (fidelity) measures are not presented.

\section{r1: Sub-montane moist tussock grassland of the South Eastern Highlands bioregion}

Scientific Name: Poa sieberiana - Themeda australis Ranunculus lappulaceus - Coronidium sp. 'Alps' - Plantago gaudichaudii-Brachyscome scapigera

$\begin{array}{ll}\text { Number of samples: } & 22 \\ \text { Richness [mean }( \pm \mathrm{SD})]: & 20(5) \\ \text { Slope (degrees): } & (0) 2-5(10) \\ \text { Altitude (m asl): } & (717) 919-1129(1171) \\ \text { Ave. Annual Rainfall }(\mathrm{mm}): & (683) 725-800(897) \\ \text { Temp. Annual Range }\left({ }^{\circ} \mathrm{C}\right): & (25.0) 25.4-26.9(27.7)\end{array}$

Vegetation Description: Community r1 is a dense moist tussock grassland dominated by Poa sieberiana and/or Themeda australis in the upper stratum with a variety of forbs in the inter-tussock spaces, including Brachyscome scapigera, Asperula spp. (Asperula conferta or Asperula scoparia), Coronidium sp. 'Alps', Plantago antarctica, Hydrocotyle algida, Ranunculus lappaceus, Geranium antrorsum and Leptorhynchos squamatus. Other grasses are present including Rytidosperma spp., Elymus scaber and Hemarthria uncinata. A variety of rushes Juncus spp. and sedges Carex spp. may also be present. Isolated or scattered trees may occur including Eucalyptus pauciflora subsp. pauciflora, Eucalyptus dalrympleana, Eucalyptus ovata or Acacia melanoxylon. There may be isolated shrubs or patches of shrubs including Hakea microcarpa, Discaria pubescens, Banksia marginata, Bossiaea riparia, Bursaria spinosa and Mirbelia oxylobioides. Trees and shrubs increase in density at ecotones with adjacent woodland and forest communities. Relatively undisturbed sites may have a variety of uncommon grassland forbs, including Prasophyllum wilkinsoniorum, Diplarrena moraea and Thysanotus tuberosus.

This community is found on a variety of substrates but most commonly on colluvium or alluvium on footslopes and flats. It also occurs on basalt and granite lithologies and on midslopes and plateaux. Poor soil drainage, seasonal waterlogging and severe frosts drive the distribution of this community, as they restrict the establishment of woody species. Community r1 occurs in the southern ACT (Namadgi NP) and the adjacent Yaouk area in NSW. Elsewhere in NSW, it occurs near Delegate, Nunnock Swamp (South East Forests NP), Kydra River and the upper headwaters of the Shoalhaven River (Deua NP). Degraded sites (i.e. lacking some of the main species that define this community) may be difficult to distinguish from degraded sites of Community r2 [Poa labillardierei - Themeda australis - Juncus sp. wet tussock grassland of footslopes, drainage lines and flats of the South Eastern Highlands bioregion] or Community r7 [Themeda australis - Rytidosperma sp. Poa sieberiana moist tussock grassland of the South Eastern Highlands bioregion].

\section{Characteristic Species:}

Species

C/A Freq

Acaena novae-zelandiae

1

Acaena ovina

Asperula spp.

$1 \quad 27$

195 
Brachyscome scapigera

Carex spp.

Chrysocephalum apiculatum

Coronidium sp. 'Alps'

Craspedia spp.

Cynoglossum suaveolens

Elymus scaber

Epilobium spp.

Euchiton spp.

Geranium antrorsum

Geranium spp.

Hemarthria uncinata

Hydrocotyle laxiflora

Juncus spp.

Leptorhynchos squamatus

Luzula spp.

Microlaena stipoides

Oreomyrrhis eriopoda

Oxalis perennans

Plantago antarctica

Plantago gaudichaudii

Poa labillardierei

Poa sieberiana

Ranunculus lappaceus

Rumex brownii

Rytidosperma spp.

Scleranthus biflorus

Solenogyne gunnii

Stylidium graminifolium sens. lat.

Themeda australis

Veronica gracilis

Viola betonicifolia

Wahlenbergia spp.
Lomandra longifolia

Threatened communities: EPBC Act 1999 - Natural Temperate Grassland of the Southern Tablelands of NSW and the Australian Capital Territory; NC Act 1980 - Natural Temperate Grassland.

Equivalent vegetation types: This community is equivalent to Group 1 (Rehwinkel unpub.).

Frequently occurring weeds: The naturally open nature of this community made it highly attractive to pastoral management. Common weeds are those typical of other grassy ecosystems of the region, including Anthoxanthum odoratum, Hypochaeris radicata and Acetosella vulgaris.

Threats: This community has been extensively cleared and remnants are subject to continued small-scale clearing, weed invasion and grazing pressures.

Reservation status: Poorly reserved. Occurs in Deua NP, Namadgi NP, South East Forests NP and Yaouk NR. Also on Nature Conservation Trust covenanted lands in the upper Shoalhaven River area.

Extent of clearing: Unknown, although throughout its range only $3 \%$ of the Natural Temperate Grassland of the Southern Tablelands of NSW and the Australian Capital Territory TEC remains in high ecological integrity, relative to its pre-European settlement extent (Environment ACT 2006).

References: Environment ACT (2006) National recovery plan for natural temperate grassland of the southern tablelands (NSW and ACT): an endangered ecological community. Environment ACT, Canberra; Rehwinkel, R. (unpublished) Revision of PATN analysis of grassland associations within the Natural Temperate Grassland Endangered Ecological Community in the Southern Tablelands of NSW. August 2009. NSW Department of Environment and Climate Change, Queanbeyan. Unpublished Report.

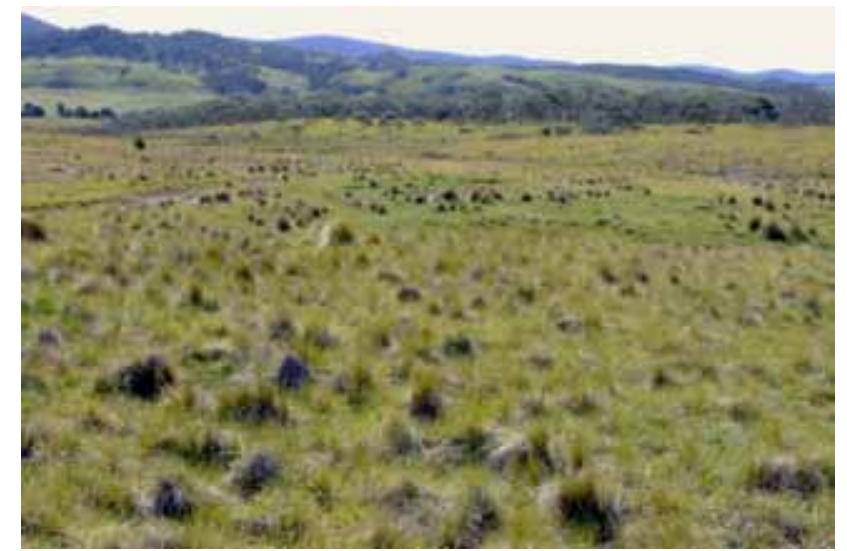

Plate r1: Poa sieberiana and Themeda australis dominate this forbrich example of Community r 1 in the Jerrabatgulla Creek area south of Braidwood.

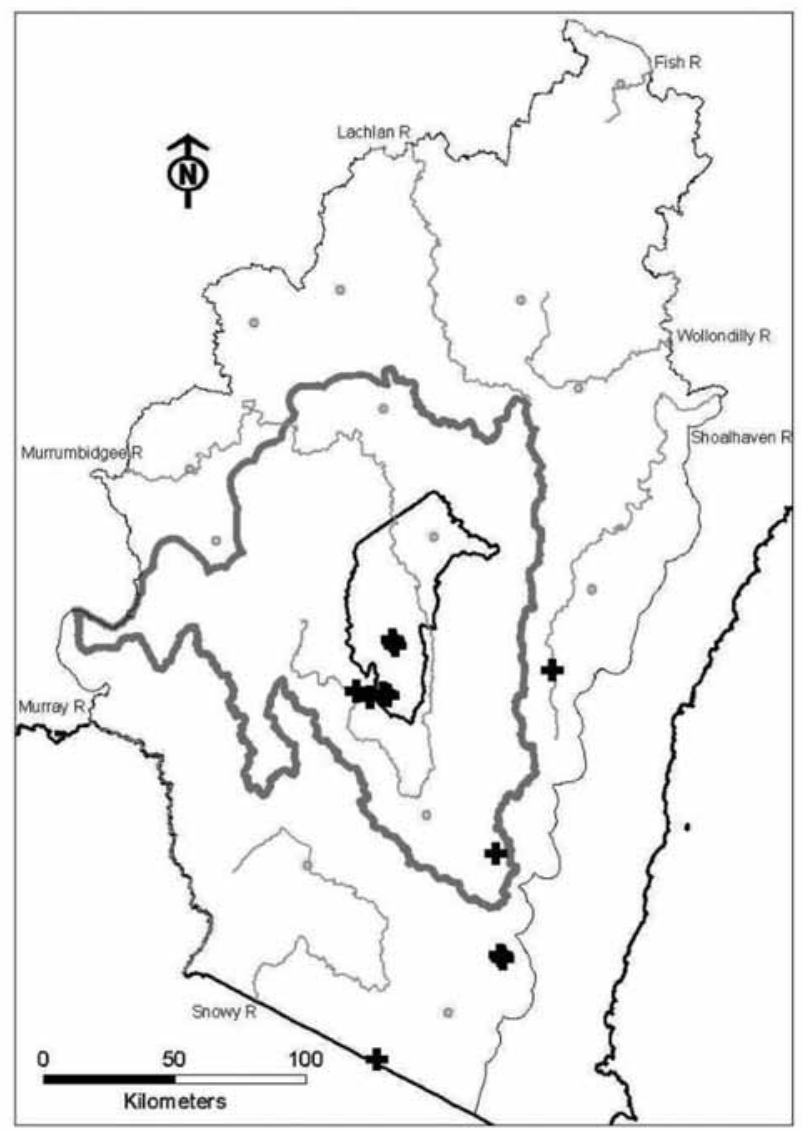

Fig. r1: Distribution of field samples assigned to this community. 


\section{r2: Poa labillardierei - Themeda australis - Juncus $s p$. wet tussock grassland of footslopes, drainage lines and flats of the South Eastern Highlands bioregion}

Scientific Name: Poa labillardierei - Themeda australis Juncus spp.

$\begin{array}{ll}\text { Number of samples: } & 45 \\ \text { Richness [mean }( \pm \mathrm{SD})]: & 17(3) \\ \text { Slope (degrees): } & (0) 2-6(15) \\ \text { Altitude (m asl): } & (562) 608-857(1313) \\ \text { Ave. Annual Rainfall }(\mathrm{mm}): & (526) 649-731(877) \\ \text { Temp. Annual Range }\left({ }^{\circ} \mathrm{C}\right): & (24.9) 26.5-27.7(28.8)\end{array}$

Vegetation Description: Community $r 2$ is a tall, dense or mid-dense wet tussock grassland dominated by Poa labillardierei usually with Themeda australis, the sedge Carex appressa and rush Juncus spp. in the upper stratum and a variety of grasses and forbs in the intertussock spaces, including Microlaena stipoides, Rytidosperma spp., Elymus scaber, Acaena ovina, Asperula spp. (Asperula conferta or Asperula scoparia), Euphrasia spp., Coronidium sp. 'Alps' and Hemarthria uncinata. Isolated or scattered trees may be present, including Eucalyptus pauciflora subsp. pauciflora, Eucalyptus viminalis, Eucalyptus rubida Eucalyptus stellulata, Eucalyptus aggregata, Eucalyptus bridgesiana, Acacia dealbata, Acacia mearnsii or Acacia melanoxylon. Isolated shrubs or patches of shrubs may also occur including Kunzea parvifolia, Melaleuca parvistaminea, Astroloma humifusum, Einadia nutans and Hakea microcarpa. Trees and shrubs increase in density where this community merges into the adjacent woodland communities. Relatively undisturbed sites may have a variety of uncommon grassland forbs including Craspedia spp., Geranium antrorsum, Calocephalus citreus, Ranunculus lappaceus and Brachyscome decipiens.

Community $\mathrm{r} 2$ is found on colluvium or alluvium and on drainage lines in footslopes and particularly on the broad flats associated with creeks and rivers. Poor soil drainage associated with frequent seasonal waterlogging and, to a lesser degree winter frosts, drive the distribution of this community as they restrict the establishment of woody taxa. It is distributed widely across the region wherever suitable habitat exists. Degraded sites (i.e. lacking some of the main diagnostic taxa) may be confused with degraded examples of Community r3 [Rytidosperma sp. - Themeda australis - Juncus sp. tussock grassland of occasionally wet sites of the South Eastern Highlands bioregion] or Community r7 [Themeda australis - Rytidosperma sp. - Poa sieberiana moist tussock grassland of the South Eastern Highlands bioregion].

\section{Characteristic Species:}

\section{Species}

C/A Freq

Acaena novae-zelandiae

Acaena ovina

Aristida spp.

Asperula spp.

Carex appressa

Carex spp.

Coronidium sp. 'Alps'

Craspedia spp.

Elymus scaber

Epilobium spp.

Eragrostis spp.

Euchiton spp.

Geranium spp.

Hemarthria uncinata

Hydrocotyle algida

Hypericum gramineum

Juncus spp.

Lachnagrostis spp.

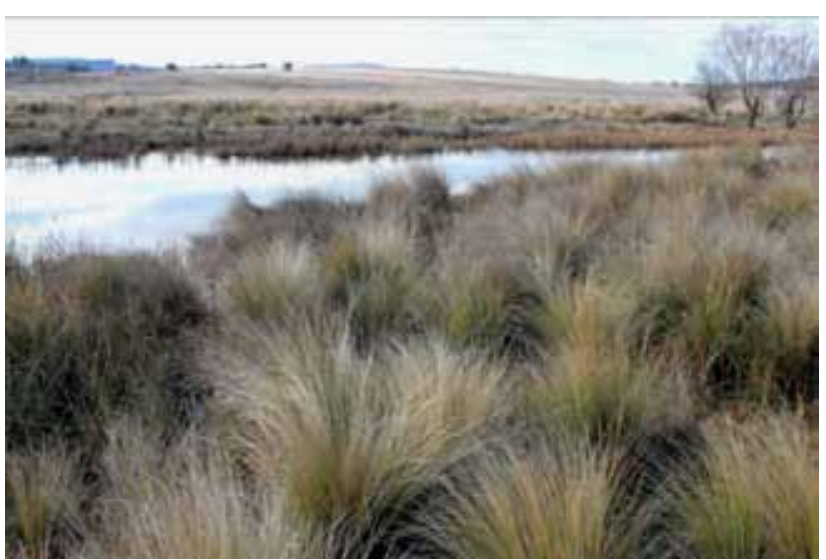

Plate r2: Tall tussocks of Poa labillardierei dominate this example of Community site on the Molonglo River, while grasses and forbs characteristic of wetter areas occupy the inter-tussock spaces.

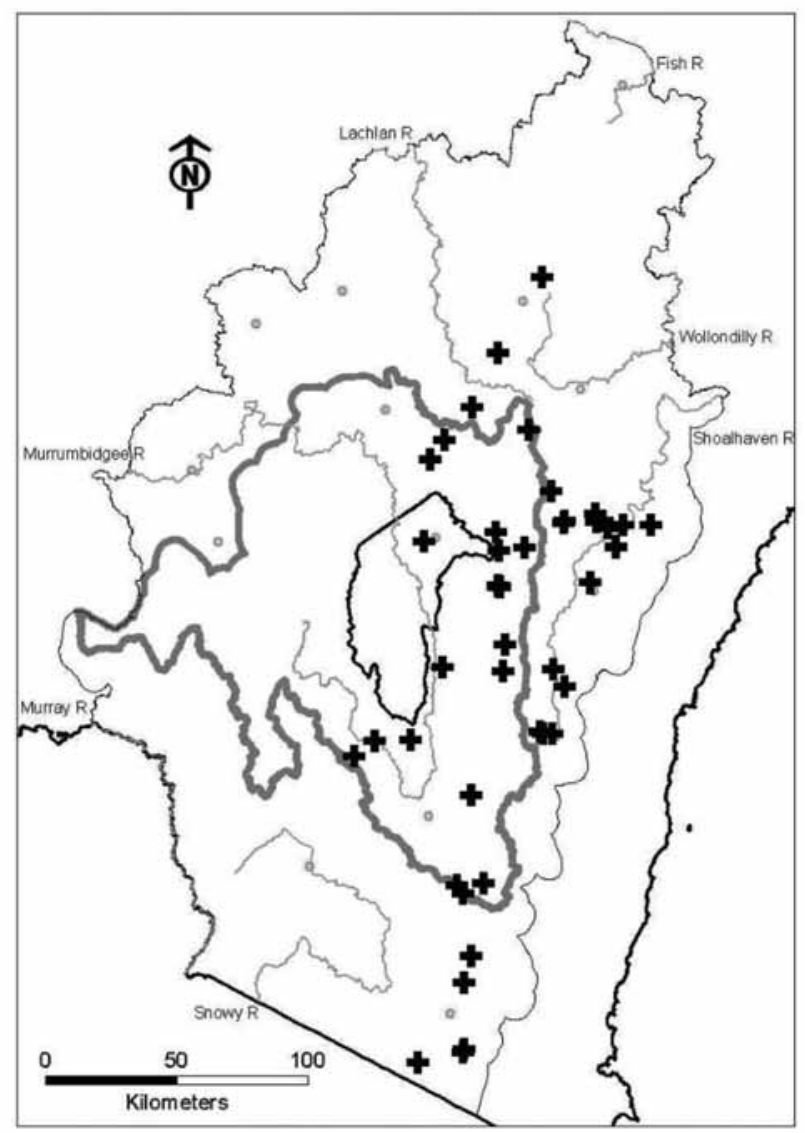

Fig. r2: Distribution of field samples assigned to this community. 
Leptorhynchos squamatus

Microlaena stipoides

Oxalis perennans

Panicum effusum

Persicaria prostrata

Poa labillardierei

Poa meionectes

Rumex brownii

Rytidosperma spp.

Schoenus apogon

Scleranthus biflorus

Solenogyne gunnii

Themeda australis

Threatened communities: EPBC Act 1999 - Natural Temperate Grassland of the Southern Tablelands of NSW and the Australian Capital Territory; NC Act 1980 - Natural Temperate Grassland.

Equivalent vegetation types: Community 8 (Benson 1994); Group 2 (Rehwinkel unpub.); Draft VCA 635 [Tall wet tussock grassland on footslopes, depressions and flats of the South Eastern Highlands bioregion] (Benson in prep.)

Frequently occurring weeds: Because this grassland community occurs on sites of high soil fertility, it has a long history of grazing, clearing and exotic pasture introduction. The most frequently recorded species within this community are Hypochaeris radicata, Acetosella vulgaris, Phalaris aquatica, Holcus lanatus, Bromus spp., Vulpia spp., Festuca arundinacea and Paspalum dilatatum, which are all typical of heavily grazed sites on fertile soil.

Threats: This community has been extensively cleared and remnants are subject to nutrient run-on from adjacent fertilised crops and pastures, small-scale clearing, weed invasion and grazing pressures.

Reservation status: Poorly reserved. Occurs in Deua NP, Tinderry NR and Yaouk NR, with a very minor occurrence at Turallo NR. It is also found on Nature Conservation Trust covenanted land in the upper Shoalhaven River, and at the Scottsdale Bush Heritage Reserve near Cooma.

Extent of clearing: Clearing figures are unavailable for grassland communities. Throughout its range only 3\% of the Natural Temperate Grassland of the Southern Tablelands of NSW and the Australian Capital Territory TEC remains in high ecological integrity, relative to its pre-European settlement extent (Environment ACT 2006).

References: Benson, J.S. (1994) The native grasslands of the Monaro region: southern tablelands of New South Wales. Cunninghamia 3: 609-650; Benson, J.S. (in prep.) New South Wales vegetation classification and assessment: Part 4. Plant communities of the west South Eastern Highlands and Australian Alps bioregions. Botanic Gardens Trust, Sydney; Environment ACT (2006) National recovery plan for natural temperate grassland of the southern tablelands (NSW and ACT): an endangered ecological community. Environment ACT, Canberra; Rehwinkel, R. (unpublished) Revision of PATN analysis of grassland associations within the Natural Temperate Grassland Endangered Ecological Community in the Southern Tablelands of NSW. August 2009. NSW Department of Environment and Climate Change, Queanbeyan. Unpublished Report.

\section{r3: Rytidosperma sp. - Themeda australis - Juncus $s p$. tussock grassland of occasionally wet sites of the South Eastern Highlands bioregion}

Scientific Name: Rytidosperma spp. - Themeda australis Juncus spp. - Schoenus apogon - Haloragis heterophyllaLachnagrostis spp.

$\begin{array}{ll}\text { Number of samples: } & 15 \\ \text { Richness [mean }( \pm \mathrm{SD})]: & 22(8) \\ \text { Slope (degrees): } & (0) 0-2(5) \\ \text { Altitude (m asl): } & (586) 644-713(860) \\ \text { Ave. Annual Rainfall }(\mathrm{mm}): & (593) 666-746(984) \\ \text { Temp. Annual Range }\left({ }^{\circ} \mathrm{C}\right): & (27.0) 27.9-28.5(29.4)\end{array}$

Vegetation Description: Community r3 is a dense to mid-dense, low to mid-high tussock grassland dominated by wallaby-grasses (Rytidosperma spp.) and/or Themeda australis, with rushes (Juncus spp.) in the upper stratum and a variety of smaller grasses, sedges and forbs in the lower stratum. Lower stratum species include Lachnagrostis spp., Schoenus apogon, Haloragis heterophylla, Hydrocotyle algida, Carex appressa, Amphibromus spp. and Elymus scaber. Isolated or scattered trees may be present, including Eucalyptus ovata, Eucalyptus rubida and Eucalyptus pauciflora subsp. pauciflora. Trees increase in density at ecotones with adjacent woodland or (rarely) forest communities. Relatively undisturbed sites have a variety of uncommon grassland forbs including Craspedia spp., Dichopogon fimbriatus, Montia australasica and Calotis anthemoides.

This community is found most commonly on flats on or adjacent drainage lines or wetlands, and occasionally on footslope and midslope situations. Substrates are colluvium or alluvium derived from sedimentary or granite parent material. Poor soil drainage associated with frequent seasonal waterlogging and severe winter frosts drive the distribution of this community, as they restrict the establishment of woody taxa. This community occurs in the Bondo and Murrumbateman subregions of the South Eastern Highlands bioregion and the upper Shoalhaven valley. Degraded sites (i.e. lacking some of the main diagnostic taxa) may be confused with degraded examples of Community r2 [Poa labillardierei - Themeda australis - Juncus sp. wet tussock grassland of footslopes, drainage lines and flats of the South Eastern Highlands bioregion], although Community $\mathrm{r} 3$ generally occurs on drier sites than those occupied by Community r2. Community r7 [Themeda australis - Rytidosperma sp. - Poa sieberiana moist tussock grassland of the South Eastern Highlands bioregion] is another grassland community with which Community r3 frequently co-occurs.

\section{Characteristic Species:}

Species C/A Freq

Acaena ovina Amphibromus spp.

Asperula spp. Austrostipa bigeniculata

Calotis anthemoides

Carex appressa

Carex spp.

Coronidium sp. 'Alps'

Craspedia spp.

Cynodon dactylon

Deyeuxia quadriseta

Dichelachne spp.

Dichopogon fimbriatus

Drosera peltata

Elymus scaber

Epilobium spp.

Eragrostis spp.

Euchiton spp.

\section{C/A}

$\begin{array}{rr}1 & 29 \\ 1 & 48\end{array}$

$\begin{array}{ll}1 & 43 \\ 1 & 24\end{array}$

124

124

57

57

133

133

133

124

133

$1 \quad 29$

48

$1 \quad 62$

52

$1 \quad 43$

90 


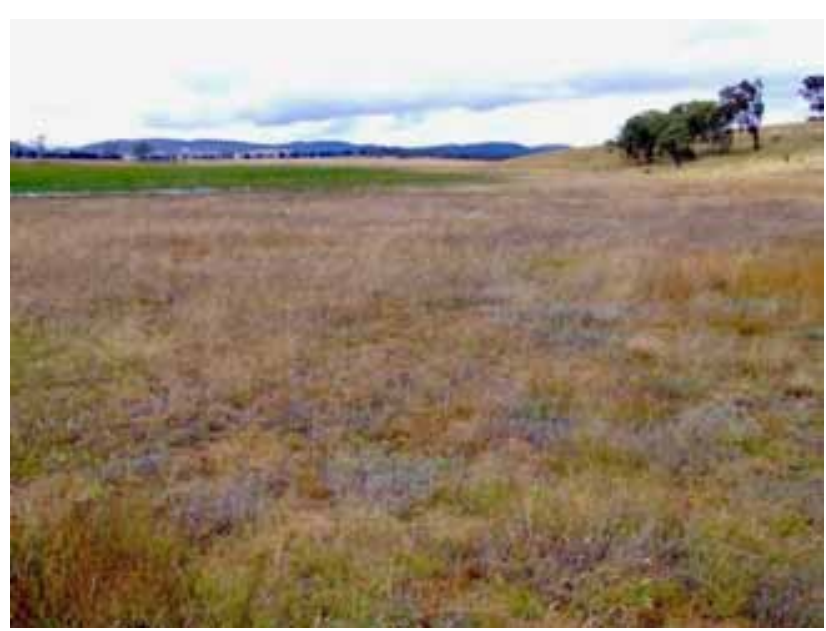

Plate r3: Occupying a seasonally moist zone between the wetland and a dryer area occupied by Community $\mathrm{r} 7$, this moist Community r3 site adjacent to Rowes Lagoon is dominated by Themeda australis, Rytidosperma spp. and a suite of other moisture-loving grasses and forbs.

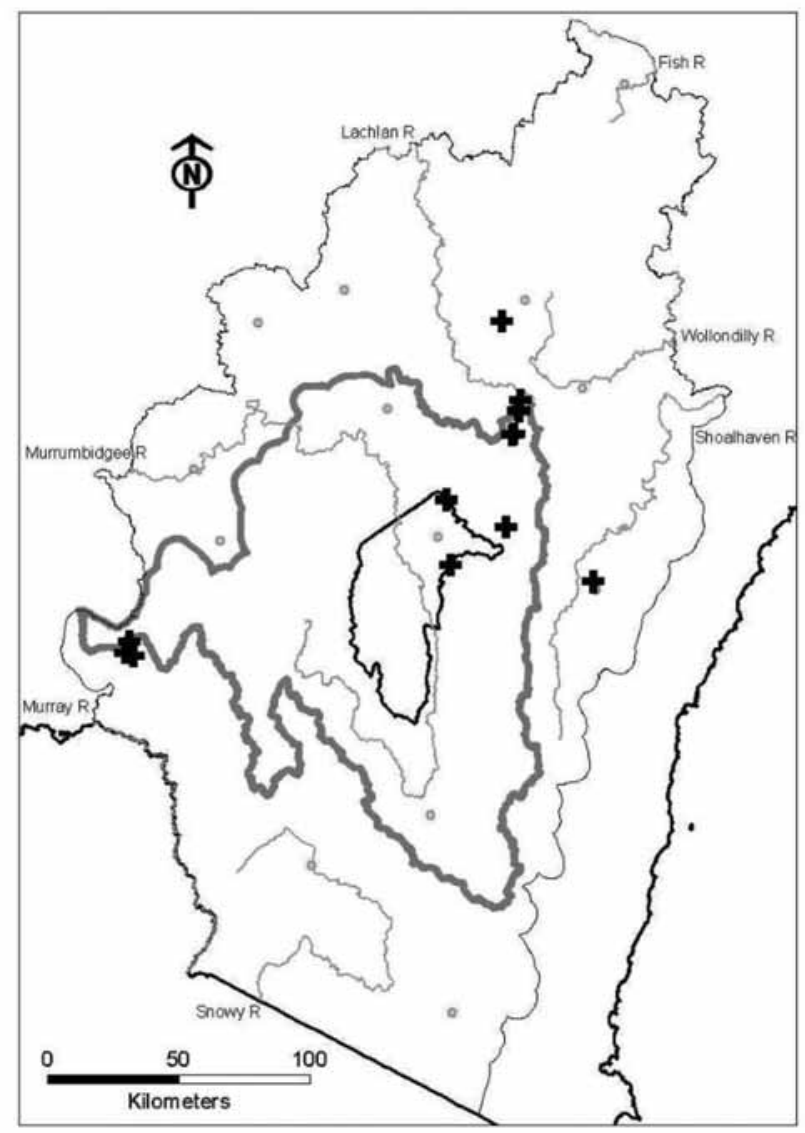

Gonocarpus tetragynus

Haloragis heterophylla

Hemarthria uncinata

Hydrocotyle algida

Hypericum gramineum

Hypoxis spp.

Isotoma fluviatilis

Juncus spp.

Lachnagrostis spp.

Luzula spp.

Lythrum hyssopifolia

Microlaena stipoides

Microtis spp.

Montia australasica

Oxalis perennans

Persicaria prostrata

Poa labillardierei

Poa sieberiana

Rumex brownii

Rytidosperma spp.

Schoenus apogon

Themeda australis

Triptilodiscus pygmaeus

Wahlenbergia spp.

Wurmbea dioica

Threatened communities: EPBC Act 1999 - Natural Temperate Grassland of the Southern Tablelands of NSW and the Australian Capital Territory; NC Act 1980 - Natural Temperate Grassland.

Equivalent vegetation types: Group 3 (Rehwinkel unpub.), Draft VCA 637 [Wallaby Grass - Blown Grass - Rush moist tussock grassland of seasonally wet sites in the South Eastern Highlands bioregion] (Benson in prep.).

Frequently occurring weeds: The weeds Anthoxanthum odoratum, Hypochaeris radicata, Acetosella vulgaris, Holcus lanatus, Paspalum dilatatum, Festuca arundinacea, Vulpia spp. and Phalaris aquatica were common in this community

Threats: This community has been extensively cleared and remnants are subject to small-scale clearing, weed invasion, grazing pressures, and nutrient run-on from adjacent fertilised crops and pastures.

Reservation status: Poorly reserved. There is a very minor occurrence at Turallo NR and at Mulligans Flat NR.

Extent of clearing: Unknown, although throughout its range, only $3 \%$ of the Natural Temperate Grassland of the Southern Tablelands of NSW and the Australian Capital Territory TEC remains in high ecological integrity, relative to its pre-European settlement extent (Environment ACT 2006).

References: Benson, J.S. (in prep.) New South Wales vegetation classification and assessment: Part 4. Plant communities of the west South Eastern Highlands and Australian Alps bioregions. Botanic Gardens Trust, Sydney; Environment ACT (2006) National recovery plan for natural temperate grassland of the southern tablelands (NSW and ACT): an endangered ecological community. Environment ACT, Canberra; Rehwinkel, R. (unpublished) Revision of PATN analysis of grassland associations within the Natural Temperate Grassland Endangered Ecological Community in the Southern Tablelands of NSW. August 2009. NSW Department of Environment and Climate Change, Queanbeyan. Unpublished Report.

Fig. r3: Distribution of field samples assigned to this community. 


\section{r4: Lacustrine grass-forbland of the South Eastern Highlands bioregion}

Scientific Name: Lachnagrostis spp. - Wilsonia rotundifolia - Carex bichenoviana - - Selliera radicans - Juncus spp.

Number of samples:

Richness [mean $( \pm \mathrm{SD})]$ :

Slope (degrees):

Altitude (m asl):

Ave. Annual Rainfall (mm):

$10(5)$

(0) $0-0(0)$

(709) 709-709 (709)

(629) 637-650 (657)

Temp. Annual Range $\left({ }^{\circ} \mathrm{C}\right)$ :

(28.1) $28.1-28.2(28.2)$

Vegetation Description: Community $\mathrm{r} 4$ is a variable lake-margin and dry lake-bed vegetation type with structure and composition varying in response to lake wetting and drying cycles. Structure ranges from very open to dense, low to mid-high, forbland to tussock grassland, sometimes with patches of sedgeland. Dominant species include Lachnagrostis spp., Carex bichenoviana and Juncus spp. in the upper stratum, and a variety of forbs and shorter grasses in the lower stratum including Wilsonia rotundifolia, Selliera radicans, Dichondra repens, Ranunculus diminutus, Cynodon dactylon, Chenopodium glaucum, Rytidosperma spp., Lythrum hyssopifolia, Panicum effusum and Centella asiatica. During shallow inundation the forbs Wilsonia rotundifolia, Selliera radicans and Ranunculus diminutus may survive for extended periods, including their underground parts, re-emerging first during drying phases to create a dense forbland. Wilsonia rotundifolia and Selliera radicans are particularly prevalent in brackish lakes such as Lacke George and Lake Bathurst. Grasses (particularly Lachnagrostis spp.) and forbs characteristic of drier habitats re-colonise drying lake margins over time. Dry phases may last in excess of ten years, occasionally allowing establishment of eucalypt saplings.

The five samples used to define this community were from the bed and foreshores of Lake George. Community $\mathrm{r} 4$ is also known from similar broad lake beds of Lake Bathurst, the margins of Rowes Lagoon and some lakes of the Monaro. The beds of these tableland lakes are alluvial mud, silt and sand. The combined factors of seasonal waterlogging, cracking clays, extended dry periods and severe winds limit the establishment of woody taxa. The Lake Bathurst example is distinct in that it has isolated populations of Dodonaea procumbens, Pelargonium sp. Striatellum (G. W. Carr 10345), Schoenus nitens, Rulingia prostrata and the only NSW record of Lawrencia spicata. Rowes Lagoon is distinct in that it has an isolated population of Rulingia prostrata and several daisies including Chrysocephalum apiculatum, Calocephalus citreus and Leptorhynchos squamatus. This community may also form on some of the Monaro lakes when they are dry. Populations of Pelargonium sp. Striatellum (G. W. Carr 10345) have been recorded on at least two of the Monaro lakes belonging to this community.

At ecotones between drier sites, Community $\mathrm{r} 4$ may merge with Community r3 [Rytidosperma sp. - Themeda australis - Juncus sp. tussock grassland of occasionally wet sites of the South Eastern Highlands bioregion], which occurs above the shorelines of Rowes Lagoon and Breadalbane Lagoon. When indundated for extended periods, sites occupied by Community $\mathrm{r} 4$ are most likely to become Community L12 [Freshwater sedge-herb marsh of shallow, commonly inundated wetlands of the eastern South Eastern Highlands bioregion] or, when significantly deeper, Community L4 [Freshwater sedge-herb marsh of deep semi-permanent and/or slightly saline wetlands of the eastern South Eastern Highlands bioregion].

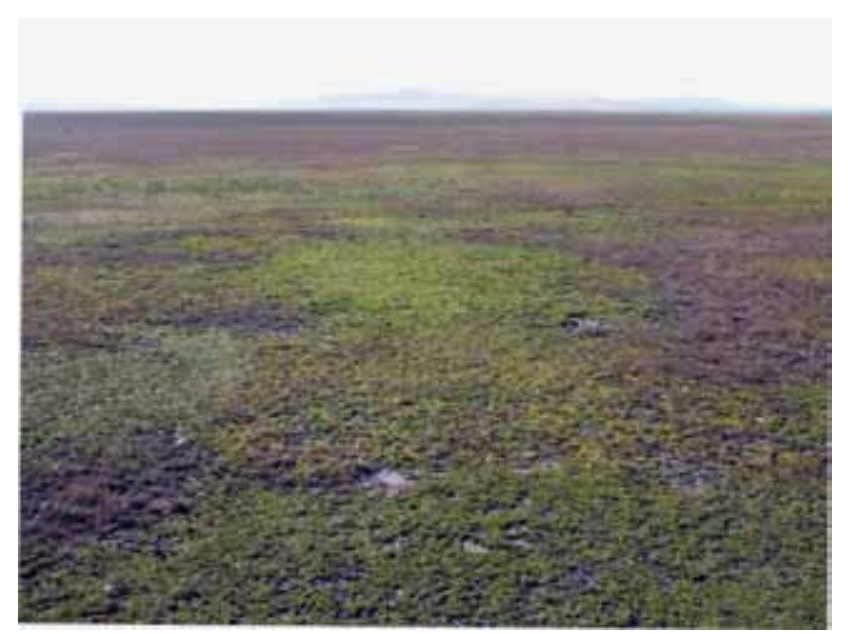

Plate r4: During long droughts, the dry lakebed of Lake George is occupied by Community r4, dominated by Lachnagrostis filiformis and 9.

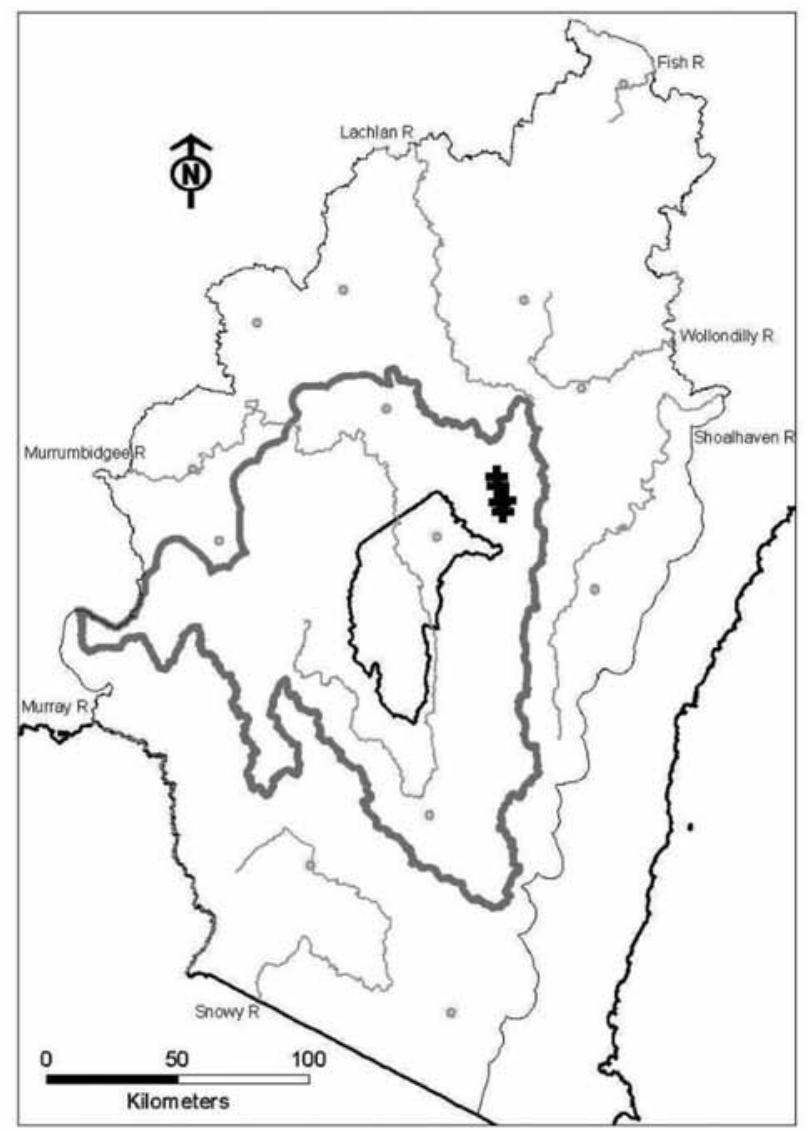

Fig. r4: Distribution of field samples assigned to this community. 


\section{Characteristic Species:}

$\begin{array}{lll}\text { Species } & \text { C/A } & \text { Freq } \\ \text { Bothriochloa macra } & 1 & 20 \\ \text { Brachyscome graminea } & 1 & 20 \\ \text { Carex bichenoviana } & 3 & 80 \\ \text { Centella asiatica } & 1 & 20 \\ \text { Chenopodium glaucum } & 1 & 60 \\ \text { Chloris truncata } & 1 & 20 \\ \text { Convolvulus angustissimus } & 1 & 20 \\ \text { Cynodon dactylon } & 1 & 60 \\ \text { Dichondra repens } & 1 & 40 \\ \text { Epilobium } \text { spp. } & 1 & 40 \\ \text { Juncus } \text { spp. } & 2 & 60 \\ \text { Lachnagrostis spp. } & 4 & 100 \\ \text { Lythrum hyssopifolia } & 1 & 40 \\ \text { Panicum effusum } & 1 & 20 \\ \text { Pennisetum alopecuroides } & 1 & 20 \\ \text { Persicaria prostrata } & 1 & 20 \\ \text { Ranunculus diminutus } & 1 & 80 \\ \text { Rumex brownii } & 1 & 40 \\ \text { Rytidosperma } \text { spp. } & 1 & 40 \\ \text { Selliera radicans } & 2 & 80 \\ \text { Wilsonia rotundifolia } & 3 & 100\end{array}$

Threatened communities: EPBC Act 1999 - Natural Temperate Grassland of the Southern Tablelands of NSW and the Australian Capital Territory.

Equivalent vegetation types: Identified by Rehwinkel (unpub.) as Group 4. In its wetland state, this community is equivalent to p51 [Tableland Lacustrine Herbfield] identified by Tozer et al. (2010). Recognised as Draft VCA 636 [Lacustrine Ephemeral Grassland of the South Eastern Highlands bioregion] (Benson in prep).

Frequently occurring weeds: An unusual suite of weed species has been recorded for this community, reflecting not only its disturbance history but also its unique lacustrine environment. The most frequently recorded species are Aster subulatus, Nassella dichotoma, Nassella neesiana, Hypochaeris radicata, Plantago coronopus and Polygonum aviculare.

Threats: The community is subject to continuing grazing pressures at all sites, and is severely threatened by weed invasion at Lake Bathurst. At this location, recent and ongoing weed control is threatening some native components.

Reservation status: Not known to occur in any conservation reserves.

Extent of clearing: Unknown, although throughout its range, only $3 \%$ of the Natural Temperate Grassland of the Southern Tablelands of NSW and the Australian Capital Territory TEC remains in high ecological integrity, relative to its pre-European settlement extent (Environment ACT 2006).

References: Benson, J.S. (in prep.) New South Wales vegetation classification and assessment: Part 4. Plant communities of the west South Eastern Highlands and Australian Alps bioregions. Botanic Gardens Trust, Sydney; Environment ACT (2006) National recovery plan for natural temperate grassland of the southern tablelands (NSW and ACT): an endangered ecological community. Environment ACT, Canberra; Rehwinkel, R. (unpublished) Revision of PATN analysis of grassland associations within the Natural Temperate Grassland Endangered Ecological Community in the Southern Tablelands of NSW. August 2009. NSW Department of Environment and Climate Change, Queanbeyan. Unpublished Report; Tozer, M.G., Turner, K., Keith, D.A., Tindall, D., Pennay, C., Simpson, C., MacKenzie, B., Beukers, P. \& Cox, S. (2010) Native vegetation of southeast NSW: a revised classification and map for the coast and eastern tablelands. Cunninghamia 11: 359-406.

\section{r5: Rytidosperma sp. - Austrostipa bigeniculata - Chrysocephalum apiculatum tussock grassland of the South Eastern Highlands bioregion}

\author{
Scientific Name: Rytidosperma spp. - Austrostipa \\ bigeniculata - Bothriochloa macra - Lomandra bracteata - \\ Themeda australis - Chrysocephalum apiculatum \\ Number of samples:
Richness [mean $( \pm \mathrm{SD})]$ :
Slope (degrees):
Altitude (m asl):
Ave. Annual Rainfall $(\mathrm{mm})$ :
Temp. Annual Range $\left({ }^{\circ} \mathrm{C}\right)$ : \\ 82 \\ 22 (6) \\ (0) $1-4(22)$ \\ (456) 568-709 (1021) \\ (521) 611-658 (711) \\ (26.6) 27.9-28.3 (30.0)
}

Vegetation Description: Community r5 is a mid-dense to dense, low to tall tussock grassland dominated by Rytidosperma spp. (mainly Rytidosperma carphoides and Rytidosperma auriculatum), Bothriochloa macra, Austrostipa bigeniculata and Themeda australis. Chrysocephalum apiculatum and Lomandra bracteata are common components of the lower stratum. Other grasses and forbs are present, including Panicum effusum, Plantago varia, Austrostipa scabra, Elymus scaber, Goodenia pinnatifida, Triptilodiscus pygmaeus, Calocephalus citreus, Schoenus apogon and Tricoryne elatior. One of the very few NSW populations of Lepidium hyssopifolium is found in this community.

Isolated or scattered trees and tall shrubs may be present including Eucalyptus melliodora, Eucalyptus blakelyi, Eucalyptus rubida, Eucalyptus bridgesiana, Eucalyptus pauciflora subsp. pauciflora or Acacia dealbata. Smaller shrubs may occur including Lissanthe strigosa, Daviesia genistifolia, Melichrus urceolatus and Acacia genistifolia. Trees and shrubs increase in density where this community merges with the adjacent woodland communities. Relatively undisturbed sites have a variety of uncommon grassland forbs, including Eryngium ovinum, Tricoryne elatior, Calocephalus citreus, Pimelea curviflora, Rutidosis leptorrhynchoides, Wurmbea dioica, Microtis spp., Dichopogon fimbriatus, Bulbine bulbosa and Calotis anthemoides.

Community r5 is found on a variety of topographic situations, including footslopes, midslopes and flats and on a variety of substrates, including sedimentary strata, colluvium, alluvium or granite. The combined factors of severe winter and spring frosts, exposure to hot drying westerly winds in summer, and to a lesser degree seasonal waterlogging and cracking clays, limit the establishment of woody taxa in this community. This grassland is mainly found in the Murrumbateman subregion, but is also found in the Shoalhaven River valley. Degraded sites (i.e. lacking some of the main species that define this community) may be difficult to distinguish from degraded examples of Community r3 [Rytidosperma $s p$. - Themeda australis - Juncus sp. tussock grassland of occasionally wet sites of the South Eastern Highlands bioregion] or Community r7 [Themeda australis - Rytidosperma sp. - Poa sieberiana moist tussock grassland of the South Eastern Highlands bioregion].

\section{Characteristic Species:}

$\begin{array}{lll}\text { Species } & \text { C/A } & \text { Freq } \\ \text { Acaena ovina } & 1 & 54 \\ \text { Aristida spp. } & 1 & 22 \\ \text { Asperula conferta } & 1 & 43 \\ \text { Austrostipa bigeniculata } & 3 & 85 \\ \text { Austrostipa scabra } & 1 & 43 \\ \text { Bothriochloa macra } & 3 & 84 \\ \text { Calocephalus citreus } & 1 & 36 \\ \text { Chloris truncata } & 1 & 35 \\ \text { Chrysocephalum apiculatum } & 3 & 80 \\ \text { Convolvulus angustissimus } & 1 & 52 \\ \text { Desmodium varians } & 1 & 42 \\ \text { Dichondra repens } & 1 & 20\end{array}$


Elymus scaber

Eryngium ovinum

Euchiton involucratus

Glycine tabacina

Goodenia pinnatifida

Hypericum gramineum

Juncus spp.

Leptorhynchos squamatus

Lomandra bracteata

Microlaena stipoides

Oxalis perennans

Panicum effusum

Plantago varia

Poa sieberiana

Rumex brownii

Rumex dumosus

Rytidosperma carphoides

Rytidosperma spp.

Schoenus apogon

Solenogyne dominii

Themeda australis

Tricoryne elatior

Triptilodiscus pygmaeus

Vittadinia muelleri

Wahlenbergia spp.
Threatened communities: EPBC Act 1999 - Natural Temperate Grassland of the Southern Tablelands of NSW and the Australian Capital Territory; NC Act 1980 - Natural Temperate Grassland.

Equivalent vegetation types: Community 1 (Benson 1994), Group 5 (Rehwinkel unpub.).

Frequently occurring weeds: The most frequently recorded weed species in this community include a number of common pasture weeds, but also some of the most damaging noxious weeds in the State. These include Eragrostis curvula, Nassella trichotoma, Hypericum perforatum, Nassella neesiana, Hypochaeris radicata, Acetosella vulgaris, Vulpia spp., Cirsium vulgare and Phalaris aquatica.

Threats: This community has been extensively cleared and remnants are subject to small-scale clearing, grazing pressures and nutrient run-on from adjacent fertilised crops and pastures. The abundance of several noxious weeds within this community is an indication of past disturbance, but also highlights the importance of managing against future impacts, particularly to native species diversity and cover.

Reservation status: Poorly reserved in NSW. Known from Queanbeyan NR and Dunlop NR. It is also informally reserved at Days Hill Reserve (a local government reserve at Bungendore).

Extent of clearing: Unknown, although throughout its range, only 3\% of the Natural Temperate Grassland of the Southern Tablelands of NSW and the Australian Capital Territory TEC remains in high ecological integrity, relative to its pre-European settlement extent (Environment ACT 2006).

References: Benson, J.S. (1994) The native grasslands of the Monaro region: southern tablelands of New South Wales. Cunninghamia 3: 609-650; Environment ACT (2006) National recovery plan for natural temperate grassland of the southern tablelands (NSW and ACT): an endangered ecological community. Environment ACT, Canberra; Rehwinkel, R. (unpublished) Revision of PATN analysis of grassland associations within the Natural Temperate Grassland Endangered Ecological Community in the Southern Tablelands of NSW. August 2009. NSW Department of Environment and Climate Change, Queanbeyan. Unpublished Report.

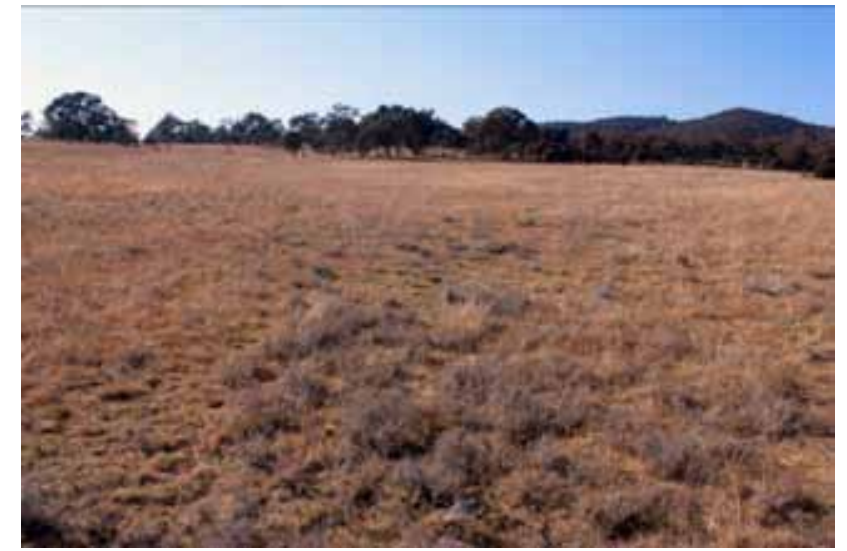

Plate r5: On dry sites in regions from the ACT and northwards, such as here at Queanbeyan Nature Reserve, Community r5 is generally dominated or co-dominated by Austrostipa spp., Rytidosperma spp. and Bothriochloa macra, with the most common forbs being Chrysocephalum apiculatum and several Lomandra spp.

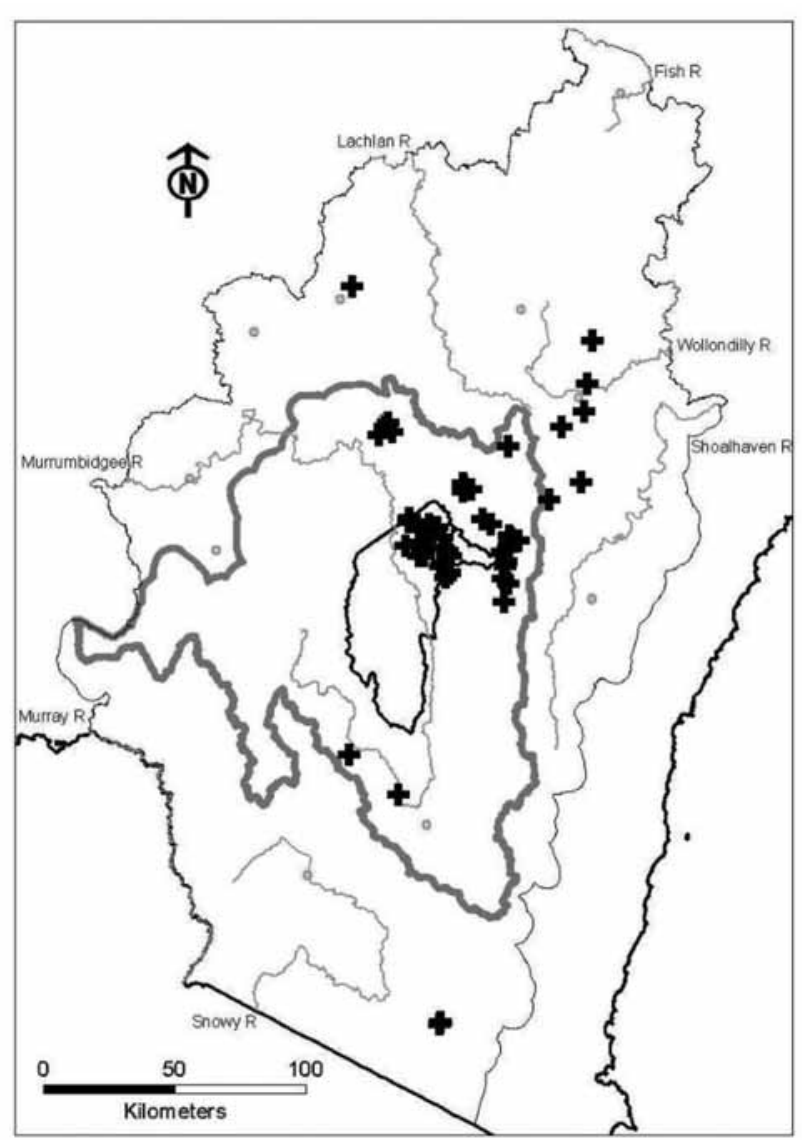

Fig. r5: Distribution of field samples assigned to this community. 


\section{r6: Dry tussock grassland of the Monaro in the South Eastern Highlands bioregion}

Scientific Name: Poa sieberiana - Rytidosperma spp. Themeda australis - Austrostipa scabra - Acaena ovina Asperula conferta - Chrysocephalum apiculatum

$\begin{array}{ll}\text { Number of samples: } & 110 \\ \text { Richness [mean }( \pm \mathrm{SD})]: & 22(6) \\ \text { Slope (degrees): } & (0) 2-6(13) \\ \text { Altitude (m asl): } & (674) 866-1016(1206) \\ \text { Ave. Annual Rainfall }(\mathrm{mm}): & (496) 518-612(765) \\ \text { Temp. Annual Range }\left({ }^{\circ} \mathrm{C}\right): & (25.9) 27.3-28.2(29.5)\end{array}$

Vegetation Description: Community r6 is an open to dense, mid-high to tall tussock grassland dominated by one or more of the following in the upper stratum: Poa sieberiana, Rytidosperma spp., Themeda australis, Austrostipa scabra and Austrostipa bigeniculata. There is a diversity of forbs and other grasses in the inter-tussock spaces, including Chrysocephalum apiculatum, Acaena ovina, Asperula conferta, Wahlenbergia spp., Scleranthus diander, Elymus scaber, Plantago varia, Poa meionectes, Bothriochloa macra, Brachyscome heterodonta, Enneapogon nigricans and Leptorhynchos squamatus. Isolated or scattered trees may be present, including Eucalyptus pauciflora subsp. pauciflora, Eucalyptus lacrimans, Acacia dealbata or Acacia rubida. Isolated patches of shrubs may also occur, generally containing Einadia nutans, Melicytus sp. 'Snowfields', Cryptandra amara, Pimelea glauca, Discaria pubescens, Mirbelia oxylobioides and Dodonaea procumbens. Trees and shrubs increase in density in ecotones with adjacent woodland communities or on rocky sites. Relatively undisturbed sites have a variety of uncommon grassland forbs including Geranium antrorsum, Rutidosis leiolepis, Swainsona sericea, Cullen tenax, Pimelea curviflora and Stackhousia monogyna.

This community is found on a variety of substrates; most commonly on basalt and sedimentary strata, occasionally occurring on granite, and rarely on colluvium or alluvium. It commonly occurs on midslope, upperslope and plateau situations, and rarely on footslopes and flats. It occurs within the drier portions of the Monaro region, commonly referred to as the Monaro rainshadow. Severe winter and spring frosts, exposure to hot drying westerly winds in summer, periodic snow and the occurrence of cracking clays (particularly on colluvial soils derived from basalt) all serve to limit the establishment of woody taxa in this community. Community r2 [Poa labillardierei-Themeda australis - Juncus sp. wet tussock grassland of footslopes, drainage lines and flats of the South Eastern Highlands bioregion] may be found in moist depressions and drainage lines adjacent to this community. Sites along the wetter fringe of the region, especially degraded sites (i.e. lacking some of the main species that define this community) may be confused with degraded examples of Community $\mathrm{r} 7$ [Themeda australis - Rytidosperma sp. - Poa sieberiana moist tussock grassland of the South Eastern Highlands bioregion].

\section{Characteristic Species:}

Species

Acaena ovina

Asperula conferta

Austrostipa bigeniculata

Austrostipa scabra

Bothriochloa macra

Brachyscome heterodonta

Brachyscome rigidula

Carex spp.

Chrysocephalum apiculatum

Convolvulus angustissimus

Crassula sieberiana

Cryptandra amara

Cullen tenax

Cymbonotus lawsonianus

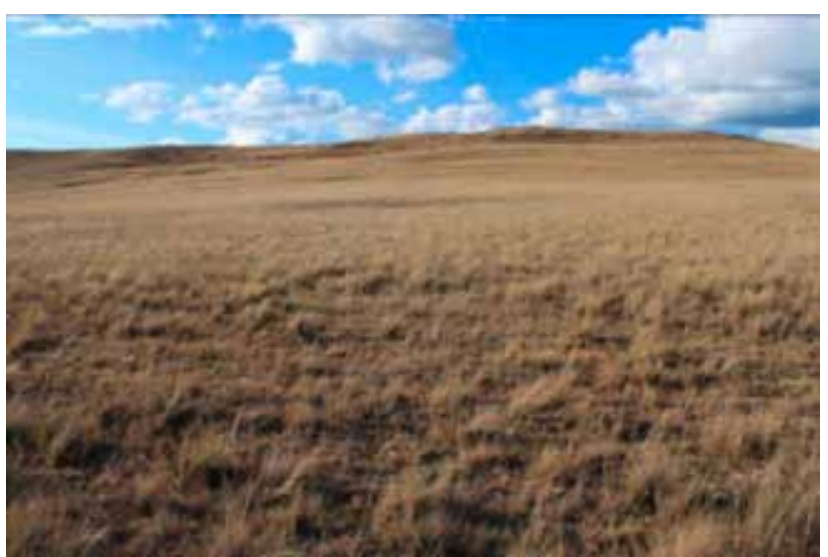

Plate r6: Typical of the dry rain-shadow regions of the Monaro, such as here at Kuma Nature Reserve south of Cooma, Community r6 sites are dominated by Poa sieberiana and, in undisturbed areas, Themeda australis. A characteristic suite of forbs and shrubs include Rutidosis leiolepis, Calotis glandulosa, Dodonaea procumbens and Melicytus sp. 'Snowfields'.

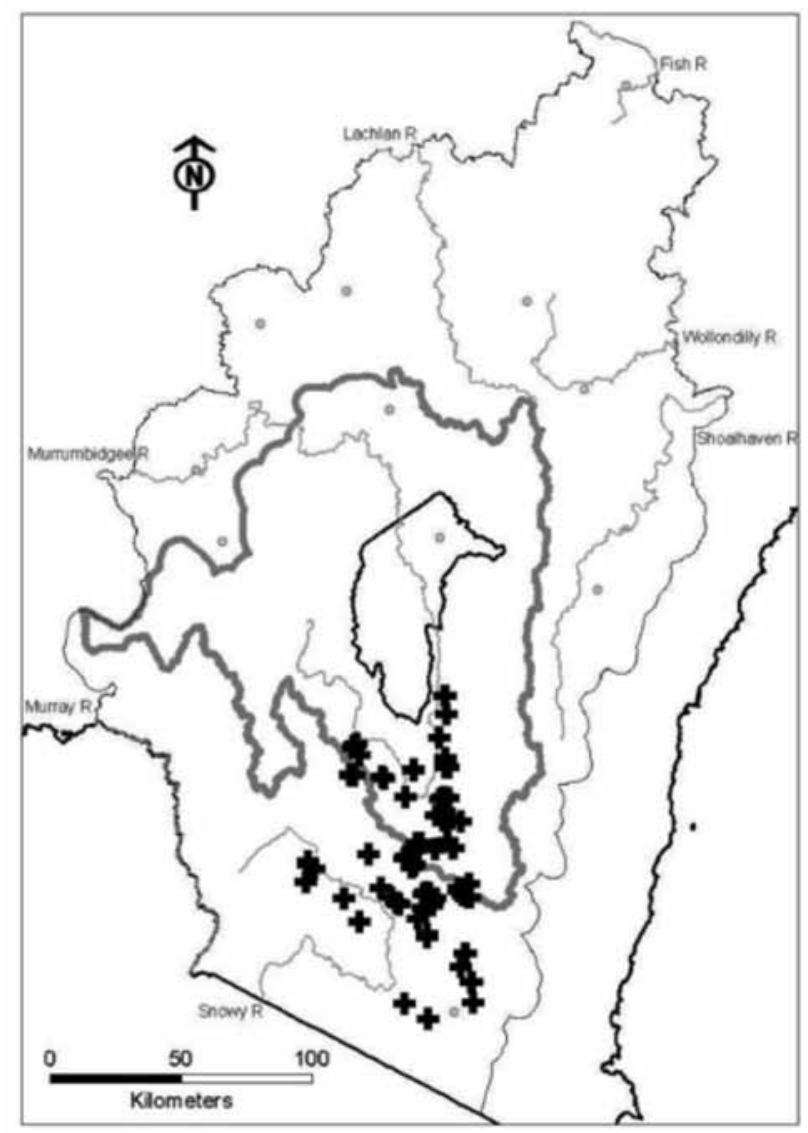

Fig. r6: Distribution of field samples assigned to this community. 
Desmodium varians

Dichelachne spp.

Dichondra repens

Dichondra sp.A

Einadia nutans

Elymus scaber

Enneapogon nigricans

Epilobium spp.

Euchiton spp.

Geranium antrorsum

Glycine clandestina

Glycine tabacina

Goodenia pinnatifida

Leptorhynchos squamatus

Melicytus sp. 'Snowfields'

Oxalis perennans

Pimelea curviflora

Pimelea glauca

Poa meionectes

Poa sieberiana

Rumex brownii

Rytidosperma spp.

Scleranthus biflorus

Scleranthus diander

Solenogyne gunnii

Stackhousia monogyna

Swainsona sericea

Themeda australis

Vittadinia cuneata

Vittadinia mueller

Vittadinia triloba

Wahlenbergia spp.

Threatened communities: EPBC Act 1999 - Natural Temperate Grassland of the Southern Tablelands of NSW and the Australian Capital Territory.

Equivalent vegetation types: Group 6 (Rehwinkel unpub.), which includes Sub-groups 6a, 6b and 6c. These subgroups correspond with Benson (1994) Communities 4, 3 b and 3a respectively. The higher diversity components of Community 5 (Benson 1994) also occur in this community.

Frequently occurring weeds: Like Community r5, the most frequently recorded weed species in this community include several common pasture weeds, as well as a number of noxious weeds. These include Eragrostis curvula, Nassella trichotoma, Hypericum perforatum, Hypochaeris radicata, Acetosella vulgaris, Vulpia spp., Cirsium vulgare and Onopordum acanthium.

Threats: This community has been extensively cleared and/or modified with remnants subject to small-scale clearing, weed invasion and grazing pressures.

Reservation status: Poorly reserved. Occurs in Kuma NR south-east of Cooma and Namadgi NP. Informally reserved at Old Cooma Common and at the Bush heritage Australia reserve, Scottsdale.

Extent of clearing: Unknown, although throughout its range, only $3 \%$ of the Natural Temperate Grassland of the Southern Tablelands of NSW and the Australian Capital Territory TEC remains in high ecological integrity, relative to its pre-European settlement extent (Environment ACT 2006).

References: Benson, J.S. (1994) The native grasslands of the Monaro region: southern tablelands of New South Wales. Cunninghamia 3: 609-650; Environment ACT (2006) National recovery plan for natural temperate grassland of the southern tablelands (NSW and ACT): an endangered ecological community. Environment ACT, Canberra; Rehwinkel, R. (unpublished) Revision of PATN analysis of grassland associations within the Natural Temperate Grassland Endangered Ecological Community in the Southern Tablelands of NSW. August 2009. NSW Department of Environment and Climate Change, Queanbeyan. Unpublished Report.

\section{r7: Themeda australis - Rytidosperma sp. - Poa sieberiana moist tussock grassland of the South Eastern Highlands bioregion}

Scientific Name: Themeda australis - Rytidosperma spp. - Poa sieberiana - Leptorhynchos squamatus Chrysocephalum apiculatum

$\begin{array}{ll}\text { Number of samples: } & 133 \\ \text { Richness [mean }( \pm \mathrm{SD})]: & 23(7) \\ \text { Slope (degrees): } & (0) 1-4(14) \\ \text { Altitude (m asl): } & (283) 641-820(1185) \\ \text { Ave. Annual Rainfall }(\mathrm{mm}): & (509) 647-716(995) \\ \text { Temp. Annual Range }\left({ }^{\circ} \mathrm{C}\right): & (25.0) 26.7-28.0(30.1)\end{array}$

Vegetation Description: Community r7 is an open to dense, mid-high to tall tussock grassland with the upper stratum dominated by Themeda australis and with a sub-dominance of Rytidosperma spp. and Poa sieberiana. Inter-tussock spaces are generally occupied by herbaceous taxa including Chrysocephalum apiculatum, Leptorhynchos squamatus, Microlaena stipoides, Wahlenbergia spp., Asperula conferta, Juncus spp., Acaena ovina, Elymus scaber, Schoenus apogon and Plantago varia. Isolated or scattered trees may be present, including Eucalyptus pauciflora subsp. pauciflora, Eucalyptus rubida, Eucalyptus aggregata, Eucalyptus melliodora, Acacia dealbata or Acacia mearnsii. Isolated shrubs or patches of shrubs may also occur including Melicytus sp. 'Snowfields', Hovea linearis, Pimelea glauca, Lissanthe strigosa, Daviesia latifolia, Daviesia mimosoides, Leucopogon fraseri, Melichrus urceolatus, Bossiaea buxifolia, Cryptandra amara and Kunzea parvifolia. Trees and shrubs increase in density at ecotones with adjacent woodland communities. Relatively undisturbed sites have a variety of uncommon grassland forbs including Hypericum japonicum, Tricoryne elatior, Pimelea curviflora, Microtis spp., Prasophyllum petilum, Calocephalus citreus, Eryngium ovinum, Craspedia spp., Ranunculus lappaceus, Rutidosis leptorrhynchoides, Bulbine bulbosa, Stackhousia monogyna and Wurmbea dioica.

This community is found on midslopes and footslopes and to a lesser degree on flats. It is most commonly found on sedimentary, colluvium and granite lithologies, and infrequently on alluvium and basalt. It is distributed widely, being found in the Murrumbatemen and Crookwell subregions of the South Eastern Highlands, the Shoalhaven Valley, and in moister outer fringes of the Monaro region beyond rainshadow areas. Outliers occur near Tumbarumba, Tumut, Bathurst and Orange. Severe winter and spring frosts, exposure to hot, drying westerly winds in summer, occasional waterlogging and the occurrence of cracking clays limit the establishment of woody taxa.

Community r7 grades into Community r2 [Poa labillardierei-Themeda australis - Juncus sp. wet tussock grassland offootslopes, drainage lines and flats of the South Eastern Highlands bioregion] and Community r3 [Rytidosperma sp. - Themeda australis - Juncus sp. tussock grassland of occasionally wet sites of the South Eastern Highlands bioregion] in moist depressions and drainage lines. Where distribution overlaps, it may be confused with Community r6 [Dry tussock grassland of the Monaro in the South Eastern Highlands bioregion]. Confusion between this community and those above may occur where the communities intergrade, especially in degraded sites (i.e. those lacking some of the main diagnostic taxa that define Community r7). 


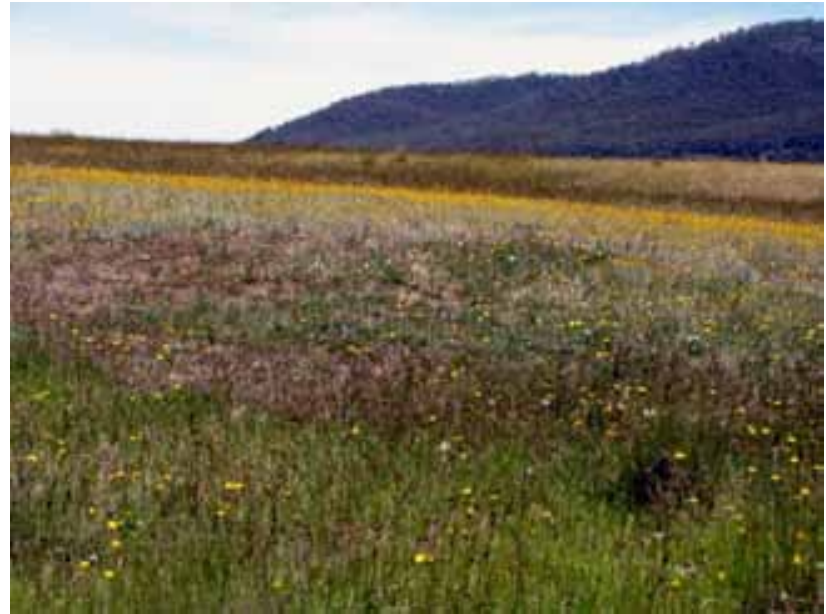

Plate r7: Widespread in the wetter locations such as this floristically diverse site at Steve's TSR near Delegate, Community r7 is dominated by Themeda australis, with the forbs Chrysocephalum apiculatum, Leptorhynchos squamatus and Asperula conferta often occurring in high cover.

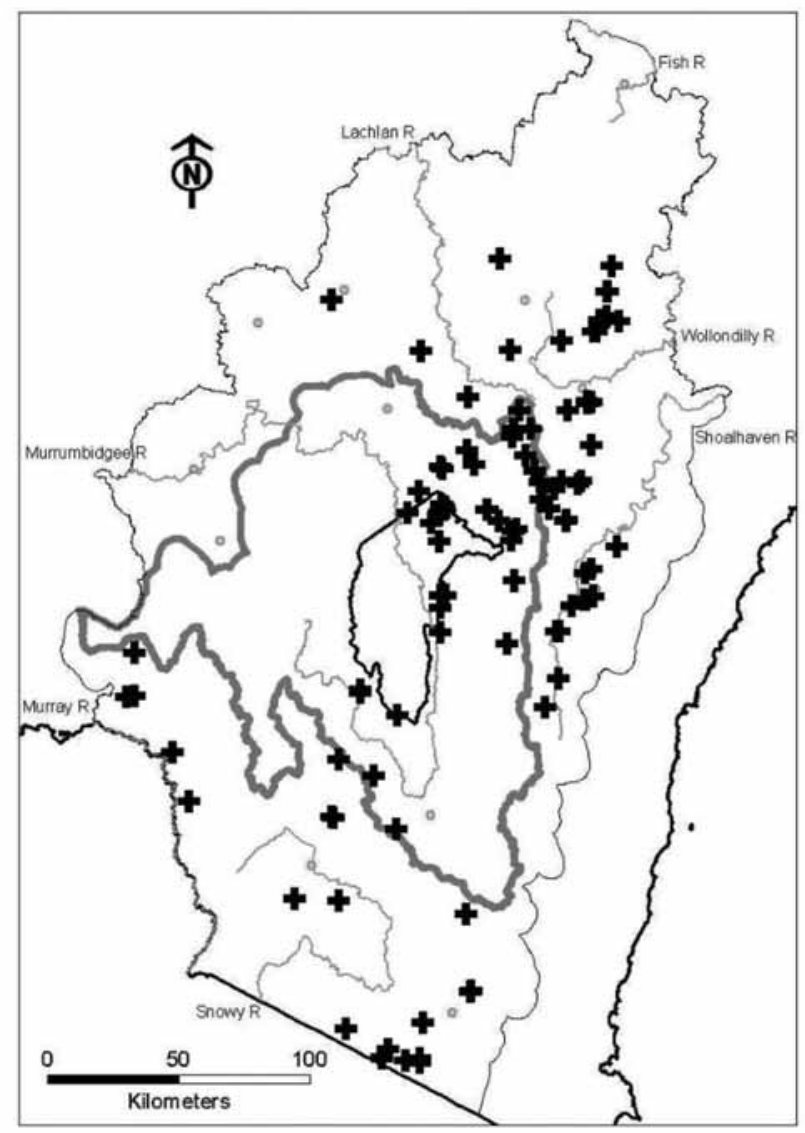

Fig. r7: Distribution of field samples assigned to this community.
Characteristic Species:

Species

C/A Freq

Acaena ovina

Asperula conferto

Austrostipa bigeniculata

Bothriochloa macra

Carex spp.

Chrysocephalum apiculatum

Convolvulus angustissimus

Dichelachne spp.

Drosera peltata

Elymus scaber

Epilobium spp.

Eryngium ovinum

Euchiton spp.

Glycine tabacina

Gonocarpus tetragynus

Haloragis heterophylla

Hypericum japonicum

Juncus spp.

Leptorhynchos squamatus

Lomandra bracteata

Luzula spp.

Microlaena stipoides

Microtis spp.

Oxalis perennans

Panicum effusum

Pimelea curviflora

Poa labillardierei

Poa sieberiana

Rumex dumosus

Rytidosperma spp.

Schoenus apogon

Scleranthus biflorus

Scleranthus fasciculatus

Solenogyne dominii

Solenogyne gunnii

Themeda australis

Tricoryne elatior

Triptilodiscus pygmaeus

Vittadinia muelleri

Wahlenbergia spp.

Threatened communities: EPBC Act 1999 - Natural Temperate Grassland of the Southern Tablelands of NSW and the Australian Capital Territory; NC Act 1980 - Natural Temperate Grassland.

Equivalent vegetation types: Community 2 (Benson 1994), Group 7 (Rehwinkel unpub.).

Frequently occurring weeds: Like other grassland communities, the most frequently recorded weed species in this community include several common pasture weeds, as well as a number of noxious weeds. These include Eragrostis curvula, Nassella trichotoma, Hypericum perforatum, Hypochaeris radicata, Acetosella vulgaris, Vulpia spp. Cirsium vulgare and Onopordum acanthium.

Threats: This community has been extensively cleared and/or modified with remnants subject to small-scale clearing, weed invasion and grazing pressures.

Reservation status: Poorly reserved. Occurs in Turallo NR and Scabby Range NR, as may occur in conservation reserves in the ACT. Likely to occur at Dangelong NR. It is also known from a local government reserve near Bungendore (Days Hill Reserve) and Nature Conservation Trust covenanted lands in the upper Shoalhaven catchment.

Extent of clearing: Unknown, although throughout its range, only $3 \%$ of the Natural Temperate Grassland of the Southern Tablelands of NSW and the Australian Capital Territory TEC remains in high ecological integrity, relative to its pre-European settlement extent (Environment ACT 2006). 
References: Benson, J.S. (1994) The native grasslands of the Monaro region: southern tablelands of New South Wales. Cunninghamia 3: 609-650; Environment ACT (2006) National recovery plan for natural temperate grassland of the southern tablelands (NSW and ACT): an endangered ecological community. Environment ACT, Canberra; Rehwinkel, R. (unpublished) Revision of PATN analysis of grassland associations within the Natural Temperate Grassland Endangered Ecological Community in the Southern Tablelands of NSW. August 2009. NSW Department of Environment and Climate Change, Queanbeyan. Unpublished Report.

\section{r8: Themeda australis - Lomandra filiformis - Aristida ramosa dry tussock grassland in the South Eastern Highlands bioregion}

Scientific Name: Themeda australis - Lomandra filiformis Rytidosperma spp. - Microlaena stipoides - Aristida ramosa - Chrysocephalum apiculatum

$\begin{array}{ll}\text { Number of samples: } & 18 \\ \text { Richness [mean }( \pm \mathrm{SD})]: & 26(9) \\ \text { Slope (degrees): } & (0) 1-8(13) \\ \text { Altitude (m asl): } & (453) 512-683(876) \\ \text { Ave. Annual Rainfall }(\mathrm{mm}): & (620) 658-673(725) \\ \text { Temp. Annual Range }\left({ }^{\circ} \mathrm{C}\right): & (26.3) 27.5-28.3(28.4)\end{array}$

Vegetation Description: Community r8 is an open to dense, mid to tall tussock grassland with the upper stratum dominated by Themeda australis, Aristida ramosa, Lomandra filiformis and Austrostipa densiflora. Other gramonoids may include Rytidosperma spp., Microlaena stipoides, Lomandra multiflora, Austrostipa scabra and Poa sieberiana. Inter-tussock spaces are generally occupied by a diverse range of forbs including Chrysocephalum apiculatum, Wahlenbergia spp., Pimelea curviflora, Goodenia hederacea subsp. hederacea and Gonocarpus tetragynus. Isolated or scattered trees may be present including Eucalyptus pauciflora subsp. pauciflora, Eucalyptus melliodora, Jacksonia scoparia, Acacia mearnsii or Acacia dealbata. Isolated patches of shrubs may also occur including Lissanthe strigosa, Hibbertia obtusifolia, Melichrus urceolatus, Astroloma humifusum, Bursaria spinosa, Dillwynia sericea and Dodonaea boroniifolia. Trees and shrubs increase in density at ecotones with adjacent woodland communities, and shrubs may be especially dense in rocky areas. Relatively undisturbed sites have a variety of herbecaous taxa uncommon in grassland communities including Pimelea curviflora, Tricoryne elatior, Dianella revoluta, Boerhavia dominii, Stylidium graminifolium sens. lat., Bulbine glauca, Cymbopogon refractus and Dianella longifolia.

This community is most commonly found on midslopes and upperslopes, although it can infrequently occur on rocky flats adjacent to creeks. It is found most commonly on soils derived from sedimentary strata and infrequently from granite, usually on steep exposed northwest-facing slopes, including in river gorges. Sites generally overlook extensive valleys or plains; thus they are subjected to hot, drying north-westerly winds in summer, which is a main determinant of species composition in this community. It is sparsely distributed, with isolated occurrences in the Yass, Goulburn, Tarago and Braidwood regions. Often, Community r8 occurs adjacent to Community r7 [Themeda australis - Rytidosperma sp. - Poa sieberiana moist tussock grassland of the South Eastern Highlands bioregion], which occurs on moister sites downslope. Confusion between these two communities is expected to occur where the communities intergrade, and especially in degraded examples (i.e. lacking some of the main diagnostic taxa that define these communities). Community r8 does not occur in the Monaro, where it is generally replaced by a subtype of Community r6 [Dry Tussock Grassland of the Monaro in the South Eastern Highlands bioregion].

\section{Characteristic Species:}

Species

Acacia rubida

Acaena ovina

Aristida ramosa

Astroloma humifusum

Austrostipa bigeniculata

Austrostipa densiflora

Austrostipa scabra

Boerhavia dominii

Bothriochloa macra

Brachyloma daphnoides

Bulbine glauca

Bursaria spinosa

Carex spp.

Cheilanthes spp.

Chrysocephalum apiculatum

Convolvulus angustissimus

Crassula sieberiana

Cryptandra amara

Cymbopogon refractus

Dianella longifolia

Dianella revoluta

Dillwynia sericea

Diuris punctata

Dodonaea boroniifolia

Elymus scaber

Enneapogon nigricans

Eragrostis spp.

Euchiton spp.

Glycine tabacina

Gonocarpus tetragynus

Goodenia hederacea subsp. hederacea

Hibbertia obtusifolia

Hovea linearis

Hypericum gramineum

Laxmannia gracilis

Leptorhynchos squamatus

Lissanthe strigosa

Lomandra filiformis

Lomandra longifolia

Lomandra multiflora

Luzula spp.

Melichrus urceolatus

Microlaena stipoides

Microtis spp.

Opercularia hispida

Oxalis perennans

Panicum effusum

Pimelea curviflora

Plantago varia

Poa sieberiana

Rumex brownii

Rytidosperma pallidum

Rytidosperma spp.

Schoenus apogon

Solenogyne dominii

Stylidium graminifolium sens. lat.

Thelymitra spp.

Themeda australis

Tricoryne elatior

Triptilodiscus pygmaeus

Vittadinia muelleri

Wahlenbergia spp.

Westringia eremicola 


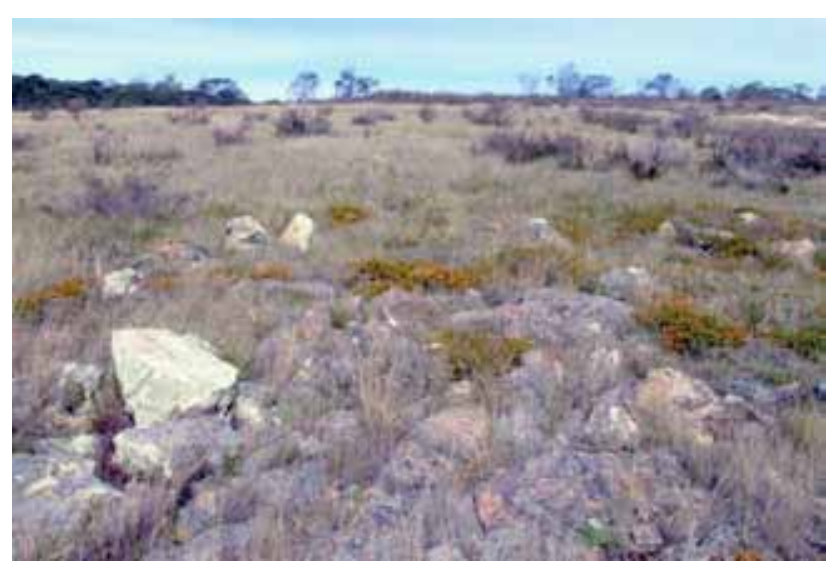

Plate r8: Found on dry, steep, often west-facing sites, like this one in the Jerrabatgulla Creek area near Braidwood, Community r8 sites are often dominated or co-dominated by Themeda australis and Aristida ramosa and have a high cover of Lomandra filiformis and Chrysocephalum apiculatum, along with a diversity of other forbs and sub-shrubs.

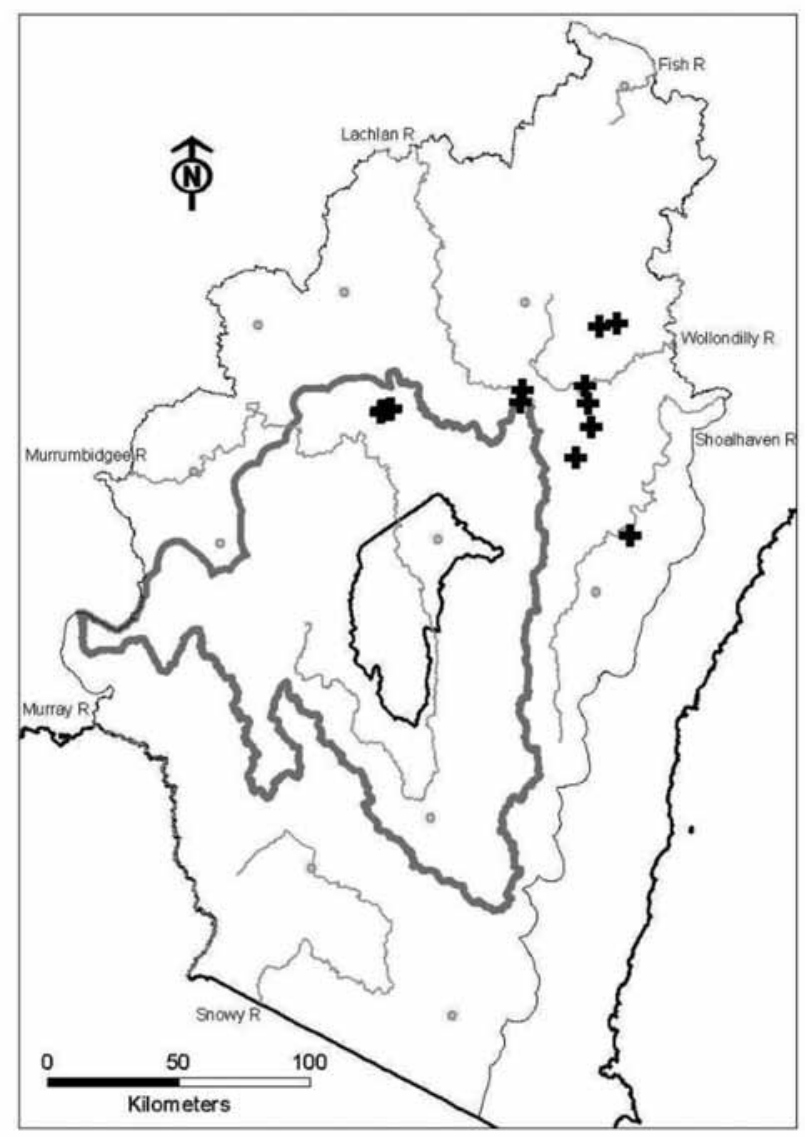

Threatened communities: EPBC Act 1999 - Natural Temperate Grassland of the Southern Tablelands of NSW and the Australian Capital Territory. Although not yet assessed in the ACT, if confirmed this community would be listed under the NC Act 1980 - Natural Temperate Grassland.

Equivalent vegetation types: Group 8 (Rehwinkel unpub.).

Frequently occurring weeds: Consistent with other natural grassland communities described here, the most common weeds were either common pasture species, or noxious weeds. These include Eragrostis curvula, Nassella trichotoma, Hypericum perforatum, Hypochaeris radicata, Acetosella vulgaris, Vulpia spp., Cirsium vulgare and Onopordum acanthium.

Threats: This community has been extensively cleared and/or modified with remnants subject to small-scale clearing, weed invasion and grazing pressures.

Reservation status: Not known to occur in any formal conservation reserves, however it occurs on Nature Conservation Trust covenanted land in the upper Shoalhaven catchment.

Extent of clearing: Unknown, although throughout its range, only 3\% of the Natural Temperate Grassland of the Southern Tablelands of NSW and the Australian Capital Territory TEC remains in high ecological integrity, relative to its pre-European settlement extent (Environment ACT 2006).

References: Environment ACT (2006) National recovery plan for natural temperate grassland of the southern tablelands (NSW and ACT): an endangered ecological community. Environment ACT, Canberra; Rehwinkel, R. (unpublished) Revision of PATN analysis of grassland associations within the Natural Temperate Grassland Endangered Ecological Community in the Southern Tablelands of NSW. August 2009. NSW Department of Environment and Climate Change, Queanbeyan. Unpublished Report.

Fig. r8: Distribution of field samples assigned to this community. 


\section{Appendix 2: Equivalent communities in recent classifications}

Prefixes: a (McDougall \& Walsh 2007); b (Benson 1994); bj (Benson \& Jacobs 1994); g (Gellie 2005); e, m and p (Tozer et al. 2010), R (Rehwinkel unpub.), VCA (Benson et al. 2010)

NOTE: In a new classification such as this, where new plot data are added and the spatial extent is different from previous classifications, exact equivalence between plant communities identified in different classifications is unlikely. In this table we identify the closest match to previous classifications and, where analysis of previous communities found no match in the current classification, we indicate which new plant communities the majority of plots were assigned to.

\section{Plant Community (this study)}

a14: Prickly Snow-grass - Tufted Sedge subalpine valley grassland of the Australian Alps Bioregion

a2: Alpine Baeckea - Swamp Heath - Candle Heath - Sphagnum wetland of the Australian Alps Bioregion (Bog)

a22: Snow-grass - Herbfield Celmisia - Woolly Billy-button grassland of the Australian Alps Bioregion

a30: Dwarf Snow-grass - Fine-leaved Snow-grass - Silver Carraway Granite Buttercup grassland of the Australian Alps Bioregion

a33: Leafy Bossiaea - Mountain Cassinia - Yellow Kunzea - Alpine Hovea heathland of the Australian Alps Bioregion

a34: Weeping Snow shrub-grass woodland of the Australian Alps Bioregion

a38: Kangaroo Grass - Rodd's Bedstraw - Alpine Sunray grassland of steep limestone slopes in the Australian Alps Bioregion

a39: Feldmark Heath - Carpet Heath - Snow-grass heath of the Australian Alps Bioregion

a42: Epacris - Fine-leaved Snow-grass - Bog Parrot-pea grassy heathland of the Australian Alps Bioregion

a43: Dwarf Bossiaea - Kangaroo Grass low open heathland of the Australian Alps Bioregion

a46: Alpine Mint-bush - Alpine Orites - Kosciuszko Nematolepis shrubland in the Australian Alps Bioregion

a51: Mountain Plum Pine - Crag Wallaby-grass - Snow-daisy low sparse shrubland of rock outcrops of the Australian Alps Bioregion a54: Mountain Plum Pine - Tall Rice-flower shrubland of screes and boulder-fields of the Australian Alps Bioregion

a6: Dwarf Buttercup - Mud Pratia - Tufted Sedge herbfield of shallow depressions in the Australian Alps Bioregion

a7: Bog Buttercup - Creeping Raspwort herbfield of wetland margins in the Australian Alps Bioregion

a8: Tufted Sedge - Mud Water-milfoil - Tufted Hair-grass sedgeland of the Australian Alps Bioregion (Fen)

a9: Tufted Sedge - Small River-buttercup - Common Reed aquatic herbfield of waterways in the Australian Alps and South Eastern Highlands Bioregions

e24: Mountain Gum - Snow Gum very tall dry shrubby woodland to open forest primarily in the Kybeyan - Gourock subregion of the South Eastern Highlands Bioregion

e59: Small-fruit Hakea - Mountain Baeckea - Myrtle Tea-tree subalpine bog heathland on the coastal ranges of the South Eastern Highlands Bioregion

g36: Button Tea-tree - Yellow Kunzea - Burgan dry shrubland on skeletal ridges primarily of the Namadgi Region

\section{Equivalents and similar communities}

a14: Subalpine valley grassland; b7: Poa costiniana - Epilobium billardierianum subsp. cinereum - Brachyscome scapigera-Asperula gunnii montane, sod-tussock grassland

Combination of a2: Richea continentis - Carpha nivicola - Sphagnum cristatum wet heathland and a3: Baeckea gunniana-Callistemon pityoides - Sphagnum cristatum wet heathland

Combination of a18: Poa fawcettiae - Uncinia sulcata grassland and a22: Poa fawcettiae - Euphrasia collina grassland

Combination of a30: Poa hiemata - Poa clivicola grassland and a31: Poa hookeri grassland; b6: Poa spp. - Geranium antrosum - Scleranthus biflorus - Leptorhynchos squamatus - Ranunculus graniticola montane sod-tussock grassland

Combination of a33: Northern Alps Hovea montana open heathland, a35: Bossiaea foliosa-Epacris petrophila heathland and a36: Broadway Bossiaea foliosa closed heathland a34: Eucalyptus lacrimans low open woodland

a38: Themeda triandra - Leucochrysum albicans grassland a39: Kosciuszko alpine Epacris - Kunzea open heathland

a42: Epacris celata - Poa clivicola open Heathland a43: Bossiaea riparia dwarf heathland

Combination of a23: Grevillea australis - Nematolepis ovatifolia open heathland and a46: Nematolepis ovatifolia - Prostanthera cuneata closed heathland

a51: Austrodanthonia alpicola - Grevillea australis open heathland

a54: Podocarpus lawrencei closed heathland

a6: Lobelia surrepens - Ranunculus millanii herbfield

a7: Hypericum japonicum - Ranunculus pimpinellifolius herbfield

a8. Fen

a9: Aquatic

Largely equivalent to e24: Subalpine Dry Shrub Forest (but includes plots originally assigned to p338). g64: Southern East Tableland Edge Shrub/Grass Dry Forest is divided between e24 and e26 (the latter of which occurs to the east outside the study area)

e59: Southeast Sub-alpine Bog

g36: Montane / Sub-Alpine Dry Rocky Shrubland 
L3: Freshwater sedge-herb marsh of shallow ephemeral lakes of the eastern South Eastern Highlands Bioregion

L4: Freshwater sedge-herb marsh of deep semi-permanent and/ or slightly saline wetlands of the eastern South East ern Highlands Bioregion

m31: Ribbon Gum - Snow Gum - Shiny Cassinia tall shrub-grass woodland to open forest of gullies in quartz-rich ranges in the Monaro and Kybeyan-Gourock subregions of the NSW South Eastern Highlands

m51: Brittle Gum - Scribbly Gum shrub-grass tall dry sclerophyll woodland on exposed quartz-rich slopes and ridges at primarily in the Monaro and Kybeyan-Gourock subregions of the South Eastern Highlands Bioregion

p10: Black Sheoak - Silvertop Ash tall shrubby dry sclerophyll woodland to open forest primarily in the Bungonia subregion of the South Eastern Highlands Bioregion

p14: Red Stringybark - Scribbly Gum - Redanther Wallaby Grass tall grass-shrub dry sclerophyll woodland to open forest on loamy ridges of the central South Eastern Highlands Bioregion

p220: Ribbon Gum - Snow Gum tableland flats tall grassy woodland primarily on granitoids in the Kybean-Gourock and Monaro subregions of the South Eastern Highlands Bioregion

p32d: River Sheoak dry forest on sand/gravel alluvial soils along major watercourses of the South Eastern Highlands and upper South Western Slopes Bioregions

p338: Brown Barrel wet sclerophyll very tall grass-herb open forest primarily of the Gourock and Tallaganda Ranges in the South Eastern Highlands Bioregion

p520: Ribbon Gum swamp very tall woodland on sandy alluvial soils along drainage lines of the eastern South Eastern Highlands Bioregion

p56: Mountain Tea-tree - Small-fruit Hakea - River Lomatia riparian shrubland of the eastern South Eastern Highlands Bioregion

p8: Silvertop Ash - Narrow-leaved Peppermint tall shrubby dry sclerophyll woodland to open forest primarily on sedimentary ridges of the eastern South Eastern Highlands Bioregion

r1: Sub-montane moist tussock grassland of the South Eastern Highlands Bioregion

r2: River Tussock - Kangaroo-grass - Rush wet tussock grassland of footslopes, drainage lines and flats of the South Eastern Highlands Bioregion

r3: Wallaby-grass - Kangaroo Grass - Rush tussock grassland of occasionally wet sites of the South Eastern Highlands Bioregion

r4: Lacustrine ephemeral grassland of the South Eastern Highlands Bioregion

r5: Wallaby-grass - Tall Speargrass - Common Everlasting tussock grassland of the South Eastern Highlands Bioregion

r6: Dry tussock grassland of the Monaro in the South Eastern Highlands Bioregion
Approximately equivalent to bj3

A modification and range extension of bj4

Largely a combination of g73: Eastern Tableland Dry Shrub/Grass Forest and g74: South Eastern Tablelands Dry Shrub/Grass/Herb Forest

Closest to g115: South East Tablelands Dry Shrub/Tussock Grass Forest but including some plots originally assigned to other communities (mainly g73, g75, g109, g110)

A westward extension of p10: Eastern Tablelands Dry Forest; g15: North East Tableland Dry Shrub Forest

A westward extension of p14; largely a combination of g114: Tablelands Dry Shrub/Tussock Grass Forest; and parts of g109: Widespread Tablelands Dry Shrub/Tussock Grass Forest and g121: Western Slopes Grass/Herb Dry Forest.

Largely equivalent to p220: Southern Tableland Flats Forest but contains several plots assigned in the same classification to p520: Tableland Swamp Flats Forest. Contains plots from g73: Eastern Tableland Dry Shrub/Grass Forest and g74: South Eastern Tablelands Dry Shrub/Grass/Herb Forest.

VCA 85: River Oak forest and woodland wetland of the NSW Southwestern Slopes and South Eastern Highlands Bioregions

p338: Southern Range Wet Forest; combination of g55: Eastern Tableland Fern/Herb/Grass Moist Forest, g56: Tableland and Escarpment Moist Herb/Fern Grass Forest and part of g95: Tableland Acacia Moist Herb Forest.

Largely equivalent to p520: Southern Tableland Flats Forest. Contains plots from g89: Eastern Tablelands Acacia/Herb/Grass Forest and g146: Tableland Dry Herb/Grass Woodland.

Equivalent to p56

p8: Tableland Ridge Forest; a combination of g59: Eastern Tableland and Escarpment Shrub/Fern Dry Forest and g112: Eastern Tablelands Dry Shrub Forest.

r1: Sub-montane moist tussock grassland of the South Eastern Highlands Bioregion

b8: Poa labillardieri tall tussock grassland, R2: River Tussock Kangaroo-grass - Rush wet tussock grassland of footslopes, drainage lines and flats of the South Eastern Highlands Bioregion, VCA635: River Tussock - Kangaroo - Grass - Rush wet tussock grassland of footslopes, drainage lines and flats of the South Eastern Highlands Bioregion.

r3: Wallaby-grass - Kangaroo Grass - Rush tussock grassland of seasonally wet sites of the South Eastern Highlands Bioregion. VCA637: Wallaby-grass - Kangaroo Grass - Rush tussock grassland of seasonally wet sites of the South Eastern Highlands Bioregion.

r4: Lacustrine ephemeral grassland of the South Eastern Highlands Bioregion. VCA636: Lacustrine Ephemeral Grassland of the South Eastern Highlands Bioregion.

b1: Danthonia spp. - Asperula conferta - Bothriochloa macra low grassland on the northern Monaro, r5: Wallaby-grass - Tall Speargrass - Common Everlastings tussock grassland of the South Eastern Highlands Bioregion.

Combination of b3: Themeda australis - Poa sieberiana -

Chrysocephalum apiculatum - Acaena ovina tall grassland and b4: Poa sieberiana - Acaena ovina grassland on basalt, southern Monaro; r6: Dry tussock grassland of the Monaro in the South Eastern Highlands Bioregion. 
r7: Kangaroo Grass - Wallaby-grass - Snow-grass moist tussock grassland of the South Eastern Highlands Bioregion

r8: Kangaroo Grass - Purple Wire-grass - Wattle Mat-rush dry tussock grassland in the Southern Tablelands region of the South Eastern Highlands Bioregion

L12: Freshwater sedge-herb marsh of shallow, commonly inundated wetlands of the eastern South Eastern Highlands Bioregion p23: Red Stringybark - Broad-leaved Peppermint tall dry sclerophyll grassy woodland on loamy rises primarily in the Bungonia subregion of the South Eastern Highlands Bioregion

p24: Yellow Box - Blakely's Red Gum tall grassy woodland on undulating sedimentary and acid-volcanic substrates in the Goulburn area of the South Eastern Highlands Bioregion

p9: Brittle Gum - Scribbly Gum tall shrubby dry sclerophyll woodland Largely equivalent to p9: Tableland Low Woodland but including some on infertile low ridges and hills primarily of the Bungonia subregion of plots originally assigned to p14, p15 and p23.

the South Eastern Highlands Bioregion

u105: Broad-leaved Peppermint - Brittle Gum - Red Stringybark tall shrub-grass dry sclerophyll woodland to open forest of lower ranges of the western South Eastern Highlands and upper South Western Slopes Bioregions

u118: Black Sallee grass-herb woodland in drainage depressions and moist valley flats in the South Eastern Highlands and Australian Alps Bioregions

u148: Red Stringybark - Red Box grass-forb tall woodland to open forest of the upper South Western Slopes and western South Eastern Highlands Bioregions

u150: Broad-leaved Peppermint - Mountain Gum tall grass-forb woodland to open forest of the South Eastern Highlands and Australian Alps Bioregions

u152: Robertson's Peppermint - Red Stringybark very tall grass-forb sheltered woodland to open forest of the southwest South Eastern Highlands and upper South Western Slopes Bioregions

u158: Alpine Sallee mid-high shrub-grass subalpine woodland of the Australian Alps Bioregion

u159: Black Sassafras temperate rainforest of wet sheltered slopes in the Australian Alps Bioregion

u165: Robertson's Peppermint very tall shrubby woodland to open forest primarily of the Bondo subregion of the South Eastern Highlands

u173: River Red Gum +/- Apple Box very tall grass-forb riparian woodland on alluvial flats in the South Eastern Highlands and upper South Western Slopes Bioregions

u178: Yellow Box - Apple Box tall grassy woodland of the South Eastern Highlands

u18: Bundy - Broad-leaved Peppermint mid-high shrubby woodland to open forest on granite substrates primarily in the Namadgi Region

u181: River Bottlebrush - Burgan rocky riparian shrubland in the South Eastern Highlands and upper South Western Slopes Bioregions

u19: Blakely's Red Gum - Yellow Box +/- White Box tall grassy woodland of the Upper South Western Slopes and western South Eastern Highlands Bioregions

u191: Black Cypress Pine - Brittle Gum tall dry woodland on hills primarily in the Cooma Region

u193: Small-fruit Hakea - Drumstick Heath - Swamp Heath Subalpine Swamp Heathland of the Australian Alps and western South Eastern Highlands Bioregions b2: Themeda australis - Juncus filiformis grassland of the ACT; r7:

Kangaroo Grass - Wallaby-grass - Snow-grass moist tussock grassland of the South Eastern Highlands Bioregion.

r8: Kangaroo Grass - Purple Wire-grass - Wattle Mat-rush dry tussock grassland in the Southern Tablelands region of the South Eastern Highlands Bioregion.

Combination of bj1 and bj2.

Largely equivalent to p23: Tableland Hills Grassy Woodland but with many new plots to the west and some plots originally assigned to p24: Tableland Grassy Box-Gum Woodland.

Largely equivalent to p24: Tableland Grassy Box-Gum Woodland. but with many new plots to the west

Largely a combination of g108: Western Tablelands Dry Herb/Grass Forest and g110: Tablelands Dry Shrub/Grass Forest but with some g109).

No equivalent. All but one plot was not available for previous classifications.

No clear equivalent; contains many new plots and plots originally assigned to g116: Western Slopes Herb/Grass Woodland, g119: Western Tablelands Dry Shrub/Grass Forest, g120: Western Slopes Shrub/Herb/Grass Dry Forest and g121: Western Slopes Grass/Herb Dry Forest and has affinities with VCA290: Red Stringybark - Red Box - Long-leaved Box - Inland Scribbly Gum tussock grass - shrub low open forest on hills in the southern part of the NSW South-western Slopes Bioregion

Most similar to g103: Western Montane Dry Fern/Grass Forest but contains plots originally assigned to several other communities (mainly g75, g105, g107, g109, g110).

Largely a combination of g93: Western Tablelands Herb/Grass Dry Forest and g94: South West Slopes Acacia Dry Herb/Grass Forest but including some plots originally assigned to other communities (mainly g103, g104 and g119)

Combination of g128: Sub-alpine Dry Shrub/Herb Woodland and g130: Sub-alpine Shrub/Grass Woodland with many new plots.

Largely equivalent to g172: Kosciuszko Western Escarpment Cool Temperate Rainforest

Similar to VCA295; incorporates g106: Montane Dry Shrub/ Tussock Forest but including some plots originally assigned to other communities (mainly g103, g104 and g82)

Largely defined by new plots but incorporates g43: Western Slopes Riparian Moist Sedge Woodland.

Largely defined by new plots but contains several plots previously assigned to g160: Northern Slopes Dry Grass Woodland

Probably simiar or equivalent to g79: Montane Dry Shrub/Tussock Grass Forest.

Largely defined by new plots; contains plots originally assigned to g82: Western Montane Acacia Fern/Herb Forest.

Incorprates g117: Western Slopes Dry Grass Woodland and contains plots previously assigned to g116: Western Slopes Herb/Grass Woodland, g154: Tableland Dry Grassy Woodland and g160: Northern Slopes Dry Grass Woodland

No equivalent but possibly related to g79: Montane Dry Shrub/Tussock Grass Forest.

Largely defined by new plots; contains plots originally assigned to g123: Montane Wet Heath/Bog and g124: Western Montane Wet Heath/Herb Grass Woodland. plots originally assigned to other communities (mainly g103 and 
u20: Kurrajong - Blackthorn - Kangaroo Grass mid-high shrub-grass open woodland on limestone karsts in the Wee Jasper area

u207: Jounama Snow Gum - Snow Gum mid-high shrubby woodland on granitoids primarily of the Namadgi Region

u21: Broad-leaved Peppermint - Candlebark tall dry sclerophyll woodland to open forest of quartz-rich ranges of the upper South East Highlands and lower Australian Alps Bioregions

u22: Mountain Gum - Snow Gum grass-forb very tall woodland to open forest of the Australian Alps and South Eastern Highlands Bioregions

u23: Snow Gum - Drumstick Heath - Myrtle Tea-tree tall woodland to open forest of drainage depressions primarily of the South Eastern Highlands Bioregion

u239: Alpine Ash - Mountain Gum +/- Snow Gum wet sclerophyll open forest of the Australian Alps and South Eastern Highlands Bioregions

u27: Snow Gum - Candlebark tall grassy woodland in frost hollows and gullies primarily of the South Eastern Highlands Bioregion

u28: Snow Gum - Mountain Gum - Daviesia mimosoides tall dry grass-shrub subalpine woodland to open forest of the Australian Alps and South Eastern Highlands Bioregions

u29: Apple Box - Broad-leaved Peppermint tall shrub-grass woodland primarily on granitoids of the South Eastern Highlands Bioregion u40: Alpine Ash very tall wet sclerophyll woodland primarily of the Australian Alps Bioregion

u43: Bundy - Hickory Wattle - Drooping Sheoak - Western Wedding Bush tall grassy open woodland Serpentinite in the CoolacGoobarragandra area of the upper NSW Southwestern Slopes Bioregion

u52: Ribbon Gum - Robertson's Peppermint very tall wet sclerophyll open forest primarily of the Bondo Subregion of the South Eastern Highlands Bioregion

u53: Mountain Gum - Blackwood tall wet sclerophyll open forest primarily on granitoids of the Australian Alps and western South Eastern Highlands Bioregions

u66: Bundy - Red Stringybark mid-high grassy herbaceous open woodland of the South Eastern Highlands and Upper Slopes Subregion of the South Western Slopes Bioregion

u78: Snow Gum mid-high grassy woodland of the South Eastern Highlands Bioregion
No equivalent; defined by new plots.

Probably equivalent to g127: Sub-alpine Dry Shrub/Herb/Grass Woodland but mostly defined by new plots.

Largely defined by new plots but contains plots previously assigned to g74: South Eastern Tablelands Dry Shrub/Grass/Herb Forest and g75: Tablelands Shrub/Tussock Grass Forest

Incorporates g97: Montane Acacia/Dry Shrub/Herb/Grass Forest and g100: ACT Montane Dry Shrub/Grass Forest with plots from g95: Tableland Acacia Moist Herb Forest, g96: Tableland Tussock Grass/ Herb Forest, g99: Montane Dry Shrub/Herb/Grass Forest, g101: NorthWestern Montane Dry Shrub/Herb/Grass Forest, g102: Brindabella Montane Dry Fern/Grass Forest, g103: Western Montane Dry Fern/ Grass Forest, and g104: Tableland Acacia/Herb/Grass Forest

Defined by many new plots but includes plots previously assigned to g124: Western Montane Wet Heath/Herb Grass Woodland and g146: Tableland Dry Herb/Grass Woodland.

No clear equivalent; mostly new plots but incorporates some plots from $\mathrm{g} 86, \mathrm{~g} 87, \mathrm{~g} 99$ and $\mathrm{g} 102$

No equivalent. Defined by plots not used in previous classifications. May have some affinities with $\mathrm{g} 100$.

Mostly defined by new plots but contains some plots previously assigned to g98: Western Montane Moist Shrub Forest

No equivalent; defined by plots not used in previous classifications.

Closest to g87: Western Escarpment Moist Shrub/Herb/Grass Forest but with many new plots and a few plots from g82 and g86

Equivalent to VCA301: Drooping Sheoke - Ricinocarpus bowmanniigrasstree tall open shrubland of the Coolac - Tumut Serpentinite Belt.

Largely a combination of g82: Western Montane Acacia Fern/Herb Forest, g83: Montane Riparian Moist Shrub/Grass/Herb Forest and g102: Brindabella Montane Dry Fern/Grass Forest

Most closely related to g86: Western Sub-alpine Moist Shrub Forest but including some plots originally assigned to g85

No equivalent; defined by plots not used in previous classifications.

Comprises plots mostly from p22: Frost Hollow Grassy Woodland and p24: Tableland Grassy Box-Gum Woodland. The community is effectively a subset of those communities.

\section{References}

Benson, J.S. (1994) The native grasslands of the Monaro region: southern tablelands of New South Wales. Cunninghamia 3: 609-650.

Benson, J.S. \& Jacobs, S.W.L. (1994) Plant communities of the Monaro lakes. Cunninghamia 3: 651-676.

Benson, J.S., Richards, P.G., Waller, S. \& Allen, C.B. (2010) New South Wales vegetation classification and assessment: Part 3. Plant communities of the NSW Brigalow Belt South, Nandewar and west New England bioregions and update of NSW Western Plains and South Western Slopes plant communities. Version 3 of the NSW VCA database. Cunninghamia 11: 457-579. Botanic Gardens Trust, Sydney.

Gellie, N.J.H. (2005) Native vegetation of the southern forests: South Eastern Highlands, Australian Alps, South West Slopes and South East Corner bioregions. Cunninghamia 9: 219-254.

McDougall, K.L. \& Walsh, N.G. (2007) Treeless vegetation of the Australian Alps. Cunninghamia 10: 1-57.

Rehwinkel, R. (unpublished) Revision of PATN analysis of grassland associations within the Natural Temperate Grassland Endangered Ecological Community in the Southern Tablelands of NSW. August 2009 [URL: http://www.gbwcmn.net.au/sites/default/files/ Revision_PATN_Rehwinkel09 .pdf]. Website accessed July 9 2012. NSW Department of Environment and Climate Change, Queanbeyan. Unpublished Report.

Tozer, M.G. (2003) The native vegetation of the Cumberland Plain, western Sydney: systematic classification and field identification of communities. Cunninghamia 8: 1-75. 